\title{
ANÁLISE NUMÉRICA E EXPERIMENTAL DE BLOCOS DE CONCRETO ARMADO SOBRE DUAS ESTACAS SUBMETIDOS À AÇÃO DE FORÇA CENTRADA E EXCÊNTRICA
}

\author{
Rodrigo Gustavo Delalibera
}

Tese apresentada à Escola de Engenharia de São Carlos, da Universidade de São Paulo, como parte dos requisitos para obtenção do título de Doutor em Engenharia de Estruturas.

Orientador: José Samuel Giongo

São Carlos 
Ficha catalográfica preparada pela Seção de Tratamento da Informação do Serviço de Biblioteca - EESC/USP

Delalibera, Rodrigo Gustavo

Análise numérica e experimental de blocos de concreto armado sobre duas estacas submetidos à ação de força centrada e excêntrica / Rodrigo Gustavo Delalibera. -São Carlos, 2006 .

Tese (Doutoramento) -- Escola de Engenharia de São Carlos-Universidade de São Paulo, 2006.

Área: Engenharia de Estruturas.

Orientador: Prof. Dr. José Samuel Giongo.

1. Bloco sobre estacas. 2. Bielas e tirantes.

3. Análise experimental. 4. Análise numérica.

5. Fundações. I. Título. 
FOLHA DE JULGAMENTO

Candidato: Engenheiro RODRIGO GUSTAVO DELALIBERA

Tese defendida e julgada em 02/06/2006 perante a Comissão Julgadora:

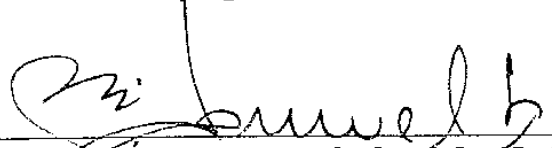

Prof. Dr. JOSE-SAMUEL GIONGO (Orientador)

(Escola de Engenharia de São Carlos/USP)

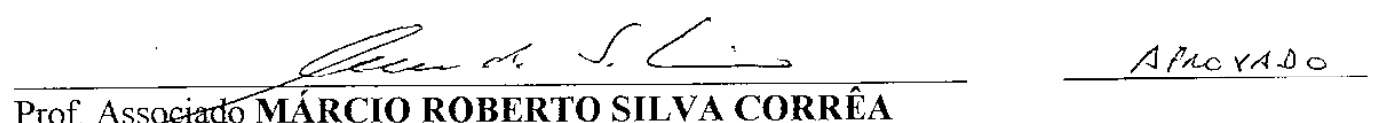

(Escola de Engenharia de São Carlos/USP)

Prof. Titular fOSÉ HENRIQUE AĹBIERO

Aren

(Escola de/Engenharia de São Carlos/USP)

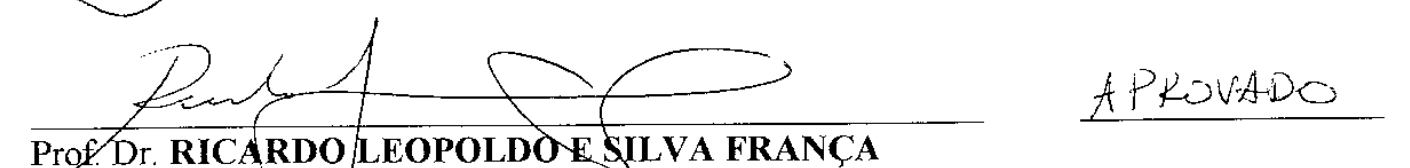

Prof. Dr. RICARDO LEOPOLDO E SILVA FRANCA

(Escola Politécnica/USP)

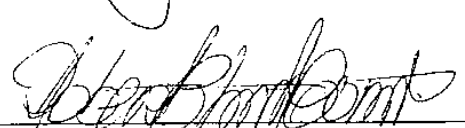

Prof. Dr. ROBERTO CHUST CARVALHO

(Universidade Federal de São Carlos/UFSCar)

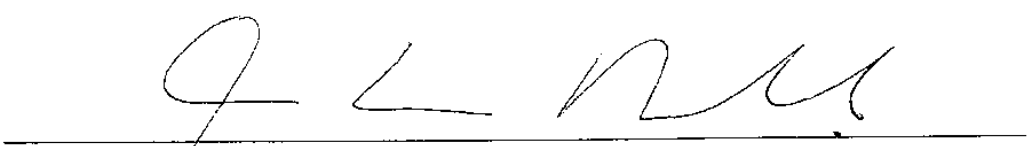

Prof Associado MARCIO ANTONIO RAMALHO

Coordenadora do Programa de Pós-Graduação em

Engenharia Civil (Engenharia de Estruturas)

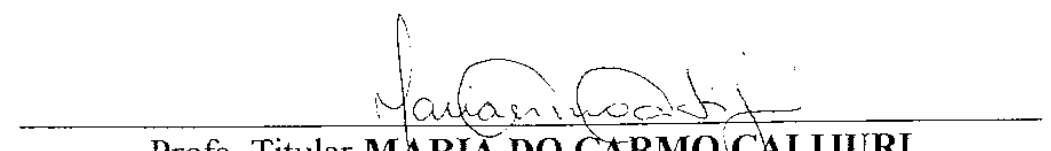

Profa. Titular MARIÁ DO CARMO CALIJURI

Presidente da Comissão de Pós-Građuação 

À Minha esposa, minha filha, meus pais e minha irmã: Inês; Larissa; Moacir; Cristina; e Roberta; dedico este trabalho. 

"Fora da caridade não há salvação."

Allan Kardec, E.S.E, Cap. XV. 



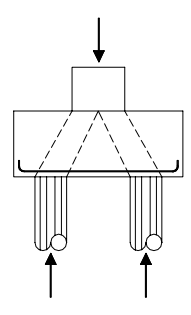

AGRADECIMENTOS

Ao final de mais uma etapa de minha vida profissional, agradeço primeiramente a DEUS, por ter me dado sabedoria, oportunidade e perseverança sem as quais eu não teria condições de realizar este trabalho.

A minha esposa, Inês, por sempre ter estado ao meu lado, pelas palavras de incentivo nas horas difíceis, por sua confiança em meu trabalho e principalmente por existir em minha vida.

A minha filha, Larissa, que apesar da pouca idade sempre me alegrava com seus carinhos, sorrisos e afeto. Agradeço a DEUS todos os dias por ter me permitido ser seu pai nesta vida.

Aos meus pais, Moacir e Cristina, que sempre me apoiaram e incentivaram nas horas árduas. Meu pai tenha fé e esperança que juntos venceremos e superaremos esta fase de nossas vidas. Minha mãe, uma guerreira, sempre forte, obrigado por tudo.

A minha irmã, meu cunhado e minha sobrinha, pelo incentivo e confiança. Minha irmã, que sua carreira seja grandiosa e que minha sobrinha tenha muita saúde.

Ao meu orientador, mais que isso, meu grande amigo, obrigado pelo apoio indispensável neste trabalho. Saiba que o admiro como homem e que aprendi muito com você.

Ao professor Toshiaki Takeya, sempre pronto a ajudar e com quem divido os méritos deste trabalho.

Aos professores Márcio Roberto Silva Corrêa e Roberto Chust Carvalho pelas sugestões e contribuições no exame de qualificação.

A Todos os professores do Departamento de Engenharia de Estruturas pelas contribuições indispensáveis.

A Todos os funcionário do Departamento de Engenharia de Estruturas, em especial ao Eng. Masaki Kawabata Neto, sempre prestativo e disposto o qual tenho a honra de ser seu amigo.

Aos grandes amigos de pós-graduação, Andrei Merlin, André Velami, Fernado Menezes, Ricardo Dias, Ricardo Carrazedo e Humberto Correia Lima Júnior, pela amizade sincera e momentos de descontração compartilhados. 



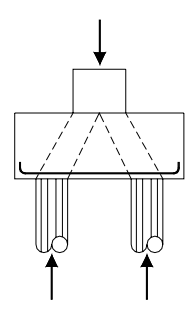

CRÉDITOS

A elaboração deste trabalho só foi possível em função do apoio de instituições e empresas, por meio de sugestões e apoio técnico-financeiro. Assim são dignos de crédito:

- CNPq - Conselho Nacional de Desenvolvimento Científico e Tecnológico

Pela concessão de bolsa de estudos.

- FAPESP - Fundação de Amparo à Pesquisa do Estado de São Paulo

Pelo auxílio à pesquisa correspondente ao processo 2005/000182-5.

- Camargo Corrêa Industrial S.A.

Por meio do Engenheiro João Paulo Fernandes Guimarães.

- Belgo Siderurgia S.A.

Por meio do Engenheiro Luciano Módena.

- $\quad$ IBTS - Instituto brasileiro de telas soldadas

Por meio do Engenheiro João Batista Rodrigues da Silva.

- Anchortec industrial de comercial Ltda.

Por meio da Sra. Priscila Cardoso.

- Coplas S.A.

Por meio da Sra. Érica Tonieti. 

LISTA DE SÍMBOLOS

\section{CAPÍTULO 1 - INTRODUÇÃO}

1.1. Introdução 1

1.2. Justificativa 5

1.3. Objetivo 6

1.4. Método 6

$\begin{array}{lll}\text { 1.5. } & \text { Apresentação da Tese } & 7\end{array}$

\section{CAPÍTULO 2 - REVISÃO BIBLIOGRÁFICA}

2.1. Considerações iniciais 9

2.1.1. Pesquisas com ênfase experimental 9

2.1.2. Pesquisas com ênfase numérica 21

2.1.3. Analogia de Bielas e Tirantes 30

2.1.4. Recomendações normativas $\quad 37$

2.2. Comentários Finais 39

\section{CAPÍTULO 3 - ANÁLISE DE VARIÂNCIA}

3.1. Considerações iniciais 41

3.2. Determinação das variáveis 42

3.3. $\quad$ Formulação da análise de variância 47

3.4. Análise numérica 49

3.4.1. Propriedades dos modelos $\quad 50$

3.4.2. Elementos finitos utilizados 52

3.4.3. Propriedades dos materiais 52

3.4.4. Análise comparativa 54

3.4.5. Influência do comprimento da estaca e do solo 60 
3.4.6.

3.4.7.

3.4.8.

3.4.9.

3.5.

4.1.

4.2.

4.2.1.

4.2.2.

4.2.3.

4.2.4.

4.2.5.

4.2.6.

4.3.

4.4.

4.5.

4.6.

4.7.

5.1.

5.2.

5.2.1.

5.2.2.

5.2.3.

5.3.

5.3.1.

5.3.3.

Análise dos blocos sobre duas estacas com excentricidade igual a zero

Análise dos blocos sobre duas estacas com excentricidade igual a cinco centímetros

Análise dos blocos sobre duas estacas com excentricidade igual a dez centímetros

Análise dos resultados

77

Comentários finais

80

\section{CAPÍTULO 4 - DIMENSIONAMENTO, PROJETO E CONSTRUÇÃO DOS MODELOS}

Considerações iniciais $\quad 81$

Dimensionamento e detalhamento dos modelos 83

Dimensionamento dos blocos 83

Dimensão dos blocos $\quad 84$

Verificação das tensões nodais $\quad 86$

Dimensionamento da armadura principal de tração 88

Ancoragem da armadura principal de tração 88

$\begin{array}{ll}\text { Armaduras complementares } & 90\end{array}$

Dimensionamento das estacas $\quad 93$

Dimensionamento dos pilares $\quad 94$

Detalhamento das armaduras $\quad 96$

Dosagem do concreto $\quad 101$

Execução dos modelos $\quad 104$

CAPÍTULO 5 - DESCRIÇÃO E APRESENTAÇÃO DOS

RESULTADOS EXPERIMENTAIS

$\begin{array}{ll}\text { Considerações iniciais } & 107\end{array}$

Equipamentos e instrumentos utilizados $\quad 107$

Extensômetro mecânico 110

Extensômetros elétricos de resistência 115

$\begin{array}{ll}\text { Transdutores de deslocamentos } & 120\end{array}$

Descrição dos ensaios experimentais $\quad 121$

Comportamento geral dos modelos 122

Deformação nas faces dos blocos 134

$\begin{array}{ll}\text { Aberturas das fissuras } & 149\end{array}$ 
$\begin{array}{lll}\text { 5.3.4. } & \text { Reações nas estacas } & 157\end{array}$

5.3.5. Deslocamentos horizontais e verticais 157

5.3.6. Deformações nas armaduras 161

5.3.6.1. Deformação na armadura principal de tração 161

5.3.6.2. Deformações nas armaduras complementares superiores 165

5.3.6.3. Deformações nos estribos horizontais 168

5.3.6.4. Deformações nos estribos verticais 170

5.3.6.5. Deformações na armadura complementar sugerida pelo autor $\quad 175$

5.3.7. Ensaios complementares 176

5.3.7.1 Ensaio de compressão de corpos-de-prova cilíndricos de 177

$\begin{array}{lllll}\text { 5.3.7.2 Ensaio de compressão diametral de corpos-de-prova } & 179\end{array}$ cilíndricos de concreto

Ensaios pra determinação do módulo de deformação tangente inicial do concreto

Resistência ao escoamento e módulo de elasticidade das barras de aço

\section{CAPÍTULO 6 - ANÁLISE DOS RESULTADOS \\ EXPERIMENTAIS}

6.1. Considerações iniciais

$\begin{array}{lll}\text { 6.2. } & 189\end{array}$

6.3. Influência da rigidez dos blocos 191

6.4. Influência do arranjo das armaduras 194

6.4.1. Armadura de costura - sugerida 195

$\begin{array}{ll}\text { 6.4.2. } & 197\end{array}$

6.4.3. Armadura principal de tração projetada com ganchos a 180 198

$\begin{array}{lll}\text { 6.5. Influência da excentricidade } & 199\end{array}$

6.6. Deformação na armadura principal de tração - tirante 202

$\begin{array}{lll}\text { 6.7. } & \text { Abertura das fissuras } & 208\end{array}$

6.8. Deformações e tensões nas zonas nodais inferior e 210 $\begin{array}{ll}\text { superior } & 210 \\ \text { Forma geométrica da biela de compressão } & 221\end{array}$

6.9. Forma geométrica da biela de compressão 221

CAPÍTULO 7 - SIMULAÇÃO NUMÉRICA

7.1. Considerações iniciais 
7.2. Discretização, condições de contorno e solicitações

$\begin{array}{lll}\text { 7.3. } & \mathbf{2 2 9}\end{array}$

7.3.1. Tensões principais 230

7.3.2. Fluxo de tensões 236

7.3.3. Tensões nas armaduras 241

$\begin{array}{lll}\text { 7.3.4. } & \text { Relação força vs. deslocamento } & 244\end{array}$

CAPÍTULO 8 - MODELO PROPOSTO DE BIELAS E TIRANTES

8.1. Considerações iniciais 249

8.2. Idealização do modelo 249

8.3. Equacionamento do modelo 251

8.3.1. Modelo considerando força centrada 251

8.3.2. Modelo considerando força excêntrica 253

8.3.3. Áreas de aço dos tirantes 255

8.3.4. Armadura mínima de fendilhamento 255

8.3.5. Detalhamento da armadura de fendilhamento 258

8.4. Tensões limites 258

8.5 Considerações necessárias para o dimensionamento da estaca 261

$\begin{array}{ll}\text { 8.6. } & 262\end{array}$

\section{CAPÍTULO 9 - CONCLUSÃO}

9.1. Considerações finais 265

9.2. Principais conclusões 265

$\begin{array}{lll}\text { 9.3. Sugestões para trabalhos futuros } & 269\end{array}$

REFERÊNCIAS BIBLIOGRÁFICAS

$\begin{array}{ll}\text { ANEXO A } & 279\end{array}$

$\begin{array}{ll}\text { ANEXO B } & 287\end{array}$

$\begin{array}{ll}\text { ANEXO C } & 293\end{array}$ 


\section{LISTA DE SÍMBOLOS}

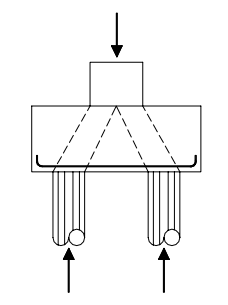

Coeficiente para determinação da resistência da biela e teor de

$\alpha$

$\beta$

$\checkmark$

$\phi$

$\varepsilon$

$\theta, \theta_{1}$ e $\theta_{1}$

$\varepsilon_{0^{\circ}}, \varepsilon_{45^{\circ}}$ e $\varepsilon_{90^{\circ}}$

$\varepsilon_{1}$ e $\varepsilon_{2}$

$\alpha_{1}$ e $\alpha_{2}$

$\sigma_{1}$ e $\sigma_{2}$

$\eta_{1}, \eta_{2}$ e $\eta_{3}$

$\tau_{b}$

$\sigma_{b, P 25}$

$\sigma_{b, z i}$

$\sigma_{\mathrm{b}, \mathrm{zs}}$

$\sigma_{\text {bi,P50 }}$

$\sigma_{\mathrm{bs}, \mathrm{P} 50}$

$\sigma_{\text {ef,biela }}$

$\phi$ est

$\gamma_{f}$

$\sigma_{\lim }$

$\sigma_{\lim , \mathrm{e} \neq 0}$

$\sigma_{\lim , \mathrm{P} 50, \mathrm{zi}}$ argamassa.

Coeficiente para determinação da resistência da biela.

Coeficiente de Poisson.

Diâmetro da barra.

Deformações.

Ângulo de inclinação da biela de compressão.

Deformações do concreto na face do bloco.

Deformações principais.

Direções principais.

Tensões principais.

Coeficientes para determinação da resistência de ancoragem.

Tensão de aderência.

Tensão na biela para os modelos das séries B35P25 e B45P25.

Tensão na biela de compressão junto à estaca.

Tensão na biela de compressão junto ao pilar.

Tensão na biela junto à estaca, para os modelos da série B35P50 e B45P50 com e $=0$.

Tensão na biela junto ao pilar, para os modelos da série B35P50 e B45P50 com e $=0$.

Tensão efetiva na biela.

Diâmetro da estaca.

Coeficiente de majoração dos esforços.

Tensão limite na biela de compressão.

Tensão limite na biela de compressão para modelos com $\mathrm{e} \neq 0$.

Tensão limite da biela junto à estaca para modelos da série B35P50 e $\mathrm{B} 45 \mathrm{P} 50 \mathrm{com} \mathrm{e}=0$. 
Tensão limite da biela junto ao pilar para modelos da série B35P50 e

$\theta_{\mathrm{m}}, \theta_{\mathrm{m} 1}$ e $\theta_{\mathrm{m} 2}$ Ângulos de inclinação médios da biela de compressão.

Coeficiente de minoração do aço.

$\sigma_{\mathrm{s}, \mathrm{ef}}$

Tensão efetiva na armadura de tração.

$\delta_{\mathrm{T}}$

Deslocamento dos transdutores.

$\varepsilon_{\mathrm{y}}$

Deformação das barras de aço.

$\sigma_{\mathrm{y}}$

Tensão na armadura.

$\varepsilon_{\mathrm{y}, \mathrm{m}}$

$\sigma_{\mathrm{zni}}$

$\sigma_{\mathrm{zns}}$

A

Deformação média das barras de aço.

Tensão na zona nodal inferior.

Tensão na zona nodal superior.

a/c

Comprimento do bloco.

$A_{b, z i}$

Relação água - cimento.

$A_{b, z s}$

Área da biela de compressão junto à estaca.

$A_{\text {est }}$

Área da biela de compressão junto ao pilar.

$a_{f}$

Área da seção transversal da estaca.

Distância horizontal - modelo proposto de bielas e tirantes.

$a_{p}$

Comprimento da seção do pilar.

$a_{r}$

$A_{s, \text { cal }}$

$A_{s, e f}$

Massa do agregado miúdo.

Área de armadura calculada.

Área de armadura efetiva.

$A_{s, \text { malha }}$

Área das barras de aço da armadura em malha.

$A_{s, \text { min }}$

Área mínima das barras de aço.

$A_{s c}$

Área das barras de aço da armadura superior.

$A_{s t}$

Área das barras de aço da armadura principal de tração.

$A_{s w}$

Área de aço das barras das armaduras complementares.

$a_{x}$

Dimensão da estaca na direção considerada.

$B_{\text {Lx }}$

Comprimento do bloco.

$B_{L y}$

Largura do bloco.

C

Coesão do solo.

d Altura útil do bloco.

e Excentricidade.

E Módulo de elasticidade.

e excentricidade adotada.

$\mathrm{E}_{\mathrm{c}} \quad$ Módulo de elasticidade longitudinal do concreto. 


\begin{tabular}{|c|c|}
\hline $\mathrm{E}_{\mathrm{ci}}$ & Módulo de deformação inicial do concreto. \\
\hline$E_{c i, e x p}$ & Módulo de deformação inicial experimental do concreto. \\
\hline$E_{c i, m, \exp }$ & Módulo de deformação médio inicial experimental do concreto. \\
\hline $\mathrm{E}_{\mathrm{cs}}$ & Módulo de deformação secante do concreto. \\
\hline $\mathrm{e}_{\text {real }}$ & Excentricidade real. \\
\hline $\mathrm{E}_{\mathrm{s}}$ & Módulo de elasticidade longitudinal do aço. \\
\hline$E_{\text {solo }}$ & Módulo de elasticidade longitudinal do solo. \\
\hline Est $_{1}$ e Est ${ }_{2}$ & Estacas um e dois. \\
\hline $\mathrm{F}$ & Força normal ou vertical. \\
\hline $\mathrm{F}_{0}$ & Resultado do teste ANOVA. \\
\hline$f_{b}$ & Resistência da biela. \\
\hline$f_{b k}$ & Resistência característica de aderência. \\
\hline$f_{c}$ & Resistência à compressão do concreto. \\
\hline$f_{c d}$ & Resistência de cálculo à compressão do concreto. \\
\hline$f_{c k}$ & Resistência característica à compressão do concreto. \\
\hline$f_{c m}$ & Resistência média à compressão do concreto. \\
\hline$F_{\text {critico }}$ & Fator de comparação do teste ANOVA. \\
\hline$f_{\text {ctk }}$ & Resistência característica do concreto à tração. \\
\hline$f_{c t k, i n f}$ & Resistência característica à tração do concreto com valor inferior. \\
\hline $\mathrm{F}_{\mathrm{est}}$ & Força na estaca. \\
\hline $\mathrm{F}_{\mathrm{r}}$ & Força relativa à primeira fissura. \\
\hline$f_{t}$ & Resistência à tração do concreto. \\
\hline $\mathrm{f}_{\mathrm{t}}$ & Resistência à tração experimental do concreto. \\
\hline$F_{\text {teo }}$ & Força teórica. \\
\hline $\mathrm{f}_{\mathrm{tm}, \exp }$ & Resistência média a tração experimental do concreto. \\
\hline $\mathrm{F}_{\mathrm{u}}$ & Força última. \\
\hline$f_{u}$ & Tensão de ruptura das barras de aço. \\
\hline $\mathrm{F}_{\mathrm{u}, \exp }$ & Força última experimental. \\
\hline $\mathrm{F}_{\mathrm{u}, \text { num }}$ & Força última numérica. \\
\hline$f_{y}$ & Resistência ao escoamento das barras de aço. \\
\hline$f_{y, m}$ & Resistência media ao escoamento das barras de aço. \\
\hline$f_{y d}$ & Resistência de cálculo ao escoamento das barras de aço. \\
\hline$f_{y k}$ & Resistência característica ao escoamento das barras de aço. \\
\hline $\mathrm{h}$ & Altura total do bloco. \\
\hline$h_{f}$ & Dimensão vertical - modelo proposto de bielas e tirantes. \\
\hline$h_{x}$ & Dimensão do pilar na direção considerada. \\
\hline
\end{tabular}


$\mathrm{h}_{\mathrm{y}}$

I

$\ell_{\mathrm{b}}$

$\ell_{b, \min }$

$\ell_{\mathrm{b}, \text { nec }}$

Lest

$\mathrm{m}$

M

$M_{1 d \text { min }}$

$\emptyset_{\text {efetivo }}$

$\varnothing_{\text {nom }}$

$\mathrm{p}_{\mathrm{b}}$

$\mathrm{R}_{\text {Asw,C }}$

$R_{c t, \text { min }}$

$\mathrm{R}_{\text {est,- }}$

$\mathrm{R}_{\mathrm{est},+}$

$\mathrm{R}_{\mathrm{st}}$

$R_{\text {st,ponta }}$

$\mathrm{S}$

$T_{f}, T_{f 1}, e T_{f 2}$

$T_{p}$
Dimensão do pilar na direção considerada.

Inércia.

Comprimento de ancoragem básico.

Comprimento de ancoragem mínimo.

Comprimento de ancoragem necessário.

Distância entre os eixos das estacas.

Massa seca.

Momentos.

Momento mínimo de cálculo.

Diâmetro efetivo das barras de aço.

Diâmetro nominal das barras de aço.

Massa do agregado graúdo.

Força de tração perpendicular à biela.

Força de tração mínima.

Reação da estaca menos solicitada.

Reação da estaca mais solicitada.

Força de tração no tirante.

Força de tração na ponta do tirante.

Espaçamento entre barras.

Tirantes secundários - fendilhamento.

Tirante principal. 


\section{RESUMO}

DELALIBERA, R. G. (2006). Análise experimental e numérica de blocos de concreto armado sobre duas estacas submetidos à ação de força centrada e excêntrica. São Carlos. Tese (Doutorado) - Escola de Engenharia de São Carlos, Universidade de São Paulo.

A pesquisa teve como objetivo analisar e discutir o comportamento de blocos de concreto armado sobre duas estacas submetidos à ação de força centrada e excêntrica. Desenvolveu-se uma análise numérica tridimensional não-linear de blocos de concreto armado sobre duas estacas. A análise numérica levou em consideração a fissuração do concreto e a influência das armaduras no comportamento estrutural dos blocos. Por meio da análise numérica, foi possível perceber o comportamento e a forma geométrica das bielas de compressão, com isso, obteve-se melhor entendimento do modelo de Bielas (Escoras) e Tirantes aplicado a blocos de concreto armado sobre duas estacas. A geometria observada nos modelos numéricos analisados preliminarmente difere da usualmente sugerida por vários autores. Realizou-se investigação experimental de blocos, com o fim principal de observar, de modo mais abrangente, a geometria das bielas de compressão. A instrumentação foi posicionada nas faces dos blocos com extensômetros espaçados de modo a ocuparem boa parte da largura e, conseqüentemente, indicarem as suas geometrias. A análise experimental de blocos sobre duas estacas submetidos à ação de força excêntrica permitiu observar o comportamento das bielas e tirantes que diferem dos observados quando a força é centrada. Também foi analisada a eficiência dos ganchos das barras de aço que compõem os tirantes, verificando-se que os ganchos podem ser omitidos sem prejuízo da segurança estrutural dos blocos. Em função dos resultados obtidos por meio das análises experimental e numérica desenvolveram-se modelos de bielas e tirantes aplicados a blocos sobre duas estacas.

Palavras-chave: blocos sobre estacas; bielas e tirantes; análise experimental; análise numérica; fundações. 



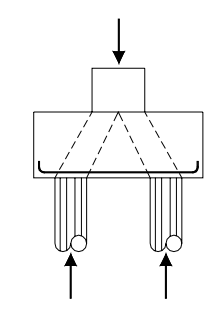

ABSTRACT

DELALIBERA, R. G. (2006). Numerical and experimental analysis of two pile caps submitted to the action of a load centered and eccentric. São Carlos. Thesis (Doctorate) - School of engineering of São Carlos, University of São Paulo.

The research had as objective to analyze and to argue about the behavior of two pile caps submitted to the action of a centered and eccentric load. A nonlinear three-dimensional numerical analysis of two pile caps was developed. The numerical analysis included the cracking and the influence of the reinforcement in the structural behavior of the pile caps. By the numerical analysis, it was possible to perceive the behavior and the geometric form of the strut, with this understand the model strut-andtie applied to the two pile caps. The geometry observed in the numerical models analyzed at first differs from the usually suggested by some authors. This project realized experimental tests of piles caps to observe the geometry of the struts. The instrumentation was located in the faces of the pile caps with spaced strain-gages in order to occupy good part of the width and, consequently, indicate its geometry. The experimental analysis of two pile caps submitted to the eccentric load allowed the behavior observation of the strut and tie that differ from the one observed when the load was centered. Also the efficiency of the hooks of the reinforced bar was analyzed, therefore, in the experimental analysis of pile caps already developed, it was verified that the hooks can be omitted without damage of the structural security of the pile caps. For treating the procedure defined in the project, and taking advantage of the experimental analysis realized, it was understood that this requirement can be analyzed and that the results will bring benefits to the project. In function of the results obtained through the experimental and numeric analysis strut-and-tie models were developed to be applied in two pile caps.

Keyswords: pile caps; strut-and-tie; experimental analysis; experimental analysis; fundations. 



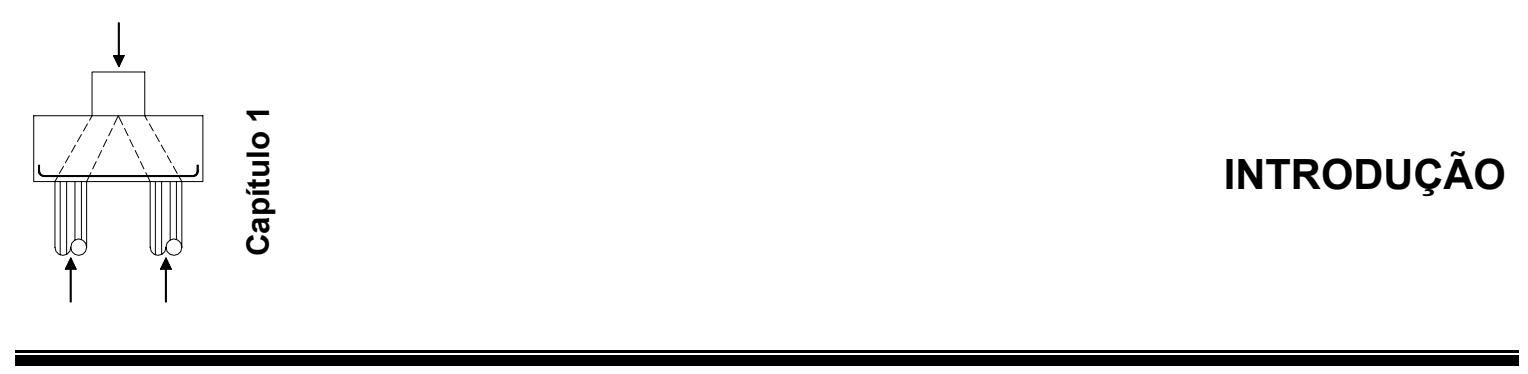

\subsection{Considerações iniciais}

A escolha do tipo de fundação para uma determinada construção é feita após estudo que considere as condições técnicas e econômicas da obra. Por meio do conhecimento dos parâmetros do solo, da intensidade das ações, dos edifícios limítrofes e dos tipos de fundações disponíveis no mercado, o engenheiro pode escolher qual a melhor a alternativa para satisfazer tecnicamente e economicamente 0 caso em questão.

As fundações em estacas são adotadas quando o solo em suas camadas superficiais não é capaz de suportar ações oriundas da superestrutura, sendo necessário, portanto, buscar resistência em camadas profundas. Quando for necessária a utilização de fundação em estacas, faz-se necessário a construção de outro elemento estrutural, o bloco de coroamento, também denominado bloco sobre estacas. Nos casos de fundações em tubulões também há necessidade de blocos de coroamento para transferência das ações.

Blocos sobre estacas são importantes elementos estruturais cuja função é transferir as ações da superestrutura para um grupo de estacas. Esses elementos estruturais, apesar de serem fundamentais para a segurança da superestrutura, geralmente não permitem a inspeção visual quando em serviço, sendo assim, é importante o conhecimento de seu real comportamento nos Estados Limites de Serviço e Último. A Figura 1.1 ilustra esse elemento estrutural.

Grande parte das pesquisas desenvolvidas em relação ao tema nos últimos anos, concentra-se em dois tipos de análise: análise teórica elástica e linear compreendendo a analogia das bielas e tirantes e a teoria de viga e análise de resultados experimentais. Normalmente emprega-se a teoria de viga nos blocos ditos flexíveis e a analogia das bielas e tirantes nos blocos chamados de rígidos. Fica 
evidenciado que para o dimensionamento e verificação desses elementos estruturais, é necessário o prévio conhecimento de suas dimensões.

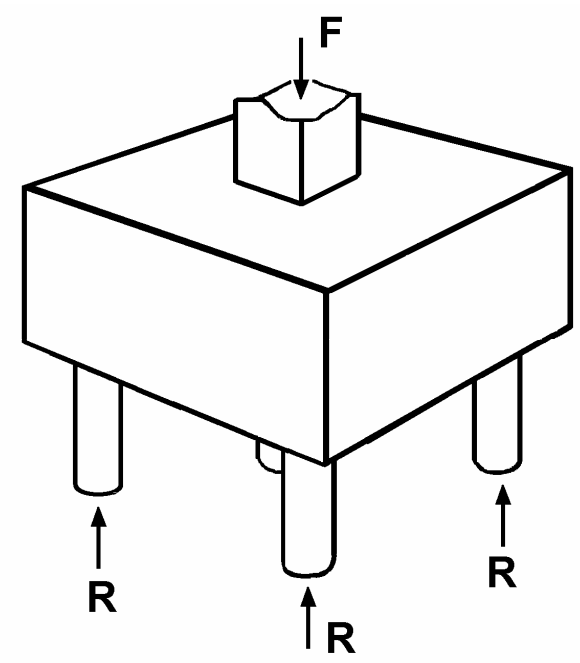

Figura 1.1 - Bloco sobre estacas.

O comportamento estrutural de blocos sobre estacas pode ser definido utilizando-se a analogia de bielas e tirantes, por ser tratarem de regiões descontínuas, onde não são válidas as hipóteses de Bernoulli. No modelo de bielas e tirantes as verificações de compressão nas bielas são as mesmas que as do Modelo de Blévot (1967), porém as tensões nas regiões nodais (entende-se por regiões nodais as ligações estaca-bloco e pilar-bloco) têm valores diferentes das tensões limites sugeridas por Blévot. O Código Modelo do CEB-FIP (1990) sugere geometrias para os nós das regiões nodais, sendo possível realizar as verificações de tensões nessas regiões.

O modelo de bielas e tirantes pode ser adotado considerando o fluxo de tensões na estrutura, utilizando o processo do caminho das mínimas forças, sugerido por Schalich et al. (1987). Estas tensões podem ser obtidas por meio de uma análise elástica e linear ou não, utilizando métodos numéricos, como por exemplo, o método dos elementos finitos.

Segundo a NBR 6118:2003, "blocos são estruturas de volume usadas para transmitir às estacas as cargas de fundação", ou seja, todas as dimensões externas têm a mesma ordem de grandeza. São tratados como elementos estruturais especiais, que não respeitam a hipótese das seções planas permanecerem planas após a deformação, por não serem suficientemente longos para que se dissipem as perturbações localizadas. A NBR 6118:2003 classifica o comportamento estrutural dos 
blocos em rígidos ou flexíveis. No caso de blocos rígidos o modelo estrutural adotado para o dimensionamento pode ser tridimensional, linear ou não, e modelos de bielatirante tridimensionais, sendo esse último o preferido por definir melhor a distribuição de forças nas bielas e tirantes. A NBR 6118:2003 não traz em seu texto recomendações para verificação e dimensionamento deste elemento, apenas sugere quais os critérios a utilizar.

A falta de conhecimento da forma geométrica do fluxo de tensões que formam as bielas de compressão em blocos sobre estacas, submetidos a forças centradas e excêntricas, faz com que esse trabalho seja interessante e importante para o meio científico, pois com o conhecimento da formação dessas bielas de compressão, poderse-á analisar com melhor exatidão o fluxo de tensões de compressão desenvolvido nos blocos, melhorando assim, o projeto estrutural e estabelecendo critérios para a verificação das tensões de compressão nas bielas. Além disso, as hipóteses adotadas pela NBR 6118:2003: "no caso de conjunto de blocos e estacas rígidos, com espaçamentos de 2,5. $\phi$ a 3. $\phi$ (onde $\phi$ é o diâmetro da estaca), pode se admitir plana (significa que a seção transversal da cabeça da estaca é solicitada por tensões uniformes) a distribuição de carga nas estacas"; e "para blocos flexíveis ou casos extremos de estacas curtas ou tubulões, apoiadas em substrato muito rígido, a hipótese anterior precisa ser revista"; necessitam ser estudadas, pois, em análise por meio de modelos numéricos de blocos rígidos observou-se que a distribuição de força nas estacas não é uniforme, sendo necessário, portanto, adaptação das hipóteses utilizadas.

Para isso, um estudo estatístico (análise de variância com base nos resultados das análises numéricas) a respeito do comportamento do fluxo de tensões de compressão e da capacidade portante dos blocos de concreto armado sobre duas estacas foi desenvolvido. Foram escolhidas quatro variáveis para análise estatística: dimensões da seção transversal da estaca; dimensões da seção transversal do pilar; excentricidade da ação vertical aplicada no bloco; e altura do bloco. Essas variáveis foram escolhidas, pois têm influência direta no fluxo de tensões de compressão e tração, além disso, trabalhos existentes no meio técnico indicam que essas variáveis são relevantes na análise estrutural de blocos sobre estacas; entre eles pode-se citar: Miguel et al. (2000) e Walraven \& Lehwalter (1989). Em função da não-linearidade do problema, foram tomados três parâmetros de estudo para cada variável, resultando assim, numa análise fatorial $3^{4}$, totalizando oitenta e um blocos sobre duas estacas.

A simulação numérica foi desenvolvida por meio de programas de computador baseados no método dos elementos finitos e levou em consideração a fissuração do 
concreto, a não-linearidade dos materiais (concreto e aço) e a não-linearidade geométrica do elemento estrutural (não-linearidade geométrica).

O fenômeno da aderência aço-concreto não foi considerado na simulação numérica.

A fim de verificar a acuidade dos resultados dos modelos numéricos, foi feito um estudo comparativo com resultados de ensaios experimentais de blocos existentes na literatura técnica. Só após a verificação dos resultados oriundos da análise numérica é que foi desenvolvido o estudo estatístico.

Não existe na literatura técnica estudo estatístico, mesmo que numérico, do comportamento estrutural de blocos sobre estacas de concreto armado.

Após o desenvolvimento da análise numérica, tendo em mãos resultados que indicam o comportamento estrutural dos blocos sobre estacas, foram realizados ensaios experimentais com intuito de atestar os resultados numéricos e fornecer maior quantidade de informações a respeito do comportamento estrutural dos blocos de concreto armado sobre estacas. Para isso foram ensaiados quatorze blocos, tendo como variáveis: a seção transversal do pilar, a altura dos blocos, a excentricidade da ação vertical aplicada e a existência ou não dos ganchos na armadura principal de tração.

Em relação aos ganchos da armadura do tirante, a sua utilização deverá ser revista e analisada, pois há divergência em relação à sua eficiência. Miguel (2000) conclui que a deformação no gancho é praticamente zero não exercendo influência na força última (ruína). Esse fenômeno também foi observado por Rausch et al. (1997) e Taylor \& Clarke (1976). Leonhardt \& Mönnig (1978) também recomendam ancoragem reta, desprezando o gancho, pois como a armadura dos tirantes sobre as estacas é fortemente comprimida perpendicularmente ao plano horizontal das estacas, a utilização de ancoragem reta é eficiente. As afirmações anteriores foram constatadas nos ensaios realizados pelo autor e são apresentados nos Capítulo 5 e 6.

Por meio dos resultados experimentais obtidos, fizeram-se sugestões para os critérios de ancoragem da armadura principal de tração - tirante, desprezando-se a utilização de ganchos.

A finalidade de se aplicar excentricidade na força vertical, foi simular a existência de momentos nos blocos, pois é alterada consideravelmente a configuração dos fluxos de tensões nos blocos. Sendo assim, tornou-se necessário adequar o modelo de bielas e tirantes para aplicação em blocos sobre estacas submetidas à força vertical e momento. 
Existem poucas informações na literatura sobre a utilização do modelo de bielas e tirantes aplicados a blocos submetidos à ação vertical e momento. FUSCO (1994) traz algumas recomendações. O CEB-FIP (1970), MORAES (1976), ALONSO (1983), CALAVERA (1991), entre outros, apresentam métodos de cálculos para blocos sobre estacas submetidas à ação vertical e momento, porém, o método utilizado é o da superposição de efeitos, que consiste em calcular a força em cada estaca somando-se separadamente os efeitos da força vertical e dos momentos, não levando em consideração o novo comportamento do fluxo de tensões.

Com base nos resultados experimentais e numéricos, foram propostos dois modelos de bielas e tirantes que levam em consideração a existência ou não de excentricidade da força vertical.

Sugeriu-se nova geometria para as bielas de compressão, com base na distribuição dos fluxos das tensões principais de compressão e nos modos de ruínas observados durante os ensaios.

Tensões limites para a verificação da segurança das bielas comprimidas junto aos pilares e às estacas também foram apresentadas.

\subsection{Justificativa}

Este trabalho justifica-se pela importância que o elemento estrutural blocos sobre estacas têm na estrutura de uma edificação. A falta de conhecimento da forma geométrica das bielas de compressão no Estado Limite Último para aplicação da analogia de bielas e tirantes, a divergência entre os métodos analíticos utilizados no dimensionamento e verificação dos blocos e a falta de normalização deste elemento estrutural são alguns aspectos que tornam este trabalho necessário.

Outro fato importante é que, apesar da analogia de biela e tirante ser garantida pela teoria do Limite inferior ou Teorema Estático (havendo um bloco sobre estacas, existem inúmeros modelos possíveis de treliças que representam campos de tensões estaticamente equilibrados e plasticamente admissíveis), o modelo que se utiliza para a aplicação da analogia de bielas e tirantes é feito usando trajetórias de tensões principais elásticas. Há assim, uma incompatibilidade nas formulações, ou seja, o modelo de bielas e tirantes é plasticamente garantido, porém, sua modelagem é feita por meio de trajetórias de tensões elásticas que não levam em contam o esmagamento e fissuração do elemento estrutural. Faz-se necessário, portanto, rever a hipótese anterior e criar modelos de bielas e tirantes obtidos por meio de fluxos de tensões em regime plástico. 


\subsection{Objetivo}

Os objetivos principais deste trabalho são apresentados a seguir:

- Analisar a formação das bielas de compressão por meio de resultados numéricos e experimentais;

- Analisar a contribuição dos ganchos da armadura principal nas fases de serviço e de ruína;

- Propor um modelo refinado de bielas e tirantes para blocos sobre duas estacas baseado em resultados experimentais e numéricos;

\subsection{Método}

O método a empregar é o relativo a trabalhos com ênfase em análise numérica e experimental. Definidos os modelos que foram estudados, análise estatística foi desenvolvida, utilizando valores obtidos por meio de simulações numéricas. Os blocos de concreto armado sobre estacas foram analisados numericamente por meio de programa de computador baseado nos métodos dos elementos finitos - MEF. As nãolinearidades física e geométrica foram consideradas. A fissuração do concreto e a armadura do bloco também foram levadas em consideração. Para a análise não-linear dos blocos via elementos finitos, utilizou-se o programa ANSYS ${ }^{\circledR}$ (ANalyser SYStem). O ANSYS ${ }^{\circledR}$ é um programa para análise não-linear de estruturas por meio do método dos elementos finitos, desenvolvido pela empresa norte-americana ANSYS, Inc.

Análise experimental de quatorze modelos foi desenvolvida, sendo realizados os seguintes ensaios:

- Ensaios para a determinação das propriedades mecânicas das barras e fios de aço utilizados;

- Ensaios preliminares para dosagem do concreto: resistência à compressão e à tração, módulo de deformação longitudinal e consistência;

- Ensaios de corpos-de-prova cilíndricos de concreto, para controle da resistência e determinação do módulo de elasticidade dos concretos utilizados dos modelos;

- Ensaios de quatro séries de blocos, série B35P25 (bloco sobre duas estacas com altura de trinta e cinco centímetros e pilar com seção transversal de vinte e cinco centímetros de lado), série B45P25 (bloco sobre duas estacas com 
altura de quarenta e cinco centímetros e pilar com seção transversal de vinte e cinco centímetros de lado), série B35P50 (bloco sobre duas estacas com altura de trinta e cinco centímetros e pilar com seção de vinte e cinco centímetros por cinqüenta centímetros) e série B45P50 (bloco sobre duas estacas com altura de quarenta e cinco centímetros e pilar com seção de vinte e cinco centímetros por cinqüenta centímetros).

Análises dos resultados experimentais foram desenvolvidas e por fim, conclusões foram apresentadas.

\subsection{Apresentação da tese}

A seguir, apresentam-se a ordem e os conteúdos dos capítulos que constituem esta tese:

CAPÍTULO 1: Introdução - apresentação do tema, justificativas, objetivos e método empregado no trabalho;

CAPÍtULO 2: Revisão bibliográfica - apanhado geral dos trabalhos desenvolvidos sobre o tema, apresentando críticas e obtendo informações importantes para o desenvolvimento da tese;

CAPÍTULO 3: Análise de variância - análise estatística desenvolvida por meio de simulações numéricas com objetivos de otimizar os ensaios experimentais;

CAPÍTULO 4: Dimensionamento, projeto e construção dos modelos - critérios utilizados para o dimensionamento e execução dos modelos experimentais;

CAPÍTULO 5: Descrição e apresentação dos resultados experimentais descrição do programa experimental e dos resultados dos ensaios desenvolvidos nessa pesquisa;

CAPÍTULO 6: Análise dos resultados experimentais - análise e críticas dos resultados experimentais obtidos por meio dos ensaios realizados; 
CAPÍTULO 7: Simulação numérica - simulação numérica dos modelos ensaiados experimentalmente;

CAPÍTULO 8: Modelo proposto de bielas e tirantes - apresentação de modelos analíticos de bielas e tirantes utilizados para o dimensionamento de blocos sobre duas estacas;

CAPÍTULO 9: Conclusão - apresentação das conclusões obtidas em função da realização desse trabalho;

REFERÊNCIAS BIBLIOGRÁFICAS: Artigos, livros e normas citados na tese;

ANEXOS: Informações importantes de assuntos abordados na tese. 


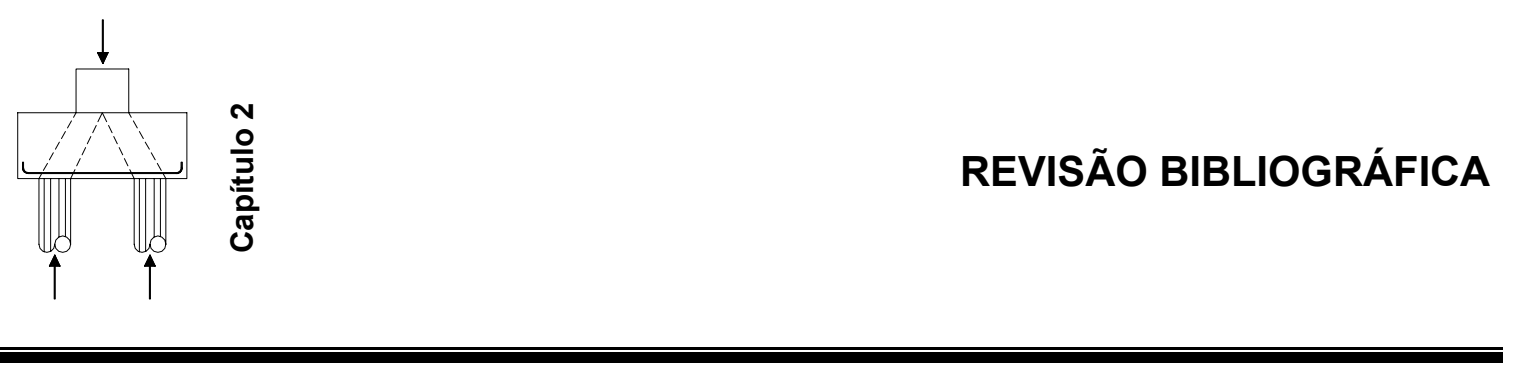

\subsection{Considerações iniciais}

A revisão bibliográfica foi dividida em quatro partes: a primeira expõe pesquisas com ênfase experimental; a segunda parte comenta as pesquisas com ênfase numérica; e a terceira, apresenta os critérios utilizados na analogia de bielas e tirantes; a quarta e última parte expõem as recomendações utilizadas em algumas normas.

\subsubsection{Pesquisas com ênfase experimental}

Em 1957, Hobbs \& Stein (1957) pesquisaram o comportamento de blocos sobre duas estacas por meio de análises teóricas e experimentais. Foram ensaiados setenta modelos em escala reduzida na relação 1:3. Os pesquisadores desenvolveram uma solução analítica fundamentada na teoria da elasticidade bidimensional e comparou os resultados teóricos com os resultados experimentais obtidos por meio dos ensaios. Os pesquisadores concluíram que pode-se obter economia na área de aço da armadura principal se forem utilizadas barras curvas (ver Figura 2.1).

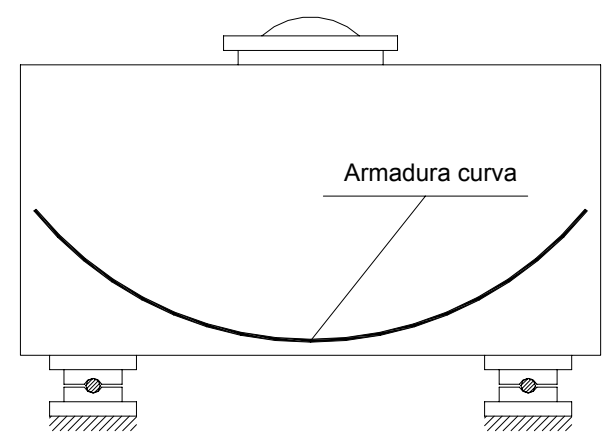

Figura 2.1 - Armadura curva, Bloco ensaiado por Hobbs \& Stein (1957). 
Até aquela época, os blocos eram tratados como vigas, não existindo, portanto, formulações para peças com perturbação de tensão envolvendo praticamente todo o elemento estrutural (regiões D), sendo assim, houve evolução no método de dimensionamento dos blocos.

Blévot \& Frémy (1967) realizaram ensaios em cem blocos sobre estacas com a finalidade de estudar a influência de diferentes arranjos de armadura. Em blocos sobre quatro estacas, os autores constataram que distribuindo a armadura uniformemente, a força última é reduzida de $20 \%$ em comparação com blocos com a mesma taxa de armadura, porém, dispostas sobre as estacas. Em blocos sobre três estacas essa redução foi de $50 \%$. As observações experimentais relatadas por Blévot \& Frémy (1967) são base para a maioria das formulações para dimensionamento de blocos sobre estacas existentes na literatura técnica. A diminuição da força última dos blocos projetados com armadura em malha ocorreu pela inexistência de armadura de suspensão. Esse fenômeno é explicado por Leonhardt \& Mönnig (1978) e constatado nos ensaios de Taylor \& Clarke (1976). Machado (1979) também verifica a necessidade de armadura de suspensão para os blocos com armadura em malha. $O$ esquema de ensaio utilizado por Blevót \& Frémy (1967) é semelhante ao apresentado na Figura 2.5a. A seguir são descritos com maiores detalhes os ensaios realizados por Blévot \& Frémy (1967).

Para os modelos sobre duas estacas, os pesquisadores ensaiaram blocos com largura de $40 \mathrm{~cm}$, com pilares de $30 \mathrm{~cm}$ x $30 \mathrm{~cm}$ e inclinação da biela em relação à face inferior do bloco maior que $40^{\circ}$. A disposição da armadura dos tirantes apresentava dois tipos de arranjos: barras lisas com ganchos (ver Figura 2.2a) e barras com mossas ou saliências sem ganchos (Ver Figura 2.2b).

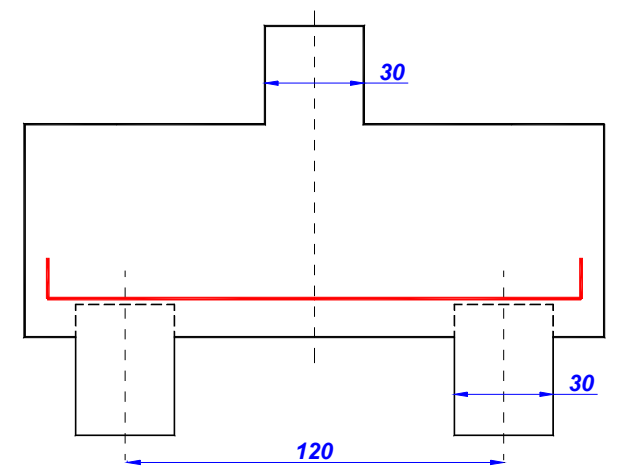

a) modelo com armadura em barras lisas com ganchos

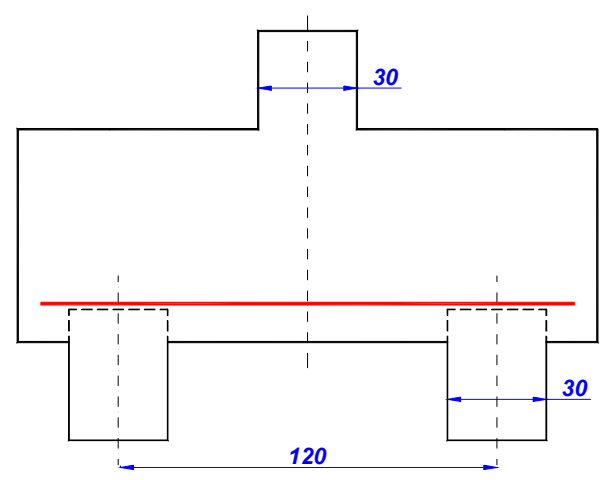

b) modelo com armadura em barras com saliências sem ganchos

Figura 2.2 - Blocos sobre duas estacas, Blévot \& Frémy (1967). 
Blévot \& Frémy (1967) observaram que houve ocorrência de várias fissuras antes da ruína, sendo que essas ocorreram pelo esmagamento da biela de concreto junto ao pilar ou junto à estaca, ou simultaneamente. Observou-se que ocorreu escorregamento das barras nos modelos armados com barras com mossas ou nervuras, sem ganchos. Fenômeno semelhante foi observado por Miguel (2000), porém, o escorregamento só aconteceu após a ruptura da biela de compressão.

Com relação aos blocos sobre três estacas Blévot \& Frémy (1967) utilizaram diferentes tipos de arranjo de armadura: armadura segundo os lados unindo as estacas; armadura em laço contornando as estacas; armaduras dispostas nas medianas passando pela projeção do pilar; combinação entre as armaduras segundo os lados e medianas; e por fim, armadura em malha. A Figura 2.3 ilustra esses modelos.

Os quatro primeiros modelos foram eficientes, porém, a armadura segundo os lados foi preponderante. O modelo ensaiado com armadura distribuída em malha (ver Figura 2.3e) apresentou força última $50 \%$ menor da prevista no dimensionamento. Como já foi mencionado, isso ocorreu pela falta da armadura de suspensão, pois, "em situações em que a distância entre os eixos das estacas for maior que três vezes o diâmetro das mesmas, faz-se necessário dispor, no banzo, armadura de suspensão" justificativa apresentada por Leonhardt \& Mönning (1978).

Com relação às fissuras, os blocos armados segundo os lados e com laços (ver Figura 2.3a e 2.3b) apresentaram melhor eficiência em relação às faces laterais, porém ineficiente na face inferior do bloco.

Na maioria dos modelos, a ruína ocorreu por tração do concreto a partir do surgimento de fissuras iniciadas na região das estacas - fendilhamento.

Nos modelos com ângulos de inclinação das bielas entre $40^{\circ}$ e $55^{\circ}$ os valores de força última obtidos pela analogia de bielas foram maiores que os valores de ensaio. Porém, para os blocos com ângulo menor que $40^{\circ}$ e maior que $55^{\circ}$, as forças últimas obtidas nos ensaios foram menores do que as calculadas, portanto, contra a segurança.

O efeito da punção também foi observado nessa série de ensaios. Os pesquisadores constataram que respeitando o limite inferior de $40^{\circ}$ não há risco de punção.

Todos os modos de ruína, para os blocos com ângulo de inclinação da biela entre $40^{\circ}$ e $55^{\circ}$, ocorreram com ações superiores aos indicados pela analogia das Bielas e aconteceram após o escoamento da armadura principal, e não houve ruína por punção. 

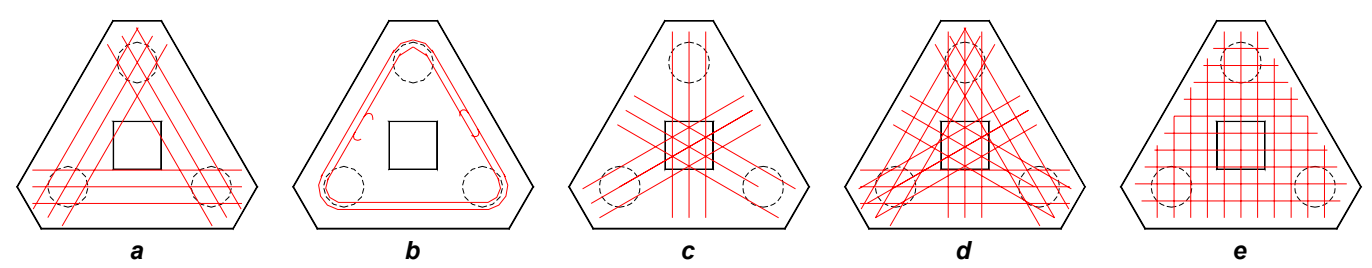

Figura 2.3 - Blocos sobre três estacas, Blévot \& Frémy (1967).

Blévot \& Frémy (1967) também ensaiaram modelos de blocos sobre quatro estacas com cinco tipos de arranjos de armadura: armadura segundo os lados do bloco; armadura em laço contornando as estacas; armadura segundo as diagonais; combinação entre armaduras segundo as medianas e laços; e, armadura em malha. Os arranjos das armaduras dos modelos ensaiados são mostrados na Figura 2.4.

As disposições de armaduras dos modelos a e d mostraram-se igualmente eficientes, já o modelo com armadura distribuída em malha (ver Figura 2.4e) apresentou eficiência de $80 \%$.

Quanto à fissuração, o modelo com armadura segundo as diagonais (ver Figura 2.4c) apresentou número maior de fissuras para forças "com pequena intensidade". O modelo b apresentou fissuração excessiva na face inferior do bloco, mostrando a necessidade de se utilizar armadura secundária em malha.

Também foram observadas ruínas a partir de fissuras iniciadas junto às estacas. Não observaram ruína por punção. Os resultados dos modelos ensaiados mostraram-se coerentes com resultados teóricos por meio da analogia das Bielas.

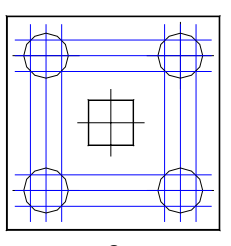

a

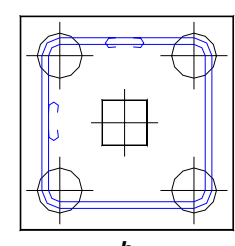

b

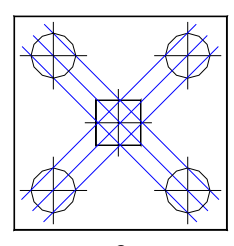

$c$

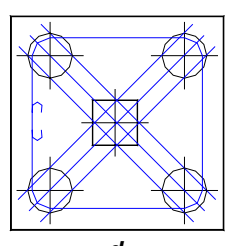

d

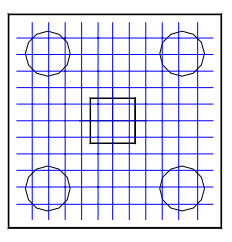

Figura 2.4 - Blocos sobre quatro estacas, Blévot \& Frémy (1967).

MAUTONI (1972), mediante resultados de ensaios em blocos sobre duas estacas, estabeleceu um método para determinar a força e o mecanismo de ruína por meio de uma expressão que leva em consideração a taxa crítica de armadura. Os blocos foram ensaiados com o trecho representativo do pilar recebendo a força por meio de um prato com articulação esférica fixa. Os dois apoios dos blocos foram suportados por articulações móveis. Na Figura 2.5 é mostrado um dos blocos ensaiados. 
Os modelos foram desenvolvidos com a finalidade de analisar blocos sobre dois apoios, mas podem ser utilizados para análise de consolos sem armadura de costura. Foram ensaiados 20 blocos com dois tipos de arranjo de armadura: laçada contínua na horizontal e armadura em bigode.

$\mathrm{Na}$ armadura "em bigode" (ver Figura 2.5b) as barras eram inclinadas, cada uma com dois trechos semicirculares, melhorando as condições de ancoragem e contendo ainda ganchos nas extremidades. O arranjo da armadura em laçada contínua foi disposta em camadas, suas extremidades eram semicirculares separadas por um trecho central retangular.

Nos modelos ensaiados adotou-se largura de $15 \mathrm{~cm}$ e variaram-se as dimensões de altura e vão entre estacas. As propriedades geométricas de um dos modelos (bloco B1-A) são apresentadas na Figura 2.6.

Mautoni (1972) observou que o início da fissuração ocorreu para forças próximas de $40 \%$ das forças de ruína. A primeira fissura surgiu no meio do vão, na região inferior do bloco, junto à armadura de tração. A fissuração se estabilizou para forças em torno de $70 \%$ da força última. Observou também, que, as fissuras formaram-se paralelamente às bielas de compressão.

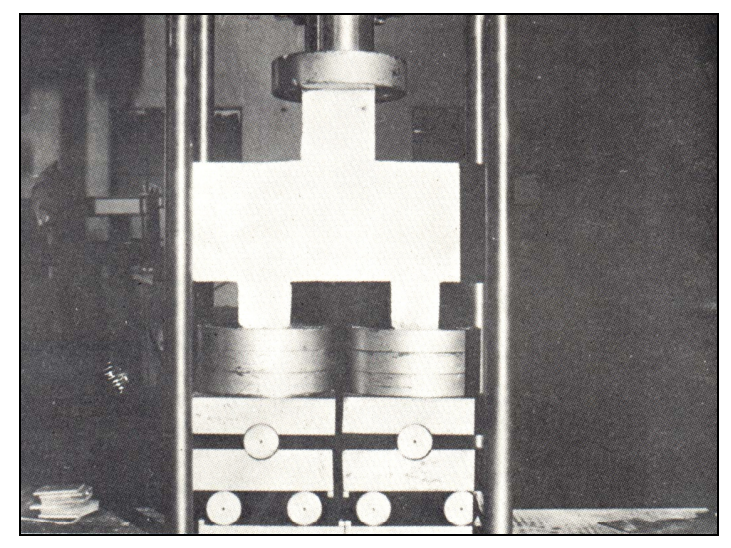

a

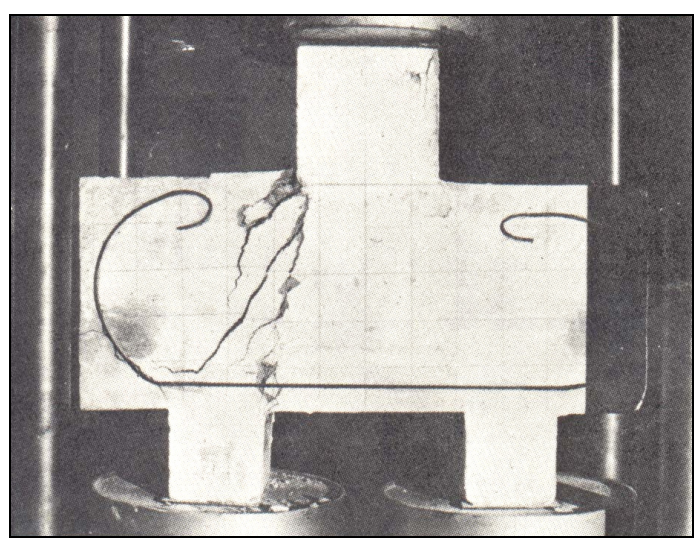

$\boldsymbol{b}$

Figura 2.5 - Bloco ensaiado por Mautoni (1972) - a) Configuração do ensaio; b) Detalhe da armadura em bigode.

As ruínas ocorreram por fendilhamento das bielas de compressão, apresentando plano de ruptura entre a face interna da estaca e a face interna do pilar. Esse tipo de ruptura não é adequado, por se tratar de ruptura frágil. O ideal seria o prévio escoamento das barras da armadura do tirante, ocasionando assim, ruptura dúctil. Porém, a difícil inspeção visual deste tipo de elemento estrutural em situações 
reais, faz com que o escoamento da armadura não seja observado. Assim, o elemento estrutural poderá ir a ruína também por deformação excessiva da armadura.

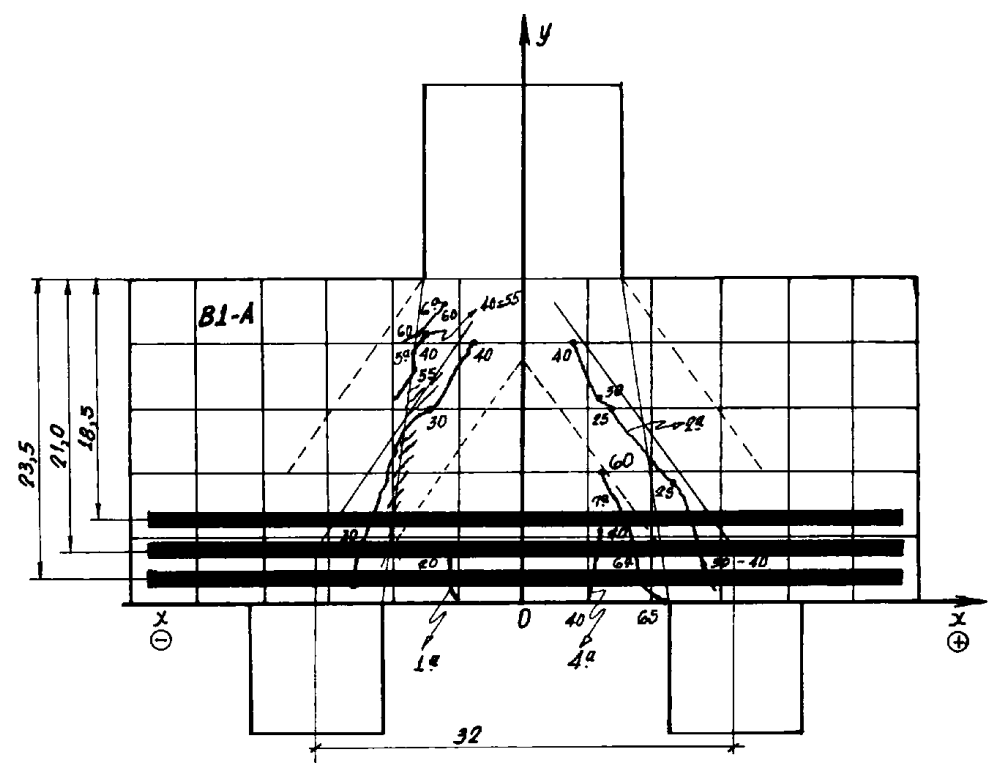

Figura 2.6 - Propriedades geométricas do bloco B1-A, Mautoni (1972).

Mautoni (1972), relatou as desvantagens de cada tipo de arranjo de armaduras empregada em sua pesquisa. A armadura em "bigode" apresentou grande consumo de aço e inconvenientes na ancoragem. A armadura em laçada contínua mostrou-se pouco produtiva na montagem, além disso, em função das várias camadas de barras de aço utilizadas nos ensaios, observou redução da altura útil do bloco.

Clarke (1973) ensaiou quinze blocos sobre quatro estacas em escala reduzida, com o objetivo de estudar a influência da disposição da armadura e a ancoragem das barras. Ao distribuir a armadura uniformemente em malha encontrou uma redução de $14 \%$ na força de ruína. Para os blocos ensaiados com armadura concentrada sobre as estacas, observou que a ancoragem das barras foi influenciada pela ação confinante das bielas de compressão. Isso significa, que os ganchos da armadura que compõem os tirantes, poderão ser abolidos, utilizando apenas ancoragem reta. Além disso, observou também que a ausência da armadura de suspensão nos blocos projetados com armadura em malha provocou diminuição da capacidade portante.

Taylor \& Clarke (1976) apresentaram resultados experimentais mostrando a influência do arranjo da armadura no comportamento estrutural de blocos sobre quatro estacas. Os pesquisadores ensaiaram blocos quadrados com dimensões de $75 \mathrm{~cm}$ e $95 \mathrm{~cm}$, e espaçamento entre estacas igual a duas vezes o diâmetro da mesma. $\mathrm{O}$ diâmetro das estacas foi de $20 \mathrm{~cm}$. A altura total dos modelos foi fixada em $45 \mathrm{~cm}$. 
Três arranjos de armadura e quatro tipos de ancoragens foram considerados, como mostra a Figura 2.7.

Nas etapas iniciais de carregamento todos os blocos se comportaram de maneira semelhante, com fissuras verticais se formando nas linhas de eixo das estacas, nas quatro faces do bloco. Na maioria dos casos a ruína se deu por fendilhamento, as fissuras diagonais se formaram de maneira brusca em duas ou mais faces do bloco. Foram observadas duas formas diferentes de ruptura por fendilhamento, uma delas era semelhante à ruína por cisalhamento de vigas (ver Figura 2.8a), a segunda teve a forma apresentada na Figura $2.8 \mathrm{~b}$.

Os modelos com ancoragem tipo (1) e (2) e distribuição de armadura segundo os lados apresentaram forças últimas $15 \%$ superiores aos blocos armados com armadura em malha, fato que comprova o que já foi dito sobre a armadura de suspensão. Os blocos com armadura segundo as diagonais tiveram praticamente a mesma força última que os blocos com armadura em malha.

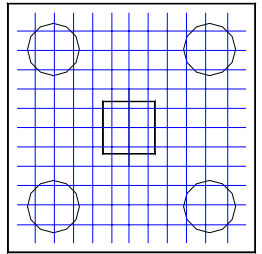

a) armadura em malha

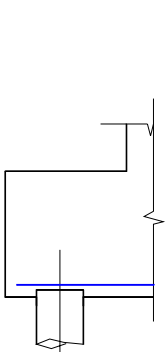

(1)

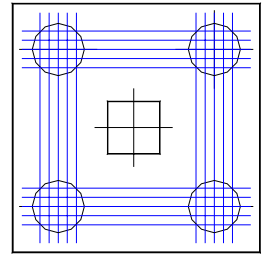

b) armadura segundo os lados

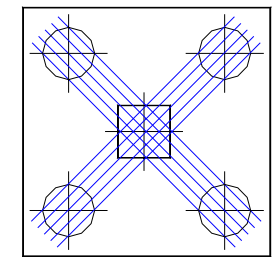

c) armadura segundo as diagonais

Arranjos de armadura

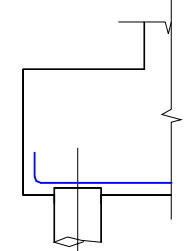

(2)

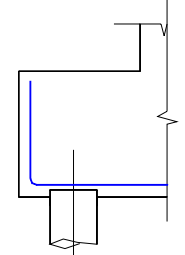

(3)

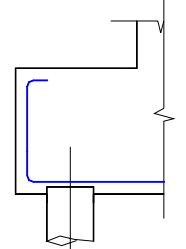

(4)

Tipos de ancoragem

Figura 2.7 - Arranjo de armadura e tipos de ancoragem, Blocos ensaiados por Taylor \& Clarke (1976).

Para o caso das armaduras distribuídas em malha o tipo de ancoragem teve influência mais importante nas forças últimas. A ancoragem tipo (3) aumentou a força última em 30\%. Segundo Taylor \& Clarke (1976) esse aumento ocorreu, provavelmente, pelo aumento da capacidade de resistência à força cortante, pois a 
ancoragem funcionou como armadura de suspensão. Nenhum aumento adicional foi obtido com ancoragem tipo (4).

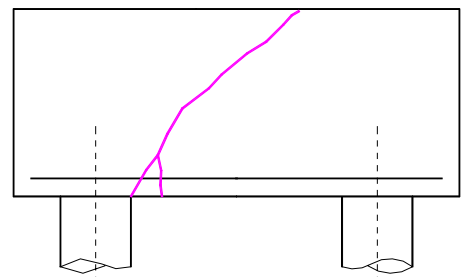

a

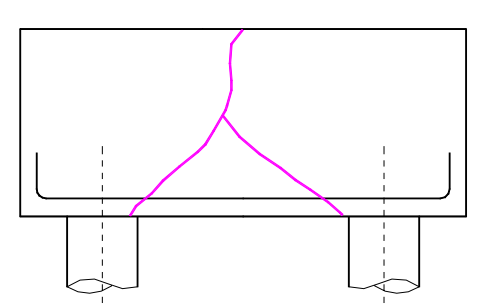

b

Figura 2.8 - Tipos de ruptura observdas, Taylor \& Clarke (1976).

Sabnis \& Gogate (1984) sugeriram um procedimento para o projeto de bloco sobre estacas, baseados em ensaios de blocos sobre quatro estacas. Nos ensaios variou-se a quantidade das armaduras distribuídas. Os autores concluíram que taxa de armadura principal acima de 0,2\% (essa taxa é a relação entre a área das barras da armadura principal de tração e a área da seção de meio de vão do bloco) teve pouca ou nenhuma importância na força de ruína. Esse resultado mostra que a ruína dos blocos depende da capacidade das bielas comprimidas de suportarem tensões de compressão (esmagamento) e tração (fendilhamento).

Fusco (1985), ensaiou doze vigas de concreto armado com o objetivo de obter informações sobre o valor limite da tensão de cisalhamento. Em cada viga ensaiada, basicamente interessava a força de ruptura por compressão diagonal do concreto e o acompanhamento do panorama de fissuração apresentada em suas faces. Os resultados dos ensaios mostraram que se pode admitir que a ruptura diagonal por compressão do concreto ocorra quando se atinge o valor de $f_{c d}$. Observou também que houve total eficiência de transmissão das tensões diagonais, por engrenamento dos agregados, através das fissuras macroscópicas visíveis nas faces das vigas. Concluiu que, o panorama de fissuração superficial nas faces da viga não delineia a campo de compressão diagonal com precisão suficiente, para que a inclinação das bielas de compressão possa ser por elas determinado. A inclinação efetiva das bielas de compressão obedece a outras restrições, como as condições de contorno impostas pelo carregamento e pelos apoios e pela aderência das bielas à armadura longitudinal de flexão.

Em 1989, Walraven \& Lehwalter (1989), apresentaram pesquisa sobre a capacidade portante de bielas de compressão em vigas curtas. Os pesquisadores 
sugeriram modificações no modelo de treliça utilizado na analogia de bielas e tirante embasados em resultados experimentais. Foram ensaiadas sessenta vigas curtas, variando-se: tipo de agregado; diâmetro máximo do agregado (miúdo e graúdo); altura da viga; inclinação da biela de compressão; e, por fim, arranjos de armadura (armadura horizontal na alma da viga; armadura horizontal na face superior da viga; estribos verticais). As vigas foram apoiadas em cilindros e carregadas com força centrada, aplicada no meio do vão, na face superior da viga. As primeiras vinte e nove vigas foram armadas apenas com barras de aço instaladas na face inferior da viga, sem qualquer armadura transversal.

Todas as vigas apresentaram comportamento semelhante e ao atingir cerca de $50 \%$ da força última, surgia a primeira fissura.

Constataram que a variação do diâmetro máximo do agregado não teve influência significativa na capacidade portante das vigas.

Em função dos resultados experimentais, Walraven \& Lehwalter (1989), sugeriram que o fluxo das forças internas em uma viga ainda pode ser descrito por meio de um modelo de treliça, porém, a capacidade portante da biela de compressão foi é definida de modo diferente do convencional, pois seus ensaios mostraram que a ruptura da biela comprimida se deu na região de introdução da força, em um dos lados da biela. Em função disto concluíram que as bielas sob efeito do carregamento sofreram rotação, de modo que na região nodal superior, o qual não gira, surgiu um momento. A concentração de tensões nessa região provocou encurtamento num dos lados da biela de compressão. O comportamento é melhor entendido por meio da Figura 2.9, onde o nó superior não é articulado, mas rígido à flexão.

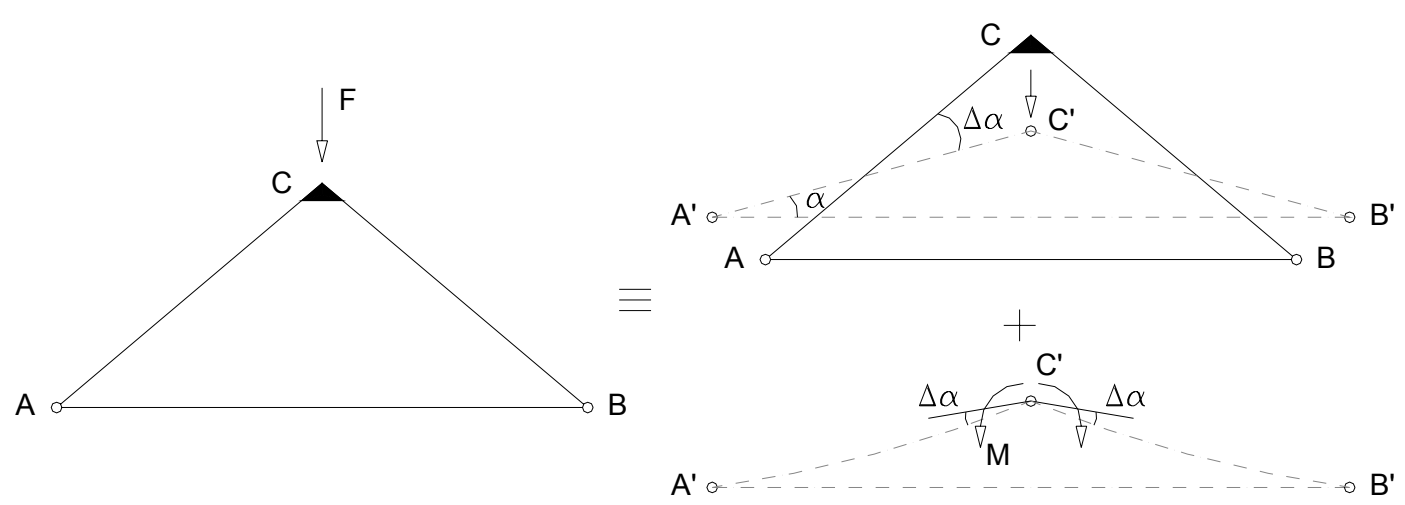

Figura 2.9 - Estrutura equivalente, Walrawen \& Lehwalter (1989).

Assim, na biela de compressão surge além de força normal, momento fletor, o qual é facilmente obtido considerando-se as rigidezes ao alongamento do banzo 
tracionado e ao encurtamento da biela de compressão. Os pesquisadores lembram que, ao calcular a deformação na biela de compressão, a forma da biela não é prismática. Não julgo ser um método adequado, pois considerar a existência de momento fletor em um elemento rígido a meu ver não é correto. Além disto não fica caracterizada a existência de flexão em vigas curtas.

Os pesquisadores também concluíram que para o caso das vigas projetadas com armadura vertical, houve aumento significativo da força última.

Em 1990, ADEBAR et al. (1990) realizaram ensaios em seis blocos de concreto armado sobre quatro e seis estacas, com a finalidade de observar a viabilidade do modelo tridimensional de bielas e tirantes no dimensionamento de blocos sobre estacas. A Figura 2.10 apresenta os blocos ensaiados pelos pesquisadores. No ensaio foram observados: relações força vs. deslocamento; força distribuída entre as estacas; as deformações nas barras da armadura; e, forças de fissuração e de ruína. ADEBAR et al. (1990) obtiveram as seguintes conclusões: os procedimentos indicados pelo ACl 318 (1983) não foram compatíveis com os resultados experimentais. Isso se deveu ao fato do critério do $\mathrm{ACl}$ não levar em consideração a altura útil do bloco e desprezar a influência da quantidade e distribuição das barras da armadura longitudinal; os blocos com grandes alturas sofreram grandes deformações pouco antes da ruína, pois não tiveram flexibilidade suficiente para distribuir uniformemente as forças nas estacas; os blocos não tiveram comportamento de vigas; o modelo de bielas e tirantes representou melhor o comportamento estrutural dos blocos; as bielas de compressão não romperam por esmagamento do concreto. A ruína do bloco aconteceu após uma das bielas de compressão não suportar tensões de tração (fendilhamento) provocadas em decorrência da expansão das tensões de compressão.

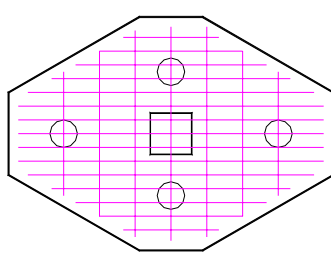

Bloco A

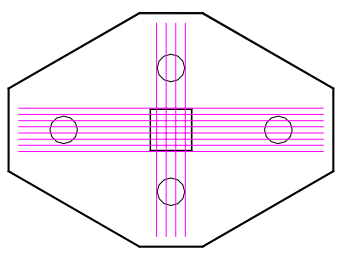

Bloco D

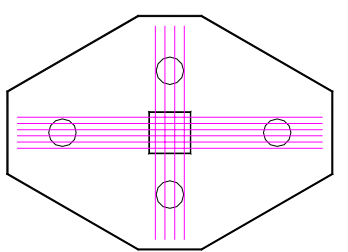

Bloco B

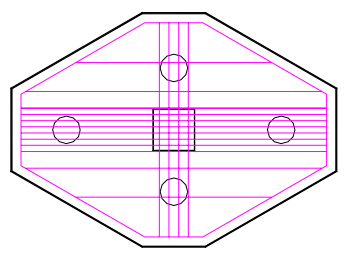

Bloco E

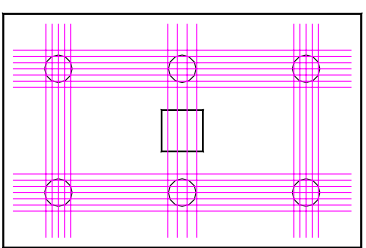

Bloco C

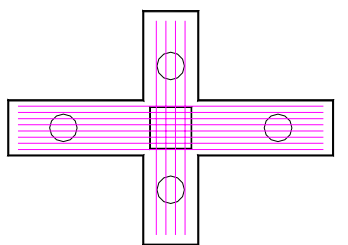

Bloco F

Figura 2.10 - Blocos ensaiados por Adebar et al. (1990). 
Com base nas observações experimentais e resultados numéricos obtidos por meio do Método dos Elementos Finitos (ver Figura 2.11a), os autores sugeriram um modelo refinado de bielas e tirantes. Pode notar que entre os pontos de aplicação de força onde as tensões de compressão se "expandem" surgem tensões de tração. No modelo sugerido, essas tensões de tração são absorvidas por um tirante instalado na região central da biela de compressão, posicionado entre à cabeça da estaca e a base do pilar (ver Figura 2.11b).

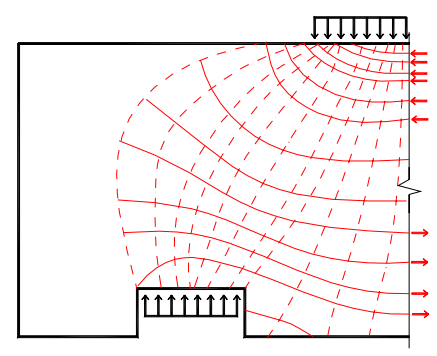

a

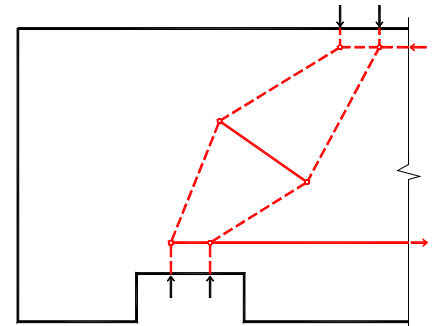

b

Figura 2.11 - Modelo de bielas e tirantes sugerido por Adebar et al. (1990) - a) Expansão do fluxo de tensões de compressão; b) Modelo refinado de bielas e tirante.

Carvalho (1994) ensaiou blocos sobre duas, três e quatro estacas com força centrada em condições similares à obra. Os ensaios dos protótipos foram interrompidos antes que os mesmos viessem a romper, pois o solo não foi capaz de suportar maiores forças. As barras de aço que compunham a armadura do bloco não atingiram a força de escoamento. O pesquisador conclui que é possível desconsiderar a reação do solo sobre o bloco e que a força que o pilar transmite às fundações se distribui igualmente entre as estacas (nos casos de força centrada).

lyer \& Sam (1996), analisaram o comportamento dos blocos retangulares sobre duas e quatro estacas, por meio de análise fotoelástica tridimensional. Os resultados revelaram regiões com altos valores de tensões de tração, servindo de orientação para o detalhamento da armadura. Este ensaio apenas conseguir analisar o bloco ante do início da primeira fissura, portanto, seus valores são similares a uma análise numérica considerando que os materiais tenham comportamento elástico. Isto não representa o real comportamento dos blocos.

Em 1997, Rausch et al. (1997) ensaiaram blocos de concreto armado sobre duas estacas em escala reduzida (relação 1:2). Para o dimensionamento do bloco utilizou-se o modelo de bielas e tirantes. Os autores obtiveram algumas conclusões interessantes, como: o método das bielas supõe que as barras inferiores (tirantes) se deformem livremente, mas, como as estacas atuam limitando essa deformação, 
verificou-se que quando as barras atravessaram às bielas de compressão existentes sobre as estacas, ocorreu redução significativa destas deformações; os ensaios demonstraram que a armadura do tirante calculada pelo método das bielas e tirantes é conservadora, o que na prática significa que essa armadura poderá ser diminuída; no modelo teórico, admite-se que o tirante tenha deformações constantes ao longo de seu comprimento, isso não foi observado nos ensaios, pois, para valores de forças próximas da força de ruína do bloco, as deformações obtidas no tirante na região das estacas tiveram valores próximos de zero e em alguns casos valores negativos. Essa afirmação é importante, pois, coloca-se em dúvida a eficiência dos ganchos no detalhamento das armaduras dos blocos sobre estacas.

Miguel (2000) realizou analise numérica e experimental de blocos de concreto armado sobre três estacas submetidos a ação de força centrada. A autora concluiu que o método das bielas desenvolvido por Blévot \& Frémy (1967) é conservador indicando margem de segurança de $12 \%$. Todos os modelos ensaiados tiveram ruína por fendilhamento das bielas de compressão, em função da rápida expansão do fluxo de tensões na mesma, acompanhado do escoamento das barras da armadura principal. A autora sugeriu valores limites de tensões nas zonas nodais $\left(\sigma_{\mathrm{zni}} \leq 0,40 . \mathrm{f}_{\mathrm{cm}}\right.$, na zona nodal superior; $\sigma_{\mathrm{zni}} \leq 0,50 . \mathrm{f}_{\mathrm{cm}}$, na zona nodal inferior, para o blocos com diâmetro das estacas igual a $20 \mathrm{~cm}$; e $\sigma_{z n i} \leq 0,30 . f_{c m}$, na zona nodal inferior, para o blocos com diâmetro das estacas igual a $30 \mathrm{~cm}$ ) para que não venha a ocorrer ruína por fendilhamento das bielas comprimidas. Essa limitação de tensões nas zonas nodais segue um consenso no meio técnico, ou seja, em todos os modelos de cálculo para blocos sobre estacas apresentados na literatura técnica, baseados nos estudos de Blévot \& Frémy (1967), existem limitações de tensões nas bielas de compressão. Essa limitação é estipulada em função da resistência característica do concreto à compressão.

Chan \& Poh (2000), fizeram um estudo experimental do comportamento de blocos pré-moldados sobre estacas. Três blocos foram ensaiados até a ruína. Um dos blocos foi moldado no local e os outros dois eram pré-moldados. O objetivo da pesquisa foi comparar o comportamento entre os blocos sobre estacas pré-moldados com os blocos sobre estacas moldados no local. Observou-se que a metodologia utilizada para o dimensionamento de blocos sobre estacas, pode ser utilizada em blocos pré-moldados, sendo que em alguns casos, os resultados foram conservativos. 


\subsubsection{Pesquisas com ênfase numérica}

Em 1988, Cook \& Mitchell (1988) compararam resultados do modelo de bielas e tirantes, com resultados obtidos por meio de uma análise numérica baseada no método dos elementos finitos - MEF e com resultados experimentais. O objetivo do trabalho era fornecer critérios mais apropriados para a utilização do modelo de bielas e tirantes em regiões de descontinuidade da estruturas e em regiões com forças concentradas. Esse é um dos primeiros trabalhos que levou em consideração a não linearidade física do concreto. Os pesquisadores concluíram que o modelo de bielas e tirantes forneceu estimativa muito conservadora, quando comparado com a análise numérica e com os resultados experimentais.

lyer \& Sam (1991) estudaram o comportamento de blocos sobre três estacas por meio de análise elástica linear tridimensional. Apresentaram solução formulada na teoria da elasticidade, em termos de vetor de Galerkin. As componentes deste vetor foram expressas em séries duplas de Fourier. No método proposto, as distribuições de tensões no bloco foram obtidas considerando as condições de contorno pela superposição de quatro soluções elásticas tridimensionais, para um bloco retangular sujeito a diferentes carregamentos em suas faces. O bloco analisado é mostrado na Figura 2.12.

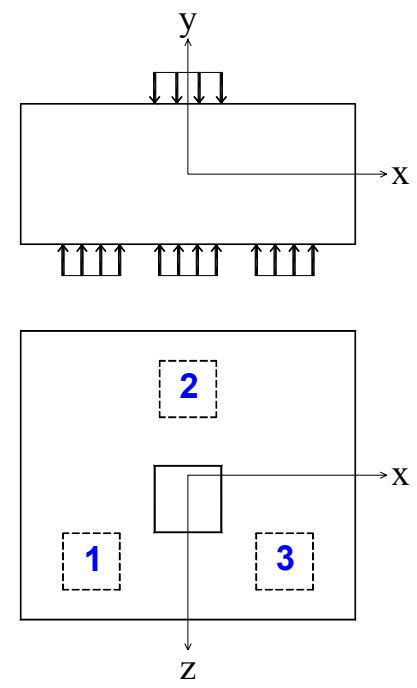

Figura 2.12 - Bloco analisado numericamento por lyer \& Sam (1991).

Apesar dos blocos serem em concreto armado, admitiu-se que os mesmos tinham comportamento elástico e linear e material homogêneo e isotrópico, pois, a 
distribuição de tensões sugere uma solução inicial fornecendo critérios para estudos mais refinados.

Analisando as tensões máximas de tração nas direções x e z (Figura 2.12) os autores concluíram que o valor máximo na direção $x$ foi desenvolvido ao longo do plano $y-z$ com a face do bloco na região entre as estacas 1 e 3 considerando a relação entre altura e espaçamento entre estacas igual a unidade. Esta região mudava de posição em direção ao centro de gravidade, conforme esta relação diminuía. O mesmo ocorreu com relação a tensão de tração máxima na direção $z$, mas a região compreendida ficou próxima à face do pilar junto à estaca 2 .

Dos métodos existentes, a analogia de treliça [Blévot \& Frémy (1967)] e a teoria de flexão que considera o bloco como sendo uma viga apoiada em estacas, os pesquisadores concluíram que nenhum deles é satisfatório, pois, não conferem com as localizações e magnitudes de tensões máximas com precisão.

Em 1992, lyer \& Sam (1992) conduziram análises análogas feitas na pesquisa desenvolvida por eles em 1991, para blocos sobre duas e quatro estacas.

Asin et al. (1994) analisaram numericamente o comportamento de vigas parede contínuas por meio do Método dos Elementos Finitos - M.E.F, utilizando o programa para computador SBETA. Os pesquisadores obtiveram boa correlação dos resultados numéricos quando comparados com os resultados experimentais e concluíram que o sucesso da análise numérica é dependente da rede de elementos finitos utilizada como também dos parâmetros de transferência de cisalhamento utilizados.

lyer \& Sam (1995 - a) realizaram um estudo tridimensional não-linear do comportamento de blocos de concreto armado sobre quatro estacas. A análise numérica foi baseada no método dos elementos finitos e a consideração da nãolinearidade física do concreto foi considerada. A fluência do concreto como também o fenômeno da aderência aço-concreto não foram levados em consideração. O trabalho tinha como objetivo analisar os resultados de força e deslocamento, das deformações nas armaduras, da formação de fissuras e da força de ruína. O comportamento multiaxial do concreto, incluindo deformações plásticas, fissuração, escoamento da armadura, o fenômeno tension-stiffening e a alteração do coeficiente de Poisson foram considerados na análise. Os autores constataram que para baixas intensidades de forças o comportamento de viga foi predominante nos blocos, enquanto, para altas intensidades de forças, o bloco resistiu pela ação da biela, indiferente do arranjo da armadura. Também foi observado que a região de concreto localizada na base do pilar, como a região de concreto localizada no topo das estacas, foram esmagadas e solicitadas para romperem por punção nas regiões do pilar e das estacas. A análise 
não-linear via método dos elementos finitos, utilizando modelo tridimensional foi capaz de estimar com precisão o comportamento e a força última dos blocos de concreto.

lyer \& Sam (1995 - b) também investigaram a influência que o arranjo de armadura provoca no comportamento estrutural dos blocos. Os pesquisadores analisaram numericamente três blocos sobre quatro estacas, com as mesmas propriedades mecânicas e geométricas, porém, com variação do arranjo das armaduras. Foram analisados os seguintes tipos de arranjo de armadura: armadura distribuída em malha; armadura distribuída entre as estacas; e armadura distribuída nas diagonais, passando pela projeção do pilar (ver Figura 2.13). Os resultados obtidos divergem dos resultados obtidos por outros pesquisadores que realizaram ensaios experimentais, pois, a armadura distribuída em malha foi a que forneceu ao bloco maior capacidade portante, e a armadura distribuída entre as estacas foi a que apresentou menor força última. Esse problema ocorreu provavelmente em função do elemento finito utilizado para modelar o concreto do bloco. Nas regiões onde não existiam elementos de barra que representavam as barras de aço da armadura, o elemento utilizado para a modelagem do concreto não foi capaz de transmitir às forças para outros elementos que continham os elementos de barras.
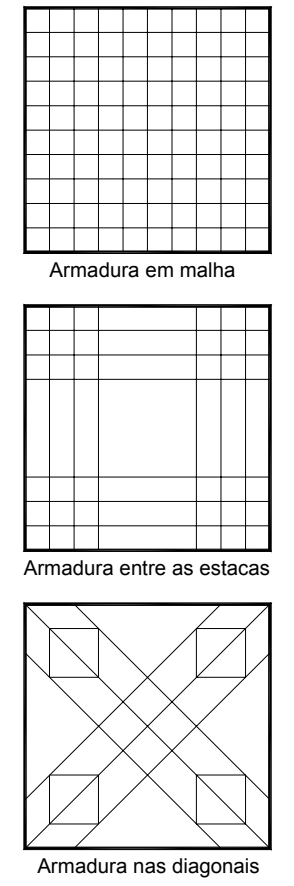

Figura 2.13 - Blocos analisados por lyer \& Sam. (1995).

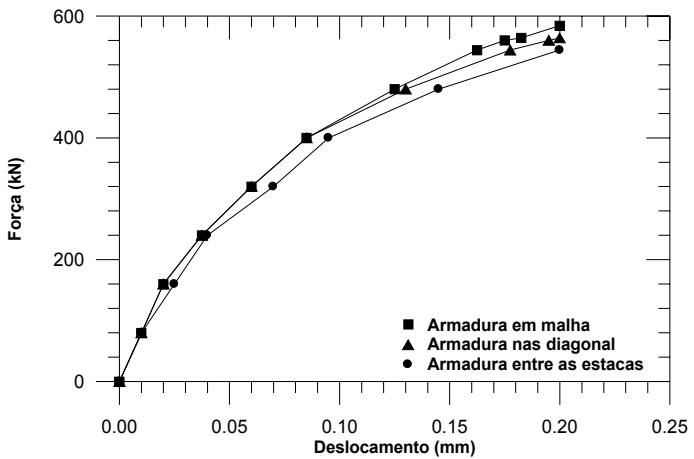

Oliveira (1998), desenvolveu um programa de computador capaz de gerar fluxos de tensões principais, que por sua vez, foram empregados na modelagem 
automática das bielas e dos tirantes em estruturas planas de concreto armado. $O$ programa considera que o material tenha comportamento elástico e linear. Apesar de não levar em consideração os critérios da não-linearidade física, o programa mostrase capaz de auxiliar o engenheiro a modelar (utilizando a analogia das bielas e tirantes) estruturas planas de concreto armado com razoável precisão.

No ano de 2000, ITURRIOZ et al. (2000) analisaram numericamente por meio de um programa de computador baseado no método dos elementos finitos, um bloco de concreto armado sobre duas estacas. O bloco analisado foi ensaiado por RAUSCH et al. (1997). Na análise numérica os autores utilizaram o programa de computador ANSYS (ANalyser SYStem), o elemento finito utilizado foi o SOLID 65 (elemento existente na biblioteca do ANSYS), a armadura foi considerada distribuída ao longo do elemento com rigidez uniaxial, tendo comportamento elastoplástico. Foi permitida a fissuração do concreto em cada ponto de integração em três direções ortogonais. Os autores, mesmo desconsiderando a aderência aço-concreto, obtiveram resultados satisfatórios.

Também em 2000, Longo (2000) modelou estruturas de concreto pelo método de bielas e tirantes utilizando o método dos elementos finitos. A modelagem foi feita em função do fluxo das tensões principais em vigas pré-moldadas de concreto armado, simplesmente apoiadas e contínuas. Algumas das vigas tinham altura constante e outras apresentavam descontinuidades. Também foram estudados modelos para forças próximas aos extremos e vigas com apoios de altura reduzida. Para a análise numérica foi utilizado o programa de computador $\mathrm{SALT}^{\circledR} \mathrm{com}$ elementos finitos quadrados no estado plano de tensões. A análise foi elástica e linear. $O$ autor conclui que o modelo de bielas e tirantes pode ser usado como um importante procedimento para o projeto. A grande vantagem desse modelo é a boa representação do comportamento das estruturas.

Delalibera \& Giongo (2004 - a) simularam numericamente blocos sobre duas estacas. O objetivo do trabalho foi investigar a influência que as dimensões em planta do pilar e das estacas provocam no comportamento estrutural dos blocos. As não linearidades física (do material) e geométrica (do elemento estrutural) foram levadas em consideração. Considerou-se também aderência perfeita entre o aço e o concreto. As barras de aço que formavam a armadura do bloco foram modeladas com comportamento elastoplástico perfeito. O comportamento do concreto foi determinado por meio do modelo desenvolvido por Desayi \& Krishman (1964). Por meio de análise estatística, os autores concluíram que a altura do bloco é fator preponderante no valor das tensões nas regiões nodais inferior e superior. 
Munhoz et al. (2004 - a) analisaram numericamente blocos sobre duas estacas com o objetivo de contribuir para o estudo de critérios de projeto. O trabalho realizou uma análise do comportamento de blocos de concreto armado sobre duas estacas, submetidos à ação de força centrada. Na análise numérica foi utilizado programa de computador baseado no Método dos Elementos Finitos. Foi considerado comportamento elástico e linear para os materiais que compunham os blocos. Por meio da simulação numérica, tensões nas direções principais dos modelos tridimensionais foram analisadas. Por fim, resultados obtidos por meio da análise numérica foram comparados com resultados obtidos por meio de modelos analíticos empregados no dimensionamento de blocos sobre estacas. Verificou-se que existe grande variabilidade nos resultados. Esse trabalho é semelhante ao desenvolvido por Longo (2000), diferenciando-se apenas num aspecto, no trabalho de Longo (2000) apenas foram analisadas estruturas planas, já nesse trabalho, analisaram-se estruturas volumétricas.

Souza et al. (2004) simularam uma viga parede com forma geométrica complexa, utilizado o programa de computador baseado do Método dos Elementos Finitos - DIANA. A priori, os pesquisadores analisaram o elemento estrutural com comportamento elástico e linear. Posteriormente, simularam o mesmo elemento estrutural, porém, considerando a propriedades não-lineares dos materiais concreto e aço. Uma das principais conclusões dos pesquisadores foi que a ruína da viga parede se deu pelo esgotamento da capacidade resistente das barras de aço utilizadas para controle de fissuração. Isso significa que o modelo de bielas e tirantes deve ser corretamente utilizado, obtendo, treliças estaticamente admissíveis e áreas de aços suficientes para absorverem as deformações de tração.

Munhoz et al. (2004 - b) por meio de simulações numéricas, analisaram a influencia da rigidez do bloco de coroamento em estaqueamento paralelos com ações verticais excêntricas. Nas análises foram levadas em consideração as não linearidades físicas dos materiais, como também, a não linearidade geométrica do elemento estrutural. Os pesquisadores simularam três blocos sobre quatro estacas, variando à altura dos mesmos em função do ângulo de inclinação das bielas de compressão. Os pilares tinham seção de $45 \mathrm{~cm} \times 45 \mathrm{~cm}$ e as estacas com $38 \mathrm{~cm}$ de diâmetro. Para o concreto, utilizou-se o critério de ruptura Concrete existente no programa ANSYS ${ }^{\circledR}$ e, para o aço adotou-se o comportamento elastoplástico perfeito. Para o concreto, adotou-se resistência característica à compressão igual a $25 \mathrm{MPa} e$ para as barras de aço, adotou-se resistência característica de escoamento igual a 500 $\mathrm{MPa}$. Considerou-se aderência perfeita entre o concreto e as barras de aço. A Figura 
2.14 mostra a rede de elementos finitos e as condições de contorno utilizadas nos blocos.

Não se aplicaram forças nos blocos forças últimas, e sim, forças de projeto. Constatou-se, o que já era esperado, que nos blocos com menor altura (menor rigidez) as fissuras foram mais intensas. A Figura 2.15 mostra a intensidade das fissuras observada nas análises.

Os pesquisadores constaram que o método da superposição dos efeitos é conservador e que o modelo numérico apresentou valores de forças menores nas cabeças das estacas, pois a redistribuição de força foi influenciada pela rigidez do bloco de coroamento.

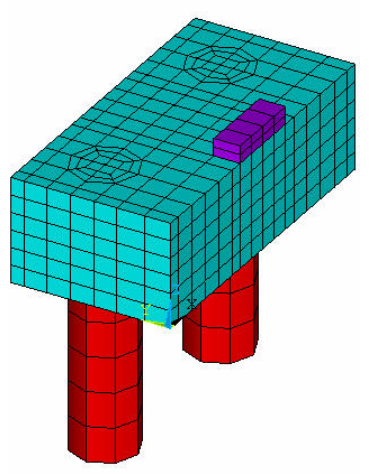

a

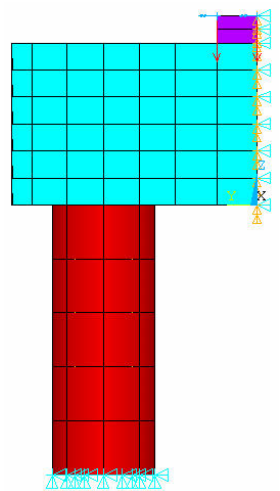

b

Figura 2.14 - Blocos analisados por Munhoz et al. (2004), a) rede de elementos finitos; b) condições de contorno.

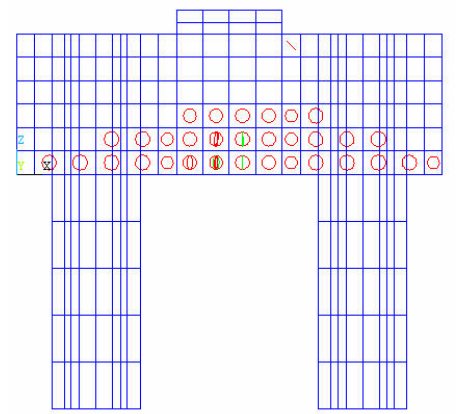

$h=60 \mathrm{~cm}$

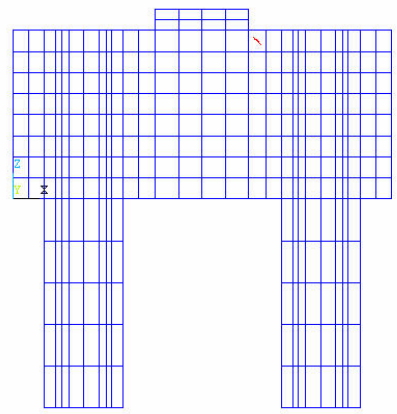

$h=81 \mathrm{~cm}$

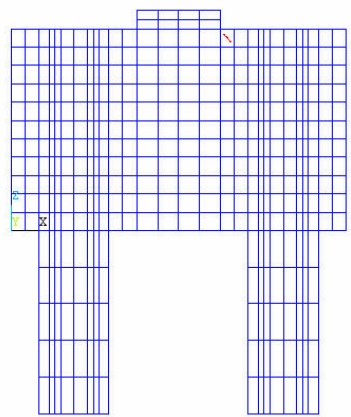

$h=110 \mathrm{~cm}$

Figura 2.15 - Configuração final da fissuração nos modelos numéricos.

Delalibera \& Giongo (2004 - b) também analisaram a influência da rigidez dos blocos de coroamento, porém, em estaqueamento em linha. Os pesquisadores simularam um bloco com três estacas em linha. Os blocos tinham as mesmas propriedades geométricas, variando-se apenas o ângulo de inclinação das bielas de 
compressão ( $\theta$ igual a $30^{\circ}, 45^{\circ}$ e $60^{\circ}$ ). Variaram-se também as rigidezes, $E l$, dos blocos e o tipo de solo que serviu de apoio para as estacas. Os pesquisadores analisaram três situações possíveis, duas com estacas apoiadas em solos diferentes e a última considerando as indicações de Moraes (1976). A Figura 2.16 mostra as duas situações de solo utilizadas.

Por meio de estudo estatístico, os pesquisadores obtiveram nove combinações para cada tipo de análise, totalizando vinte e sete simulações. Utilizando o critério ANOVA (analise de variância), os pesquisadores concluíram que: a rigidez do bloco como também a representação do solo como contínuo tem importância relevante na distribuição de força nas cabeças das estacas; em situações onde pode-se desprezar o atrito lateral na interface-estaca solo, o ângulo de inclinação da biela de compressão é o principal fator que influi na distribuição de força nas cabeças das estacas (tubulões); contatou-se também, que os blocos considerados rígidos com ângulo de inclinação da biela de compressão maior que quarenta e cinco graus em relação ao tirante, apresentam melhores resultados quanto à distribuição de força nas cabeças das estacas; o método proposto por Moraes (1976), onde não existe diferença entre tipos de solo, pode levar a resultados equivocados nas reações das estacas.
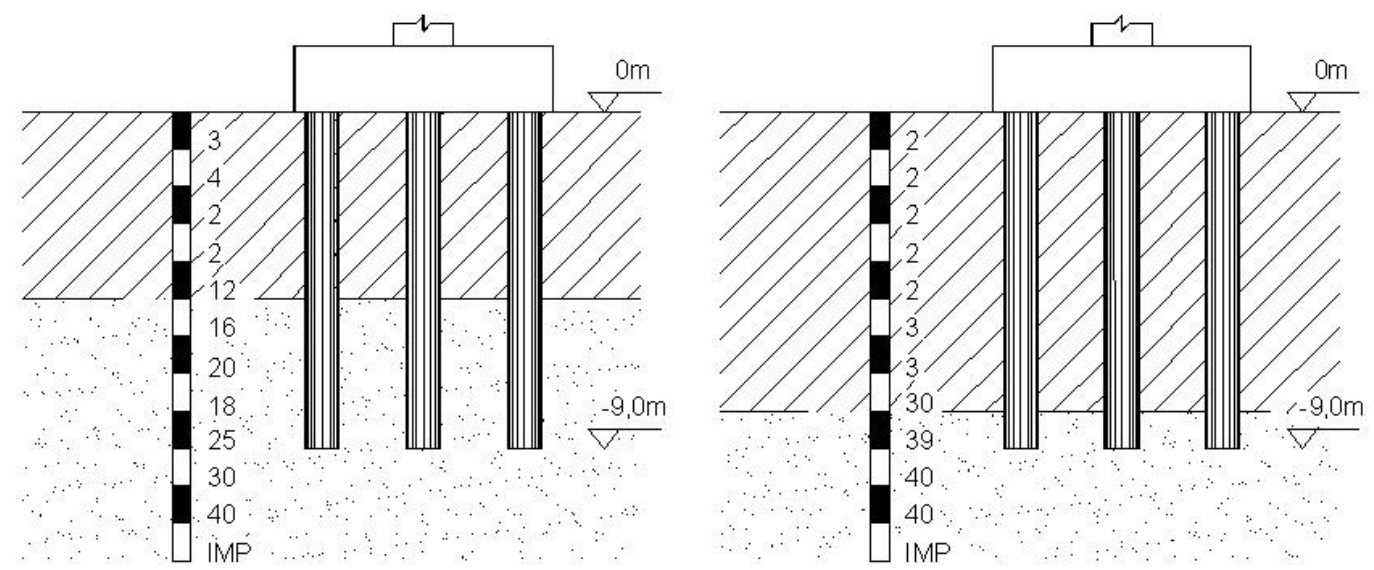

Figura 2.16 - Tipos de solo utilizados nas análises, Delalibera \& Giongo (2004).

Munhoz et al. (2005 - a), por meio de simulações numéricas analisaram comportamento de blocos sobre cinco estacas. Os blocos tinham geometria quadrada com uma estaca em cada vértice e uma estaca central, como mostra a Figura 2.17. Os pesquisadores concluíram que para que as estacas tenham aproximadamente às mesmas reações o bloco necessita ter uma grande altura, inviabilizando economicamente sua construção, além disto, o bloco passaria a ter comportamento similar à viga parede. Concluíram que a utilização de blocos sobre cinco estacas 
sendo uma central é contra a segurança e que a utilização de blocos em forma de pentágono é mais adequado.

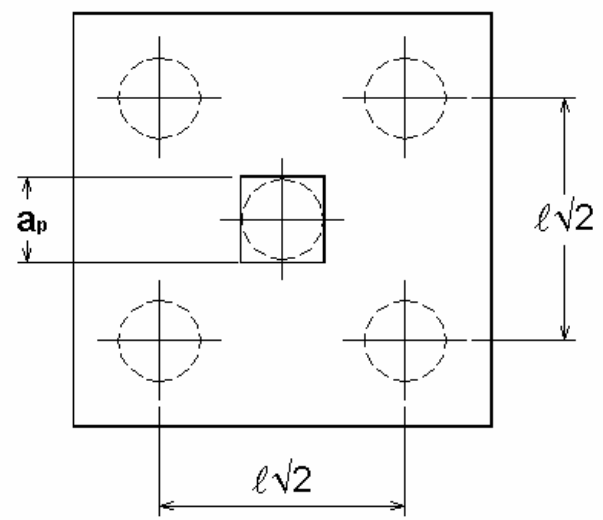

Figura 2.17 - Blocos sobre cinco estacas, MUNHOZ et al.(2004-c).

Munhoz et al. (2005 - b) também analisaram o comportamento de blocos sobre uma estaca, também chamados de blocos de transição. O objetivo do trabalho foi verificar os métodos analíticos de cálculo utilizados para o dimensionamento deste tipo de elemento. Foram realizadas análises numéricas, as quais forneceram subsídios para a sugestão de modelos de bielas e tirantes. Os autores concluíram que a adaptação da teoria de blocos parcialmente carregados pode nem sempre fornecer bons resultados no caso de blocos sobre uma estaca, principalmente quando se têm variações de seções de pilares e estacas. Observaram que, em função das variações na altura dos blocos houve grande mudança nos campos de tensão o que não é considerado na metodologia utilizada e sugerem um modelo de bielas e tirantes para o dimensionamento deste elemento.

Delalibera \& Giongo (2005 - a) também analisaram a influências das armaduras adicionais em blocos sobre duas estacas. Para isto, simularam numericamente dezoito blocos sobre duas estacas, sendo seis projetados sem nenhum tipo de armadura adicional, seis utilizando os critérios para dimensionamento de armaduras adicionais para blocos sobre estacas apresentados no Boletim $n^{\circ} 78$ do CEB (1970) e na norma espanhola EHE (2002) e seis projetados com as sugestões de Adebar et al. (1990). As Figuras 2.18 e 2.19 apresentam os tipos de armadura adicionais utilizadas nos blocos analisados numericamente. Observa-se que as armaduras adicionais sugeridas pelas normas são dispostas ao longo das faces dos 
blocos, enquanto que as armaduras sugeridas por Adebar et al. (1990) concentra-se nas seções dos blocos sobre as estacas.

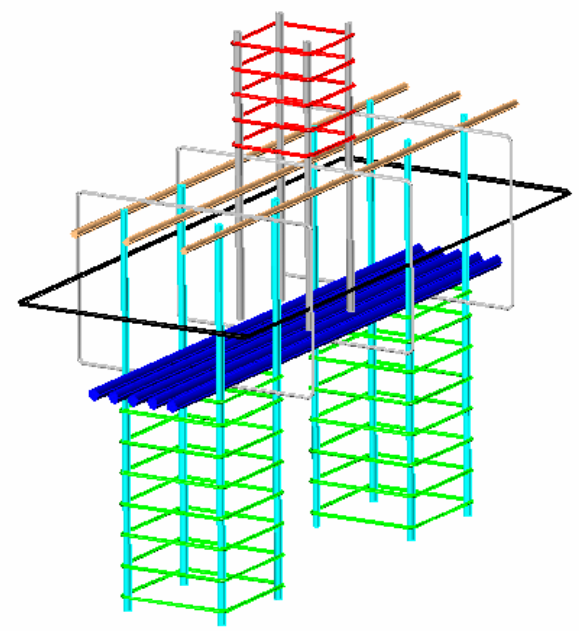

Figura 2.18 - Detalhamento dos blocos, CEB (1970) e EHE (2002).

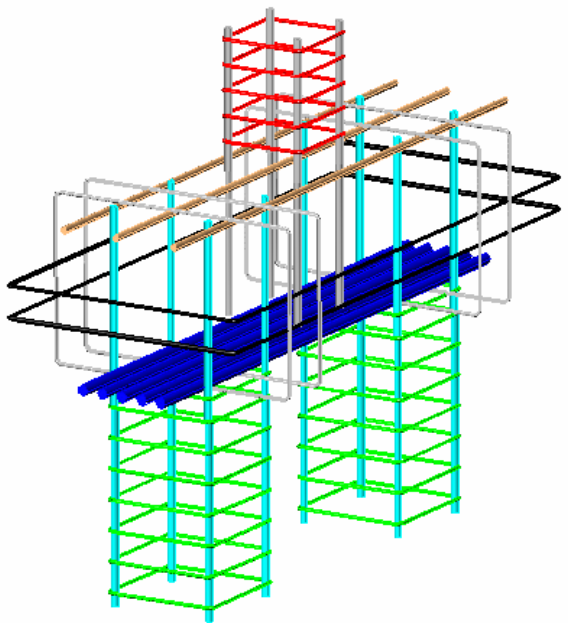

Figura 2.19 - Detalhamento dos blocos, Adebar et al. (1990).

Com relação às armaduras adicionais dispostas nas faces laterais dos blocos, os autores verificaram que são pouco solicitadas não contribuindo significativamente no desempenho estrutural dos blocos em função de estarem posicionadas nas faces dos blocos. As mesmas ficaram restritas à limitação de abertura de fissuras. Os critérios apresentados pelo boletim de informações $n^{\circ} 78$ do CEB (1970), pela norma espanhola EHE (2002) e por Adebar et al. (1990) consideram as seções transversais das barras das armaduras adicionais com valores maiores que as necessárias. Sugeriram diâmetros menores, cerca de um por cento da área de aço do tirante para 
as armaduras posicionadas nas faces laterais dos blocos e cinco por cento para a armadura complementar superior.

Os autores sugerem que devem ser dispostas armaduras adicionais posicionadas perpendicularmente às bielas de compressão para evitar a ruína dos blocos por fendilhamento.

\subsubsection{Analogia de Bielas e Tirantes}

A analogia de bielas e tirantes é uma generalização clássica da analogia de treliça, introduzida por Ritter \& Mörsch no início do século passado. Essa concepção é uma das mais duradouras da história do concreto armado.

Após várias décadas de estudos analíticos e experimentais, pesquisadores sugeriram modificações para o aperfeiçoamento ao modelo proposto, mas, mantendo a idéia básica. Os resultados das pesquisas sugeriram a utilização de uma treliça, Treliça de Morsch generalizada, cuja inclinação das diagonais comprimidas (bielas) com a horizontal passou a ser adotada de maneira compatível com os modelos sugeridos após análise experimental, enquanto no modelo original essa inclinação era constante e com valor igual a $45^{\circ}$.

A analogia de bielas e tirantes também é conhecida como Escoras e Tirantes; lembrando que existe diferença entre os termos biela e escora: as bielas sempre são inclinadas e as escoras podem ser inclinadas ou não em relação aos tirantes.

Schlaich et al. (1987) sugeriram a utilização dos modelos de bielas e tirantes de modo generalizado para o estudo de qualquer elemento estrutural.

Os modelos de bielas e tirantes são idealizações que substituem o elemento estrutural por uma estrutura de barras comprimidas e tracionadas, articuladas nos nós. As bielas e tirantes são representações discretas dos campos de tensão nos elementos estruturais de concreto armado. As bielas representam campos de tensão de compressão, enquanto os tirantes representam campos de tensão de tração, que devem ser absorvidos por barras de aço.

A Figura 2.20 mostra possíveis configurações das bielas de compressão segundo Schlaich \& Schäfer (1991), sendo que a Figura 2.20a representa uma distribuição paralela de tensões, ocorrendo quando as tensões se distribuem uniformemente sem perturbação. Este campo é típico de regiões B. A Figura 2.20b mostra a distribuição de tensões em linhas curvilíneas com afunilamento da seção, forças concentradas são introduzidas e propagadas por meio de curvaturas 
acentuadas. A difusão dessas tensões provoca compressão biaxial ou triaxial (abaixo do ponto de aplicação da força) e trações transversais, que combinada com a compressão longitudinal pode provocar fissuras longitudinais. Como, a resistência do concreto à tração é muito baixa, normalmente se dispõem barras de aço na direção transversal. A Figura 2.20c representa uma distribuição radial de tensões, provocadas por forças concentradas introduzidas e propagadas de maneira suave. Não se desenvolvem trações transversais.

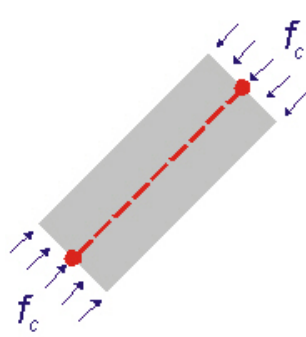

a

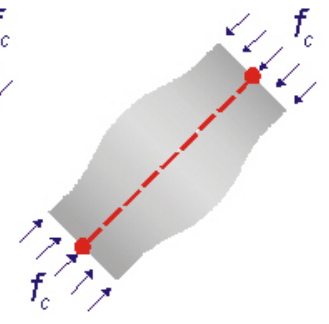

b

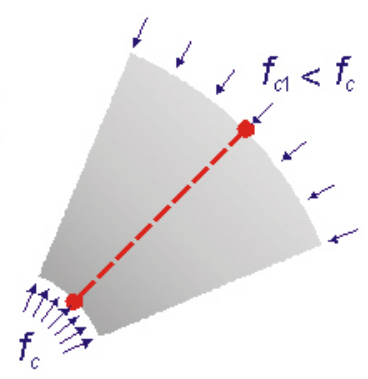

C

Figura 2.20 - Possíveis configurações das bielas de compressão, Strut-and-Tie Resource Website (2001).

A aplicação da analogia de bielas e tirantes geralmente se dá em regiões conhecidas como regiões $D$, quê são regiões onde a distribuição de tensões é nãolinear e que não obedecem a hipótese de Bernoulli. Nessas regiões há variações complexas de tensões, que podem ser produzidas por descontinuidades estáticas (forças concentradas e reações) e geométricas (mudanças abruptas na geometria). Por outro lado, em estruturas existem regiões contínuas que são denominadas regiões $B$. Nessas regiões são válidas as hipóteses de Bernoulli, ou seja, há uma variação linear na tensão atuante na seção transversal.

A divisão da estrutura em regiões $B$ e $D$ pode ser feita considerando as trajetórias de tensões nas proximidades das regiões descontínuas. Baseado no princípio de Saint Venant, a extensão de uma região $D$ tem aproximadamente a mesma dimensão da altura das regiões $B$ adjacentes, contada a partir da descontinuidade (geométrica ou estática). Exemplos de regiões B e D são ilustradas na Figura 2.21.

Segundo Macgregor (1988), as bielas e os tirantes são dispostos de tal maneira que os centros de gravidade de cada membro da treliça e as linhas de ação de todas as ações externamente aplicadas coincidam em cada nó, como mostra a Figura 2.22a. Esta exigência pode limitar as dimensões das bielas. A região nodal do 
apoio na Figura 2.22a é redesenhada com armadura distribuída em camadas na Figura 2.22b e com cobrimento maior na Figura 2.22c. Simplificadamente, o modelo pode ser representado como mostrado na Figura $2.22 \mathrm{~d}$, onde as bielas de compressão são substituídas por linhas tracejadas e os tirantes, por linhas contínuas.

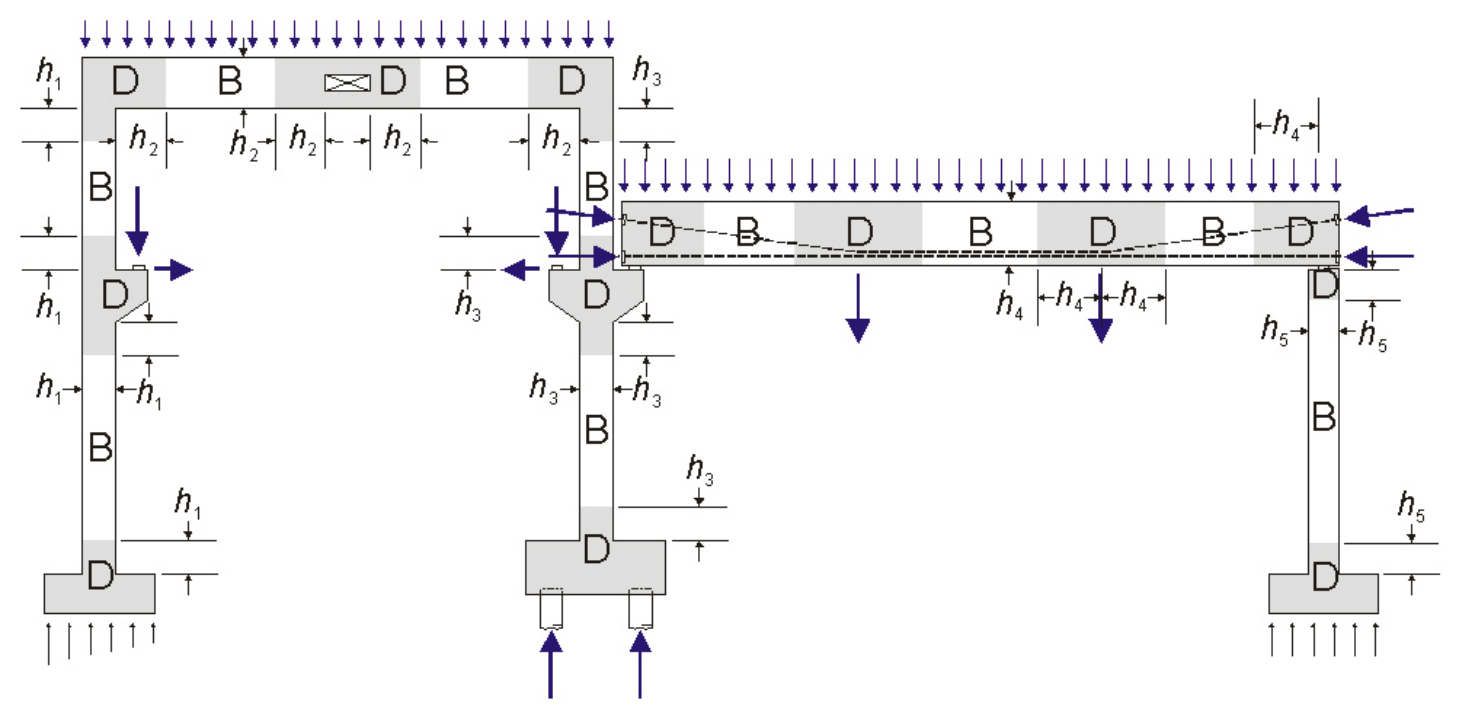

Figura 2.21 - Divisão de uma estrutura em regiões B e D, Strut-and-Tie Resource Website (2001).

Silva \& Giongo (2000) sugerem que o modelo de bielas e tirantes pode ser definido por meio do fluxo de tensões na estrutura, usando o processo do caminho de carga. Caso se disponha de tensões elásticas e suas direções principais obtidas de uma análise elástica, o desenvolvimento do modelo é imediato. Essa análise elástica pode ser feita utilizando métodos numéricos, como por exemplo, o método dos elementos finitos. A direção das bielas pode ser adotada de acordo com a direção média das tensões de compressão, ou os elementos mais importantes (bielas e tirantes) podem ser posicionados no centro de gravidade dos diagramas de tensão correspondentes. Caso se deseje determinar a força última na estrutura, o modelo pode ser adaptado para outro estágio de carregamento, alterando a posição das bielas e dos tirantes, aumentando assim, a resistência da estrutura. Para isso, utiliza-se análise plástica para a determinação do fluxo de tensões.

Vários pesquisadores utilizam o fluxo de tensões principais para geração automática de modelos de bielas e tirantes, entre eles podem ser citados: Harisis \& Fardis (1991), Oliveira (1998) e Longo (2000).

A Figura 2.22 apresenta o modelo de bielas e tirantes aplicado para uma vigaparede simplesmente apoiada submetida a uma força concentrada no meio do vão. As áreas sombreadas representam as regiões nodais. 

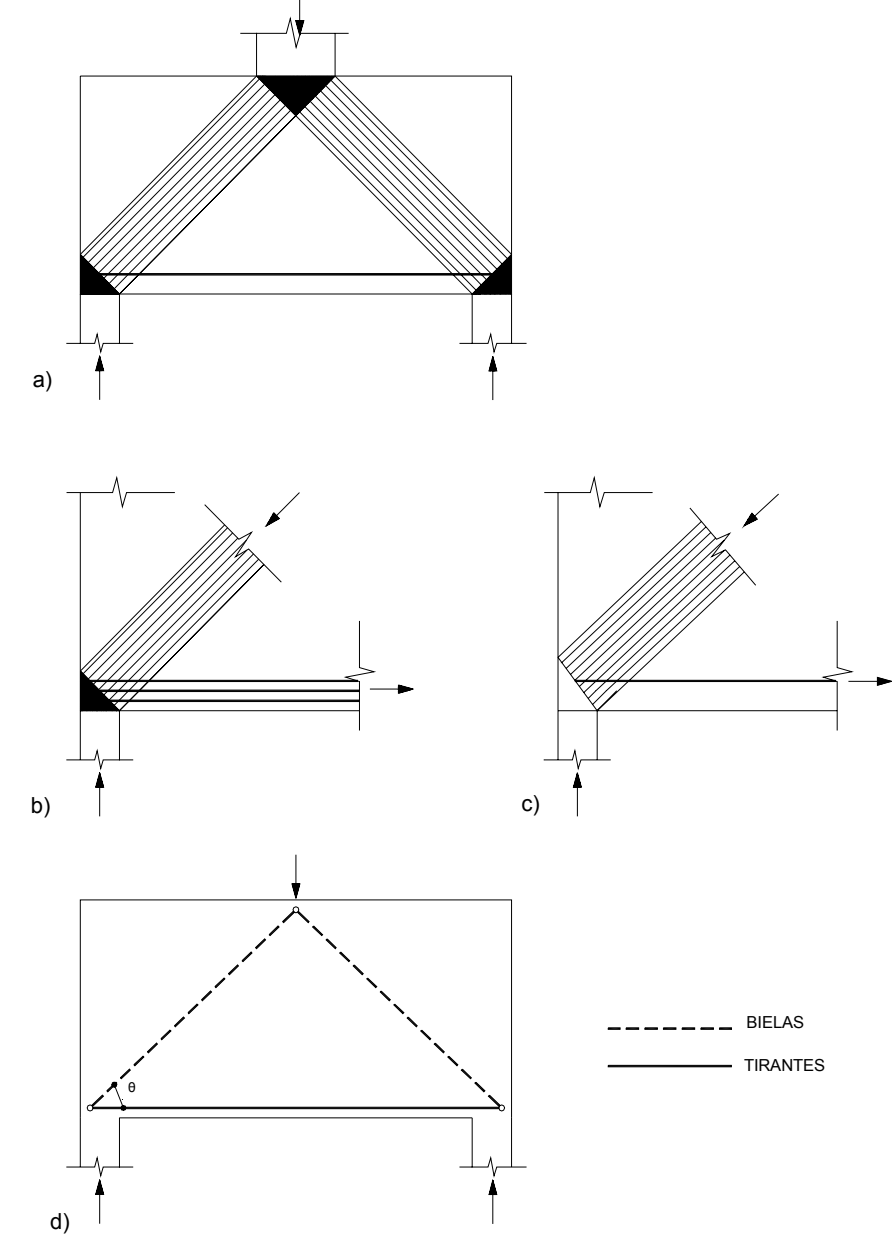

Figura 2.22 - Definição da geometria do modelo, Silva \& Giongo (2000).

Para um mesmo elemento estrutural pode-se encontrar vários modelos de bielas e tirantes que atendam as condições de equilíbrio entre forças internas e externas, por isso, a obtenção de modelos ótimos fica restrita a experiência do engenheiro. A obtenção de modelos otimizados é uma tarefa difícil que exige bastante experiência, entretanto, segundo Schailch et al. (1987), percebe-se que as ações tentam utilizar o caminho de mínimas forças e deformações. Como os tirantes das armaduras são muito mais deformáveis que as bielas de concreto, o modelo com tirantes mais curtos é o melhor. Esse critério pode ser formulado matematicamente por meio da Expressão 2.1.

$\sum \mathrm{F}_{\mathrm{i}} \cdot \ell_{\mathrm{i}} \cdot \varepsilon_{\mathrm{mi}}=$ mínimo

Sendo: $F_{i}$, a força aplicada; $\ell_{i}$, o comprimento; e $\varepsilon_{\mathrm{mi}}$, a deformação específica média. Todas essas grandezas referidas à biela ou ao tirante $\mathrm{i}$. 
A Expressão 1 é obtida do Princípio da Energia de Deformação Mínima para comportamento elástico e linear de bielas e tirantes após a fissuração. A contribuição das bielas pode geralmente ser omitida porque as deformações das bielas são usualmente muitas menores do que aquelas dos tirantes.

Tjhin \& Kuchma (2002) concluíram que as trajetórias de tensões principais obtidas de uma solução elástica linear satisfazem os Estados Limites de Serviço e Último, mas advertem ser uma aproximação, pois no Estado Limite Último, o fluxo de tensões sofre mudanças significativa, isso será demonstrado no Capítulo 3 deste texto.

Munhoz (2004) apresenta uma seqüência para a aplicação do método de caminho de carga em um bloco sobre duas estacas (ver Figura 2.23), sendo que, devem ser seguidas às seguintes etapas:

- Forças distribuídas no contorno devem ser substituídas por forças concentradas equivalentes;

- Todos os caminhos de carga devem ser desenhados, alinhados e não podem se interceptar;

- Ações opostas devem ser interligadas por caminhos de carga os mais curtos possíveis;

- Linhas curvas devem ser substituídas por linhas retas, que representam as bielas e tirantes;

- Se for preciso, bielas e tirantes devem ser adicionados para equilibrar os nós.

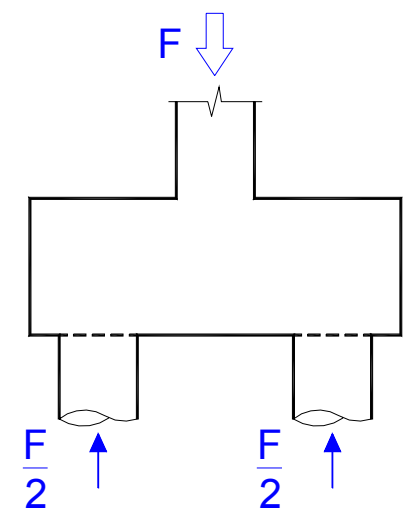

$\frac{F}{2} \uparrow$
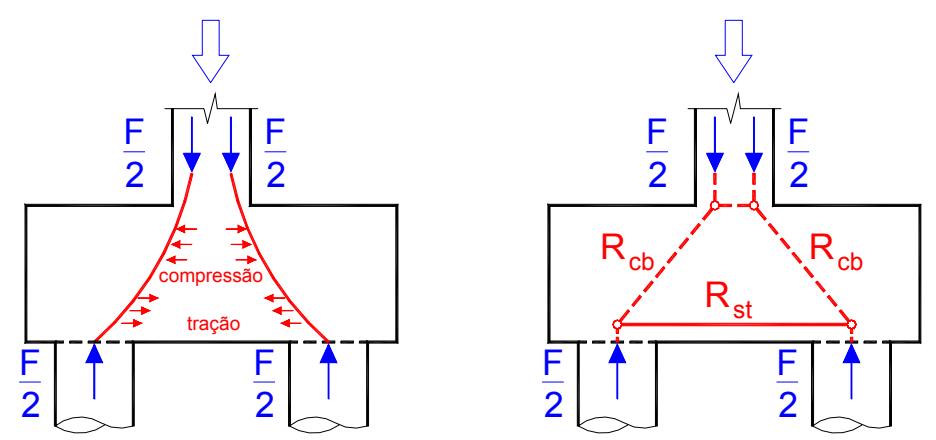

Figura 2.23 - Aplicação do caminho de carga em blocos sobre duas estacas, Munhoz (2004).

Conhecido o modelo adequado para uma determinada região de uma estrutura, as forças atuantes nas bielas e nos tirantes são calculas por meio do equilíbrio entre 
forças externas e internas. O dimensionamento dos tirantes e a verificação das bielas e dos nós devem satisfazer limites estipulados em normas.

Vários pesquisadores sugerem tensões limites para as regiões nodais, entre eles destacam-se: Schafer \& Schlaich (1988), Schlaich \& Schafer (1991) e Adebar \& Zhou (1995).

Schafer \& Schlaich (1988) propõem os seguintes valores de resistência para as bielas de compressão:

- $\quad 0,85 . f_{c d}$, para um estado de tensão uniaxial e sem perturbação;

- $0,68 . f_{c d}$, para campos de compressão com fissuras paralelas às tensões de compressão;

- $\quad$ 0,51.f $f_{c d}$, para campos de compressão com fissuras inclinadas.

Em outro artigo Schlaich \& Schafer (1991) propõem que os valores limites de resistência para as bielas de compressão sejam:

- $\quad 1,0 . f_{c d}$, para um estado de tensão uniaxial e sem perturbação;

- $0,8 . f_{c d}$, para campos de compressão com fissuras paralelas às tensões de compressão;

- $\quad$ 0,6. $f_{c d}$, para campos de compressão com fissuras inclinadas.

Nota-se, por meio dos dois trabalhos anteriores, que a obtenção de valores corretos para as tensões limites nas regiões nodais é uma tarefa difícil e depende de vários fatores, como: o tipo de elemento estrutural, tipo de detalhamento de armadura utilizado; condições de contorno; fissuração do elemento estrutural; ações externas aplicadas; entre outros.

Adebar \& Zhou (1995) sugerem os seguintes limites:

$\mathrm{f}_{\mathrm{b}}=0,6 \cdot \mathrm{f}_{\mathrm{ck}} \cdot(1+2 \cdot \alpha \cdot \beta)$

- Para zona nodal superior:

$$
\begin{aligned}
& \alpha=0,33 \cdot\left[\sqrt{\frac{\mathrm{A}_{2}}{\mathrm{~A}_{1}}}-1\right] \leq 1 \\
& 0 \leq \beta \leq 0,33 \cdot\left(2 \cdot \frac{\mathrm{d}}{\mathrm{c}}-1\right)
\end{aligned}
$$


Sendo, $A_{1}$ é a área onde atua o carregamento, $A_{2}$ é a área onde atua a reação do carregamento, d é a altura útil do bloco sobre estacas e c é a dimensão do pilar quadrado, para pilares circulares, a dimensão c é o diâmetro.

- Para zona nodal inferior:

$$
\begin{aligned}
& \alpha=0,33 \cdot\left[\sqrt{\frac{\mathrm{A}_{2}}{\mathrm{~A}_{1}}}-1\right] \leq 1 \\
& 0 \leq \beta \leq 0,33 \cdot\left(\frac{\mathrm{d}}{\mathrm{d}_{\mathrm{p}}}-1\right)
\end{aligned}
$$

Sendo, $A_{1}$ é a área onde atua o carregamento, $A_{2}$ é a área onde atua a reação do carregamento, d é a altura útil do bloco sobre estacas e $d_{p}$ é o diâmetro da estaca.

A forma geométrica da biela é a grande incógnita, pois, até os dias atuais, existe divergência de como proceder para sua determinação.

O Código Modelo do CEB-FIP (1990) sugere geometrias para os nós das regiões nodais e, com isto, é possível fazer verificações de tensões nessas regiões. Segundo o Código Modelo CEB-FIP (1990) existem quatro tipos de nós: nós somente com força de compressão (região nodal superior - interface pilar-bloco); nós com ancoragens somente de barras paralelas (região nodal inferior - blocos sobre duas estacas - interface estaca-bloco); nós com tirantes em direções ortogonais (região nodal inferior - blocos com mais de duas estacas - interface estaca-bloco); e nós com barras dobradas (não aplicável em blocos sobre estacas).

A norma canadense CSA Standard A23.3 (1994) também sugere regiões nodais, que são semelhantes ao método do Código Modelo do CEB-FIP (1990), mudando apenas a tensões limites nessas regiões. O ACI SP-208 (2002) também traz recomendações a respeito da geometria e as tensões limites em regiões nodais superiores e inferiores.

As forças nos tirantes são absorvidas pela armadura; a reta que contém o centro de gravidade das barras da armadura deve coincidir com o eixo do tirante no modelo. A área de armadura necessária é obtida diretamente por meio da força no tirante e da resistência de escoamento do aço considerando o estado limite último dada por: 
$A_{s t}=\frac{R_{s t, d}}{f_{y d}}$

Sendo: $R_{s t, d}$ a força de cálculo no tirante e $f_{y d}$ a resistência de cálculo ao escoamento das barras de aço da armadura do tirante.

Apesar de vários pesquisadores [Adebar et al. (1990), Siao (1993) e Munhoz (2004)] concluírem que o método de dimensionamento e verificação de blocos sobre estacas, desenvolvido por Blévot \& Frémy (1967), necessita de adaptações, ainda é o principal modelo utilizado no projeto estrutural de blocos sobre estacas.

\subsubsection{Recomendações normativas}

Em relação às recomendações normativas é feito um breve relato sobre os procedimentos utilizados pela NBR 6118:2003, pela EHE (2002), pelo ACl-318M (1994), pela CSA Standard A23.3-94, pela BS 8110 (1985) e pelo Boletim 73 do CEBFIP (1970).

A NBR 6118:2003 sugere modelos tridimensionais lineares ou não e modelos de bielas e tirantes tridimensionais, sendo esse último, o preferido por definir melhor a distribuição de esforços pelos tirantes. A NBR 6118:2003 não traz em seu texto nenhuma recomendação quanto a verificação ao cisalhamento e quanto a verificação de tensões nas bielas, apenas afirma que o modelo de bielas e tirantes pode ser utilizado.

A norma brasileira vigente de projeto de estruturas de concreto armado, também classifica os blocos rígidos como sendo aqueles que têm comportamento estrutural caracterizado por flexão nas duas direções, mas com trações essencialmente concentradas nas linhas sobre estacas (reticulado definido pelo eixo das estacas, com faixas de largura igual a 1,2 vez seu diâmetro), forças transmitidas do pilar para as estacas essencialmente por bielas de compressão, de forma e dimensões complexas, trabalho ao cisalhamento, também em duas direções, não apresentando ruptura por tração diagonal, e sim por compressão das bielas. Para blocos flexíveis, a NBR 6118:2003 recomenda uma análise mais completa, desde a distribuição das ações nas estacas, dos tirantes de tração, até a necessidade da verificação da punção. 
Segundo a NBR 6118:2003, blocos de concreto armado sobre estacas podem ser considerados rígidos ou flexíveis. Para que os blocos sejam rígidos é necessário que a relação abaixo seja respeitada, caso contrário, serão considerados flexíveis.

$\mathrm{h} \geq\left(\frac{\mathrm{a}-\mathrm{a}_{\mathrm{p}}}{3}\right)$

Sendo: h, a altura do bloco, a, a dimensão do bloco em uma determinada direção e $a_{p}$, a dimensão do pilar na mesma direção.

A norma espanhola EHE (2002) fornece expressões que permitem determinar a área das barras da armadura para os casos mais freqüentes de blocos sobre estacas, conforme o modelo de treliça adotado. A EHE (2002) não indica recomendações para a verificação das tensões nas bielas comprimidas.

O código americano ACl-318 (1994) adota hipóteses simplificadas para o dimensionamento de blocos sobre estacas. Recomenda o uso da teoria da flexão e a verificação da altura mínima do bloco para resistir à força cortante.

A norma canadense CSA Standard A23.3-94 (1994) utiliza o modelo de bielas e tirantes para o dimensionamento de blocos sobre estacas em situações onde não se aplica a teoria de viga. Primeiramente determina-se a geometria do elemento estrutural, após, determina-se a altura útil do bloco para que não ocorra ruína por punção na interface estaca-bloco e pilar-bloco. As áreas das barras de aço da armadura são determinadas utilizando a analogia de biela e tirante e, as tensões nas bielas são verificadas utilizando as recomendações de Adebar \& Zhou (1995). A norma canadense permite a utilização da teoria de vigas em situações particulares.

A BS 8110 (1985) permite a utilização da analogia de bielas e tirantes e teoria de viga para o dimensionamento e verificação dos blocos sobre estacas, mas, a analogia de bielas e tirantes só pode ser utilizada quando o espaçamento entre os eixos das estacas não forem superiores a três vezes o diâmetro das mesmas.

O Boletim $n^{\circ} 73$ do CEB-FIP (1970) utiliza a teoria de viga para o dimensionamento dos blocos e as verificações das tensões normais e tangenciais são feitas em seções pré-determinadas. Esse método indica verificações de segurança para tensões normais e tangenciais com esforços solicitantes determinados em seções transversais particulares. O dimensionamento é feito utilizando a teoria de viga. Este procedimento diverge da NBR 6118:2003, que considera que blocos rígidos não respeitam a hipótese de seções planas. 


\subsection{Comentários finais}

Os itens anteriores procuram apresentar e esclarecer os assuntos pertinentes ao projeto e detalhamento de blocos sobre estacas, sendo assim, inicialmente fez-se breve comentário relativo aos blocos sobre estacas e sua necessidade na estrutura.

Após isso, fez-se um breve relato de várias pesquisas desenvolvidas nas últimas décadas referentes ao tema da pesquisa. Esse relato teve como meta direcionar a pesquisa para caminhos ainda não estudados acerca do tema blocos de concreto armado sobre estacas, como: melhor esclarecimento a respeito da distribuição de tensões e a forma geométrica das bielas de compressão produzidas por ações externas; existência ou não de ganchos nas armaduras que compõem os tirantes, pois, estes não alteraram a força última nos blocos sobre estacas ensaiados, ficando restrito somente à segurança na ancoragem das barras.

Fez-se um breve comentário do modelo de bielas e tirantes e observou-se a viabilidade de sua aplicação em blocos de concreto armado sobre estacas.

Por fim, foram apresentadas algumas restrições e recomendações normativas para blocos de concreto armado sobre estacas. Foi possível observar que a norma brasileira NBR 6118:2003 não traz nenhuma recomendação para a verificação de tensões nas bielas comprimidas, caso seja utilizado o modelo de bielas e tirantes para o dimensionamento de blocos de concreto armado. 



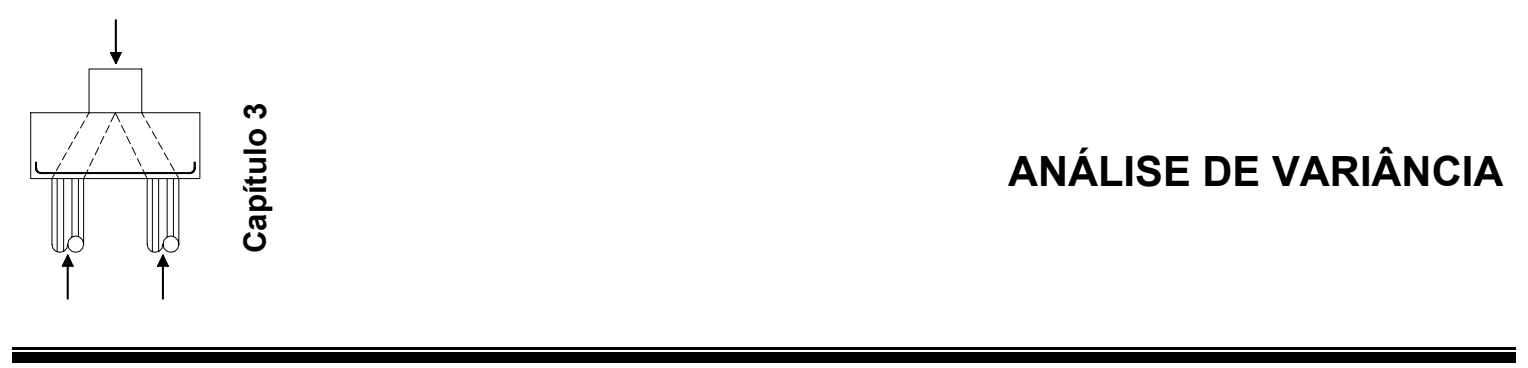

\subsection{Considerações iniciais}

Esta parte do texto tem como meta fornecer subsídios para melhor compreensão do comportamento estrutural de blocos sobre duas estacas e otimizar o número de variáveis que serão investigadas experimentalmente. Para isso, planejamento estatístico foi feito por meio de uma análise de variância. A análise de variância foi desenvolvida utilizando resultados numéricos obtidos por meio de programa de computador baseado no Método dos Elementos Finitos.

Com a análise de variância, foi possível estabelecer quais as variáveis relevantes a serem analisadas experimentalmente, lembrado que, a análise experimental tem como objetivo obter com precisão satisfatória a forma geométrica das bielas de compressão, como também, investigar a influência que os ganchos das barras de aço dos tirantes exercem no comportamento estrutural dos blocos.

Para o desenvolvimento da análise numérica, utilizou-se o programa de computador ANSYS, sendo que, as não linearidades física (do material) e geométrica (da estrutura) foram levadas em consideração.

A análise de variância é um teste estatístico amplamente difundido entre os analistas, e visa fundamentalmente verificar se existe diferença significativa entre as médias e se os fatores exercem influência em alguma variável dependente.

Os fatores propostos podem ser de origem qualitativa ou quantitativa, mas a variável dependente necessariamente deverá ser contínua.

A principal aplicação da ANOVA (analise of variance) é a comparação de médias oriundas de grupos diferentes, também chamados tratamentos.

Existem dois tipos de problemas a serem resolvidos por meio da Anova: fatores fixos ou fatores aleatórios. A aleatoriedade determina a questão do problema. 
$\mathrm{Na}$ grande maioria dos casos trata-se de fatores fixos, afinal o segundo tipo de problema (aleatório) somente surgirá quando ocorrer um estudo envolvendo uma escolha aleatória de fatores.

A análise de variância é amplamente utilizada em diversas áreas, por exemplo: na indústria, com objetivo de otimizar a linha de produção; na medicina, com o objetivo de identificar quais fatores são importantes no tratamento de uma determinada patologia. Na Engenharia Civil, sua utilização ainda é restrita, porém, já existem trabalhos desenvolvidos utilizando a técnica, como por exemplo: Delalibera (2002), Lima Júnior (2003) e Delalibera \& Giongo (2004 - b).

$\mathrm{Na}$ análise de variância desenvolvida neste trabalho, utilizaram-se fatores fixos, escolhendo quatro variáveis de estudo: a seção transversal das estacas; a seção transversal dos pilares; a altura dos blocos; e a excentricidade de força aplicada nos modelos. As variáveis escolhidas totalizaram oitenta e um casos de combinações.

\subsection{Determinação das variáveis}

Por meio da revisão bibliográfica foi possível determinar os fatores que tem importância relevante no comportamento estrutural dos blocos:

- Altura do bloco: função do ângulo de inclinação da biela de compressão em relação ao tirante de aço - $\theta$;

- Área das barras de aço da armadura tracionada: também é função do ângulo de inclinação da biela de compressão e da resistência característica ao escoamento das barras de aço;

- Armaduras adicionais para absorverem as tensões de tração existentes na direção perpendicular a biela de compressão;

- Diâmetro máximo do agregado;

- Excentricidade da aplicação da força no bloco;

- Força nominal da estaca: função das propriedades mecânica e geométrica das estacas;

- Geometria da seção transversal do pilar;

- Resistência característica do concreto à compressão;

- Tipo de ancoragem da armadura principal de tração - tirante.

Dentre os fatores citados acima, alguns podem ser descartados, pois já foram objetos de estudos de outros pesquisadores. 
Segundo Walraven \& Lehwalter (1989), a variação do diâmetro máximo da agregado graúdo e a variação do agregado miúdo não tiveram qualquer influência significativa na capacidade portante dos elementos estruturais ensaiados. Em função dessa afirmação, a variável, diâmetro máximo do agregado não foi considerada.

Ensaios realizados por Blévot \& Frémy (1967), Taylor \& Clarke (1976), Adebar et al. (1990) e Miguel (2000), confirmaram que o melhor arranjo para as armaduras dos tirantes é o arranjo em que as barras de aço ficam concentradas numa faixa sobre as estacas. Assim, a variável, tipo de detalhamento das armaduras, também foi descartada.

Taylor \& Clarke (1976) e Miguel (2000), observaram nos seus ensaios que a existência de ganchos nas barras de aço que constituem os tirantes não modifica o comportamento estrutural dos blocos no Estado Limite Último, porém, algumas normas e códigos, NBR 6118:2003, a EHE (2002), o ACI SP-208 (2002), BS 8110 (1985), o CBH-87 (1987) e o CEB-FIP (1970), recomendam a sua utilização. Burke (1997), por meio de pesquisas realizadas por Minor \& Jirsa (1975) e Marquer \& Jirsa (1975) adaptou uma equação que exprime a força no ganho do tirante, levando em consideração o efeito favorável do confinamento que a biela de compressão exerce na cabeça da estaca. Decidiu-se então, analisar por meio de ensaios experimentais a influência que os ganchos exercem no comportamento dos blocos. É válido recordar que a norma canadense CSA Standard A23.3-94 (1994) não utiliza ancoragem com ganchos.

Sabe-se também, que a ruína de blocos rígidos, geralmente ocorre por esmagamento ou fendilhamento das bielas de compressão. Observa-se que a armadura do tirante não é fator preponderante na determinação da força última para blocos rígidos. Por isso, decidiu-se fixar a taxa de armadura em todos os modelos.

Em trabalho anterior, Delalibera \& Giongo (2004 - a) observaram que a resistência característica do concreto à compressão não tem importância relevante na rigidez dos blocos de coroamento, como também, não apresenta influência na distribuição do fluxo de tensões. Verificou-se que a altura do bloco é fator preponderante na determinação da força última e na formação da biela de compressão. Por meio dessas afirmações, concluiu-se que a resistência característica do concreto à compressão é um fator fixo e que a altura do bloco deverá ser investigada nos modelos experimentais.

Fusco (1985) conclui que a inclinação efetiva das bielas de compressão obedece às condições de contorno impostas pelos apoios e pelo carregamento, sendo assim, verifica-se que as dimensões das seções transversais das estacas e dos 
pilares exercem influência direta na distribuição do fluxo de tensões, como também, na determinação da força última.

$\mathrm{Na}$ análise de variância, a armadura adicional destinada a absorver as forças de tração oriundas do fendilhamento da biela de compressão, não foi levada em consideração, pois a existência de tal armadura modificaria o fluxo de tensões de compressão e a força última no bloco.

Em relação à excentricidade da força de compressão, Machado (1979) e Fusco (1994) apresentam solução para blocos sobre estacas utilizando a analogia de bielas e tirantes, porém, a escassez de bibliografia sobre o assunto, fez com que essa variável fosse analisada.

Portanto, as variáveis escolhidas para a análise de variância foram: a seção transversal das estacas e dos pilares, a altura dos blocos e a excentricidade da força de compressão.

Com essas variáveis, um planejamento fatorial foi desenvolvido gerando três grupos de análise:

- Grupo A: blocos com variação nas seções das estacas e dos pilares e na altura, com excentricidade igual a zero da força de compressão;

- Grupo B: blocos com variação nas seções das estacas e dos pilares e na altura, com excentricidade igual a cinco centímetros da força de compressão;

- Grupo C: blocos com variação nas seções das estacas e dos pilares e na altura, com excentricidade igual a dez centímetros da força de compressão.

Como todos os ensaios experimentais e análises numéricas desenvolvidas até hoje tratam somente de pilares de seção transversal quadrada, optou-se pela escolha das seguintes seções de pilares: $20 \mathrm{~cm} \times 20 \mathrm{~cm} ; 20 \mathrm{~cm} \times 30 \mathrm{~cm}$ e $20 \mathrm{~cm} \times 40 \mathrm{~cm}$. Essas seções foram escolhidas, pois abrangem seções de pilares de estruturas correntes de concreto armado.

Nas estacas, por facilidade na modelagem numérica, optou-se pela utilização de seções transversais quadradas com as seguintes dimensões: $20 \mathrm{~cm} \times 20 \mathrm{~cm}$, $25 \mathrm{~cm} \times 25 \mathrm{~cm}$ e $30 \mathrm{~cm} \times 30 \mathrm{~cm}$. Observa-se que essas seções são comumente empregadas, quando utilizam-se estacas pré-moldadas.

Com relação à altura do bloco, optou-se por investigar variações do ângulo de inclinação da biela de compressão de $35^{\circ}, 45^{\circ}$ e $55^{\circ}$. Observa-se que o limite recomendado por Blévot \& Frémy $(1967)\left(45^{\circ} \leq \theta \leq 55\right)$ foi investigado. O ângulo de $35^{\circ}$ foi escolhido em função das recomendações de Fusco (1994), que afirma que 
pode-se utilizar ângulo de inclinação da biela não inferior a $\operatorname{arctg}(2 / 3)$ em relação à horizontal. Nas Tabelas 3.2, 3.2 e 3.4 são mostrados os blocos que foram analisados.

Em cada grupo desenvolveu-se um planejamento fatorial de $3^{3}$, ou seja, três fatores sendo que para cada fator fizeram-se três variações.

A nomenclatura dos blocos deve ser entendida da seguinte maneira, por exemplo, B45P30E25e0 significa: bloco sobre duas estacas com ângulo de inclinação

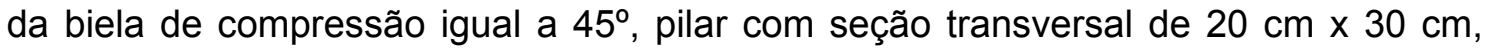
estaca com seção transversal igual a $25 \mathrm{~cm} \times 25 \mathrm{~cm}$ e excentricidade da força de compressão igual a zero.

Tabela 3.1 - Blocos o Grupo A, excentricidade igual a zero $(e=0)$.

\begin{tabular}{c|c|c|c}
\hline \hline Blocos & $\begin{array}{c}\text { Inclinação da biela }-\theta \\
\text { (graus) }\end{array}$ & $\begin{array}{c}\text { Seção do pilar } \\
\text { (cm) }\end{array}$ & $\begin{array}{c}\text { Seção da estacas } \\
\text { (cm) }\end{array}$ \\
\hline B35P20E20e0 & 35 & $20 \times 20$ & $20 \times 20$ \\
\hline B35P20E25e0 & 35 & $20 \times 20$ & $25 \times 25$ \\
\hline B35P20E30e0 & 35 & $20 \times 20$ & $30 \times 30$ \\
\hline B35P30E20e0 & 35 & $20 \times 30$ & $25 \times 20$ \\
\hline B35P30E25e0 & 35 & $20 \times 30$ & $30 \times 30$ \\
\hline B35P30E30e0 & 35 & $20 \times 30$ & $20 \times 20$ \\
\hline B35P40E20e0 & 35 & $20 \times 40$ & $25 \times 25$ \\
\hline B35P40E25e0 & 35 & $20 \times 40$ & $30 \times 30$ \\
\hline B35P40E30e0 & 35 & $20 \times 40$ & $20 \times 20$ \\
\hline B45P20E20e0 & 45 & $20 \times 20$ & $25 \times 25$ \\
\hline B45P20E25e0 & 45 & $20 \times 20$ & $30 \times 30$ \\
\hline B45P20E30e0 & 45 & $20 \times 20$ & $20 \times 20$ \\
\hline B45P30E20e0 & 45 & $20 \times 30$ & $25 \times 25$ \\
\hline B45P30E25e0 & 45 & $20 \times 30$ & $30 \times 30$ \\
\hline B45P30E30e0 & 45 & $20 \times 30$ & $20 \times 20$ \\
\hline B45P40E20e0 & 45 & $20 \times 40$ & $25 \times 25$ \\
\hline B45P40E25e0 & 45 & $20 \times 40$ & $30 \times 30$ \\
\hline B45P40E30e0 & 45 & $20 \times 40$ & $20 \times 20$ \\
\hline B55P20E20e0 & 55 & $20 \times 20$ & $25 \times 25$ \\
\hline B55P20E25e0 & 55 & $20 \times 20$ & $30 \times 30$ \\
\hline B55P20E30e0 & 55 & $20 \times 20$ & $20 \times 20$ \\
\hline B55P30E20e0 & 55 & $20 \times 30$ & $25 \times 25$ \\
\hline B55P30E25e0 & 55 & $20 \times 30$ & $30 \times 30$ \\
\hline B55P30E30e0 & 55 & $20 \times 30$ & $20 \times 20$ \\
\hline B55P40E20e0 & 55 & $20 \times 40$ & $25 \times 25$ \\
\hline B55P40E25e0 & 55 & $20 \times 40$ & $30 \times 30$ \\
\hline B55P40E30e0 & 55 & $20 \times 40$ & \\
\hline \hline
\end{tabular}


Tabela 2.3 - Grupo B, excentricidade igual a cinco centímetros ( e = $5 \mathrm{~cm}$ ).

\begin{tabular}{c|c|c|c}
\hline \hline Blocos & $\begin{array}{c}\text { Inclinação da biela }-\theta \\
\text { (graus) }\end{array}$ & $\begin{array}{c}\text { Seção do pilar } \\
\text { (cm) }\end{array}$ & $\begin{array}{c}\text { Seção da estacas } \\
\text { (cm) }\end{array}$ \\
\hline B35P20E20e5 & 35 & $20 \times 20$ & $20 \times 20$ \\
\hline B35P20E25e5 & 35 & $20 \times 20$ & $25 \times 25$ \\
\hline B35P20E30e5 & 35 & $20 \times 20$ & $30 \times 30$ \\
\hline B35P30E20e5 & 35 & $20 \times 30$ & $20 \times 20$ \\
\hline B35P30E25e5 & 35 & $20 \times 30$ & $30 \times 30$ \\
\hline B35P30E30e5 & 35 & $20 \times 30$ & $20 \times 20$ \\
\hline B35P40E20e5 & 35 & $20 \times 40$ & $25 \times 25$ \\
\hline B35P40E25e5 & 35 & $20 \times 40$ & $30 \times 30$ \\
\hline B35P40E30e5 & 35 & $20 \times 40$ & $20 \times 20$ \\
\hline B45P20E20e5 & 45 & $20 \times 20$ & $25 \times 25$ \\
\hline B45P20E25e5 & 45 & $20 \times 20$ & $30 \times 30$ \\
\hline B45P20E30e5 & 45 & $20 \times 20$ & $20 \times 20$ \\
\hline B45P30E20e5 & 45 & $20 \times 30$ & $25 \times 25$ \\
\hline B45P30E25e5 & 45 & $20 \times 30$ & $30 \times 30$ \\
\hline B45P30E30e5 & 45 & $20 \times 30$ & $20 \times 20$ \\
\hline B45P40E20e5 & 45 & $20 \times 40$ & $25 \times 25$ \\
\hline B45P40E25e5 & 45 & $20 \times 40$ & $30 \times 30$ \\
\hline B45P40E30e5 & 45 & $20 \times 40$ & $20 \times 20$ \\
\hline B55P20E20e5 & 55 & $20 \times 20$ & $25 \times 25$ \\
\hline B55P20E25e5 & 55 & $20 \times 20$ & $30 \times 30$ \\
\hline B55P20E30e5 & 55 & $20 \times 20$ & $20 \times 20$ \\
\hline B55P30E20e5 & 55 & $20 \times 30$ & $25 \times 25$ \\
\hline B55P30E25e5 & 55 & $20 \times 30$ & $30 \times 30$ \\
\hline B55P30E30e5 & 55 & $20 \times 30$ & $20 \times 20$ \\
\hline B55P40E20e5 & 55 & $20 \times 40$ & $25 \times 25$ \\
\hline B55P40E25e5 & 55 & $20 \times 40$ & $30 \times 30$ \\
\hline B55P40E30e5 & 55 & $20 \times 40$ & \\
\hline \hline
\end{tabular}

Tabela 3.3 - Grupo C, excentricidade igual a dez centímetros $(\mathrm{e}=10 \mathrm{~cm})$.

\begin{tabular}{c|c|c|c}
\hline Blocos & $\begin{array}{c}\text { Inclinação da biela }-\theta \\
\text { (graus) }\end{array}$ & $\begin{array}{c}\text { Seção do pilar } \\
\text { (cm) }\end{array}$ & $\begin{array}{c}\text { Seção da estacas } \\
\text { (cm) }\end{array}$ \\
\hline B35P20E20e10 & 35 & $20 \times 20$ & $20 \times 20$ \\
\hline B35P20E25e10 & 35 & $20 \times 20$ & $25 \times 25$ \\
\hline B35P20E30e10 & 35 & $20 \times 20$ & $30 \times 30$ \\
\hline B35P30E20e10 & 35 & $20 \times 30$ & $20 \times 20$ \\
\hline B35P30E25e10 & 35 & $20 \times 30$ & $30 \times 30$ \\
\hline B35P30E30e10 & 35 & $20 \times 30$ & $20 \times 20$ \\
\hline B35P40E20e10 & 35 & $20 \times 40$ & $25 \times 25$ \\
\hline B35P40E25e10 & 35 & $20 \times 40$ & $30 \times 30$ \\
\hline B35P40E30e10 & 35 & $20 \times 40$ & $20 \times 20$ \\
\hline B45P20E20e10 & 45 & $20 \times 20$ & $25 \times 25$ \\
\hline B45P20E25e10 & 45 & $20 \times 20$ & $30 \times 30$ \\
\hline B45P20E30e10 & 45 & $20 \times 20$ & $20 \times 20$ \\
\hline B45P30E20e10 & 45 & $20 \times 30$ & $25 \times 25$ \\
\hline B45P30E25e10 & 45 & $20 \times 30$ & $30 \times 30$ \\
\hline B45P30E30e10 & 45 & $20 \times 30$ & $20 \times 20$ \\
\hline B45P40E20110 & 45 & $20 \times 40$ & $25 \times 25$ \\
\hline B45P40E25e10 & 45 & $20 \times 40$ & $30 \times 30$ \\
\hline B45P40E30e10 & 45 & $20 \times 40$ & $20 \times 20$ \\
\hline B55P20E20110 & 55 & $20 \times 20$ & $25 \times 25$ \\
\hline B55P20E25e10 & 55 & $20 \times 20$ & $30 \times 30$ \\
\hline B55P20E30e10 & 55 & $20 \times 20$ & $20 \times 20$ \\
\hline B55P30E201010 & 55 & $20 \times 30$ & $25 \times 25$ \\
\hline B55P30E25e10 & 55 & $20 \times 30$ & $30 \times 30$ \\
\hline B55P30E30e10 & 55 & $20 \times 30$ & $20 \times 20$ \\
\hline B55P40E20e10 & 55 & $20 \times 40$ & $25 \times 25$ \\
\hline B55P40E25e10 & 55 & $20 \times 40$ & $30 \times 30$ \\
\hline B55P40E30e10 & 55 & $20 \times 40$ & \\
\hline \hline
\end{tabular}




\subsection{Formulação da análise de variância}

Sejam $A, B$ e $C$ os fatores principais fixos da análise de variância, $a, b$ e $c$, as variações desses fatores e $n$ o número de réplicas. Em geral existirá abc...n combinações possíveis.

Se todos os fatores do experimento forem fixados, pode-se facilmente formular o problema, obtendo resultados que indicam quais dos fatores analisados são importantes como também suas combinações.

Para verificar a relevância de um determinado fator principal fixo ou combinações entre os fatores principais, faz-se a relação entre a média dos quadrados de cada fator principal ou combinação dos fatores principais pela média dos quadrados dos erros. A divisão entre a média dos quadrados de cada fator principal ou combinação dos fatores principais pela média dos erros é chamada de $F_{0}$.

O número de graus de liberdade de cada fator principal é igual ao número de variações de cada fator menos a unidade. O número de graus de liberdade dos fatores principais combinados é o produto entre os fatores principais que foram combinados.

A Tabela 3.4 apresenta uma analise de variância com três fatores.

Tabela 3.4 - Análise de variância, equacionamento geral, Montgomery (1996).

\begin{tabular}{|c|c|c|c|c|}
\hline Fatores & $\begin{array}{l}\text { Soma dos } \\
\text { quadrados }\end{array}$ & Graus de Liberdade & Média dos Quadrados & $F_{0}$ \\
\hline$A$ & $\mathrm{SS}_{\mathrm{A}}$ & $a-1$ & $\mathrm{MS}_{\mathrm{A}}=\mathrm{SS}_{\mathrm{A}} /(\mathrm{a}-1)$ & $\mathrm{F}_{0}=\frac{\mathrm{MS}_{\mathrm{A}}}{\mathrm{MS}_{\mathrm{E}}}$ \\
\hline$B$ & $\mathrm{SS}_{\mathrm{B}}$ & $b-1$ & $\mathrm{MS}_{\mathrm{B}}=\mathrm{SS}_{\mathrm{b}} /(\mathrm{b}-1)$ & $F_{0}=\frac{M S_{B}}{M S_{E}}$ \\
\hline$C$ & $\mathrm{SS}_{\mathrm{C}}$ & $c-1$ & $\mathrm{MS}_{\mathrm{C}}=\mathrm{SS}_{\mathrm{c}} /(\mathrm{c}-1)$ & $F_{0}=\frac{M S_{C}}{M S_{E}}$ \\
\hline$A \times B$ & $\mathrm{SS}_{\mathrm{AB}}$ & $(a-1)(b-1)$ & $\mathrm{MS}_{\mathrm{AB}}=\mathrm{SS}_{\mathrm{AB}} /[(\mathrm{a}-1)(\mathrm{b}-1)]$ & $\mathrm{F}_{0}=\frac{\mathrm{MS}_{\mathrm{AB}}}{\mathrm{MS}_{\mathrm{E}}}$ \\
\hline$A \times C$ & $\mathrm{SS}_{\mathrm{AC}}$ & $(a-1)(c-1)$ & $M S_{A C}=S S_{A C} /[(a-1)(c-1)]$ & $\mathrm{F}_{0}=\frac{\mathrm{MS}_{\mathrm{AC}}}{\mathrm{MS}_{\mathrm{E}}}$ \\
\hline$B \times C$ & $\mathrm{SS}_{\mathrm{BC}}$ & $(b-1)(c-1)$ & $M S_{B C}=S S_{B C} /[(b-1)(c-1)]$ & $F_{0}=\frac{M S_{B C}}{M S_{E}}$ \\
\hline$A \times B \times C$ & $S S_{A B C}$ & $(a-1)(b-1)(c-1)$ & $\mathrm{MS}_{\mathrm{ABC}}=\mathrm{SS}_{\mathrm{ABC}} /[(\mathrm{a}-1)(\mathrm{b}-1)(\mathrm{c}-1)]$ & $F_{0}=\frac{M S_{A B C}}{M S_{E}}$ \\
\hline Erro & $\mathrm{SS}_{\mathrm{E}}$ & $a b c(n-1)$ & $\mathrm{MS}_{\mathrm{E}}=\mathrm{SS}_{\mathrm{E}} /[\mathrm{abc}(\mathrm{n}-1)]$ & \\
\hline Total & $\mathrm{SS}_{\mathrm{T}}$ & $a b c n-1$ & & \\
\hline
\end{tabular}

A soma total dos quadrados é calculada por meio da Expressão 3.1. 


$$
\mathrm{SS}_{\mathrm{T}}=\sum_{\mathrm{i}=1}^{\mathrm{a}} \sum_{\mathrm{j}=1 \mathrm{k}=1}^{\mathrm{b}} \sum_{\mathrm{k}=1}^{\mathrm{c}} \sum_{\mathrm{l}=1}^{\mathrm{n}} \mathrm{y}_{\mathrm{ijkl}}^{2}-\frac{\mathrm{y}^{2} \ldots}{\mathrm{abcn}}
$$

A soma dos quadrados de cada fator principal são definidos por meio dos fatores $\mathrm{A}\left(\mathrm{y}_{\mathrm{i} . . .}\right), \mathrm{B}\left(\mathrm{y}_{\mathrm{j} . . .}\right)$ e $\mathrm{C}\left(\mathrm{y}_{. . k .}\right)$, portanto, tem-se:

$$
\begin{aligned}
& \mathrm{SS}_{\mathrm{A}}=\sum_{\mathrm{i}=1}^{\mathrm{a}} \frac{\mathrm{y}_{\mathrm{i} . \ldots}^{2}}{\mathrm{bcn}}-\frac{\mathrm{y}_{\ldots \ldots}^{2}}{\mathrm{abcn}} \\
& \mathrm{SS}_{\mathrm{B}}=\sum_{\mathrm{i}=1}^{\mathrm{a}} \frac{\mathrm{y}_{\mathrm{j} . \mathrm{j}}^{2}}{\mathrm{acn}}-\frac{\mathrm{y}_{\ldots . \ldots}^{2}}{\mathrm{abcn}} \\
& \mathrm{SS}_{\mathrm{C}}=\sum_{\mathrm{i}=1}^{\mathrm{a}} \frac{\mathrm{y}_{. . \mathrm{k} .}^{2}}{\mathrm{abn}}-\frac{\mathrm{y}_{\ldots . .}^{2}}{\mathrm{abcn}}
\end{aligned}
$$

A soma dos quadrados das combinações $A \times B, A \times C$, e $B \times C$ são expressas por meio das Expressões 3.5, 3.6 e 3.7. E a Equação 3.8 define a soma dos quadrados da combinação de todos os fatores.

$$
\begin{aligned}
& \mathrm{SS}_{\mathrm{AB}}=\sum_{\mathrm{i}=1}^{\mathrm{a}} \sum_{\mathrm{j}=1}^{\mathrm{b}} \frac{\mathrm{y}_{\mathrm{ij...}}^{2}}{\mathrm{cn}}-\frac{\mathrm{y}_{\ldots \ldots}^{2}}{\mathrm{abcn}}-\mathrm{SS}_{\mathrm{A}}-\mathrm{SS}_{\mathrm{B}} \\
& \mathrm{SS}_{\mathrm{AC}}=\sum_{\mathrm{i}=1}^{\mathrm{a}} \sum_{\mathrm{k}=1}^{\mathrm{c}} \frac{\mathrm{y}_{\mathrm{i} . \mathrm{k} .}^{2}}{\mathrm{bn}}-\frac{\mathrm{y}_{\ldots . .}^{2}}{\mathrm{abcn}}-\mathrm{SS}_{\mathrm{A}}-\mathrm{SS}_{\mathrm{C}} \\
& \mathrm{SS}_{\mathrm{BC}}=\sum_{\mathrm{j}=1}^{\mathrm{b}} \sum_{\mathrm{k}=1}^{\mathrm{c}} \frac{\mathrm{y}_{. \mathrm{jk} .}^{2}}{\mathrm{an}}-\frac{\mathrm{y}_{\ldots \ldots}^{2}}{\mathrm{abcn}}-\mathrm{SS}_{\mathrm{B}}-\mathrm{SS}_{\mathrm{C}} \\
& \mathrm{SS}_{\mathrm{ABC}}=\sum_{\mathrm{i}=1}^{\mathrm{a}} \sum_{\mathrm{j}=1}^{\mathrm{b}} \sum_{\mathrm{k}=1}^{\mathrm{c}} \frac{\mathrm{y}_{\mathrm{i} \mathrm{j} \mathrm{k} .}^{2}}{\mathrm{n}}-\frac{\mathrm{y}_{\ldots}^{2}}{\mathrm{abcn}}-\mathrm{SS}_{\mathrm{A}}-\mathrm{SS}_{\mathrm{B}}-\mathrm{SS}_{\mathrm{C}}-\mathrm{SS}_{\mathrm{AB}}-\mathrm{SS}_{\mathrm{AC}}-\mathrm{SS}_{\mathrm{BC}}
\end{aligned}
$$

Por fim, a soma dos quadrados do erro é definida pela Equação 3.9.

$$
\mathrm{SS}_{\mathrm{E}}=\mathrm{SS}_{\mathrm{T}}-\sum_{\mathrm{i}=1 \mathrm{j}=1 \mathrm{k}=1}^{\mathrm{b}} \sum_{\mathrm{j}=1}^{\mathrm{c}} \frac{\mathrm{y}_{. \mathrm{jjk} .}^{2}}{\mathrm{n}}-\frac{\mathrm{y}^{2} \ldots}{\mathrm{abcn}}
$$

Para verificação da relevância de uma determinada variável principal fixa ou combinada, aplica-se o teste $F$. Por meio de valores tabelados de $F_{\text {critico, }}$, fornecidos por Montgomery (1996), compara-se o valor calculado de $F_{0}$ com o valor de $F_{\text {critico. }}$ Se o 
valor calculado de $\mathrm{F}_{0}$ for maior que o valor tabelado de $F_{\text {critico }}$ significa que esse fator é relevante, caso contrário, implica que o fator não possui importância significativa. Os valores de $F_{\text {critico }}$ são função do número de graus de liberdade de cada variável e do número de graus de liberdade total.

\subsection{Análise numérica}

O objetivo da análise numérica foi fornecer resultados para a aplicação do critério ANOVA, sendo assim, blocos sobre duas estacas com excentricidades iguais a zero, cinco e dez centímetros foram simulados. A análise numérica não tinha como objetivo calibrar curvas de resultados experimentais, mas sim, apresentar tendências de comportamento dos modelos analisados.

Os modelos foram dimensionados com os critérios de Blévot \& Frémy (1967), sendo que, as taxas de armadura foram fixadas, pois não eram objetos de análise. $A$ distância entre os eixos das estacas também foi fixada, variando-se apenas as dimensões das seções transversais das mesmas. Utilizaram-se como tensões limites para verificação das tensões nas zonas nodais superior e inferior os valores observados pelos pesquisadores franceses durantes seus ensaios, ou seja, 1,40. $\mathrm{f}_{\mathrm{ck}}$ junto ao pilar e $\mathrm{f}_{\mathrm{ck}}$ junto à estaca (maiores detalhes são descritos no Capítulo 4).

A geometria de todos os modelos foram criadas no programa de computador AutoCad $^{\circledR}$ (versão 2000) e exportada para o programa de computador ANSYS $^{\circledR}$, por meio de extensão SAT.

Para verificar se os resultados obtidos por meio da análise numérica eram coerentes, uma análise comparativa foi desenvolvida. Nessa análise, resultados experimentais de blocos sobre estacas foram comparados com o resultados numéricos.

Em função da influência da rigidez das estacas na distribuição do fluxo de tensões, o Professor Assistente do Departamento de Engenharia de Estruturas Toshiaki Takeia, sugeriu que fossem simulados blocos com estacas de comprimentos reais. Não foi observada diferença significativa na distribuição do fluxo de tensões, assim, foi possível simular os modelos com alturas menores de estacas (semelhante aos ensaios experimentais de blocos sobre estacas).

Por meio dos resultados das simulações numéricas, verificou-se que existem diferenças significativas na distribuição do fluxo de tensões quando comparados com o critério de Blévot \& Frémy (1967). 


\subsubsection{Propriedades dos modelos}

Para o dimensionamento dos blocos, utilizou-se um bloco padrão, ou seja, todos os blocos terão as mesmas dimensões em planta do bloco padrão, variando-se apenas as alturas e as seções transversais das estacas e dos pilares. O bloco padrão adotado tem seção transversal das estacas iguais a $25 \mathrm{~cm} \times 25 \mathrm{~cm}$ e seção transversal do pilar igual a $20 \mathrm{~cm} \times 30 \mathrm{~cm}$.

A altura dos blocos foi calculada de acordo com os critérios de Blévot \& Frémy (1967), para ângulos de inclinação da biela de compressão de $35^{\circ}, 45^{\circ}$ e $55^{\circ}$. A área das barras de aço da armadura do tirante foi calcula para um ângulo de inclinação da biela de compressão igual a $35^{\circ}$ e fixada nos demais modelos.

As dimensões em planta foram calculadas utilizando-se as recomendações de Albiero \& Cintra (1984) e da NBR 6122:1986.

O embutimento das estacas na face inferior do bloco seguiu sugestão de Montoya et al. (2000), embutindo dez centímetros do fuste da estaca no interior do bloco.

A Figura 3.1 mostra as dimensões dos blocos analisados numericamente.
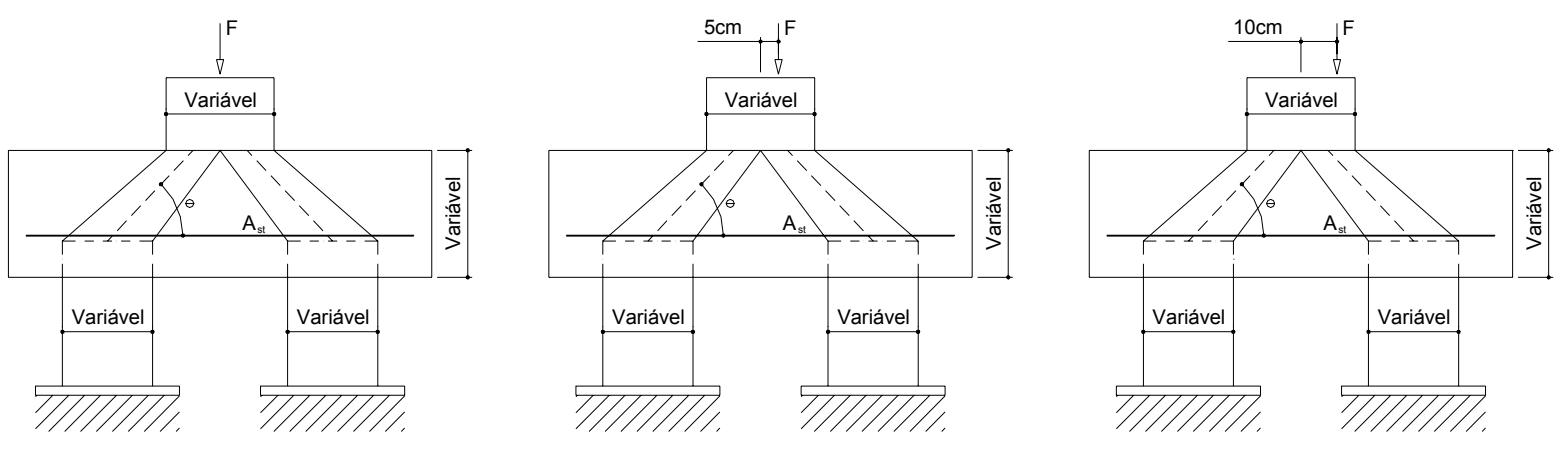

Figura 3.1 - Blocos analisados numericamente.

Optou-se por utilizar ancoragem reta, pois verificou-se por meio das recomendações da NBR 6118:2003 que o gancho não era necessário (critérios de ancoragens em apoios extremos). Ao admitir essa hipótese, o pesquisador desprezou a recomendação da NBR 6118:2003 que exige a utilização de ganchos em blocos sobre estacas.

Em todos os blocos, adotou-se resistência característica do concreto à compressão $\left(f_{c k}\right)$ igual a $20 \mathrm{MPa}$ e aço CA-50 nas barras de aço dos tirantes.

A Tabela 3.5 mostra as propriedades dos blocos analisados. 
Tabela 3.5 - Propriedades dos blocos analisados, para e $=0, e=5 \mathrm{~cm} \mathrm{e} \mathrm{e}=10 \mathrm{~cm}$.

\begin{tabular}{|c|c|c|c|c|c|c|c|c|}
\hline Blocos & $\begin{array}{c}\text { Inclinação } \\
\text { da biela - } \\
\theta \\
\text { (graus) } \\
\end{array}$ & $\begin{array}{l}\text { Seção } \\
\text { do pilar } \\
\text { (cm) }\end{array}$ & $\begin{array}{c}\text { Seção } \\
\text { da } \\
\text { estacas } \\
\text { (cm) }\end{array}$ & $\begin{array}{c}A_{s t} \\
\left(\mathrm{~cm}^{2}\right)\end{array}$ & $\begin{array}{l}B_{1 x} \\
(\mathrm{~cm})\end{array}$ & $\begin{array}{l}B_{l y} \\
(\mathrm{~cm})\end{array}$ & $\begin{array}{c}\text { h } \\
(\mathrm{cm})\end{array}$ & $\begin{array}{c}\text { Classificação } \\
\text { NBR 6118:2003 }\end{array}$ \\
\hline B35P20E20e0 & 35 & $20 \times 20$ & $20 \times 20$ & 18,90 & 117,50 & 55 & 25 & Flexível \\
\hline B35P20E25e0 & 35 & $20 \times 20$ & $25 \times 25$ & 18,90 & 117,50 & 55 & 25 & Flexível \\
\hline B35P20E30e0 & 35 & $20 \times 20$ & $30 \times 30$ & 18,90 & 117,50 & 55 & 25 & Flexível \\
\hline B35P30E20e0 & 35 & $20 \times 30$ & $20 \times 20$ & 18,90 & 117,50 & 55 & 25 & Flexível \\
\hline B35P30E25e0 & 35 & $20 \times 30$ & $25 \times 25$ & 18,90 & 117,50 & 55 & 25 & Flexível \\
\hline B35P30E30e0 & 35 & $20 \times 30$ & $30 \times 30$ & 18,90 & 117,50 & 55 & 25 & Flexível \\
\hline B35P40E20e0 & 35 & $20 \times 40$ & $20 \times 20$ & 18,90 & 117,50 & 55 & 25 & Flexível \\
\hline B35P40E25e0 & 35 & $20 \times 40$ & $25 \times 25$ & 18,90 & 117,50 & 55 & 25 & Flexível \\
\hline B35P40E30e0 & 35 & $20 \times 40$ & $30 \times 30$ & 18,90 & 117,50 & 55 & 25 & Flexível \\
\hline B45P20E20e0 & 45 & $20 \times 20$ & $20 \times 20$ & 18,90 & 117,50 & 55 & 35 & Rígido \\
\hline B45P20E25e0 & 45 & $20 \times 20$ & $25 \times 25$ & 18,90 & 117,50 & 55 & 35 & Rígido \\
\hline B45P20E30e0 & 45 & $20 \times 20$ & $30 \times 30$ & 18,90 & 117,50 & 55 & 35 & Rígido \\
\hline B45P30E20e0 & 45 & $20 \times 30$ & $20 \times 20$ & 18,90 & 117,50 & 55 & 35 & Rígido \\
\hline B45P30E25e0 & 45 & $20 \times 30$ & $25 \times 25$ & 18,90 & 117,50 & 55 & 35 & Rígido \\
\hline B45P30E30e0 & 45 & $20 \times 30$ & $30 \times 30$ & 18,90 & 117,50 & 55 & 35 & Rígido \\
\hline B45P40E20e0 & 45 & $20 \times 40$ & $20 \times 20$ & 18,90 & 117,50 & 55 & 35 & Rígido \\
\hline B45P40E25e0 & 45 & $20 \times 40$ & $25 \times 25$ & 18,90 & 117,50 & 55 & 35 & Rígido \\
\hline B45P40E30e0 & 45 & $20 \times 40$ & $30 \times 30$ & 18,90 & 117,50 & 55 & 35 & Rígido \\
\hline B55P20E20e0 & 55 & $20 \times 20$ & $20 \times 20$ & 18,90 & 117,50 & 55 & 45 & Rígido \\
\hline B55P20E25e0 & 55 & $20 \times 20$ & $25 \times 25$ & 18,90 & 117,50 & 55 & 45 & Rígido \\
\hline B55P20E30e0 & 55 & $20 \times 20$ & $30 \times 30$ & 18,90 & 117,50 & 55 & 45 & Rígido \\
\hline B55P30E20e0 & 55 & $20 \times 30$ & $20 \times 20$ & 18,90 & 117,50 & 55 & 45 & Rígido \\
\hline B55P30E25e0 & 55 & $20 \times 30$ & $25 \times 25$ & 18,90 & 117,50 & 55 & 45 & Rígido \\
\hline B55P30E30e0 & 55 & $20 \times 30$ & $30 \times 30$ & 18,90 & 117,50 & 55 & 45 & Rígido \\
\hline B55P40E20e0 & 55 & $20 \times 40$ & $20 \times 20$ & 18,90 & 117,50 & 55 & 45 & Rígido \\
\hline B55P40E25e0 & 55 & $20 \times 40$ & $25 \times 25$ & 18,90 & 117,50 & 55 & 45 & Rígido \\
\hline $\mathrm{B} 55 \mathrm{P} 40 \mathrm{E} 30 \mathrm{e} 0$ & 55 & $20 \times 40$ & $30 \times 30$ & 18,90 & 117,50 & 55 & 45 & Rígido \\
\hline
\end{tabular}

Nota: $\mathrm{B}_{\mathrm{lx}}$ e $\mathrm{B}_{\mathrm{ly}}$ são os comprimentos dos blocos em planta.

A distância entre os eixos das estacas de todos os blocos foi igual a sessenta e cinco centímetros.

Utilizando as indicações de Moraes (1976), fez-se uma previsão da capacidade portante dos blocos e verificou-se que todos romperiam por fendilhamento da biela de compressão, pois a tensão de tração no concreto foi superior ao valor limite $\left(f_{c t k}-\right.$ resistência característica do concreto à tração). Isso não se confirmou nos modelos numéricos, pois os blocos resistiram a forças superiores a calculadas pelo critério de Moraes (1976).

Com relação aos pilares e as estacas, adotou-se resistência característica do concreto à compressão igual a $50 \mathrm{MPa}$, evitando assim, ruptura desses elementos. A armadura das estacas e dos pilares foram compostas por quatro barras de aço com diâmetro de $16 \mathrm{~mm}$ e resistência característica de escoamento igual a $500 \mathrm{MPa}$, totalizando área de aço igual a $8,0 \mathrm{~cm}^{2}$. 


\subsubsection{Elementos finitos utilizados}

Para a modelagem do material concreto, utilizou-se o elemento finito Solid 65. Esse elemento possui oito nós com três graus de liberdade por nó - translações nas direções $x, y$ e $z$. O elemento apresenta deformações plásticas, fissuração e esmagamento em três direções ortogonais. No elemento Solid 65, a fissuração ocorre quando a tensão principal de tração em qualquer direção atinge a superfície de ruptura. Depois da fissuração, o módulo de elasticidade do concreto torna-se igual a zero na direção considerada. O esmagamento ocorre quando todas as tensões de compressão atingem a superfície de ruptura, subseqüentemente, o módulo de elasticidade torna-se igual a zero em todas as direções. A Figura 3.2 apresenta o elemento Solid 65.

$\mathrm{Na}$ modelagem das barras de aço da armadura foi utilizado o elemento finito Link 8. Esse elemento tem dois nós, sendo que cada nó possui três graus de liberdade - translações nas direções x, y e z. A Figura 3.3 mostra esse elemento. Optou-se por esse elemento, pois as armaduras nos modelos eram discretas.

Nos modelos, não foi considerado o fenômeno da aderência entre as barras de aço e o concreto. Apesar disso, os resultados das comparações entre resultados experimentais e numéricos mostraram-se satisfatórios.

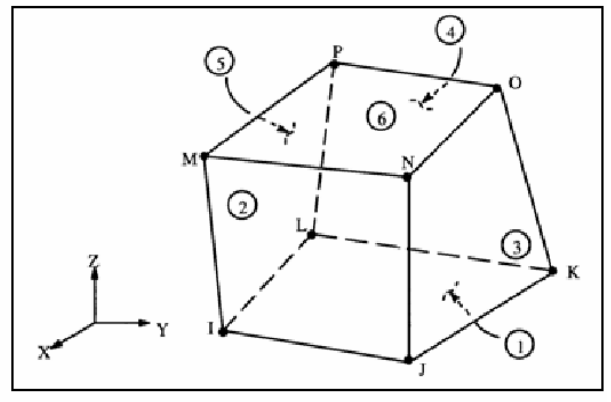

Figura 3.2 - Solid 65, Ansys ${ }^{\circledR}$ (1988).

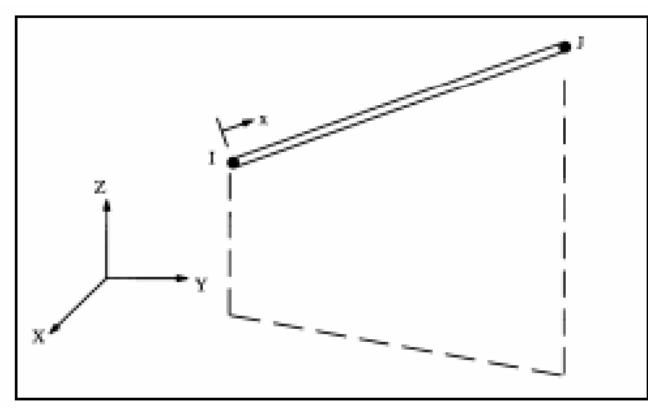

Figura 3.3 - Link 8, Ansys $^{\circledR}$ (1988).

\subsubsection{Propriedades dos materiais}

Desenvolver um modelo capaz de representar o comportamento do concreto o mais próximo do real é um desafio. O concreto armado é um material quase-frágil e tem diferentes comportamentos na compressão e na tração. 
Na compressão, a curva tensão vs. deformação do concreto é elástica e linear até aproximadamente $30 \%$ da força última de compressão. Após esse ponto, o concreto perde rigidez e segue ganhando resistência até a força de ruptura. Depois disso, não há aumento da resistência sofrendo amolecimento. Na tração, a curva tensão vs. deformação do concreto é aproximadamente elástica e linear até a tensão de tração máxima. Após esse ponto, o concreto fissura e sua resistência é nula.

Para modelar o material concreto, é necessário fornecer ao programa Ansys ${ }^{\circledR}$ os seguintes dados de entrada: módulo de elasticidade longitudinal do concreto; resistência última do concreto à compressão e tração; coeficiente de Poisson; e coeficientes de transferência de cisalhamento. $\mathrm{O}$ Ansys ${ }^{\circledR}$ também permite como dado de entrada, a inclusão de uma curva tensão vs. deformação para representar as propriedades mecânicas do concreto. Isso normalmente é feito, quando por problemas de convergência, o processamento é interrompido bruscamente por esmagamento precoce do concreto. Kachlakev et al. (2001) trazem maiores informações sobre esse fenômeno. Nos modelos analisados, não ocorreu este problema.

O módulo de elasticidade longitudinal do concreto, $E_{c}$, como também, a resistência última à tração, $\mathrm{f}_{\mathrm{tk}}$, foram determinadas com base nas recomendações da NBR 6118:2003. O coeficiente de Poisson, $v$, adotado para o concreto foi igual a 0,2 e os coeficientes de transferência cisalhamento, $\beta$ adotados foram iguais a 1 para fissuras abertas e fechadas. Os coeficientes $\beta$ utilizaram esse valor, pois testes feitos demonstraram maior eficiência na convergência do processamento quando utilizou-se o valor mencionado.

Foi utilizado o critério de ruptura Concrete fornecido pelo ANSYS. O modelo é capaz de simular o comportamento do material concreto. Para a definição da superfície de ruptura se faz necessário apenas dois parâmetros: as resistências à compressão e tração últimas do concreto. O critério de ruptura Concrete é análogo ao critério de ruptura de Willam-Warnke. A Figura 3.4 apresenta a superfície de ruptura.

Para as barras de aço, adotou-se comportamento elastoplástico perfeito. $\mathrm{O}$ módulo de elasticidade utilizado foi igual a $210 \mathrm{GPa}$, o coeficiente de Poisson igual a 0,3 e a resistência característica ao escoamento igual a $500 \mathrm{MPa}$.

O elemento finito Solid 65, permite que o fenômeno tension stiffening, que nada mais é, do que a rigidez residual do material entre fissuras seja considerada. Incorporam-se também ao modelo elementos de armadura, adequados para modelagem de estrutura de concreto armado. Em todas as análises numéricas o tension stiffening foi implementado. 
Por meio de testes feitos anteriormente, constatou-se que o critério de NewtonRaphson foi o que apresentou melhores resultados quanto à convergência dos modelos, sendo assim, em todas as análises utilizou-se esse critério.

No Anexo A encontram-se mais informações a respeito do critério de ruptura utilizado na modelagem.

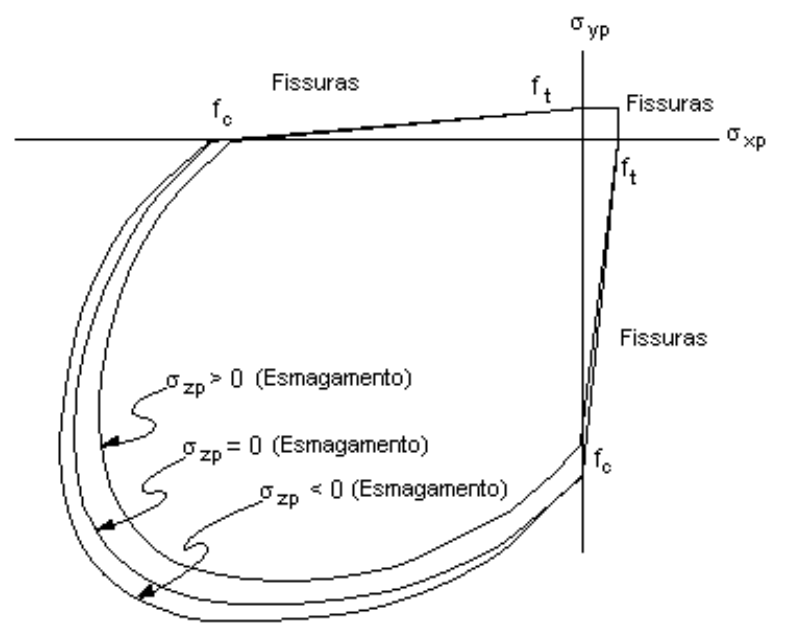

$\mathrm{f}_{\mathrm{c}}$, resistência à compressão; $\mathrm{f}_{\mathrm{t}}$, resistência à tração; $\sigma_{\mathrm{zp}}$, tensão na direção $z$, no ponto considerado.

Figura 3.4 - Superfície de ruptura, Concrete, Ansys ${ }^{\circledR}$ (1988).

\subsubsection{Análise comparativa}

Visando verificar se os modelos adotados para a análise numérica dos blocos sobre duas estacas mostram tendência de comportamento correta, fizeram-se análises comparativas de ensaios experimentais de vários pesquisadores, entre eles estão: Mautoni (1972), Adebar et al. (1990), Sam \& lyer (1995) e Chan \& Poh (2000).

$\mathrm{Na}$ análise comparativa, também utilizaram-se os mesmos elementos finitos empregados nas análises dos blocos sobre duas estacas, ou seja, o Solid 65 discretizando o material concreto e o Link 8 - modelando as barras de aço. Todas as propriedades mecânicas e geométricas adotadas na análise comparativa foram as mesmas dos ensaios experimentais. As condições de contorno empregadas nos modelos numéricos tentaram representar as condições de contorno empregadas nos experimentos com maior grau de realidade possível, o mesmo acontecendo com o carregamento. 
A primeira análise comparativa trata-se do bloco B1-A ensaiado por Mautoni (1972). O bloco teve ruptura por cisalhamento com força última igual a $800 \mathrm{kN}$. A primeira fissura surgiu com aproximadamente trinta por cento da força última, cerca de $240 \mathrm{kN}$. O bloco tinha altura de vinte e cinco centímetros, o pilar era quadrado com área igual a $225 \mathrm{~cm}^{2}$ e as estacas tinham seções transversais iguais a $10 \mathrm{~cm} \times 15 \mathrm{~cm}$. O concreto apresentou resistência à compressão igual a 32,30 $\mathrm{MPa}$ e as barras de aço do tirante apresentavam resistência ao escoamento igual a $720 \mathrm{MPa}$. Como não existiam informações sobre o módulo de elasticidade e sobre os coeficientes de Poisson do aço e concreto, adotaram-se as recomendações da NBR 6118:2003. As Figuras 2.5 e 2.6 mostram os blocos ensaiados por Mautoni (1972).

Aplicou-se no modelo numérico trezentos incrementos de força, sendo que, para cada incremento o valor da força aplicada era de 2,67 kN.

$\mathrm{O}$ valor da força que originou a primeira fissura no modelo numérico foi de $312,33 \mathrm{kN}$. Ocorreu diferença de $23,15 \%$ com relação ao valor da força que originou a primeira fissura no modelo experimental. Isso ocorreu, pois, no modelo experimental, a força que provocou a primeira fissura foi determinada em função de observação visual, ou seja, a primeira fissura visível ao olho humano. Com relação à força última, o modelo numérico, apresentou força última de $799,98 \mathrm{kN}$, praticamente, não ocorrendo diferença com o valor obtido experimentalmente.

A Figura 3.5 mostra a configuração final obtida no experimento e na simulação do bloco B1-A.

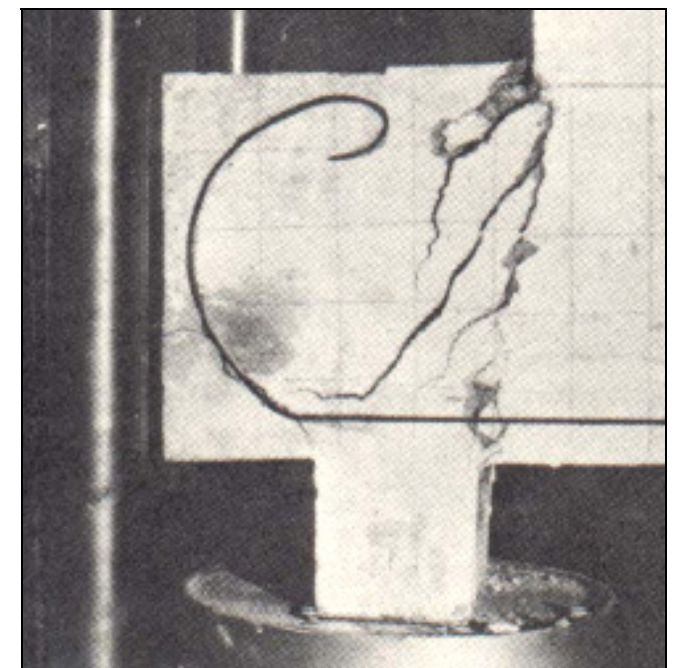

a) experimental

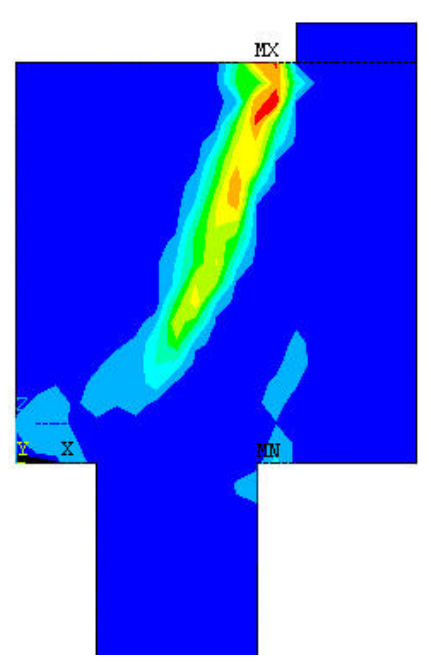

b) numérico

Figura 3.5 - Configuracção final do bloco B1-A. 
A segunda análise comparativa trata-se dos blocos ensaiados por Adebar et al. (1990). Foram simulados os blocos A, B, C, D e F. Maiores detalhes dos blocos podem ser vistos na Figura 12. Todos os blocos tinham altura de sessenta centímetros e coeficientes de Poisson iguais 0,3 e 0,2 para aço e concreto respectivamente. Em todos o blocos foram aplicados quinhentos incrementos de força.

O Bloco A era constituído por quatro estacas com diâmetro de vinte centímetros e pilar com seção transversal quadrada com trinta centímetros de lado. A resistência média do concreto à compressão $\left(f_{c m}\right)$ obtida nos ensaios foi igual a 27,10 MPa. As barras de aço possuíam resistência ao escoamento igual a $479 \mathrm{MPa}$. No ensaio, a primeira fissura surgiu com força igual a $1186 \mathrm{kN}$ e a força de ruptura foi igual a $1781 \mathrm{kN}$. No modelo numérico, a primeira fissura ocorreu com força igual a 1403,86 e a força de ruína obtida foi igual a $1781,10 \mathrm{kN}$.

O Bloco B possuía as mesmas propriedades geométricas do Bloco $\mathrm{A}$, porém, a armadura era distribuída sobre as estacas, enquanto que no Bloco $\mathrm{A}$, a armadura era distribuída em malha. A resistência do concreto a compressão foi de $24,80 \mathrm{MPa}$ e a resistência ao escoamento das barras de aço dos tirantes foi a mesma do Bloco A. No ensaio, a primeira fissura surgiu para uma força de 1679 kN, já, no modelo numérico, a primeira fissura ocorreu com $1505,71 \mathrm{kN}$. A força de ruína experimental foi registrada com valor igual a $2189 \mathrm{kN}$ e na simulação numérica, a força obtida foi de $2186 \mathrm{kN}$.

O Bloco C tinha seis estacas com diâmetros de vinte centímetros e pilar com a mesma seção transversal dos demais modelos. A resistência média do concreto à compressão era de 27,10 MPa enquanto que a resistência ao escoamento das barras de aço dos tirantes tinha valor igual $479 \mathrm{MPa}$. A primeira fissura no ensaio surgiu para uma força de $1780 \mathrm{kN}$ e a força de ruptura observada foi de 2892 kN. No modelo numérico essas forças foram de 1588,30 kN e 2647,70 kN respectivamente.

O Bloco $D$ era semelhante ao Bloco $B$, mudando-se apenas a área das barras de aço da armadura do tirante. A resistência do concreto à compressão foi igual a $30,30 \mathrm{MPa}$ e a resistência ao escoamento das barras igual a de $486 \mathrm{MPa}$. A primeira fissura apresentou-se para a força de $1122 \mathrm{kN}$ e a ruptura do bloco se deu para a força de $3222 \mathrm{kN}$. Na simulação numérica, a força que originou a primeira fissura foi de 1097,74 kN e a força de ruína observada foi de 3212,17 kN. Apesar de obter boa correlação entre as forças de fissuração e última, a simulação numérica apresentou diferenças significativas em relação à rigidez do bloco ensaiado experimentalmente (ver Figura 3.9).

O Bloco $F$ tinha as mesmas propriedades mecânicas do Bloco $B$, porém, mudou-se apenas a forma geométrica do mesmo. A força que provocou a primeira 
fissura no ensaio foi igual a $650 \mathrm{kN}$ e a força de ruína observada foi igual a $3026 \mathrm{kN}$. Na simulação numérica, essas forças foram de 501,94 kN e 2589,74 kN.

As Figuras 3.6, 3.7, 3.8, 3.9 e 3.10 mostram as correlações obtidas entre os resultados experimentais e numéricos e a Tabela 3.6 as relações entre as forças últimas experimentais e numéricas.

Tabela 3.6 - Relações entre resultados numéricos e experimentais.

\begin{tabular}{c|c|c|c}
\hline \hline Blocos & $\begin{array}{c}\mathbf{F}_{\mathbf{u}, \mathbf{e x p}} \\
(\mathbf{k N})\end{array}$ & $\begin{array}{c}\mathbf{F}_{\mathbf{u}, \text { num }} \\
(\mathbf{k N})\end{array}$ & $\mathbf{F}_{\mathbf{u}, \text { exp }} / \mathbf{F}_{\mathbf{u}, \text { num }}$ \\
\hline Bloco A & 1781 & 1781,10 & 0,99 \\
\hline Bloco B & 2189 & 2186 & 1,00 \\
\hline Bloco C & 2892 & 2647,7 & 1,09 \\
\hline Bloco D & 3222 & 3212,70 & 1,01 \\
\hline Bloco F & 3026 & 2589,74 & 1,17 \\
\hline \hline
\end{tabular}

Nota: $F_{u, e x p}$, força última obtida experimental; $F_{u, n u}$, força última obtida numericamente.

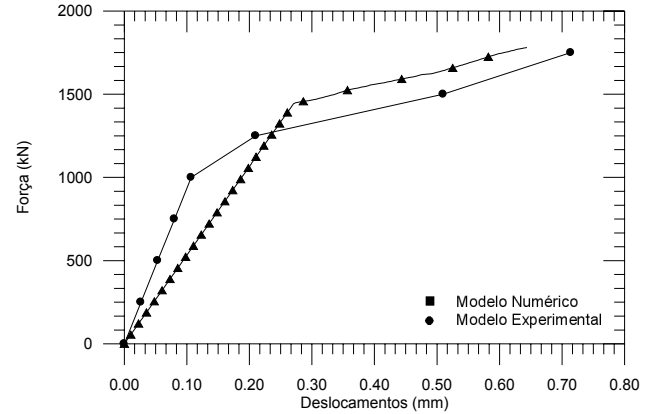

Figura 3.6 - Bloco A, Adebar et al. (1990).

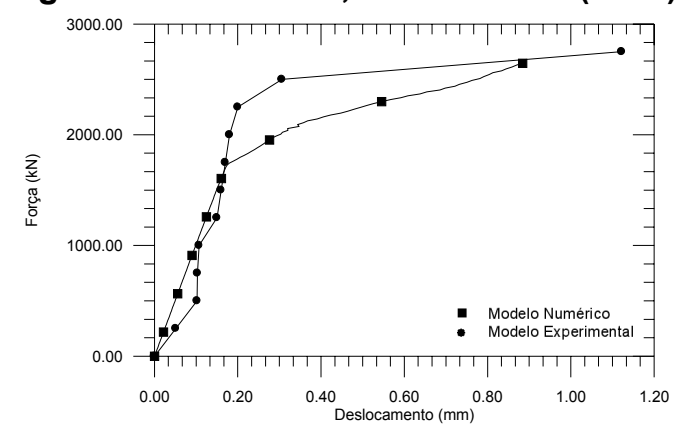

Figura 3.8 - Bloco C, Adebar et al. (1990).

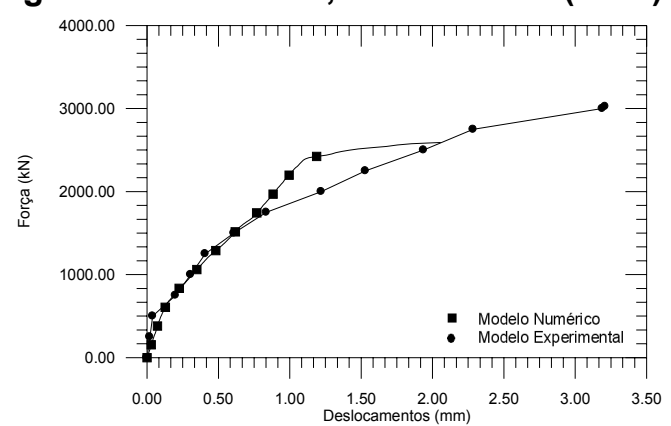

Figura 3.10 - Bloco F, Adebar et al. (1990).

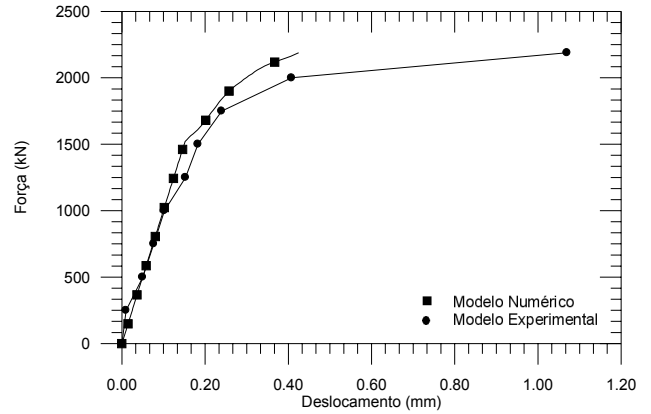

Figura 3.7 - Bloco B, Adebar et al. (1990).

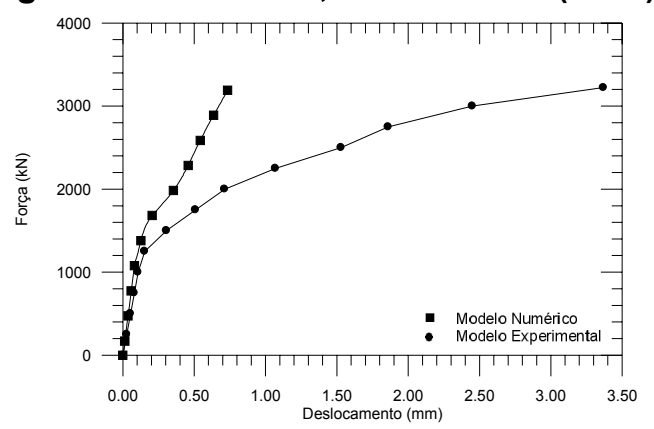

Figura 3.9 - Bloco D, Adebar et al. (1990). 
A terceira análise comparativa refere-se aos blocos simulados numericamente por lyer \& Sam (1995). Foram simulados os blocos com arranjo de armadura distribuída em malha e sobre as estacas (ver Figura 2.13).

Os blocos tinham altura de vinte e dois centímetros e cinco milímetros e eram compostos por quatros estacas com seção transversal quadrada de $10 \mathrm{~cm} \times 10 \mathrm{~cm}$. Os pilares também tinham seção quadrada com $14,14 \mathrm{~cm} \times 14,14 \mathrm{~cm}$ de lado. $A$ resistência característica do concreto era igual a $19 \mathrm{MPa}$ e a resistência característica ao escoamento das barras de aço igual a $300 \mathrm{MPa}$. O coeficiente de Poisson adotado para aço e concreto foi 0,3 e 0,2 respectivamente. Nas simulações numéricas adotaram-se 345 incrementos de força. As forças últimas obtidas nas análises desenvolvidas por lyer \& Sam (1995) foram de: $600 \mathrm{kN}$, para armadura em malha e $560 \mathrm{kN}$, para armadura sobre as estacas. Na simulação numérica desenvolvida neste texto, as forças encontradas foram de: $582,17 \mathrm{kN}$ para os blocos com arranjo de armadura distribuída em malha e $594,59 \mathrm{kN}$ para os blocos com arranjo de armadura distribuída sobre as estacas. As Figuras 3.11 e 3.12 apresentam as correlações entre os resultados obtidos.

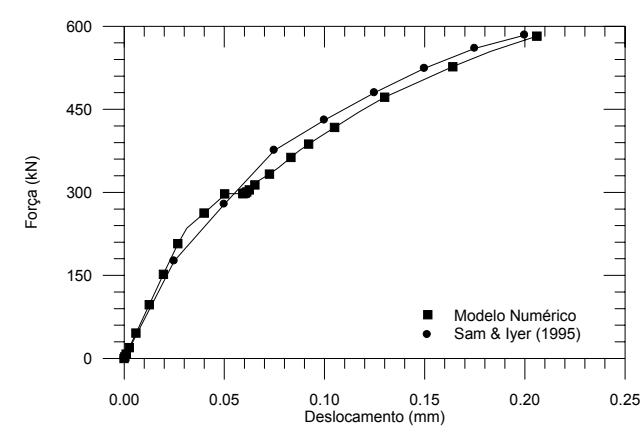

Figura 3.11 - Armadura distribuída em malha, Sam \& lyer (1995).

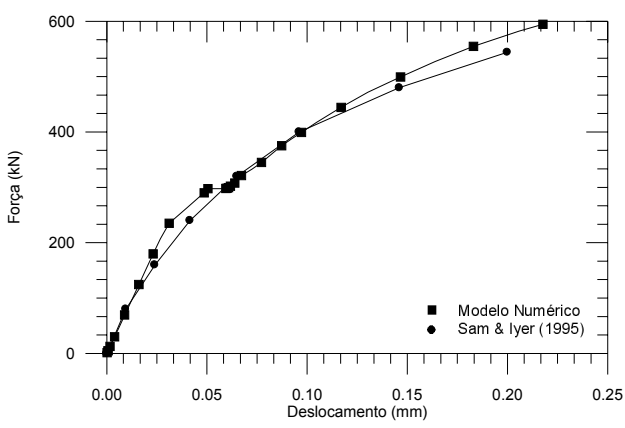

Figura 3.12 - Armadura distribuída sobre as estacas, Sam \& lyer (1995).

Observa-se nas Figuras 3.11 e 3.12, que existe ótima correlação entre os resultados, indicando que o modelo adotado na análise numérica foi coerente.

A quarta e última análise comparativa é referente aos blocos analisados experimentalmente por Chan \& Poh (2000). Foram ensaiados três blocos (Bloco A, Bloco $\mathrm{B}$ e Bloco $\mathrm{C}$ ), sendo que dois eram pré-moldados e um moldado in-loco.

O Bloco A tinha dimensões em planta de $100 \mathrm{~cm} \times 100 \mathrm{~cm}$ e altura de $40 \mathrm{~cm}$. Era apoiado sobre quatro estacas de seção transversal de $15 \mathrm{~cm} \times 15 \mathrm{~cm}$ e carregado por um pilar com seção transversal de $20 \mathrm{~cm}$ x $20 \mathrm{~cm}$. A resistência do concreto foi de 
39,70 MPa e o coeficiente de Poisson e o módulo de deformação longitudinal do concreto foram calculados de acordo com as recomendações da NBR 6118:2003, pois não havia informações sobre esses dados. O coeficiente de Poisson adotado foi igual a 0,2 e o módulo de elasticidade transversal do concreto igual a $29992 \mathrm{MPa}$. As barras de aço tinham resistência ao escoamento igual a 480,70 $\mathrm{MPa}$. O coeficiente de Poisson e o Módulo de deformação longitudinal do aço também foram adotados segundo as recomendações da NBR 6118:2003, sendo seu valores iguais a 0,3 e 210GPa, respectivamente. A armadura era distribuída em malha com espaçamento de $11 \mathrm{~cm}$. No modelo numérico, aplicaram-se seiscentos incrementos de força. A primeira fissura surgiu para uma força de $840 \mathrm{kN}$ e a força de ruptura foi de $1230 \mathrm{kN}$. Na simulação numérica, os valores da força de fissuração e última foram: 704, 42 kN e $1228 \mathrm{kN}$ respectivamente.

O Bloco B tinha as mesmas propriedades geométricas do Bloco A, porém, parte do Bloco B era pré-moldado. A parte pré-moldada era constituída por uma casca com $7,5 \mathrm{~cm}$ de largura e altura igual a altura do bloco. Essa casca era posicionada em todo o perímetro do bloco. A resistência a compressão do concreto pré-moldado foi igual a 33,4 MPa. A parte do bloco que foi moldado no local teve resistência à compressão igual a 38,3 MPa. A Figura 3.13 mostra esquematicamente o bloco prémoldado. Os módulos de elasticidade do concreto e do aço, como também os coeficientes de Poisson, foram determinados com os critérios da NBR 6118:2003. A primeira fissura surgiu para uma força de $900 \mathrm{kN}$ e a ruptura se deu para uma força de $1250 \mathrm{kN}$. Os valores numéricos da força que provocou a primeira fissura foi igual a 696,7 kN e o valor da força última foi igual a $1247,45 \mathrm{kN}$.

O Bloco $\mathrm{C}$ tinha as mesmas propriedades geométricas do Bloco $\mathrm{B}$, apenas sofrendo alteração em sua altura, que era de $30 \mathrm{~cm}$. As resistências dos concretos moldado no local e pré-moldado foram de 36,40 MPa e 35,80 MPa. Os módulos de elasticidade longitudinal do concreto e aço também foram determinados por meio da NBR 6118:2003. A primeira fissura ocorreu para a força de $450 \mathrm{kN}$ e a força de ruptura foi igual a $870 \mathrm{kN}$. No modelo numérico, a força que provocou a primeira fissura foi igual a $383,41 \mathrm{kN}$ e a força última foi igual a $865 \mathrm{kN}$.

As Figuras $3.14,3.15$ e 3.16 mostram as correlações entre os resultados experimentais e numéricos. 


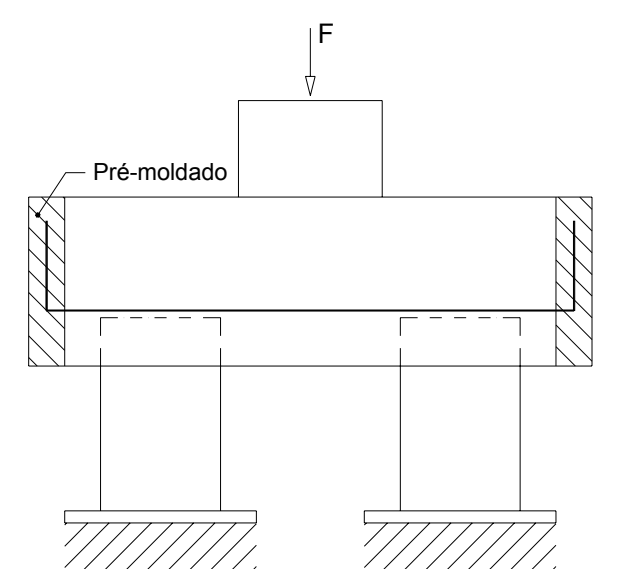

Figura 3.13 - Propriedades gerais do Blocos ensaiados por Chan \& Poh (2000).

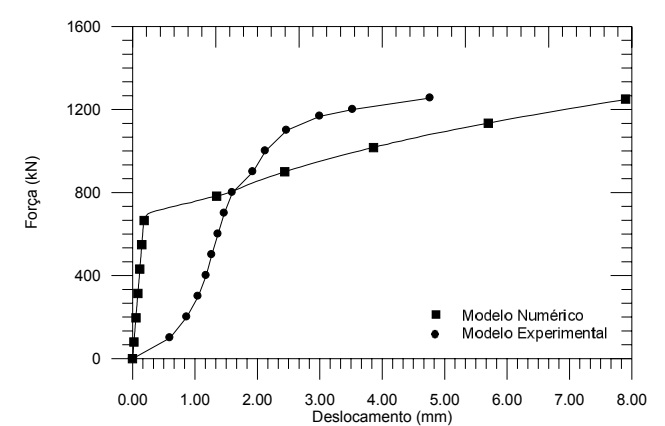

Figura 3.15 - Bloco B, Chan \& Poh (2000).

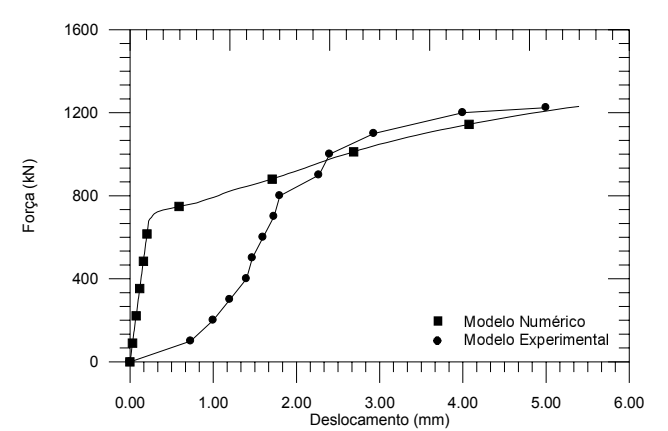

Figura 3.14 - Bloco A, Chan \& Poh (2000).

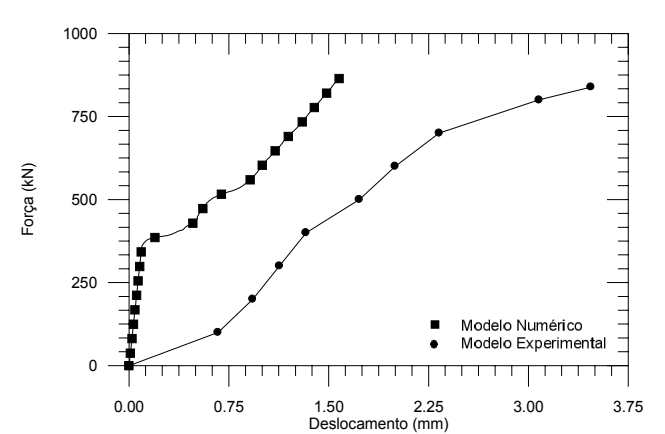

Figura 3.16 - Bloco C, Chan \& Poh (2000).

Verifica-se por meio das Figuras 3.14, 3.15 e 3.16, que as correlações entre os resultados experimentais e numéricos não apresentaram resultados satisfatórios. Porém, em relação à força últimas e de fissuração, constata-se que houve boa concordância entre os resultados. A diferença entre as curvas experimental e numérica dos gráficos acima, provavelmente se deu, em função da rotação dos apoios nos ensaios experimentais, o qual não foi considerado na análise numérica, pois o elemento finito utilizado não o permite.

Apesar da modelagem numérica não apresentar resultados satisfatórios em alguns dos experimentos, conclui-se que a análise numérica pode representar o comportamento estrutural dos blocos sobre duas estacas com razoável precisão.

\subsubsection{Influência do comprimento da estaca e do solo}

Como o ensaio de blocos com estacas de comprimentos reais são de difícil execução, simularam-se blocos com estacas de comprimentos reais, com objetivo de observar o comportamento do fluxo de tensões principais. Para isso, quatro blocos 
foram modelados - três com estacas com comprimentos reais e um com estacas de pequena altura. Na modelagem utilizou-se o bloco padrão para ângulo de inclinação da biela de compressão igual a $45^{\circ}$. O comprimento das estacas foi determinado em função do resultado da sondagem executada pelo Departamento de Geotecnia no campus I da USP em São Carlos. Assim, o comprimento calculado para as estacas foi de 9,0 m. A Figura 3.17 mostra o resultado da sondagem a percussão (S.P.T.) e a Figura 40 os blocos analisados numericamente.

O atrito entre a estaca e o solo não foi levado em consideração. Para o solo existente em torno do fuste da estaca, adotou-se comportamento plástico (critério de ruptura Drucker-Prager). O resultado da sondagem a percussão e as propriedades mecânicas do solo foram obtidas em Senna Júnior (1993).

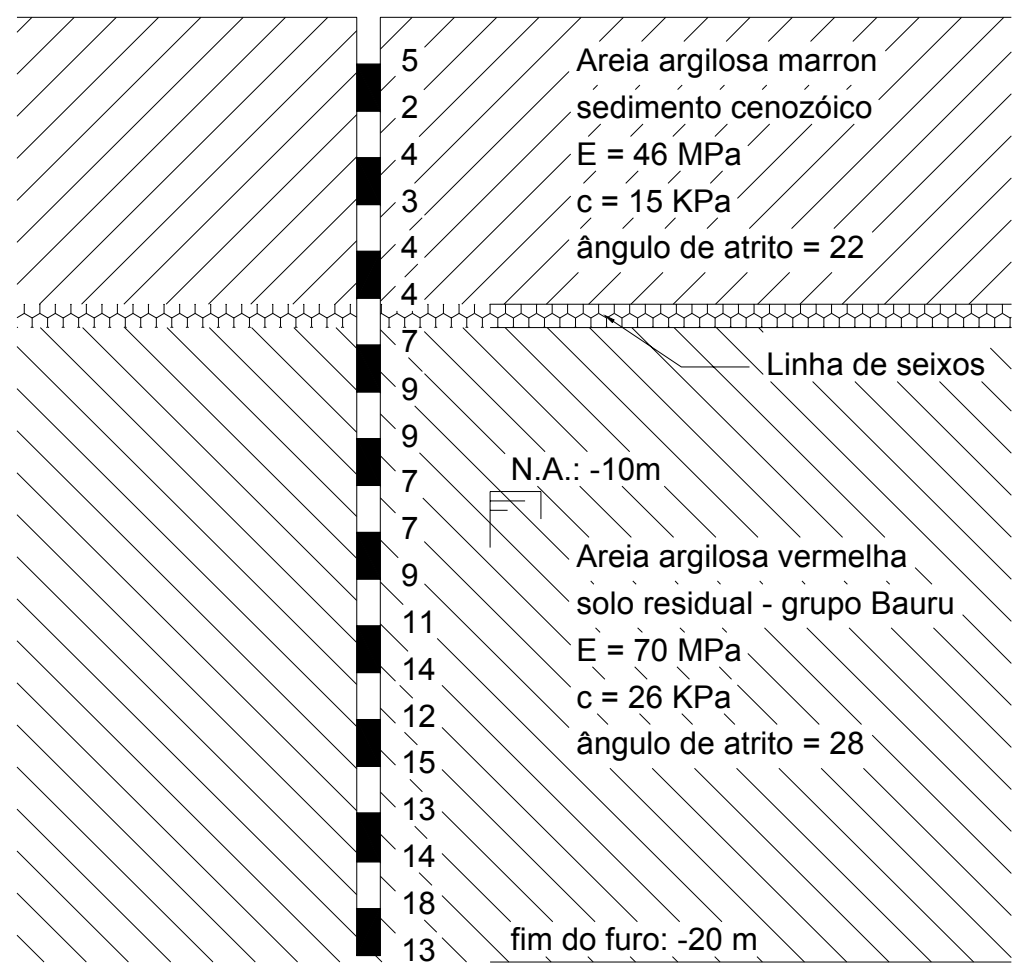

Figura 3.17 - Resultado do ensaio de SPT, Senna Júnior (1993).

Na modelagem do solo, utilizou-se o modelo do Meio Contínuo elástico (Solo 1, 4 e 5 - Figura 3.18) e elastoplástico (Solo 1 e 2 - Figura 3.18). O solo poderia ser modelado utilizando as hipóteses de Winkler (pressões de contato são proporcionais aos recalques), porém, segundo Velloso (1996), o modelo do Meio Contínuo representa com maior precisão o fenômeno da interação solo-estrutura.

Para evitar que ocorresse perturbação localizada de tensões no ponto de aplicação da força, modelou-se uma placa de aço na cabeça do pilar com espessura 
de cinco centímetros e material elástico e linear, o mesmo ocorrendo em toda a análise numérica desenvolvida.

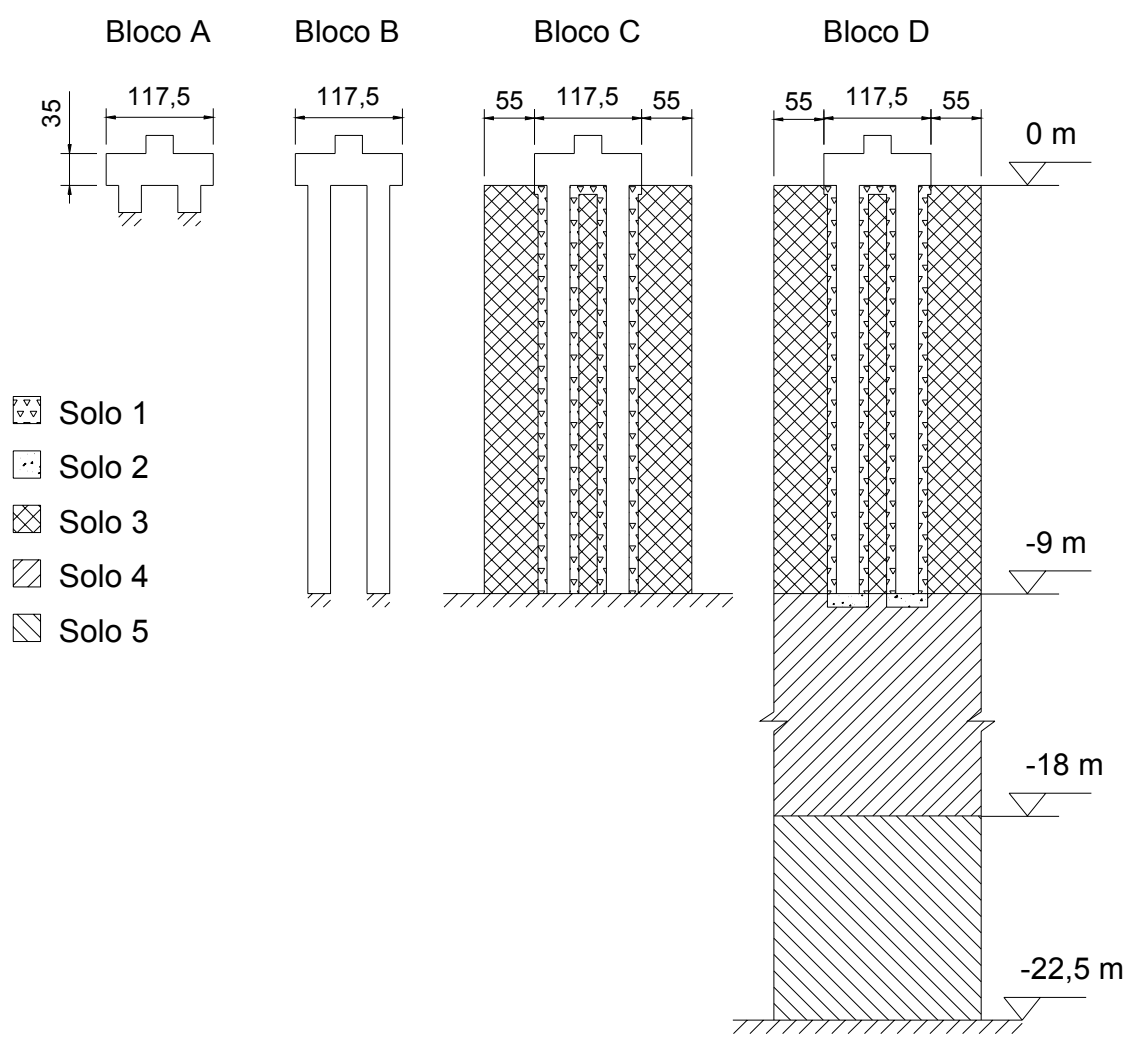

Figura 3.18 - Blocos analisados com comprimento real da estaca.

A força foi aplicada por meio de cem incrementos, admitindo-a centrada. Nos modelos onde não existia a contribuição do solo (Bloco A e B), aplicou-se força até a ruína do bloco. Nos demais modelos, a ação aplicada correspondeu à capacidade de carga das estacas, ou seja, $600 \mathrm{kN}$.

Como se pretendia analisar o comportamento dos blocos, adotou-se nas estacas e nos pilares, concreto com resistência característica à compressão igual a 50 MPa. Os coeficientes de transferência de cisalhamento também tiveram valor igual a 1. O módulo de elasticidade do aço e do concreto, como também os seus respectivos coeficientes de Poisson, foram determinados com auxílio da NBR 6118:2003. As taxas de armadura foram iguais em todos os modelos, sendo que, as áreas de armadura das estacas, dos pilares e dos tirantes foram as mesmas utilizadas na análise de variância dos blocos sobre duas estacas.

A Tabela 3.7 mostra maiores detalhes dos critérios utilizados na modelagem e as Figuras 3.19 e 3.20 mostram a discretização utilizada (elementos finitos com comprimentos iguais a $2,5 \mathrm{~cm}$ ) de um dos blocos analisados. 
Tabela 3.7 - Critérios utilizados na modelagem.

\begin{tabular}{|c|c|c|c|c|}
\hline $\begin{array}{l}\text { Elemento } \\
\text { Estrutural }\end{array}$ & Elemento Finito & $\begin{array}{c}\text { Constantes } \\
\text { Reais } \\
\end{array}$ & $\begin{array}{l}\text { Propriedades } \\
\text { dos Materiais }\end{array}$ & $\begin{array}{c}\text { Informações } \\
\text { adicionais }\end{array}$ \\
\hline Pilar & Solid 65 & 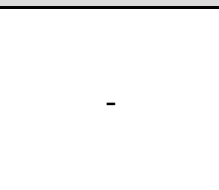 & $\begin{array}{c}\mathrm{E}_{\mathrm{c}}=33658 \mathrm{MPa} \\
\mathrm{v}=0,3 \\
\mathrm{f}_{\mathrm{ck}}=50 \mathrm{MPa} \\
\mathrm{f}_{\mathrm{tk}}=4,07 \mathrm{MPa} \\
\beta=1\end{array}$ & $\begin{array}{l}\text { Comportamento } \\
\text { plástico - Concrete }\end{array}$ \\
\hline Bloco & Solid 65 & - & $\begin{array}{c}\mathrm{E}_{\mathrm{c}}=21287 \mathrm{MPa} \\
v=0,3 \\
\mathrm{f}_{\mathrm{ck}}=20 \mathrm{MPa} \\
\mathrm{f}_{\mathrm{tk}}=2,21 \mathrm{MPa} \\
\beta=1\end{array}$ & $\begin{array}{l}\text { Comportamento } \\
\text { plástico - Concrete }\end{array}$ \\
\hline Estaca & Solid 65 & - & $\begin{array}{c}\mathrm{E}_{\mathrm{c}}=33658 \mathrm{MPa} \\
v=0,3 \\
\mathrm{f}_{\mathrm{ck}}=50 \mathrm{MPa} \\
\mathrm{f}_{\mathrm{tk}}=4,07 \mathrm{MPa} \\
\beta=1\end{array}$ & $\begin{array}{l}\text { Comportamento } \\
\text { plástico - Concrete }\end{array}$ \\
\hline$A_{s, \text { tirante }}$ & Link 8 & $\begin{array}{c}\mathrm{A}_{\mathrm{s}}=3,15 \mathrm{~cm}^{2} \\
\varepsilon_{\mathrm{i}}=0\end{array}$ & $\begin{array}{c}E_{s}=210 \mathrm{MPa} \\
\mathrm{f}_{\mathrm{y}}=500 \mathrm{MPa} \\
v=0,3\end{array}$ & $\begin{array}{c}\text { Comportamento } \\
\text { elastoplástico } \\
\text { perfeito }\end{array}$ \\
\hline $\mathrm{A}_{\mathrm{S}, \text { pilar e estacas }}$ & Link 8 & $\begin{array}{c}\mathrm{A}_{\mathrm{s}}=1,25 \mathrm{~cm}^{2} \\
\varepsilon_{\mathrm{i}}=0\end{array}$ & $\begin{array}{c}\mathrm{E}_{\mathrm{s}}=210 \mathrm{MPa} \\
\mathrm{f}_{\mathrm{y}}=500 \mathrm{MPa} \\
v=0,3\end{array}$ & $\begin{array}{c}\text { Comportamento } \\
\text { elastoplástico } \\
\text { perfeito }\end{array}$ \\
\hline Placa de aço & Solid 65 & & $\begin{array}{c}\mathrm{E}_{\mathrm{s}}=210 \mathrm{MPa} \\
v=0,3\end{array}$ & $\begin{array}{c}\text { Comportamento } \\
\text { elástico }\end{array}$ \\
\hline Estribos & Link 8 & $\begin{array}{c}\mathrm{A}_{\mathrm{s}}=0,50 \mathrm{~cm}^{2} \\
\varepsilon_{\mathrm{i}}=0\end{array}$ & $\begin{array}{c}\mathrm{E}_{\mathrm{s}}=210 \mathrm{MPa} \\
\mathrm{f}_{\mathrm{y}}=500 \mathrm{MPa} \\
v=0,3\end{array}$ & $\begin{array}{c}\text { Comportamento } \\
\text { elastoplástico } \\
\text { perfeito }\end{array}$ \\
\hline Solo 1 & Solid 65 & - & $\begin{array}{c}\mathrm{E}_{\text {solo }}=46 \mathrm{MPa} \\
\mathrm{c}=15 \mathrm{KPa} \\
\phi_{\text {solo }}=22 \\
v=0,3\end{array}$ & $\begin{array}{c}\text { Comportamento } \\
\text { plástico - Drucker- } \\
\text { Prager }\end{array}$ \\
\hline Solo 2 & Solid 65 & - & $\begin{array}{c}\mathrm{E}_{\text {solo }}=70 \mathrm{MPa} \\
\mathrm{c}=26 \mathrm{KPa} \\
\phi_{\text {solo }}=28 \\
\nu=0,3\end{array}$ & $\begin{array}{c}\text { Comportamento } \\
\text { plástico - Drucker- } \\
\text { Prager }\end{array}$ \\
\hline Solo 3 & Solid 65 & - & $\begin{array}{c}\mathrm{E}_{\text {solo }}=46 \mathrm{MPa} \\
v=0,3\end{array}$ & $\begin{array}{c}\text { Comportamento } \\
\text { elástico }\end{array}$ \\
\hline Solo 4 & Solid 65 & - & $\begin{array}{c}\mathrm{E}_{\text {solo }}=70 \mathrm{MPa} \\
v=0,3\end{array}$ & $\begin{array}{c}\text { Comportamento } \\
\text { elástico }\end{array}$ \\
\hline Solo 5 & Solid 65 & - & $\begin{array}{c}\mathrm{E}_{\text {solo }}=1000 \mathrm{MPa} \\
v=0,3\end{array}$ & $\begin{array}{c}\text { Comportamento } \\
\text { elástico }\end{array}$ \\
\hline
\end{tabular}

Nota: c é a coesão do solo e $\phi_{\text {solo }}$ é o ângulo de atrito interno.

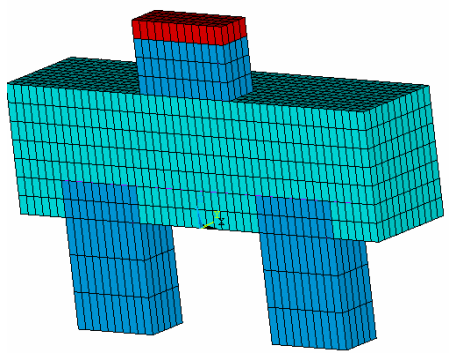

Figura 3.19 - Rede de elementos finitos.

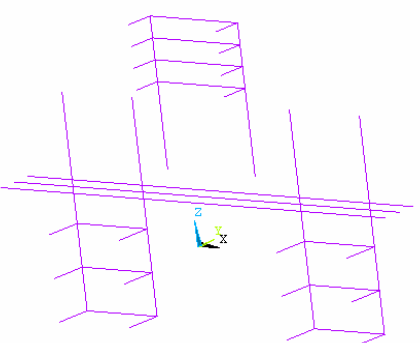

Figura 3.20 - Armadura discretizada. 
Por meio das Figuras 3.21, 3.22, 3.23 e 3.24, observa-se que existe maior concentração de tensões de compressão nas seções do bloco logo abaixo do pilar e nas seções das estacas mais afastadas da borda do bloco. Verificou-se que as estacas não são solicitadas de maneira uniforme, ou seja, as seções mais afastadas das bordas do bloco foram mais solicitadas que as seções mais próximas da borda. Este fenômeno ocorreu em todos os modelos analisados.

Em função da diferença entre as intensidades das forças aplicadas nos blocos sem a presença do solo, que foram maiores, em relação aos blocos modelados com o solo, ocorreram diferenças nas intensidades das tensões principais de compressão.

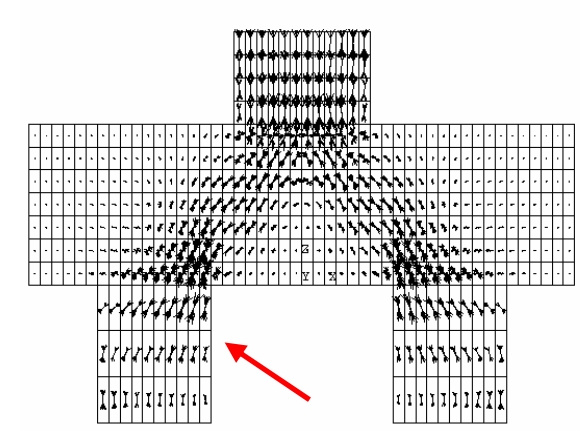

Figura 3.21 - Fluxo das tensões principais de compressão, Bloco A.

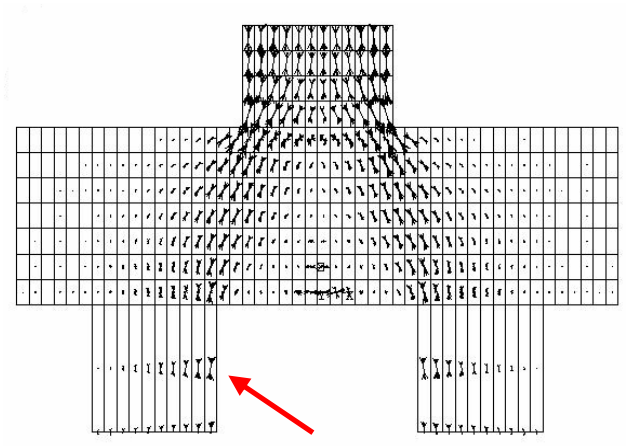

Figura 3.23 - Fluxo das tensões principais de compressão, Bloco C.

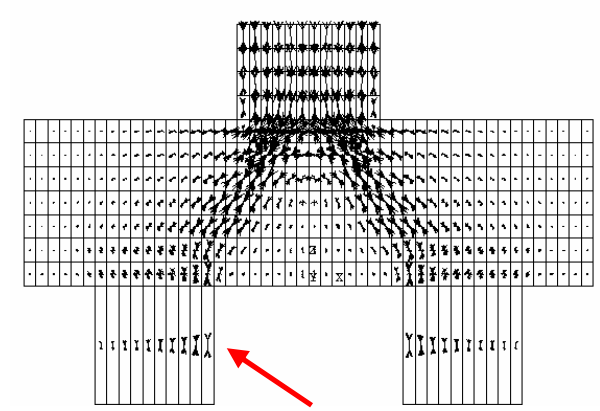

Figura 3.22 - Fluxo das tensões principais de compressão, Bloco B.

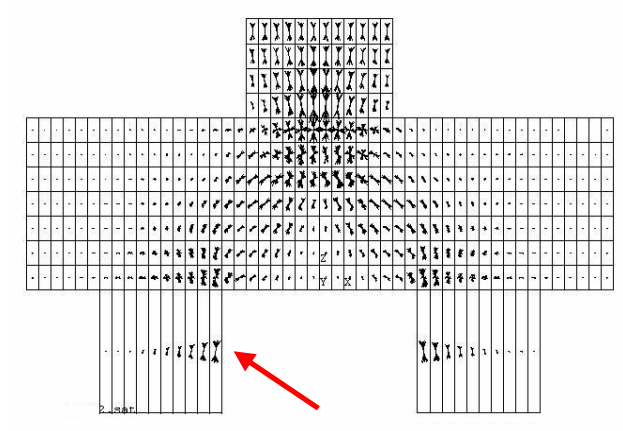

Figura 3.24 - Fluxo das tensões principais de compressão, Bloco D.

A Tabela 3.8 apresenta resultados das intensidades das tensões principais de compressão dos blocos analisados e a Figura 3.25 mostram as seções onde essas tensões foram consideradas. 


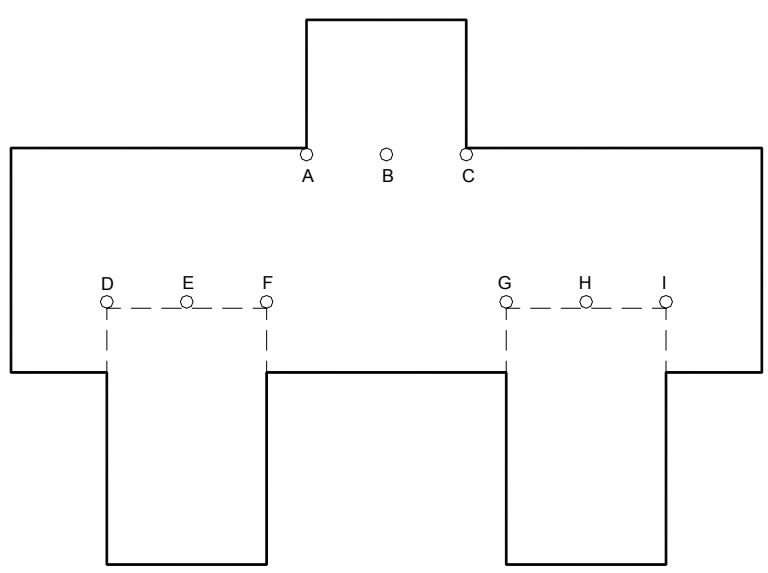

Figura 3.25 - Seções nodais investigadas.

Tabela 3.8 - Intensidades das tensões principais de compressão.

\begin{tabular}{c|c|c|c|c}
\hline \hline \multirow{2}{*}{ Seções } & \multicolumn{4}{|c}{ Tensões principais de compressão (MPa) } \\
\cline { 2 - 5 } & Bloco A & Bloco B & Bloco C & Bloco D \\
\hline A & 16,7 & 11,5 & 13,3 & 11,7 \\
\hline B & 11,9 & 7,5 & 22 & 21,3 \\
\hline C & 16,7 & 11,5 & 13,3 & 11,7 \\
\hline D = & 5,10 & 3,5 & 4,2 & 2,10 \\
\hline E = H & 10,9 & 7,5 & 13,3 & 11,7 \\
\hline F = G & 28,3 & 19,5 & 30,6 & 21,3 \\
\hline \hline
\end{tabular}

Por meio dos valores apresentados na Tabela 3.8 é possível concluir que as seções $F$ e G, na zona nodal inferior (junto às estacas) foram mais solicitadas.

Como nos modelos apenas foram aplicadas forças centradas, constatou-se que na zona nodal superior (junto ao pilar) a seção mais solicitada foi a seção B.

Em função destes resultados, todas as análises desenvolvidas (numéricas e experimentais) foram feitas utilizando estacas curtas.

Um resultado interessante constatado durante estas análises foi com relação à uniformização das tensões principais de compressão nas estacas. Nos blocos $B, C$ e $D$, que tinham estacas com comprimentos longos, se comparadas com o comprimento das estacas do bloco $A$, verificou-se que as tensões se uniformizaram aproximadamente a $1 / 3$ da altura do fuste da estaca.

3.4.6. Análise dos blocos sobre duas estacas com excentricidade igual a zero

A modelagem dos blocos seguiu os critérios apresentados nos itens 3.4.1, 3.4.2 e 3.4.3. Foram analisados vinte e sete blocos com excentricidade da força de compressão igual a zero, com variações nas seções transversais das estacas e dos 
pilares. Os blocos apresentaram comportamento semelhante em relação à força de fissuração e à distribuição de tensões nas direções principais

A Tabela 3.9 apresenta resultados das análises numéricas realizadas.

Tabela 3.9 - Resultados obtidos por meio da análise numérica do blocos com e $=0$.

\begin{tabular}{c|c|c|c|c|c|c}
\hline \hline & \multirow{2}{*}{ Blocos } & $\begin{array}{c}\text { Seção do } \\
\text { pilar } \\
(\mathrm{cm})\end{array}$ & $\begin{array}{c}\text { Seção da } \\
\text { estacas } \\
(\mathrm{cm})\end{array}$ & $\begin{array}{c}\boldsymbol{\theta} \\
\text { (graus) }\end{array}$ & $\begin{array}{c}\mathbf{h} \\
(\mathrm{cm})\end{array}$ & \multicolumn{2}{|c}{$\begin{array}{c}\mathbf{F}_{\mathbf{u}} \\
(\mathrm{kN})\end{array}$} \\
\cline { 5 - 7 } & & & & Blévot & Num. \\
\hline B35P20E20e0 & $20 \times 20$ & $20 \times 20$ & 35 & 25 & 368 & 610 \\
\hline B35P20E25e0 & $20 \times 20$ & $25 \times 25$ & 35 & 25 & 368 & 670 \\
\hline B35P20E30e0 & $20 \times 20$ & $30 \times 30$ & 35 & 25 & 368 & 766 \\
\hline B35P30E20e0 & $20 \times 30$ & $20 \times 20$ & 35 & 25 & 553 & 681 \\
\hline B35P30E25e0 & $20 \times 30$ & $25 \times 25$ & 35 & 25 & 553 & 851 \\
\hline B35P30E30e0 & $20 \times 30$ & $30 \times 30$ & 35 & 25 & 553 & 1031 \\
\hline B35P40E20e0 & $20 \times 40$ & $20 \times 20$ & 35 & 25 & 737 & 908 \\
\hline B35P40E25e0 & $20 \times 40$ & $25 \times 25$ & 35 & 25 & 737 & 1135 \\
\hline B35P40E30e0 & $20 \times 40$ & $30 \times 30$ & 35 & 25 & 737 & 1362 \\
\hline B45P20E20e0 & $20 \times 20$ & $20 \times 20$ & 45 & 35 & 560 & 694 \\
\hline B45P20E25e0 & $20 \times 20$ & $25 \times 25$ & 45 & 35 & 560 & 988 \\
\hline B45P20E30e0 & $20 \times 20$ & $30 \times 30$ & 45 & 35 & 560 & 1077 \\
\hline B45P30E20e0 & $20 \times 30$ & $20 \times 20$ & 45 & 35 & 737 & 1031 \\
\hline B45P30E25e0 & $20 \times 30$ & $25 \times 25$ & 45 & 35 & 840 & 1166 \\
\hline B45P30E30e0 & $20 \times 30$ & $30 \times 30$ & 45 & 35 & 840 & 1345 \\
\hline B45P40E20e0 & $20 \times 40$ & $20 \times 20$ & 45 & 35 & 737 & 1195 \\
\hline B45P40E25e0 & $20 \times 40$ & $25 \times 25$ & 45 & 35 & 1120 & 1375 \\
\hline B45P40E30e0 & $20 \times 40$ & $30 \times 30$ & 45 & 35 & 1120 & 1650 \\
\hline B55P20E20e0 & $20 \times 20$ & $20 \times 20$ & 55 & 45 & 752 & 987 \\
\hline B55P20E25e0 & $20 \times 20$ & $25 \times 25$ & 55 & 45 & 752 & 1185 \\
\hline B55P20E30e0 & $20 \times 20$ & $30 \times 30$ & 55 & 45 & 752 & 1256 \\
\hline B55P30E20e0 & $20 \times 30$ & $20 \times 20$ & 55 & 45 & 1127 & 1256 \\
\hline B55P30E25e0 & $20 \times 30$ & $25 \times 25$ & 55 & 45 & 1127 & 1453 \\
\hline B55P30E30e0 & $20 \times 30$ & $30 \times 30$ & 55 & 45 & 1127 & 1571 \\
\hline B55P40E20e0 & $20 \times 40$ & $20 \times 20$ & 55 & 45 & 1503 & 1465 \\
\hline B55P40E25e0 & $20 \times 40$ & $25 \times 25$ & 55 & 45 & 1503 & 1722 \\
\hline B55P40E30e0 & $20 \times 40$ & $30 \times 30$ & 55 & 45 & 1503 & 1925 \\
\hline \hline
\end{tabular}

Nota: Num., valor obtido por meio da simulação numérica; Blévot, valor calculado por meio dos critérios de Blévot \& Fremy (1967); $F_{u}$, força última.

Por meio da análise numérica, observou-se que existem diferenças significativas nas áreas das bielas de compressão junto à estaca, quando comparadas com as áreas das bielas calculadas utilizando os critérios de Blévot \& Fremy (1967). Observou-se que as áreas das estacas efetivamente comprimidas pelas bielas de compressão nos modelos numéricos possuem áreas aproximadamente iguais à metade da área calculada com os critérios de Blévot \& Frémy (1967), isso indica, que existe equívoco nos valores das tensões verificadas quando se utiliza o critério dos pesquisadores franceses. Faz-se necessário, portanto, estabelecer critérios rigorosos para a determinação da forma geométrica das bielas de compressão. 
A Figura 3.26 mostra a distribuição do fluxo de tensão na direção principal de compressão para o bloco padrão - B45P30E20e0, como também, a forma geométrica das bielas de compressão sugerida. No Anexo B encontram-se todas as figuras dos fluxos de tensões na direção principal de compressão no Estado Limite Último. Todos os blocos tiveram comportamento semelhante ao do bloco mostrado na Figura 3.26. Observa-se por meio desta figura que apenas parte da estaca é solicitada de maneira mais intensa.
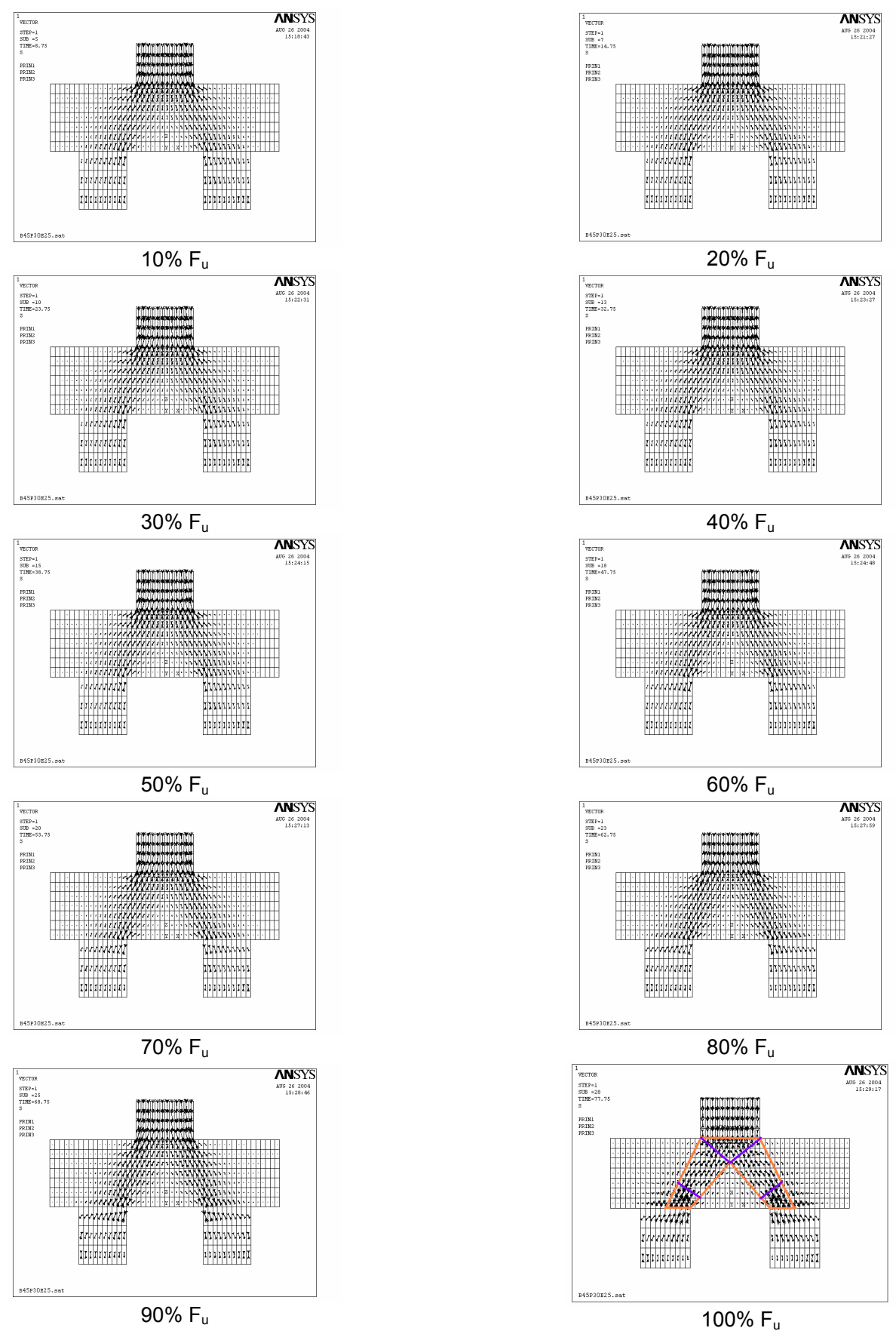

Figura 3.26 - Distribuição do fluxo de tensões principais de compressão, modelo B45P30E25e0. 
A Figura 3.27 apresenta curvas força vs. deslocamento da seção de meio de vão dos blocos analisados numericamente.
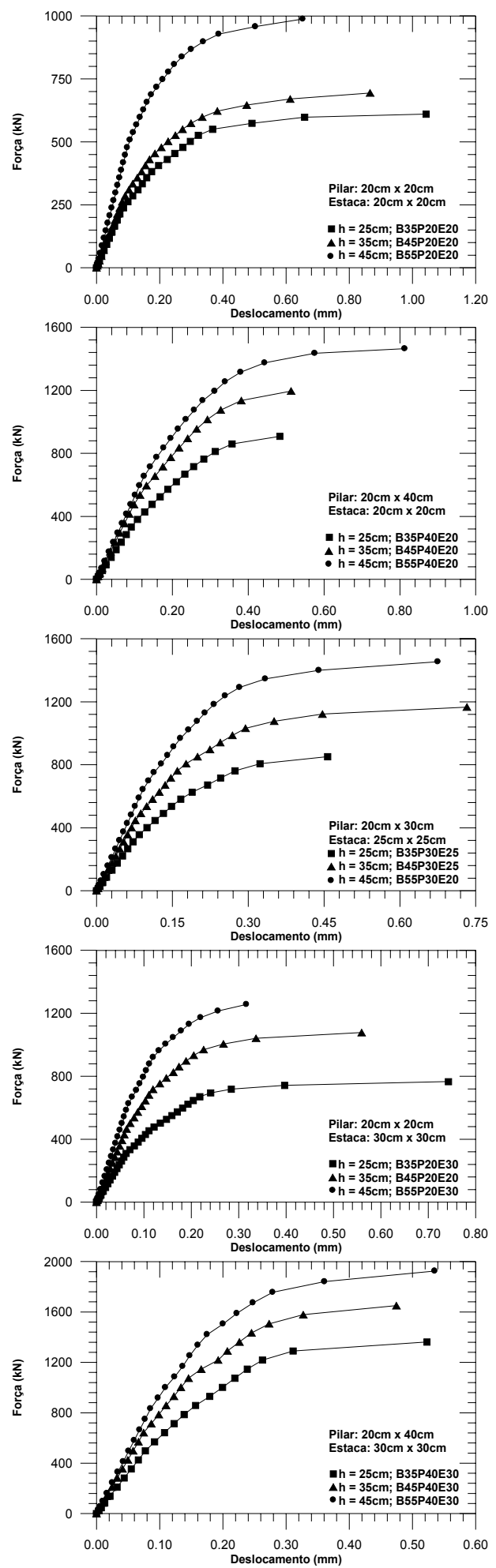
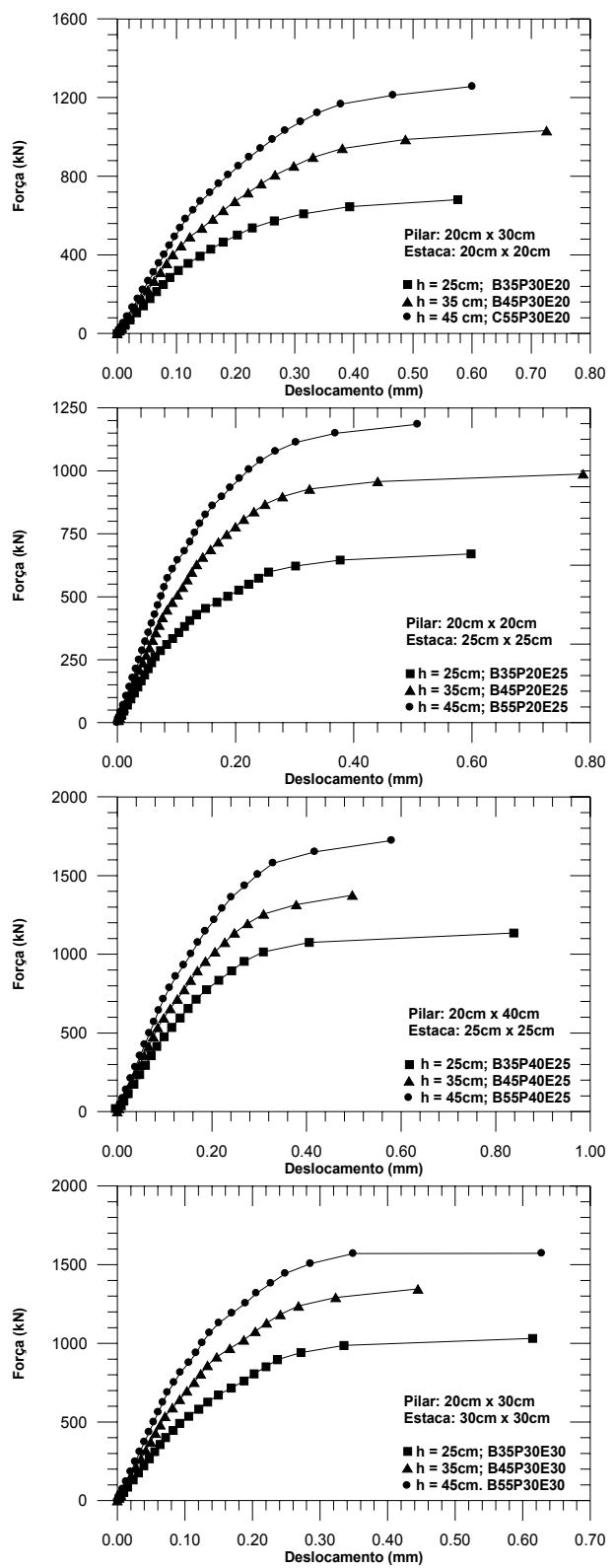

Figura 3.27 - Curvas força vs. deslcoamento, blocos com e = 0 (Grupo A). 
Por meio da Figura 3.27, observou-se que a capacidade portante dos blocos é diretamente afetada pelo ângulo de inclinação das bielas de compressão.

Verificou-se que a primeira fissura surge em torno de $50 \%$ da força última. Essa constatação está de acordo com os resultados de Mautoni (1972), Walraven \& Lehwalter (1989), Adebar et al (1990) e Miguel (2000). Além disso, atentou-se que os blocos com maior altura apresentaram menores forças na armadura principal de tração, evidenciando o efeito de arco existente nos blocos com ângulo de inclinação da biela de compressão maior que $55^{\circ}$.

Por fim, a Figura 3.28 apresenta o panorama de fissuração do bloco B45P30E25e0. Os demais blocos tiveram panorama de fissuração semelhante ao apresentado.
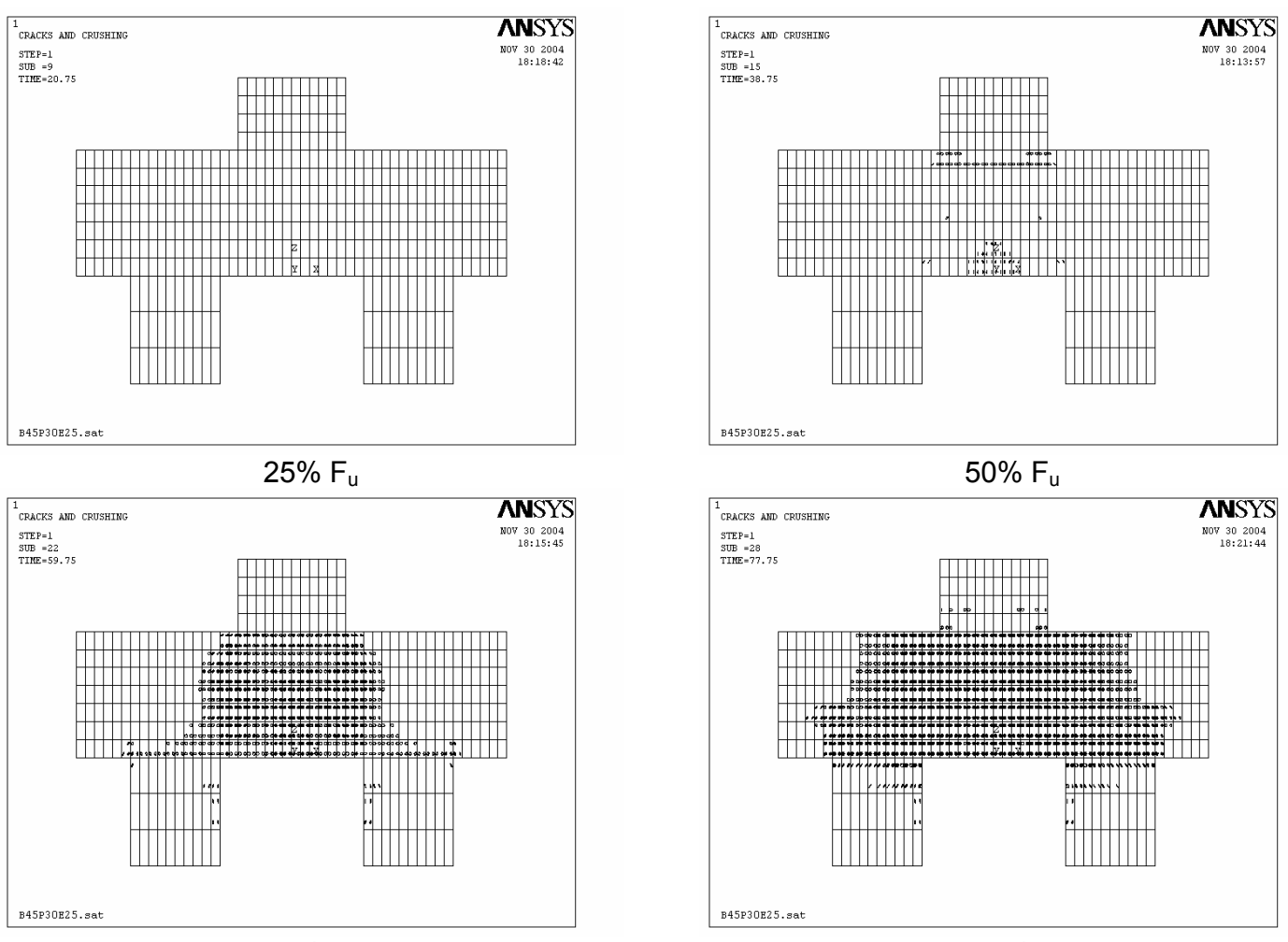

$75 \% \mathrm{Fu}_{\mathrm{u}}$

$100 \% \mathrm{Fu}_{\mathrm{u}}$

Figura 3.28 - Panorama de fissuração, bloco B45P30E25e0.

3.4.7. Análise dos blocos sobre duas estacas com excentricidade igual a cinco centímetros

As análises numéricas desenvolvidas nesse item são análogas às desenvolvidas no item 3.4.6, porém, deslocou-se a posição da força de compressão 
na direção paralela ao eixo longitudinal das estacas (direção X) cinco centímetros em relação ao centro geométrico do pilar.

Esses blocos também apresentaram comportamento semelhante em relação à força de fissuração e à distribuição de tensões nas direções principais.

A Tabela 3.10 apresenta resultados das análises numéricas desenvolvidas.

Tabela 3.10 - Resultados obtidos por meio da análise numérica do blocos com e $=5$.

\begin{tabular}{|c|c|c|c|c|c|c|}
\hline \multirow[t]{2}{*}{ Blocos } & \multirow{2}{*}{$\begin{array}{l}\text { Seção do } \\
\text { pilar } \\
(\mathrm{cm})\end{array}$} & \multirow{2}{*}{$\begin{array}{c}\text { Seção da } \\
\text { estacas } \\
(\mathrm{cm})\end{array}$} & \multirow{2}{*}{$\begin{array}{c}\theta \\
\text { (graus) }\end{array}$} & \multirow{2}{*}{$\begin{array}{c}\mathbf{h} \\
(\mathrm{cm})\end{array}$} & \multicolumn{2}{|c|}{$\begin{array}{c}\mathbf{F}_{\mathbf{u}} \\
(\mathrm{kN})\end{array}$} \\
\hline & & & & & Blévot & Num. \\
\hline B35P20E20e5 & $20 \times 20$ & $20 \times 20$ & 35 & 25 & 368 & 495 \\
\hline B35P20E25e5 & $20 \times 20$ & $25 \times 25$ & 35 & 25 & 368 & 600 \\
\hline B35P20E30e5 & $20 \times 20$ & $30 \times 30$ & 35 & 25 & 368 & 814 \\
\hline B35P30E20e5 & $20 \times 30$ & $20 \times 20$ & 35 & 25 & 553 & 609 \\
\hline B35P30E25e5 & $20 \times 30$ & $25 \times 25$ & 35 & 25 & 553 & 732 \\
\hline B35P30E30e5 & $20 \times 30$ & $30 \times 30$ & 35 & 25 & 553 & 859 \\
\hline B35P40E20e5 & $20 \times 40$ & $20 \times 20$ & 35 & 25 & 737 & 1016 \\
\hline B35P40E25e5 & $20 \times 40$ & $25 \times 25$ & 35 & 25 & 737 & 669 \\
\hline B35P40E30e5 & $20 \times 40$ & $30 \times 30$ & 35 & 25 & 737 & 1163 \\
\hline B45P20E20e5 & $20 \times 20$ & $20 \times 20$ & 45 & 35 & 560 & 707 \\
\hline B45P20E25e5 & $20 \times 20$ & $25 \times 25$ & 45 & 35 & 560 & 792 \\
\hline B45P20E30e5 & $20 \times 20$ & $30 \times 30$ & 45 & 35 & 560 & 812 \\
\hline B45P30E20e5 & $20 \times 30$ & $20 \times 20$ & 45 & 35 & 737 & 904 \\
\hline B45P30E25e5 & $20 \times 30$ & $25 \times 25$ & 45 & 35 & 840 & 1044 \\
\hline B45P30E30e5 & $20 \times 30$ & $30 \times 30$ & 45 & 35 & 840 & 1129 \\
\hline B45P40E20e5 & $20 \times 40$ & $20 \times 20$ & 45 & 35 & 737 & 1048 \\
\hline B45P40E25e5 & $20 \times 40$ & $25 \times 25$ & 45 & 35 & 1120 & 1364 \\
\hline B45P40E30e5 & $20 \times 40$ & $30 \times 30$ & 45 & 35 & 1120 & 1397 \\
\hline B55P20E20e5 & $20 \times 20$ & $20 \times 20$ & 55 & 45 & 751 & 716 \\
\hline B55P20E25e5 & $20 \times 20$ & $25 \times 25$ & 55 & 45 & 751 & 806 \\
\hline B55P20E30e5 & $20 \times 20$ & $30 \times 30$ & 55 & 45 & 751 & 806 \\
\hline B55P30E20e5 & $20 \times 30$ & $20 \times 20$ & 55 & 45 & 1127 & 1129 \\
\hline B55P30E25e5 & $20 \times 30$ & $25 \times 25$ & 55 & 45 & 1127 & 1279 \\
\hline B55P30E30e5 & $20 \times 30$ & $30 \times 30$ & 55 & 45 & 1127 & 787 \\
\hline B55P40E20e5 & $20 \times 40$ & $20 \times 20$ & 55 & 45 & 1503 & 1328 \\
\hline B55P40E25e5 & $20 \times 40$ & $25 \times 25$ & 55 & 45 & 1503 & 1475 \\
\hline B55P40E30e5 & $20 \times 40$ & $30 \times 30$ & 55 & 45 & 1503 & 1553 \\
\hline
\end{tabular}

Nota: Num., valor obtido por meio da simulação numérica; Blévot, valor calculado por meio dos critérios de Blévot \& Fremy (1967); $F_{u}$, força última.

Por meio da análise numérica, verificou-se que também existem diferenças nas áreas das bielas de compressão quando comparadas com o critério estabelecido por Blévot \& Frémy (1967), pois apenas parte das estacas estão solicitadas de maneira mais intensa.

A Figura 3.29 apresenta gráficos da distribuição do fluxo de tensão na direção principal de compressão para o bloco padrão - B45P30E20e5. Também é mostrada a forma geométrica das bielas de compressão (sugerida) no Estado Limite Último. No 
Anexo B encontram-se todas as figuras dos fluxos das tensões principais de compressão.

Todos os blocos modelados com excentricidade igual a cinco centímetros tiveram comportamento semelhante ao do bloco mostrado na Figura 3.29.
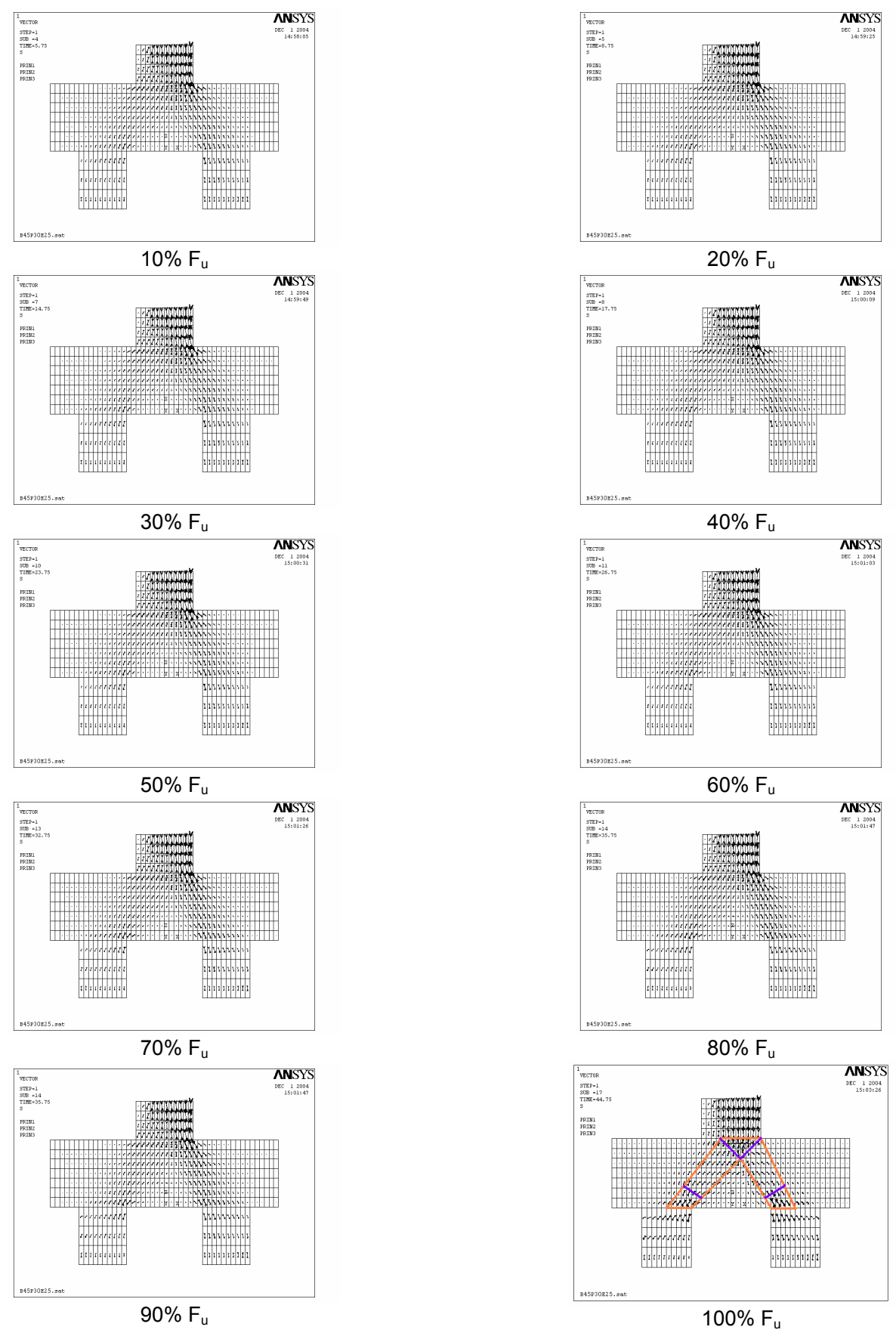

Figura 3.29 - Distribuição do fluxo de tensões principais de compressão, modelo B45P30E25e5.

A Figura 3.30 apresenta curvas força vs. deslocamento na seção de meio de vão dos blocos analisados numericamente. 
Analisando a Figura 3.30, constatou-se que os blocos com alturas maiores apresentaram maior capacidade portante, comprovando que o ângulo de inclinação da biela de compressão é fator preponderante para a capacidade portante dos blocos.
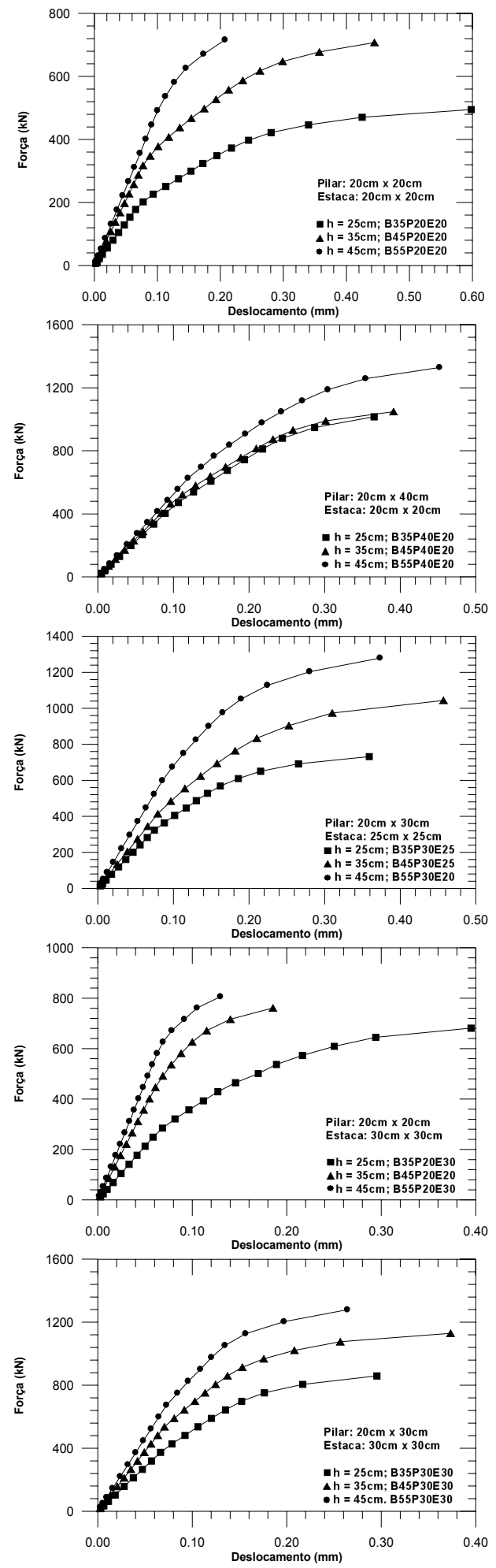

Figura 3.30 - Curvas força vs. deslcoamento, blocos com e = 5 (Grupo B).
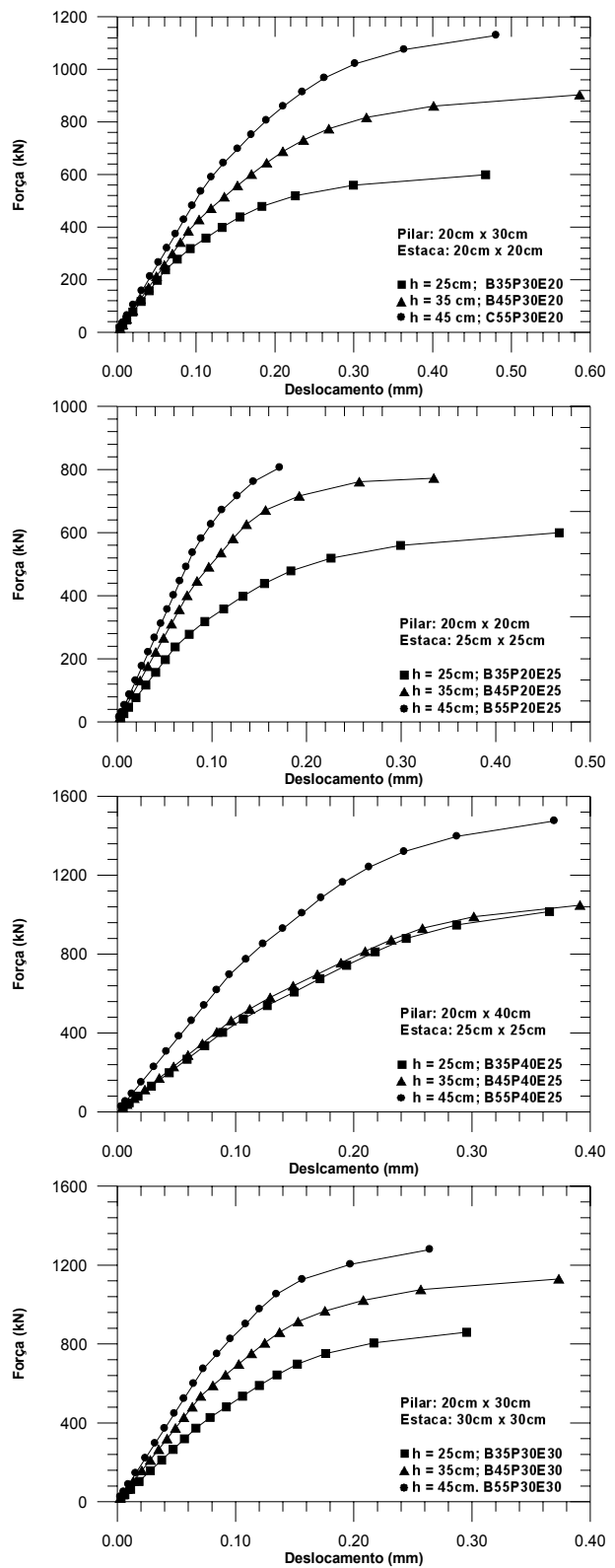
A primeira fissura também surgiu em torno de $50 \%$ da força última, semelhante aos blocos com excentricidade igual a zero.

Por fim, a Figura 3.31 apresenta o panorama de fissuração do bloco B45P30E25e5. Os demais blocos apresentaram o mesmo panorama de fissuração.
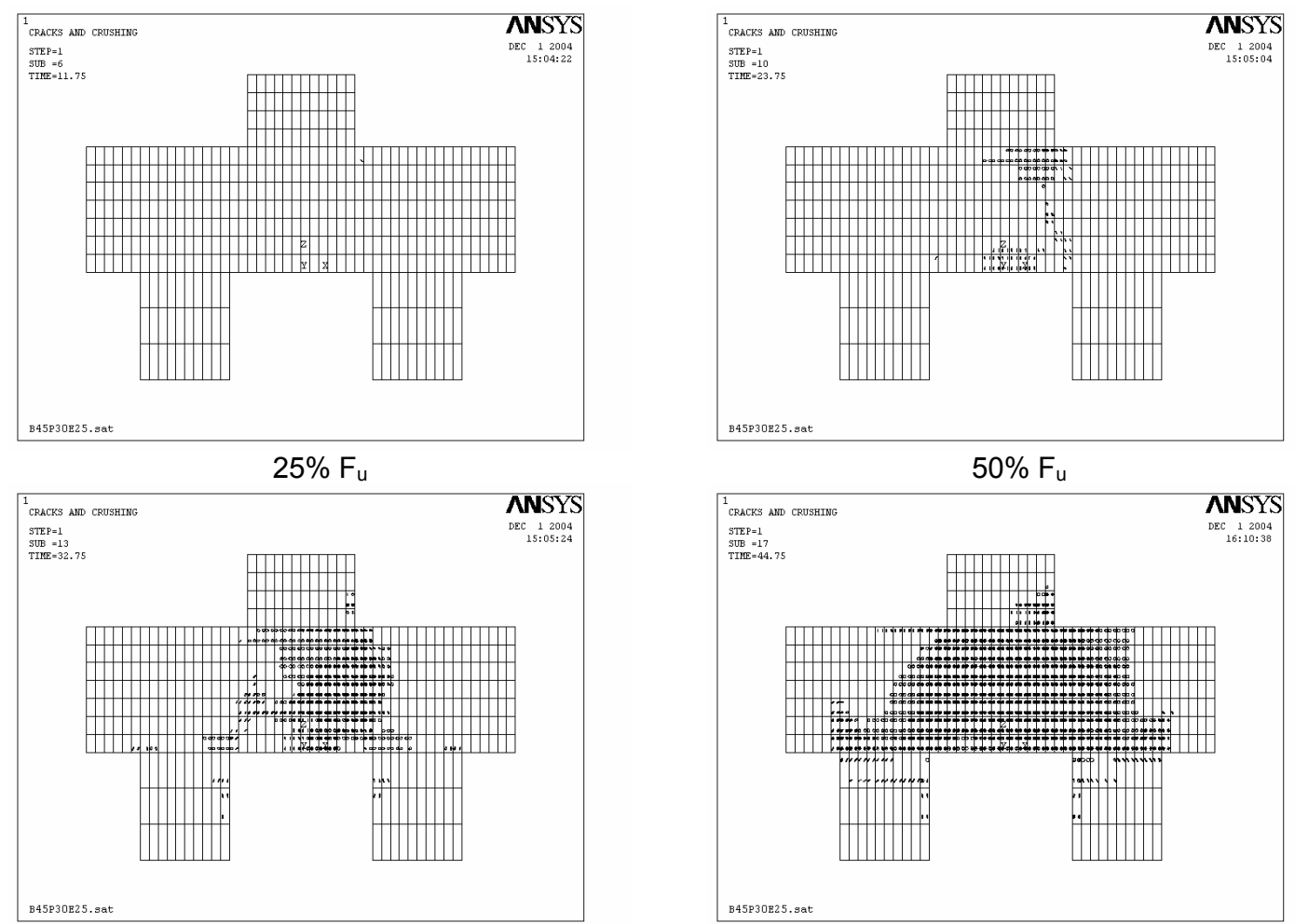

$75 \% \mathrm{~F}_{\mathrm{u}}$

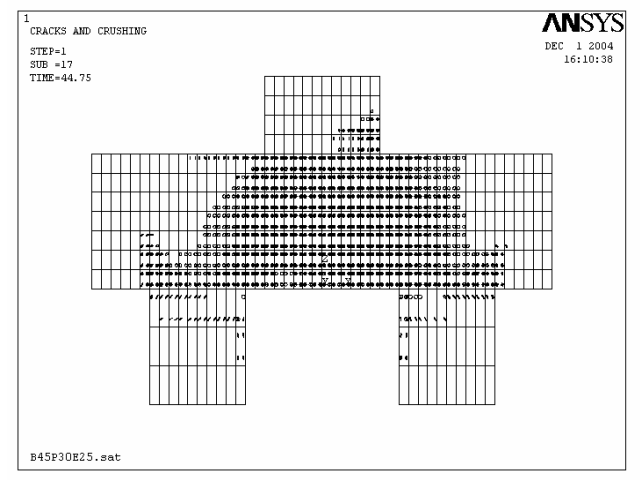

$100 \% \mathrm{Fu}_{\mathrm{u}}$

Figura 3.31 - Panorama de fissuração, bloco B45P30E25e5.

Por meio da figura anterior, nota-se que a fissuração é mais intensa na região do bloco mais solicitada pela força de compressão aplicada no topo do pilar.

3.4.8. Análise dos blocos sobre duas estacas com excentricidade igual a dez centímetros

As análises numéricas desenvolvidas nesse item são análogas às desenvolvidas no item 3.4.6 e 3.4.7, porém, deslocou-se a posição da força de compressão na direção longitudinal do bloco (direção $\mathrm{X}$ ) dez centímetros em relação ao centro geométrico do pilar.

Esses blocos também apresentaram comportamento semelhante em relação à força de fissuração e à distribuição de tensões nas direções principais.

A Tabela 3.11 apresenta resultados das análises numéricas desenvolvidas. 
Tabela 3.11 - Resultados obtidos por meio da análise numérica do blocos com e $=10$.

\begin{tabular}{c|c|c|c|c|c|c}
\hline \hline & \multirow{2}{*}{ Blocos } & $\begin{array}{c}\text { Seção do } \\
\text { pilar }\end{array}$ & $\begin{array}{c}\text { Seção da } \\
\text { estacas } \\
(\mathbf{c m})\end{array}$ & $\begin{array}{c}\boldsymbol{\theta} \\
\text { (graus) }\end{array}$ & $\begin{array}{c}\mathbf{h} \\
(\mathbf{c m})\end{array}$ & \multicolumn{2}{|c}{$\begin{array}{c}\mathbf{F}_{\mathbf{u}} \\
\text { (kN) }\end{array}$} \\
\cline { 5 - 7 } & & & & Blévot & Num. \\
\hline B35P20E20e0 & $20 \times 20$ & $20 \times 20$ & 35 & 25 & 368 & 299 \\
\hline B35P20E25e0 & $20 \times 20$ & $25 \times 25$ & 35 & 25 & 368 & 287 \\
\hline B35P20E30e0 & $20 \times 20$ & $30 \times 30$ & 35 & 25 & 368 & 239 \\
\hline B35P30E20e0 & $20 \times 30$ & $20 \times 20$ & 35 & 25 & 553 & 434 \\
\hline B35P30E25e0 & $20 \times 30$ & $25 \times 25$ & 35 & 25 & 553 & 561 \\
\hline B35P30E30e0 & $20 \times 30$ & $30 \times 30$ & 35 & 25 & 553 & 676 \\
\hline B35P40E20e0 & $20 \times 40$ & $20 \times 20$ & 35 & 25 & 737 & 675 \\
\hline B35P40E25e0 & $20 \times 40$ & $25 \times 25$ & 35 & 25 & 737 & 788 \\
\hline B35P40E30e0 & $20 \times 40$ & $30 \times 30$ & 35 & 25 & 737 & 913 \\
\hline B45P20E20e0 & $20 \times 20$ & $20 \times 20$ & 45 & 35 & 560 & 374 \\
\hline B45P20E25e0 & $20 \times 20$ & $25 \times 25$ & 45 & 35 & 560 & 341 \\
\hline B45P20E30e0 & $20 \times 20$ & $30 \times 30$ & 45 & 35 & 560 & 358 \\
\hline B45P30E20e0 & $20 \times 30$ & $20 \times 20$ & 45 & 35 & 737 & 673 \\
\hline B45P30E25e0 & $20 \times 30$ & $25 \times 25$ & 45 & 35 & 840 & 747 \\
\hline B45P30E30e0 & $20 \times 30$ & $30 \times 30$ & 45 & 35 & 840 & 672 \\
\hline B45P40E20e0 & $20 \times 40$ & $20 \times 20$ & 45 & 35 & 737 & 913 \\
\hline B45P40E25e0 & $20 \times 40$ & $25 \times 25$ & 45 & 35 & 1120 & 1021 \\
\hline B45P40E30e0 & $20 \times 40$ & $30 \times 30$ & 45 & 35 & 1120 & 1021 \\
\hline B55P20E20e0 & $20 \times 20$ & $20 \times 20$ & 55 & 45 & 751 & 311 \\
\hline B55P20E25e0 & $20 \times 20$ & $25 \times 25$ & 55 & 45 & 751 & 349 \\
\hline B55P20E30e0 & $20 \times 20$ & $30 \times 30$ & 55 & 45 & 751 & 358 \\
\hline B55P30E20e0 & $20 \times 30$ & $20 \times 20$ & 55 & 45 & 1127 & 694 \\
\hline B55P30E25e0 & $20 \times 30$ & $25 \times 25$ & 55 & 45 & 1127 & 607 \\
\hline B55P30E30e0 & $20 \times 30$ & $30 \times 30$ & 55 & 45 & 1127 & 822 \\
\hline B55P40E20e0 & $20 \times 40$ & $20 \times 20$ & 55 & 45 & 1503 & 1129 \\
\hline B55P40E25e0 & $20 \times 40$ & $25 \times 25$ & 55 & 45 & 1503 & 1183 \\
\hline B55P40E30e0 & $20 \times 40$ & $30 \times 30$ & 55 & 45 & 1503 & 1277 \\
\hline \hline
\end{tabular}

Nota: Num., valor obtido por meio da simulação numérica; Blévot, valor calculado por meio dos critérios de Blévot \& Fremy (1967); $F_{u}$, força última.

Por meio da análise numérica, verificou-se que também nestes casos, ocorreram diferenças nas áreas das bielas de compressão quando comparadas com o critério estabelecido por Blévot \& Frémy (1967). Nestas análises, constatou-se que apenas parte da seção transversal da estaca foi solicitada de maneira mais intensa.

A Figura 3.32 apresenta gráficos da distribuição do fluxo das tensões principais de compressão para o bloco padrão - B45P30E20e10. Nesta figura também é mostrada a forma geométrica das bielas de compressão (sugerida) no Estado Limite Último. No Anexo B encontram-se todas as figuras dos fluxos das tensões principais de compressão no Estado Limite Último. Todos os blocos modelados com excentricidade igual a dez centímetros tiveram comportamento semelhante ao do bloco da Figura 3.32.

Por meio desta figura observaram-se maiores concentrações de tensões em regiões específicas: abaixo do pilar na direção da aplicação da força de compressão e nas seções das estacas mais afastadas das bordas dos blocos. 

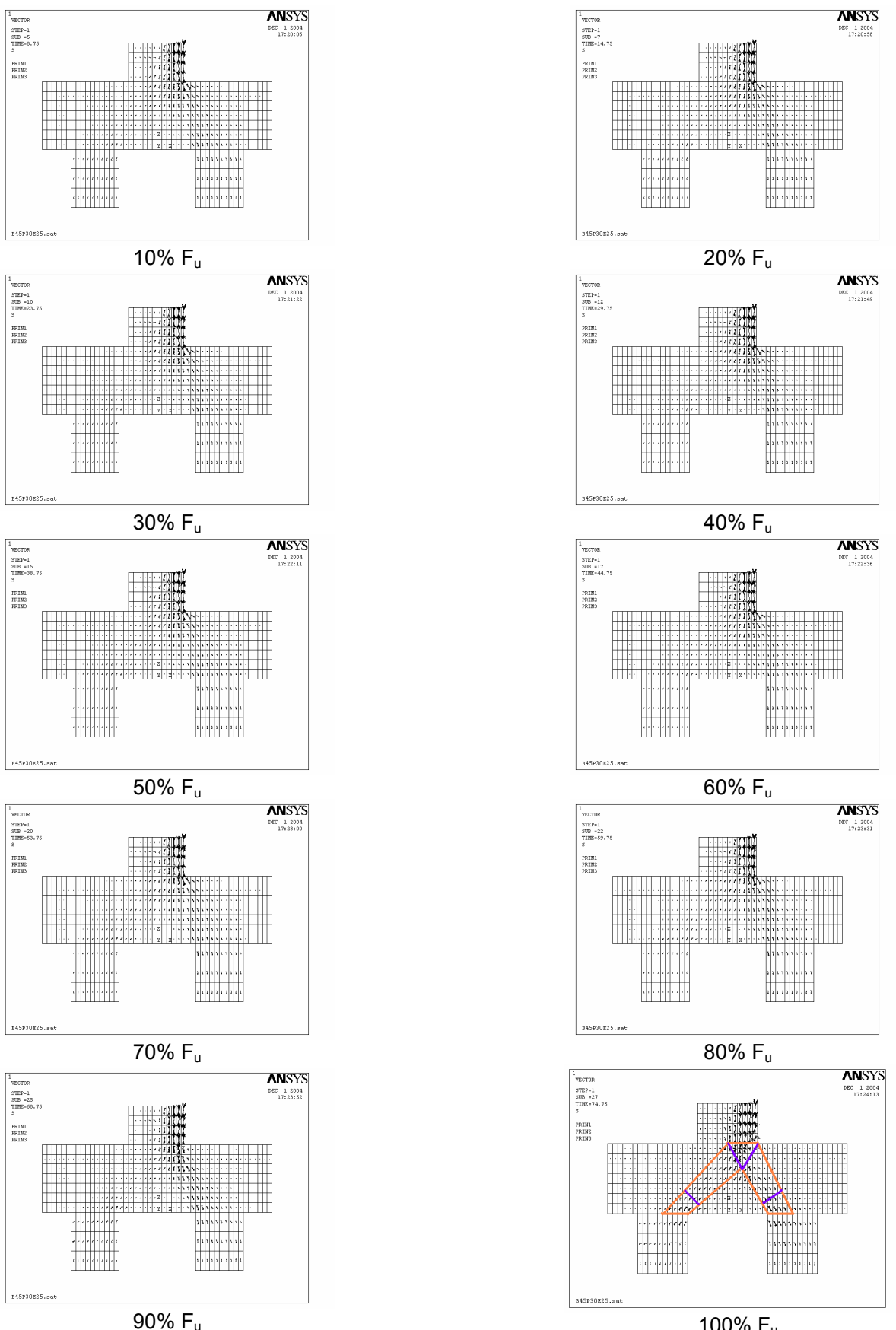

Figura 3.32 - Distribuição do fluxo de tensões principais de compressão, modelo B45P30E25e10.

A Figura 3.33 mostra curvas força vs. deslocamento da seção de meio de vão dos blocos analisados numericamente. 

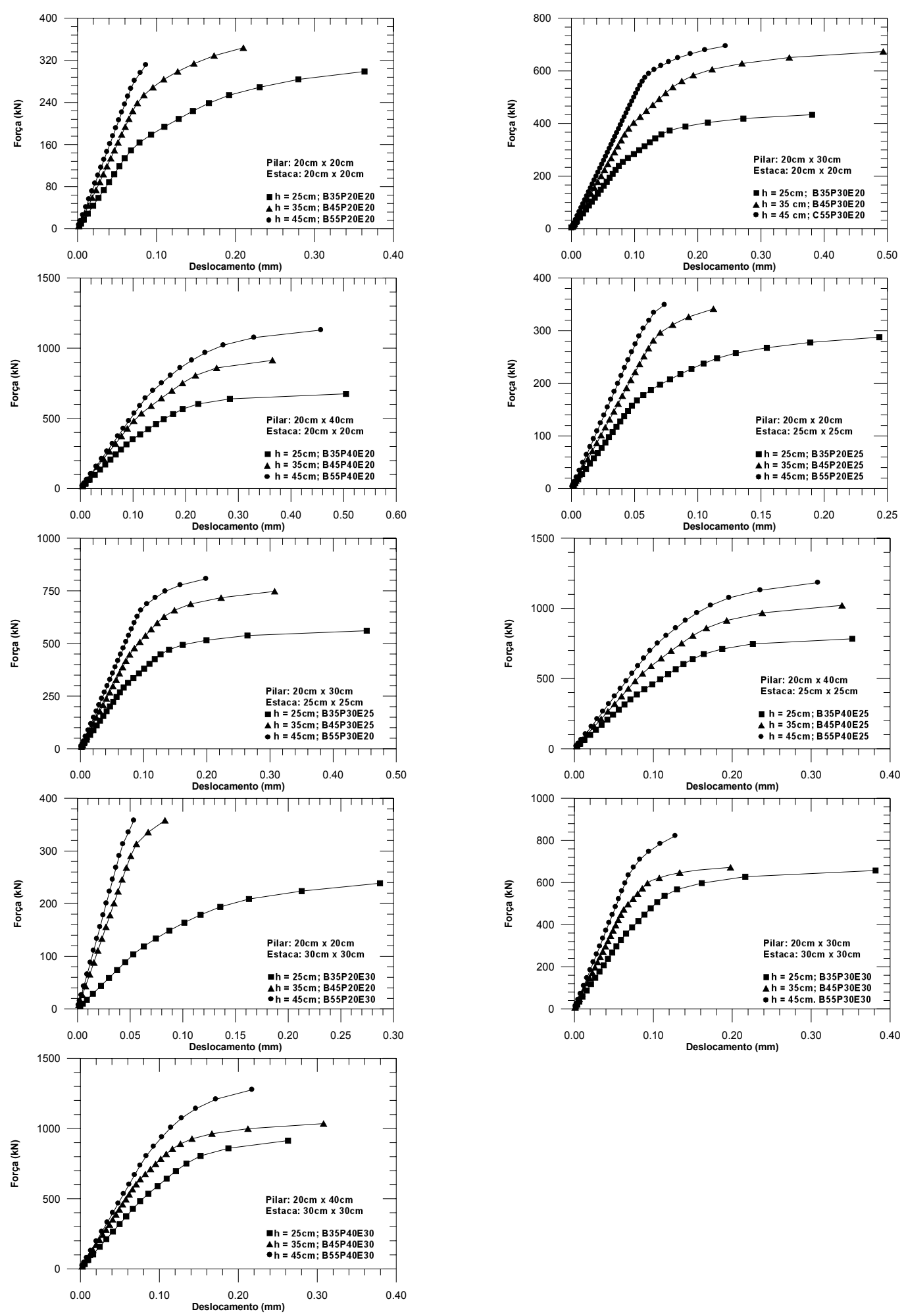

Figura 3.33 - Curvas força vs. deslcoamento, blocos com e = 10 (Grupo C).

Analisando a Figura 3.33, verificou-se que os blocos mais rígidos foram os que apresentaram maiores forças últimas. Fica evidente que o ângulo de inclinação da biela de compressão é essencial na determinação da força última nos blocos sobre estacas. 
A primeira fissura também surgiu em torno de $50 \%$ da força última, fenômeno semelhante aos blocos com excentricidade igual a zero e cinco centímetros.

A Figura 3.34 mostra o panorama de fissuração do bloco B45P30E25e10.
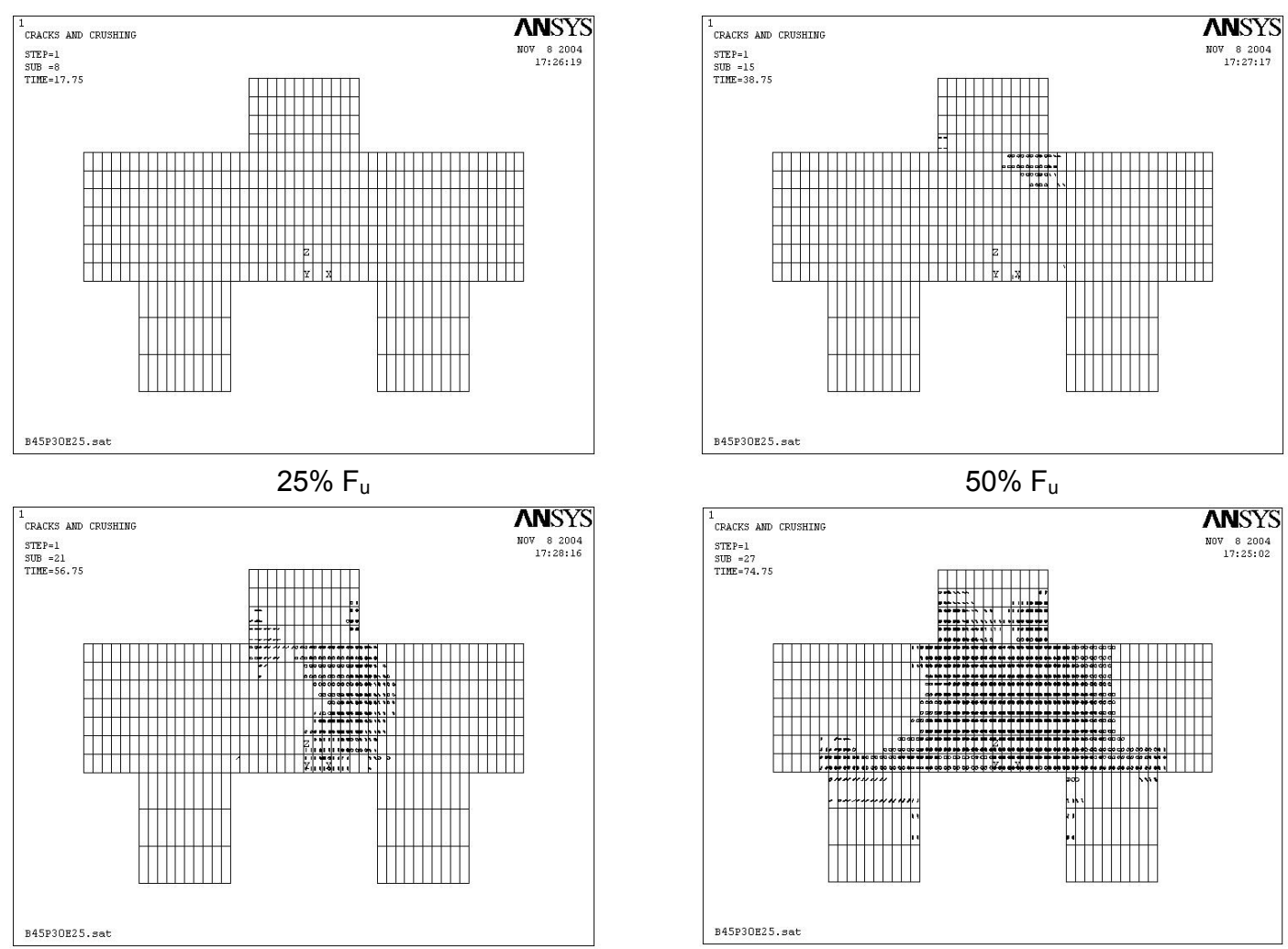

$75 \% \mathrm{~F}_{\mathrm{u}}$

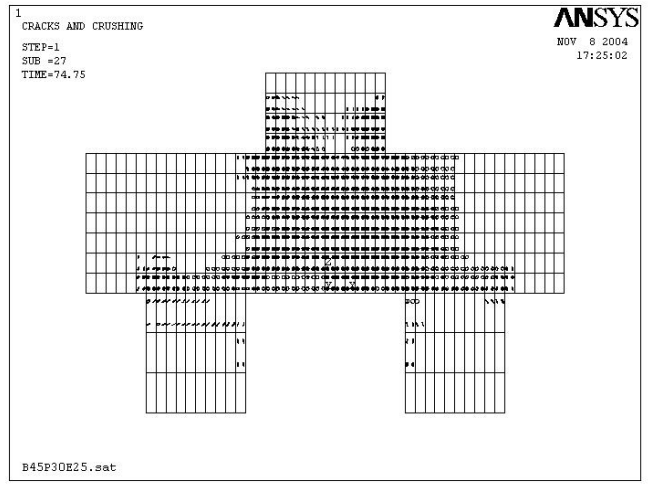

$100 \% \mathrm{~F}_{\mathrm{u}}$

Figura 3.34 - Panorama de fissuração, bloco B45P30E25e10.

\subsubsection{Análise dos resultados}

Por meio dos resultados obtidos nos itens 3.4.6, 3.4.7 e 3.4.8, desenvolveu-se análise de variância com o objetivo de verificar quais das variáveis estudas possui importância relevante no comportamento estrutural dos blocos sobre estacas.

Primeiramente foram analisados os blocos com excentricidade de carregamento igual a zero, seguidos dos blocos com excentricidade da força de compressão igual a cinco centímetros e por último, os blocos com excentricidade igual a dez centímetros.

Em todas as análises utilizou-se nível de significância de $95 \%\left(F_{\text {critico, 0,05) }}\right)$.

A Tabela 3.12 mostra os resultados para os blocos do Grupo A (e =0). 
Tabela 3.12 - Análise de variânica, Anova, blocos do Grupo A $(e=0)$.

\begin{tabular}{|c|c|c|c|c|c|}
\hline \multirow[b]{2}{*}{ Fatores } & \multicolumn{4}{|c|}{ Força última } & \multirow[b]{2}{*}{$\begin{array}{c}\mathbf{F}_{\text {crítico, 0,05 }} \\
\mathbf{n}=\mathbf{2 6}\end{array}$} \\
\hline & $\begin{array}{l}\text { Soma dos } \\
\text { quadrados }\end{array}$ & $\begin{array}{l}\text { Graus de } \\
\text { Liberdade }\end{array}$ & $\begin{array}{l}\text { Média dos } \\
\text { Quadrados }\end{array}$ & $F_{0}$ & \\
\hline$h$ & $5,238.10^{5}$ & 2 & $2,619.10^{5}$ & 2,96 & 3,37 \\
\hline$A_{p}$ & $6,523 \cdot 10^{5}$ & 2 & $3,262.10^{5}$ & 3,70 & 3,37 \\
\hline$A_{e}$ & $2,074.10^{5}$ & 2 & $1,037.10^{5}$ & 1,17 & 3,37 \\
\hline$h \times A_{p}$ & $2,844.10^{5}$ & 4 & $7,11.10^{4}$ & 0,80 & 2,74 \\
\hline$h \times A_{e}$ & $1,941.10^{5}$ & 4 & $4,853.10^{4}$ & 0,55 & 2,74 \\
\hline$A_{p} \times A_{e}$ & $3,856.10^{5}$ & 4 & $9,637.10^{4}$ & 1,09 & 2,74 \\
\hline Erro & $7,075.10^{5}$ & 8 & $8,843.10^{4}$ & - & - \\
\hline Total & $2,955.10^{6}$ & 26 & - & - & - \\
\hline
\end{tabular}

Nota: $h$, altura do bloco; $A_{p}$, área da seção transversal do pilar; $A_{e}$, área da seção transversal da estaca; $h \times A_{p}$, acoplamento entre a altura do bloco e a área da seção transversal do pilar; $h \times A_{e}$, acoplamento entre a altura do bloco e a área da seção transversal da estaca; e $A_{p} \times A_{e}$, acoplamento entre a área da seção transversal do pilar e a área da seção transversal da estacas.

Por meio da Tabela 3.12, conclui-se que para os blocos do Grupo A, ou seja, blocos com força centrada, a variável $A_{p}$ (área do pilar) tem importância relevante em relação à capacidade portante dos blocos, seguida pela variável altura. Estes resultados mostram que as rupturas dos modelos analisados numericamente ocorreram por esmagamento do concreto na zona nodal superior, junto ao pilar.

A Tabela 3.13 apresenta os resultados dos blocos do Grupo B.

Tabela 3.13 - Análise de variânica, Anova, blocos do Grupo B ( e = $5 \mathrm{~cm})$.

\begin{tabular}{|c|c|c|c|c|c|}
\hline \multirow[b]{2}{*}{ Fatores } & \multicolumn{4}{|c|}{ Força última } & \multirow[b]{2}{*}{$\begin{array}{c}F_{\text {crítico, } 0,05} \\
\mathbf{N}=\mathbf{2 6}\end{array}$} \\
\hline & $\begin{array}{l}\text { Soma dos } \\
\text { quadrados }\end{array}$ & $\begin{array}{l}\text { Graus de } \\
\text { Liberdade }\end{array}$ & $\begin{array}{l}\text { Média dos } \\
\text { Quadrados }\end{array}$ & $F_{0}$ & \\
\hline$h$ & $1,129.10^{6}$ & 2 & $5,646.10^{5}$ & 29.02 & 3,37 \\
\hline$A_{p}$ & $5,159.10^{5}$ & 2 & $2,579 \cdot 10^{5}$ & 13,26 & 3,37 \\
\hline$A_{e}$ & $1,011.10^{5}$ & 2 & $5,053.10^{5}$ & 2,6 & 3,37 \\
\hline$h \times A_{p}$ & $1,047.10^{5}$ & 4 & $2,617.10^{4}$ & 1,34 & 2,74 \\
\hline$h \times A_{e}$ & $6,805.10^{5}$ & 4 & $1,701.10^{4}$ & 1,95 & 2,74 \\
\hline$A_{p} \times A_{e}$ & $1,518.10^{5}$ & 4 & $3,795.10^{4}$ & 0,87 & 2,74 \\
\hline Erro & $1,557.10^{5}$ & 8 & $1,946.10^{4}$ & - & - \\
\hline Total & $2,226.10^{6}$ & 26 & - & - & - \\
\hline
\end{tabular}

Nota: $h$, altura do bloco; $A_{p}$, área da seção transversal do pilar; $A_{e}$, área da seção transversal da estaca; $h \times A_{p}$, acoplamento entre a altura do bloco e a área da seção transversal do pilar; $h \times A_{e}$, acoplamento entre a altura do bloco e a área da seção transversal da estaca; e $A_{p} \times A_{e}$, acoplamento entre a área da seção transversal do pilar e a área da seção transversal da estacas.

Por meio da Tabela 3.13, verifica-se que a força última $\left(F_{u}\right)$ é influenciada preponderantemente pela altura do bloco e pela seção transversal do pilar. Estes resultados indicam que a escolha das variáveis foi coerente e que em função das bielas terem sido solicitadas por diferentes intensidades de tensões, função da 
existência de excentricidade, a variável $A_{p}$ deixa de ser preponderante, porém, ainda é fator importante na determinação da capacidade última dos blocos.

A Tabela 3.14 mostra os resultados para os blocos do Grupo C.

Tabela 3.14 - Análise de variânica, Anova, blocos do Grupo C.

\begin{tabular}{|c|c|c|c|c|c|}
\hline \multirow[b]{2}{*}{ Fatores } & \multicolumn{4}{|c|}{ Força última } & \multirow[b]{2}{*}{$\begin{array}{c}F_{\text {crítico, 0,05 }} \\
\mathbf{N}=\mathbf{2 6}\end{array}$} \\
\hline & $\begin{array}{l}\text { Soma dos } \\
\text { quadrados }\end{array}$ & $\begin{array}{l}\text { Graus de } \\
\text { Liberdade }\end{array}$ & $\begin{array}{l}\text { Média dos } \\
\text { Quadrados }\end{array}$ & $F_{0}$ & \\
\hline$h$ & $2,034.10^{6}$ & 2 & $1,017.10^{6}$ & 284,38 & 3,37 \\
\hline$A_{p}$ & $1,664.10^{5}$ & 2 & $8,319.10^{4}$ & 23,27 & 3,37 \\
\hline$A_{e}$ & $2,581.10^{4}$ & 2 & $1,289.10^{4}$ & 3,61 & 3,37 \\
\hline$h \times A_{p}$ & $1,207.10^{5}$ & 4 & $3,018.10^{4}$ & 8,44 & 2,74 \\
\hline$h \times A_{e}$ & $2,219.10^{4}$ & 4 & $5,551.10^{3}$ & 0,885 & 2,74 \\
\hline$A_{p} \times A_{e}$ & $1,266.10^{4}$ & 4 & $3,165.10^{3}$ & 1,552 & 2,74 \\
\hline Erro & $2,861.10^{4}$ & 8 & $3,575.10^{3}$ & - & - \\
\hline Total & $2,409.10^{6}$ & 26 & - & - & - \\
\hline
\end{tabular}

Nota: $h$, altura do bloco; $A_{p}$, área da seção transversal do pilar; $A_{e}$, área da seção transversal da estaca; $h \times A_{p}$, acoplamento entre a altura do bloco e a área da seção transversal do pilar; $h \times A_{e}$, acoplamento entre a altura do bloco e a área da seção transversal da estaca; e $A_{p} \times A_{e}$, acoplamento entre a área da seção transversal do pilar e a área da seção transversal da estacas.

Analisando os resultados da Tabela 3.14 , deduz-se que a altura do bloco é fator preponderante para a determinação da força última dos blocos, além disto, constata-se que a área do pilar, a área da estaca e o acoplamento entre a altura do bloco e a área do pilar desempenham papel importante para o comportamento estrutural dos blocos.

Observado a distribuição dos fluxos das tensões principais de compressão, sugeriu-se uma representação das geometrias das bielas de compressão. As Figuras 3.35 e 3.36 apresentam esta representação. A geometria apresentada será confrontada com resultados experimentais.

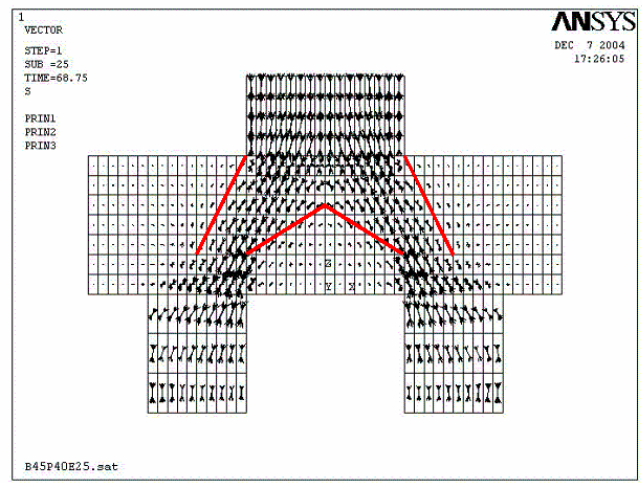

Figura 3.35 - Geometria sugerida para as bielas de compressão, para blocos com força centrada.

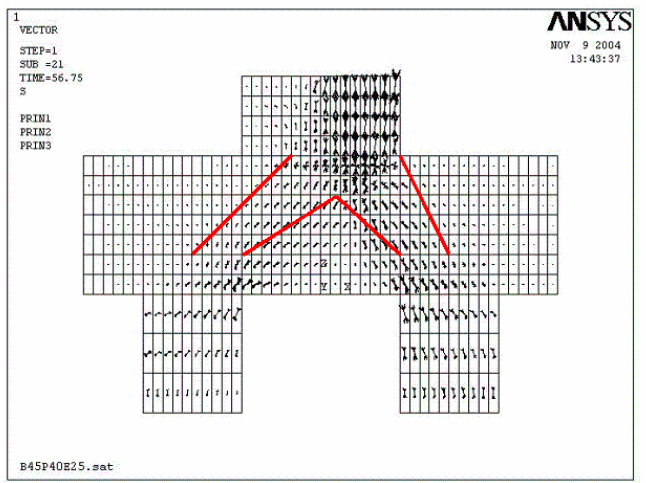

Figura 3.36 - Geometria sugerida para as bielas de compressão, para blocos com força excêntrica. 
Ao contrário do que afirma Adebar et al. (1990) não verificou-se expansão do fluxo de tensões na iminência da ruptura dos blocos.

No Capítulo 8 deste texto apresenta-se o equacionamento para o modelo proposto de Bielas e Tirantes, formulado em função da distribuição dos fluxos das tensões principais de compressão.

\subsection{Comentários Finais}

Verificou-se que a capacidade portante dos blocos aumenta em função do aumento do ângulo de inclinação da biela de compressão.

Por meio da análise numérica, confirmou-se que a existência de excentricidade diminui a capacidade portante do bloco.

Analisando os diagramas de fluxo de tensões na direção principal de compressão, observou-se que a hipótese de se considerar que toda a área da seção transversal da cabeça estaca contribui para a determinação das tensões na região nodal inferior não é valida, faz-se necessário, portanto, alterar o critério de verificação de tensões nas bielas de compressão junto ao pilar e principalmente junto às estacas.

Em função de observações da distribuição do fluxo das tensões principais de compressão sugeriu-se uma forma geométrica para biela de compressão. É válido dizer, que essa geometria foi verificada por meio dos ensaios experimentais desenvolvidos.

Em função do estudo da variância desenvolvido, conclui-se que as variáveis analisadas (ângulo de inclinação da biela de compressão, área da seção transversal da estaca, área da seção transversal do pilar e excentricidade da força de compressão aplicada ao bloco) possuem influência relevante no comportamento estrutural dos blocos sobre duas estacas, porém, constatou-se que as variáveis preponderantes são: ângulo de inclinação da biela de compressão (função da altura do bloco, pois a distância entre os eixos das estacas foi fixada), a área da seção transversal do pilar e a posição da força de compressão. Sendo assim, na análise experimental, faz-se necessária a investigação destas variáveis. 


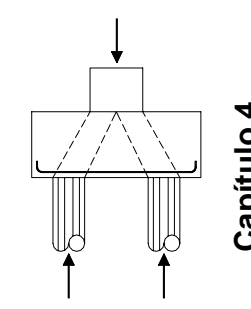

DIMENSIONAMENTO, PROJETO E CONSTRUÇÃO DOS

MODELOS

\subsection{Considerações iniciais}

Neste capítulo são apresentados os critérios de dimensionamento e detalhamentos utilizados nos modelos ensaiados no Laboratório de Estruturas da Escola de Engenharia de São Carlos, Universidade de São Paulo. Além disso, são apresentadas as propriedades mecânicas dos materiais (concreto e aço) utilizados na construção dos modelos.

No dimensionamento dos modelos utilizaram-se as recomendações sugeridas por Blévot \& Frémy (1967) bem como as indicações contidas na NBR 6118:2003.

Foram ensaiados quatorze blocos sobre duas estacas com variações nos arranjos das armaduras, no ângulo de inclinação das bielas de compressão (altura do bloco), nas seções transversais dos pilares e na posição da aplicação da força de compressão (excentricidades iguais e diferentes de zero). Esses fatores foram determinados em função da análise de variância apresenta no capitulo três.

Cada modelo possui uma sigla, cujo significado é apresentado, no exemplo: B35P25E25e0,

- B35: bloco com altura igual a trinta e cinco centímetros;

- P25: comprimentos das arestas da seção transversal do pilar igual a vinte e cinco centímetros;

- E25: comprimentos das arestas da seção transversal das estacas iguais a vinte e cinco centímetros;

- e0: excentricidade da força de compressão igual a zero.

Além das siglas já apresentadas, em alguns modelos surgem as seguintes denominações: $A_{s w, C}, A_{s w, 0}$ e $C G$, cujos significados são: $A_{s w, C}$, área da seção transversal das barras de aço da armadura transversal do bloco calculada por meio de 
processo analítico; $\mathrm{A}_{\mathrm{sw}, 0}$, área da armadura transversal do bloco igual a zero; e CG, armadura inferior de tração (tirante) detalhada com ganchos a cento e oitenta graus.

$\mathrm{Na}$ Tabela 4.1 são apresentadas as propriedades geométricas dos modelos analisados e nos itens seguintes a justificativa da adoção de cada dimensão.

Tabela 4.1 - Propriedades geométricas dos modelos analisados experimentalmente.

\begin{tabular}{|c|c|c|c|c|c|c|c|c|}
\hline SÉRIE & BLOCOS & $\begin{array}{c}\text { Dimensão } \\
\text { da estaca } \\
(\mathrm{cm})\end{array}$ & $\begin{array}{c}\text { Dimensão } \\
\text { do pilar } \\
\text { (cm) }\end{array}$ & $\begin{array}{l}B_{\mathrm{Lx}}{ }^{*} \\
(\mathrm{~cm})\end{array}$ & $\begin{array}{l}B_{\text {Ly }}{ }^{*} \\
(\mathrm{~cm})\end{array}$ & $\begin{array}{c}e_{\text {adot }} \\
(\mathrm{mm})\end{array}$ & $\begin{array}{c}\text { h } \\
\text { (cm) }\end{array}$ & Detalhes \\
\hline \multirow{5}{*}{ B35P25 } & B35P25E25e0 & $25 \times 25$ & $25 \times 25$ & 117,5 & 25 & 0 & 35 & $A_{s w} \neq 0$ \\
\hline & B35P25E25e2,5 & $25 \times 25$ & $25 \times 25$ & 117,5 & 25 & 25 & 35 & $A_{s w} \neq 0$ \\
\hline & B35P25E25e0A $A_{s w, C}$ & $25 \times 25$ & $25 \times 25$ & 117,5 & 25 & 0 & 35 & $A_{s w} \neq 0$ \\
\hline & $\mathrm{B}^{2} 5 \mathrm{P} 25 \mathrm{E} 25 \mathrm{e} 0 \mathrm{~A}_{\mathrm{sw}, 0}$ & $25 \times 25$ & $25 \times 25$ & 117,5 & 25 & 0 & 35 & $A_{s w}=0$ \\
\hline & B35P25E25e0CG & $25 \times 25$ & $25 \times 25$ & 117,5 & 25 & 0 & 35 & $A_{s w} \neq 0$ \\
\hline \multirow{5}{*}{ B45P25 } & B45P25E25e0 & $25 \times 25$ & $25 \times 25$ & 117,5 & 25 & 0 & 35 & $A_{s w} \neq 0$ \\
\hline & B45P25E25e5 & $25 \times 25$ & $25 \times 25$ & 117,5 & 25 & 50 & 45 & $A_{s w} \neq 0$ \\
\hline & $\mathrm{B} 45 \mathrm{P} 25 \mathrm{E} 25 \mathrm{e} 0 \mathrm{~A}_{\mathrm{sw}, \mathrm{C}}$ & $25 \times 25$ & $25 \times 25$ & 117,5 & 25 & 0 & 45 & $A_{s w} \neq 0$ \\
\hline & 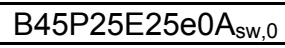 & $25 \times 25$ & $25 \times 25$ & 117,5 & 25 & 0 & 45 & $A_{s w} \neq 0$ \\
\hline & B45P25E25e0CG & $25 \times 25$ & $25 \times 25$ & 117,5 & 25 & 0 & 45 & $A_{s w}=0$ \\
\hline \multirow{2}{*}{ B35P50 } & B35P50E25e0 & $25 \times 25$ & $25 \times 50$ & 117,5 & 25 & 0 & 35 & $A_{s w} \neq 0$ \\
\hline & B35P50E25e12,5 & $25 \times 25$ & $25 \times 50$ & 117,5 & 25 & 0 & 45 & $A_{s w} \neq 0$ \\
\hline \multirow{2}{*}{ B45P50 } & B45P50E25e0 & $25 \times 25$ & $25 \times 50$ & 117,5 & 25 & 125 & 35 & $A_{s w} \neq 0$ \\
\hline & B45P50E25e12,5 & $25 \times 25$ & $25 \times 50$ & 117,5 & 25 & 125 & 45 & $A_{s w} \neq 0$ \\
\hline
\end{tabular}

Notas: $B_{L x}, B_{L y}$ são os comprimentos dos blocos nas direções $x$ (longitudinal) e y (transversal), eadot é a excentricidade da força de compressão aplicada no pilar e $A_{s w}$ são armaduras complementares.

Observa-se por meio da Tabela 4.1 que não existem abas de concreto além das estacas na direção y (ou seja, a largura do bloco é igual à largura do pilar e da estaca), pois, como pretendeu-se analisar as deformações das bielas de compressão a existência de tais abas prejudicaria as leituras dessas deformações conforme Figura 4.1.

Figura 4.1 - Propriedades geométricas dos modelos analisados experimentalmente. 


\subsection{Dimensionamento e detalhamento dos modelos}

Como já foi mencionado, todos os modelos dos blocos sobre estacas foram dimensionados utilizando as recomendações de Blévot \& Frémy (1967) e o arranjo de suas armaduras seguiram as recomendações existentes na NBR 6118:2003.

Como se pretendeu analisar a ruína do bloco por esmagamento ou fendilhamento (tensão de tração perpendicular à tensão de compressão) das bielas de compressão, as armaduras principais de tração foram projetadas de modo que suas barras não sofressem escoamento. Para isso, as áreas de ação da armadura principal de tração (tirante) foram calculadas com a reação da estaca mais solicitada.

Além disso, as resistências à compressão do concreto das estacas e dos pilares foram maiores que a resistência à compressão do concreto do bloco. Isto foi feito, para garantir que não ocorressem ruínas nas estacas nem nos pilares. Adotou-se resistência média a compressão dos pilares e das estacas iguais a $50 \mathrm{MPa}$ e a resistência média a compressão do bloco igual a $25 \mathrm{MPa}$.

Os cobrimentos das armaduras adotados foram: pilares e estacas $25 \mathrm{~mm}$; blocos, $40 \mathrm{~mm}$.

\subsubsection{Dimensionamento dos blocos}

A primeira etapa para o dimensionamento de um bloco sobre estacas é a determinação do número de estacas a serem utilizadas e de suas reações. Após isso, verificam-se as tensões nas regiões nodais superior (junto ao pilar) e inferior (junto à estaca mais solicitada). A posteriore dimensiona-se a quantidade de barras de aço necessárias para equilibrar as tensões de tração existentes na face inferior do bloco e processa-se o detalhamento das barras.

No dimensionamento de um elemento estrutural que é analisado experimentalmente, primeiramente deve-se definir o que se pretende investigar (neste caso, pretendia-se analisar o comportamento do bloco e o fluxo das tensões principais de compressão). Definida essa etapa, determina-se a máxima força que tal elemento suportará e a quantidade necessária de barras de aço. Como se pretendia que os blocos viessem à ruína por esmagamento ou fendilhamento de suas bielas de compressão, determinou-se à máxima força que cada bloco suportaria e adotou-se essa força no dimensionamento das armaduras dos blocos, das estacas e do pilares. 
Como foi descrito no capítulo três, a seção transversal da estaca é o fator que menos exerce influência no comportamento dos blocos, assim, fixou-se o comprimento das arestas da seção transversal das estacas iguais a vinte e cinco centímetros. Optou-se por seção quadrada objetivando facilitar a modelagem numérica como também, facilitar a moldagem dos modelos e a aplicação das pastilhas de aço destinadas à obtenção das leituras de deslocamento relativos entre as mesmas obtendo, assim, as intensidades das deformações de compressão e tração na face do bloco.

\subsubsection{Dimensões dos blocos}

A distância entre eixos das estacas $\left(L_{e}\right)$ foi determinada segundo a recomendação de ALBIERO \& CINTRA (1984). Desta maneira, a distância entre eixo das estacas, para o caso de estaca pré-moldadas foi determinada por meio da Expressão 4.1.

$\mathrm{L}_{\text {est }}=2,5 \cdot \phi_{\text {est }}$

sendo:

- $\quad$ est, o diâmetro ou comprimento da aresta da estaca.

Com relação a distância do eixo da estaca até a face do bloco (c), procedeu-se da seguinte maneira:

$\mathrm{c}=15+\frac{\phi_{\text {est }}}{2}$

com c e $\phi_{\text {est }}$ expressos em centímetros.

Portanto, o comprimento total dos blocos na direção longitudinal $\left(B_{L x}\right)$ foi igual a:

$\mathrm{B}_{\mathrm{Lx}}=\mathrm{L}_{\text {est }}+2 \cdot \mathrm{c}$

A Figura 4.2 apresenta tais dimensões. 


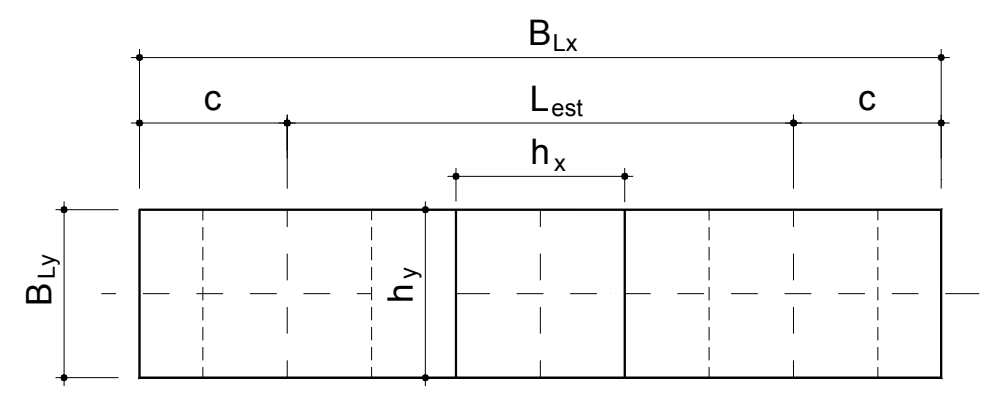

Figura 4.2 - Dimensões dos blocos sobre duas estacas.

Como o objetivo da pesquisa foi analisar o comportamento de blocos rígidos sobre duas estacas, utilizaram-se os limites inferior e superior do ângulo de inclinação da biela de compressão (Expressão 4.4) sugeridos por Blévot \& Frémy (1967) e verificou se tais dimensões satisfaziam às exigências da NBR 6118:2003. Esses limites de inclinação do ângulo das bielas de compressão garantem, sengundo Blévot, a classificação dos blocos como sendo rígidos.

$45^{\circ} \leq \theta \leq 55^{\circ}$

Analisando a Figura 4.3, determina-se a altura útil do bloco $(d)$, como também sua altura total $(h)$.

A altura útil do bloco foi determinada por meio a Expressão 4.5.

Portanto, os blocos analisados tiveram duas alturas, uma relativa ao ângulo de inclinação da biela de compressão $(\theta)$ igual a $45^{\circ}$ e outro relativo ao ângulo igual a $55^{\circ}$.

A altura total do bloco seguiu a recomendação de Montoya et al. (2000), a qual, sugere que a estaca deve ser embutida no bloco cerca de dez centímetros. A altura total do bloco $(h)$ foi determinada utilizando a Expressão 4.6.

$$
\begin{aligned}
& \mathrm{d}=\tan \theta \cdot\left(\frac{\mathrm{L}_{\text {est }}}{2}-\frac{\mathrm{h}_{\mathrm{x}}}{4}\right) \\
& \mathrm{h}=\mathrm{d}+10
\end{aligned}
$$

Com $h$ e $d$ expressos em centímetros. 


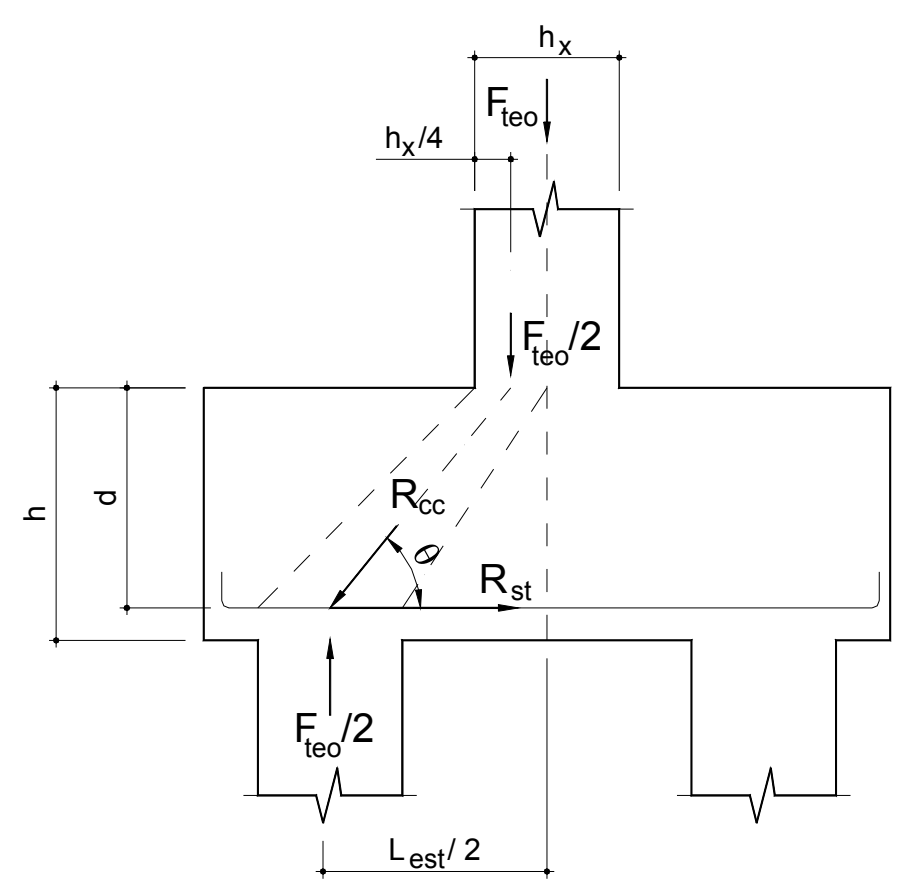

Figura 4.3 - Cálculo da altura do bloco.

Com relação aos blocos com pilares de dimensões iguais a $25 \mathrm{~cm} \times 50 \mathrm{~cm}$, adotaram-se às mesmas alturas dos demais blocos com a finalidade de verificar a influência que a seção do pilar provoca no comportamento global dos blocos.

A verificação das rigidezes do bloco foi determinada por meio da Expressão 2.5, sendo considerados todos rígidos segundo classificação da NBR 6118:2003.

\subsubsection{Verificações das tensões nodais}

Determinadas às dimensões dos blocos, a próxima etapa é a verificação das tensões nas regiões nodais superior e inferior. Porém, em se tratando de uma análise experimental, por meio dessas verificações foi possível determinar a capacidade portante de cada bloco, ou seja, determinou-se qual a intensidade da força que será utilizada para o dimensionamento da armadura principal de tração (tirante), das armaduras das estacas e dos pilares. Por meio das Expressões 4.7 e 4.8 foi possível determinar a intensidade dessa força, adotando para o dimensionamento dos tirantes, das estacas e dos pilares, o menor valor entre os dois obtidos. Essa força foi obtida, fazendo que a tensão na biela de compressão fosse igual ao seu máximo valor. 
Segundo Blévot \& Frémy (1967), a tensão na região nodal superior, ou seja, junto ao pilar é verificada por meio da expressão 4.7 , enquanto que a tensão na região nodal inferior junto à estaca é determinada aplicando a Expressão 4.8.

$$
\begin{aligned}
& \sigma_{\mathrm{zn}, \mathrm{s}}=\frac{\mathrm{F}_{\mathrm{teo}}}{\mathrm{A}_{\mathrm{p}} \cdot(\cos \theta)^{2}} \leq 1,4 \cdot \mathrm{f}_{\mathrm{ck}} \\
& \sigma_{\mathrm{zn}, \mathrm{i}}=\frac{\mathrm{R}_{\mathrm{est},+}}{\mathrm{A}_{\mathrm{e}} \cdot(\cos \theta)^{2}} \leq \mathrm{f}_{\mathrm{ck}}
\end{aligned}
$$

sendo:

- $A_{p}$, área da seção transversal do pilar;

- $A_{e}$, área da estaca;

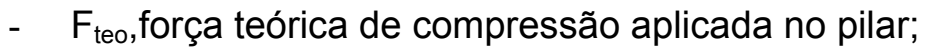

- $R_{\text {est, },+}$ reação da estaca mais solicitada;

- $\quad \sigma_{\mathrm{zn}, \mathrm{s}}$, tensão na zona nodal superior;

- $\sigma_{\mathrm{zn}, \mathrm{i}}$, tensão na zona nodal inferior.

É válido lembrar que em se tratando de análise experimental, todos os coeficientes de segurança embutidos no dimensionamento e verificação do bloco não foram considerados, desta forma, observa-se que os valores limites das tensões nas regiões nodais superior e inferior são maiores que os apresentados em diversas literaturas técnicas. O valor 1,4 existente na Expressão 4.7 vem de observações experimentais dos ensaios de Blévot \& Frémy (1967), pelos quais, verificou que a tensão no concreto junto ao pilar foi cerca de $40 \%$ superior à resistência do concreto do bloco.

Nos blocos, onde a força de compressão foi aplicada com excentricidade na direção longitudinal, as estacas apresentaram reações diferentes, assim, para a determinação das reações nas estacas mais e menos solicitadas, utilizaram-se as Expressões 4.9 e 4.10.

$$
\begin{aligned}
& \mathrm{R}_{\text {est },+}=\frac{\mathrm{F}_{\text {teo }}}{2}+\frac{\mathrm{F}_{\text {teo }} \cdot \mathrm{e}_{\text {adot }}}{\mathrm{L}_{\text {est }}} \\
& \mathrm{R}_{\text {est },-}=\frac{\mathrm{F}_{\text {teo }}}{2}-\frac{\mathrm{F}_{\text {teo }} \cdot \mathrm{e}_{\text {adot }}}{\mathrm{L}_{\text {est }}}
\end{aligned}
$$

sendo:

- $R_{\text {est,-, }}$ a reação na estaca menos solicitada. 


\subsubsection{Dimensionamento da armadura principal de tração}

Obtidos os valores das máximas intensidades das forças de compressão aplicadas em cada bloco, pode-se dimensionar a quantidade de barras de aço necessárias para absorver às tensões de tração na face inferior do bloco.

Fazendo o equilíbrio do nó junto à zona nodal inferior (ver Figura 4.3), foi possível determinar a força de tração oriunda do modelo de Bielas e Tirantes.

$$
\mathrm{R}_{\mathrm{st}}=\frac{\mathrm{R}_{\mathrm{est},+}}{\tan \theta}
$$

sendo:

- $\quad R_{s t}$ a força de tração do tirante;

Nos casos, em que não existe excentricidade da força de compressão, substitui-se o valor de $R_{\text {est, }}+$ por $F_{\text {teo }} / 2$.

$\mathrm{A}$ área de armadura do tirante $\left(A_{s t}\right)$ foi determinada do seguinte modo:

$$
A_{s t}=\frac{R_{s t}}{f_{y k}}
$$

Sendo $f_{y k}$ a resistência ao escoamento das barras de aço. Para o dimensionamento dos tirantes, como ainda não haviam sido feitos os ensaios de tração das barras de aço, utilizou-se o valor característico fornecido pela NBR 6118:2003, cujo valor é igual a $500 \mathrm{MPa}$.

\subsubsection{Ancoragem da armadura principal de tração}

A ancoragem da armadura principal de tração (tirante) foi verificada por meio das recomendações sugeridas pela NBR 6118:2003. Existem divergências entre autores no que diz respeito à ancoragem da armadura de tração de blocos sobre estacas, mais precisamente, da posição da seção onde se considera o início da ancoragem das barras de aço. Alguns autores sugerem que essa seção deve ser medida a partir do centro geométrico da estaca, outros, admitem que essa seção deve estar localizada na face mais afastada da estaca com relação a face externa do bloco. Há divergências também com relação ao valor da força a ancorar, pois, alguns autores 
sugerem que essa força deve ser igual à força no tirante, outros, sugerem que seja minorada em função da ação favorável da biela de compressão, pois, como existe grande força de compressão nessa região, as condições de ancoragem são melhoradas. Neste trabalho, utilizou-se, ancoragem reta e em alguns modelos utilizouse ancoragem com ganchos a cento e oitenta graus, com intuito de verificar a eficiência do tipo de arranjo de armadura.

Não foi adotado coeficiente para diminuição da força a ancorar e optou-se por medir o comprimento disponível para alojar as armadura de tração a partir da face mais afastada da estaca.

A existência do gancho na armadura principal de tração também é fator divergente entre normas, pois, a NBR 6118:2003 exige que todos os tirantes dos blocos sobre estacas sejam projetados com ganchos, já, a CSA Standard A23.3-94 sugere ancoragem reta.

A seguir são apresentados os critérios utilizados na verificação da ancoragem da armadura principal de tração. O comprimento de ancoragem necessário foi calculado por meio da Expressão 4.13.

$$
\ell_{\mathrm{b}, \text { nec }}=\alpha \cdot \ell_{\mathrm{b}} \cdot \frac{\mathrm{A}_{\mathrm{s}, \mathrm{aalc}}}{\mathrm{A}_{\mathrm{s}, \mathrm{ef}}} \geq \ell_{\mathrm{b}, \text { min }}
$$

sendo:

- $\alpha=1$ para barras sem gancho;

- $\alpha=0,7$ para barras tracionadas com gancho, com cobrimento no plano normal ao do gancho maior ou no máximo igual a trêz vezes o diâmetro da barra a ancorar;

- $\quad \ell_{\mathrm{b}}=\frac{\phi}{4} \cdot \frac{\sigma_{\mathrm{s}, \mathrm{ef}}}{\mathrm{f}_{\mathrm{bk}}}$ (comprimento de ancoragem básico);

$$
\begin{array}{r}
0,3 \ell_{\mathrm{b}} \\
-\quad \ell_{\mathrm{b}, \min } \geq 10 \cdot \phi ; \\
100 \mathrm{~mm}
\end{array}
$$

- $\quad f_{b k}$, resistência característica de aderência (determinada pela Expressão 4.14);

- $\quad \phi$, diâmetro de uma das barras da armadura principal de tração à ancorar;

- $\sigma_{\mathrm{s}, \mathrm{ef}}$, tensão efetiva na armadura de tração.

$\mathrm{f}_{\mathrm{bk}}=\eta_{1} \cdot \eta_{2} \cdot \eta_{3} \cdot \mathrm{f}_{\mathrm{ctk}}$

com: 
- $\quad \eta_{1}=2,25$ para barras nervuradas;

- $\quad \eta_{2}=1$ para situações de boa aderência;

- $\quad \eta_{3}=1$ para barras de aço com diâmetros inferiores a $32 \mathrm{~mm}$;

- $\mathrm{f}_{\mathrm{ctk}}=\mathrm{f}_{\mathrm{ctk}, \text { inf }}$ (Expressão 4.15).

$$
\mathrm{f}_{\mathrm{ctk}, \mathrm{inf}}=0,7 \cdot 0,3 \cdot \mathrm{f}_{\mathrm{ck}}^{2 / 3}
$$

Com $f_{c k}$ (resistência característica do concreto à compressão, lembrando que para o bloco, adotou-se o valor de $25 \mathrm{MPa}$ ) expresso em MPa.

\subsubsection{Armaduras complementares}

Embora a NBR 6118:2003 não recomende a adoção de armaduras complementares em blocos sobre estacas, algumas normas e autores internacionais recomendam sua utilização, podendo-se citar: Boletim n 73 do CEB (1970), EHE (2002), Cavalera (1991) e Montoya et al. (2000). A justificativa da adoção de tais armaduras é absorver possíveis tensões provocadas por excentricidades acidentais ocorridas nas locações das estacas e dos pilares e para limitar às aberturas das fissuras nas faces laterais dos blocos. Nesse trabalho, também será analisada a eficiência de tais armaduras. Essas armaduras são compostas por uma armadura secundária posicionada na face superior do bloco e por estribos verticais e horizontais (ver Figura 4.4).

Segundo a EHE (2002) e o Boletim, $n^{\circ} 73$ do CEB (1970) a armadura posicionada na face superior do bloco não deve ter área de aço inferior a $10 \%$ da área de aço da armadura principal de tração.

Para os estribos verticais quanto os horizontais, a EHE (2000) sugere que tenham área de aço superior a $4 \%$ da área de aço da armadura principal de tração. Já, o Boletim n 73 no CEB (1970) estabelece que tais armaduras sejam determinadas por meio da Expressão 415.

$$
\mathrm{A}_{\mathrm{s}, \text { malha }}=0,0020 \cdot \mathrm{B}_{\mathrm{Ly}} \cdot \mathrm{S}
$$




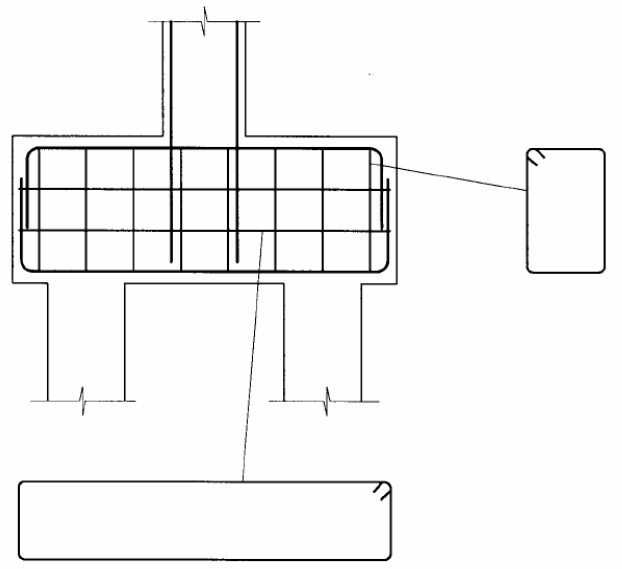

Figura 4.4 - Armaduras complementares em blocos sobre duas estacas.

$\mathrm{Na}$ Expressão 4.15, $B_{L y}$ designa a largura do bloco, em centímetros, e $s$ o espaçamento das barras da malha, também em centímetros. Se a largura $B_{L y}$ exceder a metade da altura total $h$ do bloco, deve-se substituí-la por $h / 2$.

Nos modelos analisados experimentalmente, utilizaram-se às recomendações sugeridas pelo Boletim $n^{\circ} 78$ do CEB (1970).

A Tabela 4.2 apresenta um resumo das máximas forças teóricas obtidas por meio do método de Blévot \& Frémy (1967), as quais, foram utilizadas como referência nos ensaios.

Tabela 4.2 - Força teóricas obtidas pelo método de Blévot \& Frémy (1967).

\begin{tabular}{|c|c|c|c|c|c|c|c|c|}
\hline SÉRIE & BLOCOS & $\begin{array}{c}\theta \\
\text { (graus) }\end{array}$ & $\begin{array}{c}\mathbf{h} \\
(\mathrm{cm})\end{array}$ & $\begin{array}{l}F_{\text {teo }} \\
(k N)\end{array}$ & $\begin{array}{l}\mathbf{R}_{\mathbf{s t}} \\
(\mathrm{kN})\end{array}$ & $\ell_{b, \text { nec }}$ & $\ell_{b, \text { disp }}$ & Obs. \\
\hline \multirow{5}{*}{ B35P25 } & B35P25E25e0 & 45 & 35 & 1094 & 547 & 29,94 & 36 & $A_{\mathrm{sw}, \text { norma }}$ \\
\hline & B35P25E25e2,5 & 45 & 35 & 1094 & 591 & 34,92 & 36 & $A_{s w, n o r m a}$ \\
\hline & B35P25E25e0A ${ }_{s w, C}$ & 45 & 35 & 1094 & 547 & 29,94 & 36 & $A_{s w, C}$ \\
\hline & $\mathrm{B}^{2} 5 \mathrm{P} 25 \mathrm{E} 25 \mathrm{e} 0 \mathrm{~A}_{\mathrm{sw}, 0}$ & 45 & 35 & 1094 & 547 & 29,94 & 36 & $\mathrm{~A}_{\mathrm{sw}, 0}$ \\
\hline & B35P25E25e0CG & 45 & 35 & 1094 & 547 & 35,35 & 36 & $\begin{array}{l}\text { A } \text { sw,norma } \\
\text { c/gancho }\end{array}$ \\
\hline \multirow{5}{*}{ B45P25 } & $\mathrm{B} 45 \mathrm{P} 25 \mathrm{E} 25 \mathrm{e} 0$ & 54,5 & 45 & 1448 & 517 & 26,76 & 36 & $A_{s w, n o r m a}$ \\
\hline & B45P25E25e5 & 54,5 & 45 & 1448 & 600 & 36,02 & 36 & $\mathrm{~A}_{\mathrm{sw}, \text { norma }}$ \\
\hline & $\mathrm{B} 45 \mathrm{P} 25 \mathrm{E} 25 \mathrm{e} 0 \mathrm{~A}_{\mathrm{sw}, \mathrm{C}}$ & 54,5 & 45 & 1448 & 517 & 26,76 & 36 & $\mathrm{~A}_{\mathrm{sw}, \mathrm{C}}$ \\
\hline & $\mathrm{B} 45 \mathrm{P} 25 \mathrm{E} 25 \mathrm{e} 0 \mathrm{~A}_{\mathrm{sw}, 0}$ & 54,5 & 45 & 1448 & 517 & 26,76 & 36 & $A_{s w, 0}$ \\
\hline & B45P25E25e0CG & 54,5 & 45 & 1448 & 517 & 29,27 & 36 & $\begin{array}{l}A_{\text {sw,norma }} \\
\text { c/gancho }\end{array}$ \\
\hline \multirow{2}{*}{ B35P50 } & B35P50E25e0 & 53,1 & 35 & 2000 & 750 & - & - & $A_{\text {sw,norma }}$ \\
\hline & B35P50E25e12,5 & 53,1 & 35 & 2000 & 842 & - & - & $A_{s w, \text { norma }}$ \\
\hline \multirow{2}{*}{ B45P50 } & B45P50E25e0 & 61,8 & 45 & 2428 & 650 & - & - & $\mathrm{A}_{\mathrm{sw}, \text { norma }}$ \\
\hline & B45P50E25e12,5 & 61,8 & 45 & 2428 & 911 & - & - & $A_{s w, n o r m a}$ \\
\hline
\end{tabular}

Nota: $A_{s w n o r m a}$ representa as armaduras complementares dimensionadas por meio da Boletim $\mathrm{n}^{\circ} 78$ do CEB (1970), já, $A_{s w, 0}$, significa que tal armadura não considerada no modelo em questão. A expressão c/gancho significa que, no modelo, a armadura principal de tração foi detalhada com ganchos a $180^{\circ} \mathrm{e}$ $A_{s w, C}$ significa que estes modelos foram detalhados com uma armadura dimensionada para absorver às tensões de tração que provocam fendilhamento na biela de compressão. 
As armaduras complementares dos modelos B35P25E25e0A $\mathrm{sw}_{\mathrm{sw}, \mathrm{C}}$ e B45P25E25e0A $\mathrm{A}_{\mathrm{sw}, \mathrm{C}}$ foram dimensionadas calculando-se a força de tração perpendicular à biela de compressão $\left(R_{\text {Aswc }}\right)$ determinada por meio da solução do modelo de biela e tirante refinado sugerido pelo autor. Esse modelo é semelhante ao proposto por Adebar et al. (1990), porém, existem diferenças na geométrica da treliça, função da distribuição dos fluxos de tensões de compressão observados nas análises numéricas realizadas no Capitulo 3. A Figura 4.5 mostra os modelo sugerido.

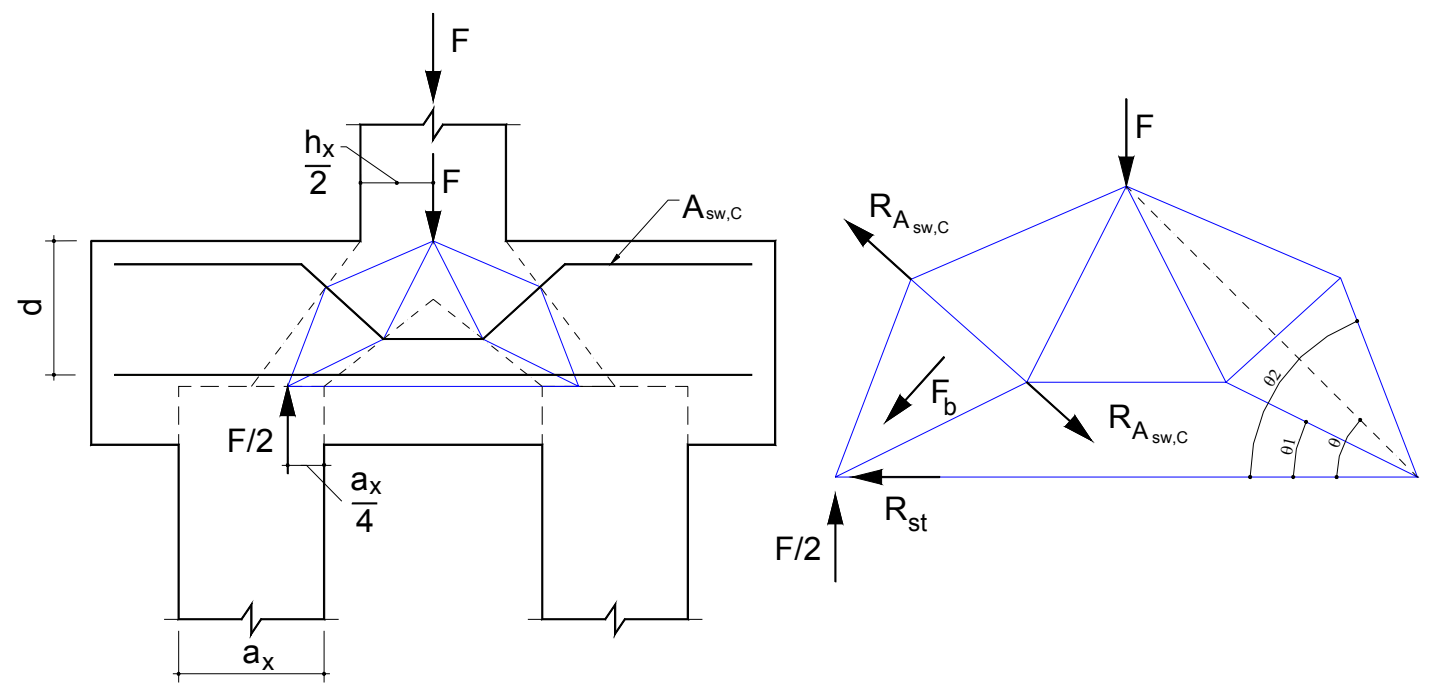

$F_{b}$, força na biela de compressão;

$\mathrm{R}_{\text {AswC, }}$ força de tração perpendicular à biela de compressão;

$\theta, \theta 1$ e $\theta 2$ são os ângulo de inclinação das forças existentes na biela de compressão.

Figura 4.5 - Modelo de biela e tirante refinado sugerido.

A força tração $R_{A s w c}$ calculada por meio do modelo refinado de biela e tirante para o modelo B35P25E25e $0 A_{s w, C}$ foi igual a $260 \mathrm{kN}$, enquanto que no modelo B45P25E25e0A $A_{s w, C}$ foi igual $261,56 \mathrm{kN}$. Com essas forças, foi possível determinar quantidade necessária de barras de aço para a armadura complementar $\mathrm{A}_{\mathrm{sw}, \mathrm{C}}$.

Observa-se por meio da Tabela 4.2 que existe diminuição na área efetiva dos modelos detalhados com ganchos em relação aos similares de suas respectivas séries. Esse fato se deu em virtude do menor comprimento necessário de ancoragem que é função da existência de gancho nas barras a ancorar. Além disso, nota-se que os modelos com a presença de excentricidade da força de compressão apresentam maior área de armadura do tirante, pois no dimensionamento foi levada em consideração a reação da estaca mais solicitada. 
Por meio da mesma tabela, observa-se que nos quatro últimos modelos a verificação do comprimento de ancoragem não foi levada em consideração. Isso foi feito propositalmente, pois em se tratando de modelos com pilares alongados, onde parte do pilar fica localizado sobre as estacas imaginou-se que as tensões de compressão nesses modelos provocariam grande redução no comprimento de ancoragem necessário. Desta maneira, optou-se por ensaiar os modelos com estas propriedades a fim de verificar se esse fenômeno ocorreria.

\subsection{Dimensionamento das estacas}

Seguindo a metodologia de outros ensaios de blocos sobre estacas, nos quais, os comprimentos das estacas ficam em torno da altura do bloco, adotou-se para os modelos analisados estacas com $40 \mathrm{~cm}$ de comprimento. A adoção de estacas curtas se faz necessário em função da facilidade de realização do ensaio, pois estacas com maior altura dificultaria a montagem dos equipamentos necessários para os ensaios.

O dimensionamento das estacas seguiu os critérios de dimensionamento de pilares da norma brasileira. Diferentemente do dimensionamento dos blocos, no dimensionamento das estacas, os coeficientes de minoração dos materiais $\gamma_{c}$ (concreto) e $\gamma_{s}$ (aço) e o de majoração dos esforços $\left(\gamma_{f}\right)$ foram levados em consideração.

Relembrando, adotou-se resistência característica do concreto à compressão igual a $50 \mathrm{MPa}$ e resistência característica de escoamento das barras de aço igual a $500 \mathrm{MPa}$.

Além da reação da estaca, determinada por meio da Expressão 4.9, também, foi levado em consideração a atuação de um momento mínimo, item 11.3.3.4.3 da NBR 6118:2003 (Expressão 4.16).

$$
\begin{aligned}
& \mathrm{M}_{1 \mathrm{~d}, \text { min }}=\mathrm{R}_{\mathrm{est},+} \cdot\left(0,015+0,03 \cdot \mathrm{h}_{\mathrm{x}}\right) \\
& \text { com } \mathrm{h}_{\mathrm{x}} \text { em metros. }
\end{aligned}
$$

Utilizando ábacos para flexão compostas em seção retangular com armadura bilateral simétrica desenvolvidos por Pinheiro (1996), determinou-se o número de barras de aço necessárias para as estacas de cada modelo. Com as Expressões 4.17, 4.18 e 4.19 foram efetuados os dimensionamentos das estacas. 


$$
\begin{aligned}
& \nu=\frac{\mathrm{R}_{\text {est, },+}}{\mathrm{h}_{\mathrm{x}} \cdot \mathrm{h}_{\mathrm{y}} \cdot \mathrm{f}_{\mathrm{cd}}} \\
& \mu=\frac{\mathrm{M}_{1 \mathrm{~d}, \min }}{\mathrm{h}_{\mathrm{x}}^{2} \cdot \mathrm{h}_{\mathrm{y}} \cdot \mathrm{f}_{\mathrm{cd}}} \\
& \mathrm{A}_{\mathrm{s}}=\frac{\omega \cdot \mathrm{h}_{\mathrm{x}} \cdot \mathrm{h}_{\mathrm{y}} \cdot \mathrm{f}_{\mathrm{cd}}}{\mathrm{f}_{\mathrm{yd}}}
\end{aligned}
$$

Sendo, $f_{c d}$ a resistência de cálculo à compressão do concreto e $f_{y d}$ a resistência de cálculo de escoamento das barras de aço.

Determinada a quantidade de barras aço necessária, calculada por meio da Expressão 4.19, verificou-se se esta área é maior que área de aço mínima determinada pela NBR 6118:2003, a qual é calculada pela Expressão 4.20. Nos casos em que foi menor que a mínima, adotou-se o valor mínimo.

$$
\mathrm{A}_{\mathrm{s}, \min }=\left(0,15 \cdot \frac{\mathrm{R}_{\mathrm{est},+}}{\mathrm{f}_{\mathrm{yd}}}\right) \geq 0,004 \cdot \mathrm{A}_{\mathrm{est}}
$$

Nas extremidades das barras posicionadas nos vértices dos estribos, foram projetados ganchos com comprimento de oito vezes o diâmetro de uma barra longitudinal da estaca. Esses ganhos fizeram-se necessários para melhorar às condições de transporte dos blocos, pois às estacas foram moldadas com data anterior à moldagem dos blocos e dos pilares.

Para a armadura transversal, adotou-se estribos com bitolas de 6,3 mm espaçados a cada dez centímetros, sendo que esse arranjo atende as exigências prescritas na NBR 6118:2003.

\subsection{Dimensionamento dos pilares}

O dimensionamento dos pilares foi análogo ao dimensionamento das estacas, salvo nos modelos que possuíam excentricidade da força de compressão. Nesses modelos verifica-se se o momento produzido pela existência da excentricidade da força de compressão aplicada no todo do pilar era maior ou menor que o momento mínimo fornecido pela Expressão 4.16. Nos casos onde esse momento foi menor que o momento mínimo, adotou-se o momento mínimo, caso contrário, adotou-se o momento determinado em função da excentricidade da força de compressão. Além 
disso fez-se necessário substituir nas Expressões 4.17 e 4.20 o valor de $R_{\text {est,++ }}$ por $F_{\text {teo }}$ que foi a força de compressão teórica prevista aplicada no topo do pilar. A área de aço calculada também foi comparada com a área de aço mínima, adotando-se o maior valor. Também na Expressão 4.20 foi necessário substituir o valor da área da estaca, $A_{\text {est }}$ pela área da seção transversal do pilar, $A_{\text {pilar. }}$ Como, em todos os modelos os pilares tinham pequena altura, os efeitos de segunda ordem foram desprezados no dimensionamento.

Para a armadura transversal dos pilares, adotaram-se barras de aço com diâmetros de $6,3 \mathrm{~mm}$, espaçadas a cada $2,5 \mathrm{~cm}$.

Além dos estribos foi necessária a inclusão de uma armadura de fretagem na cabeça do pilar. Essa armadura é primordial para absorver às tensões elevadas nessa região em função da intensidade da força aplicada. Essa armadura era composta por barras de aço com diâmetro de $6,3 \mathrm{~mm}$, colocada em toda a seção transversal do pilar, com espaçamento igual ao espaçamento dos estribos (ver Figura 4.6).

Em função da ancoragem da armadura longitudinal do pilar no bloco, foi necessário adotar barras com diâmetro de $10 \mathrm{~mm}$ para blocos com altura de $35 \mathrm{~cm}$ e barras com diâmetro de 12,5 mm para os blocos com altura de $45 \mathrm{~cm}$.

O comprimento de ancoragem básico $\left(\ell_{b}\right)$ foi determinado por meio das indicações da NBR 6118:2003, ver item 4.1.4, porém, o valor da tensão no aço $\sigma_{s, e f}$ foi substituído pela resistência de cálculo de escoamento das barras de aço, $f_{y d}$.

Todos os pilares tinha altura de vinte centímetros.

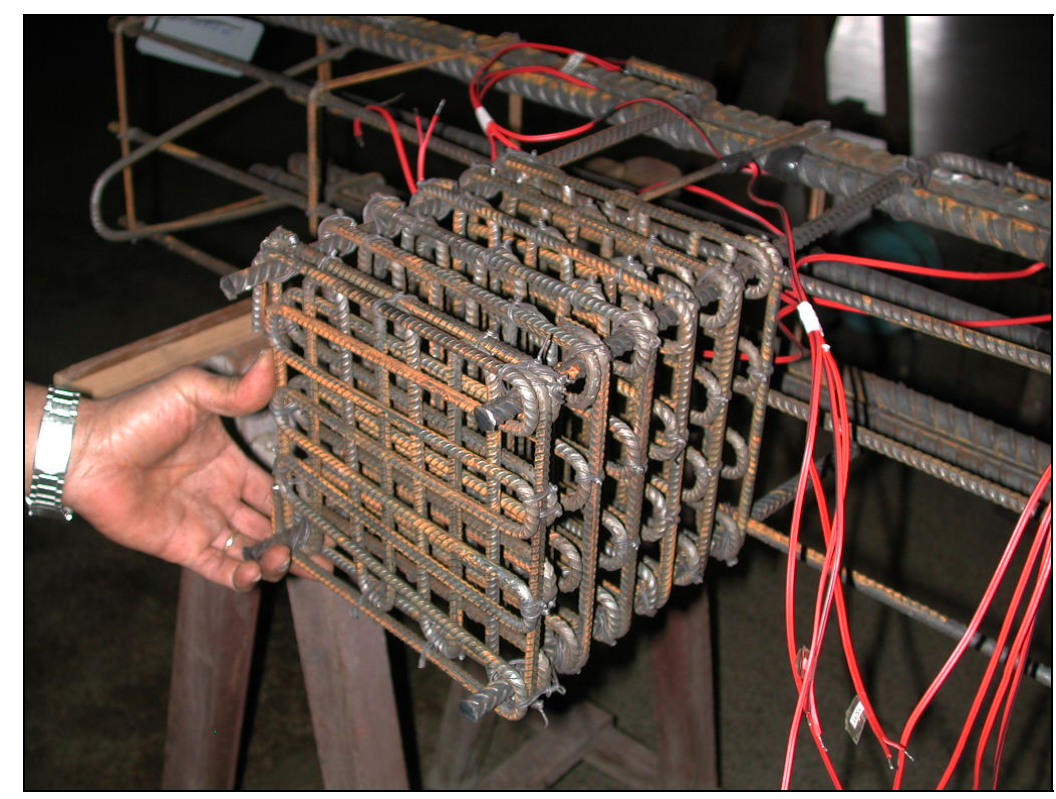

Figura 4.5 - Armadura de fretagem do pilar. 


\subsection{Detalhamento das armaduras}

Neste item são apresentados os arranjos das armaduras utilizadas para as construções dos modelos analisados experimentalmente.

A Tabela 4.3 traz informações sobre as armaduras utilizadas no arranjo dos blocos sobre estacas. Por meio dessa tabela, verifica-se que às áreas de aço da armadura principal de tração das séries B35P25 e B45P25 são iguais a menos dos modelos B35P25E25e0CG e B45P25E25e0CG. Isso ocorreu em função das exigências de ancoragem prescritas na NBR 6118:2003 e, na Tabela 4.4 são mostradas as armaduras complementares utilizadas no detalhamento dos modelos analisados experimentalmente.

Tabela 4.3 - Armadura principal de tração e armadura complementar superior.

\begin{tabular}{|c|c|c|c|c|c|c|}
\hline \multirow[b]{2}{*}{ SÉRIE } & \multirow[b]{2}{*}{ BLOCOS } & \multicolumn{3}{|c|}{ Armadura Principal } & \multicolumn{2}{|c|}{ Armadura superior } \\
\hline & & $\begin{array}{l}\text { Ast,calc } \\
\left(\mathrm{cm}^{2}\right)\end{array}$ & $A_{\text {st,adot }}$ & $\begin{array}{l}A_{\text {st,ef }} \\
\left(\mathrm{cm}^{2}\right)\end{array}$ & $\begin{array}{l}A_{\text {sc,ef }} \\
\left(\mathrm{cm}^{2}\right)\end{array}$ & A sc,adot $_{\text {s. }}$ \\
\hline \multirow{5}{*}{ B35P25 } & B35P25E25e0 & 10,94 & $5 \varnothing 20 \mathrm{~mm}$ & 15,75 & 1,58 & $3 \varnothing 8 \mathrm{~mm}$ \\
\hline & B35P25E25e2,5 & 11,81 & $5 \varnothing 20 \mathrm{~mm}$ & 15,75 & 1,58 & $3 \varnothing 8 \mathrm{~mm}$ \\
\hline & B35P25E25e0A $A_{s w, C}$ & 10,94 & $5 \varnothing 20 \mathrm{~mm}$ & 15,75 & - & - \\
\hline & B35P25E25e0A $A_{s w, 0}$ & 10,94 & $5 \varnothing 20 \mathrm{~mm}$ & 15,75 & - & - \\
\hline & B35P25E25e0CG & 10,94 & $4 \varnothing 20 \mathrm{~mm}$ & 12,60 & 1,21 & $3 ø 8 \mathrm{~mm}$ \\
\hline \multirow{5}{*}{ B45P25 } & B45P25E25e0 & 10,34 & $5 \varnothing 20 \mathrm{~mm}$ & 15,75 & 1,58 & $3 \varnothing 8 \mathrm{~mm}$ \\
\hline & B45P25E25e5 & 12,00 & $5 \varnothing 20 \mathrm{~mm}$ & 15,75 & 1,58 & $3 \varnothing 8 \mathrm{~mm}$ \\
\hline & B45P25E25e0A $A_{s w, C}$ & 10,34 & $5 \varnothing 20 \mathrm{~mm}$ & 15,75 & - & - \\
\hline & B45P25E25e0A $A_{s w, 0}$ & 10,34 & $5 \varnothing 20 \mathrm{~mm}$ & 15,75 & - & - \\
\hline & B45P25E25e0CG & 10,34 & $4 \varnothing 20 \mathrm{~mm}$ & 12,60 & 1,21 & $3 ø 8 \mathrm{~mm}$ \\
\hline \multirow{2}{*}{ B35P50 } & B35P50E25e0 & 15,00 & $6 \varnothing 20 \mathrm{~mm}$ & 18,90 & 1,89 & $3 ø 10 \mathrm{~mm}$ \\
\hline & B35P50E25e12,5 & 21,00 & $7 \varnothing 20 \mathrm{~mm}$ & 22,05 & 2,21 & $3 ø 10 \mathrm{~mm}$ \\
\hline \multirow{2}{*}{ B45P50 } & B45P50E25e0 & 13,01 & $5 \varnothing 20 \mathrm{~mm}$ & 15,75 & 1,58 & $3 ø 10 \mathrm{~mm}$ \\
\hline & B45P50E25e12,5 & 18,21 & $7 \varnothing 20 \mathrm{~mm}$ & 22,05 & 2,21 & $3 ø 10 \mathrm{~mm}$ \\
\hline
\end{tabular}

Tabela 4.4 - Armaduras complementares.

\begin{tabular}{|c|c|c|c|c|c|c|}
\hline \multirow{2}{*}{ SÉRIE } & \multirow{2}{*}{ BLOCOS } & \multicolumn{2}{|c|}{ Estribos verticais } & \multicolumn{2}{|c|}{ Estribos horizontais } & \multirow[b]{2}{*}{$A_{s w, C}$} \\
\hline & & $\begin{array}{c}\mathbf{A}_{\text {st, calc }} \\
\left(\mathrm{cm}^{2}\right)\end{array}$ & $A_{\text {st }, \text { adot }}$ & $\begin{array}{l}A_{\text {sc,ef }} \\
\left(\mathrm{cm}^{2}\right)\end{array}$ & $\mathbf{A}_{\mathrm{sc}, \text { adot }}$ & \\
\hline \multirow{5}{*}{ B35P25 } & B35P25E25e0 & 0,63 & $\varnothing 5 \mathrm{~mm} \mathrm{c} / 30 \mathrm{~cm}$ & 1,58 & $3 ø 8 \mathrm{~mm}$ & - \\
\hline & B35P25E25e2,5 & 0,63 & $\varnothing 5 \mathrm{~mm} \mathrm{c} / 30 \mathrm{~cm}$ & 1,58 & $3 ø 8 \mathrm{~mm}$ & - \\
\hline & B35P25E25e0A $A_{s w, C}$ & - & - & - & - & $3 ø 16 \mathrm{~mm}$ \\
\hline & B35P25E25e0A $A_{s w, 0}$ & - & - & - & - & - \\
\hline & B35P25E25e0CG & 0,50 & $\varnothing 5 \mathrm{~mm} \mathrm{c} / 33 \mathrm{~cm}$ & 1,21 & $3 ø 8 \mathrm{~mm}$ & - \\
\hline \multirow{5}{*}{ B45P25 } & B45P25E25e0 & 0,63 & $\varnothing 5 \mathrm{~mm} c / 30 \mathrm{~cm}$ & 1,58 & $3 ø 8 \mathrm{~mm}$ & - \\
\hline & B45P25E25e5 & 0,63 & $\varnothing 5 \mathrm{~mm} \mathrm{c} / 30 \mathrm{~cm}$ & 1,58 & $3 ø 8 \mathrm{~mm}$ & - \\
\hline & B45P25E25e0A $A_{s w, C}$ & - & - & - & - & $3 ø 16 \mathrm{~mm}$ \\
\hline & $\mathrm{B}_{45 \mathrm{P} 25 \mathrm{E} 25 \mathrm{e} 0 \mathrm{~A}_{\mathrm{sw}, 0}}$ & - & - & - & - & - \\
\hline & B45P25E25e0CG & 0,50 & $\varnothing 5 \mathrm{~mm} \mathrm{c} / 33 \mathrm{~cm}$ & 1,21 & $3 ø 8 \mathrm{~mm}$ & - \\
\hline \multirow{2}{*}{ B35P50 } & B35P50E25e0 & 0,76 & $\varnothing 6,3 \mathrm{~mm} \mathrm{c} / 26 \mathrm{~cm}$ & 1,89 & $3 ø 10 \mathrm{~mm}$ & - \\
\hline & B35P50E25e12,5 & 0,84 & $\varnothing 6,3 \mathrm{~mm} \mathrm{c} / 25 \mathrm{~cm}$ & 2,21 & $3 ø 10 \mathrm{~mm}$ & - \\
\hline \multirow{2}{*}{ B45P50 } & B45P50E25e0 & 0,52 & $\varnothing 6,3 \mathrm{~mm} \mathrm{c} / 26 \mathrm{~cm}$ & 1,58 & $3 ø 10 \mathrm{~mm}$ & - \\
\hline & B45P50E25e12,5 & 0,73 & $\varnothing 6,3 \mathrm{~mm} \mathrm{c} / 30 \mathrm{~cm}$ & 2,21 & $3 ø 10 \mathrm{~mm}$ & - \\
\hline
\end{tabular}


Nas Tabelas 4.5 e 4.6 são apresentadas as armaduras utilizadas no detalhamento das estacas e dos pilares.

Tabela 4.5 - Armadura das estacas.

\begin{tabular}{|c|c|c|c|c|c|c|c|c|c|}
\hline SÉRIE & BLOCOS & $\begin{array}{c}\mathbf{R}_{\text {est, }} \\
(\mathrm{kN})\end{array}$ & $\begin{array}{c}\mathbf{M}_{1 \mathrm{~d}, \mathrm{mi}} \\
n \\
(\mathrm{kNm})\end{array}$ & $v$ & $\mu$ & $\omega$ & $\begin{array}{c}\mathbf{A}_{\mathbf{s}, \text { calc,est }} \\
\left(\mathrm{cm}^{2}\right)\end{array}$ & $\begin{array}{c}A_{\mathbf{s}, \min _{3} \text { est }} \\
\left(\mathrm{cm}^{2}\right)\end{array}$ & $A_{s, \text { adot,est }}$ \\
\hline \multirow{5}{*}{ B35P25 } & B35P25E25e0 & 547 & 17,23 & 0,34 & 0,02 & 0 & 0 & 2,64 & $4 \varnothing 10 \mathrm{~mm}$ \\
\hline & B35P25E25e2,5 & 591 & 18,61 & 0,37 & 0,02 & 0 & 0 & 2,85 & $4 \varnothing 10 \mathrm{~mm}$ \\
\hline & B35P25E25e0A $\mathrm{Asw}, \mathrm{C}$ & 547 & 17,23 & 0,34 & 0,02 & 0 & 0 & 2,64 & $4 \varnothing 10 \mathrm{~mm}$ \\
\hline & $\mathrm{B}_{5}$ 25E25e0A $\mathrm{sw}, 0$ & 547 & 17,23 & 0,34 & 0,02 & 0 & 0 & 2,64 & $4 \varnothing 10 \mathrm{~mm}$ \\
\hline & B35P25E25e0CG & 547 & 17,23 & 0,34 & 0,02 & 0 & 0 & 2,64 & $4 ø 10 \mathrm{~mm}$ \\
\hline \multirow{5}{*}{ B45P25 } & B45P25E25e0 & 724 & 22,81 & 0,45 & 0,02 & 0 & 0 & 3,50 & $4 \varnothing 12,5 \mathrm{~mm}$ \\
\hline & B45P25E25e5 & 840 & 26,45 & 0,53 & 0,03 & 0 & 0 & 4,06 & $4 \varnothing 12,5 \mathrm{~mm}$ \\
\hline & B45P25E25e0A $\mathrm{sw}, \mathrm{C}_{\mathrm{c}}$ & 724 & 22,81 & 0,45 & 0,02 & 0 & 0 & 3,50 & $4 \varnothing 12,5 \mathrm{~mm}$ \\
\hline & B45P25E25e0A $A_{s w, 0}$ & 724 & 22,81 & 0,45 & 0,02 & 0 & 0 & 3,50 & $4 \varnothing 12,5 \mathrm{~mm}$ \\
\hline & B45P25E25e0CG & 724 & 22,81 & 0,45 & 0,02 & 0 & 0 & 3,50 & $4 \varnothing 12,5 \mathrm{~mm}$ \\
\hline \multirow{2}{*}{ B35P50 } & B35P50E25e0 & 1000 & 31,50 & 0,63 & 0,03 & 0 & 0 & 4,83 & $8 ø 10 \mathrm{~mm}$ \\
\hline & B35P50E25e12,5 & 1400 & 44,10 & 0,88 & 0,03 & 0 & 0 & 6,76 & $8 ø 10 \mathrm{~mm}$ \\
\hline \multirow{2}{*}{ B45P50 } & B45P50E25e0 & 1214 & 38,24 & 0,76 & 0,06 & 0,2 & 2 & 5,86 & $8 ø 12,5 \mathrm{~mm}$ \\
\hline & B45P50E25e12,5 & 1700 & 53,54 & 1,07 & 0,07 & 0,3 & 3 & 8,21 & $8 ø 12,5 \mathrm{~mm}$ \\
\hline
\end{tabular}

Tabela 4.6 - Armadura dos pilares.

\begin{tabular}{|c|c|c|c|c|c|c|c|c|c|c|}
\hline SÉRIE & BLOCOS & $\begin{array}{l}F_{\text {teo }} \\
(\mathrm{kN})\end{array}$ & $\begin{array}{l}\mathbf{M}_{1 \mathrm{~d}, \text { min }} \\
(\mathrm{kNm})\end{array}$ & $\begin{array}{l}\mathbf{M}_{\mathrm{d}, \text { calc }} \\
(\mathrm{kNm})\end{array}$ & $v$ & $\mu$ & $\omega$ & $\begin{array}{c}A_{\mathbf{s}, \text { calc, p }} \\
\left(\mathrm{cm}^{2}\right)\end{array}$ & $\begin{array}{c}A_{s, \min , \mathbf{p}} \\
\left(\mathrm{cm}^{2}\right)\end{array}$ & $A_{s, \text { adot,est }}$ \\
\hline \multirow{5}{*}{ B35P25 } & B35P25E25e0 & 1094 & 34,5 & 0 & 0,69 & 0,062 & 0 & 0 & 3,78 & $8 ø 10 \mathrm{~mm}$ \\
\hline & B35P25E25e2,5 & 1094 & 34,5 & 38,3 & 0,69 & 0,069 & 0 & 0 & 3,78 & $8 ø 10 \mathrm{~mm}$ \\
\hline & $\mathrm{B}$ P25E25e0A $\mathrm{A}_{\mathrm{sw}, \mathrm{C}}$ & 1094 & 34,5 & 0 & 0,69 & 0,062 & 0 & 0 & 3,78 & $8 ø 10 \mathrm{~mm}$ \\
\hline & $\mathrm{B}^{2} 5 \mathrm{P} 25 \mathrm{E} 25 \mathrm{e} 0 \mathrm{~A}_{\mathrm{sw}, 0}$ & 1094 & 34,5 & 0 & 0,69 & 0,062 & 0 & 0 & 3,78 & $8 ø 10 \mathrm{~mm}$ \\
\hline & B35P25E25e0CG & 1094 & 34,5 & 0 & 0,69 & 0,062 & 0 & 0 & 3,78 & $8 ø 10 \mathrm{~mm}$ \\
\hline \multirow{5}{*}{ B45P25 } & B45P25E25e0 & 1448 & 45,6 & 0 & 0,91 & 0,082 & 0,2 & 10,27 & 5,00 & $14 \varnothing 12,5 \mathrm{~mm}$ \\
\hline & B45P25E25e5 & 1448 & 45,6 & 72,4 & 0,91 & 0,13 & 0,3 & 15,40 & 5,00 & $14 \varnothing 12,5 \mathrm{~mm}$ \\
\hline & $\mathrm{B} 45 \mathrm{P} 25 \mathrm{E} 25 \mathrm{e} 0 \mathrm{~A}_{\mathrm{sw}, \mathrm{C}}$ & 1448 & 45,6 & 0 & 0,91 & 0,082 & 0,2 & 10,27 & 5,00 & $14 \varnothing 12,5 \mathrm{~mm}$ \\
\hline & B45P25E25e0A $A_{s w, 0}$ & 1448 & 45,6 & 0 & 0,91 & 0,082 & 0,2 & 10,27 & 5,00 & $14 \varnothing 12,5 \mathrm{~mm}$ \\
\hline & B45P25E25e0CG & 1448 & 45,6 & 0 & 0,91 & 0,082 & 0,2 & 10,27 & 5,00 & $14 \varnothing 12,5 \mathrm{~mm}$ \\
\hline \multirow{2}{*}{ B35P50 } & B35P50E25e0 & 2000 & 84 & 0 & 0,63 & 0,038 & 0 & 0 & 6,90 & $14 ø 10 \mathrm{~mm}$ \\
\hline & B35P50E25e12,5 & 2000 & 84 & 250 & 0,63 & 0,112 & 0,1 & 10,27 & 6,90 & $14 \varnothing 10 \mathrm{~mm}$ \\
\hline \multirow{2}{*}{ B45P50 } & B45P50E25e0 & 2428 & 102 & 0 & 0,76 & 0,046 & 0 & 0 & 8,40 & $14 ø 12,5 \mathrm{~mm}$ \\
\hline & B45P50E25e12,5 & 2428 & 102 & 303,5 & 0,76 & 0,136 & 0,15 & 15,40 & 8,40 & $14 ø 12,5 \mathrm{~mm}$ \\
\hline
\end{tabular}

Por meio das Tabelas 4.5 e 4.6, observa-se que foram adotados arranjos iguais para as séries, com isso foi possível padronizar a montagem das armaduras e diminuir os efeitos que essas provocariam no comportamento estrutural dos modelos.

As Figuras 4.6 a 4.10 mostram esquematicamente os arranjos das armaduras empregadas nos modelos analisados experimentalmente. A Figura 4.11 apresenta em perspectiva o arranjo da armadura dos modelos B35P25E25e0 e B35P25E25e2,5.

No Anexo $C$ encontram-se os detalhamentos das armaduras de todos os modelos. 


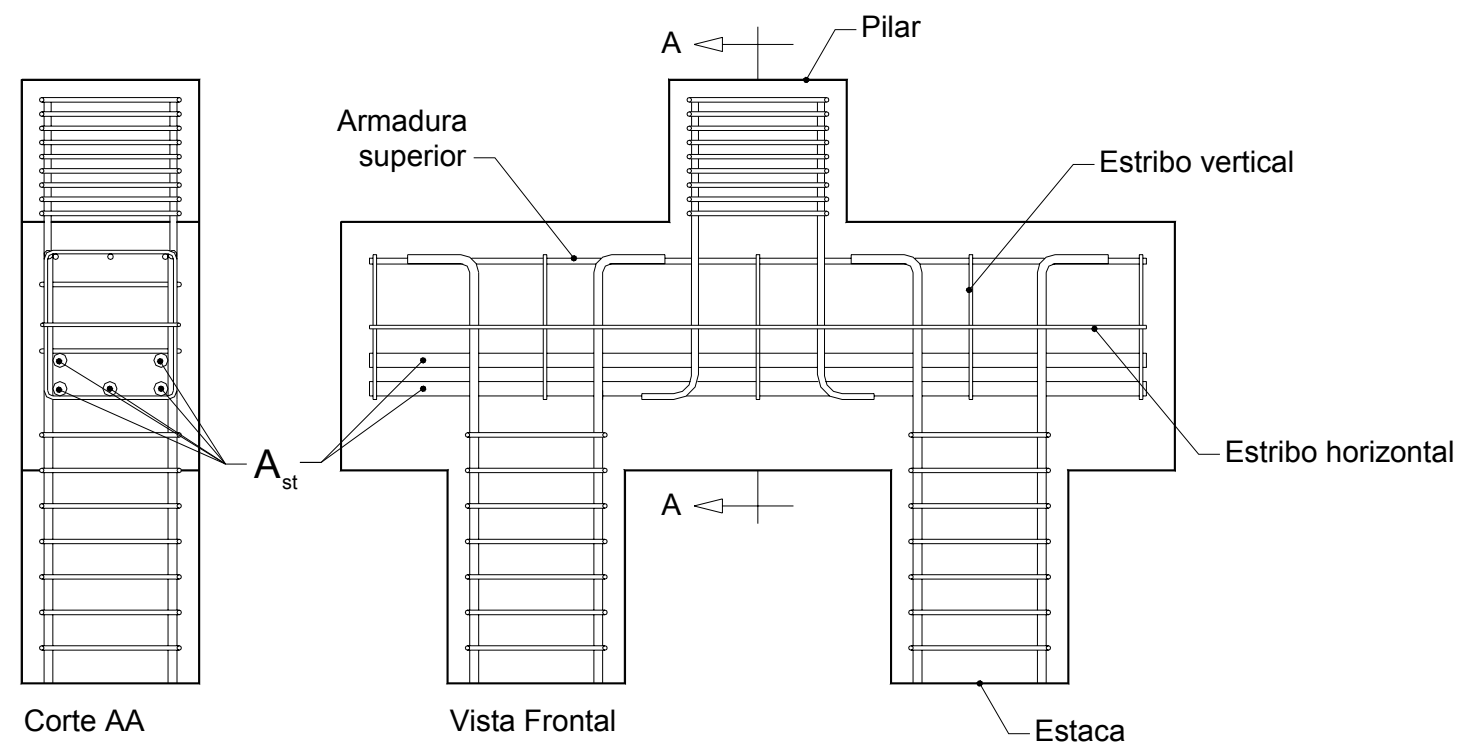

Figura 4.6 - Detalhamento esquemático, modelos: B35P25E25e0, B35P25E25e2,5, B45P25E25e0 e B35P25E25e5.

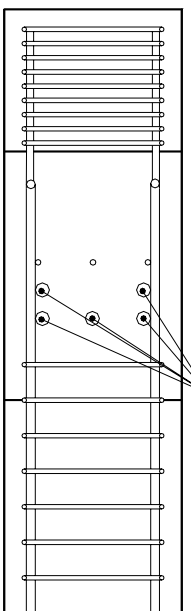

Corte AA

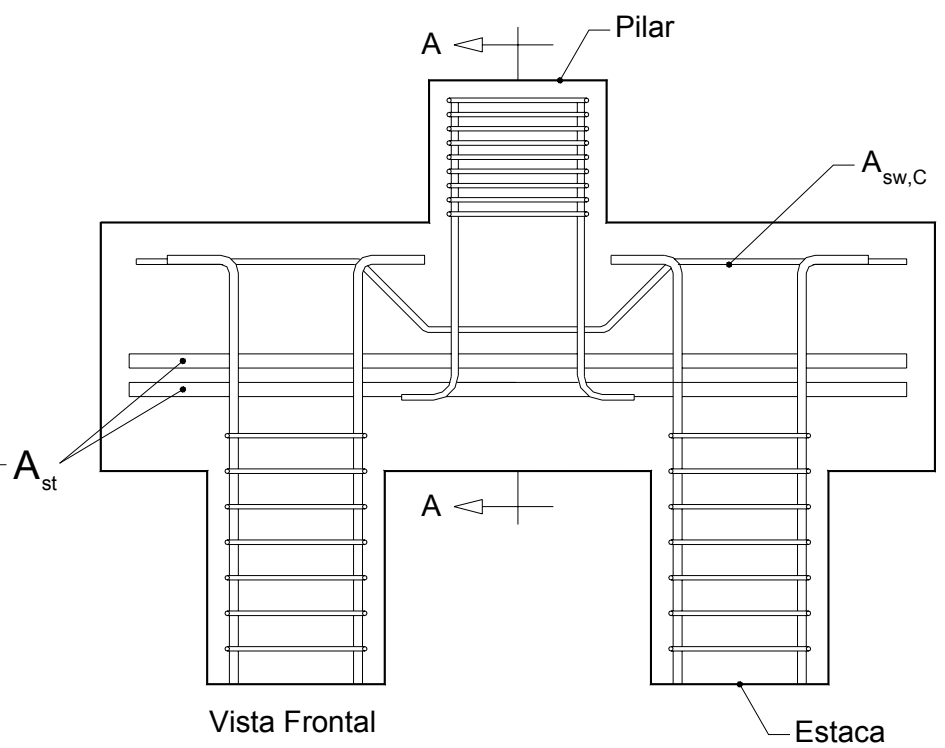

Figura 4.7 - Detalhamento esquemático, modelos: B35P25E25e0A $A_{s w, c}, B 35 P 25 E 25 e 0 A_{s w, c}$. 


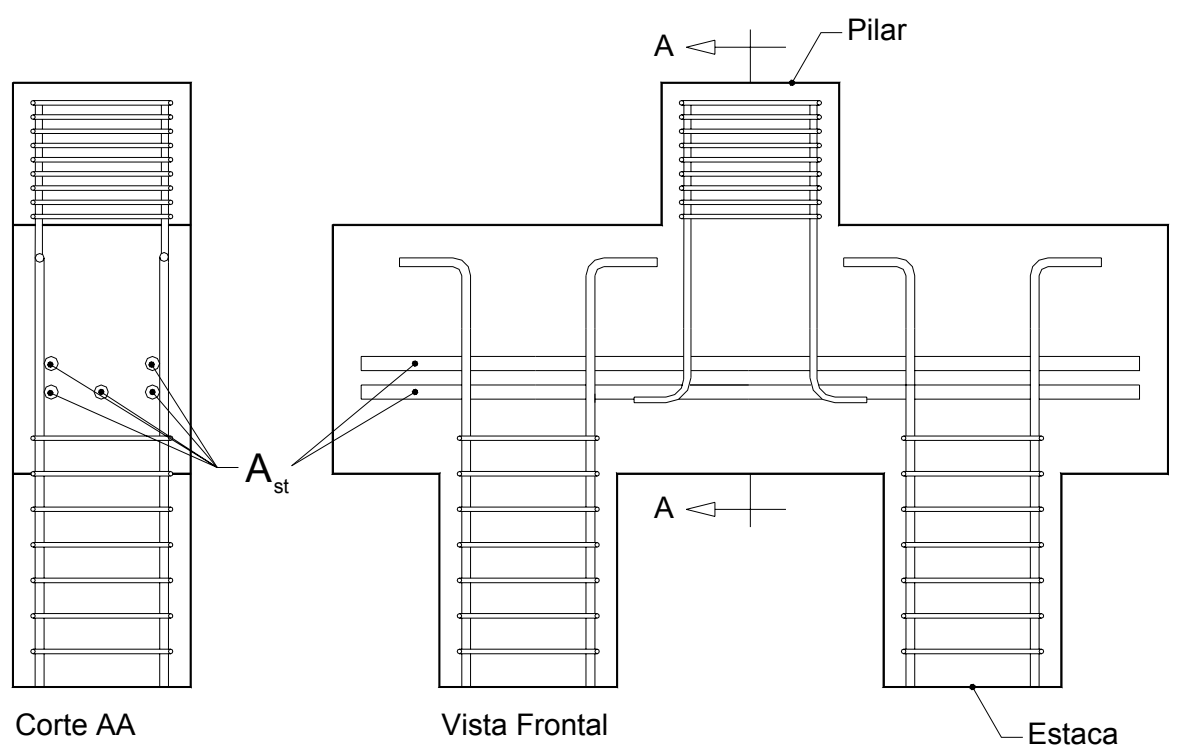

Figura 4.8 - Detalhamento esquemático, modelos: B35P25E25e0A $\mathrm{sw0}_{\text {0 }}$ B45P25E25e0A $\mathrm{sw0}_{\mathrm{sw}}$.

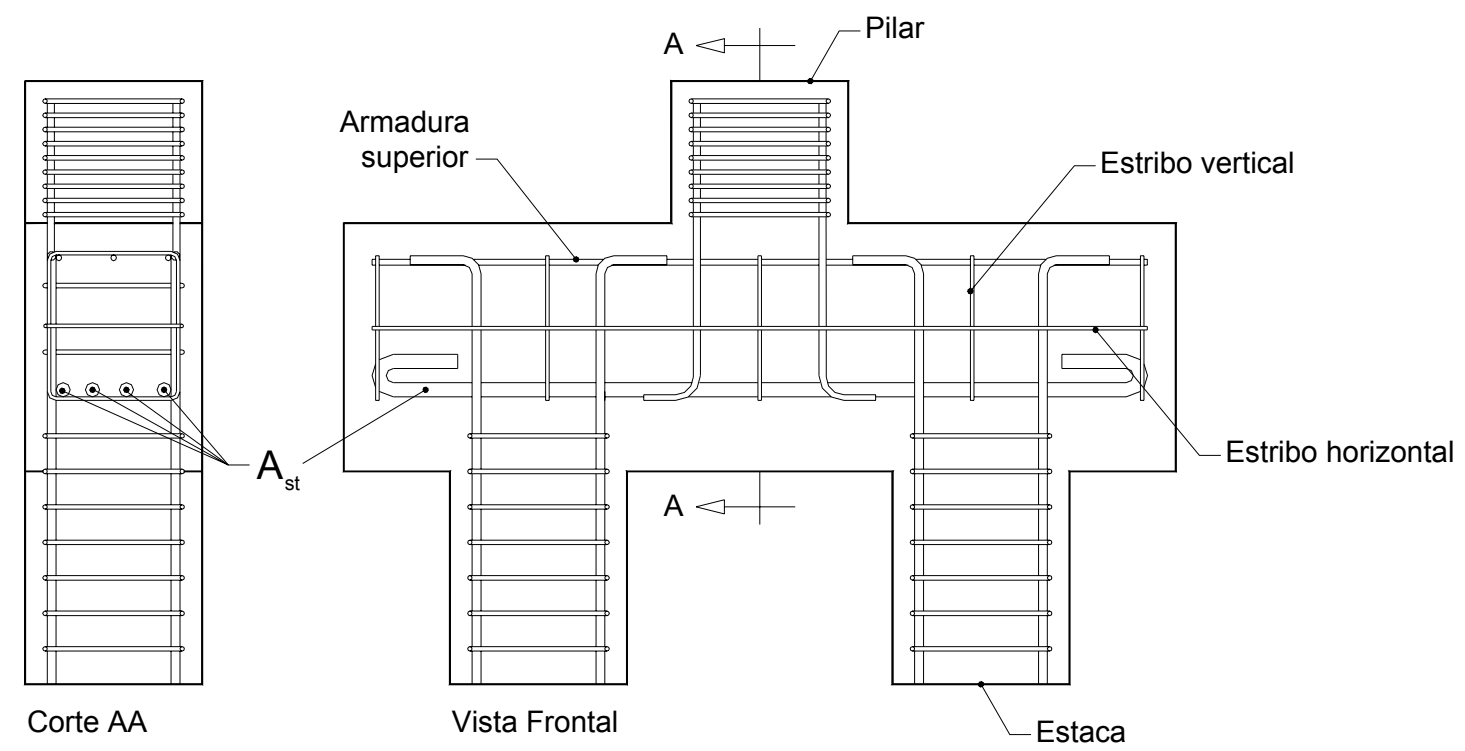

Figura 4.9 - Detalhamento esquemático, modelos: B35P45E25e0CG, B45P25E25e0CG. 


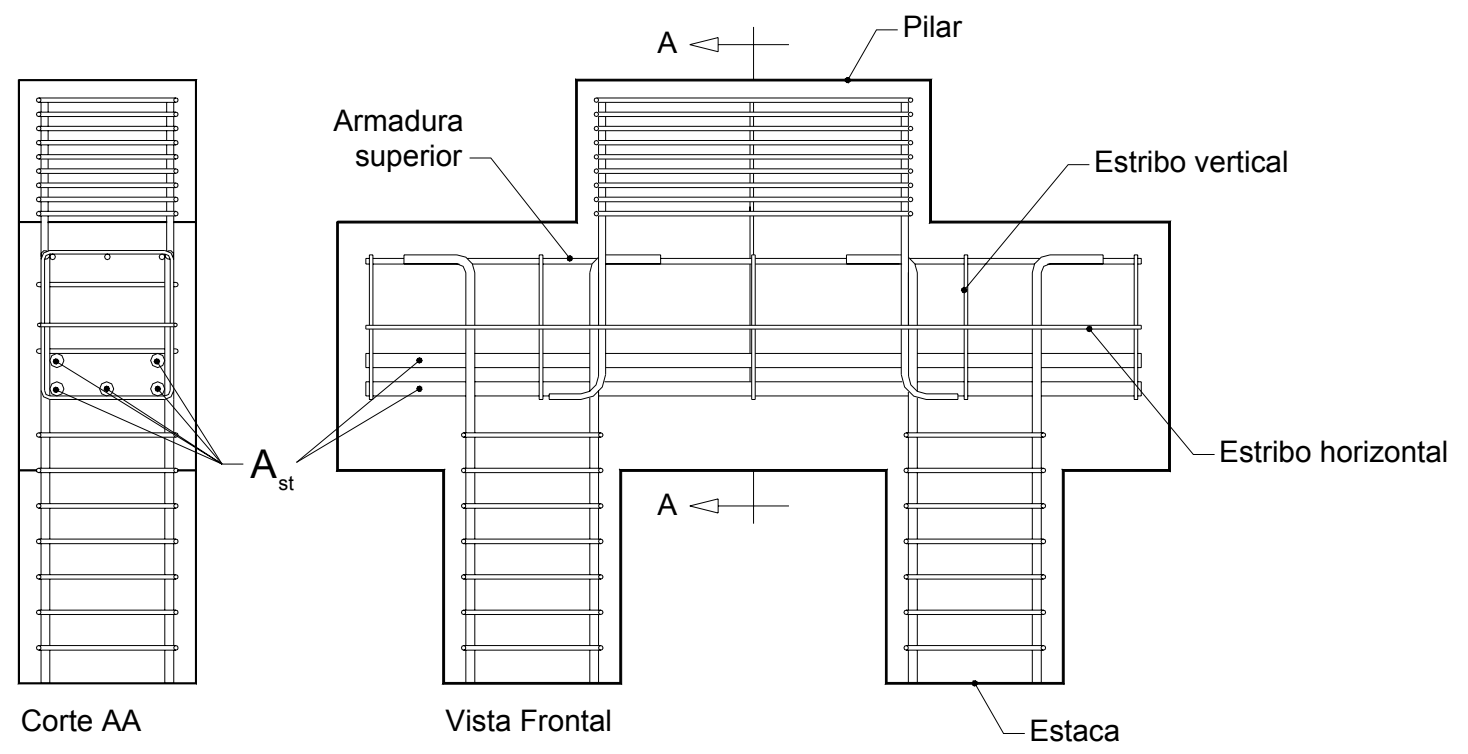

Figura 4.10 - Detalhamento esquemático, modelos: B35P50E25e0, B45P50E25e0, B35P50E25e12,5 e B45P50E25e12,5.

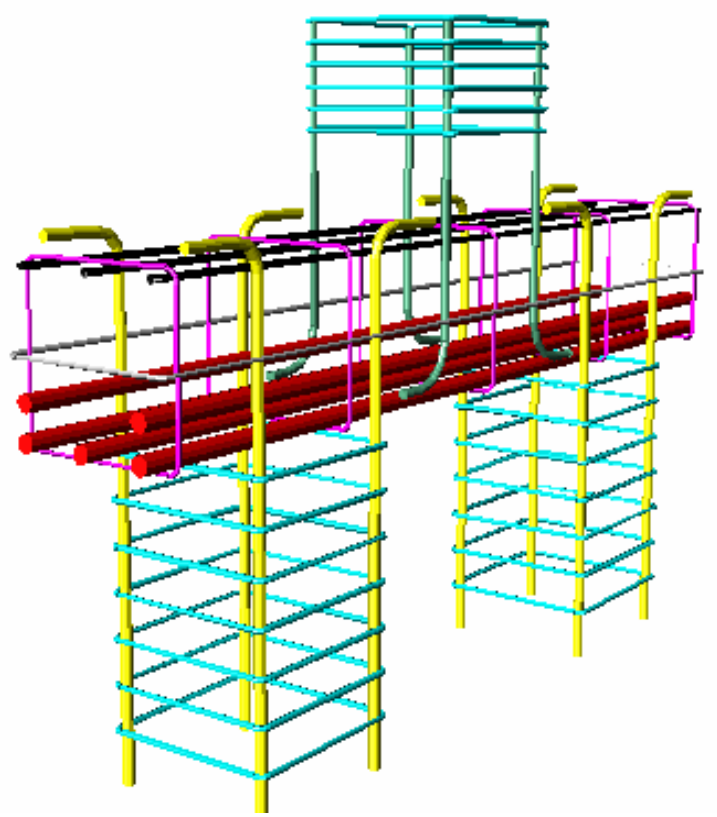

Figura 4.11 - Perspectiva, modelos B35P25E25e0 e B35P25E25e2,5. 


\subsection{Dosagem do concreto}

Como as resistências à compressão dos concretos dos pilares e estacas foram diferentes da resistência à compressão do concreto dos blocos foi necessária a elaboração de dois traços diferentes. Para isso, estudos de traços foram realizados utilizando metodologia desenvolvida por Helene \& Terzian (1995). Essa metodologia é baseada em resultados de resistências à compressão de três traços de concreto com diferentes teores de cimento, definidos como: rico, médio e pobre. Por meio desses resultados, definem-se relações necessárias para a obtenção de um traço definitivo com a resistência desejada na idade estipulada.

O cimento utilizado nos ensaios foi doado pela empresa Camargo Corrêa Cimentos S.A., marca Cauê, tipo CPII-F-32 (cimento Portland composto com filer) e CPV-ARI (cimento de alta resistência inicial). A massa específica fornecida pelo fabricante varia de $3,10 \mathrm{~g} / \mathrm{cm}^{3}$ a $3,15 \mathrm{~g} / \mathrm{cm}^{3}$. O cimento de alta resistência inicial foi utilizado nos concretos empregados nas moldagens das estacas e pilares e, o cimento Portland composto com filer foi utilizado nos concretos dos blocos.

O agregado miúdo utilizado foi uma areia tipo quartzosa, cuja granulometria foi determinada mediante indicações da NBR 7217:1987, apresentando módulo de finura igual a 2,12 e diâmetro máximo do agregado igual a 2,3 $\mathrm{mm}$. A areia foi considerada fina, pertencendo a zona 2. A massa específica foi igual a $2,62 \mathrm{~g} / \mathrm{cm}^{3}$ sendo determinada por meio das especificações da NBR 9776:1987, já, a massa unitária, calculada utilizando os critérios da NBR 7251:1982, teve valor igual 1,60 g/cm ${ }^{3}$.

O agregado graúdo utilizado foi pedra britada de origem basáltica, proveniente da região de São Carlos. A granulometria e o módulo de finura também foram determinados em função das especificações da NBR 7217:1987, sendo o valor do módulo de finura igual a 6,49, com diâmetro máximo do agregado igual a $19 \mathrm{~mm}$. As massas específica e unitária, que foram determinadas por meio das indicações da NBR 9776:1987, resultaram iguais a $2,89 \mathrm{~g} / \mathrm{cm}^{3}$ e $1,54 \mathrm{~g} / \mathrm{cm}^{3}$.

A água utilizada na produção do concreto foi de origem da rede pública de distribuição do município de São Carlos, estado de São Paulo.

Fixou-se o valor do abatimento do tronco de cone em $70 \mathrm{~mm} \pm 10 \mathrm{~mm}$. Esse valor foi obtido em Helene \& Terzian (1995) que é função da densidade da armadura do elemento estrutural a ser moldado. $O$ teor de argamassa também foi fixado, sendo seu valor igual a $50 \%$. 
Para o concreto com resistência prevista de $50 \mathrm{MPa}$, foi necessário a utilização de superplastificante, pois o cimento empregado é mais fino que os demais, necessitando de maior quantidade de água para estabelecer boa trabalhabilidade.

O superplastificante empregado foi doado pela empresa Anchortec Industrial e Comercial Ltda. (FOSROC), tipo Conplast SP430. Esse superplastificante possui massa específica entre $1,20 \mathrm{~g} / \mathrm{cm}^{3}$ a $1,22 \mathrm{~g} / \mathrm{cm}^{3}$. Adotou-se teor de adição igual a $1 \%$, pois, o fabricante recomenda a adição no intervalo de 0,8 \% a 1,5 \%. A adição de superplastificante superior ao limite estabelecido, pode provocar retardo significativo da pega, incorporação de ar, aumento de exsudação e retração plástica.

Foram moldados doze corpos-de-prova cilíndricos com quinze centímetros de diâmetro e trinta centímetros de altura, para o estudo de traço para concreto com resistência de $25 \mathrm{MPa}$ e doze corpos-de-prova cilíndricos com dez centímetros de diâmetro e vinte centímetros de altura para o estudo de traço dos concreto de $50 \mathrm{MPa}$.

Os corpos-de-prova foram ensaiados com idades iguais a 3, 7, 14 e 28 dias. Por meio dos resultados dos ensaios à compressão, determinaram-se curvas que foram utilizadas na elaboração dos traços definitivos.

A Tabela 4.7 apresenta os resultados obtidos por meio dos estudos de traços para os concreto com resistências de $25 \mathrm{MPa}$ e $50 \mathrm{MPa}$.

As quantidades dos agregados miúdo e graúdo foram determinadas por meio da Expressão 4.21, lembrando-se que o teor de argamassa $(\alpha)$ foi igual a $50 \%$.

As Figuras 4.12 e 4.13 mostram os diagramas de dosagem para os concretos de $25 \mathrm{MPa}$ e $50 \mathrm{MPa}$.

Por meio dos diagramas das Figuras 4.14 e 4.15 e da Tabela 4.7 elaboraou-se os traços para concretos com resistências de $25 \mathrm{MPa}$ e $50 \mathrm{MPa}$ aos vinte e oito dias de idade.

$$
\alpha=\frac{1+\mathrm{a}_{\mathrm{r}}}{1+\mathrm{m}}
$$

sendo:

- $\quad a_{r}$, massa do agregado miúdo;

- $\quad m=a_{r}+p_{b}$, massa seca em $\mathrm{kg} / \mathrm{m}^{3}$;

- $\quad p_{b}$, massa do agregado graúdo;

- $\quad \alpha$, teor de argamassa. 
Tabela 4.7 - Estudo de traço.

\begin{tabular}{|c|c|c|c|c|c|c|c|}
\hline \multicolumn{8}{|c|}{$25 \mathrm{MPa}$} \\
\hline \multirow{2}{*}{ Traços } & \multirow[t]{2}{*}{$a / c$} & \multirow{2}{*}{$\begin{array}{c}\text { Massa seca } \\
\left(\mathrm{kg} / \mathrm{m}^{3}\right)\end{array}$} & \multirow{2}{*}{$\begin{array}{c}\text { Cimento } \\
\left(\mathrm{kg} / \mathrm{m}^{3}\right)\end{array}$} & \multicolumn{4}{|c|}{$\begin{array}{c}\mathbf{f}_{\mathrm{cj}} \\
(\mathrm{MPa})\end{array}$} \\
\hline & & & & 3 dias & 7 dias & 14 dias & 28 dias \\
\hline Pobre & 0,68 & 1972 & 302,53 & 9,63 & 17,90 & 21,96 & 25,31 \\
\hline Médio & 0,63 & 1917 & 322,18 & 0,21 & 18,14 & 23,80 & 25,95 \\
\hline Rico & 0,43 & 1583 & 451,83 & 28,88 & 33,40 & 36,79 & 40,91 \\
\hline \multicolumn{8}{|c|}{$50 \mathrm{MPa}$} \\
\hline \multirow[t]{2}{*}{ Traços } & \multirow[t]{2}{*}{$a / c$} & \multirow{2}{*}{$\begin{array}{l}\text { Massa seca } \\
\qquad\left(\mathrm{kg} / \mathrm{m}^{3}\right)\end{array}$} & \multirow{2}{*}{$\begin{array}{c}\text { Cimento } \\
\left(\mathrm{kg} / \mathrm{m}^{3}\right)\end{array}$} & \multicolumn{4}{|c|}{$\begin{array}{c}\mathbf{f}_{\mathrm{cj}} \\
(\mathrm{MPa})\end{array}$} \\
\hline & & & & 3 dias & 7 dias & 14 dias & 28 dias \\
\hline Pobre & 0,51 & 2196 & 339,46 & 42,89 & 44,29 & 48,61 & 49,64 \\
\hline Médio & 0,31 & 2074 & 414,89 & 57,94 & 65,43 & 70,58 & 78,64 \\
\hline Rico & 0,28 & 1878 & 535,59 & 66,94 & 73,20 & 77,03 & 89,42 \\
\hline
\end{tabular}
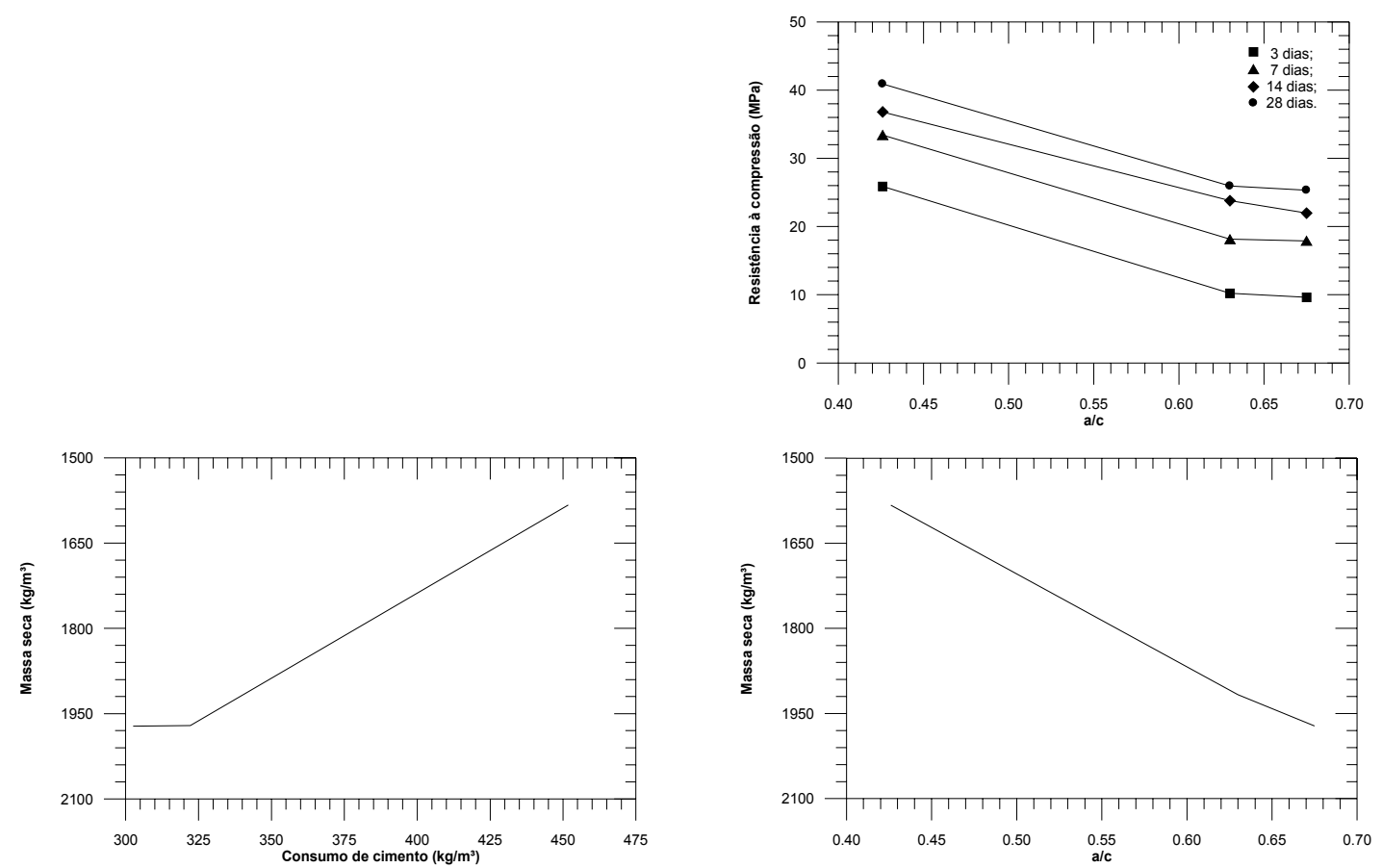

Figura 4.12 - Dosagem para concreto produzidos com cimento CP-II-F-32, $\alpha=50 \%$.

O traço em massa para concreto com resistência a compressão igual $25 \mathrm{MPa}$ aos 28 dias de idades foi igual a $1: 2,55: 3,54: 0,68$ (cimento, areia, pedra britada e a/c). A Tabela 4.8 apresenta o consumo dos materiais por metro cúbico de concreto.

Tabela 4.8 - Consumo de materiais, $\mathrm{kg} / \mathrm{m}^{3}, \mathrm{f}_{\mathrm{c}}=25 \mathrm{MPa}$.

\begin{tabular}{c|c}
\hline \hline Materiais & Consumo $\left(\mathbf{k g} / \mathbf{m}^{\mathbf{s}}\right)$ \\
\hline Cimento CP-II-F-32 & 325 \\
\hline Areia media & 828,75 \\
\hline Pedra britada 1 & 1150,50 \\
\hline Água & 221 \\
\hline \hline
\end{tabular}



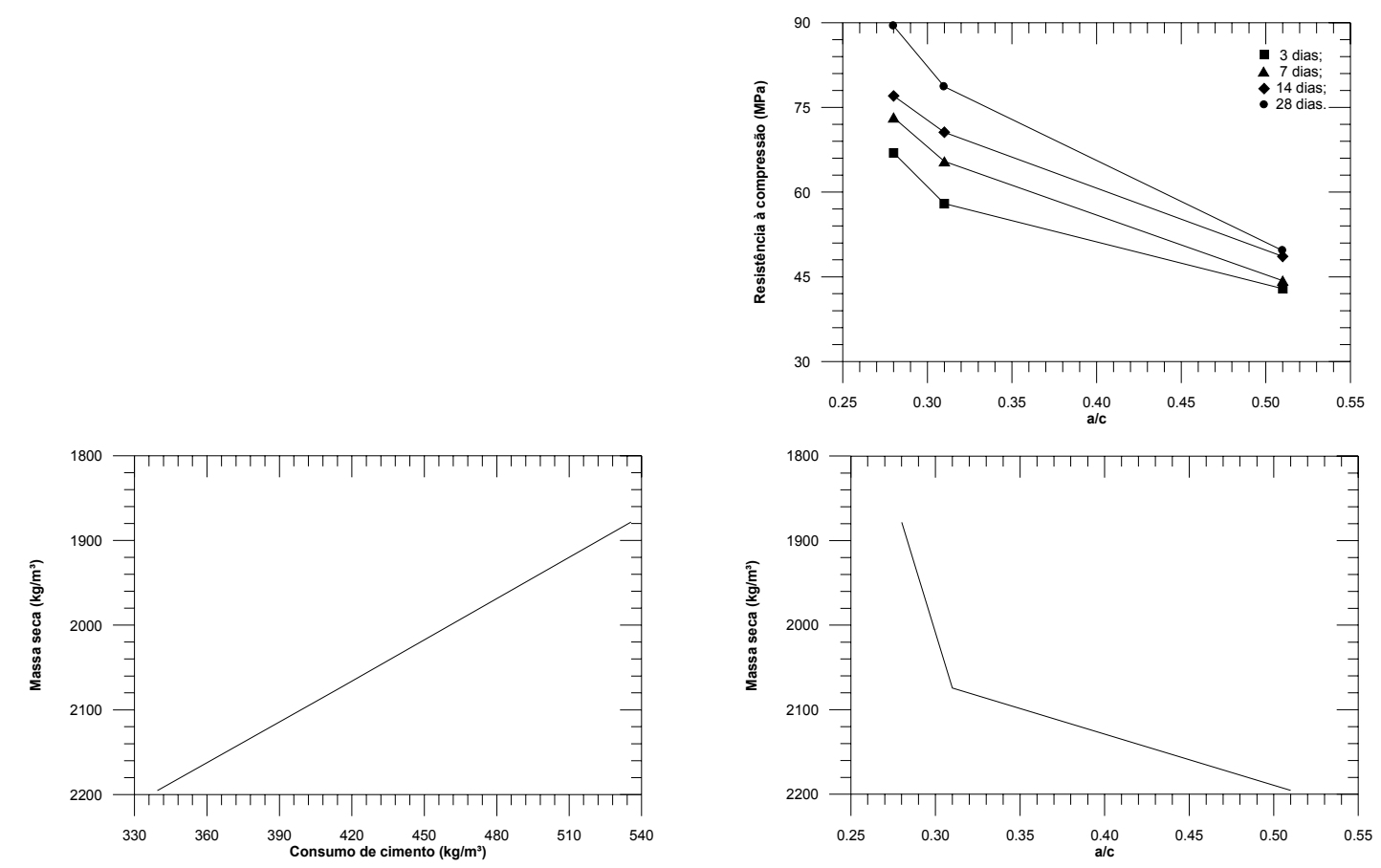

Figura 4.13 - Dosagem para concreto produzidos com cimento CP-V-ARI, $\alpha=50 \%$.

Para o concreto com resistência de $50 \mathrm{MPa}$ aos 28 dias, o traço em massa obtido foi igual a $1: 2,66: 3,66: 0,49: 0,01$ (cimento, areia, pedra britada, a/c e superplastificante).

$\mathrm{Na}$ Tabela 4.9 são apresentados os consumos dos matérias por metro cúbico de concreto.

Tabela 4.9 - Consumo de materiais, $\mathrm{kg} / \mathrm{m}^{3}, \mathrm{f}_{\mathrm{c}}=50 \mathrm{MPa}$.

\begin{tabular}{|c|c|}
\hline Materiais & Consumo $\left(\mathrm{kg} / \mathrm{m}^{\mathrm{s}}\right)$ \\
\hline Cimento CPV-ARI & 345 \\
\hline Areia media & 917,17 \\
\hline Pedra britada 1 & 1261,70 \\
\hline Água & 169 \\
\hline Aditivo superplastificante Conplast SP430 & 3,25 \\
\hline
\end{tabular}

\subsection{Execução dos modelos}

A primeira etapa da construção dos modelos foi a moldagem das estacas. Após efetuada a cura das estacas e tendo resistências suficientes para o transporte, procederam-se as moldagens dos blocos. As estacas foram posicionadas de modo que a distância entre seus eixos fosse igual a $62,5 \mathrm{~cm}$. Após isso, as fôrmas dos 
blocos foram posicionadas de modo que as estacas respeitassem o limite de embutimento estipulado que foi igual a $10 \mathrm{~cm}$. As moldagens dos pilares se deram logo após a concretagem dos blocos.

As fôrmas utilizadas para a confecção dos modelos foram produzidas com madeira compensada plastificada com $18 \mathrm{~mm}$ de espessura. Foram construídas quatro fôrmas para a moldagem das estacas e duas fôrmas para a moldagem dos blocos e pilares.

A Figura 4.14 apresenta as fôrmas de madeira e a armadura de uma das estacas utilizadas na construção dos modelos, a Figura 15, mostra as fôrmas de madeira utilizadas nas moldagens dos blocos e pilares.
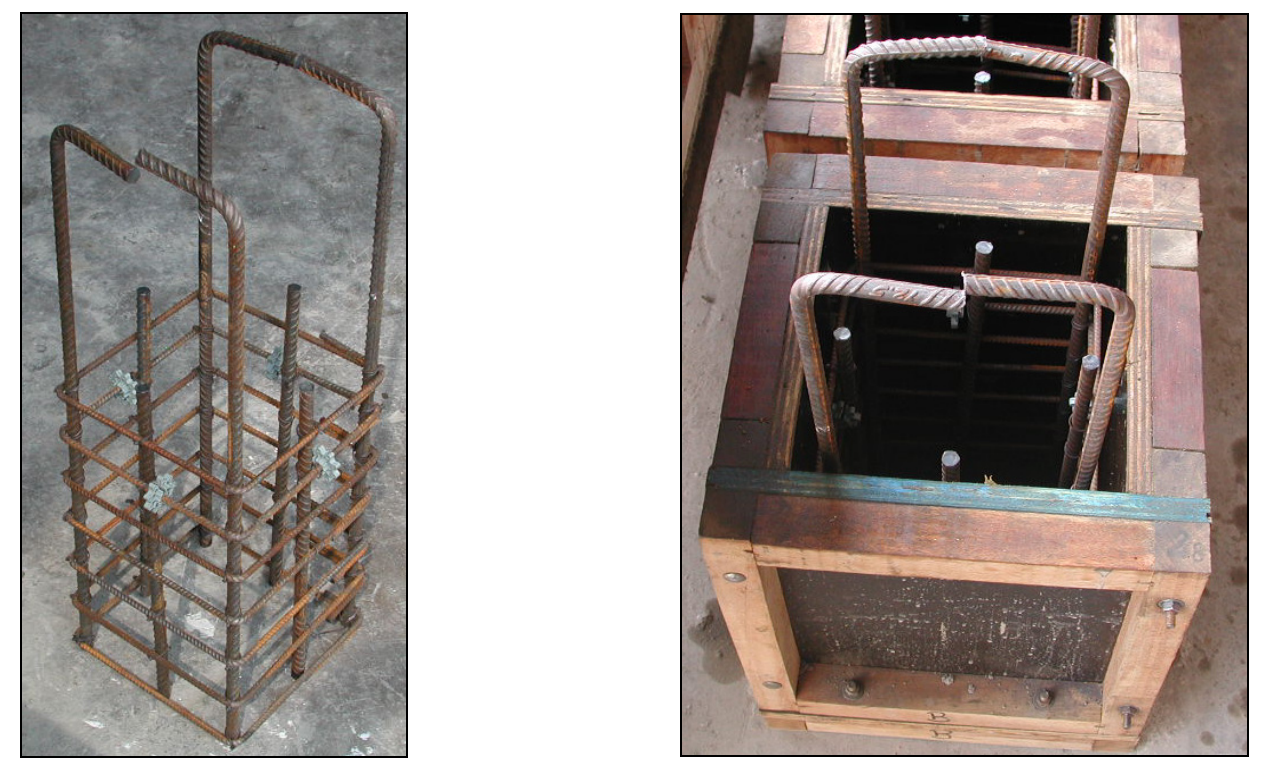

Figura 4.14 - Moldagem das estacas.
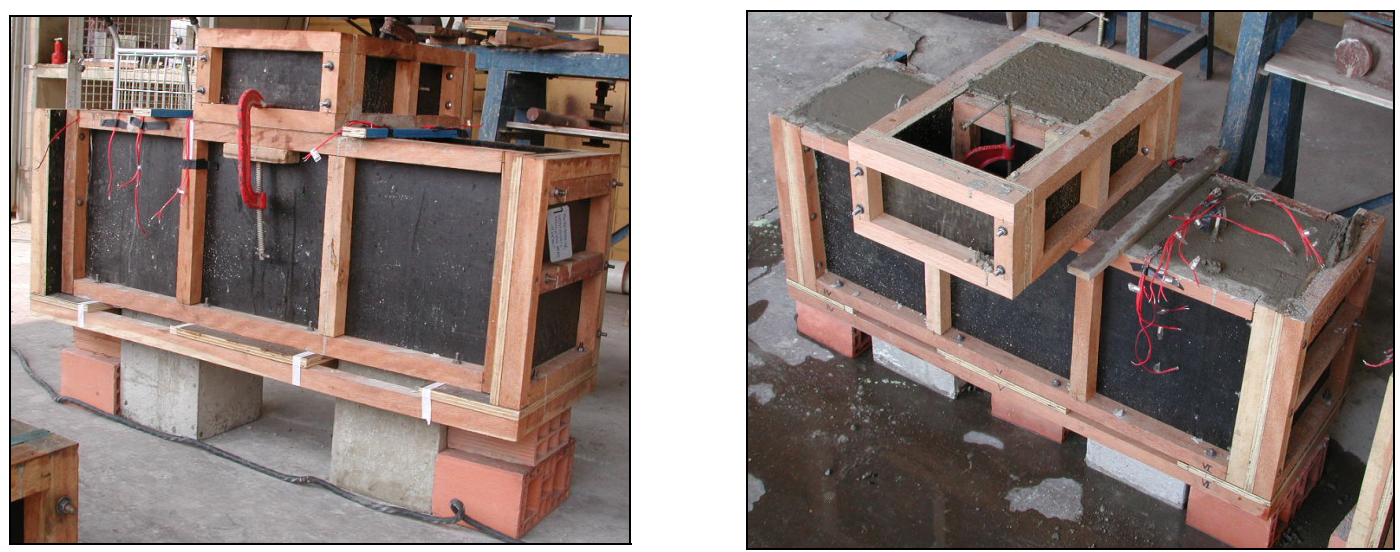

Figura 4.15 - Moldagem dos blocos. 
Por meio da Figura 4.15, observa-se o posicionamento das estacas e mostrase que a concretagem dos blocos e pilares feitas após a moldagem das estacas.

A Figura 4.16 apresenta a configuração de um dos modelos depois de efetuada a desfôrma.
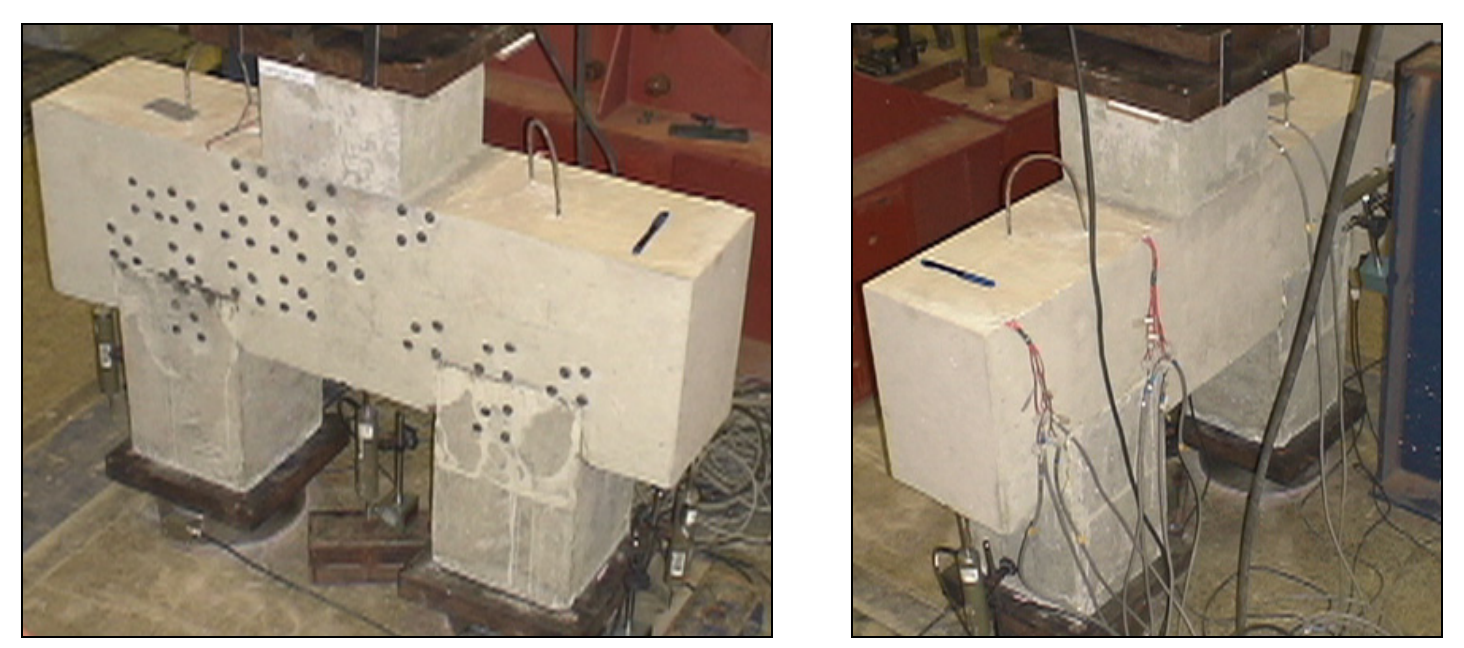

Figura 4.16 - Configuração dos modelos após a desfôrma.

No total foram produzidos no Laboratório de Estruturas da Escola de Engenharia de São Carlos, Universidade de São Paulo, 2,72 $\mathrm{m}^{3}$ de concreto e foram consumidos $647,41 \mathrm{~kg}$ de barras de aço para a construção dos modelos que foram doados pela empresa Belgo Mineira S. A., grupo Arcelor. 


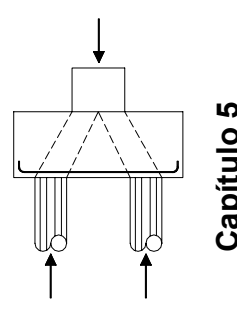

\section{DESCRIÇÃO E APRESENTAÇÃO DOS RESULTADOS}

EXPERIMENTAIS

\subsection{Considerações iniciais}

Este capitulo descreve e analisa os resultados dos ensaios realizados no Laboratório de Estruturas da Escola de Engenharia de São Carlos, Universidade de São Paulo. Primeiramente são apresentados os equipamentos e instrumentos utilizados e, por fim, a descrição dos ensaios e apresentação dos resultados.

\subsection{Equipamentos e instrumentos utilizados}

Como o objetivo da pesquisa era obter informações sobre a forma geométrica da biela de compressão, uma das faces dos blocos foi instrumentada por meio de pastilhas de aço que serviram de pontos de medidas para as deformações do concreto. As medidas dos deslocamentos relativos entre as pastilhas de aço foram obtidas por meio de extensômetro mecânico removível, modelo Tensotast fabricado pela Huggenberger. Trata-se de um instrumento constituído por um relógio comparador e dois cutelos, um fixo e outro articulado, o qual funciona como comparador. Possui sensibilidade de $0,001 \mathrm{~mm}$. Utilizou-se para os ensaios base de medida igual a $50 \mathrm{~mm}$, com isso, pôde-se obter valores de deformações de até $0,02 \%$. As informações técnicas a respeito deste aparelho foram obtidas em Takeya (2001). A justificativa para o emprego dessa metodologia é apresentada a seguir.

Alguns pesquisadores utilizaram em seus ensaios extensômetros do tipo encapsulado (embebed) que são imersos na massa de concreto, com a finalidade de medir deformações no interior do elemento, por exemplo, Adebar et al. (1990), o qual utilizou este tipo de extensômetro para obter valores de deformações das bielas de compressão. Não se optou por esse procedimento, pois, a utilização desses extensômetros poderia causar no interior do bloco um enfraquecimento do concreto na 
região onde os extensômetros seriam instalados, mudando a trajetória do fluxo de tensões de compressão das bielas.

Outros pesquisadores, como Miguel (2000), utilizaram barras de aço instrumentadas com extensômetros elétricos de resistência uniaxiais, para medir as deformações no interior da massa de concreto. As barras foram instaladas no interior do elemento estrutural ensaiado, na posição onde se desejava obter medidas de deformações. Esse procedimento também traz complicações, pois, como o aço é mais resistente que o concreto, esse se deforma, modificando, desta maneira, as deformações no concreto do entorno e a distribuição do fluxo de tensões de compressão.

Em função dos problemas descritos, optou-se pela utilização de extensômetros mecânicos, que não interferem no comportamento estrutural do bloco.

Além das deformações na face do concreto, também foram analisadas as deformações nas armaduras, para isto, utilizaram-se extensômetros elétricos de resistência uniaxiais, modelo KFG5, marca Kyowa, com fator do extensômetro (gage factor) igual a 2,11 e base de medida igual a $5 \mathrm{~mm}$.

As intensidades das forças aplicadas foram medidas por meio de células de carga. Foram utilizadas três células de carga, uma com capacidade igual a $5000 \mathrm{kN}$ e duas com capacidades iguais a $2000 \mathrm{kN}$. A célula com maior capacidade foi instalada sobre os pilares e as demais, sob as estacas, desta maneira foi possível obter o valor da força aplicada no pilar e as reações nas estacas para cada modelo analisado experimentalmente.

A força aplicada no topo do pilar foi exercida por meio de um pistão hidráulico com capacidade de $5000 \mathrm{kN}$ e curso máximo de $160 \mathrm{~mm}$. O óleo necessário para movimentar o pistão foi injetado por meio de uma bomba elétrica com controle de carga e descarga.

Como estrutura de reação, utilizou-se um pórtico metálico com capacidade de 5000 kN e a laje de reação do Laboratório de Estruturas da Escola de Engenharia de São Carlos, Universidade de São Paulo.

O sistema de aquisição de dados de força, deformações e deslocamentos, que foram fornecidos, respectivamente, pelo pistão hidráulico, transdutores e extensômetros foi o System 5100, da Measurements Group e, o programa computacional utilizado foi o StrainMart do mesmo fabricante.

As medidas dos deslocamentos foram obtidas por meio de transdutores de deslocamentos com curso máximo de $50 \mathrm{~mm}$. Também foram utilizados suportes 
magnéticos com hastes articuladas, pois, os relógios comparadores necessitavam de dispositivo de fixação para o sistema de referência das medições.

A Figura 5.1 apresenta os equipamentos utilizados no ensaio dos blocos sobre estacas.

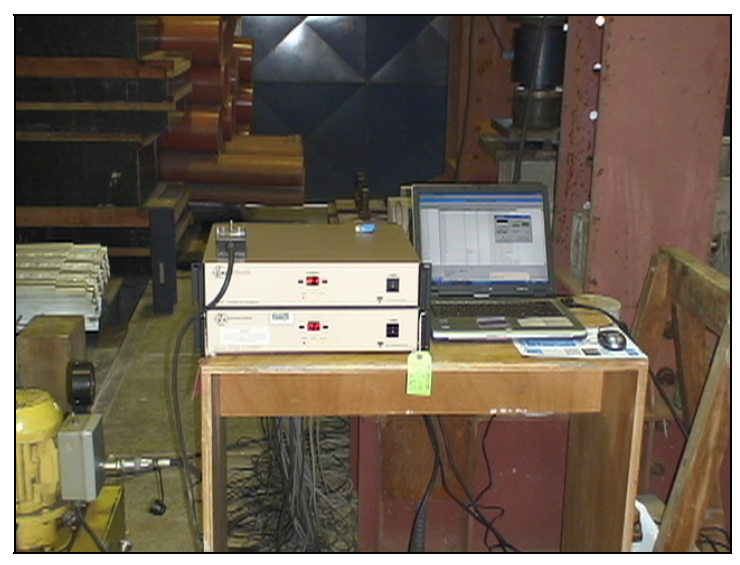

a) Sistema de aquisição de dados.

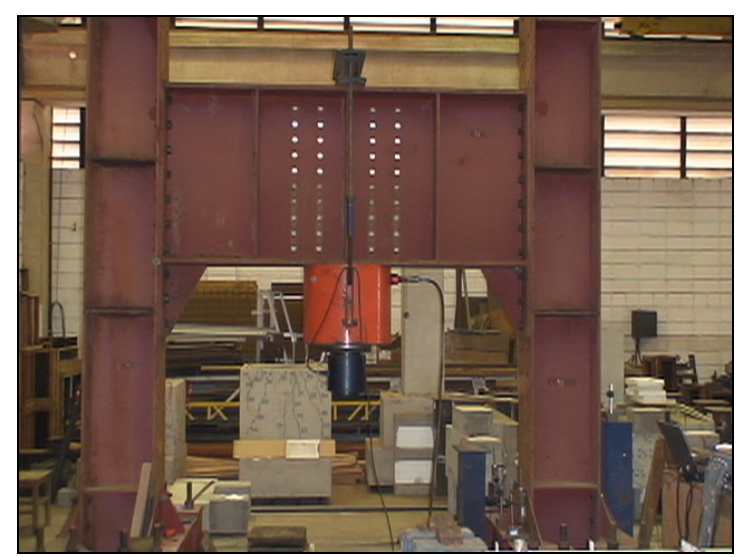

c) Pórtico metálico, capacidade de 5000 kN.

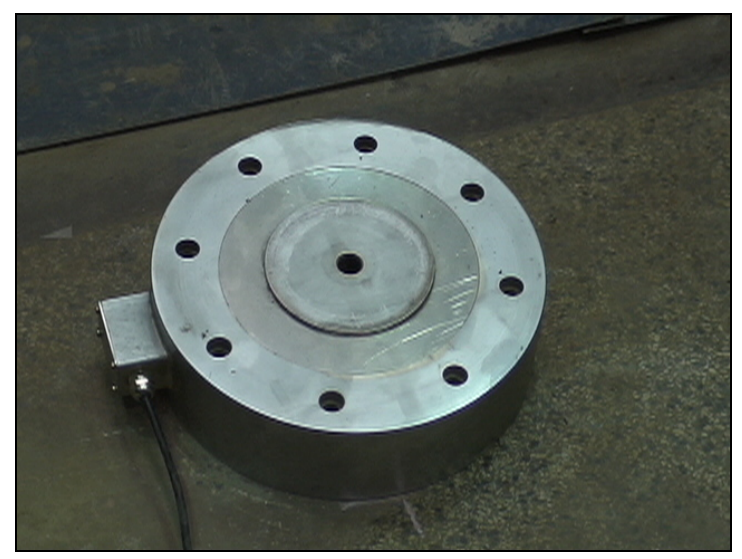

e) Célula de carga, capacidade de 2000 kN.

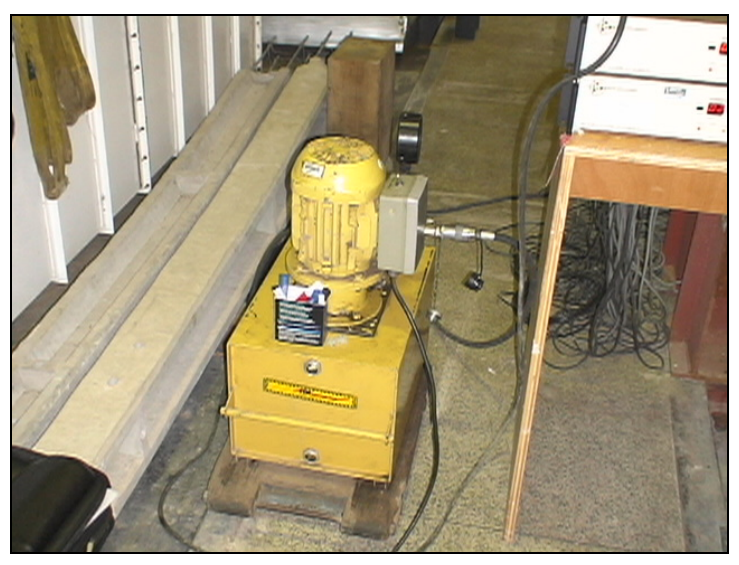

b) Bomba elétrica de carga e descarga.

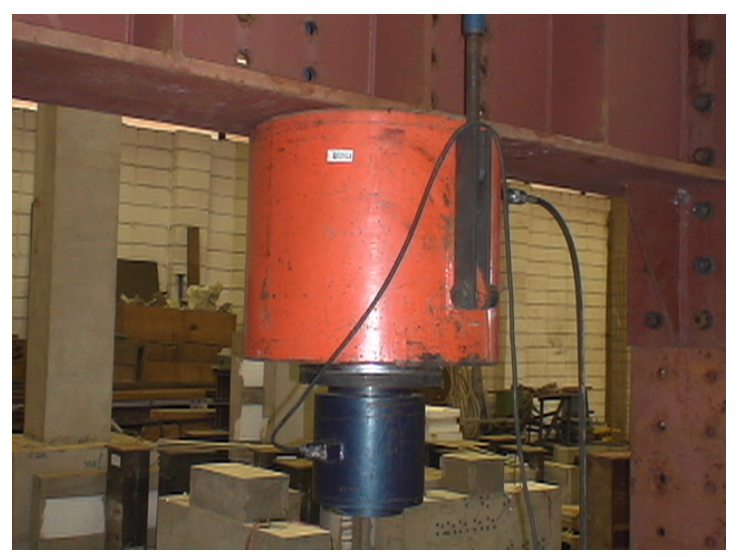

d) Pistão hidráulico e célula de carga, capacidade $5000 \mathrm{kN}$.

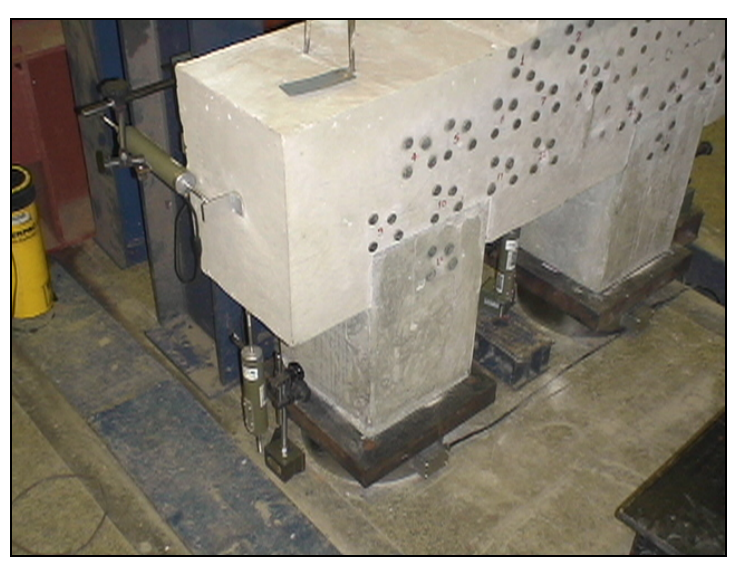

g) Transdutores de deslocamento.

Figura 5.1 - Configuração do sistema de ensaio utilizado. 
A célula de carga com capacidade de 2000 kN, mostrada na Figura 5.1, tem diâmetro de $280 \mathrm{~mm}$ e altura igual a $90 \mathrm{~mm}$. Nota-se que essa célula tem forma achatada. Essa forma foi escolhida para melhorar a estabilidade do modelo durante o ensaio.

Sobre os pilares foi instalada uma rótula de aço, que permitiu com maior rigor controlar a excentricidade aplicada ao modelo. Essa rótula permitia rotação na direção longitudinal do bloco. A Figura 5.2 apresenta a rótula de aço utilizada.

Apesar da célula de carga utilizada para medir às reações nas estacas possuir dimensões favoráveis com relação a estabilidade do modelo, a região onde se procedeu a leitura das reações das estacas tinha diâmetro menor (oito centímetros) que o diâmetro da célula. Essa pequena área em contato com a estaca poderia causar perturbações localizadas por causa da tensão, provocando o colapso da mesma. Desta maneira, fez-se necessário a utilização de placas de aço sobre as células de carga para distribuir de maneira uniforme as reações que essa exerceu nas estacas $A$ Figura 5.3 mostra a instalação dessas placas de aço.

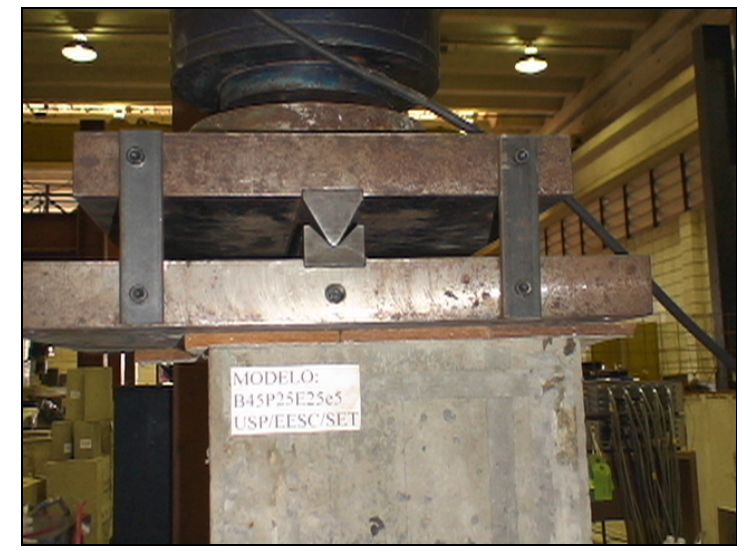

Figura 5.2 - Rótula utilizada nos ensaios.

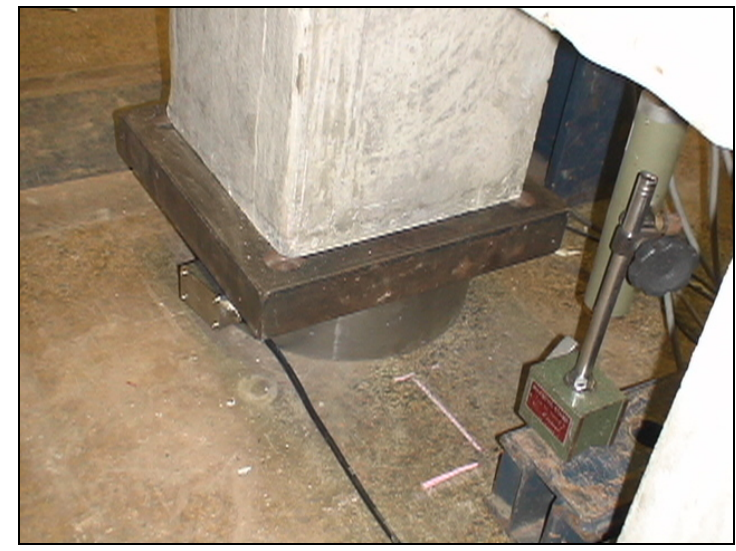

Figura 5.3 - Placa de aço sobre à célula de carga com capacidade igual a $2000 \mathrm{kN}$.

\subsubsection{Extensômetro mecânico}

As pastilhas de aço utilizadas para referência de medidas de deformações nas faces dos blocos foram obtidas por meio de doação feita pela empresa Tecumseh do Brasil Ltda. Possuíam aproximadamente $10 \mathrm{~mm}$ de diâmetro e $2 \mathrm{~mm}$ de espessura.

As pastilhas foram dispostas de maneira a formar uma roseta retangular (Figura 5.4), pois, em função das deformações obtidas nas três direções consideradas 
$\left(0^{\circ}, 45^{\circ}\right.$ e $\left.90^{\circ}\right)$ foi possível determinar as deformações principais e suas direções em cada ponto analisado. Essas pastilhas foram fixadas por meio de adesivo.

As deformações principais foram calculas por meio da Expressão 5.1 e suas direções determinadas em função da Expressão 5.2.

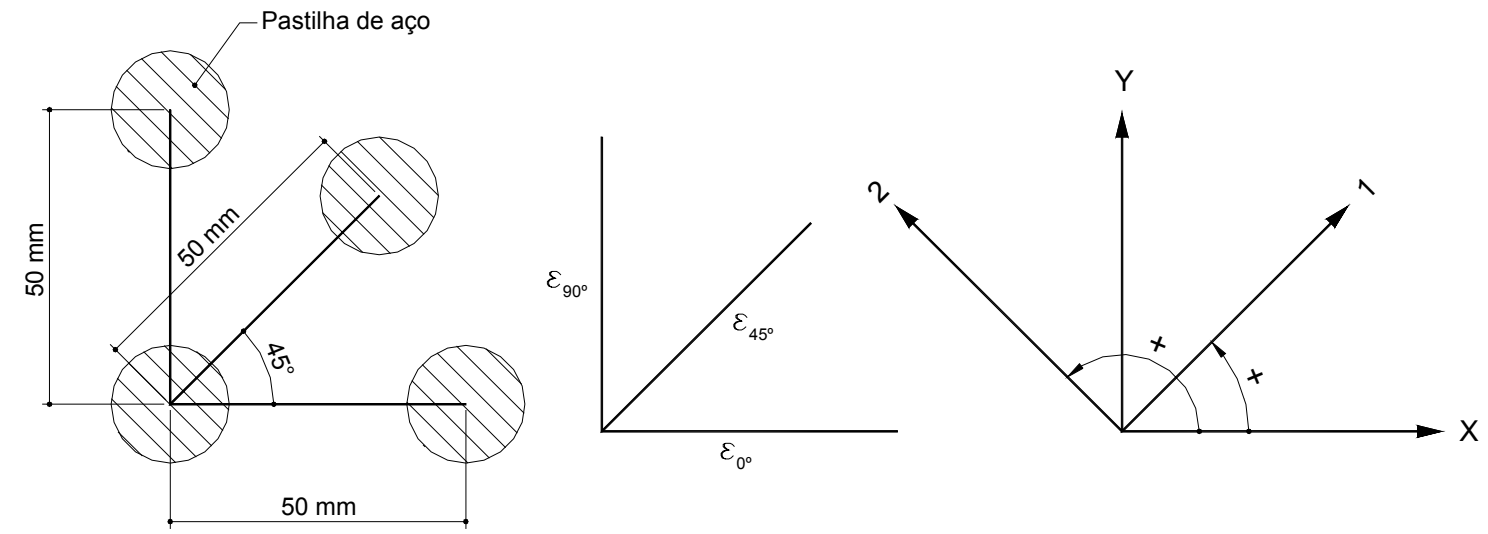

Figura 5.4 - Roseta retangular.

$$
\begin{aligned}
& \varepsilon_{1}=\frac{1}{2} \cdot\left[\varepsilon_{0^{\circ}}+\varepsilon_{90^{\circ}} \pm \sqrt{\left(\varepsilon_{0^{\circ}}-\varepsilon_{90^{\circ}}\right)^{2}+\left(2 \cdot \varepsilon_{45^{\circ}}-\varepsilon_{0^{\circ}}-\varepsilon_{90^{\circ}}\right)^{2}}\right] \\
& \alpha_{1,2}=\frac{1}{2} \arctan \frac{2 \cdot \varepsilon_{45^{\circ}}-\varepsilon_{0^{\circ}}-\varepsilon_{90^{\circ}}}{\varepsilon_{0^{\circ}}-\varepsilon_{90^{\circ}}}
\end{aligned}
$$

sendo:

- $\quad \varepsilon_{1}$ e $\varepsilon_{2}$, tensões principais;

- $\quad \alpha_{1,2}$, direções principais;

- $\varepsilon_{0^{\circ}}, \varepsilon_{45^{\circ}}$ e $\varepsilon_{90^{\circ}}$, deformações nas direções $0^{\circ}, 45^{\circ}$ e $90^{\circ}$.

Estipulou-se para cada modelo, dez leituras de deslocamentos relativos entre as pastilhas de aço. A máxima força prevista em cada bloco sobre estacas (ver Tabela 4.2) foi dividida em dez partes iguais, sendo que, para cada incremento de força aplicado por meio do cilíndrico hidráulico, efetuavam-se leituras em todos os pontos.

Nas próximas figuras são apresentadas as posições dos pontos onde foram feitas as medições dos deslocamentos relativos entre as pastilhas de aço. Em cada ponto foram efetuadas três medições por etapa de carregamento. 


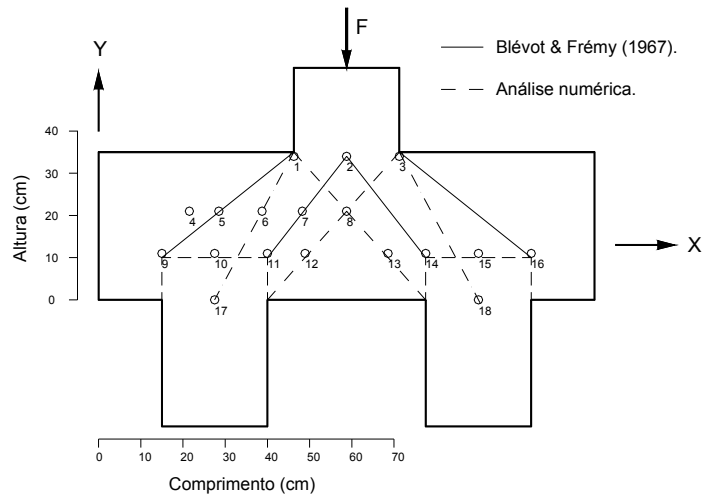

B35P25E25e0

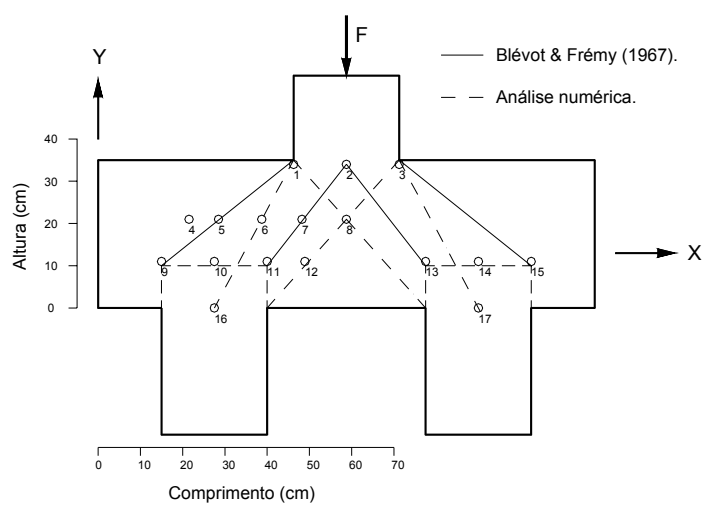

B35P25E25e0A $\mathrm{sw}, \mathrm{c}$

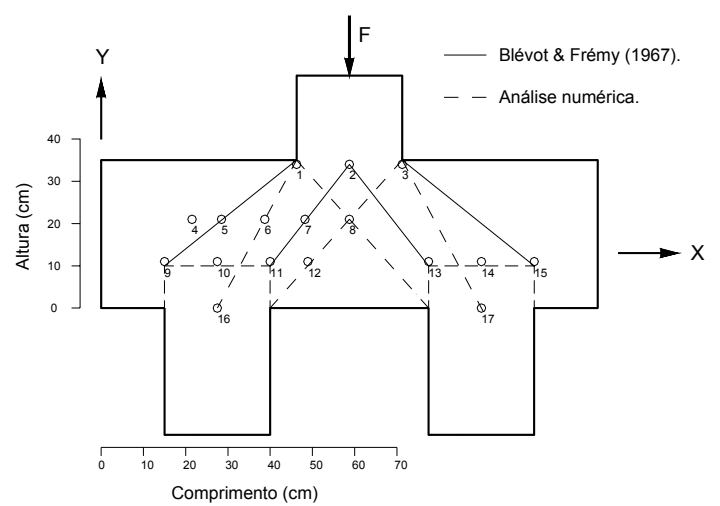

B35P25E25e0CG

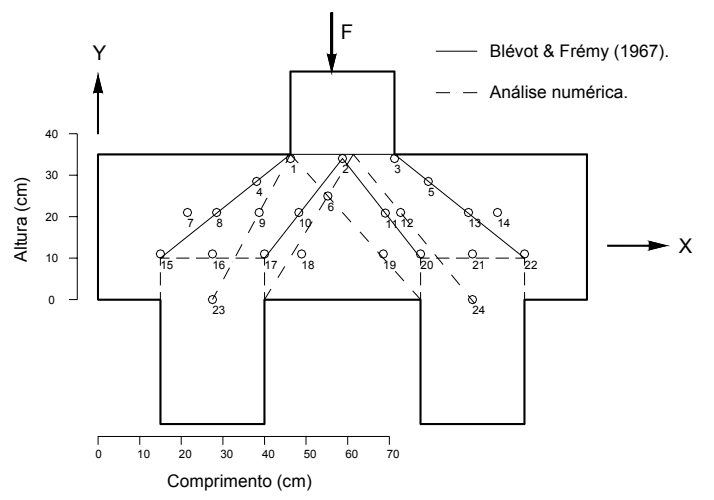

B35P25E25e2,5

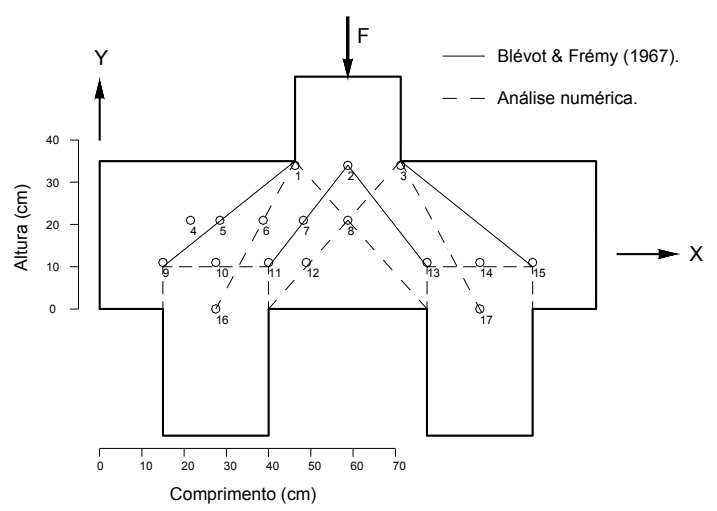

B35P25E25e0A

Figura 5.5 - Posição das pastilhas de aço nas faces dos blocos da série B35P25.

Verifica-se por meio das Figuras 5.5, 5.6, 5.7 e 5.8, que os modelos sem excentricidades das forças de compressão, portanto simétricos, existem menos pontos de leituras. Isso foi feito para diminuir o tempo das leituras durante o ensaio. 


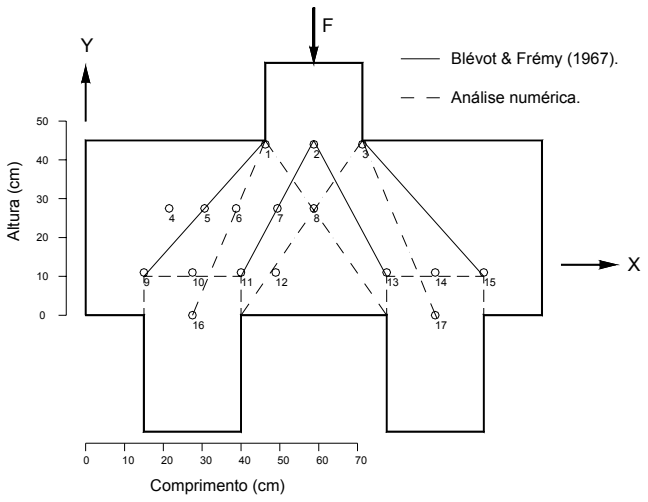

B45P25E25e0

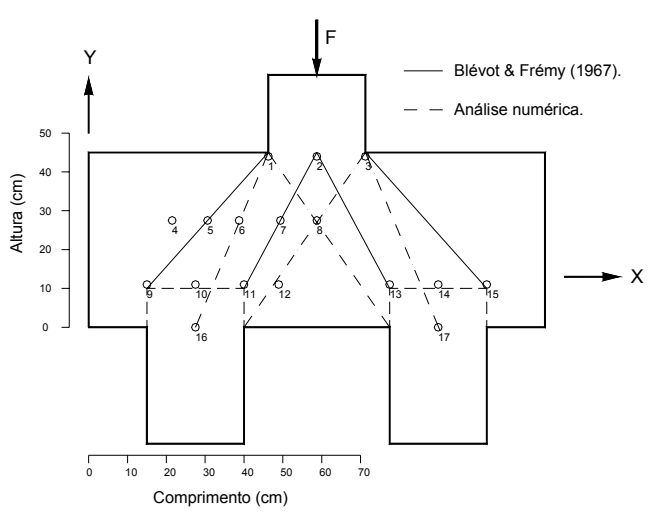

B45P25E25e0A $A_{s w, C}$

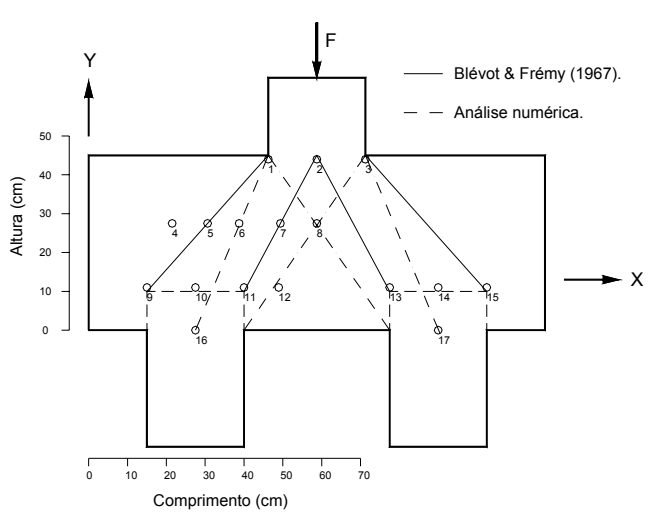

B45P25E25e0CG

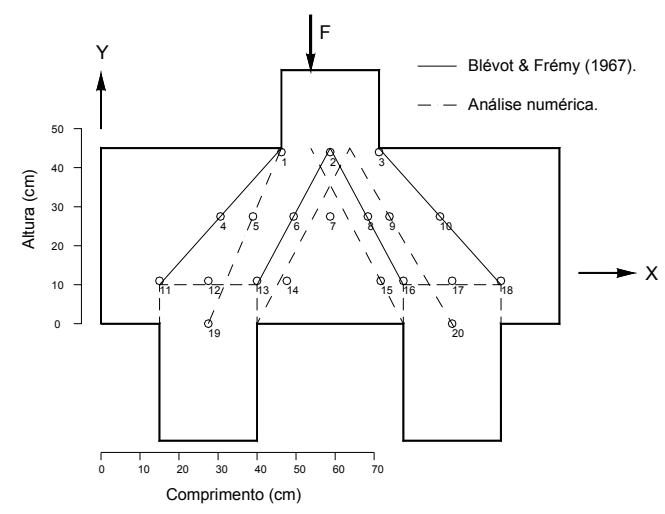

B45P25E25e5

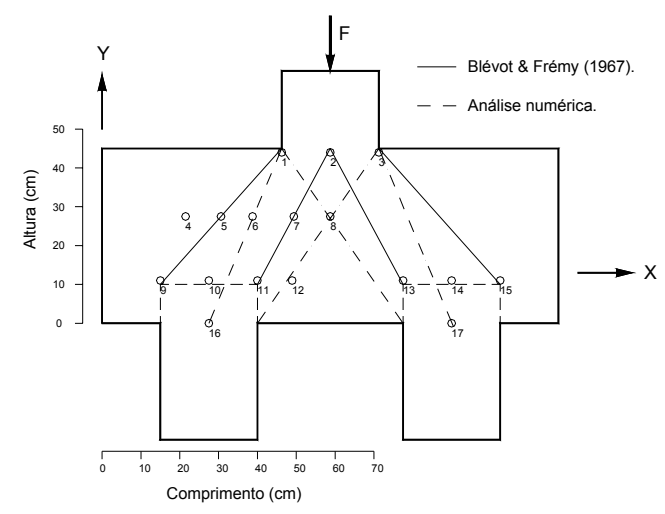

B45P25E25e0A $A_{s w, 0}$

Figura 5.6 - Posição das pastilhas de aço nas faces dos blocos da série B45P25. 


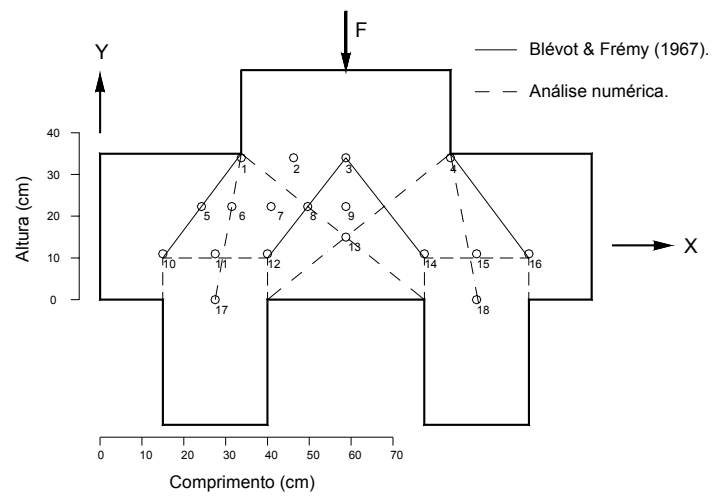

B35P50E25e0

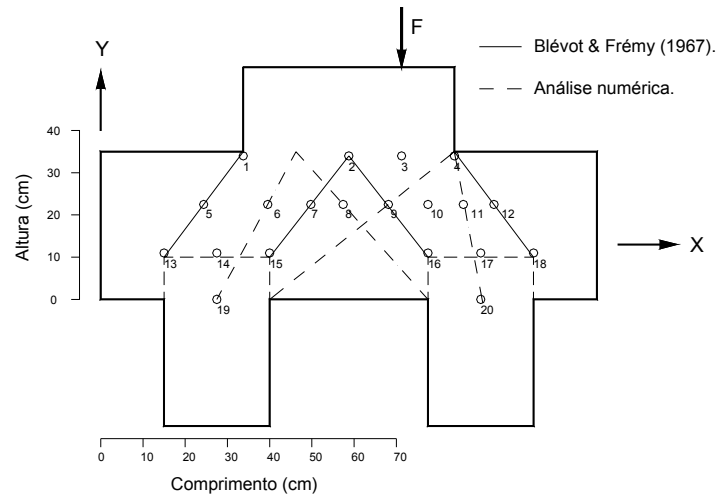

B35P50E25e12,5

Figura 5.7 - Posição das pastilhas de aço nas faces dos blocos da série B35P50.

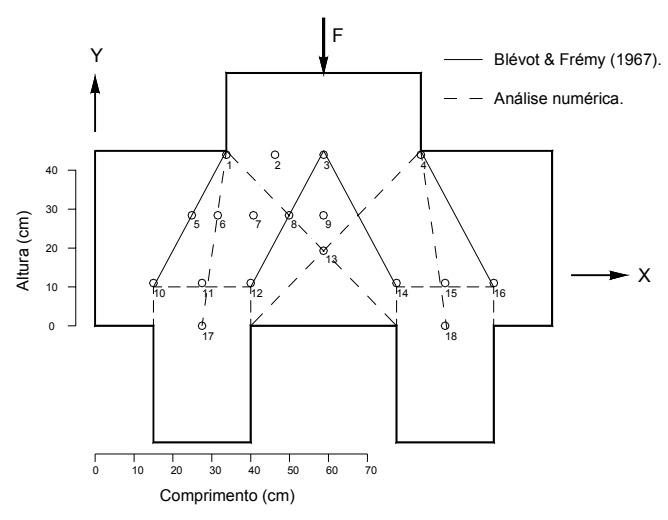

B45P50E25e0

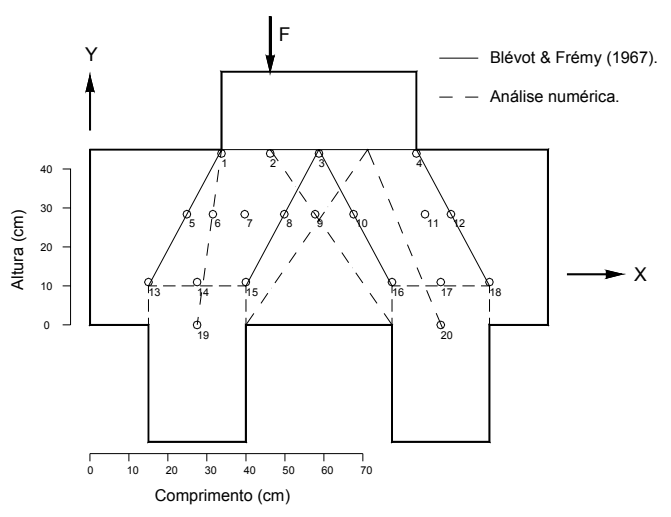

B45P50E25e12,5

Figura 5.8 - Posição das pastilhas de aço nas faces dos blocos da série B45P50.

A Figura 5.9 mostra as pastilhas de aço fixadas na face de um dos modelos de blocos sobre estacas ensaiados.
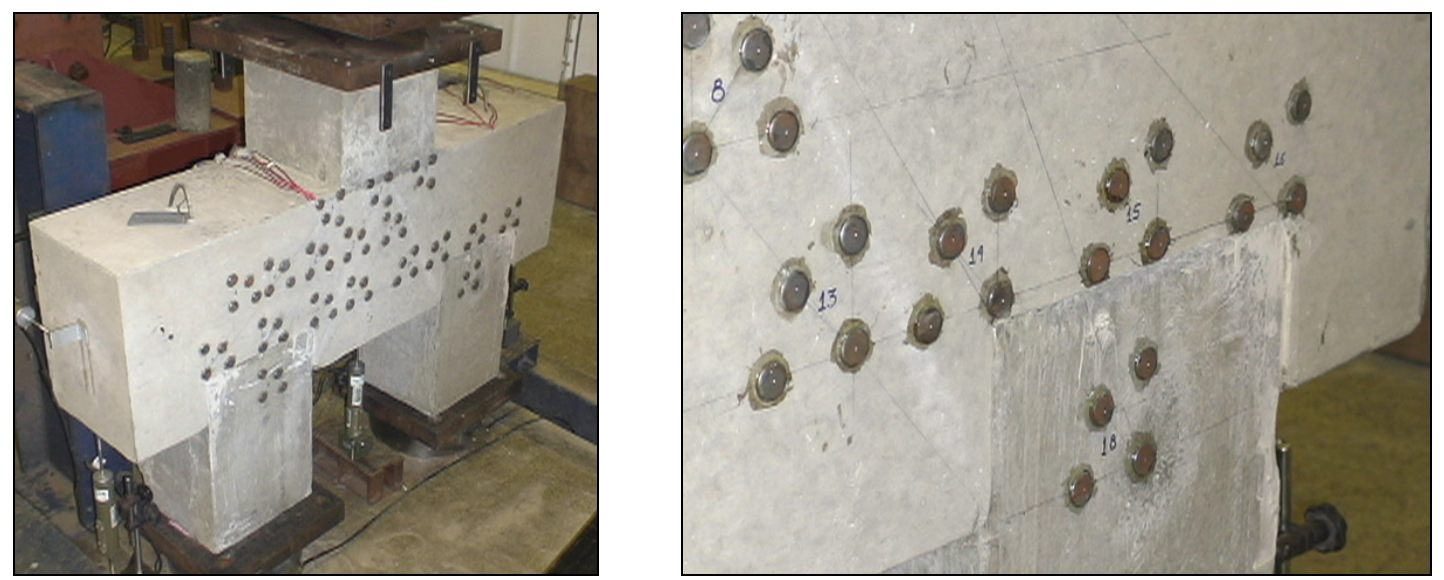

Figura 5.9 - Pastilhas de aço fixadas na superfície dos blocos. 


\subsubsection{Extensômetros elétricos de resistência}

Foram instalados extensômetros uniaxiais nas barras das armaduras principal de tração (tirante), complementar superior e nos estribos verticais e horizontais.

Por meio das deformações nas barras das armaduras, analisaram-se os comportamentos das barras de aço das armaduras principal de tração, como também, o comportamento das barras de aço das armaduras complementares.

Nos modelos B35P25E25A $A_{s w, C}$ e B45P25E25A $A_{s w, C}$, nos quais não foram colocados estribos horizontais e verticais, tão pouco, a armadura complementar superior, foram instrumentadas apenas as barras da armadura principal de tração e a barra da armadura complementar sugerida pelo autor. O mesmo ocorreu nos modelos B35P25E25A $A_{s w, 0}$ e B45P25E25A $A_{s w, 0}$, lembrando que nestes modelos apenas foram projetadas e detalhadas armaduras principais de tração.

As Figuras 5.10 a 5.15 mostram as posições onde os extensômetros foram instalados.

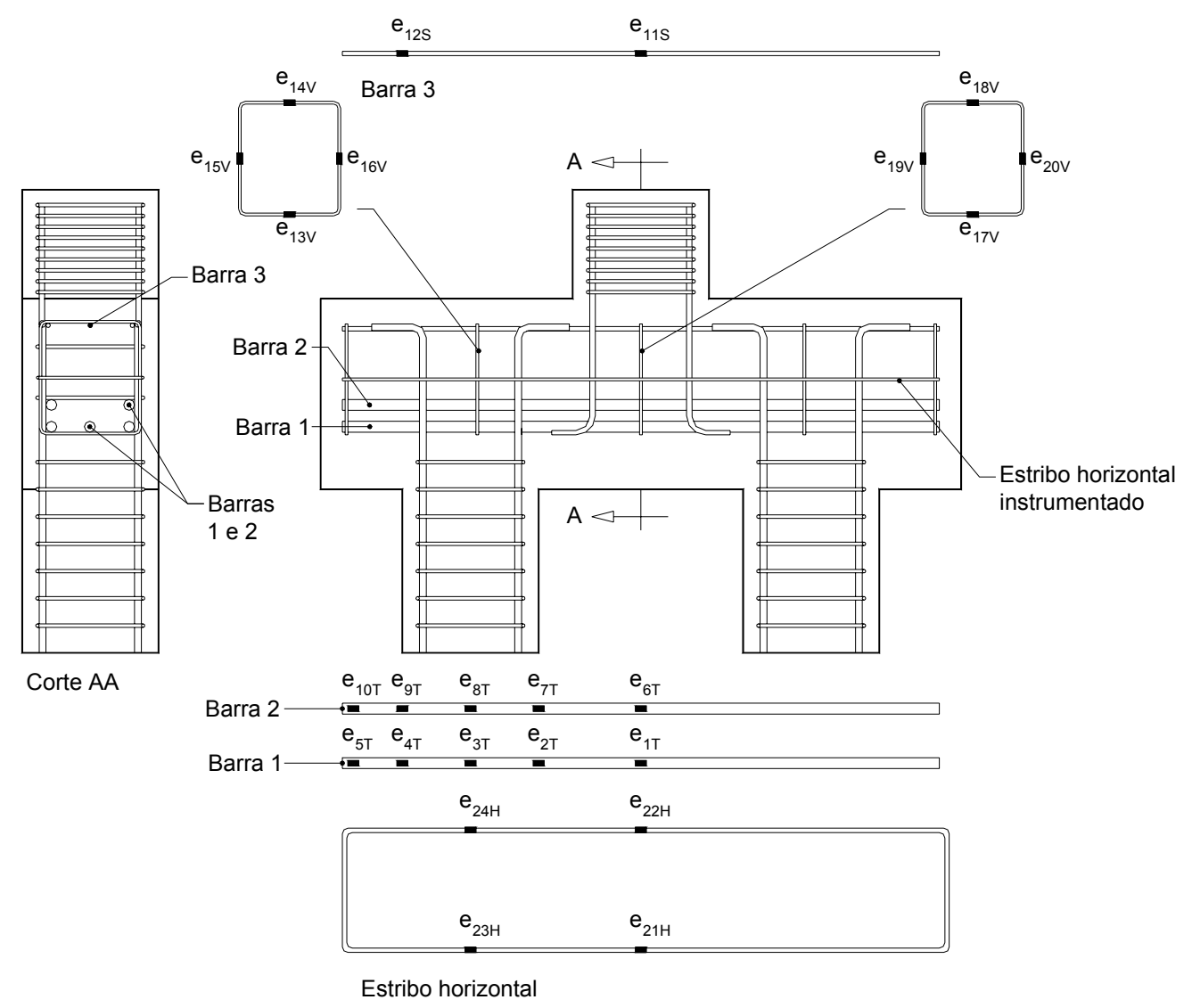

Figura 5.10 - Posição dos extensômetros, modelo B35P25E25e0 e B35P25E25e2,5. 

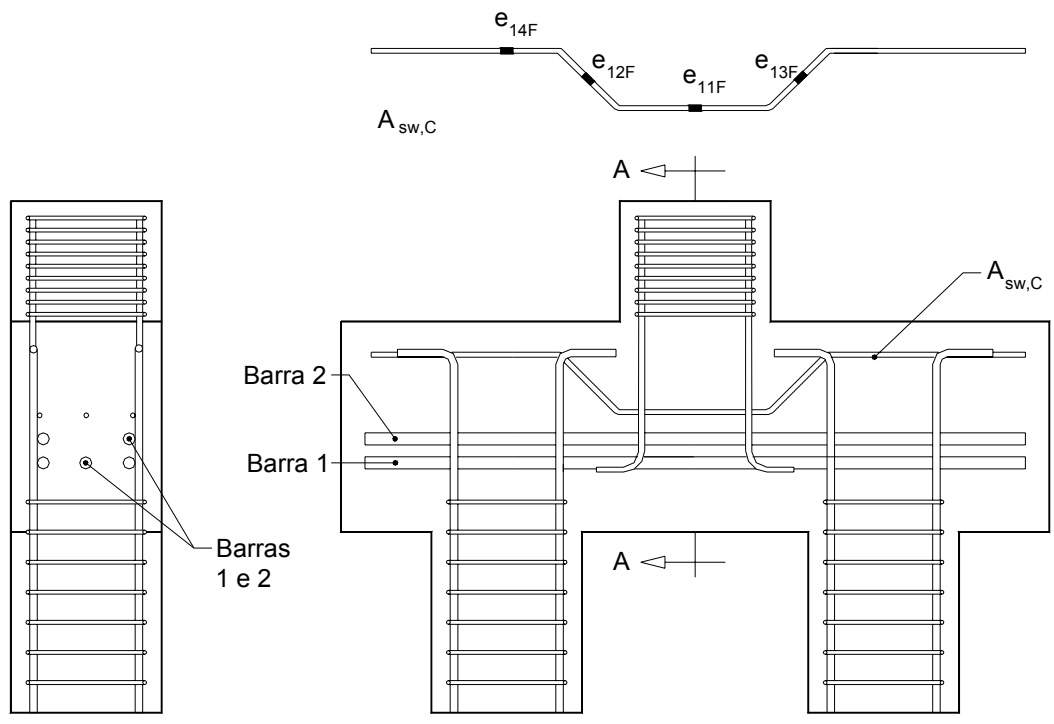

Corte AA

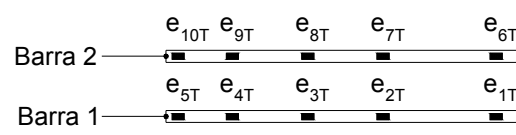

Figura 5.11 - Posição dos extensômetros, modelos B35P25E25e0A $\mathrm{sw}_{\mathrm{c}} \mathrm{e}$ B45P25E25e0A

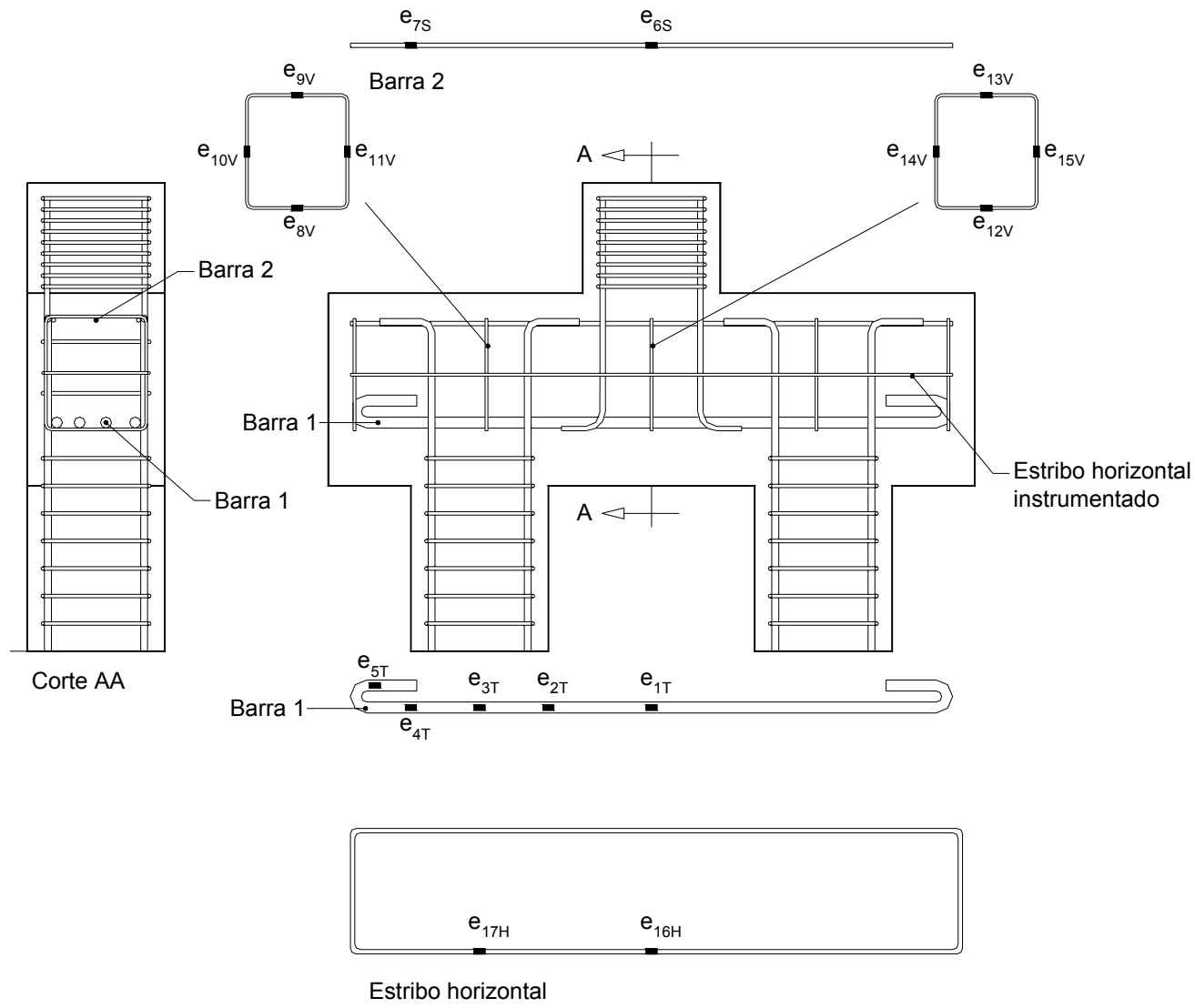

Figura 5.12 - Posição dos extensômetros, modelos B45P25E25e0CG e B45P25E25e0CG. 

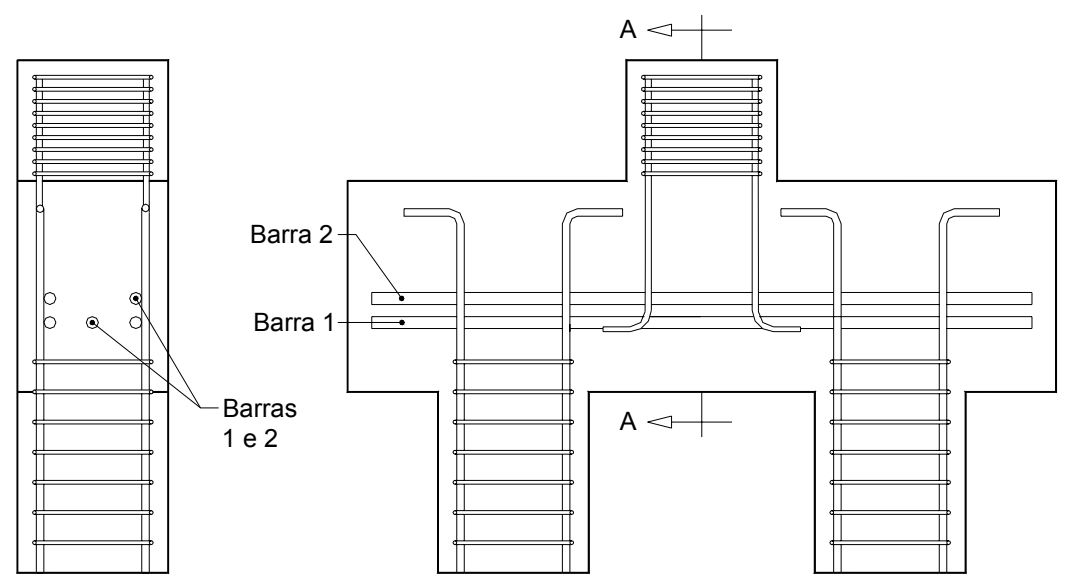

Corte AA

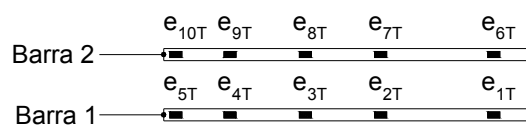

Figura 5.13 - Posição dos extensômetros, modelos B35P25E25e0A ${ }_{s w, 0} \mathrm{e}$ B45P25E25e0A
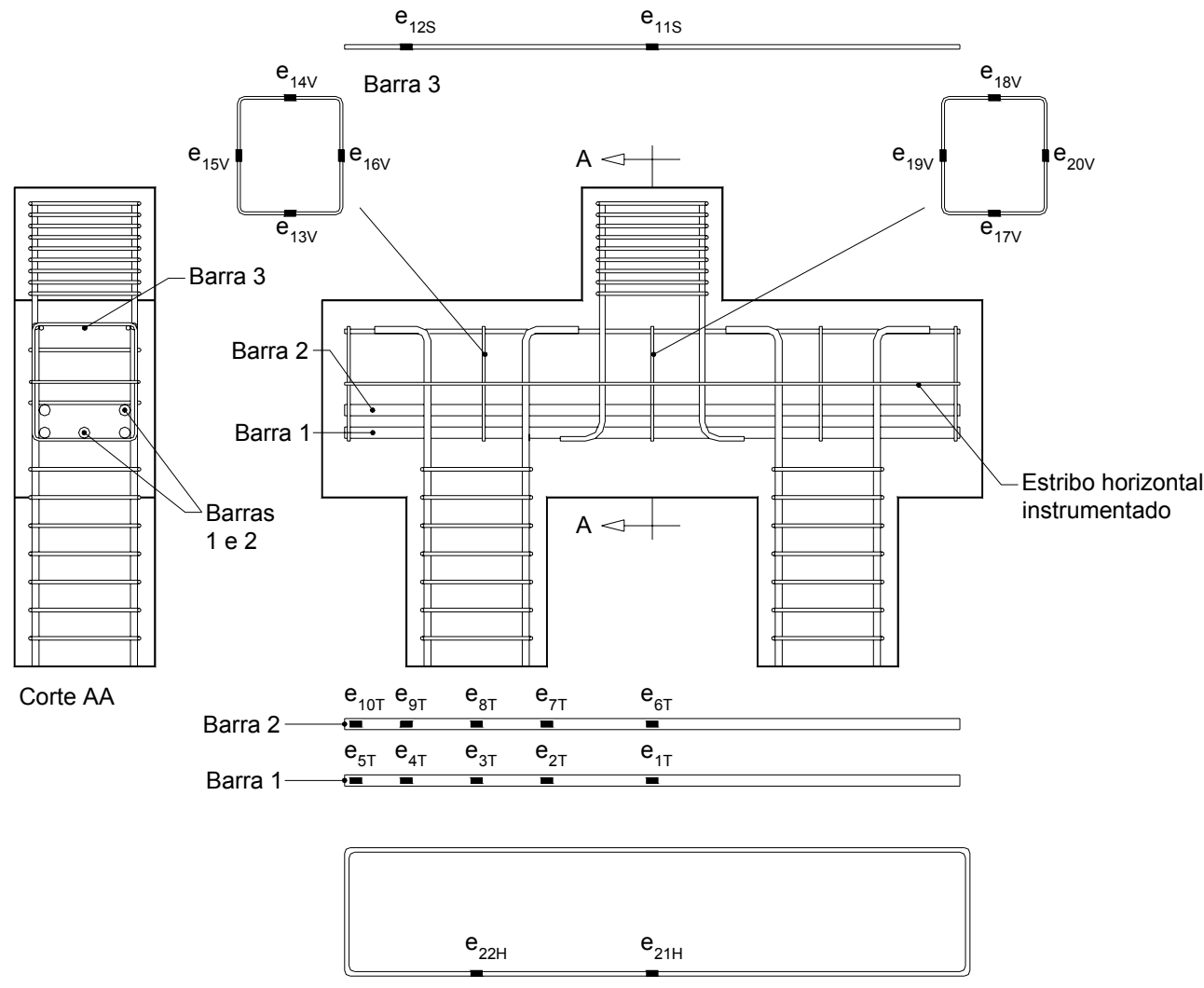

Estribo horizontal

Figura 5.14 - Posição dos extensômetros, modelos B45P25E25e0 e B45P25E25e5. 


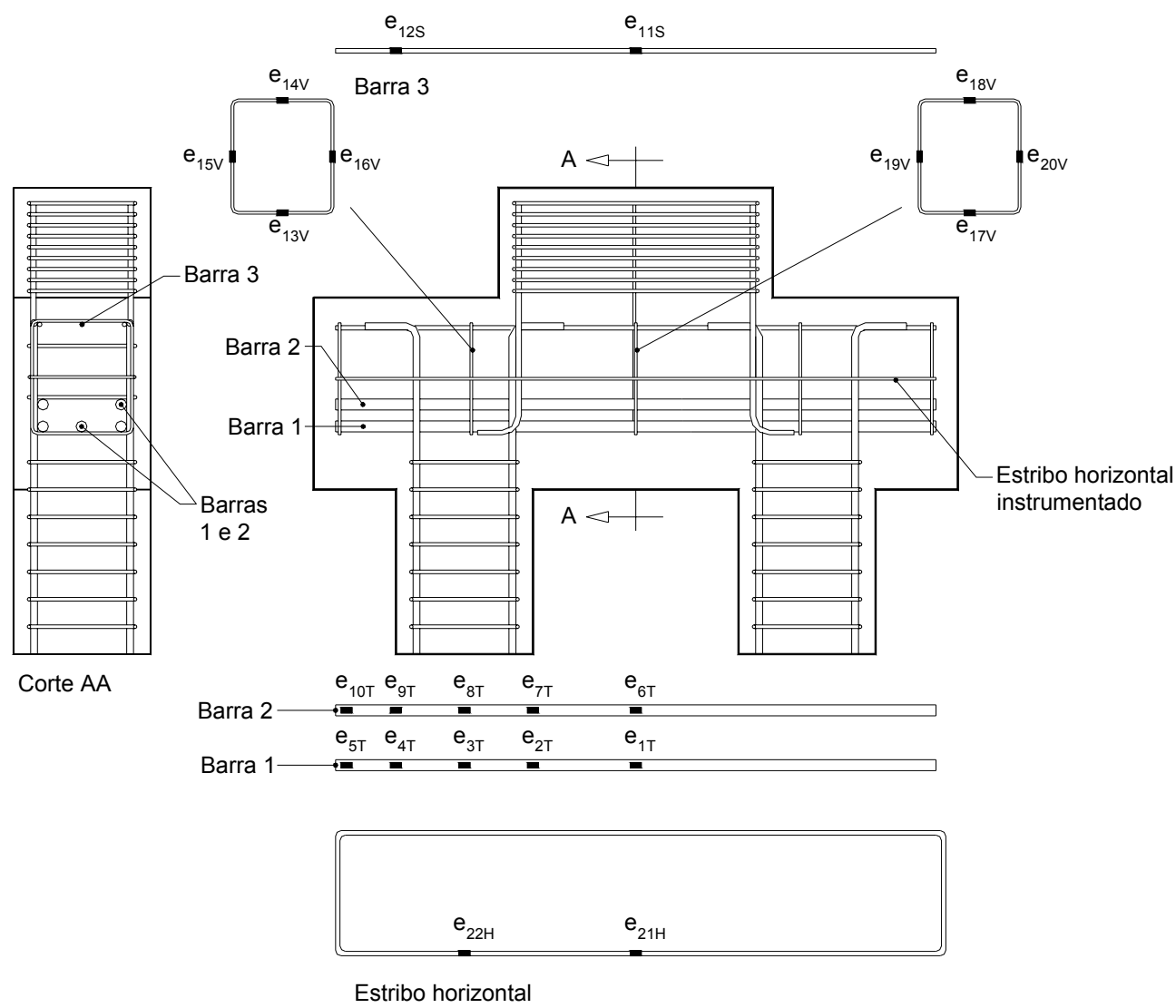

Figura 5.15 - Posição dos extensômetros, modelos B35P50E25e0, B35P50E25e12,5, B45P50E25e0 e B45P50E25e12,5.

Observa-se que nos modelos B35P25E25e0 e B35P25E25e2,5 foram instalados mais extensômetros, pois, estes foram os primeiros blocos ensaiados. Após a análise parcial dos resultados desses ensaios, optou-se por diminuir o número de extensômetros.

Os pontos instrumentados na armadura principal de tração referem-se a seção de meio do vão do bloco, seções transversais que coincidem com o fim da estaca, com o centro da estaca, com o início da estaca e com a ponta do tirante. Essas seções foram instrumentas, pois, foi possível elaborar diagramas da distribuição das tensões de tração ao longo do tirante. Como se pode perceber, apenas metade da armadura principal de tração foi instrumentada, isso foi feito, também prevendo economia no custo dos ensaios.

Optou-se também por instrumentar os estribos verticais posicionados na seção de meio do vão e na seção de meio da estaca, assim, verificou-se se esses têm influência no comportamento estrutural dos blocos sobre estacas. Além, dos estribos verticais, o estribo horizontal também foi instrumentado com o mesmo objetivo. 
A armadura complementar superior também foi analisada, sendo instrumentada na seção meio do vão do bloco e centro da estaca.

Além das armaduras complementares sugeridas por normas técnicas internacionais, a armadura complementar sugerida pelo autor também foi analisada. Assim, foi possível quantificar a intensidade da tensão de tração perpendicular à biela de compressão.

Todos os extensômetros utilizados nos modelos foram instalados pelo autor, como também, a fixação das pastilhas de aço na superfície lateral do bloco.

As Figuras 5.16, 5.17, 5.18 e 5.19 mostram extensômetros instalados em alguns modelos.

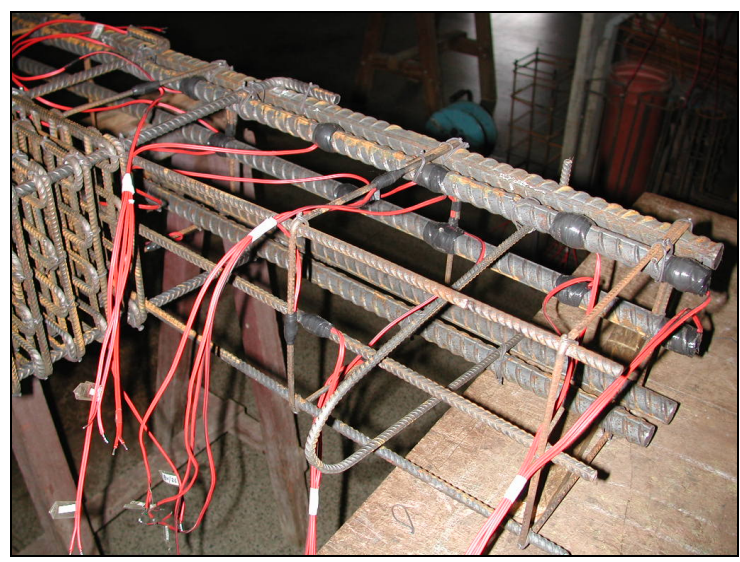

Figura 5.16 - Extensômetros instalados na armadura principal de tração, modelo

B35P25E25e0.

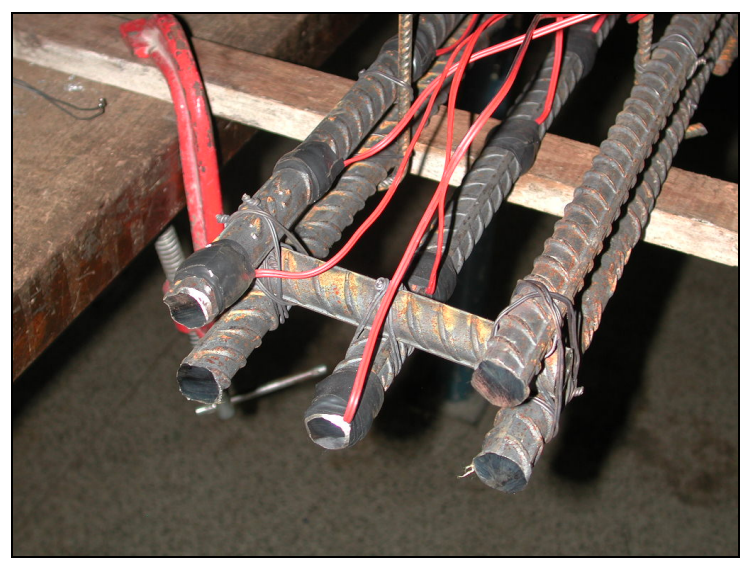

Figura 5.18 - Detalhes dos extensômetros instalados na ponta da armadura principal de tração, modelo B35P25E25A $A_{s w, 0}$.

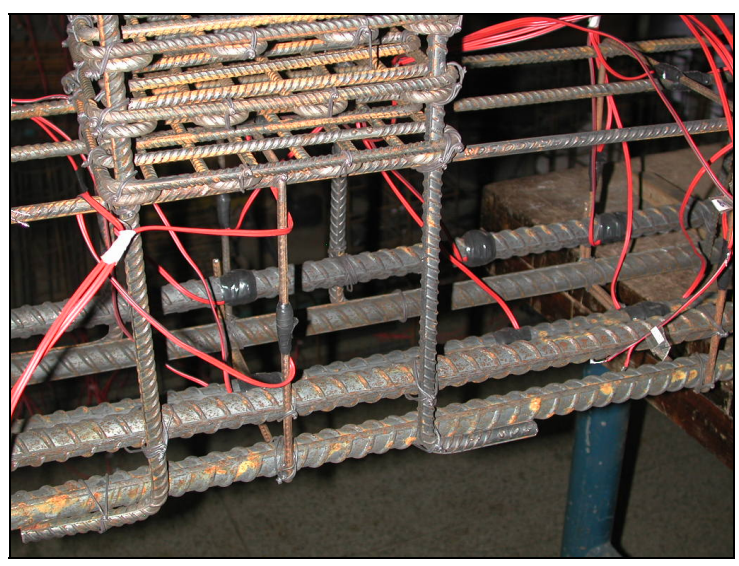

Figura 5.17 - Detalhes dos extensômetros instalados no estribo vertical, modelo B35P25E25e0.

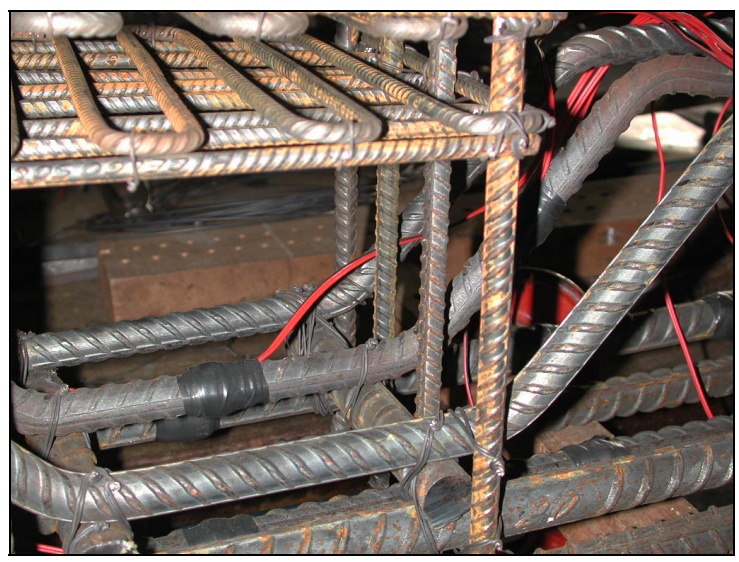

Figura 5.19 - Detalhes dos extensômetros instalados na armadura complementa $A_{s w, C}$, modelo B35P25E25A $A_{s w, c}$. 


\subsubsection{Transdutores de deslocamento}

Os deslocamentos verticais e horizontais foram medidos por meio de transdutores de deslocamentos, como já foi dito. Em todos os modelos, foram instalados cinco transdutores de deslocamento, três destinados à obtenção dos valores de deslocamentos verticais e dois de horizontais.

Os transdutores instalados de modo a obter valores de deslocamentos verticais (direção Y) foram posicionados na seção de meio de vão do bloco e nas extremidades (Figura 5.19). A finalidade do posicionamento desses transdutores foi acompanhar os deslocamentos durante os ensaios e, verificar se houve inversão do sinal dos deslocamentos nas extremidades dos blocos próximo ao Estado Limite Último.

Já, os transdutores instalados para obter deslocamentos horizontais (Direção $X$ e Z) foram posicionados de modo a obter os deslocamentos paralelo e transversal ao eixo longitudinal dos modelos ensaiados. Por meio desses transdutores foi verificado se os blocos sofreram deslocamentos horizontais.

Os transdutores de deslocamentos denominados $T_{1}, T_{2}$ e $T_{3}$ foram responsáveis pela aquisição dos valores de deslocamentos verticais, o transdutor T4 era responsável pelo registro dos deslocamentos na direção $Z$ (deslocamento horizontal) e, por fim, o transdutor T5 teve a responsabilidade de obter informações sobre os deslocamentos horizontais na direção $X$.

As Figuras 5.20 e 5.21 mostram os transdutores de deslocamentos instalados nas posições descritas. E a Figura 5.22, apresenta as posições dos transdutores de deslocamento.

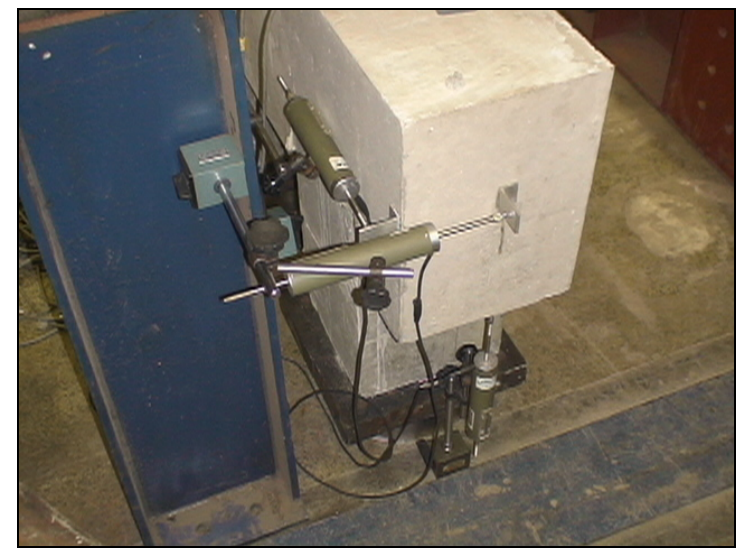

Figura 5.20 - Transdutores de deslocamentos, medidas horizontais.

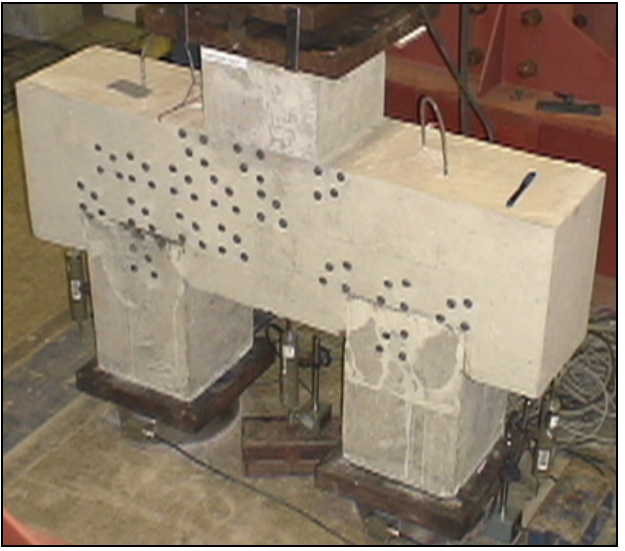

Figura 5.21 - Transdutores de deslocamentos, medidas verticais. 


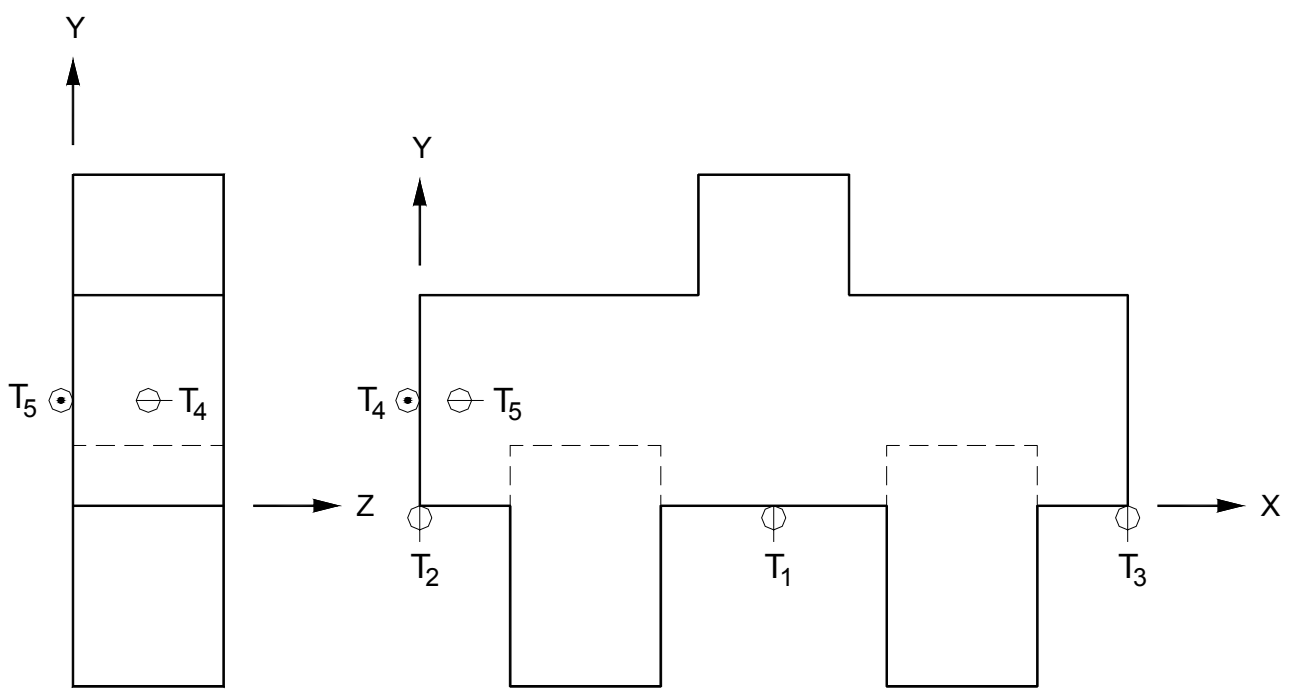

Figura 5.22 - Posição dos transdutores de deslcoamentos.

\subsection{Descrição dos ensaios e apresentação dos resultados}

O primeiro ensaio foi realizado em etapas crescentes de carregamento até o colapso com a finalidade de analisar o modo de ruína, as deformações e tensões nas fases de serviço e última, além de verificar a viabilidade do sistema de aplicação de força e de corrigir prováveis falhas. Conclui-se que o método de ensaio empregado foi correto, assim, os demais modelos seguiram os mesmos critérios do primeiro.

Em princípio os blocos seriam ensaiados com idade igual a 28 dias, porém, em função do cronograma do laboratório os ensaios foram realizados com idades mais avançadas. Esse fato trouxe conseqüências com relação à previsão das forças teóricas (Tabela 4.2), pois as resistências à compressão dos concretos principalmente dos blocos sofreram alterações significativas. Lembra-se que na produção dos concretos que foram utilizados na moldagem dos blocos utilizou-se cimento CP-II-F-32 e, como é sabido, os concretos produzidos com este tipo de cimento ganham resistência ao longo do tempo. Para os concretos produzidos com cimento CP-V-ARI, empregados na moldagem das estacas e pilares o fator tempo não trouxe maiores conseqüências.

Portanto, fez-se necessário reavaliar as forças teóricas previstas $\left(F_{\text {teo }}\right)$, apresentadas no Capítulo 4, pois, sofreram modificações em função do aumento da resistência média à compressão do concreto dos blocos. A Tabela 5.1 apresenta as novas forças teóricas previstas calculadas por meio das recomendações de Blévot \& Frémy (1967), avaliadas com as resistências médias a compressão de cada bloco, as 
quais foram obtidas por meio de ensaio de compressão de corpos-de-prova cilíndricos de concreto ensaiados de acordo com as recomendações da NBR 5739:1980.

$\mathrm{Na}$ Tabela também são apresentadas as forças últimas $\left(F_{u}\right)$ resistidas pelos modelos, como também, as forças que originaram a primeira fissura $\left(F_{r}\right)$.

Como comparação, determinou-se a força de projeto $\left(F_{d}\right)$ estabelecida com os critérios de Blévot \& Frémy (1967), sendo que as tensões nas bielas de compressão ficam restritas ao valor de 0,6.f. Machado (1979), por meio de adaptações, sugere como tensão limite o valor de 0,85. $f_{c d}$, já, Fusco (1994), sugere que essa tensão seja igual a resistência de cálculo a compressão do concreto, $\mathrm{f}_{\mathrm{cd}}$.

\subsubsection{Comportamento geral dos modelos}

Em geral, todos os modelos apresentaram comportamento semelhante. A primeira fissura surgiu na face inferior do bloco junto à estaca e propagou-se até a face superior do bloco junto ao pilar. Demais fissuras surgiram ao longo do carregamento com inclinação similar à primeira fissura. Apesar das fissuras apresentarem grandes aberturas, o bloco só deixou de resistir à força aplicada no instante em que se iniciou processo de esmagamento do concreto do bloco junto ao pilar. Verificou-se que, em função das tensões de tração existentes na direção perpendicular as bielas de compressão (fendilhamento), ocorreu diminuição no valor da força última nos modelos onde não existiam armaduras complementares $\left(B 35 P 25 E 25 A_{s w, 0}\right.$ e B45P25E25e0A $\left.A_{s w, 0}\right)$. As Figuras 5.23 e 5.24 apresentam respectivamente a posição da primeira fissura junto a estaca e o início do esmagamento do concreto na face superior do bloco junto ao pilar.

Constatou-se, que nos modelos projetados com armadura complementar sugerida pelo autor (B35P25E25A $A_{s w, C}$ e B45P25E25A $A_{s w, C}$ ), aumento da capacidade portante.

Em todos os modelos observou-se claramente, após o colapso, a formação de um arco de compressão, semelhante ao observado na análise numérica, delineando a trajetória do fluxo de tensões de compressão.

Nos Modelos com pilares com seção transversal retangular com dimensões iguais a $25 \mathrm{~cm}$ e $50 \mathrm{~cm}$, ocorreram simultaneamente esmagamentos no concreto junto à estaca mais solicitada e junto ao pilar. Isso aconteceu, provavelmente, em função da força transmitida diretamente do pilar para estaca, pois, nestes modelos parte do pilar estava posicionado sobre as estaca. 


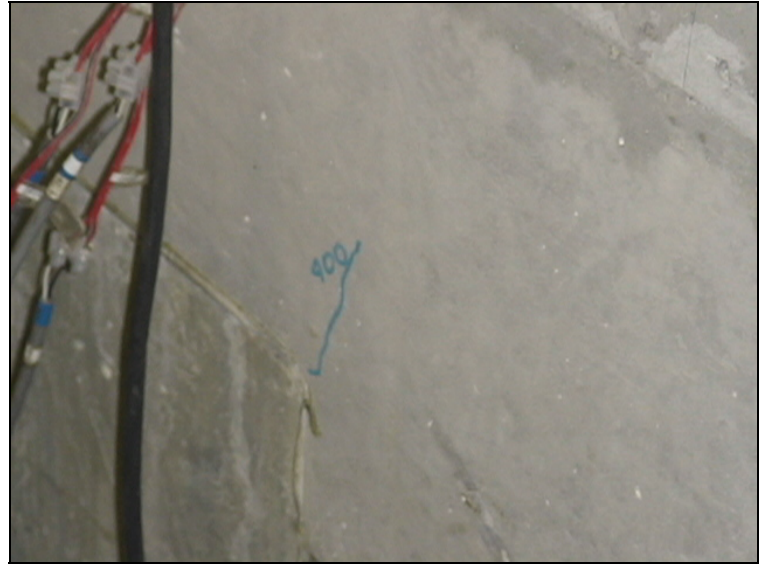

Figura 5.23 - Posição da primeira fissura, junto a estaca.

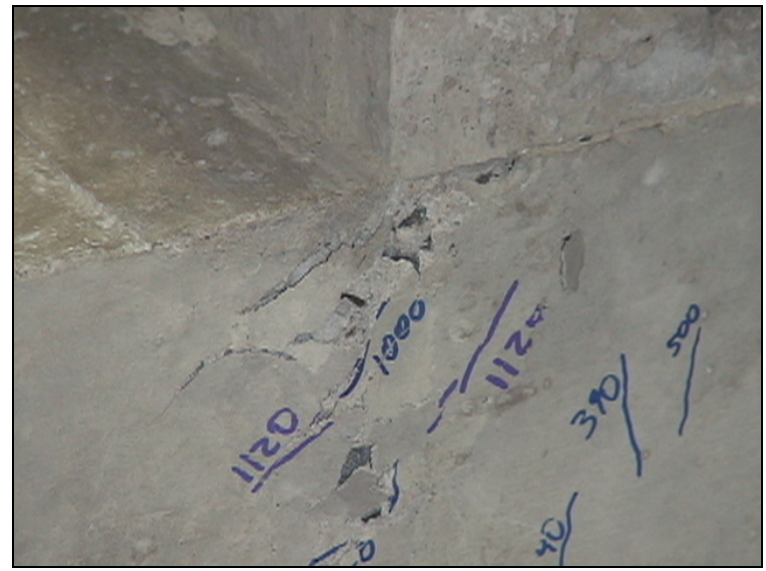

Figura 5.24 - Início do esmagamento do concreto junto ao pilar.

Todos os modelos apresentaram colapso caracterizado por esmagamento do concreto e cisalhamento, ou seja, após o esmagamento do concreto junto ao pilar e em alguns casos junto à estaca, formou-se um plano de ruptura ao longo da altura do bloco provocado pela ação de força cortante. A Figura 5.25 apresenta a configuração do plano de ruptura.
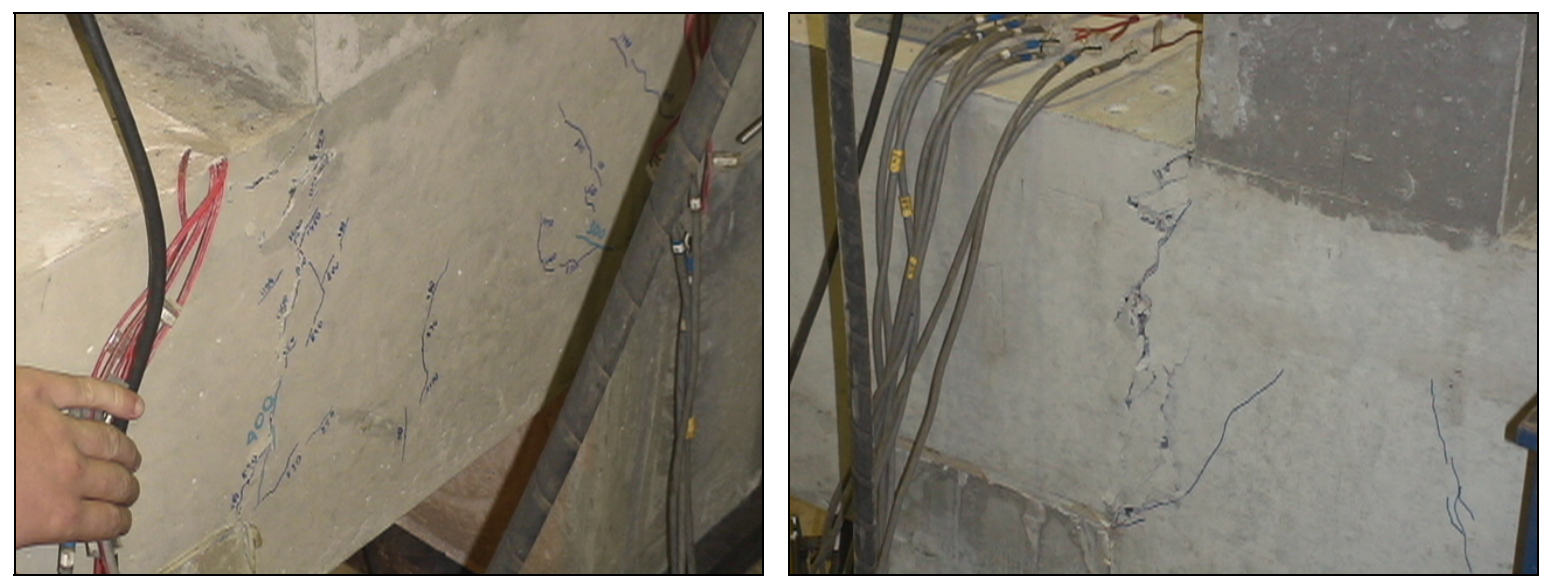

Figura 5.23 - Plano de ruptura ao longo da altura do bloco.

Como já era esperado, nos modelos em que o ângulo de inclinação da biela de compressão foi igual a $54,5^{\circ}$, as forças aplicadas foram maiores quando comparadas com as forças dos modelos com ângulo de inclinação da biela de compressão igual a $45^{\circ}$.

Os modelos que foram construídos com pilares com seção transversal retangular suportaram mais carga que os modelos construídos com pilares com seção 
transversal quadrada, em função, do aumento da área da biela de compressão junto ao pilar.

As deformações de todas as barras de aço foram menores que a deformação de escoamento das barras de aço $\left(\varepsilon_{y}\right)$. As forças de tração nos tirantes, obtidas por meio de suas deformações, também foram menores que as propostas pelo modelo de Blevót \& Fremy (1967).

Tabela 5.1 - Valores de forças obtidas nos ensaios.

\begin{tabular}{|c|c|c|c|c|c|c|c|c|c|c|}
\hline SÉRIE & BLOCOS & $\begin{array}{c}\mathbf{f}_{\mathrm{cm}} \\
(\mathrm{MPa})\end{array}$ & $\begin{array}{c}\mathbf{F}_{\mathbf{u}} \\
(\mathrm{kN})\end{array}$ & $\begin{array}{c}F_{r} \\
(k N)\end{array}$ & $\begin{array}{l}F_{\text {teo }} \\
(\mathrm{kN})\end{array}$ & $\begin{array}{c}\mathbf{F}_{\mathbf{d}} \\
(\mathrm{kN})\end{array}$ & $F_{r} / F_{u}$ & $F_{\text {teo }} / F_{u}$ & $F_{d} / F_{u}$ & $F_{r} / F_{d}$ \\
\hline \multirow{5}{*}{ B35P25 } & B35P25E25e0 & 40,6 & 1821 & 465 & 1776 & 761 & 0,26 & 0,98 & 0,42 & 0,61 \\
\hline & B35P25E25e2,5 & 40,6 & 1688 & 445 & 1776 & 761 & 0,26 & 1,05 & 0,45 & 0,58 \\
\hline & 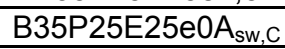 & 32,8 & 1880 & 270 & 1435 & 615 & 0,14 & 0,76 & 0,33 & 0,44 \\
\hline & $\mathrm{B}_{3} \mathrm{P} 25 \mathrm{E} 25 \mathrm{e} 0 \mathrm{~A}_{\mathrm{sw}, 0}$ & 32,8 & 1406 & 266 & 1435 & 615 & 0,19 & 1,02 & 0,44 & 0,43 \\
\hline & B35P25E25e0CG & 28,9 & 1263 & 315 & 1264 & 542 & 0,25 & 1,00 & 0,43 & 0,58 \\
\hline \multirow{5}{*}{ B45P25 } & B45P25E25e0 & 31 & 2276 & 465 & 1796 & 770 & 0,20 & 0,79 & 0,34 & 0,60 \\
\hline & B45P25E25e5 & 31 & 1972 & 522 & 1796 & 770 & 0,26 & 0,91 & 0,39 & 0,68 \\
\hline & $\mathrm{B} 45 \mathrm{P} 25 \mathrm{E} 25 \mathrm{e} 0 \mathrm{~A}_{\mathrm{sw}, \mathrm{C}}$ & 32,4 & 3055 & 482 & 1877 & 805 & 0,16 & 0,61 & 0,26 & 0,60 \\
\hline & B45P25E25e0A $A_{s w, 0}$ & 32,4 & 2090 & 305 & 1877 & 805 & 0,15 & 0,90 & 0,39 & 0,38 \\
\hline & $\mathrm{B} 45 \mathrm{P} 25 \mathrm{E} 25 \mathrm{e} 0 \mathrm{CG}$ & 28,9 & 2270 & 473 & 1674 & 718 & 0,21 & 0,74 & 0,32 & 0,66 \\
\hline \multirow{2}{*}{ B35P50 } & B35P50E25e0 & 35,8 & 3877 & 450 & 2864 & 1718 & 0,12 & 0,74 & 0,44 & 0,26 \\
\hline & B35P50E25e12,5 & 35,1 & 3202 & 585 & 2808 & 1685 & 0,18 & 0,88 & 0,53 & 0,35 \\
\hline \multirow{2}{*}{ B45P50 } & B45P50E25e0 & 35,8 & 4175 & 851 & 3477 & 2092 & 0,20 & 0,83 & 0,50 & 0,41 \\
\hline & B45P50E25e12,5 & 35,1 & 3386 & 477 & 3409 & 2045 & 0,14 & 1,01 & 0,60 & 0,23 \\
\hline \multicolumn{2}{|c|}{ Valores médios } & 33,8 & - & - & - & - & 0,19 & 0,87 & 0,42 & 0,49 \\
\hline
\end{tabular}

Notas: $\mathrm{f}_{\mathrm{cm}}$, resistência média a compressão do concreto, obtida por meio de ensaios de corpos-de-prova cilíndricos de concreto.

A força que originou a primeira fissura $\left(F_{r}\right)$ foi determinada por meio de duas hipóteses: a primeira de maneira visual, ou seja, foi registrada a força que originou a primeira fissura visível nas faces dos blocos; a segunda determinou-se o valor da força correspondente a primeira perda de rigidez no diagrama tensão vs. deformação da armadura principal de tração, relativo à posição de meio de vão do bloco (extensômetros $\mathrm{e}_{\mathrm{T} 1} \mathrm{e} \mathrm{e}_{\mathrm{T} 6}$ ). A menor força entre os dois processos foi considerada como a força de que originou a primeira fissura. As forças obtidas pelas duas hipóteses resultaram valores com a mesma ordem de grandeza.

Nos modelos em que a excentricidade foi diferente de zero, a capacidade portante diminui com relação aos modelos com excentricidade igual a zero, lembrando que os modelos foram construídos com mesmo arranjo de armadura (modelo B35P25E25e0 comparado com o modelo B35P25E25e2,5 e modelo B45P25E25e0 comparado com o modelo B45P25E25e5). 
Por meio da Tabela 5.1, conclui-se que, em média, as primeiras fissuras surgiram para uma força correspondente a vinte por cento da força última suportada por cada modelo, ou seja, $F_{r} / F_{u}=0,19$.

Verificou-se também, que nos modelos projetados sem armaduras complementares sugeridas pelo Boletim no 73 do CEB (1970) e EHE (2002), as forças relativas à primeira fissura foram menores que os modelos projetados com tais armaduras, como isso, pôde-se afirmar que esta armadura, apesar de não aumentar a capacidade portante dos blocos, retarda a formação de fissuras nas faces dos absorvendo as tensões de tração existentes.

Observa-se também, que os resultados obtidos pelo autor são próximos dos resultados observados nos ensaios de Blévot \& Fremy (1967) $\left(F_{\text {teo }} / F_{u}=0,87\right.$, em média), ou seja, o valor de $1,4 . f_{c k}$, relativo à tensão na biela de compressão junto ao pilar, observado pelos pesquisadores franceses se repetiram nos ensaios das séries B35P25 e B45P25. Porém, considerar que toda a estaca esta solicita por essa tensão é incorreto, pois observou-se nos ensaios que apenas parte da estaca é solicitada de maneira mais intensa. Recorda-se que o valor de $1,4 . f_{c k}$ somente é válido para os modelos onde ocorreram colapsos junto aos pilares, para os modelos em que as ruínas dos blocos se deram junto às estacas (série B35P50 e B45P50), esses valores são reduzidos $a f_{c k}$.

Por meio dos resultados obtidos nos ensaios, pôde-se concluir, que o valor da força de projeto apresentada por Blévot \& Fremy (1967) e Machado (1979) são extremamente conservativas, pois a relação $F_{d} / F_{u}$ em média foi de 0,42 , apresentando coeficiente de segurança igual a 2,38. Se, o Estado Limite de Abertura das Fissuras for considerado atingido para os valores de $F_{d}$, os blocos apresentariam fissuras a partir de $49 \%$ de $F_{d}$, ou seja, apenas $20 \%$ da força última.

Nota-se, que a armadura sugerida pelo autor $\left(A_{s w, c}\right.$, Figura 4.5 e 4.7$)$ teve comportamento satisfatório com relação à capacidade último dos blocos. A utilização da armadura sugerida combinada com armaduras dispostas nas faces dos blocos tornaria o elemento estrutural mais resistente e com fissuras de menor abertura. Além, disse, verificou-se, na iminência do colapso, a formação de fissuras na face superior do bloco, na região da ancoragem da armadura complementar sugerida (Figura 5.26). Essas fissuras ocorreram, pois imagina-se que a ancoragem dessas barras não foi suficiente para suportar a força de tração nela presente. Além disso, a falta de estribos verticais fez com que as fissuras apresentassem grandes aberturas na iminência da ruptura. 

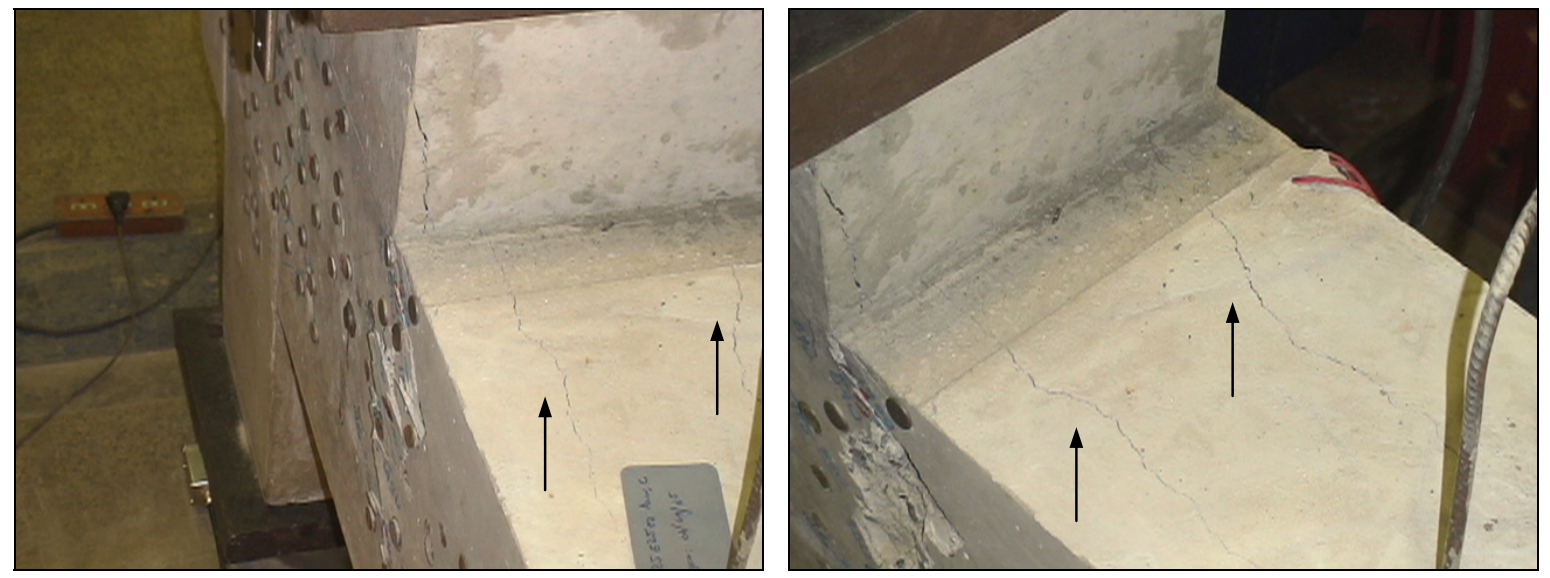

Figura 5.26 - Fissuras na face superior do bloco.

Com relação a utilização de ganchos no detalhamento dos blocos sobre estacas, verificou-se não haver nenhuma influência no que tange a força última do elemento (nos ensaios desenvolvidos). Portanto, a utilização dos ganchos pode ser revista. No item 5.3.6 serão apresentados valores das deformações nas barras de aço, onde verifica-se que as deformações na ponta do tirante e no gancho são muito pequenas. Faz-se necessário, porém, ensaios com áreas menores das barras de aço da armadura principal de tração, o que levaria o tirante a sofrer escoamento, assim, seria possível verificar se os ganchos são eficazes nestes casos (área de aço das barras da armadura principal de tração menor que o valor calculado pelos modelos de dimensionamento existentes).

As próximas Figuras 5.27 a 5.40 apresentam fotografias dos blocos após os ensaios. Por meio dessas figuras é possível visualizar a formação das fissuras, como também, a ruína por esmagamento do concreto na biela, além, disto, identifica-se a delineação de uma treliça formada pelas fissuras e pleno plano de corte. Essa treliça tem forma semelhante ao modelo apresentado a partir de resultados da análise numérica.

Por meio da Figura 5.33, observa-se que ocorreu ruína do cobrimento do concreto do pilar do modelo B35P25E25e5, em função da existência de excentricidade $\left(e_{\text {adot }}=5 \mathrm{~cm}\right)$.

A ruptura de pilar também foi observada em todos os modelos das séries B35P50 e B45P50, função da elevada força aplicada. Apesar a ruptura dos pilares, não houve interferência no comportamento dos blocos. 


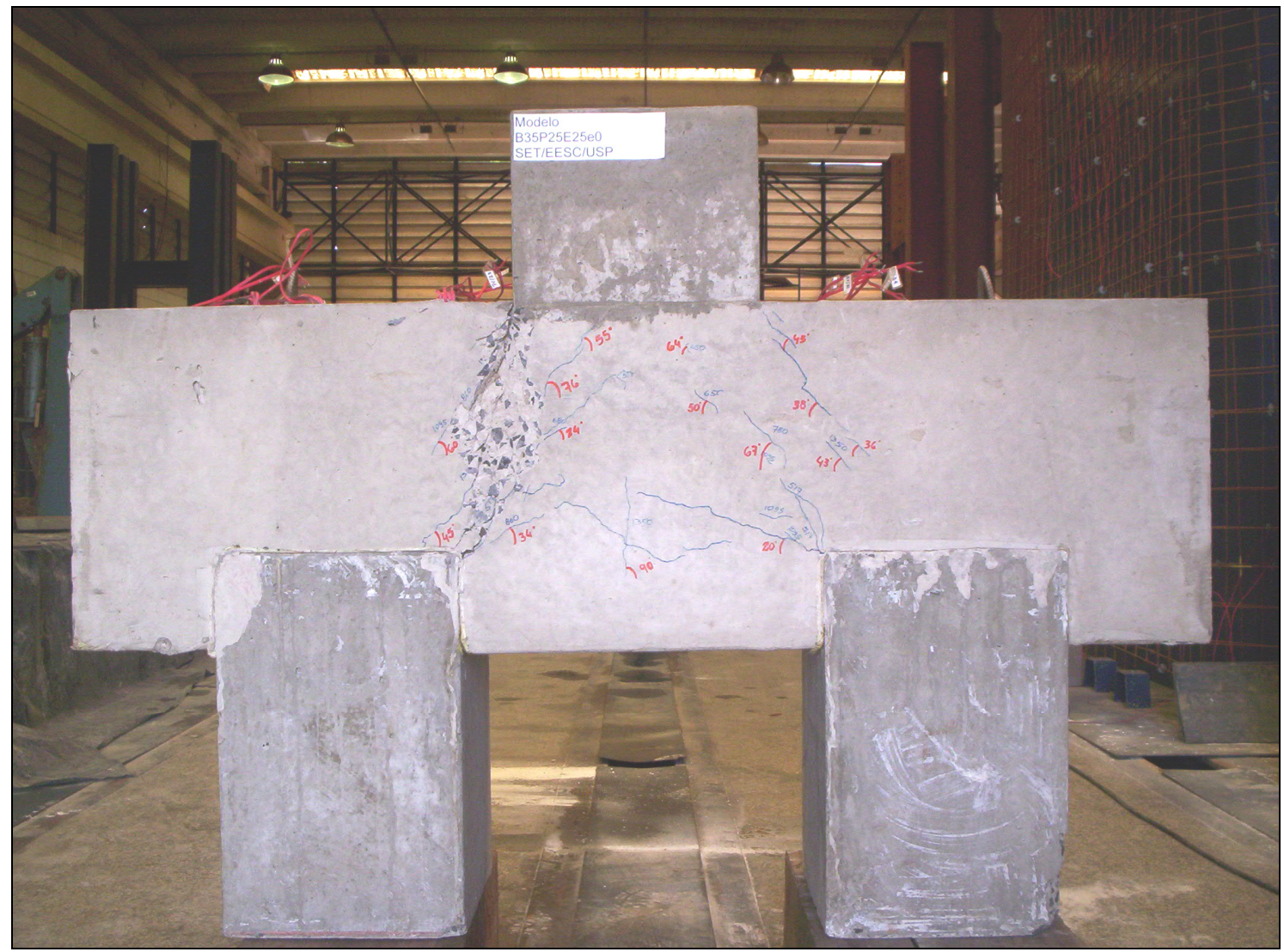

Figura 5.27- Modelo B5P25E25e0, vista frontal.

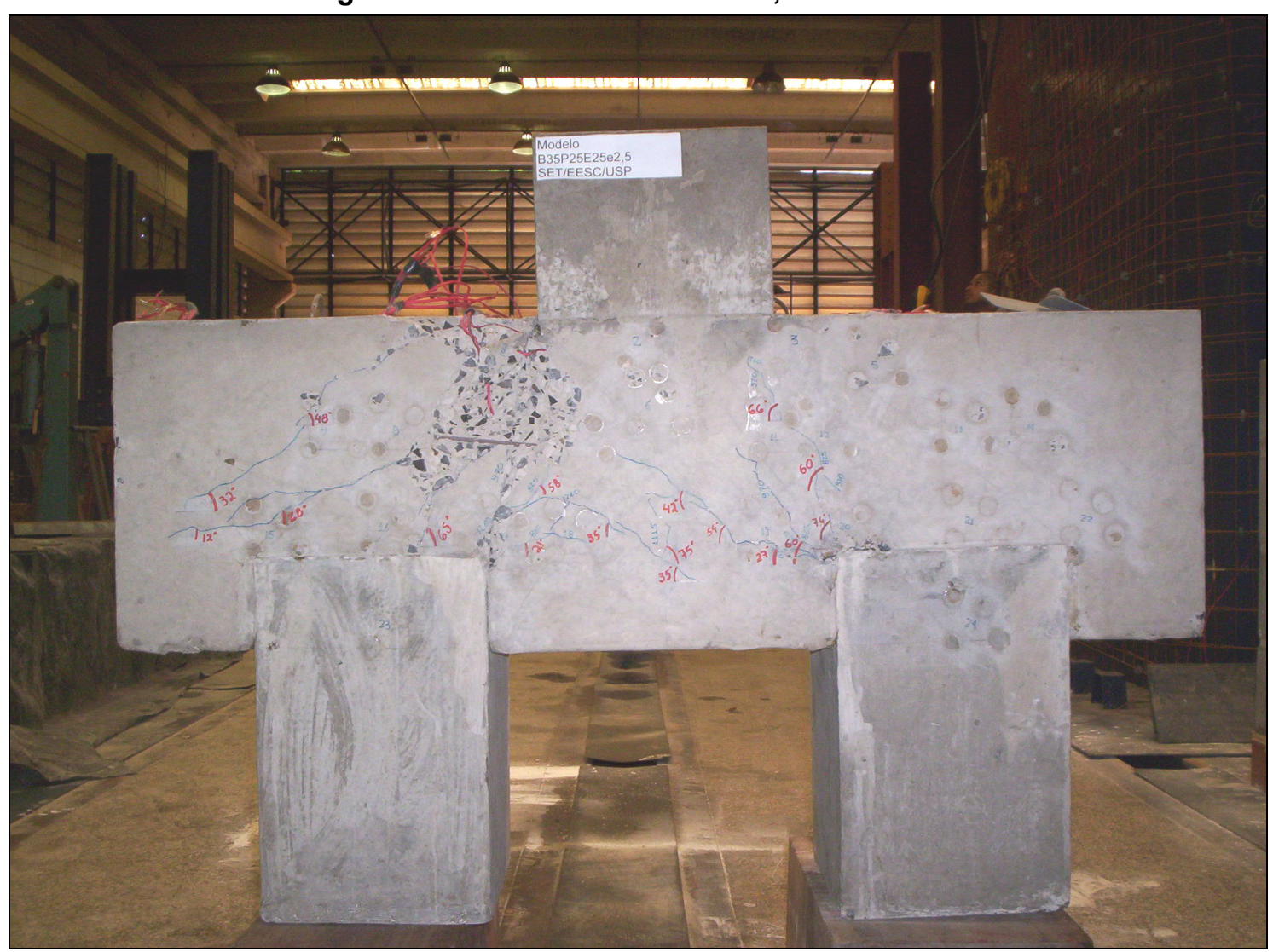

Figura 5.28 - Modelo B5P25E25e2,5, vista frontal. 


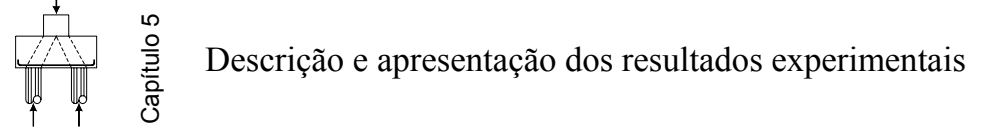

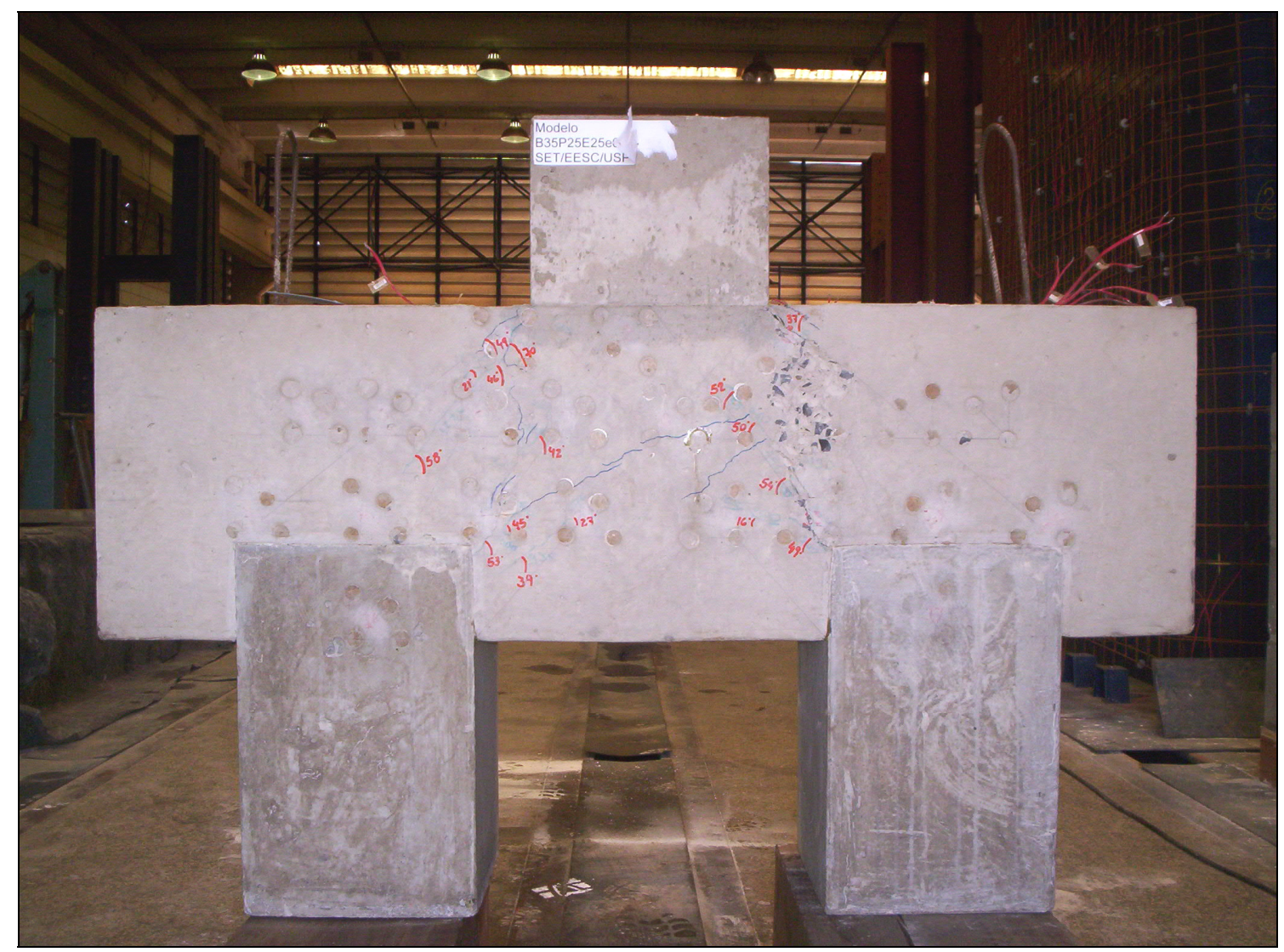

Figura 5.29 - Modelo B5P25E25e0A $\mathrm{sw}_{\mathrm{sw}}, \mathrm{\text {v }}$ vista frontal.

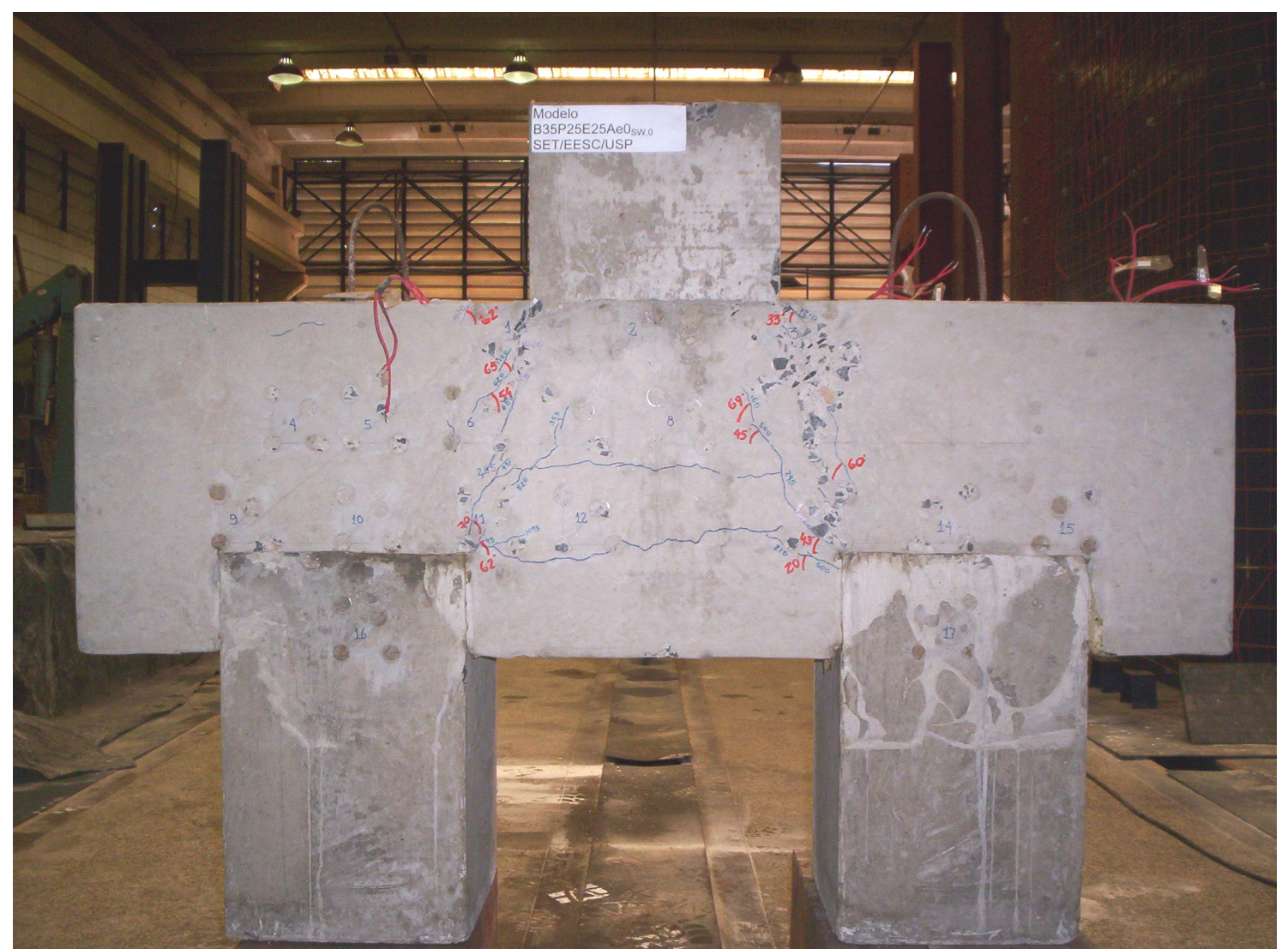

Figura 5.30 - Modelo B5P25E25e0A $\mathrm{sw}_{\mathrm{sw}, 0}$, vista frontal. 


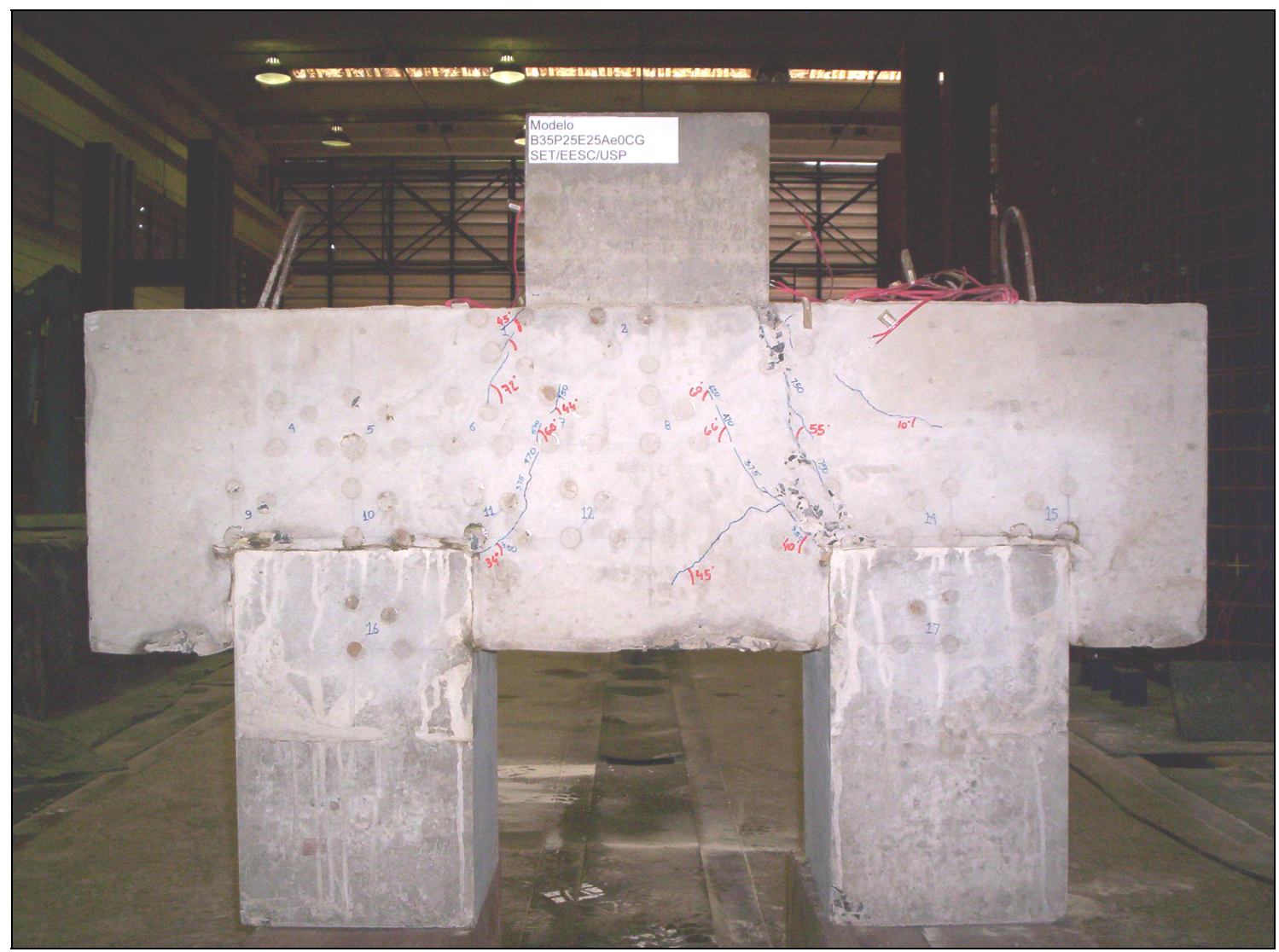

Figura 5.31 - Modelo B5P25E25e0CG, vista frontal.

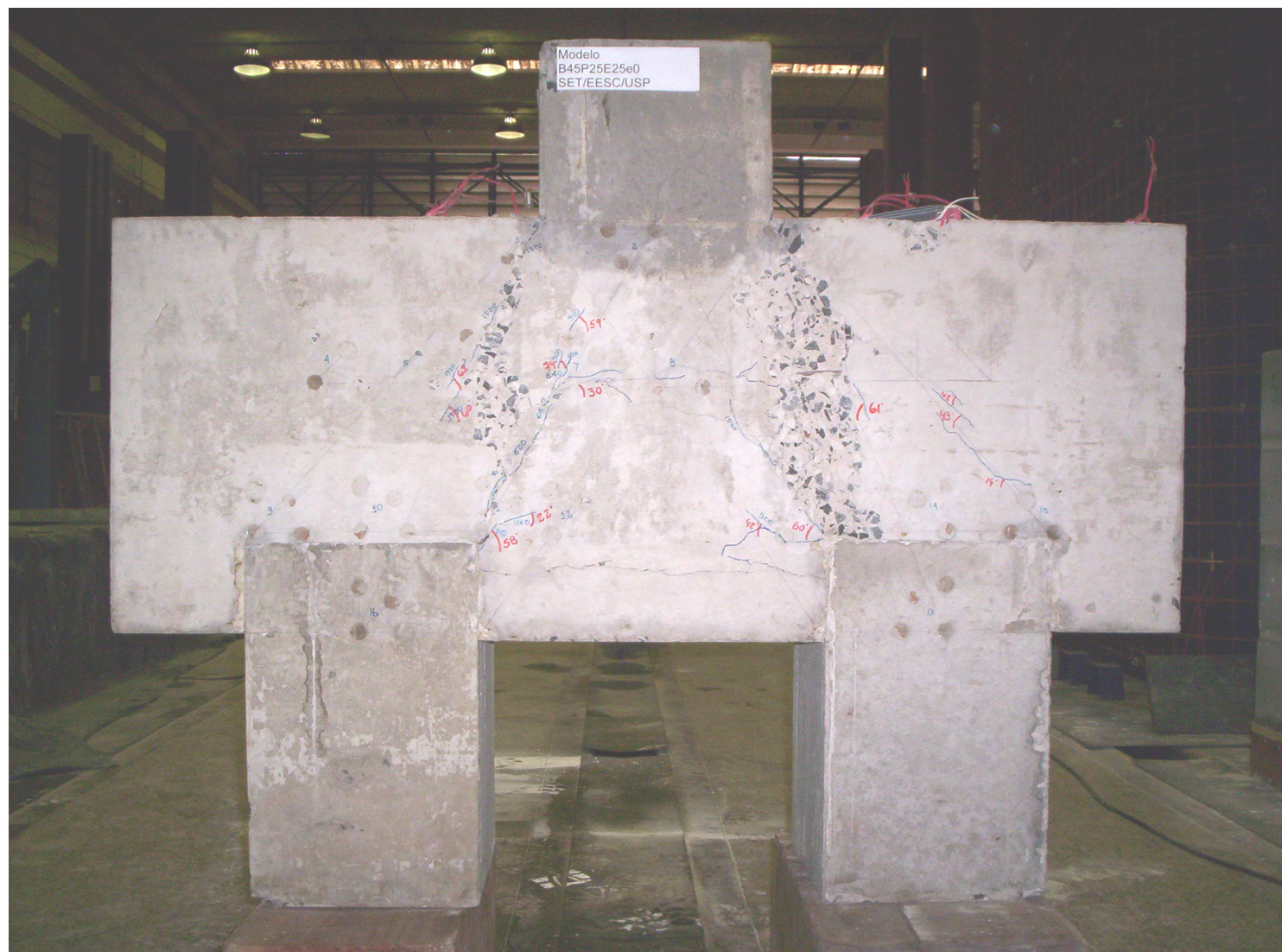

Figura 5.32 - Modelo B45P25E25e0, vista frontal. 


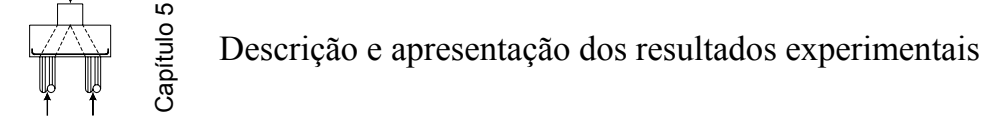

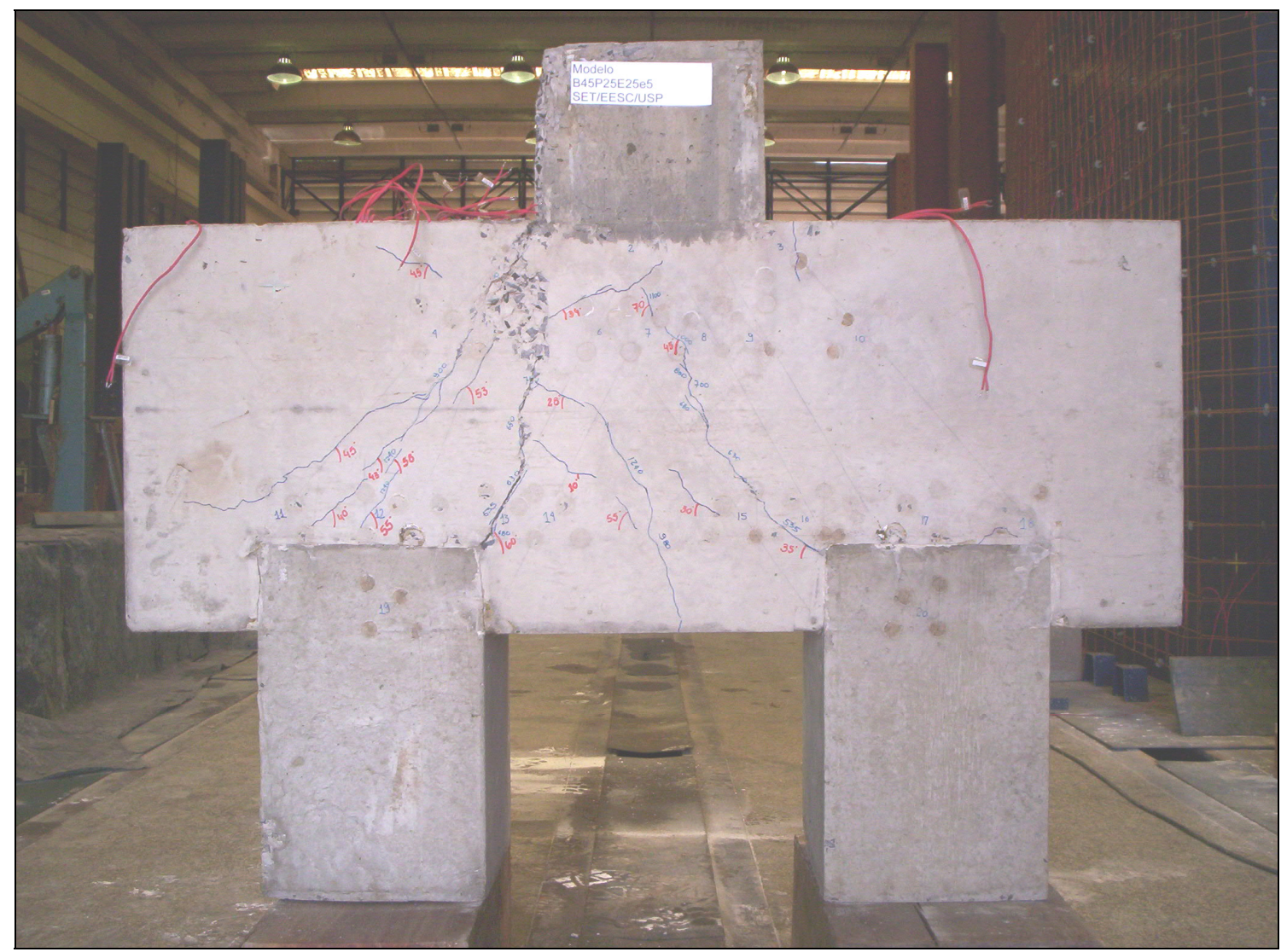

Figura 5.33 - Modelo B45P25E25e5, vista frontal.

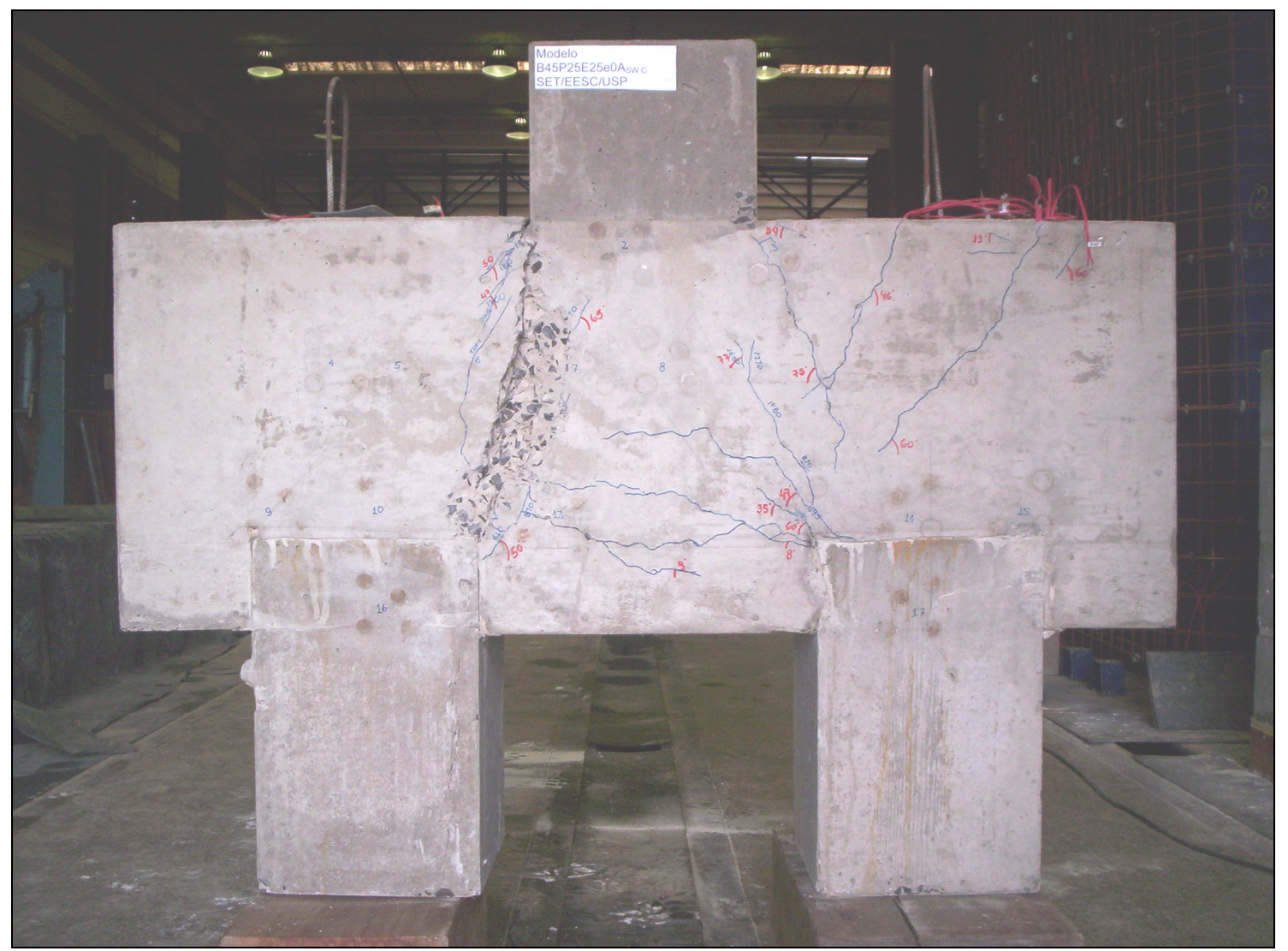

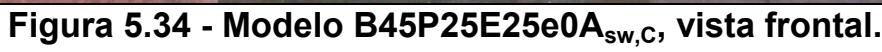


Descrição e apresentação dos resultados experimentais

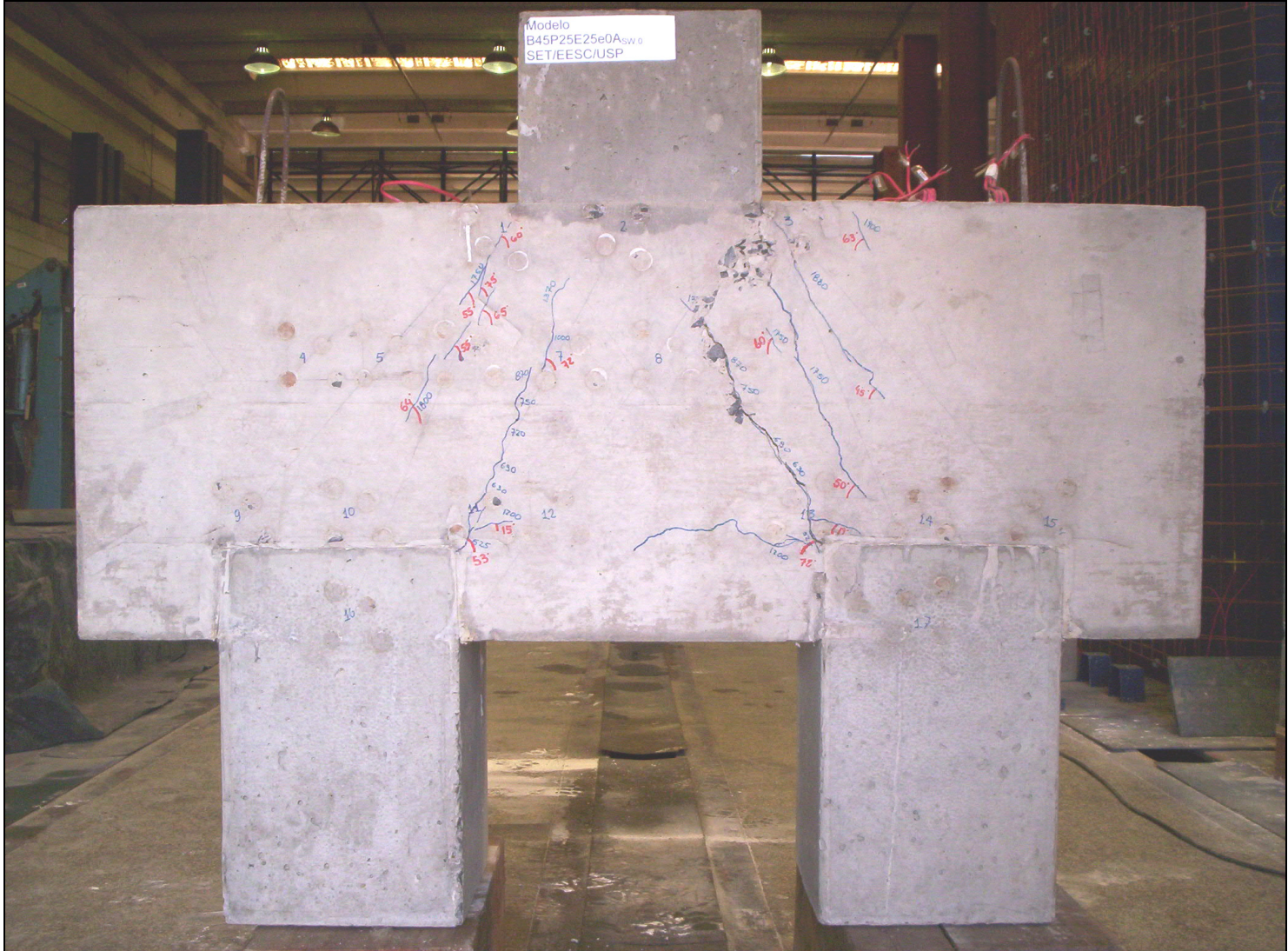

Figura 5.35 - Modelo B45P25E25e0A $\mathrm{sw}_{\mathrm{s}, 0}$, vista frontal.

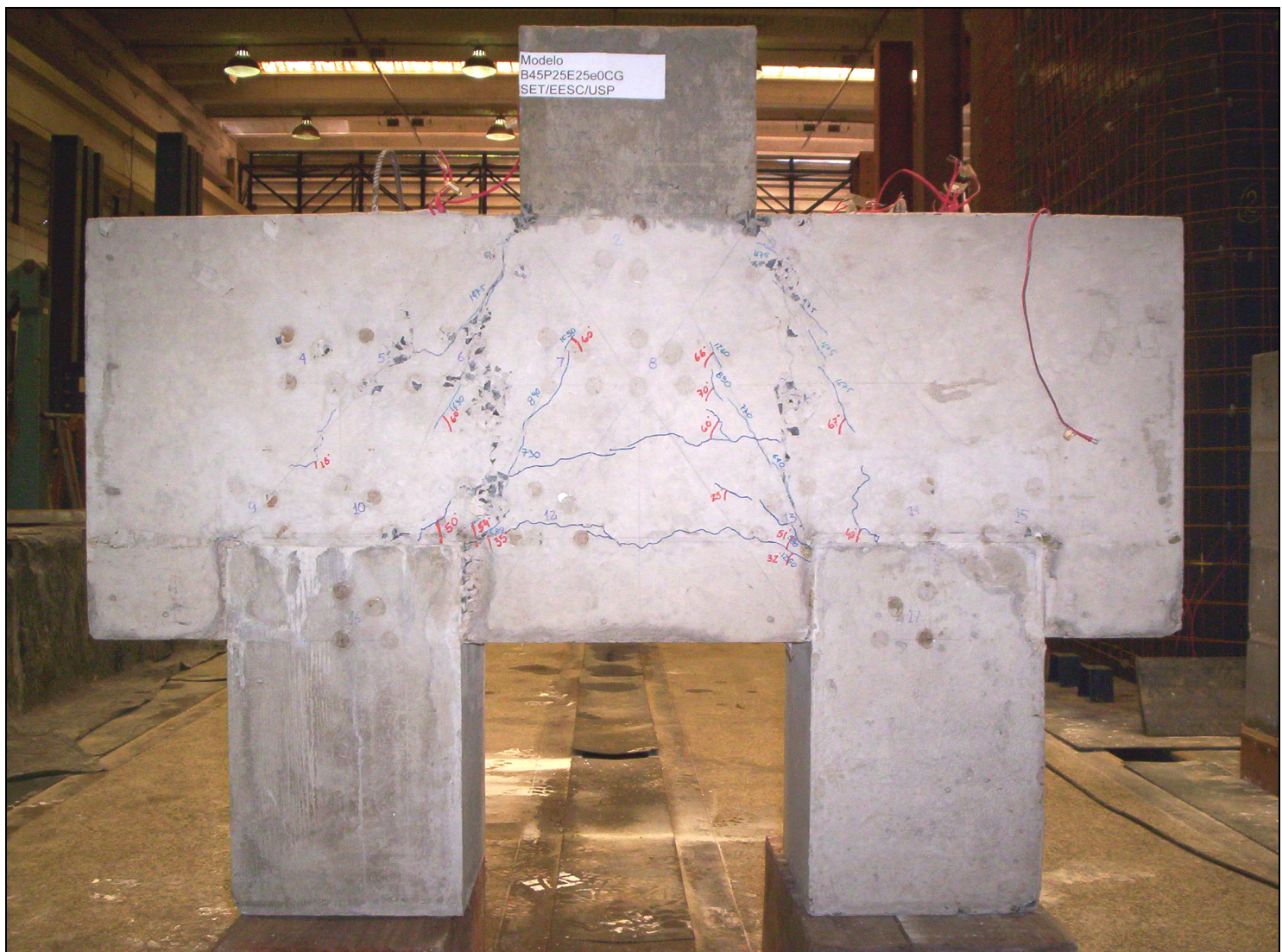

Figura 5.36 - Modelo B45P25E25e0CG, vista frontal. 


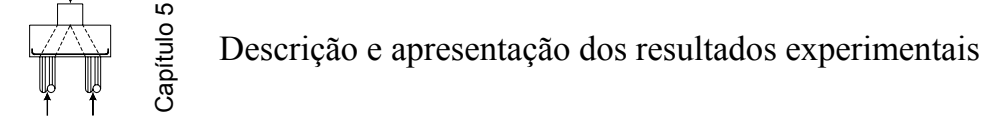

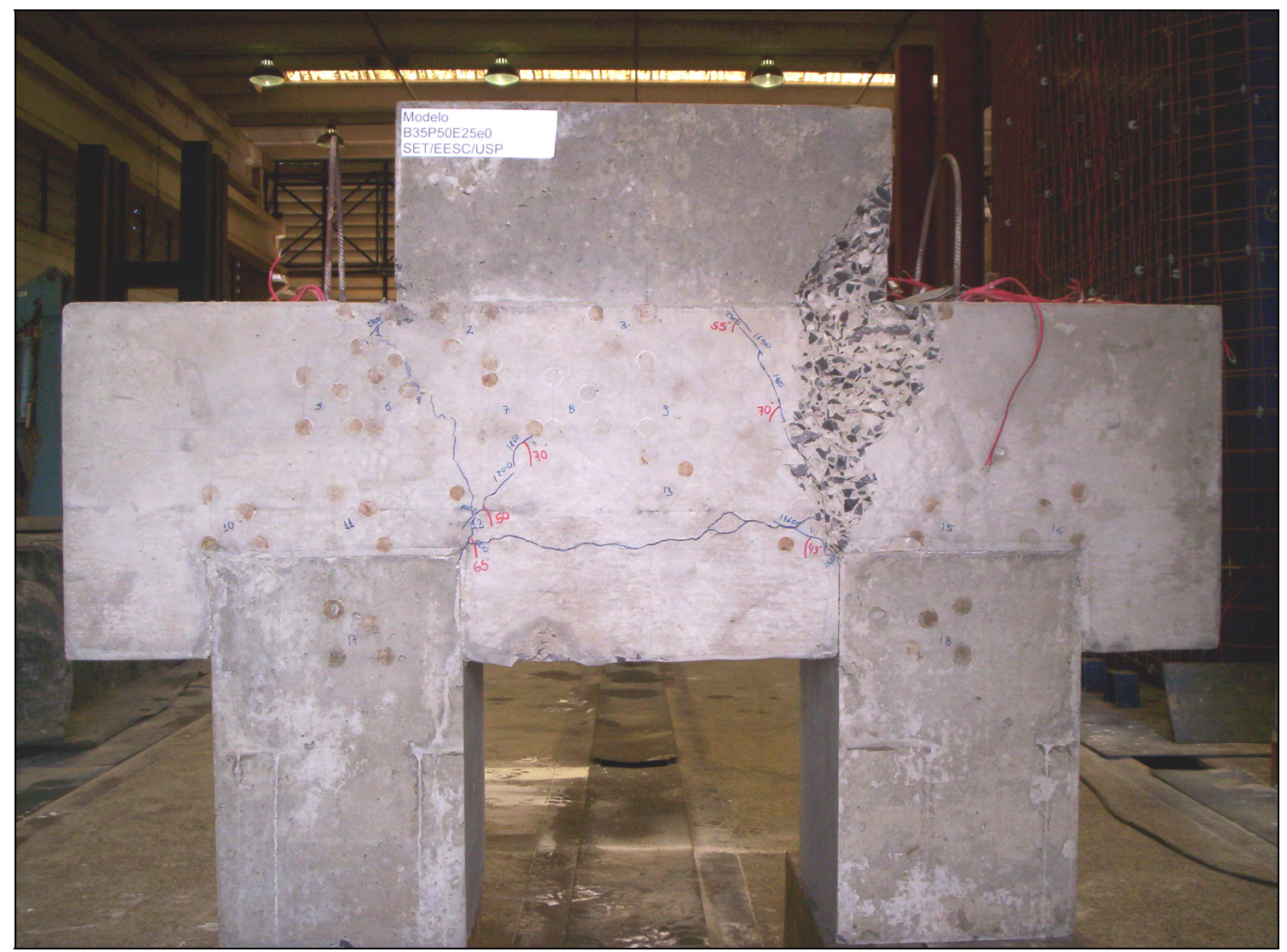

Figura 5.37 - Modelo B35P50E25e0, vista frontal.

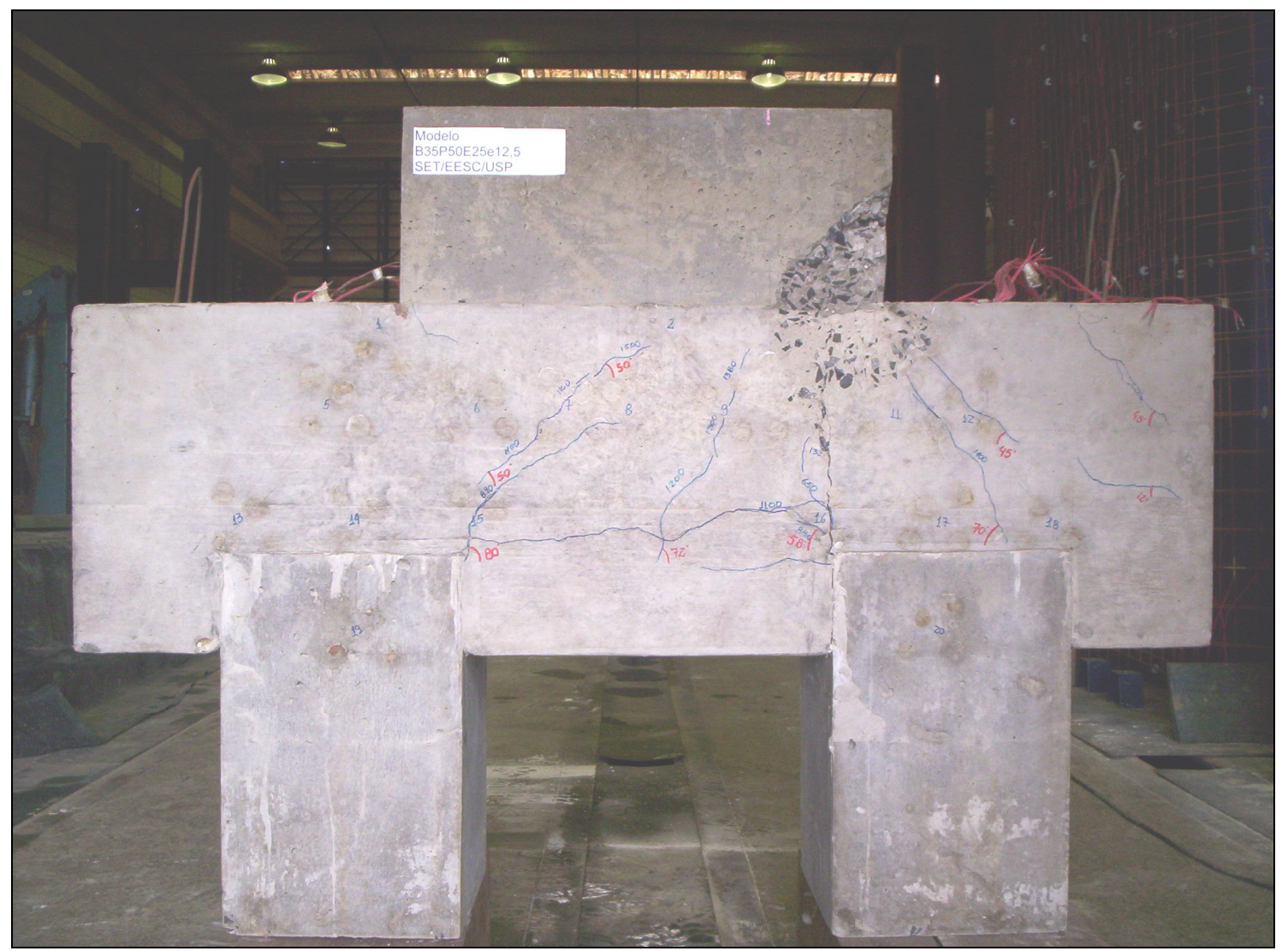

Figura 5.38 - Modelo B35P50E25e12,5, vista frontal. 


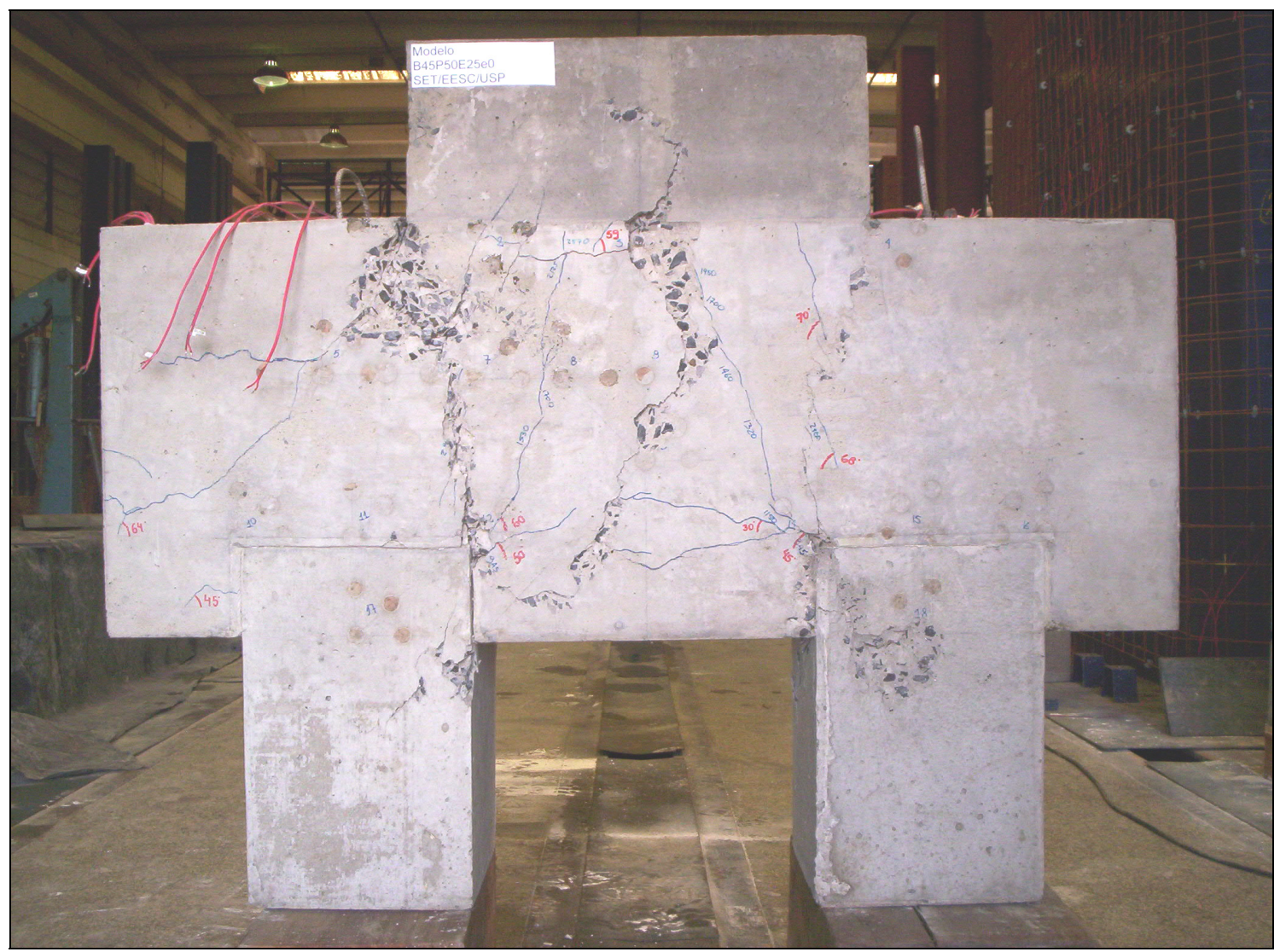

Figura 5.39 - Modelo B45P50E25e0, vista frontal.

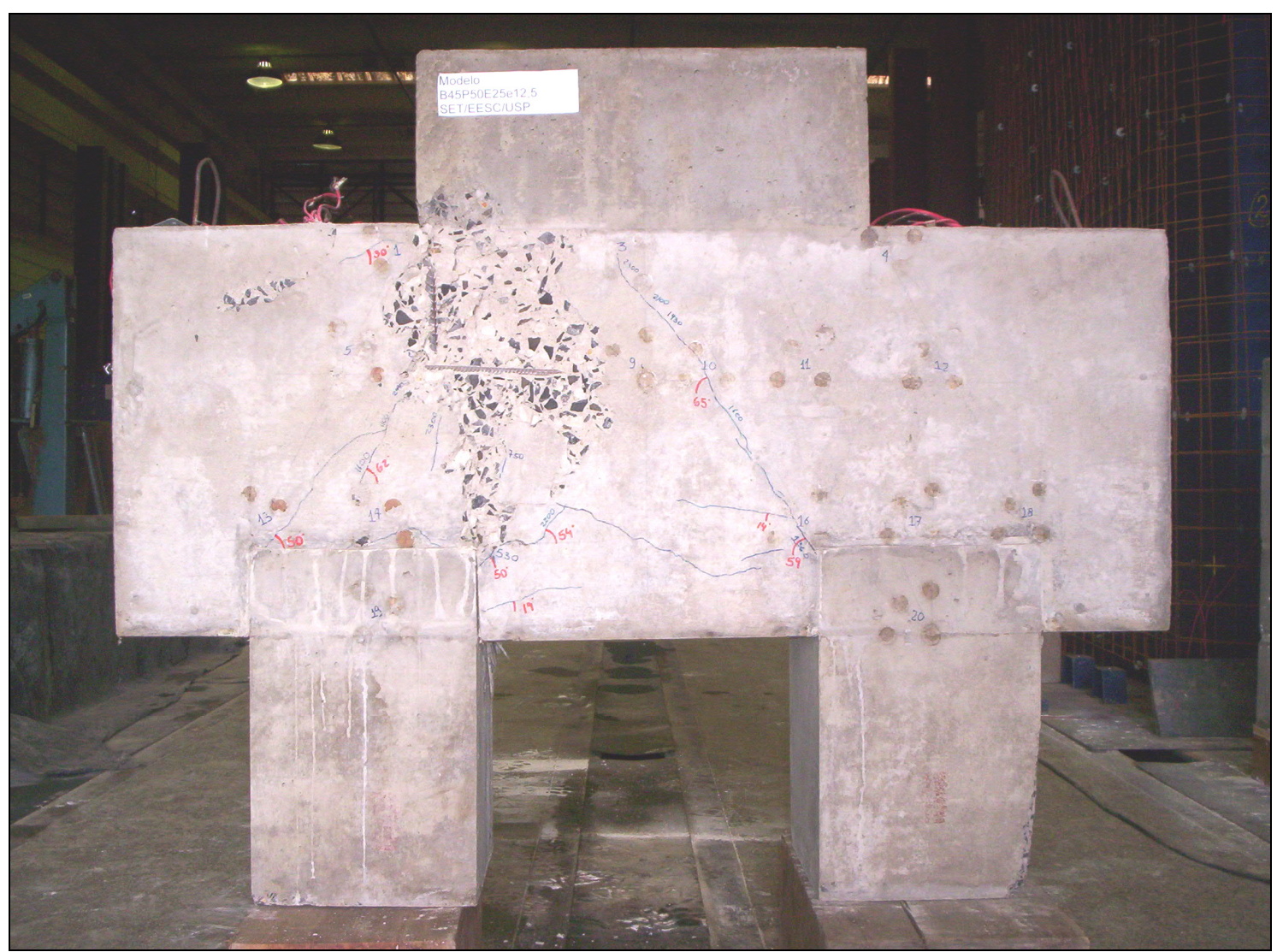

Figura 5.40 - Modelo B45P50E25e12,5, vista frontal. 


\subsubsection{Deformação nas faces dos blocos}

As deformações nos blocos foram acompanhadas por meio de medidas de deslocamentos relativos entre as pastilhas de aço fixadas nas superfícies dos blocos. Só uma superfície lateral foi analisada, pois a análise das duas faces levaria muito tempo, prejudicando o andamento dos ensaios. No total foram realizadas 5163 (cinco mil cento e sessenta e três) leituras. As leituras se iniciaram após o escorvamento dos modelos, que foi realizado com cerca de dez por cento da força teórica prevista, determinando-se a leitura inicial $\ell_{0}$. Após, procedeu-se leituras para cada incremento de força. As leituras não foram realizadas próximas aos colapsos dos modelos por questões de segurança do autor e do estagiário que auxiliou na realização dos ensaios. Em função do alto número de leituras efetuadas serão apresentadas as leituras e deformações calculadas relativas ao último incremento de força antes do surgimento da primeira fissura e do último incremento de força analisado. As demais leituras e deformações fazem parte da memória do trabalho e estão disponíveis em arquivo eletrônico.

Apesar de não se poder utilizar a teoria da elasticidade para o estudo de blocos sobre estacas em função da fissuração existente e da heterogeneidade do material concreto, as deformações principais foram determinadas, pois são calculadas apenas por rotação de eixos no ponto considerado e em regiões onde não haviam fissuras. Quando, uma fissura passava por um ponto de medida a determinação das deformações numa determinada direção ficava comprometida, pois havia ruptura à tração do concreto, ocorrendo distribuição de tensões, modificando as trajetórias das mesmas. Quando isso ocorria, as deformações principais de tração foram desprezadas, mas como o ângulo de inclinação das fissuras foi praticamente paralelo à direção da deformação principal de compressão, tomou-se como referência o valor da deformação no concreto aferida na direção $\varepsilon_{45^{\circ}}$, desde de que fissuras não atravessassem às bases de medidas. Por meio das intensidades das deformações e suas direções principais produziram-se diagramas pelos quais ficou evidenciado em que regiões dos blocos as deformações são maiores. A Figura 5.4 apresenta a convenção adotada para os ângulos das deformações principais, sendo positivo no sentido anti-horário medido partir do eixo x. As Tabelas 5.2 a 5.15 apresentam as leituras obtidas durante os ensaios como também as deformações $\varepsilon_{0^{\circ}}, \varepsilon_{45^{\circ}}, \varepsilon_{90^{\circ}}, \varepsilon_{1}$ e $\varepsilon_{2}$. As linhas destacadas com letras de cor vermelha significam que fissuras atravessaram os pontos de medições. As Figuras 5.41 a 5.54 mostram os diagramas de intensidades das deformações principais nas faces dos blocos sobre estacas. 
Descrição e apresentação dos resultados experimentais

Tabela 5.2 - Modelo B35P25E25e0.

\begin{tabular}{|c|c|c|c|c|c|c|c|c|c|c|c|c|c|}
\hline \multicolumn{14}{|c|}{$\mathrm{F}=435 \mathrm{kN}-$ antes da primeira fissura } \\
\hline \multirow{2}{*}{ Pto. } & \multicolumn{3}{|c|}{ Leitura incial $-\ell_{0}$} & \multicolumn{3}{|c|}{ Leitura final $-\ell$} & \multicolumn{3}{|c|}{ Deformações (\%o) } & \multicolumn{2}{|c|}{ Def. Prin. (\%o) } & \multicolumn{2}{|c|}{ Dir. Prin. $\left({ }^{\circ}\right)$} \\
\hline & $0^{\circ}$ & $90^{\circ}$ & $45^{\circ}$ & $0^{\circ}$ & $90^{\circ}$ & $45^{\circ}$ & $\varepsilon_{0^{\circ}}$ & $\varepsilon_{90^{\circ}}$ & $\varepsilon_{45^{\circ}}$ & $\varepsilon_{1}$ & $\varepsilon_{2}$ & $\alpha_{1}$ & $\alpha_{2}$ \\
\hline 1 & 2,67 & 2,713 & 2,6175 & 2,646 & 2,697 & 2,5735 & $-0,48$ & $-0,32$ & $-0,88$ & 0,09 & $-0,89$ & 40,3 & 130,3 \\
\hline 2 & 2,615 & 2,462 & 2,664 & 2,602 & 2,457 & 2,649 & $-0,26$ & $-0,1$ & $-0,3$ & $-0,04$ & $-0,32$ & 28,2 & 118,2 \\
\hline 3 & 2,659 & 2,455 & 2,552 & 2,643 & 2,43 & 2,5395 & $-0,32$ & $-0,5$ & $-0,25$ & $-0,23$ & $-0,59$ & 30,3 & 120,3 \\
\hline 4 & 2,7265 & 2,634 & 2,25 & 2,727 & 2,629 & 2,244 & 0,01 & $-0,1$ & $-0,12$ & 0,05 & $-0,14$ & $-26,9$ & 63,1 \\
\hline 5 & 2,2835 & 2,742 & 2,768 & 2,2795 & 2,736 & 2,7565 & $-0,08$ & $-0,12$ & $-0,23$ & 0,03 & $-0,23$ & $-40,6$ & 49,4 \\
\hline 6 & 2,162 & 2,4625 & 2,538 & 2,16 & 2,452 & 2,517 & $-0,04$ & $-0,21$ & $-0,42$ & 0,18 & $-0,43$ & $-37,0$ & 53,0 \\
\hline 7 & 2,2375 & 2,683 & 2,615 & 2,24 & 2,789 & 2,61 & 0,05 & 2,12 & $-0,1$ & 2,66 & $-0,49$ & 24,4 & 114,4 \\
\hline 8 & 2,769 & 2,2775 & 2,423 & 2,774 & 2,318 & 2,414 & 0,1 & 0,81 & $-0,18$ & 1,18 & $-0,27$ & 30,4 & 120,4 \\
\hline 9 & 2,777 & 2,625 & 2,787 & 2,768 & 2,619 & 2,781 & $-0,18$ & $-0,12$ & $-0,12$ & $-0,11$ & $-0,19$ & $-22,5$ & 67,5 \\
\hline 10 & 2,378 & 2,413 & 2,565 & 2,381 & 2,4075 & 2,556 & 0,06 & $-0,11$ & $-0,18$ & 0,15 & $-0,20$ & $-30,6$ & 59,4 \\
\hline 11 & 2,698 & 2,53 & 2,469 & 2,845 & 2,539 & 2,483 & 2,94 & 0,18 & 0,28 & 3,44 & $-0,32$ & $-21,4$ & 68,6 \\
\hline 12 & 2,375 & 2,621 & 2,883 & 2,383 & 2,635 & 2,888 & 0,16 & 0,28 & 0,1 & 0,35 & 0,09 & 31,7 & 121,7 \\
\hline 13 & 2,513 & 2,791 & 2,556 & 2,521 & 2,796 & 2,564 & 0,16 & 0,1 & 0,16 & 0,17 & 0,09 & 22,5 & 112,5 \\
\hline 14 & 2,8 & 2,29 & 2,842 & 2,938 & 2,295 & 2,825 & 2,76 & 0,1 & $-0,34$ & 3,64 & $-0,78$ & $-26,5$ & 63,5 \\
\hline 15 & 2,412 & 2,462 & 2,657 & 2,4075 & 2,47 & 2,6565 & $-0,09$ & 0,16 & $-0,01$ & 0,17 & $-0,10$ & 9,9 & 99,9 \\
\hline 16 & 2,9265 & 2,421 & 2,473 & 2,9235 & 2,431 & 2,472 & $-0,06$ & 0,2 & $-0,02$ & 0,23 & $-0,09$ & 17,3 & 107,3 \\
\hline 17 & 2,893 & 2,397 & 2,302 & 2,889 & 2,392 & 2,294 & $-0,08$ & $-0,1$ & $-0,16$ & $-0,02$ & $-0,16$ & $-40,9$ & 49,1 \\
\hline 18 & 2,548 & 2,5685 & 2,199 & 2,548 & 2,565 & 2,1965 & 0 & $-0,07$ & $-0,05$ & 0,00 & $-0,07$ & $-11,6$ & 78,4 \\
\hline \multicolumn{14}{|c|}{$F=1225 \mathrm{kN}$} \\
\hline \multirow{2}{*}{ Pto. } & \multicolumn{3}{|c|}{ Leitura incial $-\ell_{0}$} & \multicolumn{3}{|c|}{ Leitura final $-\ell$} & \multicolumn{3}{|c|}{ Deformações (\%o) } & \multicolumn{2}{|c|}{ Def. Prin. (\%o) } & \multicolumn{2}{|c|}{ Dir. Prin. $\left(^{\circ}\right)$} \\
\hline & $0^{\circ}$ & $90^{\circ}$ & $45^{\circ}$ & $0^{\circ}$ & $90^{\circ}$ & $45^{\circ}$ & $\varepsilon_{0^{\circ}}$ & $\varepsilon_{90^{\circ}}$ & $\varepsilon_{45^{\circ}}$ & $\varepsilon_{1}$ & $\varepsilon_{2}$ & $\alpha_{1}$ & $\alpha_{2}$ \\
\hline 1 & 2,67 & 2,713 & 2,6175 & 2,655 & 2,666 & 2,483 & $-0,3$ & $-0,94$ & $-2,69$ & - & -2.69 & & - \\
\hline 2 & 2,615 & 2,462 & 2,664 & 2,592 & 2,4545 & 2,6345 & $-0,46$ & $-0,15$ & $-0,59$ & 0,02 & $-0,63$ & 30,7 & 120,7 \\
\hline 3 & 2,659 & 2,455 & 2,552 & 2,621 & 2,421 & 2,545 & $-0,76$ & $-0,68$ & $-0,14$ & $-0,14$ & $\begin{array}{l}-1,30 \\
\end{array}$ & $-43,0$ & 47,0 \\
\hline 4 & 2,7265 & 2,634 & 2,25 & 2,725 & 2,629 & 2,242 & $-0,03$ & $-0,1$ & $-0,16$ & 0,04 & $-0,17$ & $-34,9$ & 55,1 \\
\hline 5 & 2,2835 & 2,742 & 2,768 & 2,2725 & 2,735 & 2,748 & $-0,22$ & $-0,14$ & $-0,4$ & 0,04 & $-0,40$ & 39,8 & 129,8 \\
\hline 6 & 2,162 & 2,4625 & 2,538 & 2,16 & 2,526 & 2,4675 & $-0,04$ & 1,27 & $-1,41$ & 2,74 & $-1,51$ & 36,0 & 126,0 \\
\hline 7 & 2,2375 & 2,683 & 2,615 & 2,225 & 2,712 & 2,589 & $-0,25$ & 0,58 & $-0,52$ & - & $-0,52$ & - & - \\
\hline 8 & 2,769 & 2,2775 & 2,423 & 2,772 & 2,27 & 2,412 & 0,06 & $-0,15$ & $-0,22$ & 0,16 & $-0,25$ & $-29,5$ & 60,5 \\
\hline 9 & 2,777 & 2,625 & 2,787 & 2,7785 & 2,619 & 2,7815 & 0,03 & $-0,12$ & $-0,11$ & 0,05 & $-0,14$ & $-20,5$ & 69,5 \\
\hline 10 & 2,378 & 2,413 & 2,565 & 2,3925 & 2,411 & 2,548 & 0,29 & $-0,04$ & $-0,34$ & 0,62 & $-0,37$ & $-35,2$ & 54,8 \\
\hline 11 & 2,698 & 2,53 & 2,469 & 2,964 & 2,532 & 2,489 & 5,32 & 0,04 & 0,4 & - & - & - & - \\
\hline 12 & 2,375 & 2,621 & 2,883 & 2,386 & 2,62 & 2,831 & 0,22 & $-0,02$ & $-1,04$ & 1,25 & $-1,05$ & $-42,0$ & 48,0 \\
\hline 13 & 2,513 & 2,791 & 2,556 & 2,5615 & 2,7905 & 2,554 & 0,97 & $-0,01$ & $-0,04$ & 1,19 & $-0,23$ & $-23,4$ & 66,6 \\
\hline 14 & 2,8 & 2,29 & 2,842 & 3,117 & 2,296 & 2,881 & 6,34 & 0,12 & 0,78 & - & - & - & - \\
\hline 15 & 2,412 & 2,462 & 2,657 & 2,411 & 2,474 & 2,755 & $-0,02$ & 0,24 & 1,96 & - & - & - & - \\
\hline 16 & 2,9265 & 2,421 & 2,473 & 2,9165 & 2,431 & 2,471 & $-0,2$ & 0,2 & $-0,04$ & 0,20 & $-0,20$ & 5,7 & 95,7 \\
\hline 17 & 2,893 & 2,397 & 2,302 & 2,89 & 2,384 & 2,28 & $-0,06$ & $-0,26$ & $-0,44$ & 0,14 & $-0,46$ & $-35,2$ & 54,8 \\
\hline 18 & 2,548 & 2,5685 & 2,199 & 2,548 & 2,565 & 2,197 & 0 & $-0,07$ & $-0,04$ & 0,00 & $-0,07$ & $-4,1$ & 85,9 \\
\hline
\end{tabular}
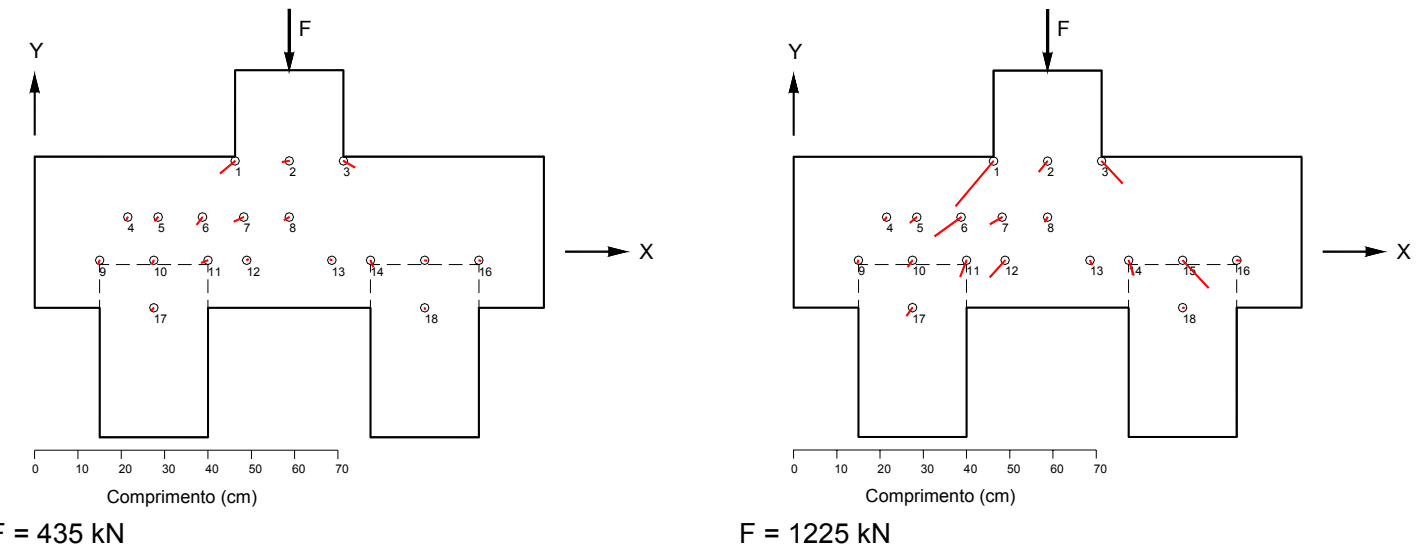

$\mathrm{F}=435 \mathrm{kN}$

$\mathrm{F}=1225 \mathrm{kN}$

Figura 5.41 - Intensidades das deformações principais, modelo B35P25E25e0. 
Tabela 5.3 - Modelo B35P25E25e2,5.

\begin{tabular}{|c|c|c|c|c|c|c|c|c|c|c|c|c|c|}
\hline \multicolumn{14}{|c|}{$\mathrm{F}=290 \mathrm{kN}-$ antes da primeira fissura } \\
\hline \multirow{2}{*}{ Pto. } & \multicolumn{3}{|c|}{ Leitura incial $-\ell_{0}$} & \multicolumn{3}{|c|}{ Leitura final $-\ell$} & \multicolumn{3}{|c|}{ Deformações (\%o) } & \multicolumn{2}{|c|}{ Def. Prin. (\%o) } & \multicolumn{2}{|c|}{ Dir. Prin. $\left({ }^{\circ}\right)$} \\
\hline & $0^{\circ}$ & $90^{\circ}$ & $45^{\circ}$ & $0^{\circ}$ & $90^{\circ}$ & $45^{\circ}$ & $\varepsilon_{0^{\circ}}$ & $x_{1}$ & $\varepsilon_{45^{\circ}}$ & $\varepsilon_{1}$ & $\varepsilon_{2}$ & $\alpha_{1}$ & $\alpha_{2}$ \\
\hline 1 & 2,618 & 2,507 & 2,803 & 2,597 & 2,485 & 2,765 & $-0,42$ & $-0,44$ & $-0,76$ & $-0,10$ & $-0,76$ & $-44,13$ & 45,87 \\
\hline 2 & 2,205 & 2,435 & 2,855 & 2,189 & 2,435 & 2,851 & $-0,32$ & 0 & $-0,08$ & 0,02 & $-0,34$ & $-13,28$ & 76,72 \\
\hline 3 & 2,543 & 2,721 & 2,435 & 2,529 & 2,718 & 2,426 & $-0,28$ & $-0,06$ & $-0,18$ & $-0,06$ & $-0,28$ & 2,60 & 92,60 \\
\hline 4 & 2,672 & 2,675 & 2,567 & 2,6725 & 2,79 & 2,5515 & 0,01 & 2,3 & $-0,31$ & 3,01 & $-0,70$ & 25,99 & 115,99 \\
\hline 5 & 2,122 & 2,428 & 2,522 & 2,124 & 2,429 & 2,5265 & 0,04 & 0,02 & 0,09 & 0,09 & $-0,03$ & 40,27 & 130,27 \\
\hline 6 & 2,601 & 2,283 & 2,135 & 2,614 & 2,279 & 2,139 & 0,26 & $-0,08$ & 0,08 & 0,26 & $-0,08$ & $-1,68$ & 88,32 \\
\hline 7 & 2,353 & 2,145 & 2,572 & 2,352 & 2,145 & 2,567 & $-0,02$ & 0 & $-0,1$ & 0,08 & $-0,10$ & 41,83 & 131,83 \\
\hline 8 & 2,527 & 2,502 & 2,714 & 2,532 & 2,502 & 2,706 & 0,1 & 0 & $-0,16$ & 0,27 & $-0,17$ & $-38,30$ & 51,70 \\
\hline 9 & 2,506 & 2,549 & 2,119 & 2,502 & 2,54 & 2,1 & $-0,08$ & $-0,18$ & $-0,38$ & 0,12 & $-0,38$ & $-39,35$ & 50,65 \\
\hline 10 & 2,874 & 2,585 & 3,112 & 2,8715 & 2,602 & 3,02 & $-0,05$ & 0,34 & $-1,84$ & 2,14 & $-1,85$ & 42,19 & 132,19 \\
\hline 11 & 2,616 & 2,627 & 2,604 & 2,617 & 2,6265 & 2,624 & 0,02 & $-0,01$ & 0,4 & 0,40 & $-0,39$ & 43,91 & 133,91 \\
\hline 12 & 2,18 & 2,385 & 2,732 & 2,2245 & 2,384 & 2,78 & 0,89 & $-0,02$ & 0,96 & 1,13 & $-0,26$ & 24,54 & 114,54 \\
\hline 13 & 2,603 & 2,753 & 2,188 & 2,608 & 2,752 & 2,191 & 0,1 & $-0,02$ & 0,06 & 0,10 & $-0,02$ & 9,22 & 99,22 \\
\hline 14 & 2,241 & 2,396 & 2,195 & 2,244 & 2,37 & 2,1975 & 0,06 & $-0,52$ & 0,05 & 0,17 & $-0,63$ & 22,00 & 112,00 \\
\hline 15 & 2,302 & 2,539 & 2,525 & 2,305 & 2,53 & 2,529 & 0,06 & $-0,18$ & 0,08 & 0,12 & $-0,24$ & 24,70 & 114,70 \\
\hline 16 & 2,572 & 2,548 & 2,76 & 2,576 & 2,545 & 2,7545 & 0,08 & $-0,06$ & $-0,11$ & 0,15 & $-0,13$ & $-29,87$ & 60,13 \\
\hline 17 & 2,516 & 2,635 & 2,586 & 2,687 & 2,636 & 2,5125 & 3,42 & 0,02 & $-1,47$ & 5,33 & $-1,89$ & $-30,97$ & 59,03 \\
\hline 18 & 2,657 & 2,478 & 2,598 & 2,675 & 2,54 & 2,615 & 0,36 & 1,24 & 0,34 & 1,44 & 0,16 & 23,14 & 113,14 \\
\hline 19 & 2,227 & 2,589 & 2,981 & 2,243 & 2,595 & 2,992 & 0,32 & 0,12 & 0,22 & 0,32 & 0,12 & 0,00 & 90,00 \\
\hline 20 & 2,826 & 2,589 & 3,194 & 2,898 & 2,62 & 3,16 & 1,44 & 0,62 & $-0,68$ & 2,79 & $-0,73$ & $-38,26$ & 51,74 \\
\hline 21 & 2,568 & 2,1755 & 2,782 & 2,572 & 2,181 & 2,779 & 0,08 & 0,11 & $-0,06$ & 0,25 & $-0,06$ & 42,24 & 132,24 \\
\hline 22 & 2,529 & 2,234 & 2,368 & 2,535 & 2,235 & 2,37 & 0,12 & 0,02 & 0,04 & 0,13 & 0,01 & $-15,48$ & 74,52 \\
\hline 23 & 2,6885 & 3,034 & 3,17 & 2,69 & 3,03 & 3,1675 & 0,03 & $-0,08$ & $-0,05$ & 0,04 & $-0,09$ & $-12,22$ & 77,78 \\
\hline 24 & 2,8395 & 2,085 & 2,8155 & 2,846 & 2,08 & 2,815 & 0,13 & $-0,1$ & $-0,01$ & 0,13 & $-0,10$ & $-6,13$ & 83,87 \\
\hline \multicolumn{14}{|c|}{$F=1260 \mathrm{kN}$} \\
\hline \multirow{2}{*}{ Pto. } & \multicolumn{3}{|c|}{ Leitura incial - $\ell_{0}$} & \multicolumn{3}{|c|}{ Leitura final $-\ell$} & \multicolumn{3}{|c|}{ Deformações (\%o) } & \multicolumn{2}{|c|}{ Def. Prin. (\%o) } & \multicolumn{2}{|c|}{ Dir. Prin. $\left(^{\circ}\right)$} \\
\hline & $0^{\circ}$ & $90^{\circ}$ & $45^{\circ}$ & $0^{\circ}$ & $90^{\circ}$ & $45^{\circ}$ & $\varepsilon_{0^{\circ}}$ & $\varepsilon_{90^{\circ}}$ & $\varepsilon_{45^{\circ}}$ & $\varepsilon_{1}$ & $\varepsilon_{2}$ & $\alpha_{1}$ & $\alpha_{2}$ \\
\hline 1 & 2,618 & 2,507 & 2,803 & 2,745 & 2,466 & 2,532 & 2,54 & $-0,82$ & $-5,42$ & - & $-5,42$ & - & - \\
\hline 2 & 2,205 & 2,435 & 2,855 & 2,171 & 2,434 & 2,833 & $-0,68$ & $-0,02$ & $-0,44$ & $-0,01$ & $-0,69$ & 7,63 & 97,63 \\
\hline 3 & 2,543 & 2,721 & 2,435 & 2,5215 & 2,6955 & 2,3925 & $-0,43$ & $-0,51$ & $-0,85$ & $-0,09$ & $-0,85$ & $-42,00$ & 48,00 \\
\hline 4 & 2,672 & 2,675 & 2,567 & 2,734 & 2,805 & 2,735 & 1,24 & 2,6 & 3,36 & 3,51 & 0,33 & $-32,36$ & 57,64 \\
\hline 5 & 2,122 & 2,428 & 2,522 & 2,12 & 2,425 & 2,526 & $-0,04$ & $-0,06$ & 0,08 & 0,08 & $-0,18$ & 42,80 & 132,80 \\
\hline 6 & 2,601 & 2,283 & 2,135 & 2,615 & 2,2785 & 2,1485 & 0,28 & $-0,09$ & 0,27 & 0,35 & $-0,16$ & 21,70 & 111,70 \\
\hline 7 & 2,353 & 2,145 & 2,572 & 2,34 & 2,144 & 2,561 & $-0,26$ & $-0,02$ & $-0,22$ & 0,00 & $-0,28$ & 16,85 & 106,85 \\
\hline 8 & 2,527 & 2,502 & 2,714 & 2,505 & 2,494 & 2,686 & $-0,44$ & $-0,16$ & $-0,56$ & 0,00 & $-0,60$ & 30,85 & 120,85 \\
\hline 9 & 2,506 & 2,549 & 2,119 & 2,759 & 2,654 & 2,013 & 5,06 & 2,1 & $-2,12$ & - & $-2,12$ & - & - \\
\hline 10 & 2,874 & 2,585 & 3,112 & 2,844 & 2,578 & 2,9635 & $-0,6$ & $-0,14$ & $-2,97$ & 2,24 & $-2,98$ & 42,47 & 132,47 \\
\hline 11 & 2,616 & 2,627 & 2,604 & 2,608 & 2,609 & 2,811 & $-0,16$ & $-0,36$ & 4,14 & - & - & - & - \\
\hline 12 & 2,18 & 2,385 & 2,732 & 2,3585 & 2,398 & 2,973 & 3,57 & 0,26 & 4,82 & - & - & - & - \\
\hline 13 & 2,603 & 2,753 & 2,188 & 2,605 & 2,748 & 2,179 & 0,04 & $-0,1$ & $-0,18$ & 0,14 & $-0,20$ & $-32,50$ & 51,50 \\
\hline 14 & 2,241 & 2,396 & 2,195 & 2,2685 & 2,371 & 2,198 & 0,55 & $-0,5$ & 0,06 & 0,55 & $-0,50$ & 1,91 & 91,91 \\
\hline 15 & 2,302 & 2,539 & 2,525 & 2,306 & 2,532 & 2,526 & 0,08 & $-0,14$ & 0,02 & 0,09 & $-0,15$ & 12,22 & 102,22 \\
\hline 16 & 2,572 & 2,548 & 2,76 & 2,569 & 2,5565 & 2,735 & $-0,06$ & 0,17 & $-0,5$ & 0,62 & $-0,51$ & 39,15 & 129,15 \\
\hline 17 & 2,516 & 2,635 & 2,586 & 2,986 & 2,734 & 2,462 & 9,4 & 1,98 & $-2,48$ & - & $-2,48$ & - & - \\
\hline 18 & 2,657 & 2,478 & 2,598 & 2,711 & 2,714 & 2,714 & 1,08 & 4,72 & 2,32 & 4,81 & 0,99 & 8,84 & 98,84 \\
\hline 19 & 2,227 & 2,589 & 2,981 & 2,242 & 2,666 & 3,0495 & 0,3 & 1,54 & 1,37 & 1,69 & 0,15 & $-17,99$ & 72,01 \\
\hline 20 & 2,826 & 2,589 & 3,194 & 2,929 & 2,641 & 3,251 & 2,06 & 1,04 & 1,14 & - & - & - & - \\
\hline 21 & 2,568 & 2,1755 & 2,782 & 2,571 & 2,185 & 2,777 & 0,06 & 0,19 & $-0,1$ & 0,36 & $-0,11$ & 36,94 & 126,94 \\
\hline 22 & 2,529 & 2,234 & 2,368 & 2,5345 & 2,235 & 2,3715 & 0,11 & 0,02 & 0,07 & 0,11 & 0,02 & 3,17 & 93,17 \\
\hline 23 & 2,6885 & 3,034 & 3,17 & 2,686 & 3,021 & 3,157 & $-0,05$ & $-0,26$ & $-0,26$ & $-0,01$ & $-0,30$ & $-22,50$ & 67,50 \\
\hline 24 & 2,8395 & 2,085 & 2,8155 & 2,843 & 2,085 & 2,815 & 0,07 & 0 & $-0,01$ & 0,09 & $-0,02$ & $-26,06$ & 63,94 \\
\hline
\end{tabular}

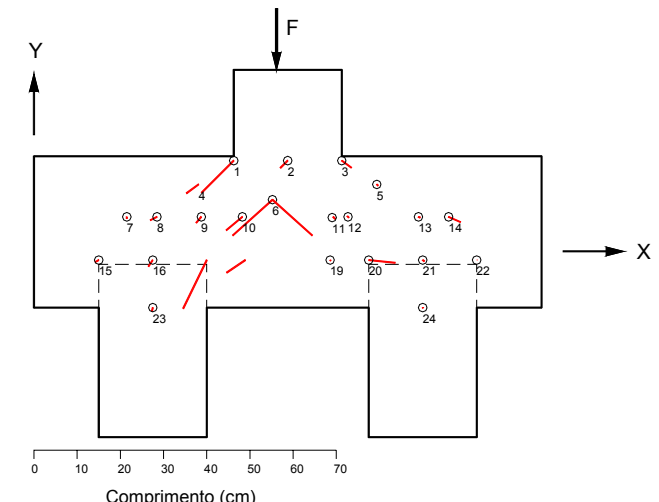

$\mathrm{F}=290 \mathrm{kN}$

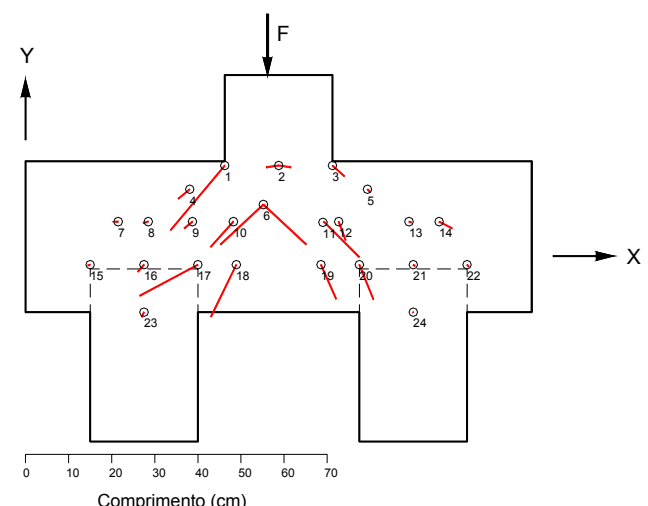

$\mathrm{F}=1260 \mathrm{kN}$

Figura 5.42 - Intensidades das deformações principais, modelo B35P25E25e2,5. 
Descrição e apresentação dos resultados experimentais

Tabela 5.4 - Modelo B35P25E25e0A sw,c.

\begin{tabular}{|c|c|c|c|c|c|c|c|c|c|c|c|c|c|}
\hline \multicolumn{14}{|c|}{$\mathrm{F}=170 \mathrm{kN}-$ antes da primeira fissura } \\
\hline \multirow{2}{*}{ Pto. } & \multicolumn{3}{|c|}{ Leitura incial $-\ell_{0}$} & \multicolumn{3}{|c|}{ Leitura final $-\ell$} & \multicolumn{3}{|c|}{ Deformações (\%o) } & \multicolumn{2}{|c|}{ Def. Prin. (\%o) } & \multicolumn{2}{|c|}{ Dir. Prin. $\left({ }^{\circ}\right)$} \\
\hline & $0^{\circ}$ & $90^{\circ}$ & $45^{\circ}$ & $0^{\circ}$ & $90^{\circ}$ & $45^{\circ}$ & $\varepsilon_{0^{\circ}}$ & $\varepsilon 90^{\circ}$ & $\varepsilon_{45^{\circ}}$ & $\varepsilon_{1}$ & $\varepsilon_{2}$ & $\alpha_{1}$ & $\alpha_{2}$ \\
\hline 1 & 2,899 & 2,364 & 2,786 & 2,8895 & 2,363 & 2,7835 & $-0,19$ & $-0,02$ & $-0,05$ & 0,00 & $-0,21$ & $-16,5$ & 73,5 \\
\hline 2 & 2,067 & 2,973 & 2,973 & 2,068 & 2,9725 & 2,9855 & 0,02 & $-0,01$ & 0,25 & 0,25 & $-0,24$ & 43,2 & 133,2 \\
\hline 3 & 2,8 & 2,848 & 2,561 & 2,7985 & 2,847 & 2,563 & $-0,03$ & $-0,02$ & 0,04 & 0,04 & $-0,09$ & $-42,8$ & 47,2 \\
\hline 4 & 2,436 & 2,617 & 2,437 & 2,443 & 2,6105 & 2,4375 & 0,14 & $-0,13$ & 0,01 & 0,14 & $-0,13$ & 1,1 & 91,1 \\
\hline 5 & 2,695 & 2,417 & 2,38 & 2,696 & 2,442 & 2,4 & 0,02 & 0,5 & 0,4 & 0,54 & $-0,02$ & $-15,1$ & 74,9 \\
\hline 6 & 2,53 & 2,791 & 2,764 & 2,5535 & 2,787 & 2,78 & 0,47 & $-0,08$ & 0,32 & 0,50 & $-0,11$ & 12,2 & 102,2 \\
\hline 7 & 2,295 & 2,7 & 2,332 & 2,319 & 2,722 & 2,3215 & 0,48 & 0,44 & $-0,21$ & 1,13 & $-0,21$ & $-44,1$ & 45,9 \\
\hline 8 & 3,025 & 2,451 & 2,591 & 3,0355 & 2,446 & 2,615 & 0,21 & $-0,1$ & 0,48 & 0,51 & $-0,40$ & 35,0 & 125,0 \\
\hline 9 & 2,637 & 2,489 & 2,691 & 2,635 & 2,516 & 2,6905 & $-0,04$ & 0,54 & $-0,01$ & 0,64 & $-0,14$ & 20,9 & 110,9 \\
\hline 10 & 2,333 & 2,436 & 2,724 & 2,362 & 2,4355 & 2,723 & 0,58 & $-0,01$ & $-0,02$ & 0,71 & $-0,14$ & $-23,0$ & 67,0 \\
\hline 11 & 2,585 & 2,564 & 2,566 & 2,644 & 2,5535 & 2,6035 & 1,18 & $-0,21$ & 0,75 & 1,23 & $-0,26$ & 10,4 & 100,4 \\
\hline 12 & 2,579 & 2,791 & 2,268 & 2,585 & 2,7805 & 2,28 & 0,12 & $-0,21$ & 0,24 & 0,28 & $-0,37$ & 30,0 & 120,0 \\
\hline 13 & 2,686 & 2,501 & 2,3845 & 2,721 & 2,494 & 2,371 & 0,7 & $-0,14$ & $-0,27$ & 0,97 & $-0,41$ & $-26,3$ & 63,7 \\
\hline 14 & 2,448 & 2,252 & 2,528 & 2,4755 & 2,252 & 2,528 & 0,55 & 0 & 0 & 0,66 & $-0,11$ & $-22,5$ & 67,5 \\
\hline 15 & 2,93 & 2,3485 & 2,332 & 2,931 & 2,381 & 2,347 & 0,02 & 0,65 & 0,3 & 0,65 & 0,02 & 3,2 & 93,2 \\
\hline 16 & 2,46 & 2,364 & 2,384 & 2,492 & 2,364 & 2,384 & 0,64 & 0 & 0 & 0,77 & $-0,13$ & $-22,5$ & 67,5 \\
\hline 17 & 2,4065 & 2,13 & 2,679 & 2,425 & 2,165 & 2,678 & 0,37 & 0,7 & $-0,02$ & 1,11 & $-0,04$ & 36,7 & 126,7 \\
\hline \multicolumn{14}{|c|}{$\mathrm{F}=1100 \mathrm{kN}$} \\
\hline \multirow{2}{*}{ Pto. } & \multicolumn{3}{|c|}{ Leitura incial $-\ell_{0}$} & \multicolumn{3}{|c|}{ Leitura final $-\ell$} & \multicolumn{3}{|c|}{ Deformações (\%o) } & \multicolumn{2}{|c|}{ Def. Prin. (\%) } & \multicolumn{2}{|c|}{ Dir. Prin. $\left({ }^{\circ}\right)$} \\
\hline & $0^{\circ}$ & $90^{\circ}$ & $45^{\circ}$ & $0^{\circ}$ & $90^{\circ}$ & $45^{\circ}$ & $\varepsilon_{0^{\circ}}$ & $\varepsilon_{90^{\circ}}$ & $\varepsilon_{45^{\circ}}$ & $\varepsilon_{1}$ & $\varepsilon_{2}$ & $\alpha_{1}$ & $\alpha_{2}$ \\
\hline 1 & 2,899 & 2,364 & 2,786 & 2,87 & 2,309 & 2,709 & $-0,58$ & $-1,1$ & $-1,54$ & - & $-1,54$ & - & - \\
\hline 2 & 2,067 & 2,973 & 2,973 & 2,054 & 2,966 & 2,872 & $-0,26$ & $-0,14$ & $-2,02$ & 1,62 & $-2,02$ & 44,1 & 134,1 \\
\hline 3 & 2,8 & 2,848 & 2,561 & 2,833 & 2,821 & 2,489 & 0,66 & $-0,54$ & $-1,44$ & 1,68 & $-1,56$ & $-34,1$ & 55,9 \\
\hline 4 & 2,436 & 2,617 & 2,437 & 2,438 & 2,609 & 2,435 & 0,04 & $-0,16$ & $-0,04$ & 0,04 & $-0,16$ & 5,7 & 95,7 \\
\hline 5 & 2,695 & 2,417 & 2,38 & 2,6845 & 2,435 & 2,386 & $-0,21$ & 0,36 & 0,12 & 0,36 & $-0,21$ & $-4,5$ & 85,5 \\
\hline 6 & 2,53 & 2,791 & 2,764 & 2,551 & 2,7825 & 2,734 & 0,42 & $-0,17$ & $-0,6$ & 0,91 & $-0,66$ & $-33,9$ & 56,1 \\
\hline 7 & 2,295 & 2,7 & 2,332 & 2,302 & 2,739 & 2,3015 & 0,14 & 0,78 & $-0,61$ & - & $-0,61$ & - & - \\
\hline 8 & 3,025 & 2,451 & 2,591 & 3,023 & 2,438 & 2,608 & $-0,04$ & $-0,26$ & 0,34 & 0,35 & $-0,65$ & 38,7 & 128,7 \\
\hline 9 & 2,637 & 2,489 & 2,691 & 2,6395 & 2,514 & 2,687 & 0,05 & 0,5 & $-0,08$ & 0,70 & $-0,15$ & 28,8 & 118,8 \\
\hline 10 & 2,333 & 2,436 & 2,724 & 2,3765 & 2,43 & 2,6175 & 0,87 & $-0,12$ & $-2,13$ & 2,93 & $-2,18$ & $-39,4$ & 50,6 \\
\hline 11 & 2,585 & 2,564 & 2,566 & 2,88 & 2,542 & 2,557 & 5,9 & $-0,44$ & $-0,18$ & - & $-0,18$ & - & - \\
\hline 12 & 2,579 & 2,791 & 2,268 & 2,6225 & 2,8 & 2,236 & 0,87 & 0,18 & $-0,64$ & 1,74 & $-0,69$ & $-36,8$ & 53,2 \\
\hline 13 & 2,686 & 2,501 & 2,3845 & 3,0105 & 2,519 & 2,389 & 6,49 & 0,36 & 0,09 & - & - & - & - \\
\hline 14 & 2,448 & 2,252 & 2,528 & 2,4695 & 2,2455 & 2,5175 & 0,43 & $-0,13$ & $-0,21$ & 0,61 & $-0,31$ & $-26,1$ & 63,9 \\
\hline 15 & 2,93 & 2,3485 & 2,332 & 2,934 & 2,379 & 2,3465 & 0,08 & 0,61 & 0,29 & 0,62 & 0,07 & 5,9 & 95,9 \\
\hline 16 & 2,46 & 2,364 & 2,384 & 2,491 & 2,3585 & 2,3755 & 0,62 & $-0,11$ & $-0,17$ & 0,82 & $-0,31$ & $-24,7$ & 65,3 \\
\hline 17 & 2,4065 & 2,13 & 2,679 & 2,437 & 2,144 & 2,668 & 0,61 & 0,28 & $-0,22$ & 1,13 & $-0,24$ & $-38,0$ & 52,0 \\
\hline
\end{tabular}

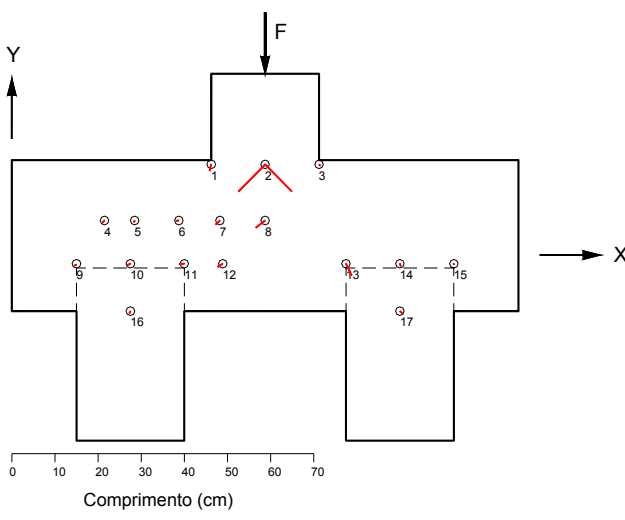

$\mathrm{F}=170 \mathrm{kN}$

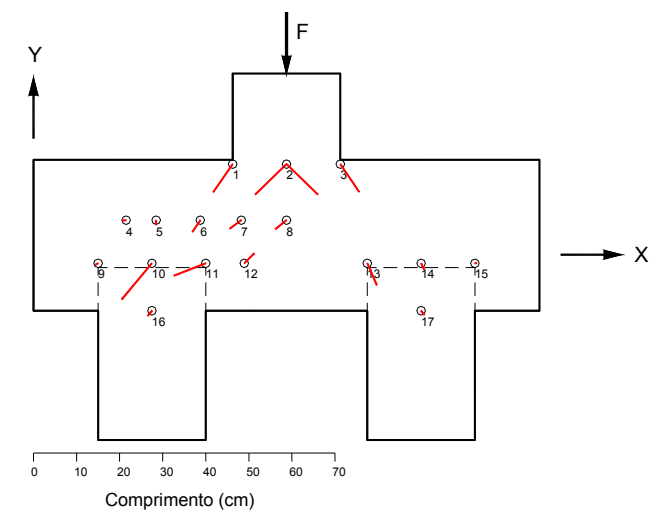

$\mathrm{F}=1100 \mathrm{kN}$

Figura 5.43 - Intensidades das deformações principais, modelo B35P25E25e0A $\mathrm{sw}_{\mathrm{s}, \mathrm{C}}$. 
Tabela 5.5 - Modelo B35P25E25e0A $\mathrm{sw}, 0$.

\begin{tabular}{|c|c|c|c|c|c|c|c|c|c|c|c|c|c|}
\hline \multicolumn{14}{|c|}{$\mathrm{F}=170 \mathrm{kN}-$ antes da primeira fissura } \\
\hline \multirow{2}{*}{ Pto. } & \multicolumn{3}{|c|}{ Leitura incial $-\ell_{0}$} & \multicolumn{3}{|c|}{ Leitura final $-\ell$} & \multicolumn{3}{|c|}{ Deformações (\%o) } & \multicolumn{2}{|c|}{ Def. Prin. (\%o) } & \multicolumn{2}{|c|}{ Dir. Prin. $\left(^{\circ}\right)$} \\
\hline & $0^{\circ}$ & $90^{\circ}$ & $45^{\circ}$ & $0^{\circ}$ & $90^{\circ}$ & $45^{\circ}$ & $\varepsilon_{0^{\circ}}$ & $\varepsilon_{90^{\circ}}$ & $\varepsilon_{45^{\circ}}$ & $\varepsilon_{1}$ & $\varepsilon_{2}$ & $\alpha_{1}$ & $\alpha_{2}$ \\
\hline 1 & 2,524 & 2,165 & 2,704 & 2,519 & 2,151 & 2,6875 & $-0,1$ & $-0,28$ & $-0,33$ & $-0,02$ & $-0,36$ & $-28,6$ & 61,4 \\
\hline 2 & 2,5585 & 3,058 & 2,4605 & 2,546 & 3,0545 & 2,4545 & $-0,25$ & $-0,07$ & $-0,12$ & $-0,06$ & $-0,26$ & $-12,0$ & 78,0 \\
\hline 3 & 2,3545 & 2,726 & 2,5175 & 2,342 & 2,72 & 2,499 & $-0,25$ & $-0,12$ & $-0,37$ & 0,01 & $-0,38$ & 35,3 & 125,3 \\
\hline 4 & 2,409 & 2,765 & 3,042 & 2,408 & 2,7615 & 3,0365 & $-0,02$ & $-0,07$ & $-0,11$ & 0,02 & $-0,11$ & $-34,5$ & 55,5 \\
\hline 5 & 2,4645 & 2,6015 & 2,924 & 2,462 & 2,596 & 2,9185 & $-0,05$ & $-0,11$ & $-0,11$ & $-0,04$ & $-0,12$ & $-22,5$ & 67,5 \\
\hline 6 & 2,627 & 2,645 & 2,787 & 2,624 & 2,6345 & 2,778 & $-0,06$ & $-0,21$ & $-0,18$ & $-0,05$ & $-0,22$ & $-15,5$ & 74,5 \\
\hline 7 & 2,476 & 2,9115 & 2,7635 & 2,516 & 2,9015 & 2,7695 & 0,8 & $-0,2$ & 0,12 & 0,83 & $-0,23$ & $-9,9$ & 80,1 \\
\hline 8 & 2,295 & 2,627 & 2,5355 & 2,294 & 2,627 & 2,532 & $-0,02$ & 0 & $-0,07$ & 0,05 & $-0,07$ & 40,3 & 130,3 \\
\hline 9 & 2,532 & 2,3975 & 2,536 & 2,532 & 2,3955 & 2,536 & 0 & $-0,04$ & 0 & 0,01 & $-0,05$ & 22,5 & 112,5 \\
\hline 10 & 2,5225 & 2,472 & 2,608 & 2,5215 & 2,4725 & 2,606 & $-0,02$ & 0,01 & $-0,04$ & 0,03 & $-0,04$ & 33,4 & 123,4 \\
\hline 11 & 2,5925 & 2,43 & 2,3825 & 2,6765 & 2,4475 & 2,387 & 1,68 & 0,35 & 0,09 & 2,15 & $-0,12$ & $-27,1$ & 62,9 \\
\hline 12 & 2,816 & 2,374 & 2,695 & 2,818 & 2,373 & 2,695 & 0,04 & $-0,02$ & 0 & 0,04 & $-0,02$ & $-9,2$ & 80,8 \\
\hline 13 & 2,374 & 2,189 & 2,596 & 2,469 & 2,188 & 2,6 & 1,9 & $-0,02$ & 0,08 & 2,23 & $-0,35$ & $-20,9$ & 69,1 \\
\hline 14 & 2,5525 & 2,425 & 2,2185 & 2,5615 & 2,427 & 2,219 & 0,18 & 0,04 & 0,01 & 0,23 & $-0,01$ & $-27,5$ & 62,5 \\
\hline 15 & 2,472 & 2,32 & 2,511 & 2,4715 & 2,3255 & 2,515 & $-0,01$ & 0,11 & 0,08 & 0,12 & $-0,02$ & $-13,3$ & 76,7 \\
\hline 16 & 2,855 & 2,198 & 2,587 & 2,8555 & 2,1945 & 2,58 & 0,01 & $-0,07$ & $-0,14$ & 0,09 & $-0,15$ & $-35,0$ & 55,0 \\
\hline 17 & 2,5405 & 2,462 & 2,1175 & 2,541 & 2,459 & 2,107 & 0,01 & $-0,06$ & $-0,21$ & 0,16 & $-0,21$ & $-39,6$ & 50,4 \\
\hline \multicolumn{14}{|c|}{$F=1020 \mathrm{kN}$} \\
\hline \multirow{2}{*}{ Pto. } & \multicolumn{3}{|c|}{ Leitura incial $-\ell_{0}$} & \multicolumn{3}{|c|}{ Leitura final $-\ell$} & \multicolumn{3}{|c|}{ Deformações (\%) } & \multicolumn{2}{|c|}{ Def. Prin. (\%o) } & \multicolumn{2}{|c|}{ Dir. Prin. $\left({ }^{\circ}\right)$} \\
\hline & $0^{\circ}$ & $90^{\circ}$ & $45^{\circ}$ & $0^{\circ}$ & $90^{\circ}$ & $45^{\circ}$ & $\varepsilon_{0^{\circ}}$ & $\varepsilon 90^{\circ}$ & $\varepsilon_{45^{\circ}}$ & $\varepsilon_{1}$ & $\varepsilon_{2}$ & $\alpha_{1}$ & $\alpha_{2}$ \\
\hline 1 & 2,524 & 2,165 & 2,704 & 2,6465 & 2,1245 & 2,5545 & 2,45 & $-0,81$ & $-2,99$ & - & $-2,99$ & - & - \\
\hline 2 & 2,5585 & 3,058 & 2,4605 & 2,535 & 3,0405 & 2,381 & $-0,47$ & $-0,35$ & $-1,59$ & 0,77 & $-1,59$ & 43,5 & 133,5 \\
\hline 3 & 2,3545 & 2,726 & 2,5175 & 2,4775 & 2,693 & 2,501 & 2,46 & $-0,66$ & $-0,33$ & - & $-0,33$ & - & - \\
\hline 4 & 2,409 & 2,765 & 3,042 & 2,459 & 2,7635 & 3,032 & 1 & $-0,03$ & $-0,2$ & 1,34 & $-0,37$ & $-26,5$ & 63,5 \\
\hline 5 & 2,4645 & 2,6015 & 2,924 & 2,5875 & 2,9015 & 2,905 & 2,46 & 6 & $-0,38$ & 9,17 & $-0,71$ & 34,5 & 124,5 \\
\hline 6 & 2,627 & 2,645 & 2,787 & 2,645 & 2,692 & 2,652 & 0,36 & 0,94 & $-2,7$ & - & $-2,7$ & - & - \\
\hline 7 & 2,476 & 2,9115 & 2,7635 & 2,7765 & 2,844 & 2,726 & 6,01 & $-1,35$ & $-0,75$ & - & $-0,75$ & - & - \\
\hline 8 & 2,295 & 2,627 & 2,5355 & 2,624 & 2,519 & 2,534 & 6,58 & $-2,16$ & $-0,03$ & 7,12 & $-2,70$ & $-13,6$ & 76,4 \\
\hline 9 & 2,532 & 2,3975 & 2,536 & 2,556 & 2,397 & 2,508 & 0,48 & $-0,01$ & $-0,56$ & 1,07 & $-0,60$ & $-36,4$ & 53,6 \\
\hline 10 & 2,5225 & 2,472 & 2,608 & 2,4775 & 2,393 & 2,6 & $-0,9$ & $-1,58$ & $-0,16$ & $-0,11$ & $-2,37$ & 36,3 & 126,3 \\
\hline 11 & 2,5925 & 2,43 & 2,3825 & 2,82 & 2,44 & 2,281 & 4,55 & 0,2 & $-2,03$ & - & $-2,03$ & - & - \\
\hline 12 & 2,816 & 2,374 & 2,695 & 2,801 & 2,708 & 2,724 & $-0,3$ & 6,68 & 0,58 & 7,55 & $-1,17$ & 18,4 & 108,4 \\
\hline 13 & 2,374 & 2,189 & 2,596 & 2,578 & 2,55 & 2,5485 & 4,08 & 7,22 & $-0,95$ & - & $-0,95$ & - & - \\
\hline 14 & 2,5525 & 2,425 & 2,2185 & 2,536 & 2,3905 & 2,21 & $-0,33$ & $-0,69$ & $-0,17$ & $-0,13$ & $-0,89$ & 31,1 & 121,1 \\
\hline 15 & 2,472 & 2,32 & 2,511 & 2,524 & 2,31 & 2,501 & 1,04 & $-0,2$ & $-0,2$ & 1,30 & $-0,46$ & $-22,5$ & 67,5 \\
\hline 16 & 2,855 & 2,198 & 2,587 & 2,858 & 2,184 & 2,569 & 0,06 & $-0,28$ & $-0,36$ & 0,19 & $-0,41$ & $-27,9$ & 62,1 \\
\hline 17 & 2,5405 & 2,462 & 2,1175 & 2,5385 & 2,452 & 2,199 & $-0,04$ & $-0,2$ & 1,63 & 1,63 & $-1,87$ & 43,7 & 133,7 \\
\hline
\end{tabular}
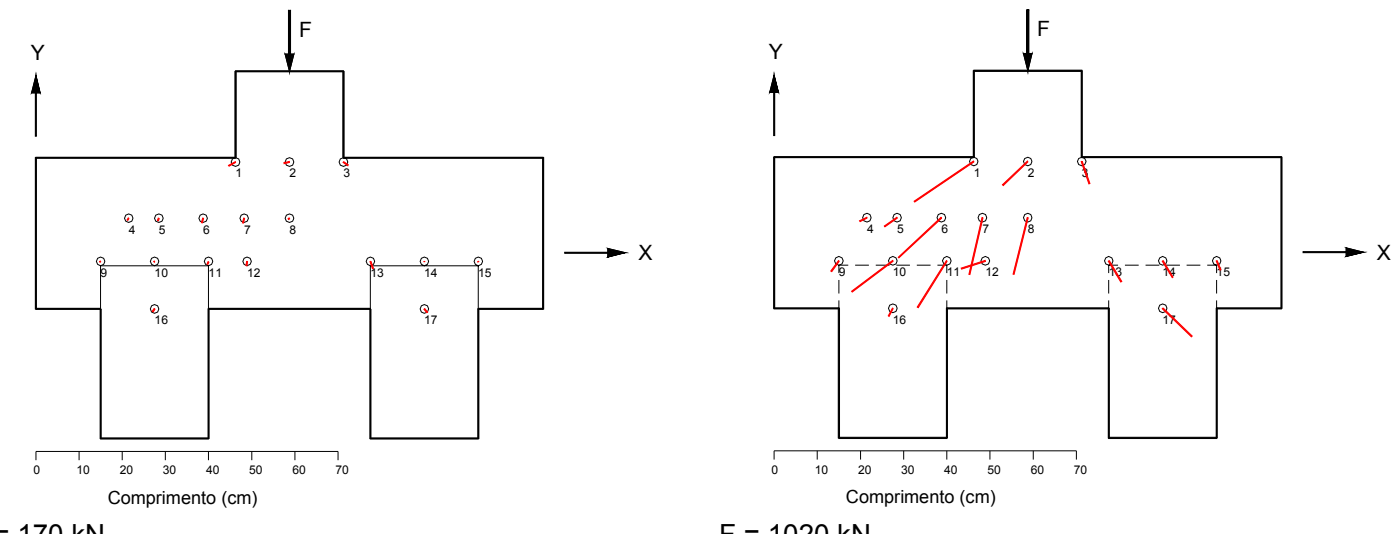

$\mathrm{F}=170 \mathrm{kN}$

$\mathrm{F}=1020 \mathrm{kN}$

Figura 5.44 - Intensidades das deformações principais, modelo B35P25E25e0A $\mathrm{sw}_{\mathrm{sw}, 0}$. 
Tabela 5.6 - Modelo B35P25E25e0CG.

\begin{tabular}{|c|c|c|c|c|c|c|c|c|c|c|c|c|c|}
\hline \multicolumn{14}{|c|}{$\mathrm{F}=200 \mathrm{kN}-$ antes da primeira fissura } \\
\hline \multirow{2}{*}{ Pto. } & \multicolumn{3}{|c|}{ Leitura incial $-\ell_{0}$} & \multicolumn{3}{|c|}{ Leitura final $-\ell$} & \multicolumn{3}{|c|}{ Deformações (\%o) } & \multicolumn{2}{|c|}{ Def. Prin. (\%o) } & \multicolumn{2}{|c|}{ Dir. Prin. $\left({ }^{\circ}\right)$} \\
\hline & $0^{\circ}$ & $90^{\circ}$ & $45^{\circ}$ & $0^{\circ}$ & $90^{\circ}$ & $45^{\circ}$ & $\varepsilon_{0^{\circ}}$ & $\varepsilon 90^{\circ}$ & $\varepsilon_{45^{\circ}}$ & $\varepsilon_{1}$ & $\varepsilon_{2}$ & $\alpha_{1}$ & $\alpha_{2}$ \\
\hline 1 & 2,1795 & 2,7035 & 2,389 & 2,174 & 2,7 & 2,38 & $-0,11$ & $-0,07$ & $-0,18$ & 0,00 & $-0,18$ & 38,7 & 128,7 \\
\hline 2 & 2,699 & 2,705 & 2,9645 & 2,694 & 2,705 & 2,961 & $-0,1$ & 0 & $-0,07$ & 0,00 & $-0,10$ & 10,9 & 100,9 \\
\hline 3 & 2,727 & 2,8595 & 2,547 & 2,7235 & 2,852 & 2,5345 & $-0,07$ & $-0,15$ & $-0,25$ & 0,04 & $-0,26$ & $-37,0$ & 53,0 \\
\hline 4 & 2,5145 & 2,53 & 2,8165 & 2,52 & 2,531 & 2,8155 & 0,11 & 0,02 & $-0,02$ & 0,16 & $-0,03$ & $-31,1$ & 58,9 \\
\hline 5 & 2,309 & 2,0215 & 2,5315 & 2,301 & 2,021 & 2,53 & $-0,16$ & $-0,01$ & $-0,03$ & 0,01 & $-0,18$ & $-18,1$ & 71,9 \\
\hline 6 & 2,421 & 2,562 & 2,667 & 2,4195 & 2,556 & 2,655 & $-0,03$ & $-0,12$ & $-0,24$ & 0,10 & $-0,25$ & $-37,4$ & 52,6 \\
\hline 7 & 2,353 & 2,409 & 2,1745 & 2,356 & 2,4065 & 2,0725 & 0,06 & $-0,05$ & $-2,04$ & 2,05 & $-2,04$ & $-44,2$ & 45,8 \\
\hline 8 & 2,35 & 2,5125 & 2,293 & 2,351 & 2,509 & 2,294 & 0,02 & $-0,07$ & 0,02 & 0,04 & $-0,09$ & 22,5 & 112,5 \\
\hline 9 & 2,4765 & 2,275 & 2,762 & 2,481 & 2,282 & 2,762 & 0,09 & 0,14 & 0 & 0,23 & 0,00 & 38,9 & 128,9 \\
\hline 10 & 2,375 & 2,238 & 2,581 & 2,3755 & 2,2405 & 2,5795 & 0,01 & 0,05 & $-0,03$ & 0,09 & $-0,03$ & 35,8 & 125,8 \\
\hline 11 & 2,341 & 2,3185 & 2,6505 & 2,374 & 2,322 & 2,651 & 0,66 & 0,07 & 0,01 & 0,83 & $-0,10$ & $-25,1$ & 64,9 \\
\hline 12 & 2,709 & 2,412 & 2,6375 & 2,711 & 2,4115 & 2,639 & 0,04 & $-0,01$ & 0,03 & 0,04 & $-0,01$ & 15,5 & 105,5 \\
\hline 13 & 2,491 & 2,8565 & 2,583 & 2,531 & 2,856 & 2,589 & 0,8 & $-0,01$ & 0,12 & 0,88 & $-0,09$ & $-17,1$ & 72,9 \\
\hline 14 & 2,726 & 2,598 & 2,597 & 2,725 & 2,598 & 2,597 & $-0,02$ & 0 & 0 & 0,00 & $-0,02$ & $-22,5$ & 67,5 \\
\hline 15 & 2,6445 & 2,506 & 3,0125 & 2,644 & 2,505 & 3,013 & $-0,01$ & $-0,02$ & 0,01 & 0,01 & $-0,04$ & 39,3 & 129,3 \\
\hline 16 & 2,319 & 2,354 & 2,4815 & 2,358 & 2,361 & 2,4935 & 0,78 & 0,14 & 0,24 & 0,85 & 0,07 & $-17,3$ & 72,7 \\
\hline 17 & 2,704 & 2,3475 & 2,495 & 2,7075 & 2,35 & 2,496 & 0,07 & 0,05 & 0,02 & 0,10 & 0,02 & $-38,0$ & 52,0 \\
\hline \multicolumn{14}{|c|}{$F=950 \mathrm{kN}$} \\
\hline \multirow{2}{*}{ Pto. } & \multicolumn{3}{|c|}{ Leitura incial $-\ell_{0}$} & \multicolumn{3}{|c|}{ Leitura final $-\ell$} & \multicolumn{3}{|c|}{ Deformações (\%o) } & \multicolumn{2}{|c|}{ Def. Prin. (\%o) } & \multicolumn{2}{|c|}{ Dir. Prin. $\left({ }^{\circ}\right)$} \\
\hline & $0^{\circ}$ & $90^{\circ}$ & $45^{\circ}$ & $0^{\circ}$ & $90^{\circ}$ & $45^{\circ}$ & $\varepsilon_{0^{\circ}}$ & $\varepsilon_{90^{\circ}}$ & $\varepsilon_{45^{\circ}}$ & $\varepsilon_{1}$ & $\varepsilon_{2}$ & $\alpha_{1}$ & $\alpha_{2}$ \\
\hline 1 & 2,1795 & 2,7035 & 2,389 & 2,1635 & 2,6675 & 2,3395 & $-0,32$ & $-0,72$ & $-0,99$ & $-0,01$ & $-1,03$ & $-33,5$ & 56,5 \\
\hline 2 & 2,699 & 2,705 & 2,9645 & 2,686 & 2,693 & 2,9585 & $\begin{array}{l}-0,26 \\
\end{array}$ & $-0,24$ & $-0,12$ & $-0,12$ & $-0,38$ & $-42,8$ & 47,2 \\
\hline 3 & 2,727 & 2,8595 & 2,547 & 2,886 & 2,954 & 2,514 & 3,18 & 1,89 & $-0,66$ & - & $-0,66$ & - & - \\
\hline 4 & 2,5145 & 2,53 & 2,8165 & 2,52 & 2,5295 & 2,8125 & 0,11 & $-0,01$ & $-0,08$ & 0,19 & $-0,09$ & $-32,6$ & 57,4 \\
\hline 5 & 2,309 & 2,0215 & 2,5315 & 2,304 & 2,017 & 2,524 & $-0,1$ & $-0,09$ & $-0,15$ & $-0,04$ & $-0,15$ & 42,4 & 132,4 \\
\hline 6 & 2,421 & 2,562 & 2,667 & 2,416 & 2,543 & 2,6325 & $-0,1$ & $-0,38$ & $-0,69$ & 0,23 & $-0,71$ & $-36,4$ & 53,6 \\
\hline 7 & 2,353 & 2,409 & 2,1745 & 2,432 & 2,4725 & 2,06 & 1,58 & 1,27 & $-2,29$ & - & $-2,29$ & - & - \\
\hline 8 & 2,35 & 2,5125 & 2,293 & 2,3505 & 2,509 & 2,2885 & 0,01 & $-0,07$ & $-0,09$ & 0,04 & $-0,10$ & $-28,2$ & 61,8 \\
\hline 9 & 2,4765 & 2,275 & 2,762 & 2,478 & 2,278 & 2,7625 & 0,03 & 0,06 & 0,01 & 0,08 & 0,01 & 33,4 & 123,4 \\
\hline 10 & 2,375 & 2,238 & 2,581 & 2,368 & 2,237 & 2,575 & $-0,14$ & $-0,02$ & $-0,12$ & $-0,01$ & $-0,15$ & 16,8 & 106,8 \\
\hline 11 & 2,341 & 2,3185 & 2,6505 & 2,6745 & 2,3125 & 2,644 & 6,67 & $-0,12$ & $-0,13$ & - & $-0,13$ & - & - \\
\hline 12 & 2,709 & 2,412 & 2,6375 & 2,7135 & 2,4285 & 2,651 & 0,09 & 0,33 & 0,27 & 0,34 & 0,08 & $-13,3$ & 76,7 \\
\hline 13 & 2,491 & 2,8565 & 2,583 & 2,896 & 3,044 & 2,5645 & 8,1 & 3,75 & $-0,37$ & - & $-0,37$ & - & - \\
\hline 14 & 2,726 & 2,598 & 2,597 & 2,712 & 2,595 & 2,5765 & $-0,28$ & $-0,06$ & $-0,41$ & 0,09 & $-0,43$ & 32,7 & 122,7 \\
\hline 15 & 2,6445 & 2,506 & 3,0125 & 2,646 & 2,504 & 3,017 & 0,03 & $-0,04$ & 0,09 & 0,10 & $-0,11$ & 34,9 & 124,9 \\
\hline 16 & 2,319 & 2,354 & 2,4815 & 2,365 & 2,357 & 2,489 & 0,92 & 0,06 & 0,15 & 1,04 & $-0,06$ & $-19,2$ & 70,8 \\
\hline 17 & 2,704 & 2,3475 & 2,495 & 2,708 & 2,337 & 2,486 & 0,08 & $-0,21$ & $-0,18$ & 0,12 & $-0,25$ & $-19,2$ & 70,8 \\
\hline
\end{tabular}

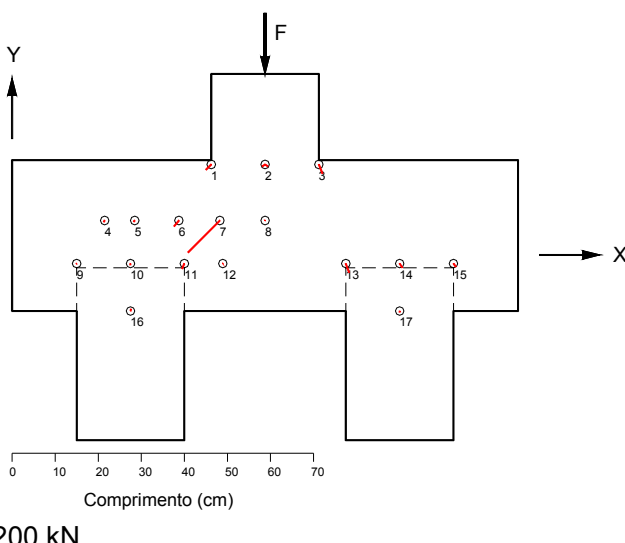

$\mathrm{F}=200 \mathrm{kN}$

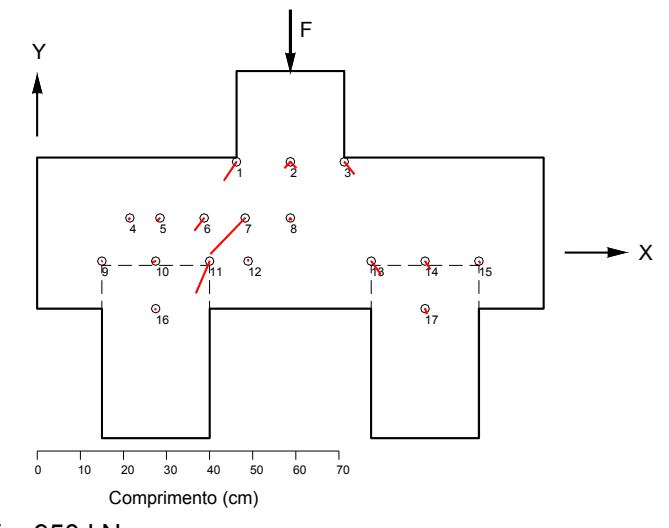

$\mathrm{F}=950 \mathrm{kN}$

Figura 5.45 - Intensidades das deformações principais, modelo B35P25E25e0CG. 
Tabela 5.7 - Modelo B45P25E25e0.

\begin{tabular}{|c|c|c|c|c|c|c|c|c|c|c|c|c|c|}
\hline \multicolumn{14}{|c|}{$\mathrm{F}=200 \mathrm{kN}-$ antes da primeira fissura } \\
\hline \multirow{2}{*}{ Pto. } & \multicolumn{3}{|c|}{ Leitura incial $-\ell_{0}$} & \multicolumn{3}{|c|}{ Leitura final $-\ell$} & \multicolumn{3}{|c|}{ Deformações (\%o) } & \multicolumn{2}{|c|}{ Def. Prin. (\%o) } & \multicolumn{2}{|c|}{ Dir. Prin. $\left({ }^{\circ}\right)$} \\
\hline & $0^{\circ}$ & $90^{\circ}$ & $45^{\circ}$ & $0^{\circ}$ & $90^{\circ}$ & $45^{\circ}$ & $\varepsilon_{0^{\circ}}$ & $\varepsilon_{90^{\circ}}$ & $\varepsilon_{45^{\circ}}$ & $\varepsilon_{1}$ & $\varepsilon_{2}$ & $\alpha_{1}$ & $\alpha_{2}$ \\
\hline 1 & 2,379 & 2,445 & 2,4765 & 2,374 & 2,4445 & 2,472 & $-0,1$ & $-0,01$ & $-0,09$ & 0,00 & $-0,11$ & 18,9 & 108,9 \\
\hline 2 & 2,351 & 2,57 & 2,487 & 2,342 & 2,567 & 2,4865 & $-0,18$ & $-0,06$ & $-0,01$ & 0,01 & $-0,25$ & $-30,7$ & 59,3 \\
\hline 3 & 2,313 & 2,3985 & 2,4105 & 2,307 & 2,395 & 2,408 & $-0,12$ & $-0,07$ & $-0,05$ & $-0,04$ & $-0,15$ & $-30,5$ & 59,5 \\
\hline 4 & 2,266 & 2,417 & 2,358 & 2,268 & 2,414 & 2,355 & 0,04 & $-0,06$ & $-0,06$ & 0,06 & $-0,08$ & $-22,5$ & 67,5 \\
\hline 5 & 2,616 & 2,484 & 2,698 & 2,61 & 2,483 & 2,6895 & $-0,12$ & $-0,02$ & $-0,17$ & 0,04 & $-0,18$ & 31,7 & 121,7 \\
\hline 6 & 2,288 & 2,5925 & 2,8 & 2,288 & 2,58 & 2,791 & 0 & $-0,25$ & $-0,18$ & 0,01 & $-0,26$ & $-11,9$ & 78,1 \\
\hline 7 & 2,443 & 2,4445 & 2,45 & 2,444 & 2,44 & 2,446 & 0,02 & $-0,09$ & $-0,08$ & 0,04 & $-0,11$ & $-19,6$ & 70,4 \\
\hline 8 & 2,288 & 2,6975 & 2,5985 & 2,291 & 2,691 & 2,696 & 0,06 & $-0,13$ & 1,95 & 1,95 & $-2,02$ & 43,6 & 133,6 \\
\hline 9 & 2,464 & 2,198 & 2,654 & 2,462 & 2,197 & 2,6535 & $-0,04$ & $-0,02$ & $-0,01$ & $-0,01$ & $-0,05$ & $-31,7$ & 58,3 \\
\hline 10 & 2,962 & 2,156 & 2,6085 & 2,965 & 2,155 & 2,6075 & 0,06 & $-0,02$ & $-0,02$ & 0,08 & $-0,04$ & $-22,5$ & 67,5 \\
\hline 11 & 2,824 & 2,6225 & 2,723 & 2,9595 & 2,622 & 2,7335 & 2,71 & $-0,01$ & 0,21 & 3,12 & $-0,42$ & $-20,0$ & 70,0 \\
\hline 12 & 2,46 & 2,365 & 2,958 & 2,457 & 2,368 & 2,955 & $-0,06$ & 0,06 & $-0,06$ & 0,08 & $-0,08$ & 22,5 & 112,5 \\
\hline 13 & 2,505 & 2,407 & 2,681 & 2,512 & 2,406 & 2,681 & 0,14 & $-0,02$ & 0 & 0,16 & $-0,04$ & $-18,4$ & 71,6 \\
\hline 14 & 2,522 & 2,226 & 2,279 & 2,5225 & 2,2255 & 2,2775 & 0,01 & $-0,01$ & $-0,03$ & 0,03 & $-0,03$ & $-35,8$ & 54,2 \\
\hline 15 & 2,622 & 2,378 & 2,312 & 2,624 & 2,378 & 2,3085 & 0,04 & 0 & $-0,07$ & 0,11 & $-0,07$ & $-38,7$ & 51,3 \\
\hline 16 & 2,68 & 2,3645 & 2,466 & 2,685 & 2,362 & 2,464 & 0,1 & $-0,05$ & $-0,04$ & 0,12 & $-0,07$ & $-20,5$ & 69,5 \\
\hline 17 & 2,545 & 2,274 & 2,6655 & 2,546 & 2,253 & 2,668 & 0,02 & $-0,42$ & 0,05 & 0,13 & $-0,53$ & 24,3 & 114,3 \\
\hline \multicolumn{14}{|c|}{$F=1700 \mathrm{kN}$} \\
\hline \multirow{2}{*}{ Pto. } & \multicolumn{3}{|c|}{ Leitura incial $-\ell_{0}$} & \multicolumn{3}{|c|}{ Leitura final $-\ell$} & \multicolumn{3}{|c|}{ Deformações (\%o) } & \multicolumn{2}{|c|}{ Def. Prin. (\%o) } & \multicolumn{2}{|c|}{ Dir. Prin. $\left({ }^{\circ}\right)$} \\
\hline & $0^{\circ}$ & $90^{\circ}$ & $45^{\circ}$ & $0^{\circ}$ & $90^{\circ}$ & $45^{\circ}$ & $\varepsilon_{0^{\circ}}^{\circ}$ & $\varepsilon_{90^{\circ}}$ & $\varepsilon_{45^{\circ}}$ & $\varepsilon_{1}$ & $\varepsilon_{2}$ & $\alpha_{1}$ & $\alpha_{2}$ \\
\hline 1 & 2,379 & 2,445 & 2,4765 & 2,525 & 2,476 & 2,336 & 2,92 & 0,62 & $-2,81$ & - & $-2,81$ & - & - \\
\hline 2 & 2,351 & 2,57 & 2,487 & 2,33 & 2,5585 & 2,4615 & $-0,42$ & $-0,23$ & $-0,51$ & $-0,12$ & $-0,53$ & 31,4 & 121,4 \\
\hline 3 & 2,313 & 2,3985 & 2,4105 & 2,297 & 2,3835 & 2,356 & $-0,32$ & $-0,3$ & $-1,09$ & 0,47 & $-1,09$ & 44,6 & 134,6 \\
\hline 4 & 2,266 & 2,417 & 2,358 & 2,259 & 2,409 & 2,341 & $-0,14$ & $-0,16$ & $-0,34$ & 0,04 & $-0,34$ & $-43,5$ & 46,5 \\
\hline 5 & 2,616 & 2,484 & 2,698 & 2,5865 & 2,472 & 2,657 & $-0,59$ & $-0,24$ & $-0,82$ & 0,03 & $-0,86$ & 33,3 & 123,3 \\
\hline 6 & 2,288 & 2,5925 & 2,8 & 2,285 & 2,742 & 2,706 & $-0,06$ & 2,99 & $-1,88$ & - & $-1,88$ & - & - \\
\hline 7 & 2,443 & 2,4445 & 2,45 & 2,38 & 2,522 & 2,3805 & $-1,26$ & 1,55 & $-1,39$ & 2,23 & $-1,94$ & 23,8 & 113,8 \\
\hline 8 & 2,288 & 2,6975 & 2,5985 & 2,271 & 2,678 & 2,583 & $-0,34$ & $-0,39$ & $-0,31$ & $-0,30$ & $-0,43$ & 32,8 & 122,8 \\
\hline 9 & 2,464 & 2,198 & 2,654 & 2,463 & 2,1885 & 2,642 & $-0,02$ & $-0,19$ & $-0,24$ & 0,05 & $-0,26$ & $-28,9$ & 61,1 \\
\hline 10 & 2,962 & 2,156 & 2,6085 & 2,966 & 2,1565 & 2,5805 & 0,08 & 0,01 & $-0,56$ & 0,65 & $-0,56$ & $-43,3$ & 46,7 \\
\hline 11 & 2,824 & 2,6225 & 2,723 & 3,3225 & 2,607 & 2,678 & 9,97 & $-0,31$ & $-0,9$ & - & $-0,9$ & - & - \\
\hline 12 & 2,46 & 2,365 & 2,958 & 2,458 & 2,459 & 2,992 & $-0,04$ & 1,88 & 0,68 & 1,91 & $-0,07$ & 7,0 & 97,0 \\
\hline 13 & 2,505 & 2,407 & 2,681 & 2,726 & 2,391 & 2,732 & 4,42 & $-0,32$ & 1,02 & - & - & - & - \\
\hline 14 & 2,522 & 2,226 & 2,279 & 2,5135 & 2,228 & 2,279 & $-0,17$ & 0,04 & 0 & 0,06 & $-0,19$ & $-15,9$ & 74,1 \\
\hline 15 & 2,622 & 2,378 & 2,312 & 2,624 & 2,381 & 2,314 & 0,04 & 0,06 & 0,04 & 0,06 & 0,04 & 22,5 & 112,5 \\
\hline 16 & 2,68 & 2,3645 & 2,466 & 2,6865 & 2,337 & 2,4425 & 0,13 & $-0,55$ & $-0,47$ & 0,22 & $-0,64$ & $-18,7$ & 71,3 \\
\hline 17 & 2,545 & 2,274 & 2,6655 & 2,543 & 2,2485 & 2,657 & $-0,04$ & $-0,51$ & $-0,17$ & $-0,02$ & $-0,53$ & 12,0 & 102,0 \\
\hline
\end{tabular}

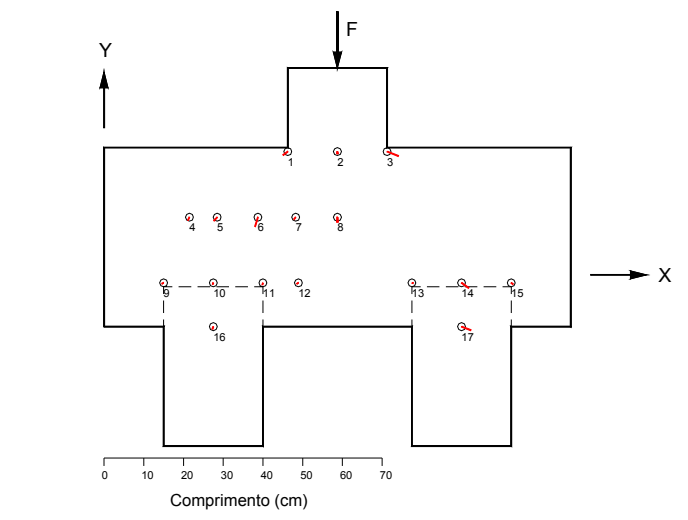

$\mathrm{F}=200 \mathrm{kN}$

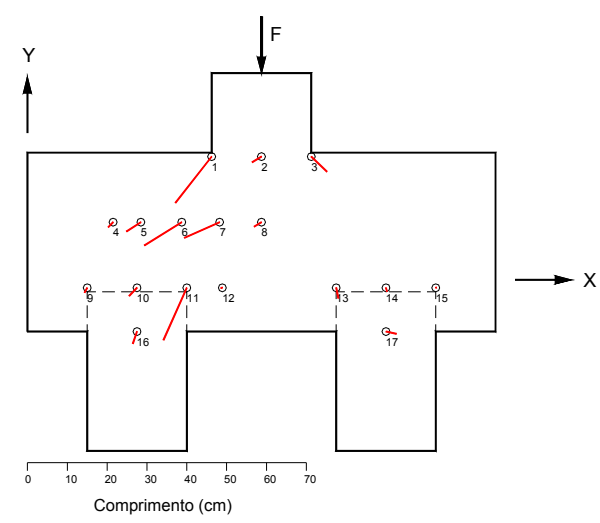

$\mathrm{F}=1700 \mathrm{kN}$

Figura 5.46 - Intensidades das deformações principais, modelo B45P25E25e0. 
Descrição e apresentação dos resultados experimentais

Tabela 5.8 - Modelo B45P25E25e5.

\begin{tabular}{|c|c|c|c|c|c|c|c|c|c|c|c|c|c|}
\hline \multicolumn{14}{|c|}{$F=400 \mathrm{kN}-$ antes da primeira fissura } \\
\hline \multirow{2}{*}{ Pto. } & \multicolumn{3}{|c|}{ Leitura incial $-\ell_{0}$} & \multicolumn{3}{|c|}{ Leitura final $-\ell$} & \multicolumn{3}{|c|}{ Deformações (\%o) } & \multicolumn{2}{|c|}{ Def. Prin. (\%o) } & \multicolumn{2}{|c|}{ Dir. Prin. $\left(^{\circ}\right)$} \\
\hline & $0^{\circ}$ & $90^{\circ}$ & $45^{\circ}$ & $0^{\circ}$ & $90^{\circ}$ & $45^{\circ}$ & $\varepsilon_{0^{\circ}}$ & $\varepsilon_{90^{\circ}}$ & $\varepsilon_{45^{\circ}}$ & $\varepsilon_{1}$ & $\varepsilon_{2}$ & $\alpha_{1}$ & $\alpha_{2}$ \\
\hline 1 & 2,741 & 2,6145 & 2,857 & 2,739 & 2,609 & 2,849 & $-0,04$ & $-0,11$ & $-0,16$ & 0,02 & $-0,17$ & $-33,8$ & 56,2 \\
\hline 2 & 2,36 & 2,434 & 2,678 & 2,3375 & 2,425 & 2,672 & $-0,45$ & $-0,18$ & $-0,12$ & $-0,08$ & $-0,55$ & $-27,7$ & 62,3 \\
\hline 3 & 2,529 & 2,5155 & 2,655 & 2,517 & 2,516 & 2,65 & $-0,24$ & 0,01 & $-0,1$ & 0,01 & $-0,24$ & $-3,4$ & 86,6 \\
\hline 4 & 2,372 & 2,36 & 2,923 & 2,371 & 2,357 & 2,921 & $-0,02$ & $-0,06$ & $-0,04$ & $-0,02$ & $-0,06$ & 0,0 & 90,0 \\
\hline 5 & 2,623 & 2,426 & 2,591 & 2,622 & 2,424 & 2,5855 & $-0,02$ & $\begin{array}{l}-0,04 \\
\end{array}$ & $-0,11$ & 0,05 & $-0,11$ & $-41,4$ & 48,6 \\
\hline 6 & 2,59 & 3,3115 & 2,701 & 2,586 & 3,306 & 2,699 & $\begin{array}{l}-0,08 \\
\end{array}$ & $-0,11$ & $\begin{array}{l}-0,04 \\
\end{array}$ & $-0,04$ & $-0,15$ & 37,4 & 127,4 \\
\hline 7 & 2,681 & 2,517 & 2,349 & 2,6715 & 2,526 & 2,351 & $-0,19$ & 0,18 & 0,04 & 0,19 & $-0,20$ & $-6,8$ & 83,2 \\
\hline 8 & 2,773 & 2,595 & 2,565 & 2,78 & 2,594 & 2,564 & 0,14 & $-0,02$ & $-0,02$ & 0,17 & $-0,05$ & $-22,5$ & 67,5 \\
\hline 9 & 2,455 & 2,6695 & 2,763 & 2,453 & 2,667 & 2,7605 & $-0,04$ & $-0,05$ & $-0,05$ & $-0,04$ & $-0,05$ & $-22,5$ & 67,5 \\
\hline 10 & 2,5095 & 2,481 & 2,584 & 2,5115 & 2,48 & 2,5825 & 0,04 & $-0,02$ & $-0,03$ & 0,06 & $-0,04$ & $\begin{array}{l}-26,6 \\
\end{array}$ & 63,4 \\
\hline 11 & 2,559 & 2,5575 & 2,631 & 2,5625 & 2,6575 & 2,6305 & 0,07 & 2 & $-0,01$ & 2,46 & $-0,39$ & 23,6 & 113,6 \\
\hline 12 & 2,51 & 2,618 & 2,624 & 2,513 & 2,618 & 2,625 & 0,06 & 0 & 0,02 & 0,06 & 0,00 & $-9,2$ & 80,8 \\
\hline 13 & 2,9125 & 2,4095 & 2,549 & 2,9265 & 2,409 & 2,554 & 0,28 & $-0,01$ & 0,1 & 0,28 & $-0,01$ & $-6,8$ & 83,2 \\
\hline 14 & 2,853 & 2,578 & 2,289 & 2,852 & 2,575 & 2,2855 & $-0,02$ & $-0,06$ & $-0,07$ & 0,00 & $-0,08$ & $-28,2$ & 61,8 \\
\hline 15 & 2,668 & 2,669 & 2,6145 & 2,6715 & 2,67 & 2,614 & 0,07 & 0,02 & $-0,01$ & 0,11 & $-0,02$ & $-32,8$ & 57,2 \\
\hline 16 & 2,604 & 2,857 & 2,4805 & 2,609 & 2,857 & 2,47 & 0,1 & 0 & $-0,21$ & 0,31 & $-0,21$ & $-39,6$ & 50,4 \\
\hline 17 & 2,491 & 2,9725 & 2,382 & 2,4935 & 2,972 & 2,381 & 0,05 & $-0,01$ & $-0,02$ & 0,07 & $-0,03$ & $\begin{array}{l}-26,6 \\
\end{array}$ & 63,4 \\
\hline 18 & 2,463 & 2,5705 & 2,6445 & 2,643 & 2,644 & 2,643 & 3,6 & 1,47 & $-0,03$ & 5,31 & $-0,24$ & $-33,7$ & 56,3 \\
\hline 19 & 2,567 & 2,5095 & 2,6775 & 2,571 & 2,5125 & 2,565 & 0,08 & 0,06 & $-2,25$ & 2,39 & $-2,25$ & $-44,9$ & 45,1 \\
\hline 20 & 2,3805 & 2,4765 & 2,5505 & 2,389 & 2,4795 & 2,547 & 0,17 & 0,06 & $-0,07$ & 0,31 & $-0,08$ & $-36,7$ & 53,3 \\
\hline \multicolumn{14}{|c|}{$F=1500 \mathrm{kN}$} \\
\hline \multirow{2}{*}{ Pto. } & \multicolumn{3}{|c|}{ Leitura incial $-\ell_{0}$} & \multicolumn{3}{|c|}{ Leitura final $-\ell$} & \multicolumn{3}{|c|}{ Deformações (\%o) } & \multicolumn{2}{|c|}{ Def. Prin. (\%o) } & \multicolumn{2}{|c|}{ Dir. Prin. $\left(^{\circ}\right)$} \\
\hline & $0^{\circ}$ & $90^{\circ}$ & $45^{\circ}$ & $0^{\circ}$ & $90^{\circ}$ & $45^{\circ}$ & $\varepsilon_{0^{\circ}}$ & $\varepsilon_{90^{\circ}}$ & $\varepsilon_{45^{\circ}}$ & $\varepsilon_{1}$ & $\varepsilon_{2}$ & $\alpha_{1}$ & $\alpha_{2}$ \\
\hline 1 & 2,741 & 2,6145 & 2,857 & 2,814 & 2,503 & 2,6435 & 1,46 & $-2,23$ & $-4,27$ & - & $-4,27$ & - & - \\
\hline 2 & 2,36 & 2,434 & 2,678 & 2,3165 & 2,396 & 2,6725 & $-0,87$ & $-0,76$ & $-0,11$ & $-0,11$ & $-1,52$ & $-42,8$ & 47,2 \\
\hline 3 & 2,529 & 2,5155 & 2,655 & 2,5115 & 2,4935 & 2,6255 & $-0,35$ & $-0,44$ & $-0,59$ & $-0,19$ & $-0,60$ & $-38,5$ & 51,5 \\
\hline 4 & 2,372 & 2,36 & 2,923 & 2,6595 & 2,3515 & 2,902 & 5,75 & $-0,17$ & $-0,42$ & - & $-0,42$ & - & - \\
\hline 5 & 2,623 & 2,426 & 2,591 & 2,616 & 2,723 & 2,5285 & $-0,14$ & 5,94 & $-1,25$ & - & $-1,25$ & - & - \\
\hline 6 & 2,59 & 3,3115 & 2,701 & 2,575 & 3,2825 & 2,697 & $-0,3$ & $-0,58$ & $-0,08$ & $-0,05$ & $-0,83$ & 34,4 & 124,4 \\
\hline 7 & 2,681 & 2,517 & 2,349 & 2,6365 & 2,511 & 2,498 & $-0,89$ & $-0,12$ & 2,98 & - & - & - & - \\
\hline 8 & 2,773 & 2,595 & 2,565 & 2,9345 & 2,5785 & 2,5325 & 3,23 & $-0,33$ & $-0,65$ & - & $-0,65$ & - & - \\
\hline 9 & 2,455 & 2,6695 & 2,763 & 2,463 & 2,641 & 2,7925 & 0,16 & $-0,57$ & 0,59 & 0,67 & $-1,08$ & 32,7 & 122,7 \\
\hline 10 & 2,5095 & 2,481 & 2,584 & 2,508 & 2,473 & 2,571 & $-0,03$ & $-0,16$ & $\begin{array}{l}-0,26 \\
\end{array}$ & 0,08 & $-0,27$ & $-34,2$ & 55,8 \\
\hline 11 & 2,559 & 2,5575 & 2,631 & 2,5525 & 2,56 & 2,622 & $-0,13$ & 0,05 & $-0,18$ & 0,13 & $-0,21$ & 28,6 & 118,6 \\
\hline 12 & 2,51 & 2,618 & 2,624 & 2,5285 & 2,722 & 2,6185 & 0,37 & 2,08 & $-0,11$ & - & $-0,11$ & - & - \\
\hline 13 & 2,9125 & 2,4095 & 2,549 & 3,2965 & 2,46 & 2,435 & 7,68 & 1,01 & $-2,28$ & - & $\begin{array}{l}-2,28 \\
\end{array}$ & - & - \\
\hline 14 & 2,853 & 2,578 & 2,289 & 2,847 & 2,61 & 2,297 & $-0,12$ & 0,64 & 0,16 & 0,65 & $-0,13$ & 7,4 & 97,4 \\
\hline 15 & 2,668 & 2,669 & 2,6145 & 2,673 & 3,0015 & 2,627 & 0,1 & 6,65 & 0,25 & - & - & - & - \\
\hline 16 & 2,604 & 2,857 & 2,4805 & 2,931 & 2,8535 & 2,459 & 6,54 & $-0,07$ & $-0,43$ & - & $-0,43$ & - & - \\
\hline 17 & 2,491 & 2,9725 & 2,382 & 2,4865 & 2,965 & 2,3715 & $-0,09$ & $-0,15$ & $-0,21$ & $-0,03$ & $-0,21$ & $-35,8$ & 54,2 \\
\hline 18 & 2,463 & 2,5705 & 2,6445 & 2,4935 & 2,571 & 2,646 & 0,61 & 0,01 & 0,03 & 0,72 & $-0,10$ & $-21,5$ & 68,5 \\
\hline 19 & 2,567 & 2,5095 & 2,6775 & 2,573 & 2,508 & 2,678 & 0,12 & $-0,03$ & 0,01 & 0,13 & $\begin{array}{l}-0,04 \\
\end{array}$ & $-12,5$ & 77,5 \\
\hline 20 & 2,3805 & 2,4765 & 2,5505 & 2,3935 & 2,459 & 2,536 & 0,26 & $-0,35$ & $-0,29$ & 0,35 & $-0,44$ & $-19,4$ & 70,6 \\
\hline
\end{tabular}
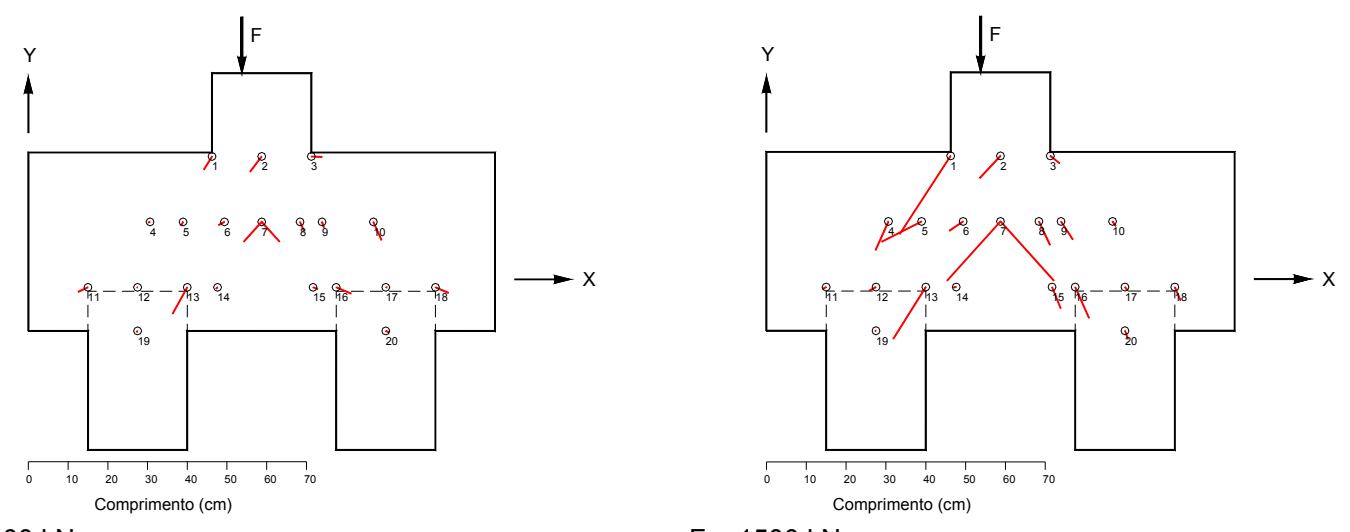

$\mathrm{F}=400 \mathrm{kN}$

$\mathrm{F}=1500 \mathrm{kN}$

Figura 5.47 - Intensidades das deformações principais, modelo B45P25E25e5. 
Tabela 5.9 - Modelo B45P25E25e0A $\mathrm{sw}_{\mathrm{s}, \mathrm{c}}$.

\begin{tabular}{|c|c|c|c|c|c|c|c|c|c|c|c|c|c|}
\hline \multicolumn{14}{|c|}{$F=450 \mathrm{kN}-$ antes da primeira fissura } \\
\hline \multirow{2}{*}{ Pto. } & \multicolumn{3}{|c|}{ Leitura incial $-\ell_{0}$} & \multicolumn{3}{|c|}{ Leitura final $-\ell$} & \multicolumn{3}{|c|}{ Deformações (\%o) } & \multicolumn{2}{|c|}{ Def. Prin. (\%o) } & \multicolumn{2}{|c|}{ Dir. Prin. $\left({ }^{\circ}\right)$} \\
\hline & $0^{\circ}$ & $90^{\circ}$ & $45^{\circ}$ & $0^{\circ}$ & $90^{\circ}$ & $45^{\circ}$ & $\varepsilon_{0^{\circ}}$ & $\varepsilon_{90^{\circ}}$ & $\varepsilon_{45^{\circ}}$ & $\varepsilon_{1}$ & $\varepsilon_{2}$ & $\alpha_{1}$ & $\alpha_{2}$ \\
\hline 1 & 2,1455 & 2,602 & 2,69 & 2,144 & 2,5945 & 2,679 & $-0,03$ & $-0,15$ & $-0,22$ & 0,05 & $-0,23$ & $-32,6$ & 57,4 \\
\hline 2 & 2,387 & 2,371 & 2,473 & 2,3945 & 2,3645 & 2,4645 & 0,15 & $-0,13$ & $-0,17$ & 0,24 & $-0,22$ & $-26,1$ & 63,9 \\
\hline 3 & 2,4255 & 2,4725 & 2,451 & 2,4145 & 2,4695 & 2,444 & $-0,22$ & $-0,06$ & $-0,14$ & $-0,06$ & $-0,22$ & 0,0 & 90,0 \\
\hline 4 & 2,386 & 2,463 & 2,475 & 2,3855 & 2,5645 & 2,573 & $-0,01$ & 2,03 & 1,96 & 2,40 & $-0,38$ & $-21,5$ & 68,5 \\
\hline 5 & 2,2625 & 2,4945 & 3,0865 & 2,266 & 2,4915 & 3,061 & 0,07 & $-0,06$ & $-0,51$ & 0,52 & $-0,51$ & $-41,4$ & 48,6 \\
\hline 6 & 2,717 & 2,595 & 2,789 & 2,717 & 2,5895 & 2,731 & 0 & $-0,11$ & $-1,16$ & 1,05 & $-1,16$ & $-43,6$ & 46,4 \\
\hline 7 & 2,7375 & 2,6745 & 2,564 & 2,7405 & 2,671 & 2,558 & 0,06 & $-0,07$ & $-0,12$ & 0,13 & $-0,14$ & $-30,3$ & 59,7 \\
\hline 8 & 2,524 & 2,559 & 2,745 & 2,506 & 2,555 & 2,741 & $-0,36$ & $-0,08$ & $-0,08$ & $-0,02$ & $-0,42$ & $-22,5$ & 67,5 \\
\hline 9 & 2,453 & 2,524 & 2,598 & 2,455 & 2,5225 & 2,591 & 0,04 & $-0,03$ & $-0,14$ & 0,15 & $-0,14$ & $-38,2$ & 51,8 \\
\hline 10 & 2,4355 & 2,788 & 2,565 & 2,4345 & 2,7855 & 2,565 & $-0,02$ & $-0,05$ & 0 & 0,00 & $-0,07$ & 33,4 & 123,4 \\
\hline 11 & 2,472 & 2,737 & 2,2175 & 2,481 & 2,736 & 2,216 & 0,18 & $-0,02$ & $-0,03$ & 0,23 & $-0,07$ & $-23,9$ & 66,1 \\
\hline 12 & 2,268 & 2,555 & 2,47 & 2,268 & 2,555 & 2,468 & 0 & 0 & $-0,04$ & 0,04 & $-0,04$ & 0 & 90 \\
\hline 13 & 2,444 & 2,5415 & 2,499 & 2,489 & 2,6245 & 2,423 & 0,9 & 1,66 & $-1,52$ & 4,11 & $-1,55$ & 41,1 & 131,1 \\
\hline 14 & 2,39 & 2,817 & 2,9815 & 2,3915 & 2,816 & 2,98 & 0,03 & $-0,02$ & $-0,03$ & 0,05 & $-0,04$ & $-27,2$ & 62,8 \\
\hline 15 & 2,6185 & 2,6855 & 2,55 & 2,619 & 2,683 & 2,55 & 0,01 & $-0,05$ & 0 & 0,02 & $-0,06$ & 16,8 & 106,8 \\
\hline 16 & 2,4155 & 2,6315 & 2,397 & 2,4095 & 2,625 & 2,394 & $-0,12$ & $-0,13$ & $-0,06$ & $-0,06$ & $-0,19$ & 42,8 & 132,8 \\
\hline 17 & 2,186 & 2,675 & 2,517 & 2,181 & 2,674 & 2,5175 & $-0,1$ & $-0,02$ & 0,01 & 0,02 & $-0,14$ & $-30,1$ & 59,9 \\
\hline \multicolumn{14}{|c|}{$F=2000 k N$} \\
\hline \multirow{2}{*}{ Pto. } & \multicolumn{3}{|c|}{ Leitura incial $-\ell_{0}$} & \multicolumn{3}{|c|}{ Leitura final $-\ell$} & \multicolumn{3}{|c|}{ Deformações (\%o) } & \multicolumn{2}{|c|}{ Def. Prin. (\%o) } & \multicolumn{2}{|c|}{ Dir. Prin. $\left(^{\circ}\right)$} \\
\hline & $0^{\circ}$ & $90^{\circ}$ & $45^{\circ}$ & $0^{\circ}$ & $90^{\circ}$ & $45^{\circ}$ & $\varepsilon_{0^{\circ}}$ & $\varepsilon 90^{\circ}$ & $\varepsilon_{45^{\circ}}$ & $\varepsilon_{1}$ & $\varepsilon_{2}$ & $\alpha_{1}$ & $\alpha_{2}$ \\
\hline 1 & 2,1455 & 2,602 & 2,69 & 2,242 & 2,529 & 2,5995 & 1,93 & $-1,46$ & $-1,81$ & - & $-1,81$ & - & - \\
\hline 2 & 2,387 & 2,371 & 2,473 & 2,383 & 2,343 & 2,4085 & $-0,08$ & $-0,56$ & $-1,29$ & 0,68 & $-1,32$ & $-38,1$ & 51,9 \\
\hline 3 & 2,4255 & 2,4725 & 2,451 & 2,391 & 2,4375 & 2,3705 & $-0,69$ & $-0,7$ & $-1,61$ & 0,22 & $-1,61$ & $-44,8$ & 45,2 \\
\hline 4 & 2,386 & 2,463 & 2,475 & 2,379 & 2,5625 & 2,568 & $-0,14$ & 1,99 & 1,86 & 2,34 & $-0,49$ & $-20,6$ & 69,4 \\
\hline 5 & 2,2625 & 2,4945 & 3,0865 & 2,256 & 2,4855 & 3,063 & $-0,13$ & $-0,18$ & $-0,47$ & 0,16 & $-0,47$ & $-42,7$ & 47,3 \\
\hline 6 & 2,717 & 2,595 & 2,789 & 2,8325 & 2,58 & 2,785 & 2,31 & $-0,3$ & $-0,08$ & 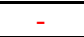 & $-0,08$ & - & - \\
\hline 7 & 2,7375 & 2,6745 & 2,564 & 2,746 & 2,689 & 2,5275 & 0,17 & 0,29 & $-0,73$ & - & $-0,73$ & - & - \\
\hline 8 & 2,524 & 2,559 & 2,745 & 2,496 & 2,543 & 2,726 & $-0,56$ & $-0,32$ & $-0,38$ & $-0,31$ & $-0,57$ & $-13,3$ & 76,7 \\
\hline 9 & 2,453 & 2,524 & 2,598 & 2,4665 & 2,5215 & 2,5945 & 0,27 & $-0,05$ & $-0,07$ & 0,35 & $-0,13$ & $-24,2$ & 65,8 \\
\hline 10 & 2,4355 & 2,788 & 2,565 & 2,429 & 2,774 & 2,555 & $-0,13$ & $-0,28$ & $-0,2$ & $-0,13$ & $-0,28$ & 1,9 & 91,9 \\
\hline 11 & 2,472 & 2,737 & 2,2175 & 2,879 & 2,6795 & 2,298 & 8,14 & $-1,15$ & 1,61 & - & - & - & - \\
\hline 12 & 2,268 & 2,555 & 2,47 & 2,2265 & 2,581 & 2,499 & $-0,82$ & 0,52 & 0,58 & 0,84 & $-1,14$ & $-23,7$ & 66,3 \\
\hline 13 & 2,444 & 2,5415 & 2,499 & 2,735 & 2,5355 & 2,4275 & 5,82 & $-0,12$ & $-1,43$ & - & $\begin{array}{l}-1,43 \\
\end{array}$ & - & - \\
\hline 14 & 2,39 & 2,817 & 2,9815 & 2,381 & 2,819 & 2,8895 & $-0,18$ & 0,04 & $-1,84$ & 1,70 & \begin{tabular}{|l|}
$-1,84$ \\
\end{tabular} & 43,2 & 133,2 \\
\hline 15 & 2,6185 & 2,6855 & 2,55 & 2,62 & 2,683 & 2,549 & 0,03 & $-0,05$ & $-0,02$ & 0,03 & $-0,05$ & $-7,0$ & 83,0 \\
\hline 16 & 2,4155 & 2,6315 & 2,397 & 2,415 & 2,599 & 2,37 & $-0,01$ & $-0,65$ & $-0,54$ & 0,05 & $-0,71$ & $-16,6$ & 73,4 \\
\hline 17 & 2,186 & 2,675 & 2,517 & 2,1815 & 2,663 & 2,5065 & $-0,09$ & $-0,24$ & $-0,21$ & $-0,08$ & $-0,25$ & $-15,5$ & 74,5 \\
\hline
\end{tabular}
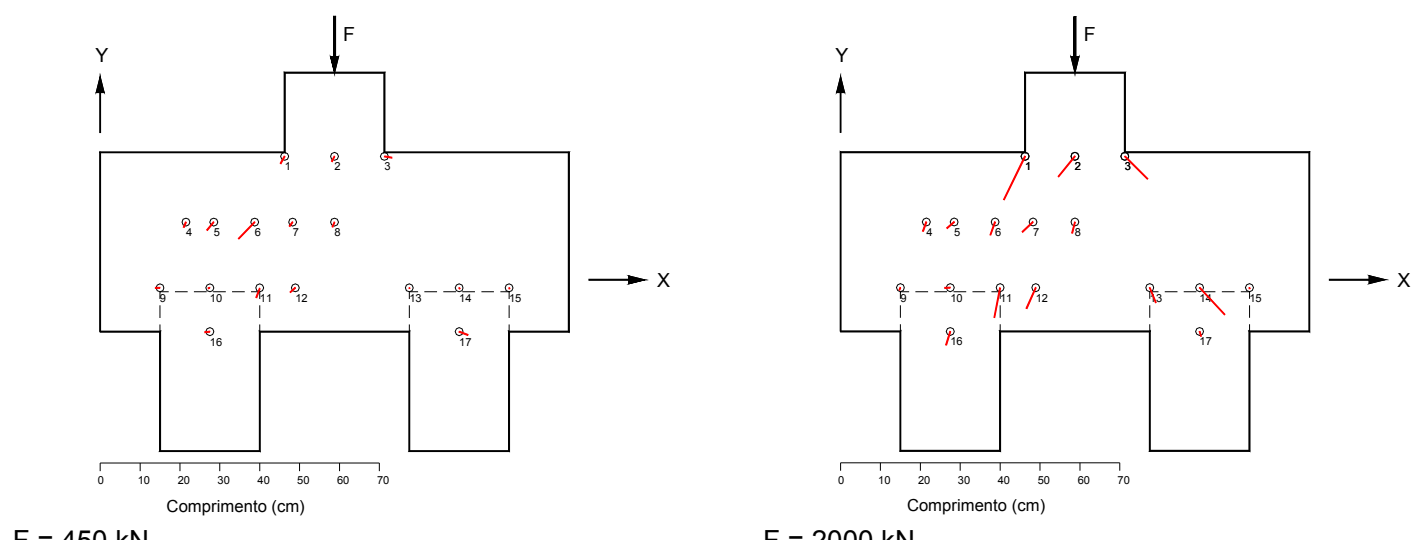

Figura 5.48 - Intensidades das deformações principais, modelo B45P25E25e0A 
Descrição e apresentação dos resultados experimentais

Tabela 5.10 - Modelo B45P25E25e0A

\begin{tabular}{|c|c|c|c|c|c|c|c|c|c|c|c|c|c|}
\hline \multicolumn{14}{|c|}{$\mathrm{F}=250 \mathrm{kN}-$ antes da primeira fissura } \\
\hline \multirow{2}{*}{ Pto. } & \multicolumn{3}{|c|}{ Leitura incial $-\ell_{0}$} & \multicolumn{3}{|c|}{ Leitura final $-\ell$} & \multicolumn{3}{|c|}{ Deformações (\%o) } & \multicolumn{2}{|c|}{ Def. Prin. (\%o) } & \multicolumn{2}{|c|}{ Dir. Prin. $\left(^{\circ}\right)$} \\
\hline & $0^{\circ}$ & $90^{\circ}$ & $45^{\circ}$ & $0^{\circ}$ & $90^{\circ}$ & $45^{\circ}$ & $\varepsilon_{0^{\circ}}$ & $\varepsilon_{90^{\circ}}$ & $\varepsilon_{45^{\circ}}$ & $\varepsilon_{1}$ & $\varepsilon_{2}$ & $\alpha_{1}$ & $\alpha_{2}$ \\
\hline 1 & 2,572 & 2,591 & 2,272 & 2,5645 & 2,574 & 2,2625 & $-0,15$ & $-0,34$ & $-0,19$ & $-0,14$ & $-0,35$ & 15,0 & 105,0 \\
\hline 2 & 2,541 & 2,831 & 2,468 & 2,538 & 2,83 & 2,466 & $-0,06$ & $-0,02$ & $-0,04$ & $-0,02$ & $-0,06$ & 0,0 & 90,0 \\
\hline 3 & 2,185 & 2,408 & 2,5355 & 2,1825 & 2,4105 & 2,533 & $-0,05$ & 0,05 & $-0,05$ & 0,07 & $-0,07$ & 22,5 & 112,5 \\
\hline 4 & 2,5535 & 2,56 & 2,594 & 2,557 & 2,559 & 2,591 & 0,07 & $-0,02$ & $-0,06$ & 0,12 & $-0,07$ & $-31,1$ & 58,9 \\
\hline 5 & 2,758 & 2,504 & 2,585 & 2,759 & 2,503 & 2,583 & 0,02 & $-0,02$ & $-0,04$ & 0,04 & $-0,04$ & $-31,7$ & 58,3 \\
\hline 6 & 2,67 & 2,418 & 2,4435 & 2,672 & 2,42 & 2,441 & 0,04 & 0,04 & $-0,05$ & 0,13 & $-0,05$ & $-45,0$ & 45,0 \\
\hline 7 & 2,638 & 2,494 & 2,5765 & 2,6425 & 2,488 & 2,576 & 0,09 & $-0,12$ & $-0,01$ & 0,09 & $-0,12$ & 1,4 & 91,4 \\
\hline 8 & 2,7075 & 2,2995 & 2,722 & 2,7105 & 2,297 & 2,7235 & 0,06 & $-0,05$ & 0,03 & 0,07 & $-0,06$ & 12,2 & 102,2 \\
\hline 9 & 2,58 & 2,684 & 2,4275 & 2,58 & 2,6845 & 2,428 & 0 & 0,01 & 0,01 & 0,01 & 0,00 & $-22,5$ & 67,5 \\
\hline 10 & 2,745 & 2,3725 & 2,548 & 2,745 & 2,3725 & 2,547 & 0 & 0 & $-0,02$ & 0,02 & $-0,02$ & 0 & 90 \\
\hline 11 & 2,5345 & 2,503 & 2,578 & 2,578 & 2,504 & 2,59 & 0,87 & 0,02 & 0,24 & 0,92 & $-0,03$ & $-12,9$ & 77,1 \\
\hline 12 & 2,518 & 2,4685 & 2,476 & 2,5195 & 2,4685 & 2,4755 & 0,03 & 0 & $-0,01$ & 0,04 & $-0,01$ & $-29,5$ & 60,5 \\
\hline 13 & 2,526 & 2,42 & 2,559 & 2,542 & 2,421 & 2,55 & 0,32 & 0,02 & $-0,18$ & 0,55 & $-0,21$ & $-33,4$ & 56,6 \\
\hline 14 & 2,539 & 2,756 & 2,508 & 2,5395 & 2,756 & 2,51 & 0,01 & 0 & 0,04 & 0,04 & $-0,03$ & 40,9 & 130,9 \\
\hline 15 & 2,7315 & 2,422 & 2,481 & 2,7315 & 2,4235 & 2,482 & 0 & 0,03 & 0,02 & 0,03 & 0,00 & $-9,2$ & 80,8 \\
\hline 16 & 2,721 & 2,6175 & 2,53 & 2,719 & 2,617 & 2,527 & $-0,04$ & $-0,01$ & $-0,06$ & 0,01 & $-0,06$ & 33,4 & 123,4 \\
\hline 17 & 2,45 & 2,4015 & 2,634 & 2,451 & 2,401 & 2,638 & 0,02 & $-0,01$ & 0,08 & 0,08 & $-0,07$ & 39,3 & 129,3 \\
\hline \multicolumn{14}{|c|}{$F=1500 \mathrm{kN}$} \\
\hline \multirow{2}{*}{ Pto. } & \multicolumn{3}{|c|}{ Leitura incial $-\ell_{0}$} & \multicolumn{3}{|c|}{ Leitura final $-\ell$} & \multicolumn{3}{|c|}{ Deformações (\%o) } & \multicolumn{2}{|c|}{ Def. Prin. (\%o) } & \multicolumn{2}{|c|}{ Dir. Prin. $\left({ }^{\circ}\right)$} \\
\hline & $0^{\circ}$ & $90^{\circ}$ & $45^{\circ}$ & $0^{\circ}$ & $90^{\circ}$ & $45^{\circ}$ & $\varepsilon_{0^{\circ}}$ & $\varepsilon_{90^{\circ}}$ & $\varepsilon_{45^{\circ}}$ & $\varepsilon_{1}$ & $\varepsilon_{2}$ & $\alpha_{1}$ & $\alpha_{2}$ \\
\hline 1 & 2,572 & 2,591 & 2,272 & 2,545 & 2,515 & 2,291 & $-0,54$ & $-1,52$ & 0,38 & 0,46 & $-2,52$ & 35,4 & 125,4 \\
\hline 2 & 2,541 & 2,831 & 2,468 & 2,5215 & 2,82 & 2,4585 & $-0,39$ & $-0,22$ & $-0,19$ & $-0,16$ & $-0,45$ & $-26,8$ & 63,2 \\
\hline 3 & 2,185 & 2,408 & 2,5355 & 2,1765 & 2,3935 & 2,508 & $-0,17$ & $-0,29$ & $-0,55$ & 0,10 & $-0,56$ & $-39,7$ & 50,3 \\
\hline 4 & 2,5535 & 2,56 & 2,594 & 2,551 & 2,5555 & 2,584 & $-0,05$ & $-0,09$ & $-0,2$ & 0,06 & $-0,20$ & $-40,6$ & 49,4 \\
\hline 5 & 2,758 & 2,504 & 2,585 & 2,754 & 2,4985 & 2,571 & $-0,08$ & $-0,11$ & $-0,28$ & 0,09 & $-0,28$ & $-42,7$ & 47,3 \\
\hline 6 & 2,67 & 2,418 & 2,4435 & 2,666 & 2,407 & 2,419 & $-0,08$ & $-0,22$ & $-0,49$ & 0,20 & $-0,50$ & $-39,2$ & 50,8 \\
\hline 7 & 2,638 & 2,494 & 2,5765 & 2,632 & 2,5545 & 2,5585 & $-0,12$ & 1,21 & $-0,36$ & - & $-0,36$ & - & - \\
\hline 8 & 2,7075 & 2,2995 & 2,722 & 2,698 & 2,694 & 2,719 & $-0,19$ & 7,89 & $-0,06$ & 9,47 & $-1,77$ & 22,0 & 112,0 \\
\hline 9 & 2,58 & 2,684 & 2,4275 & 2,582 & 2,683 & 2,4275 & 0,04 & $-0,02$ & 0 & 0,04 & $-0,02$ & $-9,2$ & 80,8 \\
\hline 10 & 2,745 & 2,3725 & 2,548 & 2,7405 & 2,369 & 2,538 & $-0,09$ & $-0,07$ & $-0,2$ & 0,04 & $-0,20$ & 42,6 & 132,6 \\
\hline 11 & 2,5345 & 2,503 & 2,578 & 2,826 & 2,499 & 2,617 & 5,83 & $-0,08$ & 0,78 & - & - & - & - \\
\hline 12 & 2,518 & 2,4685 & 2,476 & 2,524 & 2,549 & 2,526 & 0,12 & 1,61 & 1 & 1,62 & 0,11 & $-5,1$ & 84,9 \\
\hline 13 & 2,526 & 2,42 & 2,559 & 2,711 & 2,422 & 2,535 & 3,7 & 0,04 & $-0,48$ & - & $-0,48$ & - & - \\
\hline 14 & 2,539 & 2,756 & 2,508 & 2,531 & 2,7575 & 2,508 & $-0,16$ & 0,03 & 0 & 0,05 & $-0,18$ & $-17,2$ & 72,8 \\
\hline 15 & 2,7315 & 2,422 & 2,481 & 2,733 & 2,426 & 2,48 & 0,03 & 0,08 & $-0,02$ & 0,13 & $-0,02$ & 35,8 & 125,8 \\
\hline 16 & 2,721 & 2,6175 & 2,53 & 2,7225 & 2,6045 & 2,617 & 0,03 & $-0,26$ & 1,74 & 1,75 & $-1,98$ & 42,8 & 132,8 \\
\hline 17 & 2,45 & 2,4015 & 2,634 & 2,446 & 2,397 & 2,63 & $-0,08$ & $-0,09$ & $-0,08$ & $-0,08$ & $-0,09$ & 22,5 & 112,5 \\
\hline
\end{tabular}
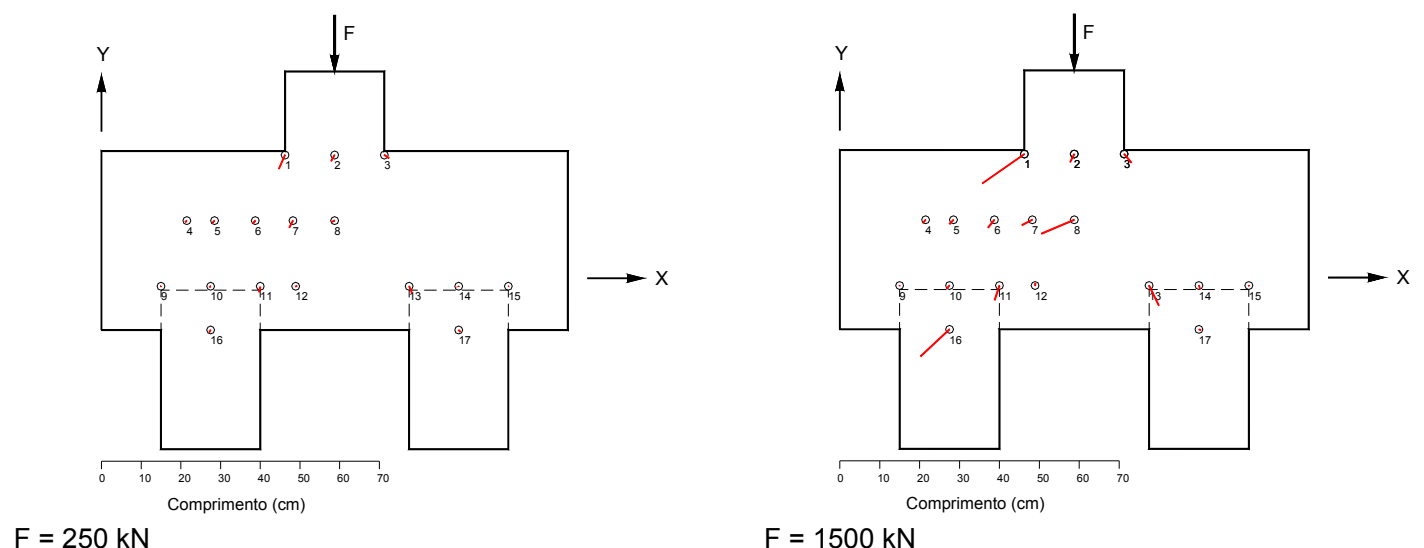

Figura 5.49 - Intensidades das deformações principais, modelo B45P25E25e0A $A_{s w, 0}$. 
Tabela 5.11 - Modelo B45P25E25e0CG.

\begin{tabular}{|c|c|c|c|c|c|c|c|c|c|c|c|c|c|}
\hline \multicolumn{14}{|c|}{$\mathrm{F}=400 \mathrm{kN}-$ antes da primeira fissura } \\
\hline \multirow{2}{*}{ Pto. } & \multicolumn{3}{|c|}{ Leitura incial $-\ell_{0}$} & \multicolumn{3}{|c|}{ Leitura final $-\ell$} & \multicolumn{3}{|c|}{ Deformações (\%o) } & \multicolumn{2}{|c|}{ Def. Prin. (\%o) } & \multicolumn{2}{|c|}{ Dir. Prin. $\left(^{\circ}\right)$} \\
\hline & $0^{\circ}$ & $90^{\circ}$ & $45^{\circ}$ & $0^{\circ}$ & $90^{\circ}$ & $45^{\circ}$ & $\varepsilon_{0^{\circ}}$ & $\varepsilon_{90^{\circ}}$ & $\varepsilon_{45^{\circ}}$ & $\varepsilon_{1}$ & $\varepsilon_{2}$ & $\alpha_{1}$ & $\alpha_{2}$ \\
\hline 1 & 2,3935 & 2,415 & 2,499 & 2,393 & 2,392 & 2,472 & $-0,01$ & $-0,46$ & $-0,54$ & 0,14 & $-0,61$ & $\begin{array}{ll}-26,8 \\
\end{array}$ & 63,2 \\
\hline 2 & 2,409 & 2,378 & 2,602 & 2,414 & 2,367 & 2,59 & 0,1 & $-0,22$ & $-0,24$ & 0,18 & $-0,30$ & $-24,2$ & 65,8 \\
\hline 3 & 2,51 & 2,174 & 2,727 & 2,499 & 2,164 & 2,699 & $-0,22$ & $-0,2$ & $-0,56$ & 0,14 & $-0,56$ & 44,2 & 134,2 \\
\hline 4 & 2,432 & 2,5155 & 2,623 & 2,432 & 2,512 & 2,617 & 0 & $-0,07$ & $-0,12$ & 0,06 & $-0,13$ & $-33,8$ & 56,2 \\
\hline 5 & 2,574 & 2,702 & 2,522 & 2,572 & 2,699 & 2,517 & $-0,04$ & $-0,06$ & $-0,1$ & 0,00 & $-0,10$ & $-39,3$ & 50,7 \\
\hline 6 & 2,7 & 2,5435 & 2,571 & 2,7 & 2,534 & 2,461 & 0 & $-0,19$ & $-2,2$ & 2,01 & $-2,20$ & $-43,7$ & 46,3 \\
\hline 7 & 2,427 & 2,7175 & 2,634 & 2,435 & 2,7125 & 2,628 & 0,16 & $-0,1$ & $-0,12$ & 0,23 & $-0,17$ & $-24,5$ & 65,5 \\
\hline 8 & 2,4205 & 2,5495 & 2,765 & 2,42 & 2,543 & 2,762 & $-0,01$ & $-0,13$ & $-0,06$ & $-0,01$ & $-0,13$ & 4,7 & 94,7 \\
\hline 9 & 2,821 & 2,555 & 2,702 & 2,827 & 2,554 & 2,701 & 0,12 & $-0,02$ & $-0,02$ & 0,15 & $-0,05$ & $-22,5$ & 67,5 \\
\hline 10 & 2,5615 & 2,605 & 2,705 & 2,567 & 2,602 & 2,702 & 0,11 & $-0,06$ & $-0,06$ & 0,15 & $-0,10$ & $-22,5$ & 67,5 \\
\hline 11 & 2,445 & 2,61 & 2,594 & 2,4825 & 2,6015 & 2,588 & 0,75 & $-0,17$ & $-0,12$ & 0,91 & $-0,33$ & $-20,9$ & 69,1 \\
\hline 12 & 2,825 & 2,537 & 2,534 & 2,828 & 2,537 & 2,535 & 0,06 & 0 & 0,02 & 0,06 & 0,00 & $-9,2$ & 80,8 \\
\hline 13 & 2,461 & 2,905 & 2,668 & 2,517 & 2,9 & 2,673 & 1,12 & $-0,1$ & 0,1 & 1,24 & $-0,22$ & $-17,0$ & 73,0 \\
\hline 14 & 2,515 & 2,889 & 2,938 & 2,515 & 2,888 & 2,939 & 0 & $-0,02$ & 0,02 & 0,02 & $-0,04$ & 35,8 & 125,8 \\
\hline 15 & 2,499 & 2,5215 & 2,513 & 2,4985 & 2,519 & 2,513 & $-0,01$ & $-0,05$ & 0 & 0,01 & $-0,07$ & 28,2 & 118,2 \\
\hline 16 & 2,51 & 2,4965 & 2,6075 & 2,5155 & 2,488 & 2,605 & 0,11 & $-0,17$ & $-0,05$ & 0,11 & $-0,17$ & $-4,1$ & 85,9 \\
\hline 17 & 2,586 & 2,525 & 2,043 & 2,591 & 2,511 & 2,041 & 0,1 & $-0,28$ & $-0,04$ & 0,11 & $-0,29$ & 7,4 & 97,4 \\
\hline \multicolumn{14}{|c|}{$F=1700 \mathrm{kN}$} \\
\hline \multirow{2}{*}{ Pto. } & \multicolumn{3}{|c|}{ Leitura incial $-\ell_{0}$} & \multicolumn{3}{|c|}{ Leitura final $-\ell$} & \multicolumn{3}{|c|}{ Deformações (\%o) } & \multicolumn{2}{|c|}{ Def. Prin. (\%o) } & \multicolumn{2}{|c|}{ Dir. Prin. $\left(^{\circ}\right)$} \\
\hline & $0^{\circ}$ & $90^{\circ}$ & $45^{\circ}$ & $0^{\circ}$ & $90^{\circ}$ & $45^{\circ}$ & $\varepsilon_{0^{\circ}}$ & $\varepsilon_{90^{\circ}}$ & $\varepsilon_{45^{\circ}}$ & $\varepsilon_{1}$ & $\varepsilon_{2}$ & $\alpha_{1}$ & $\alpha_{2}$ \\
\hline 1 & 2,3935 & 2,415 & 2,499 & 2,417 & 2,289 & 2,341 & 0,47 & $-2,52$ & $-3,16$ & - & $-3,16$ & - & - \\
\hline 2 & 2,409 & 2,378 & 2,602 & 2,405 & 2,312 & 2,5385 & $-0,08$ & $-1,32$ & $-1,27$ & 0,14 & $-1,54$ & $-21,3$ & 68,7 \\
\hline 3 & 2,51 & 2,174 & 2,727 & 2,4645 & 2,1585 & 2,605 & $-0,91$ & $-0,31$ & $-2,44$ & 1,24 & $-2,46$ & 40,3 & 130,3 \\
\hline 4 & 2,432 & 2,5155 & 2,623 & 2,428 & 2,512 & 2,6105 & $-0,08$ & $-0,07$ & $-0,25$ & 0,10 & $-0,25$ & 44,2 & 134,2 \\
\hline 5 & 2,574 & 2,702 & 2,522 & 2,561 & 2,6935 & 2,494 & $-0,26$ & $-0,17$ & $-0,56$ & 0,13 & $-0,56$ & 41,3 & 131,3 \\
\hline 6 & 2,7 & 2,5435 & 2,571 & 2,881 & 2,559 & 2,4285 & 3,62 & 0,31 & $-2,85$ & 7,06 & $-3,13$ & $-35,5$ & 54,5 \\
\hline 7 & 2,427 & 2,7175 & 2,634 & 2,5435 & 2,689 & 2,605 & 2,33 & $-0,57$ & $-0,58$ & 2,94 & $-1,18$ & $-22,6$ & 67,4 \\
\hline 8 & 2,4205 & 2,5495 & 2,765 & 2,396 & 2,523 & 2,746 & $-0,49$ & $-0,53$ & $-0,38$ & $-0,38$ & $-0,64$ & 40,6 & 130,6 \\
\hline 9 & 2,821 & 2,555 & 2,702 & 2,83 & 2,554 & 2,698 & 0,18 & $-0,02$ & $-0,08$ & 0,27 & $-0,11$ & $-29,0$ & 61,0 \\
\hline 10 & 2,5615 & 2,605 & 2,705 & 2,561 & 2,595 & 2,683 & $-0,01$ & $-0,2$ & $-0,44$ & 0,24 & $-0,45$ & $-37,1$ & 52,9 \\
\hline 11 & 2,445 & 2,61 & 2,594 & 2,6445 & 2,6905 & 2,562 & 3,99 & 1,61 & $-0,64$ & - & $-0,64$ & - & - \\
\hline 12 & 2,825 & 2,537 & 2,534 & 2,861 & 2,6445 & 2,605 & 0,72 & 2,15 & 1,42 & 2,15 & 0,72 & 0,6 & 90,6 \\
\hline 13 & 2,461 & 2,905 & 2,668 & 2,834 & 2,869 & 2,645 & 7,46 & $-0,72$ & $-0,46$ & - & $-0,46$ & - & - \\
\hline 14 & 2,515 & 2,889 & 2,938 & 2,505 & 2,8795 & 2,9255 & $-0,2$ & $-0,19$ & $-0,25$ & $-0,14$ & $-0,25$ & 42,4 & 132,4 \\
\hline 15 & 2,499 & 2,5215 & 2,513 & 2,499 & 2,521 & 2,51 & 0 & $-0,01$ & $-0,06$ & 0,05 & $-0,06$ & $-42,4$ & 47,6 \\
\hline 16 & 2,51 & 2,4965 & 2,6075 & 2,5195 & 2,466 & 2,587 & 0,19 & $-0,61$ & $-0,41$ & 0,24 & $-0,66$ & $-13,3$ & 76,7 \\
\hline 17 & 2,586 & 2,525 & 2,043 & 2,5925 & 2,4944 & 2,026 & 0,13 & $-0,612$ & $-0,34$ & 0,14 & $-0,62$ & $-7,5$ & 82,5 \\
\hline
\end{tabular}
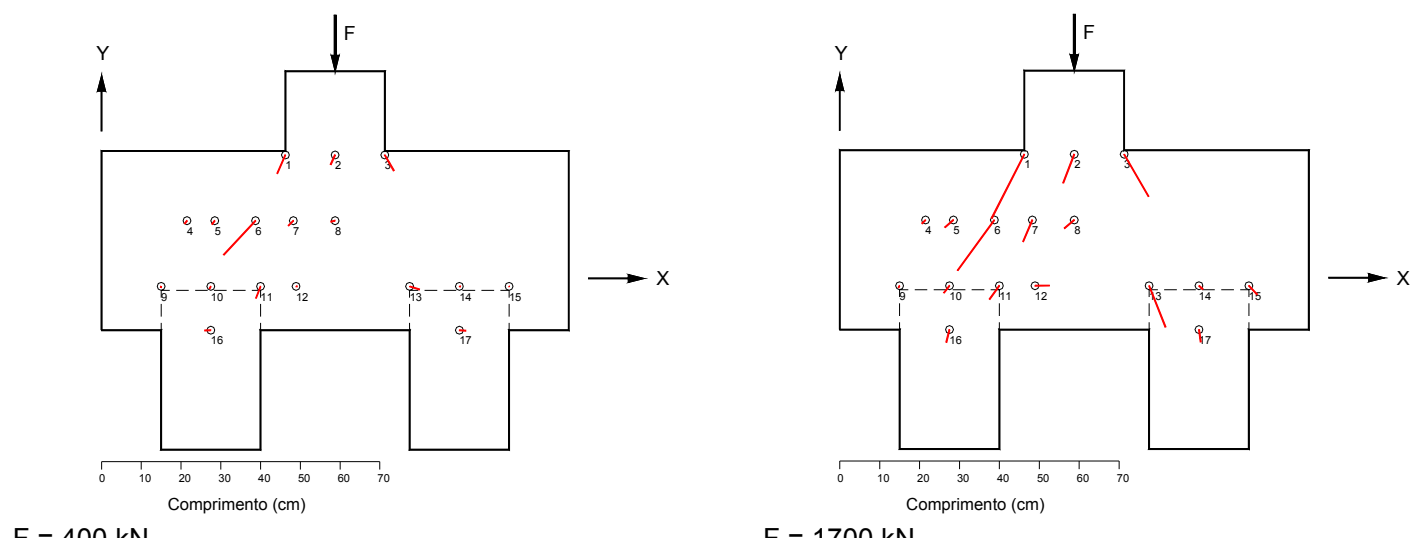

Figura 5.50 - Intensidades das deformações principais, modelo B45P25E25e0CG. 
Descrição e apresentação dos resultados experimentais

Tabela 5.12 - Modelo B35P50E25e0.

\begin{tabular}{|c|c|c|c|c|c|c|c|c|c|c|c|c|c|}
\hline \multicolumn{14}{|c|}{$F=250 \mathrm{kN}-$ antes da primeira fissura } \\
\hline \multirow{2}{*}{ Pto. } & \multicolumn{3}{|c|}{ Leitura incial $-\ell_{0}$} & \multicolumn{3}{|c|}{ Leitura final $-\ell$} & \multicolumn{3}{|c|}{ Deformações (\%o) } & \multicolumn{2}{|c|}{ Def. Prin. (\%o) } & \multicolumn{2}{|c|}{ Dir. Prin. $\left({ }^{\circ}\right)$} \\
\hline & $0^{\circ}$ & $90^{\circ}$ & $45^{\circ}$ & $0^{\circ}$ & \begin{tabular}{|c|}
$0^{\circ}$ \\
\end{tabular} & $45^{\circ}$ & $\varepsilon_{0^{\circ}}$ & $\varepsilon_{90^{\circ}}$ & $\varepsilon_{45^{\circ}}$ & $\varepsilon_{1}$ & $\varepsilon_{2}$ & $\alpha_{1}$ & $\alpha_{2}$ \\
\hline 1 & 2,548 & 2,4925 & 2,499 & 2,5425 & 2,489 & 2,4915 & $-0,11$ & $-0,07$ & $-0,15$ & $-0,03$ & $-0,15$ & 35,8 & 125,8 \\
\hline 2 & 2,691 & 2,5495 & 2,591 & 2,69 & 2,547 & 2,59 & $-0,02$ & $-0,05$ & $-0,02$ & $-0,01$ & $-0,06$ & 22,5 & 112,5 \\
\hline 3 & 2,499 & 2,0415 & 2,6455 & 2,499 & 2,039 & 2,647 & 0 & $-0,05$ & 0,03 & 0,04 & $-0,09$ & 32,8 & 122,8 \\
\hline 4 & 2,525 & 2,549 & 2,405 & 2,523 & 2,5465 & 2,402 & $-0,04$ & $-0,05$ & $-0,06$ & $-0,03$ & $-0,06$ & $-35,8$ & 54,2 \\
\hline 5 & 2,3535 & 2,401 & 2,5485 & 2,3555 & 2,401 & 2,545 & 0,04 & 0 & $-0,07$ & 0,11 & $-0,07$ & $-38,7$ & 51,3 \\
\hline 6 & 2,535 & 2,567 & 2,565 & 2,536 & 2,555 & 2,551 & 0,02 & $\begin{array}{l}-0,24 \\
\end{array}$ & $-0,28$ & 0,10 & $-0,32$ & $-26,3$ & 63,7 \\
\hline 7 & 2,795 & 2,6925 & 2,5805 & 2,795 & 2,597 & 2,582 & 0 & $-1,91$ & 0,03 & 0,42 & $-2,33$ & 22,9 & 112,9 \\
\hline 8 & 2,632 & 2,644 & 2,51 & 2,634 & 2,644 & 2,513 & 0,04 & 0 & 0,06 & 0,06 & $-0,02$ & 31,7 & 121,7 \\
\hline 9 & 2,594 & 2,503 & 3,115 & 2,496 & 2,5045 & 3,117 & $-1,96$ & 0,03 & 0,04 & 0,45 & $-2,38$ & $-22,6$ & 67,4 \\
\hline 10 & 2,486 & 2,513 & 2,13 & 2,489 & 2,513 & 2,13 & 0,06 & 0 & 0 & 0,07 & $-0,01$ & $-22,5$ & 67,5 \\
\hline 11 & 2,624 & 2,555 & 2,662 & 2,626 & 2,5555 & 2,661 & 0,04 & 0,01 & $-0,02$ & 0,07 & $-0,02$ & $-35,8$ & 54,2 \\
\hline 12 & 2,428 & 2,41 & 2,74 & 2,4995 & 2,412 & 2,7335 & 1,43 & 0,04 & $-0,13$ & 1,84 & $-0,37$ & $-25,6$ & 64,4 \\
\hline 13 & 2,565 & 2,201 & 2,5325 & 2,567 & 2,199 & 2,534 & 0,04 & $-0,04$ & 0,03 & 0,05 & $-0,05$ & 18,4 & 108,4 \\
\hline 14 & 2,827 & 2,495 & 2,57 & 2,829 & 2,512 & 2,571 & 0,04 & 0,34 & 0,02 & 0,42 & $-0,04$ & 24,3 & 114,3 \\
\hline 15 & 2,51 & 2,451 & 2,375 & 2,51 & 2,4515 & 2,376 & 0 & 0,01 & 0,02 & 0,02 & $-0,01$ & $-35,8$ & 54,2 \\
\hline 16 & 2,788 & 2,514 & 2,458 & 2,789 & 2,512 & 2,459 & 0,02 & $-0,04$ & 0,02 & 0,03 & $-0,05$ & 22,5 & 112,5 \\
\hline 17 & 2,574 & 2,511 & 2,5465 & 2,573 & 2,511 & 2,5455 & $-0,02$ & 0 & $-0,02$ & 0,00 & $-0,02$ & 22,5 & 112,5 \\
\hline 18 & 2,3505 & 2,369 & 2,474 & 2,354 & 2,368 & 2,472 & 0,07 & $-0,02$ & $-0,04$ & 0,10 & $-0,05$ & $-27,7$ & 62,3 \\
\hline \multicolumn{14}{|c|}{$F=2800 \mathrm{kN}$} \\
\hline \multirow{2}{*}{ Pto. } & \multicolumn{3}{|c|}{ Leitura incial $-\ell_{0}$} & \multicolumn{3}{|c|}{ Leitura final $-\ell$} & \multicolumn{3}{|c|}{ Deformações (\%o) } & \multicolumn{2}{|c|}{ Def. Prin. (\%o) } & \multicolumn{2}{|c|}{ Dir. Prin. $\left(^{\circ}\right)$} \\
\hline & $0^{\circ}$ & $90^{\circ}$ & $45^{\circ}$ & $0^{\circ}$ & $90^{\circ}$ & $45^{\circ}$ & $\varepsilon_{0^{\circ}}$ & $\varepsilon_{90^{\circ}}$ & $\varepsilon_{45^{\circ}}$ & $\varepsilon_{1}$ & $\varepsilon_{2}$ & $\alpha_{1}$ & $\alpha_{2}$ \\
\hline 1 & 2,548 & 2,4925 & 2,499 & 2,573 & 2,433 & 2,418 & 0,5 & $-1,19$ & $-1,62$ & - & $-1,62$ & - & - \\
\hline 2 & 2,691 & 2,5495 & 2,591 & 2,6795 & 2,5215 & 2,55 & $-0,23$ & $-0,56$ & $-0,82$ & 0,06 & $-0,85$ & $-34,4$ & 55,6 \\
\hline 3 & 2,499 & 2,0415 & 2,6455 & 2,494 & 2,1335 & 2,648 & $-0,1$ & 1,84 & 0,05 & 2,14 & $-0,40$ & 20,1 & 110,1 \\
\hline 4 & 2,525 & 2,549 & 2,405 & 2,519 & 2,49 & 2,3715 & $-0,12$ & $-1,18$ & $-0,67$ & $-0,12$ & $-1,18$ & $-1,1$ & 88,9 \\
\hline 5 & 2,3535 & 2,401 & 2,5485 & 2,3705 & 2,3995 & 2,507 & 0,34 & $-0,03$ & $-0,83$ & 1,16 & $-0,85$ & $-39,7$ & 50,3 \\
\hline 6 & 2,535 & 2,567 & 2,565 & 2,631 & 2,469 & 2,497 & 1,92 & $-1,96$ & $-1,36$ & 2,34 & $-2,38$ & $-17,3$ & 72,7 \\
\hline 7 & 2,795 & 2,6925 & 2,5805 & 2,8415 & 2,555 & 2,553 & 0,93 & $-2,75$ & $-0,55$ & 0,96 & $-2,78$ & 5,5 & 95,5 \\
\hline 8 & 2,632 & 2,644 & 2,51 & 2,664 & 2,64 & 2,507 & 0,64 & $-0,08$ & $-0,06$ & 0,78 & $-0,22$ & $-21,7$ & 68,3 \\
\hline 9 & 2,594 & 2,503 & 3,115 & 2,509 & 2,5025 & 3,119 & $-1,7$ & $-0,01$ & 0,08 & 0,41 & $-2,12$ & $-23,9$ & 66,1 \\
\hline 10 & 2,486 & 2,513 & 2,13 & 2,4885 & 2,5085 & 2,121 & 0,05 & $-0,09$ & $-0,18$ & 0,15 & $-0,19$ & $-33,2$ & 56,8 \\
\hline 11 & 2,624 & 2,555 & 2,662 & 2,624 & 2,558 & 2,639 & 0 & 0,06 & $-0,46$ & 0,52 & $-0,46$ & 43,2 & 133,2 \\
\hline 12 & 2,428 & 2,41 & 2,74 & 2,792 & 2,371 & 2,776 & 7,28 & $\begin{array}{l}-0,78 \\
\end{array}$ & 0,72 & - & - & - & - \\
\hline 13 & 2,565 & 2,201 & 2,5325 & 2,56 & 2,2055 & 2,535 & $-0,1$ & 0,09 & 0,05 & 0,10 & $-0,11$ & $-15,0$ & 75,0 \\
\hline 14 & 2,827 & 2,495 & 2,57 & 3,104 & 2,629 & 2,475 & 5,54 & 2,68 & $-1,9$ & - & $-1,9$ & - & - \\
\hline 15 & 2,51 & 2,451 & 2,375 & 2,49 & 2,439 & 2,35 & $-0,4$ & $\begin{array}{l}-0,24 \\
\end{array}$ & $-0,5$ & $-0,12$ & $-0,52$ & 33,0 & 123,0 \\
\hline 16 & 2,788 & 2,514 & 2,458 & 2,7975 & 2,513 & 2,4575 & 0,19 & $\begin{array}{c}-0,02 \\
\end{array}$ & $-0,01$ & 0,23 & $-0,06$ & $-21,1$ & 68,9 \\
\hline 17 & 2,574 & 2,511 & 2,5465 & 2,59 & 2,48 & 2,5215 & 0,32 & $-0,62$ & $-0,5$ & 0,44 & $-0,74$ & $-18,3$ & 71,7 \\
\hline 18 & 2,3505 & 2,369 & 2,474 & 2,35 & 2,34 & 2,434 & $-0,01$ & $-0,58$ & $-0,8$ & 0,28 & $-0,87$ & $-30,3$ & 59,7 \\
\hline
\end{tabular}
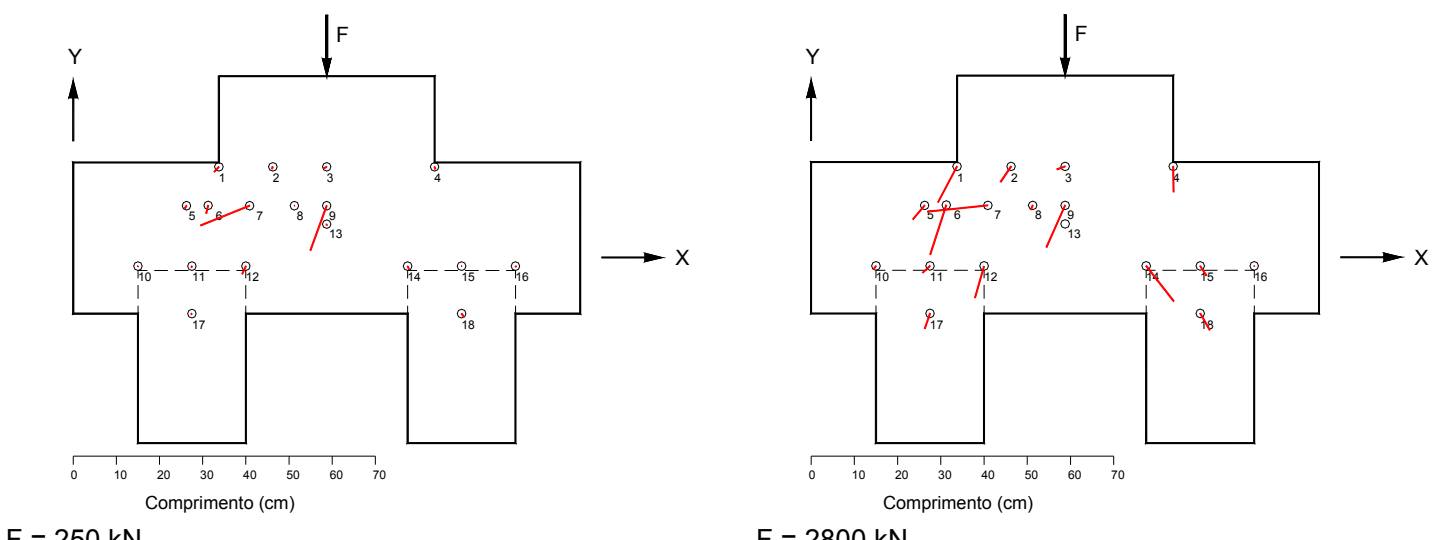

Figura 5.51 - Intensidades das deformações principais, modelo B35P50E25e0. 
Tabela 5.13 - Modelo B35P50E25e12,5.

\begin{tabular}{|c|c|c|c|c|c|c|c|c|c|c|c|c|c|}
\hline \multicolumn{14}{|c|}{$F=300 \mathrm{kN}-$ antes da primeira fissura } \\
\hline \multirow{2}{*}{ Pto. } & \multicolumn{3}{|c|}{ Leitura incial $-\ell_{0}$} & \multicolumn{3}{|c|}{ Leitura final $-\ell$} & \multicolumn{3}{|c|}{ Deformações (\%o) } & \multicolumn{2}{|c|}{ Def. Prin. (\%o) } & \multicolumn{2}{|c|}{ Dir. Prin. $\left({ }^{\circ}\right)$} \\
\hline & $0^{\circ}$ & $90^{\circ}$ & $45^{\circ}$ & $0^{\circ}$ & $90^{\circ}$ & $45^{\circ}$ & $\varepsilon_{0^{\circ}}$ & $\varepsilon_{90^{\circ}}$ & $\varepsilon_{45^{\circ}}$ & $\varepsilon_{1}$ & $\varepsilon_{2}$ & $\alpha_{1}$ & $\alpha_{2}$ \\
\hline 1 & 2,853 & 2,6495 & 2,424 & 2,855 & 2,649 & 2,42 & 0,04 & $-0,01$ & $-0,08$ & 0,11 & $-0,08$ & $-37,6$ & 52,4 \\
\hline 2 & 2,596 & 2,576 & 2,6975 & 2,595 & 2,5755 & 2,697 & $-0,02$ & $-0,01$ & $-0,01$ & $-0,01$ & $-0,02$ & $-22,5$ & 67,5 \\
\hline 3 & 2,363 & 2,403 & 2,469 & 2,356 & 2,403 & 2,467 & $-0,14$ & 0 & $-0,04$ & 0,01 & $-0,15$ & $-11,6$ & 78,4 \\
\hline 4 & 2,64 & 2,528 & 2,271 & 2,6265 & 2,5235 & 2,259 & $-0,27$ & $-0,09$ & $-0,24$ & $-0,07$ & $-0,29$ & 16,8 & 106,8 \\
\hline 5 & 2,414 & 2,56 & 2,549 & 2,415 & 2,5595 & 2,5415 & $\begin{array}{l}0,02 \\
\end{array}$ & $-0,01$ & $-0,15$ & 0,16 & $-0,15$ & $-42,2$ & 47,8 \\
\hline 6 & 2,499 & 2,395 & 2,4625 & 2,5015 & 2,395 & 2,4625 & 0,05 & 0 & 0 & 0,06 & $-0,01$ & $-22,5$ & 67,5 \\
\hline 7 & 2,577 & 2,498 & 2,685 & 2,581 & 2,498 & 2,685 & 0,08 & 0 & 0 & 0,10 & $\begin{array}{l}-0,02 \\
\end{array}$ & $-22,5$ & 67,5 \\
\hline 8 & 2,654 & 2,5675 & 2,626 & 2,6565 & 2,567 & 2,625 & 0,05 & $-0,01$ & $-0,02$ & 0,07 & $-0,03$ & $-26,6$ & 63,4 \\
\hline 9 & 2,61 & 2,552 & 2,708 & 2,614 & 2,551 & 2,7075 & 0,08 & $-0,02$ & $-0,01$ & 0,09 & $-0,03$ & $-19,3$ & 70,7 \\
\hline 10 & 2,415 & 2,7765 & 2,655 & 2,426 & 2,7765 & 2,65 & 0,22 & 0 & $-0,1$ & 0,35 & $-0,13$ & $-31,2$ & 58,8 \\
\hline 11 & 2,735 & 2,6265 & 2,5845 & 2,737 & 2,623 & 2,581 & 0,04 & $-0,07$ & $-0,07$ & 0,06 & $-0,09$ & $-22,5$ & 67,5 \\
\hline 12 & 2,502 & 2,8365 & 2,5005 & 2,5035 & 2,836 & 2,496 & 0,03 & $-0,01$ & $-0,09$ & 0,11 & $-0,09$ & $-39,3$ & 50,7 \\
\hline 13 & 2,487 & 2,5815 & 2,434 & 2,513 & 2,579 & 2,4335 & 0,52 & $-0,05$ & $-0,01$ & 0,61 & $-0,14$ & $-20,3$ & 69,7 \\
\hline 14 & 2,543 & 2,791 & 2,554 & 2,547 & 2,791 & 2,5535 & 0,08 & 0 & $-0,01$ & 0,10 & $-0,02$ & $-25,7$ & 64,3 \\
\hline 15 & 2,947 & 2,73 & 3,032 & 2,961 & 2,728 & 3,0315 & 0,28 & $-0,04$ & $-0,01$ & 0,33 & $-0,09$ & $-19,5$ & 70,5 \\
\hline 16 & 2,4865 & 2,63 & 2,84 & 2,523 & 2,625 & 2,835 & 0,73 & $-0,1$ & $-0,1$ & 0,90 & $-0,27$ & $-22,5$ & 67,5 \\
\hline 17 & 2,265 & 2,662 & 2,675 & 2,2665 & 2,662 & 2,674 & 0,03 & 0 & $\begin{array}{l}-0,02 \\
\end{array}$ & 0,05 & $\begin{array}{l}-0,02 \\
\end{array}$ & $-33,4$ & 56,6 \\
\hline 18 & 2,576 & 2,551 & 2,803 & 2,576 & 2,5505 & 2,803 & 0 & $-0,01$ & 0 & 0,00 & $-0,01$ & 22,5 & 112,5 \\
\hline 19 & 2,345 & 2,6015 & 2,4 & 2,349 & 2,601 & 2,396 & 0,08 & $-0,01$ & $-0,08$ & 0,16 & $-0,09$ & $-34,3$ & 55,7 \\
\hline 20 & 2,579 & 2,663 & 2,409 & 2,58 & 2,663 & 2,409 & 0,02 & 0 & 0 & 0,02 & 0,00 & $-22,5$ & 67,5 \\
\hline \multicolumn{14}{|c|}{$F=1500 k N$} \\
\hline \multirow{2}{*}{ Pto. } & \multicolumn{3}{|c|}{ Leitura incial - $\ell_{0}$} & \multicolumn{3}{|c|}{ Leitura final $-\ell$} & \multicolumn{3}{|c|}{ Deformações (\%o) } & \multicolumn{2}{|c|}{ Def. Prin. (\%o) } & \multicolumn{2}{|c|}{ Dir. Prin. $\left({ }^{\circ}\right)$} \\
\hline & $0^{\circ}$ & $90^{\circ}$ & $45^{\circ}$ & $0^{\circ}$ & $90^{\circ}$ & $45^{\circ}$ & $\varepsilon_{0^{\circ}}$ & $\varepsilon_{90^{\circ}}$ & $\varepsilon_{45^{\circ}}$ & $\varepsilon_{1}$ & $\varepsilon_{2}$ & $\alpha_{1}$ & $\alpha_{2}$ \\
\hline 1 & 2,853 & 2,6495 & 2,424 & 2,845 & 2,6525 & 2,421 & $-0,16$ & 0,06 & $-0,06$ & 0,06 & $-0,16$ & 2,6 & 92,6 \\
\hline 2 & 2,596 & 2,576 & 2,6975 & 2,618 & 2,639 & 2,749 & 0,44 & 1,26 & 1,03 & - & - & - & - \\
\hline 3 & 2,363 & 2,403 & 2,469 & 2,353 & 2,4165 & 2,4655 & $-0,2$ & 0,27 & $-0,07$ & 0,29 & $-0,22$ & 12,0 & 102,0 \\
\hline 4 & 2,64 & 2,528 & 2,271 & 2,546 & 2,528 & 2,161 & $-1,88$ & 0 & $-2,2$ & 0,63 & $-2,51$ & 26,6 & 116,6 \\
\hline 5 & 2,414 & 2,56 & 2,549 & 2,413 & 2,562 & 2,541 & $-0,02$ & 0,04 & $-0,16$ & 0,18 & $-0,16$ & 40,0 & 130,0 \\
\hline 6 & 2,499 & 2,395 & 2,4625 & 2,492 & 2,394 & 2,456 & $-0,14$ & $-0,02$ & $-0,13$ & 0,00 & $-0,16$ & 19,9 & 109,9 \\
\hline 7 & 2,577 & 2,498 & 2,685 & 2,571 & 2,653 & 2,671 & $-0,12$ & 3,1 & $-0,28$ & - & $-0,28$ & - & - \\
\hline 8 & 2,654 & 2,5675 & 2,626 & 2,651 & 2,568 & 2,6235 & $-0,06$ & 0,01 & $-0,05$ & 0,02 & $-0,07$ & 17,8 & 107,8 \\
\hline 9 & 2,61 & 2,552 & 2,708 & 2,706 & 2,549 & 2,8 & 1,92 & $-0,06$ & 1,84 & - & - & - & - \\
\hline 10 & 2,415 & 2,7765 & 2,655 & 2,451 & 2,7735 & 2,666 & 0,72 & $-0,06$ & 0,22 & 0,74 & $\begin{array}{l}-0,08 \\
\end{array}$ & $-7,9$ & 82,1 \\
\hline 11 & 2,735 & 2,6265 & 2,5845 & 2,733 & 2,653 & 2,557 & $-0,04$ & 0,53 & $-0,55$ & - & $-0,55$ & - & - \\
\hline 12 & 2,502 & 2,8365 & 2,5005 & 2,607 & 2,828 & 2,474 & 2,1 & $-0,17$ & $-0,53$ & - & $-0,53$ & - & - \\
\hline 13 & 2,487 & 2,5815 & 2,434 & 2,505 & 2,581 & 2,432 & 0,36 & $-0,01$ & $-0,04$ & 0,46 & $-0,11$ & $-24,6$ & 65,4 \\
\hline 14 & 2,543 & 2,791 & 2,554 & 2,5455 & 2,795 & 2,5555 & 0,05 & 0,08 & 0,03 & 0,10 & 0,03 & 33,4 & 123,4 \\
\hline 15 & 2,947 & 2,73 & 3,032 & 3,211 & 2,772 & 3,044 & 5,28 & 0,84 & 0,24 & - & - & - & - \\
\hline 16 & 2,4865 & 2,63 & 2,84 & 2,545 & 2,882 & 2,819 & 1,17 & 5,04 & $-0,42$ & - & $-0,42$ & - & - \\
\hline 17 & 2,265 & 2,662 & 2,675 & 2,259 & 2,653 & 2,664 & $-0,12$ & $-0,18$ & $-0,22$ & $-0,07$ & $\begin{array}{l}-0,23 \\
\end{array}$ & $\begin{array}{l}-33,4 \\
\end{array}$ & 56,6 \\
\hline 18 & 2,576 & 2,551 & 2,803 & 2,57 & 2,55 & 2,799 & $-0,12$ & $-0,02$ & $-0,08$ & $-0,02$ & $-0,12$ & 5,7 & 95,7 \\
\hline 19 & 2,345 & 2,6015 & 2,4 & 2,3435 & 2,609 & 2,394 & $-0,03$ & 0,15 & $-0,12$ & 0,26 & $-0,14$ & 31,7 & 121,7 \\
\hline 20 & 2,579 & 2,663 & 2,409 & 1,579 & 2,656 & 2,406 & -20 & $-0,14$ & $-0,06$ & 4,03 & $-24,17$ & $-22,6$ & 67,4 \\
\hline
\end{tabular}
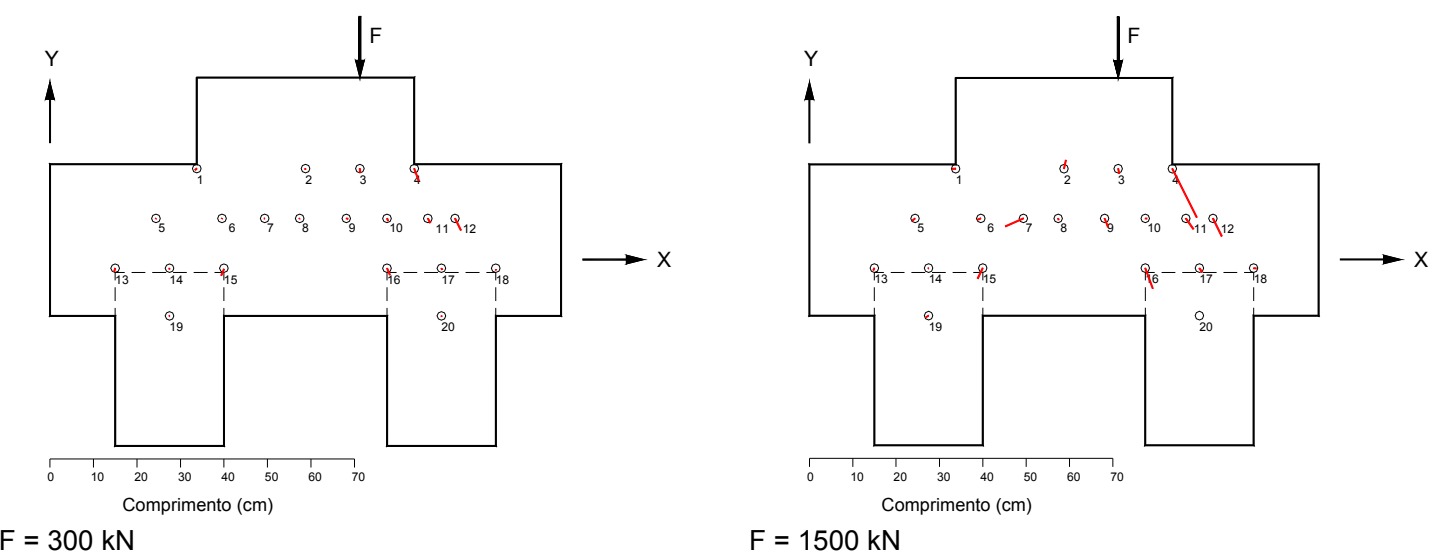

Figura 5.52 - Intensidades das deformações principais, modelo B35P50E25e12,5. 
Descrição e apresentação dos resultados experimentais

Tabela 5.14 - Modelo B45P50E25e0.

\begin{tabular}{|c|c|c|c|c|c|c|c|c|c|c|c|c|c|}
\hline \multicolumn{14}{|c|}{$F=750 \mathrm{kN}-$ antes da primeira fissura } \\
\hline \multirow{2}{*}{ Pto. } & \multicolumn{3}{|c|}{ Leitura incial $-\ell_{0}$} & \multicolumn{3}{|c|}{ Leitura final $-\ell$} & \multicolumn{3}{|c|}{ Deformações (\%o) } & \multicolumn{2}{|c|}{ Def. Prin. (\%o) } & \multicolumn{2}{|c|}{ Dir. Prin. $\left(^{\circ}\right)$} \\
\hline & $0^{\circ}$ & $90^{\circ}$ & $45^{\circ}$ & $0^{\circ}$ & $90^{\circ}$ & $45^{\circ}$ & $\varepsilon_{0^{\circ}}$ & $\varepsilon_{90^{\circ}}$ & $\varepsilon_{45^{\circ}}$ & $\varepsilon_{1}$ & $\varepsilon_{2}$ & $\alpha_{1}$ & $\alpha_{2}$ \\
\hline 1 & 2,669 & 2,858 & 2,889 & 2,671 & 2,859 & 2,885 & 0,04 & 0,02 & $-0,08$ & 0,14 & $-0,08$ & $-42,4$ & 47,6 \\
\hline 2 & 2,534 & 2,727 & 2,383 & 2,544 & 2,729 & 2,384 & 0,2 & 0,04 & 0,02 & 0,25 & $-0,01$ & $-25,7$ & 64,3 \\
\hline 3 & 2,852 & 3,087 & 3,152 & 2,8565 & 3,0925 & 3,163 & 0,09 & 0,11 & 0,22 & 0,22 & $-0,02$ & $-42,6$ & 47,4 \\
\hline 4 & 2,504 & 2,5745 & 2,6025 & 2,5115 & 2,571 & 2,6 & 0,15 & $-0,07$ & $-0,05$ & 0,18 & $-0,10$ & $-19,6$ & 70,4 \\
\hline 5 & 2,7055 & 2,605 & 2,658 & 2,707 & 2,609 & 2,658 & 0,03 & 0,08 & 0 & 0,12 & $-0,01$ & 32,8 & 122,8 \\
\hline 6 & 2,594 & 2,539 & 2,642 & 2,586 & 2,536 & 2,64 & $-0,16$ & $-0,06$ & $-0,04$ & $-0,02$ & $-0,20$ & $-27,2$ & $\begin{array}{ll}62,8 \\
\end{array}$ \\
\hline 7 & 2,3855 & 2,472 & 2,457 & 2,389 & 2,461 & 2,459 & 0,07 & $-0,22$ & 0,04 & 0,11 & $-0,26$ & 19,2 & 109,2 \\
\hline 8 & 2,62 & 2,646 & 2,566 & 2,624 & 2,6465 & 2,567 & 0,08 & 0,01 & 0,02 & 0,09 & 0,00 & $\begin{array}{l}-17,8 \\
\end{array}$ & 72,2 \\
\hline 9 & 2,321 & 2,549 & 2,706 & 2,323 & 2,548 & 2,7075 & 0,04 & $-0,02$ & 0,03 & 0,05 & $-0,03$ & $\begin{array}{ll}16,8 \\
\end{array}$ & 106,8 \\
\hline 10 & 2,41 & 2,67 & 2,591 & 2,424 & 2,672 & 2,588 & 0,28 & 0,04 & $-0,06$ & 0,41 & $-0,09$ & $-30,7$ & 59,3 \\
\hline 11 & 2,587 & 2,643 & 2,554 & 2,59 & 2,643 & 2,557 & 0,06 & 0 & 0,06 & 0,07 & $-0,01$ & 22,5 & 112,5 \\
\hline 12 & 2,7075 & 2,765 & 2,729 & 2,7275 & 2,764 & 2,7325 & 0,4 & $-0,02$ & 0,07 & 0,43 & $-0,05$ & $-14,9$ & 75,1 \\
\hline 13 & 2,696 & 2,47 & 2,8165 & 2,698 & 2,47 & 2,8185 & 0,04 & 0 & 0,04 & 0,05 & $-0,01$ & 22,5 & 112,5 \\
\hline 14 & 2,435 & 2,498 & 2,836 & 2,452 & 2,4965 & 2,8385 & 0,34 & $-0,03$ & 0,05 & 0,37 & $-0,06$ & $\begin{array}{l}-14,8 \\
\end{array}$ & 75,2 \\
\hline 15 & 2,4995 & 2,66 & 2,6045 & 2,502 & 2,659 & 2,604 & 0,05 & $-0,02$ & $-0,01$ & 0,06 & $-0,03$ & $-17,8$ & 72,2 \\
\hline 16 & 2,731 & 2,681 & 2,46 & 2,735 & 2,6805 & 2,465 & 0,08 & $-0,01$ & 0,1 & 0,11 & $-0,04$ & 27,7 & 117,7 \\
\hline 17 & 2,789 & 2,674 & 2,6555 & 2,788 & 2,6715 & 2,6555 & $-0,02$ & $-0,05$ & 0 & 0,00 & $-0,07$ & 33,4 & 123,4 \\
\hline 18 & 2,524 & 2,528 & 2,524 & 2,526 & 2,5265 & 2,525 & 0,04 & $-0,03$ & 0,02 & 0,04 & $-0,03$ & 11,6 & 101,6 \\
\hline \multicolumn{14}{|c|}{$F=3100 \mathrm{kN}$} \\
\hline \multirow{2}{*}{ Pto. } & \multicolumn{3}{|c|}{ Leitura incial - $\ell_{0}$} & \multicolumn{3}{|c|}{ Leitura final $-\ell$} & \multicolumn{3}{|c|}{ Deformações (\%o) } & \multicolumn{2}{|c|}{ Def. Prin. (\%o) } & \multicolumn{2}{|c|}{ Dir. Prin. $\left({ }^{\circ}\right)$} \\
\hline & $0^{\circ}$ & $90^{\circ}$ & $45^{\circ}$ & $0^{\circ}$ & $90^{\circ}$ & $45^{\circ}$ & $\varepsilon_{0^{\circ}}$ & $\varepsilon_{90^{\circ}}$ & $\varepsilon_{45^{\circ}}$ & $\varepsilon_{1}$ & $\varepsilon_{2}$ & $\alpha_{1}$ & $\alpha_{2}$ \\
\hline 1 & 2,669 & 2,858 & 2,889 & 2,6225 & 2,808 & 2,836 & $-0,93$ & -1 & $-1,06$ & $-0,86$ & $-1,07$ & $-34,9$ & 55,1 \\
\hline 2 & 2,534 & 2,727 & 2,383 & 2,58 & 2,69 & 2,355 & 0,92 & $-0,74$ & $-0,56$ & 1,14 & $-0,96$ & $-19,0$ & 71,0 \\
\hline 3 & 2,852 & 3,087 & 3,152 & 2,858 & 3,069 & 3,152 & 0,12 & $-0,36$ & 0 & 0,15 & $-0,39$ & 13,3 & 103,3 \\
\hline 4 & 2,504 & 2,5745 & 2,6025 & 2,5035 & 2,542 & 2,5656 & $-0,01$ & $-0,65$ & $-0,738$ & 0,19 & $-0,85$ & $-25,9$ & 64,1 \\
\hline 5 & 2,7055 & 2,605 & 2,658 & 2,701 & 2,584 & 2,727 & $-0,09$ & $-0,42$ & 1,38 & 1,39 & $-1,90$ & 42,1 & 132,1 \\
\hline 6 & 2,594 & 2,539 & 2,642 & 2,615 & 2,482 & 2,599 & 0,42 & $-1,14$ & $-0,86$ & 0,57 & $-1,29$ & $-16,3$ & 73,7 \\
\hline 7 & 2,3855 & 2,472 & 2,457 & 2,397 & 2,441 & 2,421 & 0,23 & $-0,62$ & $-0,72$ & 0,48 & $-0,87$ & $-25,5$ & 64,5 \\
\hline 8 & 2,62 & 2,646 & 2,566 & 2,6165 & 2,6335 & 2,549 & $-0,07$ & $-0,25$ & $-0,34$ & - & $-0,34$ & - & - \\
\hline 9 & 2,321 & 2,549 & 2,706 & 2,3165 & 2,544 & 2,707 & $-0,09$ & $-0,1$ & 0,02 & 0,02 & $-0,21$ & 43,8 & 133,8 \\
\hline 10 & 2,41 & 2,67 & 2,591 & 2,4225 & 2,666 & 2,575 & 0,25 & $-0,08$ & $-0,32$ & 0,52 & $-0,35$ & $-33,9$ & 56,1 \\
\hline 11 & 2,587 & 2,643 & 2,554 & 2,5765 & 2,627 & 2,537 & $-0,21$ & $-0,32$ & $-0,34$ & $-0,17$ & $-0,36$ & $-26,9$ & 63,1 \\
\hline 12 & 2,7075 & 2,765 & 2,729 & 3,167 & 2,7265 & 2,8275 & 9,19 & $-0,77$ & 1,97 & - & - & - & - \\
\hline 13 & 2,696 & 2,47 & 2,8165 & 2,694 & 2,453 & 2,815 & $-0,04$ & $-0,34$ & $\begin{array}{l}-0,03 \\
\end{array}$ & 0,03 & $-0,41$ & 23,4 & 113,4 \\
\hline 14 & 2,435 & 2,498 & 2,836 & 2,888 & 2,467 & 2,839 & 9,06 & $-0,62$ & 0,06 & - & - & - & - \\
\hline 15 & 2,4995 & 2,66 & 2,6045 & 2,4905 & 2,641 & 2,591 & $-0,18$ & $\begin{array}{l}-0,38 \\
\end{array}$ & $\begin{array}{l}-0,27 \\
\end{array}$ & $-0,18$ & $-0,38$ & 2,9 & 92,9 \\
\hline 16 & 2,731 & 2,681 & 2,46 & 2,733 & 2,68 & 2,462 & 0,04 & $-0,02$ & 0,04 & 0,05 & $-0,03$ & 22,5 & 112,5 \\
\hline 17 & 2,789 & 2,674 & 2,6555 & 2,793 & 2,6295 & 2,619 & 0,08 & $-0,89$ & $-0,73$ & 0,18 & $-0,99$ & $-16,9$ & 73,1 \\
\hline 18 & 2,524 & 2,528 & 2,524 & 2,529 & 2,479 & 2,495 & 0,1 & $-0,98$ & $-0,58$ & 0,12 & $-1,00$ & $\begin{array}{l}-7,3 \\
\end{array}$ & 82,7 \\
\hline
\end{tabular}
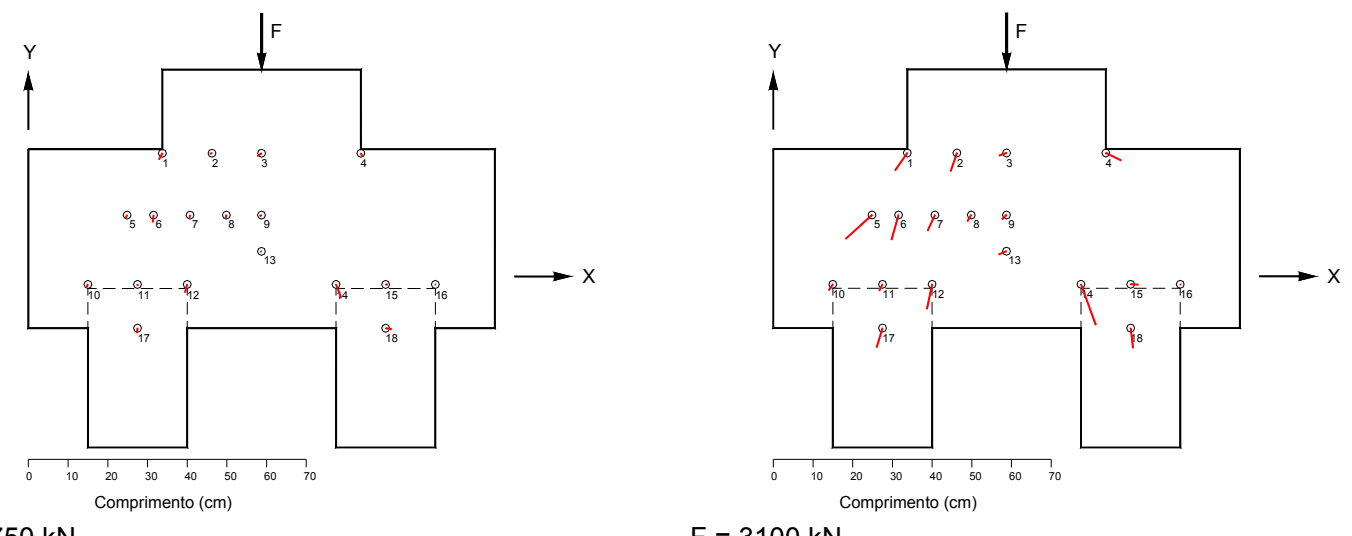

$\mathrm{F}=750 \mathrm{kN}$

$\mathrm{F}=3100 \mathrm{kN}$

Figura 5.53 - Intensidades das deformações principais, modelo B35P50E25e12,5. 
Tabela 5.15 - Modelo B45P50E25e12,5.

\begin{tabular}{|c|c|c|c|c|c|c|c|c|c|c|c|c|c|}
\hline \multicolumn{14}{|c|}{$F=350 \mathrm{kN}-$ antes da primeira fissura } \\
\hline \multirow{2}{*}{ Pto. } & \multicolumn{3}{|c|}{ Leitura incial $-\ell_{0}$} & \multicolumn{3}{|c|}{ Leitura final $-\ell$} & \multicolumn{3}{|c|}{ Deformações (\%o) } & \multicolumn{2}{|c|}{ Def. Prin. (\%o) } & \multicolumn{2}{|c|}{ Dir. Prin. $\left({ }^{\circ}\right)$} \\
\hline & $0^{\circ}$ & $90^{\circ}$ & $45^{\circ}$ & $0^{\circ}$ & $90^{\circ}$ & $45^{\circ}$ & $\varepsilon_{0^{\circ}}$ & $\varepsilon_{90^{\circ}}$ & $\varepsilon_{45^{\circ}}$ & $\varepsilon_{1}$ & $\varepsilon_{2}$ & $\alpha_{1}$ & $\alpha_{2}$ \\
\hline 1 & 2,654 & 2,37 & 2,408 & 2,541 & 2,363 & 2,3905 & $-2,26$ & $-0,14$ & $-0,35$ & 0,16 & $-2,56$ & $-19,4$ & 70,6 \\
\hline 2 & 2,499 & 2,82 & 2,713 & 2,491 & 2,517 & 2,71 & $-0,16$ & $-6,06$ & $-0,06$ & 1,13 & $-7,35$ & 23,0 & 113,0 \\
\hline 3 & 2,802 & 2,007 & 2,565 & 2,801 & 2,08 & 2,564 & $-0,02$ & 1,46 & $-0,02$ & 1,77 & $-0,33$ & 22,5 & 112,5 \\
\hline 4 & 2,6275 & 1,992 & 2,437 & 2,627 & 1,99 & 2,434 & $-0,01$ & $-0,04$ & $-0,06$ & 0,01 & $-0,06$ & $-33,4$ & 56,6 \\
\hline 5 & 2,6295 & 2,4485 & 2,593 & 2,638 & 2,4995 & 2,587 & 0,17 & 1,02 & $-0,12$ & 1,43 & $-0,24$ & 29,6 & 119,6 \\
\hline 6 & 2,088 & 2,514 & 2,751 & 2,09 & 2,509 & 2,746 & 0,04 & $-0,1$ & $-0,1$ & 0,07 & $-0,13$ & $-22,5$ & 67,5 \\
\hline 7 & 2,742 & 2,677 & 2,574 & 2,7475 & 2,674 & 2,572 & 0,11 & $-0,06$ & $-0,04$ & 0,13 & $-0,08$ & $\begin{array}{l}-18,7 \\
\end{array}$ & 71,3 \\
\hline 8 & 2,553 & 2,498 & 2,589 & 2,567 & 2,501 & 2,5995 & 0,28 & 0,06 & 0,21 & 0,29 & 0,05 & 10,0 & 100,0 \\
\hline 9 & 2,793 & 2,133 & 2,872 & 2,7945 & 2,1325 & 2,874 & 0,03 & $-0,01$ & 0,04 & 0,05 & $-0,03$ & 28,2 & 118,2 \\
\hline 10 & 2,5245 & 2,479 & 2,5475 & 2,545 & 2,4815 & 2,547 & 0,41 & 0,05 & $-0,01$ & 0,53 & $-0,07$ & $-26,6$ & 63,4 \\
\hline 11 & 2,3905 & 2,575 & 2,6595 & 2,3855 & 2,575 & 2,662 & $-0,1$ & 0 & 0,05 & 0,06 & $-0,16$ & $-31,7$ & 58,3 \\
\hline 12 & 2,441 & 2,5525 & 2,5545 & 2,443 & 2,552 & 2,553 & 0,04 & $-0,01$ & $-0,03$ & 0,07 & $-0,04$ & $-30,5$ & 59,5 \\
\hline 13 & 2,802 & 2,692 & 2,639 & 2,8035 & 2,689 & 2,633 & 0,03 & $-0,06$ & $-0,12$ & 0,10 & $-0,13$ & $-33,4$ & 56,6 \\
\hline 14 & 2,487 & 2,56 & 2,787 & 2,492 & 2,5615 & 2,7878 & 0,1 & 0,03 & 0,016 & 0,13 & 0,00 & $\begin{array}{l}-27,2 \\
\end{array}$ & 62,8 \\
\hline 15 & 2,5115 & 2,592 & 2,553 & 2,56 & 2,5965 & 2,576 & 0,97 & 0,09 & 0,46 & 0,98 & 0,08 & $-4,5$ & 85,5 \\
\hline 16 & 2,516 & 2,522 & 2,6215 & 2,514 & 2,527 & 2,6215 & $-0,04$ & 0,1 & 0 & 0,11 & $-0,05$ & 11,6 & 101,6 \\
\hline 17 & 2,656 & 2,735 & 2,8285 & 2,658 & 2,735 & 2,831 & 0,04 & 0 & 0,05 & 0,06 & $-0,02$ & 28,2 & 118,2 \\
\hline 18 & 2,816 & 2,648 & 2,578 & 2,817 & 2,6455 & 2,576 & 0,02 & $-0,05$ & $-0,04$ & 0,03 & $-0,06$ & $-17,8$ & 72,2 \\
\hline 19 & 2,657 & 2,558 & 2,518 & 2,656 & 2,548 & 2,516 & $-0,02$ & $-0,2$ & $-0,04$ & 0,00 & $-0,22$ & 18,9 & 108,9 \\
\hline 20 & 2,262 & 2,01 & 2,375 & 2,261 & 2,03 & 2,376 & $-0,02$ & 0,4 & 0,02 & 0,46 & $-0,08$ & 19,5 & 109,5 \\
\hline \multicolumn{14}{|c|}{$F=2300 \mathrm{kN}$} \\
\hline \multirow{2}{*}{ Pto. } & \multicolumn{3}{|c|}{ Leitura incial $-\ell_{0}$} & \multicolumn{3}{|c|}{ Leitura final $-\ell$} & \multicolumn{3}{|c|}{ Deformações (\%o) } & \multicolumn{2}{|c|}{ Def. Prin. (\%o) } & \multicolumn{2}{|c|}{ Dir. Prin. $\left({ }^{\circ}\right)$} \\
\hline & $0^{\circ}$ & $90^{\circ}$ & $45^{\circ}$ & $0^{\circ}$ & $90^{\circ}$ & $45^{\circ}$ & $\varepsilon_{0^{\circ}}$ & $\varepsilon_{90^{\circ}}$ & $\varepsilon_{45^{\circ}}$ & $\varepsilon_{1}$ & $\varepsilon_{2}$ & $\alpha_{1}$ & $\alpha_{2}$ \\
\hline 1 & 2,654 & 2,37 & 2,408 & 2,5625 & 2,318 & 2,31 & $-1,83$ & $-1,04$ & $-1,96$ & $-0,78$ & $-2,09$ & 26,52 & 116,5 \\
\hline 2 & 2,499 & 2,82 & 2,713 & 2,4865 & 2,782 & 2,7615 & $-0,25$ & $-0,76$ & 0,97 & 0,99 & $-2,00$ & 40,10 & 130,1 \\
\hline 3 & 2,802 & 2,007 & 2,565 & 2,794 & 1,9985 & 2,581 & $-0,16$ & $-0,17$ & 0,32 & - & - & - & \\
\hline 4 & 2,6275 & 1,992 & 2,437 & 2,629 & 1,99 & 2,438 & 0,03 & $-0,04$ & 0,02 & 0,04 & $-0,05$ & 17,77 & 107,8 \\
\hline 5 & 2,6295 & 2,4485 & 2,593 & 2,6305 & 2,4325 & 2,524 & 0,02 & $-0,32$ & $-1,38$ & 1,09 & $-1,39$ & $-41,07$ & 48,9 \\
\hline 6 & 2,088 & 2,514 & 2,751 & 2,275 & 2,4725 & 2,7715 & 3,74 & $-0,83$ & 0,41 & - & - & - & - \\
\hline 7 & 2,742 & 2,677 & 2,574 & 2,7575 & 2,6175 & 2,532 & 0,31 & $-1,19$ & $-0,84$ & 0,41 & $-1,29$ & $-14,04$ & 76,0 \\
\hline 8 & 2,553 & 2,498 & 2,589 & 2,559 & 2,481 & 2,582 & 0,12 & $-0,34$ & $-0,14$ & 0,12 & $-0,34$ & $-3,72$ & 86,3 \\
\hline 9 & 2,793 & 2,133 & 2,872 & 2,7955 & 2,1305 & 2,9615 & 0,05 & $-0,05$ & 1,79 & 1,79 & $-1,79$ & 44,20 & 134,2 \\
\hline 10 & 2,5245 & 2,479 & 2,5475 & 2,6485 & 2,483 & 2,508 & 2,48 & 0,08 & $-0,79$ & - & $\begin{array}{l}-0,79 \\
\end{array}$ & - & - \\
\hline 11 & 2,3905 & 2,575 & 2,6595 & 2,376 & 2,5655 & 2,647 & $-0,29$ & $-0,19$ & $-0,25$ & $-0,19$ & $-0,29$ & 5,65 & 95,7 \\
\hline 12 & 2,441 & 2,5525 & 2,5545 & 2,44 & 2,551 & 2,55 & $-0,02$ & $-0,03$ & $-0,09$ & 0,04 & $-0,09$ & $-42,80$ & 47,2 \\
\hline 13 & 2,802 & 2,692 & 2,639 & 2,817 & 2,6775 & 2,617 & 0,3 & $-0,29$ & $-0,44$ & 0,54 & $-0,53$ & $-28,23$ & 61,8 \\
\hline 14 & 2,487 & 2,56 & 2,787 & 2,4825 & 2,545 & 2,77 & $-0,09$ & $-0,3$ & $-0,34$ & $-0,02$ & $-0,37$ & $-27,05$ & 63,0 \\
\hline 15 & 2,5115 & 2,592 & 2,553 & 2,809 & 2,5495 & 2,598 & 5,95 & $-0,85$ & 0,9 & - & - & - & - \\
\hline 16 & 2,516 & 2,522 & 2,6215 & 2,7595 & 2,535 & 2,639 & 4,87 & 0,26 & 0,35 & - & - & - & - \\
\hline 17 & 2,656 & 2,735 & 2,8285 & 2,66 & 2,736 & 2,828 & 0,08 & 0,02 & $-0,01$ & 0,12 & $\begin{array}{c}-0,02 \\
\end{array}$ & $-31,72$ & 58,3 \\
\hline 18 & 2,816 & 2,648 & 2,578 & 2,817 & 2,645 & 2,576 & 0,02 & $-0,06$ & $-0,04$ & 0,02 & $-0,06$ & $-13,28$ & 76,7 \\
\hline 19 & 2,657 & 2,558 & 2,518 & 2,66 & 2,623 & 2,492 & 0,06 & 1,3 & $-0,52$ & 2,03 & $-0,67$ & 31,34 & 121,3 \\
\hline 20 & 2,262 & 2,01 & 2,375 & 2,258 & 1,999 & 2,369 & $-0,08$ & $-0,22$ & $-0,12$ & $-0,07$ & $-0,23$ & 11,60 & 101,6 \\
\hline
\end{tabular}
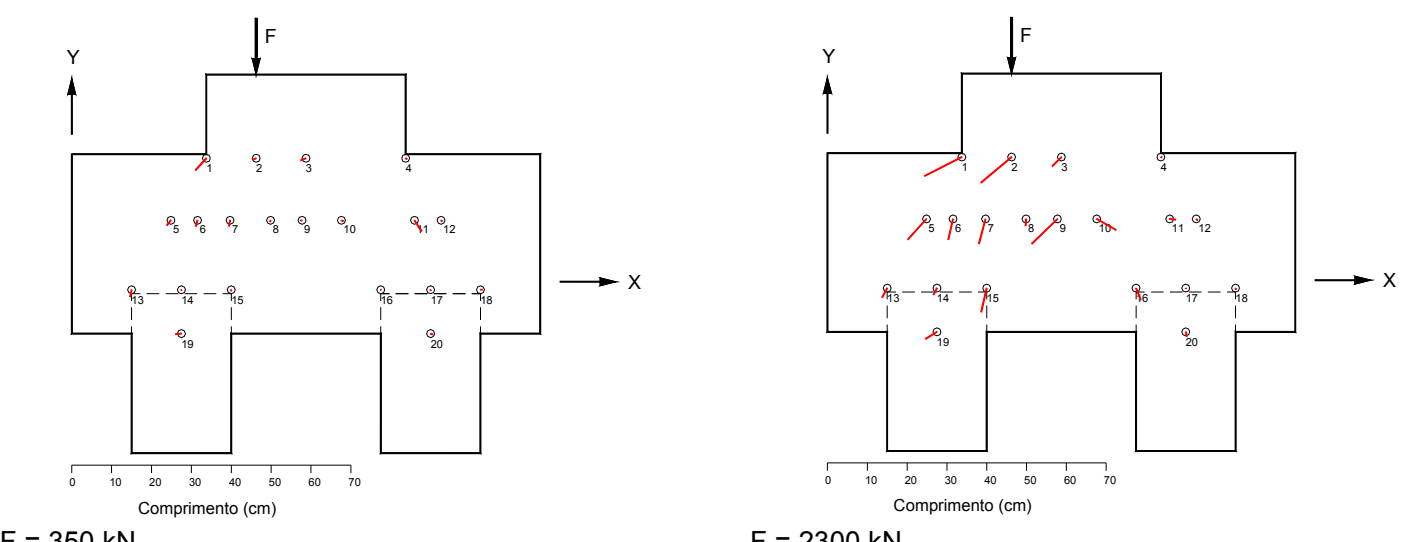

Figura 5.54 - Intensidades das deformações principais, modelo B45P50E25e12,5. 
Por meio dos diagramas anteriores verificam-se as regiões dos blocos mais solicitadas. Contata-se que as seções das estacas mais próximas das extremidades dos blocos apresentam pequenas deformações, portanto, considerar que a seção da estaca apresenta às mesmas intensidades de tensões não é correto.

\subsubsection{Aberturas das fissuras}

As aberturas das fissuras foram determinadas em função das diferenças de leituras obtidas por meio do extensômetro mecânico removível, nos diversos incrementos de forca aplicados. Tomou-se como referência, a primeira fissura que surgiu na face de cada modelo. Pelos mesmos motivos apresentados no item 5.3.2, os acompanhamentos das fissuras não foram realizados até o último incremento de força. As aberturas das fissuras foram calculadas com os deslocamentos relativos entre as pastilhas de aço referente às leituras na direção $x$ (Figura $5.4, \varepsilon_{0^{\circ}}$ ) do ponto considerado. As Tabelas 5.16 a 5.29 apresentam a evolução das fissuras ao longo do carregamento de cada modelo.

Em média, as aberturas de fissuras foram avaliadas até $69,45 \%$ da força última. Além, da justificativa apresentada acima, como o aumento da resistência à compressão do concreto provocado pela ação do tempo (ver item 5.3), alterou as forças teóricas previstas, não foi possível avaliar com precisão os incrementos de forças aplicados. As novas forças teóricas previstas só foram determinadas após os ensaios dos corpos-de-prova cilíndricos de concreto, os quais foram realizados após a conclusão dos ensaios de cada modelo. Apesar disso, pôde-se analisar o desenvolvimento das fissuras.

Tabela 5.16 - Acompanhamento das fissuras, Modelo B35P25E25e0, $F_{u}=1820,84 \mathrm{kN}$, ponto 11.

\begin{tabular}{c|c|c|c|c|c|c|c|c}
\hline \hline $\begin{array}{c}\text { Incremento de força - F } \\
(\mathrm{kN})\end{array}$ & 0 & 110 & 219 & 438 & 548 & 780 & 1005 & 1225 \\
\hline $\begin{array}{c}\mathrm{F} / \mathrm{F}_{\mathrm{u}} \\
(\%)\end{array}$ & 0 & 6,04 & 12,03 & 24,05 & 30,09 & 42,84 & 55,19 & 67,28 \\
\hline $\begin{array}{c}\text { Abertura das fissuras } \\
(\mathrm{mm})\end{array}$ & 0 & 0 & 0 & 0 & 0,147 & 0,23 & 0,263 & 0,266 \\
\hline $\begin{array}{c}\text { Abertura relativa entre } \\
\text { os incrementos de força } \\
(\mathrm{mm})\end{array}$ & 0 & 0 & 0 & 0 & 0.147 & 0,083 & 0,033 & 0,003 \\
\hline \hline
\end{tabular}


Tabela 5.17 - Acompanhamento das fissuras, Modelo B35P25E25e2,5, $F_{\mathrm{u}}=1688,42 \mathrm{kN}$, ponto 17.

\begin{tabular}{c|c|c|c|c|c|c|c}
\hline \hline $\begin{array}{c}\text { Incremento de força - F } \\
(\mathrm{kN})\end{array}$ & 0 & 145 & 435 & 825 & 970 & 1115 & 1260 \\
\hline $\begin{array}{c}\text { F/F } \\
(\%)\end{array}$ & 0 & 8,60 & 25,76 & 48,86 & 57,45 & 66,04 & 74,63 \\
\hline $\begin{array}{c}\text { Abertura das fissuras } \\
(\mathrm{mm})\end{array}$ & 0 & 0 & 0,171 & 0,34 & 0,397 & 0,436 & 0,47 \\
\hline $\begin{array}{c}\text { Abertura relativa entre } \\
\text { os incrementos de força } \\
(\mathrm{mm})\end{array}$ & 0 & 0 & 0,171 & 0,169 & 0,057 & 0,039 & 0,034 \\
\hline \hline
\end{tabular}

Tabela 5.18 - Acompanhamento das fissuras, Modelo B35P25E25e0A $A_{s w, c}, F_{u}=1880,01 \mathrm{kN}$, ponto 11 .

\begin{tabular}{c|c|c|c|c|c|c|c}
\hline \hline $\begin{array}{c}\text { Incremento de força - F } \\
(\mathrm{kN})\end{array}$ & 0 & 170 & 340 & 450 & 600 & 850 & 1100 \\
\hline $\begin{array}{c}\text { F/F } \\
(\%)\end{array}$ & 0 & 9,04 & 18,09 & 23,94 & 31,91 & 45,21 & 58,51 \\
\hline $\begin{array}{c}\text { Abertura das fissuras } \\
(\mathrm{mm})\end{array}$ & 0 & 0 & 0,087 & 0,118 & 0,146 & 0,229 & 0,295 \\
\hline $\begin{array}{c}\text { Abertura relativa entre } \\
\text { os incrementos de força } \\
(\mathrm{mm})\end{array}$ & 0 & 0 & 0,087 & 0,031 & 0,028 & 0,083 & 0,066 \\
\hline \hline
\end{tabular}

Tabela 5.19 - Acompanhamento das fissuras, Modelo B35P25E25e0A $\mathrm{sw}_{\mathrm{s}, 0}, \mathrm{~F}_{\mathrm{u}}=1406,16 \mathrm{kN}$, ponto 11.

\begin{tabular}{c|c|c|c|c|c|c}
\hline \hline $\begin{array}{c}\text { Incremento de força - F } \\
(\mathrm{kN})\end{array}$ & 0 & 170 & 340 & 510 & 680 & 1020 \\
\hline $\begin{array}{c}\mathrm{F} / \mathrm{F}_{\mathrm{u}} \\
(\%)\end{array}$ & 0 & 12,09 & 24,18 & 36,27 & 48,36 & 72,54 \\
\hline $\begin{array}{c}\text { Abertura das fissuras } \\
(\mathrm{mm})\end{array}$ & 0 & 0 & 0,118 & 0,161 & 0,221 & 0,228 \\
\hline $\begin{array}{c}\text { Abertura relativa entre } \\
\text { os incrementos de força } \\
(\mathrm{mm})\end{array}$ & .0 & 0 & 0,118 & 0,043 & 0,06 & 0,007 \\
\hline \hline
\end{tabular}

Tabela 5.20 - Acompanhamento das fissuras, Modelo B35P25E25e0CG, $F_{u}=1263,02 \mathrm{kN}$, ponto 11.

\begin{tabular}{c|c|c|c|c|c|c}
\hline \hline $\begin{array}{c}\text { Incremento de força - F } \\
(\mathrm{kN})\end{array}$ & 0 & 200 & 350 & 550 & 750 & 950 \\
\hline $\begin{array}{c}\mathrm{F} / \mathrm{F}_{\mathrm{u}} \\
(\%)\end{array}$ & 0 & 15,84 & 27,71 & 43,55 & 59,38 & 75,22 \\
\hline $\begin{array}{c}\text { Abertura das fissuras } \\
(\mathrm{mm})\end{array}$ & 0 & 0 & 0,081 & 0,152 & 0,239 & 0,334 \\
\hline $\begin{array}{c}\text { Abertura relativa entre } \\
\text { os incrementos de força } \\
(\mathrm{mm})\end{array}$ & .0 & 0 & 0,081 & 0,071 & 0,087 & 0,095 \\
\hline \hline
\end{tabular}


Tabela 5.21 - Acompanhamento das fissuras, Modelo B45P25E25e0, $F_{u}=2276,17 \mathrm{kN}$, ponto 11.

\begin{tabular}{c|c|c|c|c|c|c|c}
\hline \hline $\begin{array}{c}\text { Incremento de força - F } \\
(\mathrm{kN})\end{array}$ & 0 & 200 & 400 & 650 & 900 & 1200 & 1700 \\
\hline $\begin{array}{c}\mathrm{F} / \mathrm{F}_{\mathrm{u}} \\
(\%)\end{array}$ & 0 & 8,79 & 17,57 & 28,56 & 39,54 & 52,70 & 74,69 \\
\hline $\begin{array}{c}\text { Abertura das fissuras } \\
(\mathrm{mm})\end{array}$ & 0 & 0 & 0,093 & 0,159 & 0,217 & 0,311 & 0,499 \\
\hline $\begin{array}{c}\text { Abertura relativa entre } \\
\text { os incrementos de força } \\
(\mathrm{mm})\end{array}$ & .0 & 0 & 0,093 & 0,066 & 0,058 & 0,094 & 0,188 \\
\hline \hline
\end{tabular}

Tabela 5.22 - Acompanhamento das fissuras, Modelo B45P25E25e5, $F_{u}=1972,17 \mathrm{kN}$, ponto 13.

\begin{tabular}{c|c|c|c|c|c|c}
\hline \hline $\begin{array}{c}\text { Incremento de força - F } \\
(\mathrm{kN})\end{array}$ & 0 & 200 & 400 & 700 & 1100 & 1500 \\
\hline $\begin{array}{c}\mathrm{F} / \mathrm{F}_{\mathrm{u}} \\
(\%)\end{array}$ & 0 & 10,14 & 20,28 & 35,49 & 55,77 & 76,06 \\
\hline $\begin{array}{c}\text { Abertura das fissuras } \\
(\mathrm{mm})\end{array}$ & 0 & 0 & 0 & 0,157 & 0,249 & 0,384 \\
\hline $\begin{array}{c}\text { Abertura relativa entre } \\
\text { os incrementos de força } \\
(\mathrm{mm})\end{array}$ & .0 & 0 & 0 & 0,157 & 0,092 & 0,135 \\
\hline \hline
\end{tabular}

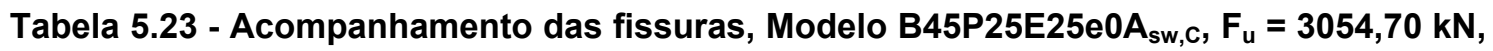
ponto 11.

\begin{tabular}{c|c|c|c|c|c|c|c|c}
\hline \hline $\begin{array}{c}\text { Incremento de força - F } \\
(\mathrm{kN})\end{array}$ & 0 & 200 & 450 & 700 & 1000 & 1400 & 1700 & 2000 \\
\hline $\begin{array}{c}\mathrm{F} / \mathrm{F}_{\mathrm{u}} \\
(\%)\end{array}$ & 0 & 6,55 & 14,73 & 22,92 & 32,74 & 45,83 & 55,65 & 65,47 \\
\hline $\begin{array}{c}\text { Abertura das fissuras } \\
(\mathrm{mm})\end{array}$ & 0 & 0 & 0 & 0,101 & 0,163 & 0,248 & 0,320 & 0,407 \\
\hline $\begin{array}{c}\text { Abertura relativa entre } \\
\text { os incrementos de força } \\
(\mathrm{mm})\end{array}$ & .0 & 0 & 0 & 0,101 & 0,062 & 0,085 & 0,072 & 0,087 \\
\hline \hline
\end{tabular}

Tabela 5.24 - Acompanhamento das fissuras, Modelo B45P25E25e0A $A_{s w, 0}, F_{u}=2089,98 \mathrm{kN}$, ponto 11.

\begin{tabular}{c|c|c|c|c|c|c}
\hline \hline $\begin{array}{c}\text { Incremento de força - F } \\
(\mathrm{kN})\end{array}$ & 0 & 250 & 500 & 750 & 1000 & 1500 \\
\hline $\begin{array}{c}\mathrm{F} / \mathrm{F}_{\mathrm{u}} \\
(\%)\end{array}$ & 0 & 11,96 & 23,92 & 35,89 & 47,85 & 71,77 \\
\hline $\begin{array}{c}\text { Abertura das fissuras } \\
(\mathrm{mm})\end{array}$ & 0 & 0 & 0,076 & 0,166 & 0,186 & 0,292 \\
\hline $\begin{array}{c}\text { Abertura relativa entre } \\
\text { os incrementos de força } \\
(\mathrm{mm})\end{array}$ & .0 & 0 & 0,076 & 0,09 & 0,02 & 0,106 \\
\hline \hline
\end{tabular}


Tabela 5.25 - Acompanhamento das fissuras, Modelo B45P25E25e0CG, $F_{u}=2270,39 \mathrm{kN}$, ponto 11.

\begin{tabular}{c|c|c|c|c|c|c|c}
\hline \hline $\begin{array}{c}\text { Incremento de força - F } \\
(\mathrm{kN})\end{array}$ & 0 & 200 & 400 & 650 & 900 & 1300 & 1700 \\
\hline $\begin{array}{c}\text { F/F } \\
(\%)\end{array}$ & 0 & 0 & 8,81 & 28,63 & 39,64 & 57,26 & 74,88 \\
\hline $\begin{array}{c}\text { Abertura das fissuras } \\
(\mathrm{mm})\end{array}$ & 0 & 0 & 0 & 0,084 & 0,123 & 0,165 & 0,2 \\
\hline $\begin{array}{c}\text { Abertura relativa entre } \\
\text { os incrementos de força } \\
(\mathrm{mm})\end{array}$ & .0 & 0 & 0 & 0,084 & 0,039 & 0,042 & 0,035 \\
\hline \hline
\end{tabular}

Tabela 5.26 - Acompanhamento das fissuras, Modelo B35P50E25e0, $F_{u}=3877,27 \mathrm{kN}$, ponto 12.

\begin{tabular}{c|c|c|c|c|c|c|c|c}
\hline \hline $\begin{array}{c}\text { Incremento de força - F } \\
(\mathrm{kN})\end{array}$ & 0 & 250 & 500 & 800 & 1200 & 1700 & 2200 & 2800 \\
\hline $\begin{array}{c}\text { F/F } \\
(\%)\end{array}$ & 0 & 6,45 & 12,90 & 20,63 & 30,95 & 43,85 & 56,74 & 72,22 \\
\hline $\begin{array}{c}\text { Abertura das fissuras } \\
(\mathrm{mm})\end{array}$ & 0 & 0 & 0,074 & 0,115 & 0,158 & 0,207 & 0,268 & 0,364 \\
\hline $\begin{array}{c}\text { Abertura relativa entre } \\
\text { os incrementos de força } \\
(\mathrm{mm})\end{array}$ & .0 & 0 & 0,074 & 0,041 & 0,043 & 0,049 & 0,061 & 0,096 \\
\hline \hline
\end{tabular}

Tabela 5.27 - Acompanhamento das fissuras, Modelo B35P50E25e12,5, $F_{u}=3202,27 \mathrm{kN}$, ponto 16.

\begin{tabular}{c|c|c|c|c|c}
\hline \hline $\begin{array}{c}\text { Incremento de força - F } \\
(\mathrm{kN})\end{array}$ & 0 & 300 & 650 & 1100 & 1500 \\
\hline $\begin{array}{c}\mathrm{F} / \mathrm{F}_{\mathrm{u}} \\
(\%)\end{array}$ & 0 & 9,37 & 20,30 & 34,35 & 46,84 \\
\hline $\begin{array}{c}\text { Abertura das fissuras } \\
(\mathrm{mm})\end{array}$ & 0 & 0 & 0,051 & 0,055 & 0,059 \\
\hline $\begin{array}{c}\text { Abertura relativa entre } \\
\text { os incrementos de força } \\
(\mathrm{mm})\end{array}$ & .0 & 0 & 0,051 & 0,004 & 0,04 \\
\hline \hline
\end{tabular}

Tabela 5.28 - Acompanhamento das fissuras, Modelo B45P50E25e0, $F_{u}=4174,94 \mathrm{kN}$, ponto 12.

\begin{tabular}{c|c|c|c|c|c|c|c}
\hline \hline $\begin{array}{c}\text { Incremento de força - F } \\
(\mathrm{kN})\end{array}$ & 0 & 350 & 750 & 1150 & 1600 & 2300 & 3100 \\
\hline $\begin{array}{c}\mathrm{F} / \mathrm{F}_{\mathrm{u}} \\
(\%)\end{array}$ & 0 & 8,38 & 17,96 & 27,55 & 38,32 & 55,09 & 74,25 \\
\hline $\begin{array}{c}\text { Abertura das fissuras } \\
(\mathrm{mm})\end{array}$ & 0 & 0 & 0 & 0,022 & 0,199 & 0,309 & 0,456 \\
\hline $\begin{array}{c}\text { Abertura relativa entre } \\
\text { os incrementos de força } \\
(\mathrm{mm})\end{array}$ & .0 & 0 & 0 & 0,022 & 0,177 & 0,11 & 0,144 \\
\hline \hline
\end{tabular}


Tabela 5.29 - Acompanhamento das fissuras, Modelo B45P50E25e12,5, $F_{u}=3385,55 \mathrm{kN}$, ponto 15.

\begin{tabular}{c|c|c|c|c|c|c}
\hline \hline $\begin{array}{c}\text { Incremento de força - F } \\
(\mathrm{kN})\end{array}$ & 0 & 350 & 750 & 1200 & 1700 & 2300 \\
\hline $\begin{array}{c}\mathrm{F} / \mathrm{F}_{\mathrm{u}} \\
(\%)\end{array}$ & 0 & 10,34 & 22,15 & 35,44 & 50,21 & 67,94 \\
\hline $\begin{array}{c}\text { Abertura das fissuras } \\
(\mathrm{mm})\end{array}$ & 0 & 0 & 0,136 & 0,193 & 0,243 & 0,298 \\
\hline $\begin{array}{c}\text { Abertura relativa entre } \\
\text { os incrementos de força } \\
(\mathrm{mm})\end{array}$ & .0 & 0 & 0,136 & 0,057 & 0,05 & 0,055 \\
\hline \hline
\end{tabular}

A Tabela 5.30 apresenta a máxima abertura de fissura registrada no último incremento de força aplicado para cada modelo, considerando todos os pontos de medidas de deslocamentos relativos entre as pastilhas de aço.

Tabela 5.30 - Máximas aberturas de fissuras.

\begin{tabular}{|c|c|c|c|c|c|c|c|}
\hline \multirow[b]{2}{*}{ Séries } & \multirow[b]{2}{*}{ Modelos } & \multirow[b]{2}{*}{ Ponto } & \multirow{2}{*}{$\begin{array}{l}F / F_{u} \\
(\%)\end{array}$} & \multirow{2}{*}{$\begin{array}{c}\text { Abertura } \\
\text { máxima } \\
(\mathrm{mm})\end{array}$} & \multirow{2}{*}{$\begin{array}{l}\text { Ângulo de } \\
\text { inclinação } \\
\text { da fissura }\end{array}$} & \multicolumn{2}{|c|}{ Valores médios } \\
\hline & & & & & & $\begin{array}{c}\text { Abertura } \\
(\mathrm{mm})\end{array}$ & Ângulo \\
\hline \multirow{5}{*}{ B35P25 } & B35P25E25e0 & 14 & 67,28 & 0,32 & $57^{\circ}$ & \multirow{5}{*}{0,37} & \multirow{5}{*}{$53,2^{\circ}$} \\
\hline & B35P25E25e2,5 & 17 & 74,63 & 0,47 & $60^{\circ}$ & & \\
\hline & B35P25E25e0A $A_{s w, C}$ & 13 & 58,51 & 0,33 & $58^{\circ}$ & & \\
\hline & $\mathrm{B}_{5}$ 25E25e0A $\mathrm{sw}, 0$ & 7 & 72,54 & 0,30 & $55^{\circ}$ & & \\
\hline & B35P25E25e0CG & 13 & 75,22 & 0,41 & $36^{\circ}$ & & \\
\hline \multirow{5}{*}{ B45P25 } & B45P25E25e0 & 11 & 74,69 & 0,50 & $60^{\circ}$ & \multirow{5}{*}{0,39} & \multirow{5}{*}{$60,4^{\circ}$} \\
\hline & B45P25E25e5 & 13 & 76,06 & 0,38 & $60^{\circ}$ & & \\
\hline & B45P25E25e0A $\mathrm{sw}, \mathrm{C}$ & 11 & 65,47 & 0,41 & $50^{\circ}$ & & \\
\hline & $\mathrm{B} 45 \mathrm{P} 25 \mathrm{E} 25 \mathrm{e} 0 \mathrm{~A}_{\mathrm{sw}, 0}$ & 11 & 71,77 & 0,29 & $72^{\circ}$ & & \\
\hline & B45P25E25e0CG & 13 & 74,88 & 0,37 & $60^{\circ}$ & & \\
\hline \multirow{2}{*}{ B35P50 } & B35P50E25e0 & 12 & 72,22 & 0,37 & $65^{\circ}$ & \multirow{2}{*}{0,32} & \multirow{2}{*}{$57,5^{\circ}$} \\
\hline & B35P50E25e12,5 & 15 & 46,84 & 0,26 & $50^{\circ}$ & & \\
\hline \multirow{2}{*}{ B45P50 } & B45P50E25e0 & 12 & 74,25 & 0,46 & $60^{\circ}$ & \multirow{2}{*}{0,38} & \multirow{2}{*}{$55^{\circ}$} \\
\hline & B45P50E25e12,5 & 15 & 67,94 & 0,30 & $50^{\circ}$ & & \\
\hline
\end{tabular}

Constata-se por meio da Tabela 5.30, que, o modelo B35P50E25e0A $\mathrm{A}_{\mathrm{sw}, 0}$, o qual, apenas foi projetado e detalhado com a armadura principal de tração, é o único que apresenta valor máximo de abertura de fissura em local diferente da posição da seção da estaca mais afastada da extremidade do bloco. Em função da ausência de armadura transversal, a máxima abertura da fissura se desenvolveu no meio da altura do bloco, evidenciando a força de tração perpendicular à biela de compressão, o fendilhamento. As Figuras 5.55 a 5.68 apresentam os blocos fissurados após a força de ruptura. Por meio dessas figuras é possível observar o desenvolvimento das fissuras durante os ensaios. 


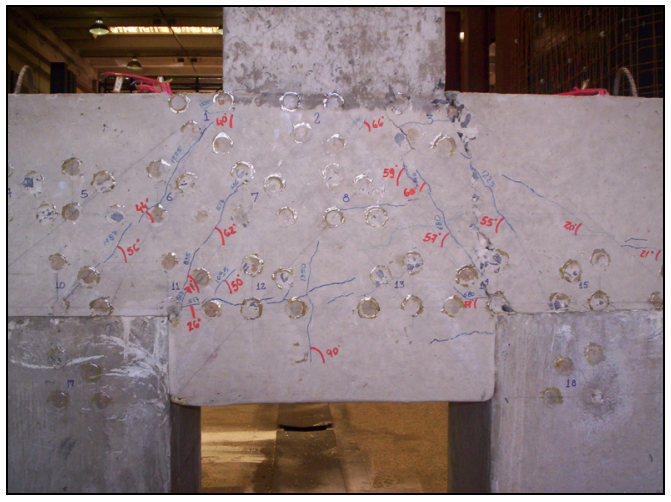

Figura 5.55 - Modelo B35P25E25e0.

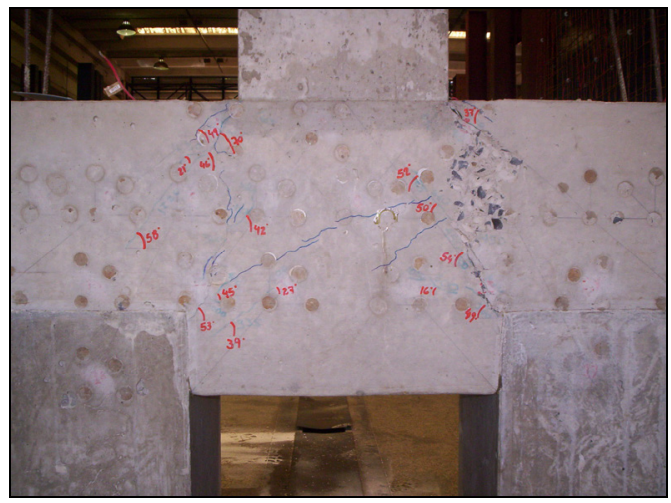

Figura 5.57 - Modelo B35P25E25e0A $\mathrm{sw}_{\mathrm{sw}, \mathrm{C}}$.

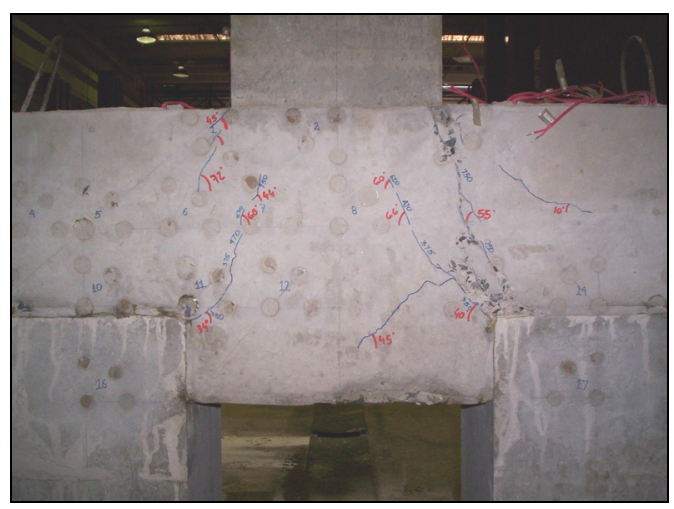

Figura 5.59 - Modelo B35P25E25e0CG.

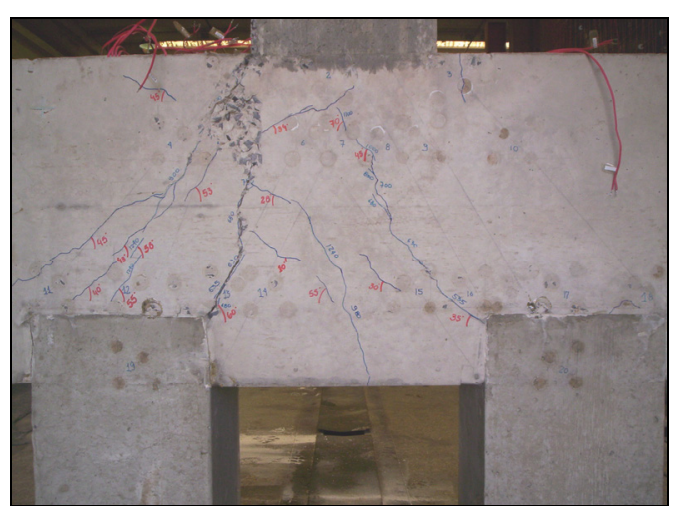

Figura 5.61 - Modelo B35P25E25e5.

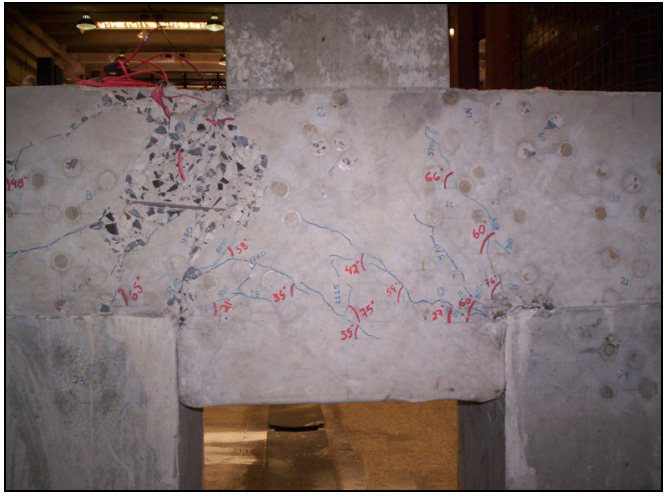

Figura 5.56 - Modelo B35P25E25e2,5.

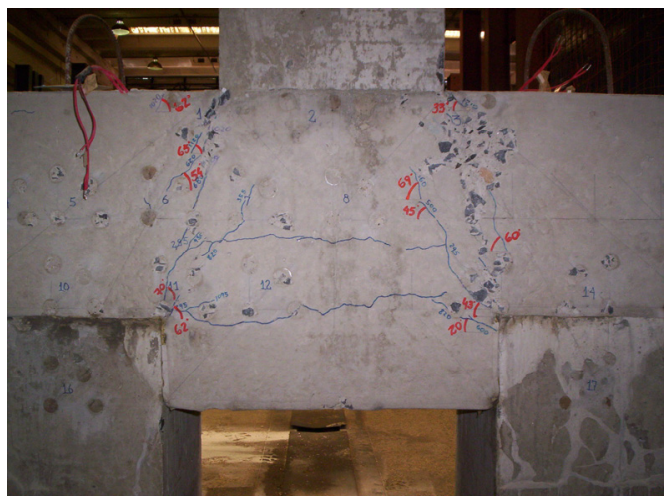

Figura 5.58 - Modelo B35P25E25e0A

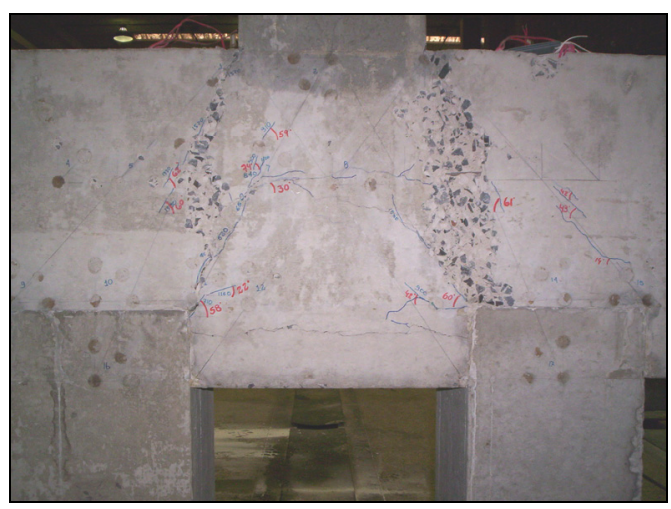

Figura 5.60 - Modelo B45P25E25e0.

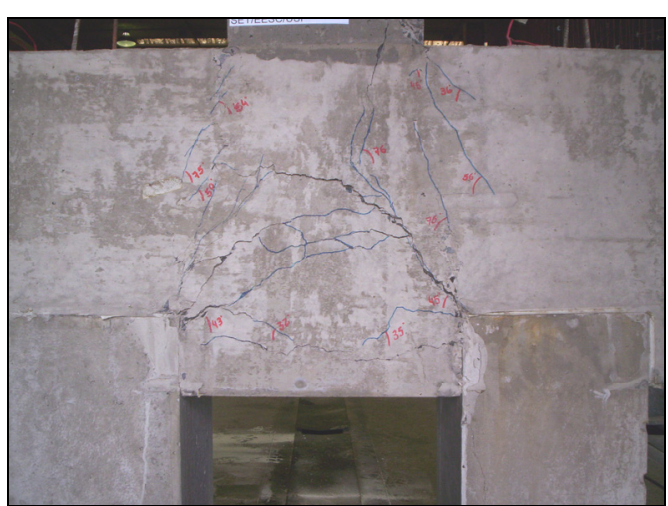

Figura 5.62 - Modelo B45P25E25e0A sw, $_{\text {C. }}$ 


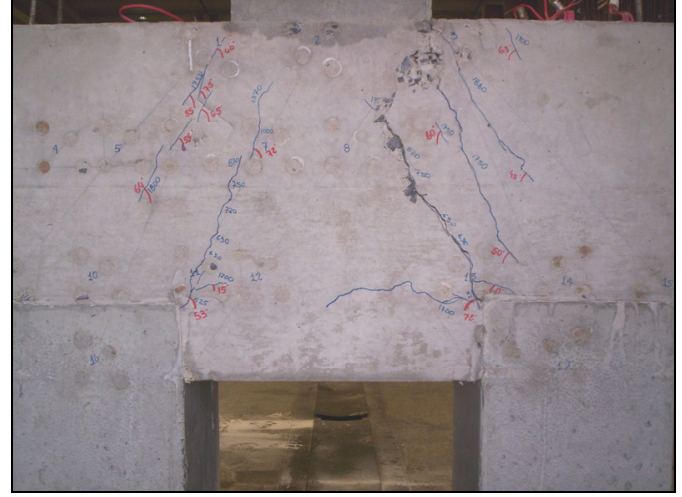

Figura 5.63 - Modelo B35P25E25e0A $\mathrm{sw}, 0$.

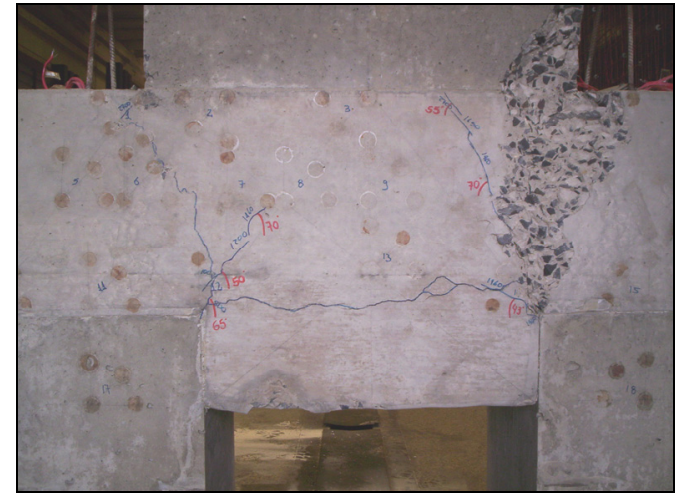

Figura 5.65 - Modelo B35P50E25e0.

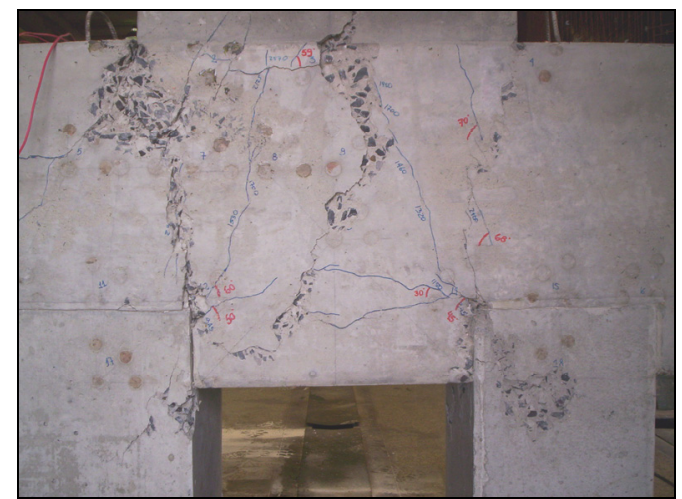

Figura 5.67 - Modelo B45P50E25e0.

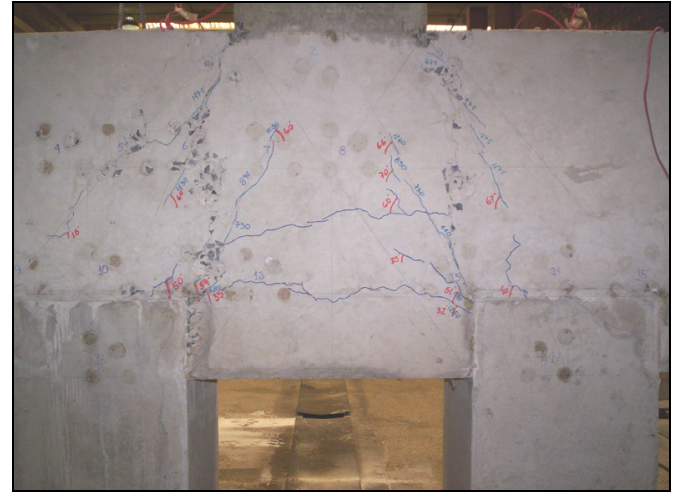

Figura 5.64 - Modelo B45P25E25e0CG.

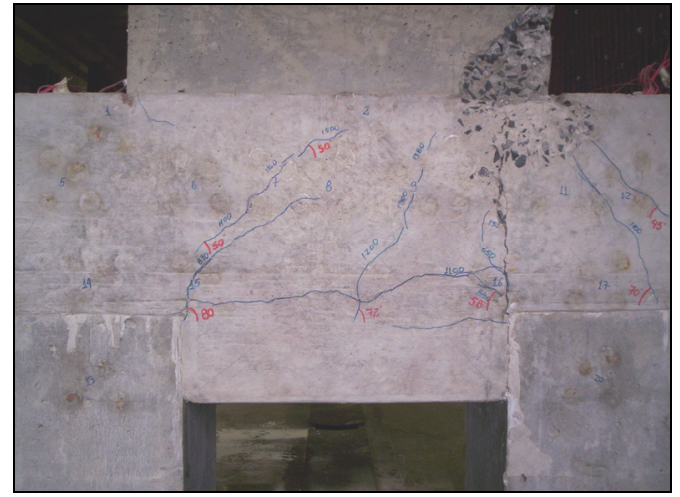

Figura 5.66 - Modelo B35P50E25e12,5.

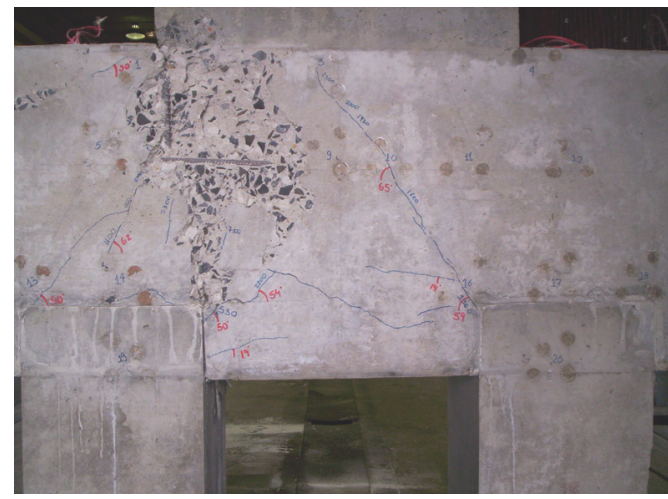

Figura 5.68 - Modelo B45P50E25e12,5.

A Figura 5.69 apresenta a evolução das fissuras do modelo B45P50E25e12,5 até a carga de ruptura. Observa-se por meio delas, a similaridade com a trajetória das tensões principais de compressão apresentada no Capítulo 3. 


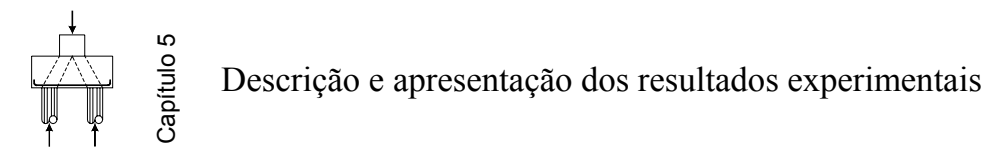
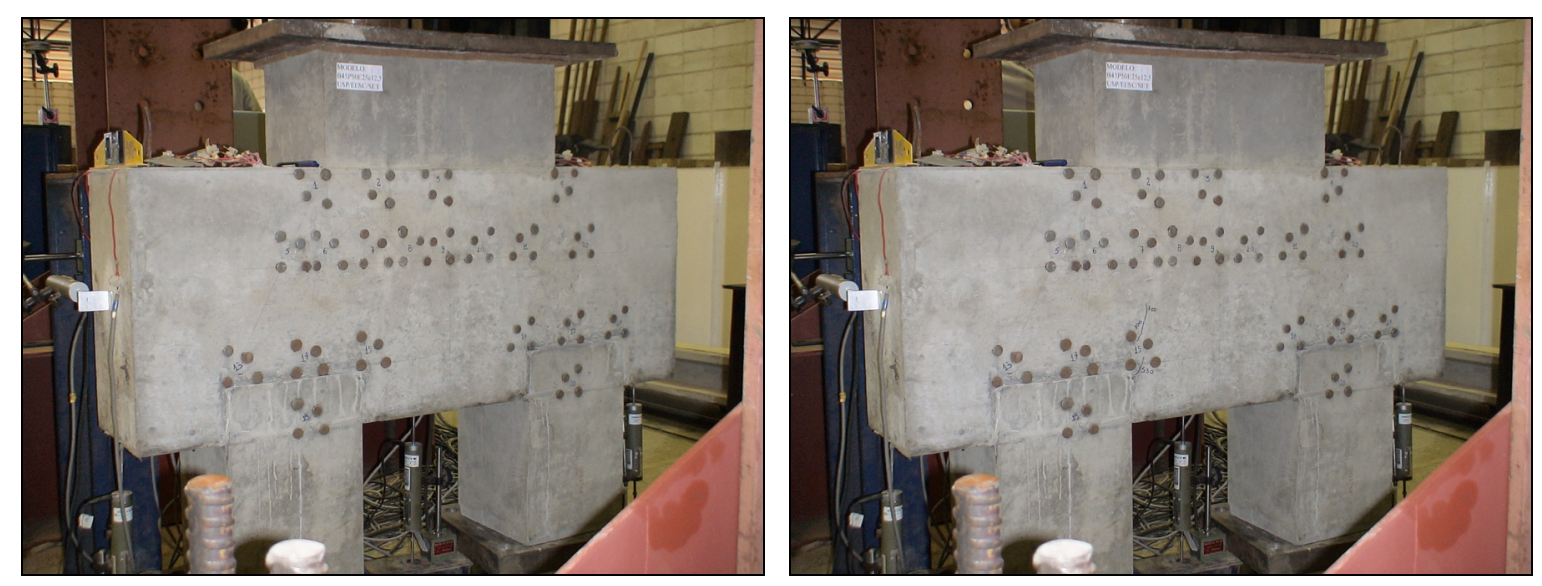

$$
F=350 \mathrm{kN}
$$

$$
F=750 \mathrm{kN}
$$
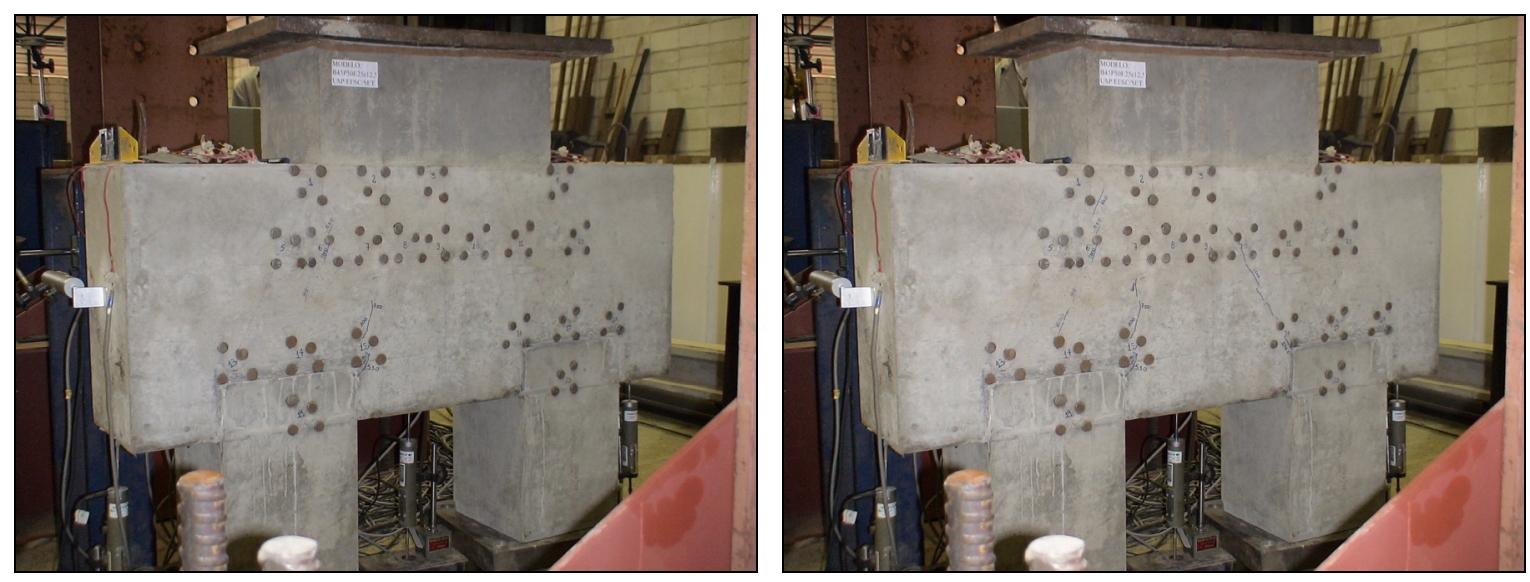

$$
F=1200 \mathrm{kN}
$$

$$
F=1700 \mathrm{kN}
$$

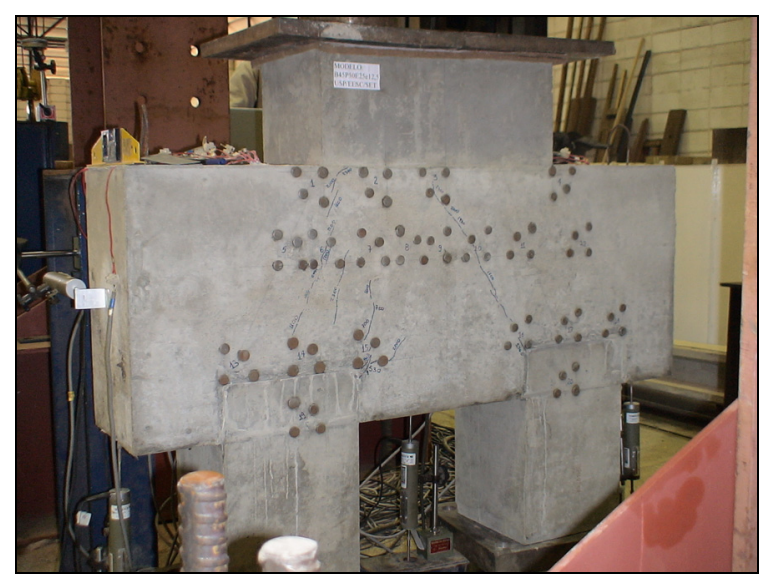

$F=2300 k N$

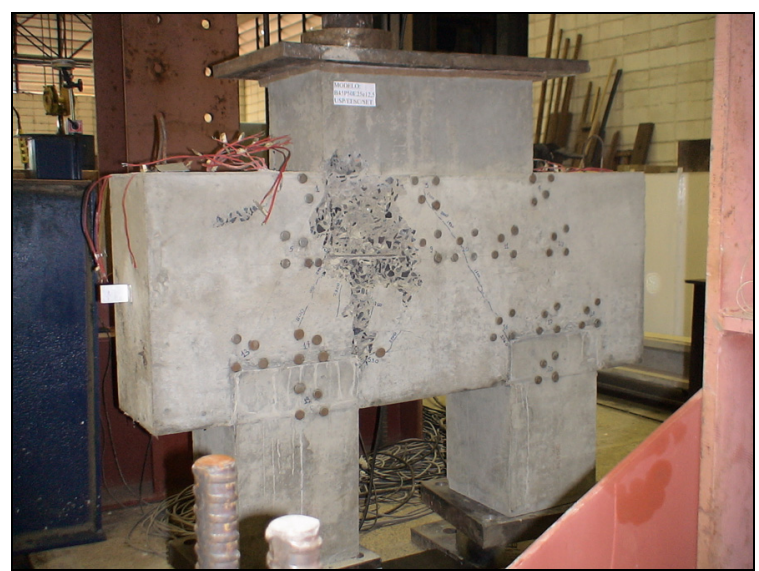

$F=3385,55 \mathrm{kN}$

Figura 5.69 - Seqüência da evolução das fissuras até a ruptura, modelo B45P50E25e12,5. 


\subsubsection{Reações nas estacas}

As reações nas estacas foram obtidas, como já foi dito, por meio de células de carga com capacidade de 2000 kN. Além, das reações nas estacas, foi possível determinar a excentricidade real existente em cada modelo, pois, mesmo sendo criterioso na montagem dos ensaios, ocorreram excentricidades acidentais por conta da construção dos modelos e montagem dos ensaios. A Tabela 5.31 apresenta os resultados obtidos.

Tabela 5.31 - Força nas estacas.

\begin{tabular}{|c|c|c|c|c|c|c|}
\hline Séries & Modelos & $\begin{array}{c}\mathbf{F}_{\mathrm{u}} \\
(\mathrm{kN})\end{array}$ & $\begin{array}{l}\text { Est }_{1} \\
(\mathrm{kN})\end{array}$ & $\begin{array}{l}\text { Est }_{2} \\
(\mathrm{kN})\end{array}$ & $\begin{array}{l}\mathbf{e}_{\text {adot }} \\
(\mathrm{cm}) \\
\end{array}$ & $\begin{array}{l}\mathbf{e}_{\text {real }} \\
(\mathrm{cm})\end{array}$ \\
\hline \multirow{5}{*}{ B35P25 } & B35P25E25e0 & 1821 & 859 & 962 & 0 & 1,8 \\
\hline & B35P25E25e2,5 & 1688 & 925 & 763 & 2,5 & 3 \\
\hline & B35P25E25e0A $\mathrm{s}_{\mathrm{sw}, \mathrm{c}}$ & 1880 & 846 & 1034 & 0 & 3,1 \\
\hline & $\mathrm{B} 35 \mathrm{P} 25 \mathrm{E} 25 \mathrm{e} 0 \mathrm{~A}_{\mathrm{sw}, 0}$ & 1406 & 693 & 713 & 0 & 0,5 \\
\hline & B35P25E25e0CG & 1263 & 577 & 686 & 0 & 2,7 \\
\hline \multirow{5}{*}{ B45P25 } & B45P25E25e0 & 2276 & 1180 & 1096 & 0 & 1,2 \\
\hline & B45P25E25e5 & 1972 & 1091 & 881 & 5 & 3,3 \\
\hline & $\mathrm{B} 45 \mathrm{P} 25 \mathrm{E} 25 \mathrm{e} 0 \mathrm{~A}_{\mathrm{sw}, \mathrm{c}}$ & 3055 & 1577 & 1478 & 0 & 1,0 \\
\hline & 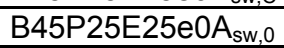 & 2090 & 1040 & 1050 & 0 & 0,2 \\
\hline & B45P25E25e0CG & 2270 & 1156 & 1114 & 0 & 0,6 \\
\hline \multirow{2}{*}{ B35P50 } & B35P50E25e0 & 3877 & 1897 & 1980 & 0 & 0,7 \\
\hline & B35P50E25e12,5 & 3202 & 1075 & 2127 & 12,5 & 10,3 \\
\hline \multirow{2}{*}{ B45P50 } & B45P50E25e0 & 4175 & 2131 & 2044 & 0 & 0,7 \\
\hline & B45P50E25e12,5 & 3386 & 2358 & 1028 & 12,5 & 12,3 \\
\hline
\end{tabular}

Notas: Est ${ }_{1}$ e Est ${ }_{2}$ são as reações nas estacas 1 e 2, e ereal é a excentricidade real existente em cada modelo. A Est ${ }_{1}$ esta posicionada a esquerda do observado, e a Est 2 à direita.

Verifica-se que, por meio da tabela anterior em alguns modelos as excentricidades reais $\left(e_{\text {real }}\right)$ tiveram valores consideráveis, por exemplo, modelo B35P25E25A $A_{s w, C}$. Apesar disso, os comportamentos dos blocos não sofreram mudanças significativa quanto ao modo de ruína.

Observa-se que os planos de ruptura se desenvolveram na região do bloco onde estavam localizadas as estacas mais solicitadas. Isso era esperado, pois, as tensões de compressão nessa região foram maiores.

\subsubsection{Deslocamentos horizontais e verticais}

Os registros obtidos por meio dos transdutores de deslocamentos, $T_{1}, T_{2}, T_{3}, T_{4}$ e $T_{5}$ são apresentados na Tabela 5.32. Nessa tabela encontram-se os valores dos deslocamentos máximos nos sentidos vertical e horizontal no instante da ruptura dos 
modelos. Os valores de $\delta_{\mathrm{T} 1}, \delta_{\mathrm{T} 2}$ e $\delta_{\mathrm{T} 3}$ são positivos para baixo e os valores de $\delta_{\mathrm{T} 4}$ e $\delta_{\mathrm{T} 5}$ são positivos segundo orientações dos eixos Z e X, respectivamente. Nas Figuras 5.70 a 5.83 encontram-se diagramas força vs. deslocamentos dos modelos ensaiados.

Tabela 5.32 - Valores máximos dos deslocamentos.

\begin{tabular}{|c|c|c|c|c|c|c|c|}
\hline Séries & Modelos & $\begin{array}{c}\mathbf{f}_{\mathrm{cm}} \\
(\mathrm{Mpa})\end{array}$ & $\begin{array}{c}\delta_{\mathrm{T} 1} \\
(\mathrm{~mm})\end{array}$ & $\begin{array}{c}\delta_{\mathrm{T} 2} \\
(\mathrm{~mm})\end{array}$ & $\begin{array}{c}\delta_{\mathrm{T} 3} \\
(\mathrm{~mm})\end{array}$ & $\begin{array}{c}\delta_{\mathrm{T} 4} \\
(\mathrm{~mm})\end{array}$ & $\begin{array}{c}\delta_{\mathrm{T} 5} \\
(\mathrm{~mm})\end{array}$ \\
\hline \multirow{5}{*}{ B35P25 } & B35P25E25e0 & 40,6 & 3,16 & $-0,02$ & 1,78 & $-3,18$ & $-0,37$ \\
\hline & B35P25E25e2,5 & 40,6 & 2,44 & 0,22 & $-0,09$ & $-0,32$ & 2,18 \\
\hline & B35P25E25e0A $A_{s w, C}$ & 32,8 & 3,41 & $-0,01$ & 1,44 & 1,59 & 0,01 \\
\hline & $\mathrm{B} 35 \mathrm{P} 25 \mathrm{E} 25 \mathrm{e} 0 \mathrm{~A}_{\mathrm{sw}, 0}$ & 32,8 & 2,42 & 0,21 & 1,30 & $-1,96$ & $-0,65$ \\
\hline & B35P25E25e0CG & 28,9 & 2,93 & $-0,21$ & 2,65 & 1,34 & $-1,67$ \\
\hline \multirow{5}{*}{ B45P25 } & B45P25E25e0 & 31 & 3,27 & 1,29 & 2,51 & $-4,53$ & $-1,15$ \\
\hline & B45P25E25e5 & 31 & 3,59 & 0,67 & 0,61 & 0,80 & $-1,49$ \\
\hline & B45P25E25e0A $A_{s w, C}$ & 32,4 & 3,03 & 1,95 & 0,723 & $-3,00$ & 0,85 \\
\hline & $\mathrm{B} 45 \mathrm{P} 25 \mathrm{E} 25 \mathrm{e} 0 \mathrm{~A}_{\mathrm{sw}, 0}$ & 32,4 & 2,49 & 1,00 & 1,52 & 1,30 & $-0,70$ \\
\hline & B45P25E25e0CG & 28,9 & 2,60 & 0,51 & 3,15 & $-0,43$ & 0,47 \\
\hline \multirow{2}{*}{ B35P50 } & B35P50E25e0 & 35,8 & 3,70 & 1,28 & 2,17 & $-0,30$ & 0,98 \\
\hline & B35P50E25e12,5 & 35,1 & 6,49 & $-1,25$ & 5,03 & $-1,66$ & $-0,31$ \\
\hline \multirow{2}{*}{ B45P50 } & B45P50E25e0 & 35,8 & 3,89 & 1,41 & 2,35 & 1,37 & 0,43 \\
\hline & B45P50E25e12,5 & 35,1 & 4,33 & 1,79 & $-0,83$ & $-1,81$ & $-0,17$ \\
\hline
\end{tabular}

Notas: $\delta_{T_{1}}, \delta_{T 2}, \delta_{T_{3}}, \delta_{T_{4}}$ e $\delta_{\text {T5 }}$ são os deslocamentos máximos obtidos por meio dos transdutores de deslocamentos $T_{1}, T_{2}, T_{3}, T_{4}$ e $T_{5}$.

Observa-se por meio da tabela anterior que em alguns modelos, nos instantes das rupturas, os deslocamentos nas extremidades apresentaram inversão de sinal, ou seja, se deslocaram no sentido contrário da aplicação da força. Isso aconteceu nos modelos menos rígidos, que são os blocos das séries B35P25 e B35P50. Nota-se também, que os deslocamentos são extremamente pequenos, assim, pôde-se concluir, que o critério de avaliação da rigidez de blocos sobre estacas apresentado pela NBR 6118:2003 esta correto.

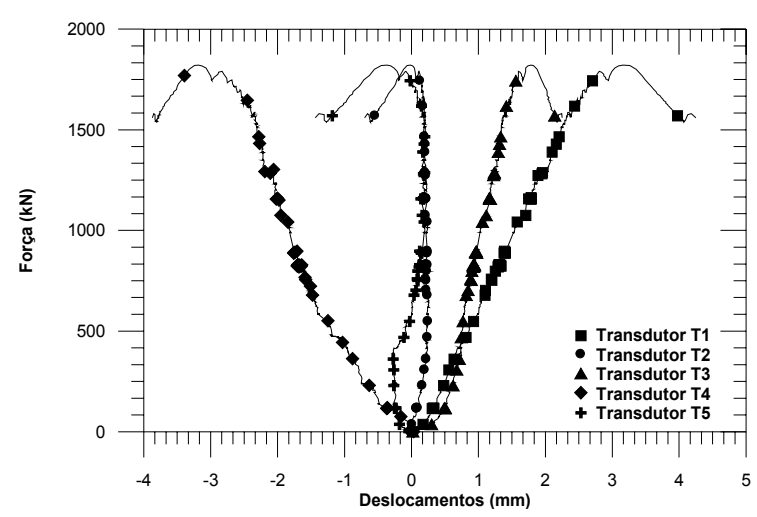

Figura 5.70 - Curvas força vs. deslocamento, modelo B35P25E25e0.

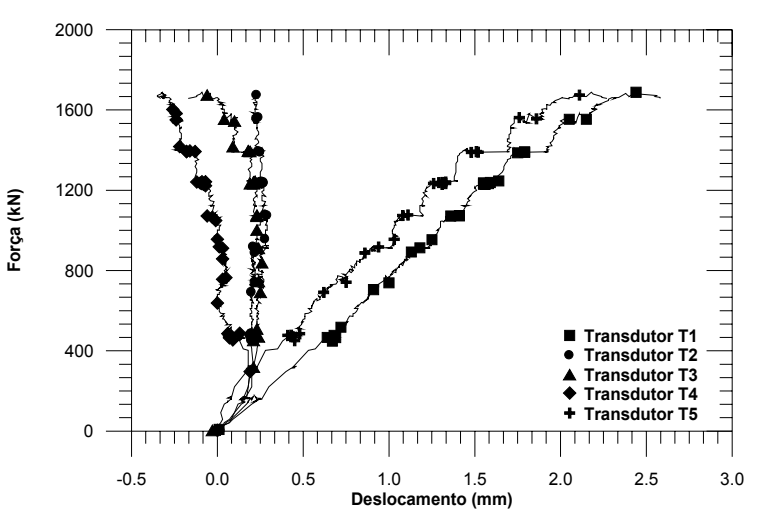

Figura 5.71 - Curvas força vs. deslocamento, modelo B35P25E25e2,5. 


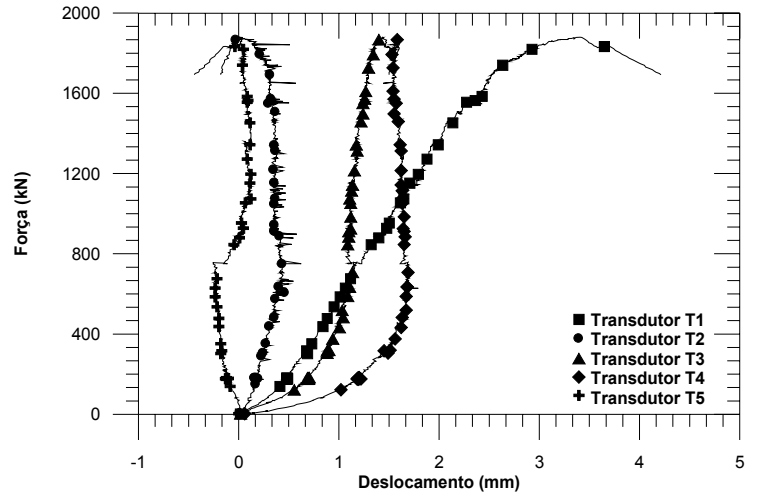

Figura 5.72 - Curvas força vs. deslocamento, modelo B35P25E25e0A $\mathrm{sw}_{\mathrm{s}, \mathrm{C}}$.

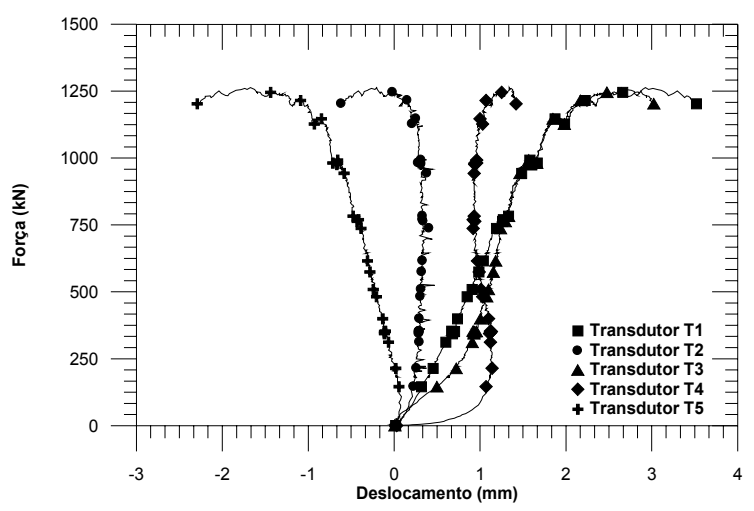

Figura 5.74 - Curvas força vs. deslocamento, modelo B35P25E25e0CG.

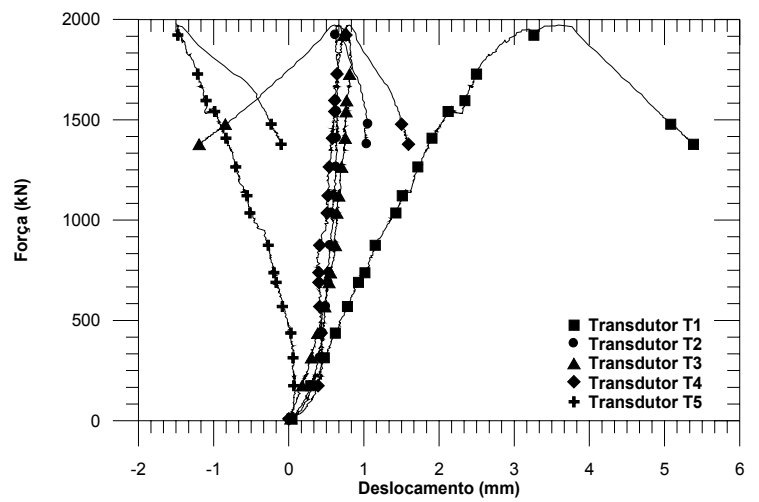

Figura 5.76 - Curvas força vs. deslocamento, modelo B45P25E25e5.

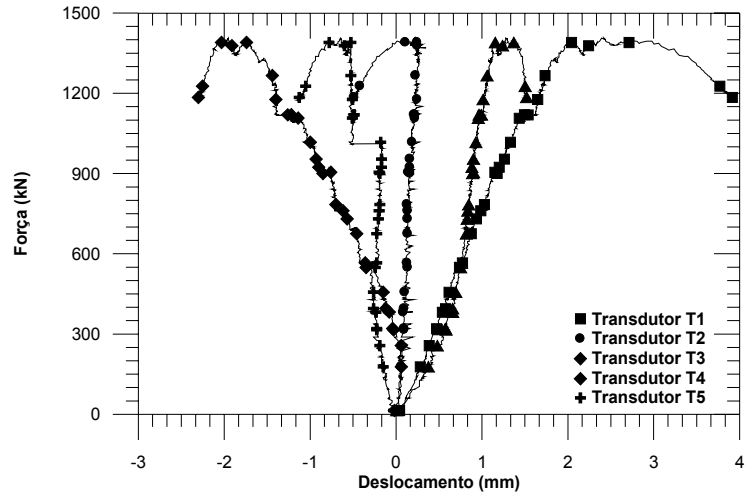

Figura 5.73 - Curvas força vs. deslocamento, modelo B35P25E25e0A $\mathrm{sw}_{\mathrm{sw}, 0}$.

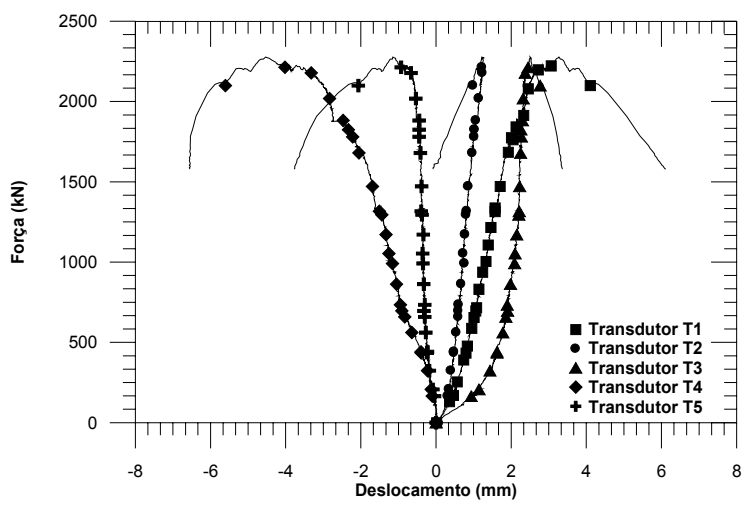

Figura 5.75 - Curvas força vs. deslocamento, modelo B45P25E25e0.

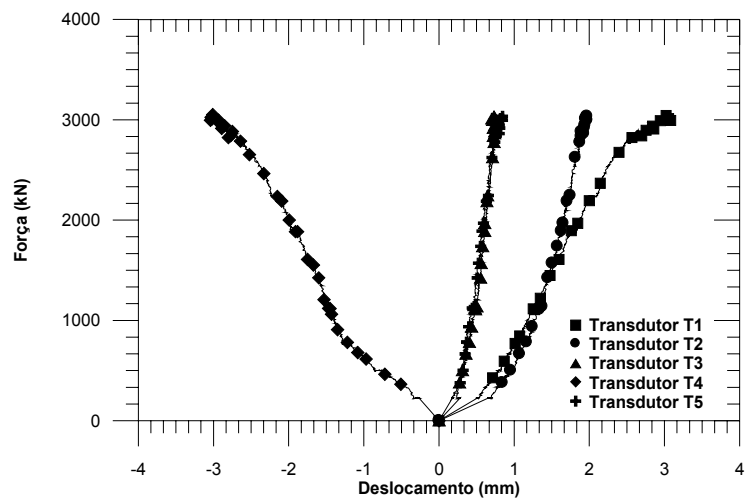

Figura 5.77 - Curvas força vs. deslocamento, modelo B45P25E25e0A $\mathrm{sw}_{\mathrm{sw}, \mathrm{C}}$. 


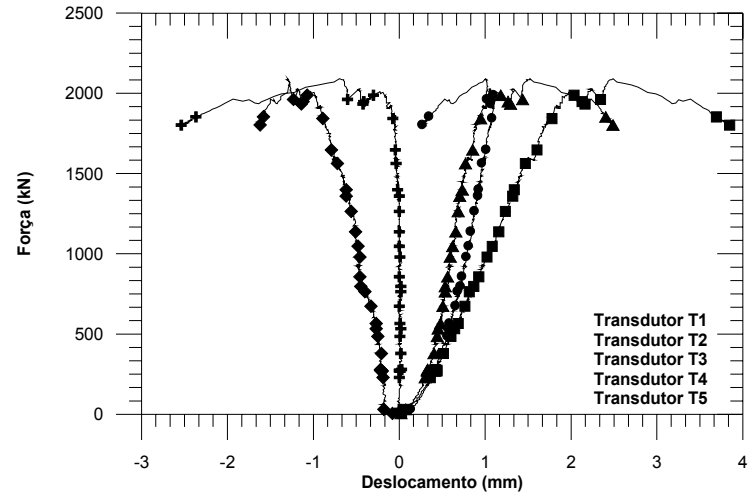

Figura 5.78 - Curvas força vs. deslocamento, modelo B45P25E25e0A

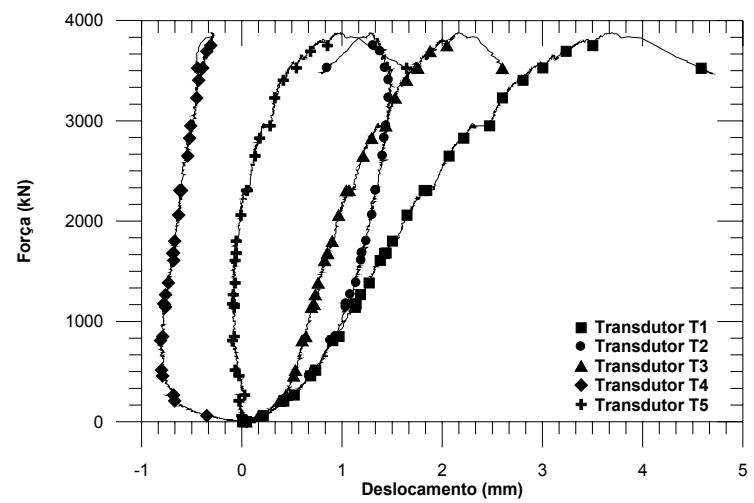

Figura 5.80 - Curvas força vs. deslocamento, modelo B35P50E25e0.

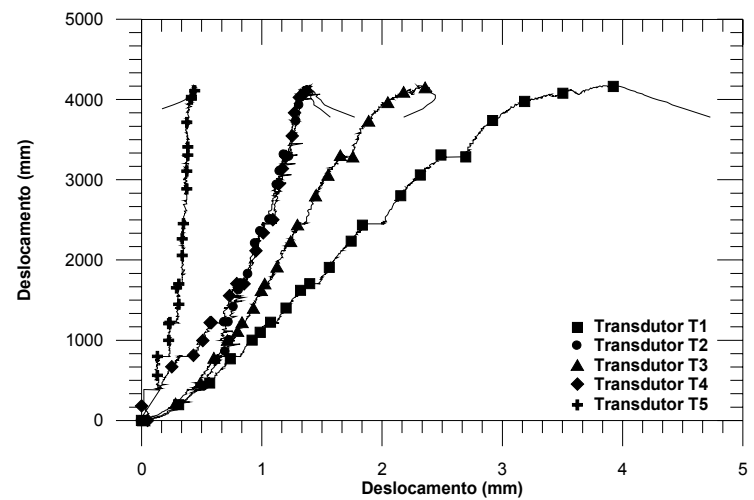

Figura 5.82 - Curvas força vs. deslocamento, modelo B45P50E25e0.

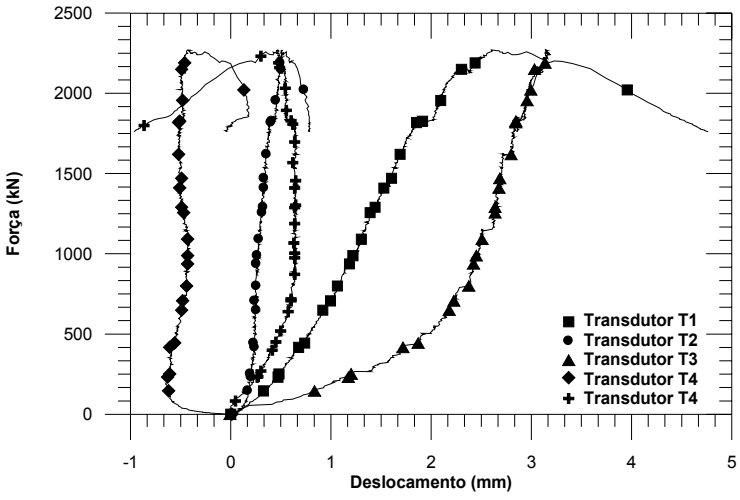

Figura 5.79 - Curvas força vs. deslocamento, modelo B45P25E25e0CG.

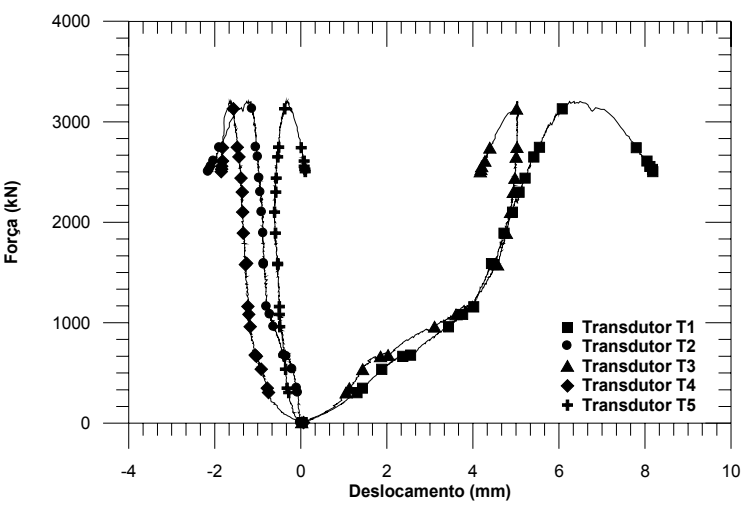

Figura 5.81 - Curvas força vs. deslocamento, modelo B35P50E25e12,5.

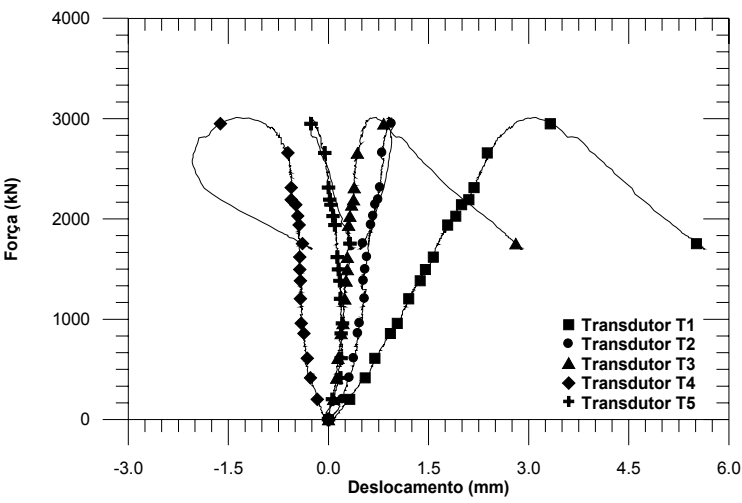

Figura 5.83 - Curvas força vs. deslocamento, modelo B45P50E25e12,5. 
Observa-se por meios dos diagramas força vs deslocamento, referentes as curvas dos transdutores $T_{1}$, que os blocos apresentaram comportamentos de estruturas frágeis, ou seja, apresentaram pequenas deformações antes da ruptura. Esse fenômeno afirma a condição de estruturas rígidas. Praticamente possuem deslocamento linear crescente até a carga de ruptura.

\subsubsection{Deformações nas armaduras}

As deformações nas barras de aço das armaduras dos blocos sobre estacas obtidas por meio de extensômetros elétricos de resistência são apresentadas nesse item. Os resultados das deformações foram divididos em cinco partes: deformações nas barras de aço da armadura principal de tração; deformações nas barras de aço da armadura complementar superior; deformações nas barras de aço dos estribos horizontais; deformações nas barras de aço dos estribos verticais; e deformação nas barras de aço da armadura sugerida pelo autor.

As posições e nomenclatura de cada extensômetro nas barras de aço dos modelos ensaiados são apresentadas nas Figuras 5.10, 5.11, 5.12, 5.13, 5.14 e 5.15.

\subsubsection{Deformações armadura principal de tração - tirante}

Nos modelos onde foram detalhadas barras da armadura principal de tração com duas camadas, foram instrumentadas duas barras de aço, uma posicionada na camada inferior e outra na camada superior, todas com diâmetros de $20 \mathrm{~mm}$.

A Tabela 5.33 apresenta valores médios das deformações das barras de aço da armadura principal de tração referente às forças últimas de cada modelo, ou seja, a media entre as deformações das barras das camadas inferior e superior.

Durante os ensaios, foram constatados problemas em alguns extensômetros, provavelmente por deficiência dos isolamentos, ou, interferência de equipamentos elétricos utilizados no laboratório durante os ensaios, como por exemplo, ponte rolante. Os extensômetros instalados na armadura principal de tração que apresentaram defeitos foram: modelo B35P25E25e5, е ет; modelo B35P25E25a0A $\mathrm{A}_{\mathrm{sw}, 0}$, $\mathrm{e}_{2 \mathrm{~T}}$; modelo B35P25E25e0CG, $\mathrm{e}_{5 \mathrm{~T}}$; modelo B45P25E25e0CG, $\mathrm{e}_{4 \mathrm{~T}} ;$ modelo B45P50E25e12,5, e 2 .

Nenhuma das barras da armadura principal de tração atingiu o valor da deformação de escoamento, igual a 2,75 \%. Observa-se na Tabela 5.33 que supor 
constante a tensão no tirante é incorreto, pois, a tensão diminui nas seções localizadas na região das estacas. Verifica-se também que as deformações nas pontas das barras da armadura principal de tração são praticamente iguais a zero, o mesmo acontecendo para os modelos detalhados com ganchos. Portanto, a eficiência do ganho para os modelo ensaiados é desprezível. Nas Figuras 5.84 a 5.85 são apresentados gráficos com curvas força vs. deformação das barras de aço da armadura principal de tração.

Tabela 5.33 - Deformações nas barras de aço da armadura principal de tração.

\begin{tabular}{|c|c|c|c|c|c|c|}
\hline \multirow[b]{2}{*}{ Modelos } & $\begin{array}{c}\left(\varepsilon_{\mathrm{e} 1 \mathrm{~T}}+\varepsilon_{\mathrm{e} 6 \mathrm{~T}}\right) / 2 \\
(\% 0)\end{array}$ & $\begin{array}{c}\left(\varepsilon_{\mathrm{e} 2 \mathrm{~T}}+\varepsilon_{\mathrm{e} 7 \mathrm{~T}}\right) / 2 \\
(\% \mathrm{o}) \\
\end{array}$ & $\begin{array}{c}\left(\varepsilon_{\mathrm{e} 3 \mathrm{~T}}+\varepsilon_{\mathrm{e} 8 \mathrm{~T}}\right) / 2 \\
(\% \mathrm{o})\end{array}$ & $\begin{array}{c}\left(\varepsilon_{\mathrm{e} 4 \mathrm{~T}}+\varepsilon_{\mathrm{e} 9 \mathrm{~T}}\right) / 2 \\
(\% \mathrm{o})\end{array}$ & $\begin{array}{c}\left(\varepsilon_{\mathrm{e} 10 \mathrm{~T}}+\varepsilon_{\mathrm{e} 11 \mathrm{~T}}\right) / 2 \\
(\%)\end{array}$ & \multirow[b]{2}{*}{$\begin{array}{c}\varepsilon_{y} \\
(\% 0)\end{array}$} \\
\hline & $\begin{array}{l}\text { Seção: meio } \\
\text { do bloco }\end{array}$ & $\begin{array}{c}\text { Seção: estaca } \\
\text { mais afastada } \\
\text { da } \\
\text { extremidade } \\
\text { do bloco }\end{array}$ & $\begin{array}{c}\text { Seção: centro } \\
\text { da estaca }\end{array}$ & $\begin{array}{c}\text { Seção: estaca } \\
\text { mais próxima } \\
\text { da } \\
\text { extremidade } \\
\text { do bloco }\end{array}$ & $\begin{array}{l}\text { Seção: ponta } \\
\text { do tirante }\end{array}$ & \\
\hline B35P25E25e0 & 1,96 & 2,25 & 0,95 & 0,15 & 0,04 & 2,75 \\
\hline B35P25E25e2,5 & 2,23 & 1,77 & 1,28 & 0,09 & 0,02 & 2,75 \\
\hline B35P25E25e0A $A_{s w, C}$ & 1,92 & 1,85 & 0,78 & 0,25 & 0,05 & 2,75 \\
\hline B35P25E25e0A $A_{s w, 0}$ & 1,70 & 1,79 & 0,77 & 0,11 & 0,02 & 2,75 \\
\hline B35P25E25e0CG & 1,61 & 1,09 & 0,58 & 0,10 & - & 2,75 \\
\hline B45P25E25e0 & 1,95 & 1.41 & 0,87 & 0,18 & 0,05 & 2,75 \\
\hline B45P25E25e5 & 2,18 & 1,58 & 1,39 & 1,27 & 0,10 & 2,75 \\
\hline B45P25E25e0A $A_{s w, C}$ & 1,86 & 2,00 & 0,62 & 0,14 & 0,03 & 2,75 \\
\hline B45P25E25e0A $A_{s w, 0}$ & 1,9 & 0,96 & 0,54 & 0,14 & 0,03 & 2,75 \\
\hline B45P25E25e0CG & 2,15 & 1,71 & 0,58 & - & 0,09 & 2,75 \\
\hline B35P50E25e0 & 2,01 & 1,73 & 1,33 & 0,25 & 0,03 & 2,75 \\
\hline B35P50E25e12,5 & 2,12 & 2,24 & 1,64 & 0,62 & 0,05 & 2,75 \\
\hline B45P50E25e0 & 2,52 & 2,58 & 1,58 & 0,51 & 0,04 & 2,75 \\
\hline B45P50E25e12,5 & 1.99 & 2,61 & 1,74 & 0,94 & 0,15 & 2,75 \\
\hline
\end{tabular}

Notas: $\varepsilon_{\text {eit }}$, são as deformações nas barras de aço da armadura principal de tração - tirante, nas posições i consideradas e, $\varepsilon_{y}$ é a deformação de escoamento das barras de aço da armadura principal de tração tirante $(\varnothing 20 \mathrm{~mm})$.

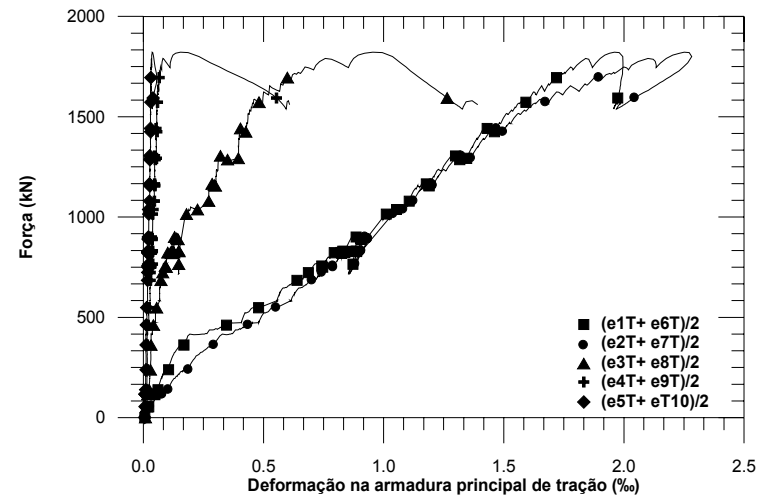

Figura 5.84 - Curva força vs. deformação, modelo B35P25E25e0.

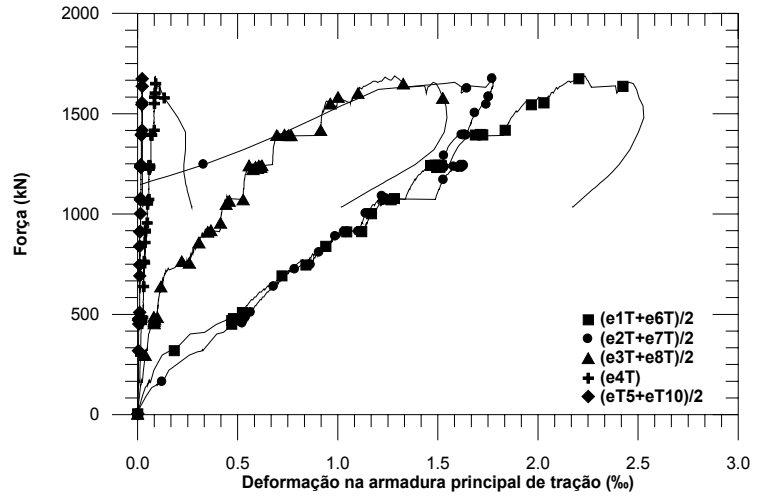

Figura 5.85 - Curva força vs. deformação, modelo B35P25E25e2,5. 


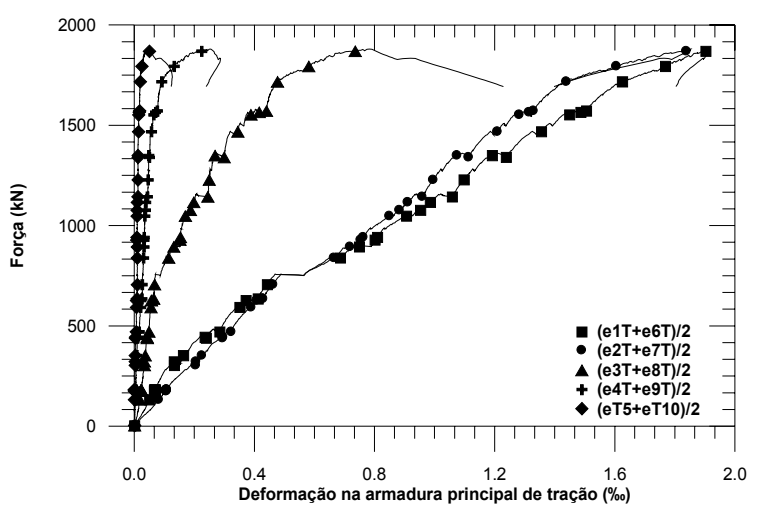

Figura 5.86 - Curva força vs. deformação, modelo B35P25E25e0A $A_{s w, C}$.

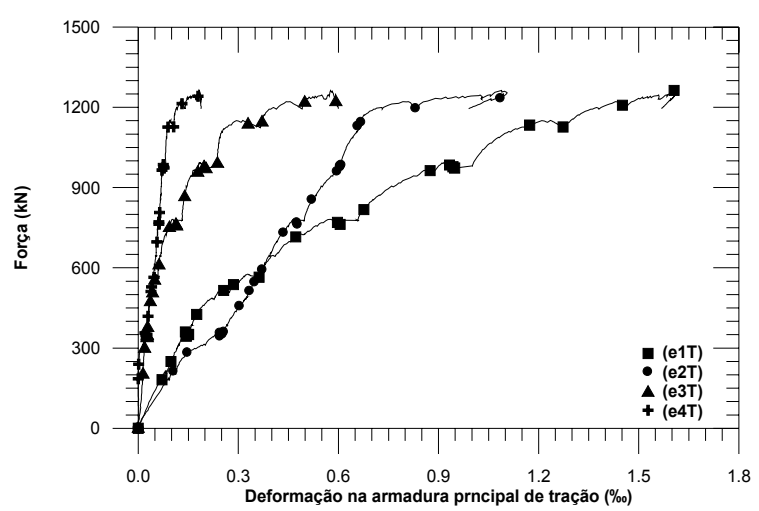

Figura 5.88 - Curva força vs. deformação, modelo B35P25E25e0CG.

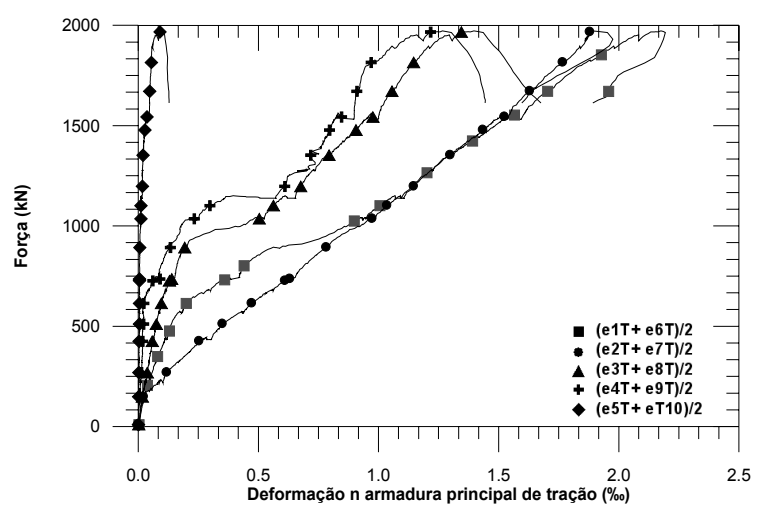

Figura 5.90 - Curva força vs. deformação, modelo B45P25E25e5.

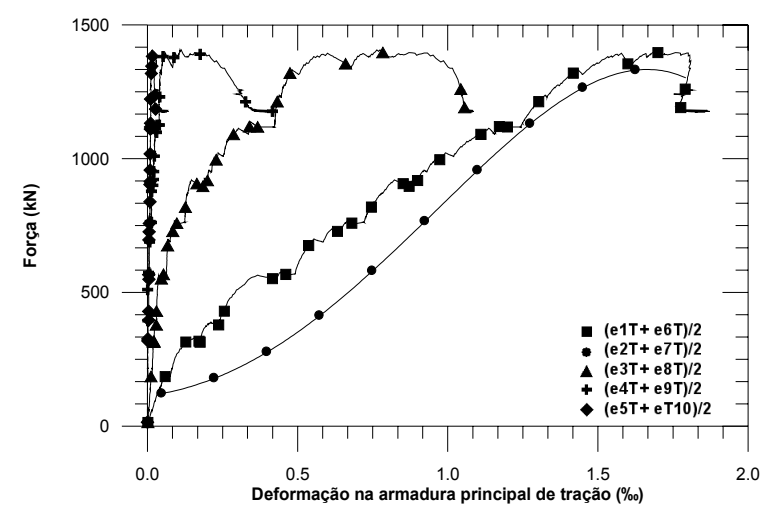

Figura 5.87 - Curva força vs. deformação,

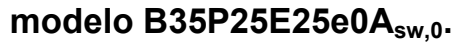

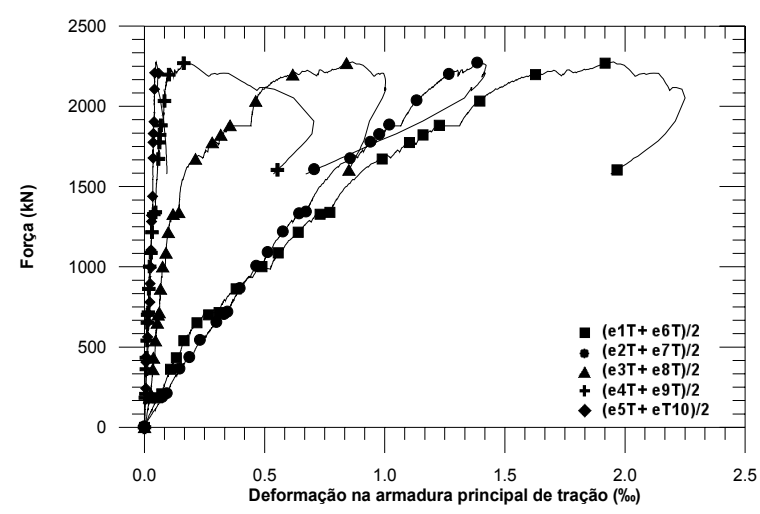

Figura 5.89 - Curva força vs. deformação, modelo B45P25E25e0.

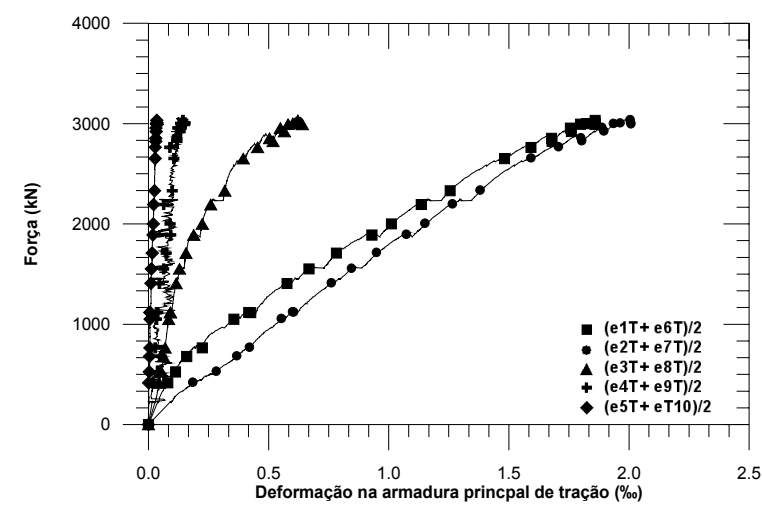

Figura 5.91 - Curva força vs. deformação, modelo B45P25E25e0A $A_{s w, c}$. 


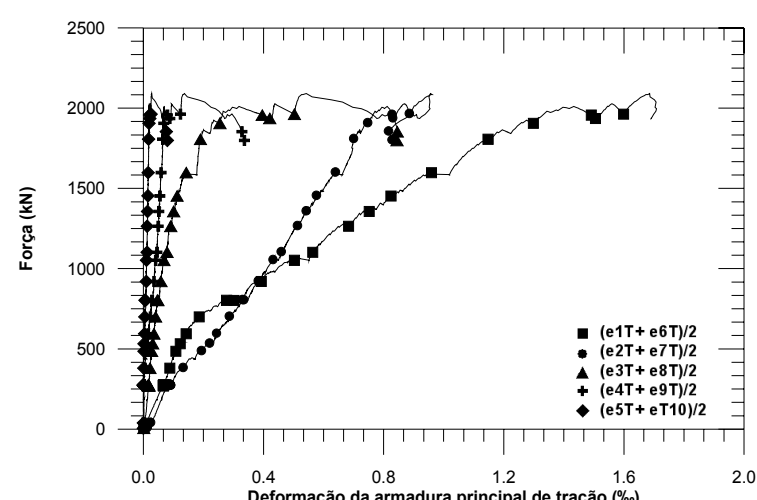

Figura 5.92 - Curva força vs. deformação, modelo B45P25E25e0A $A_{s w, 0}$.

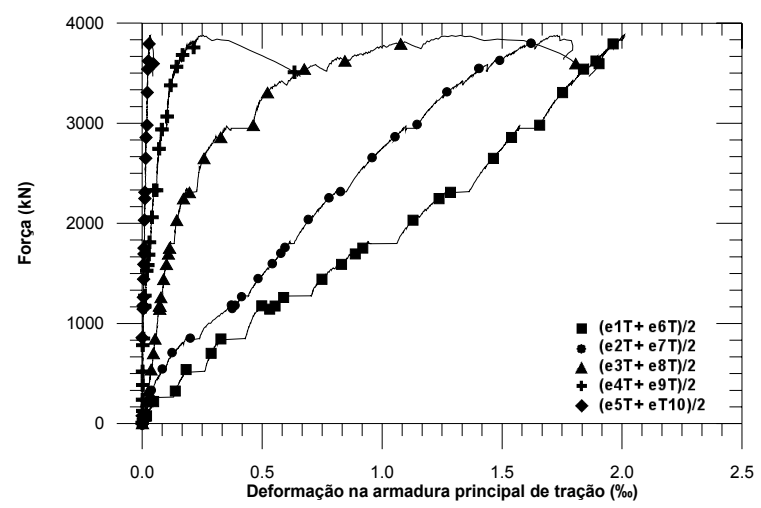

Figura 5.94 - Curva força vs. deformação, modelo B35P50E25e0.

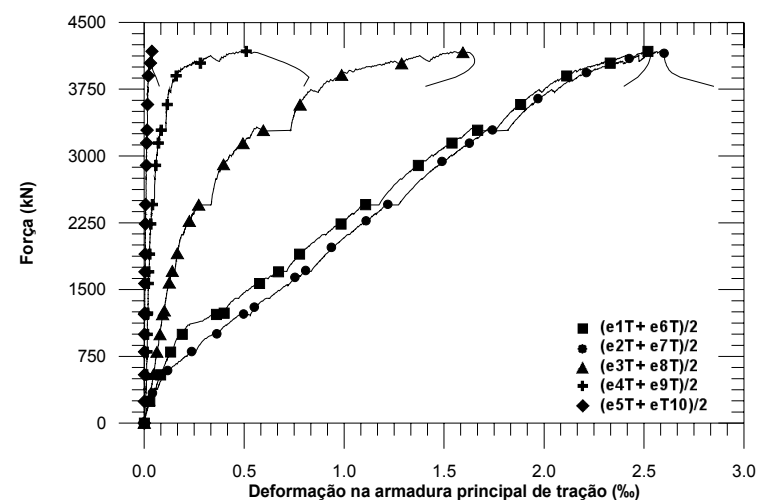

Figura 5.96 - Curva força vs. deformação, modelo B45P50E25e0.

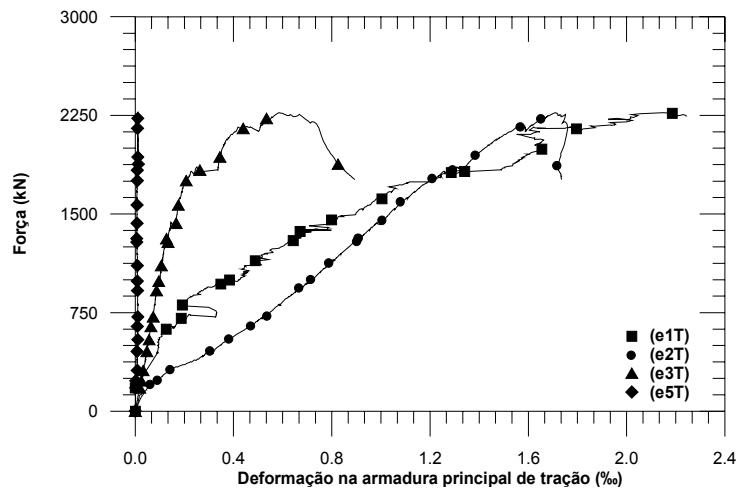

Figura 5.93 - Curva força vs. deformação, modelo B45P25E25e0CG.

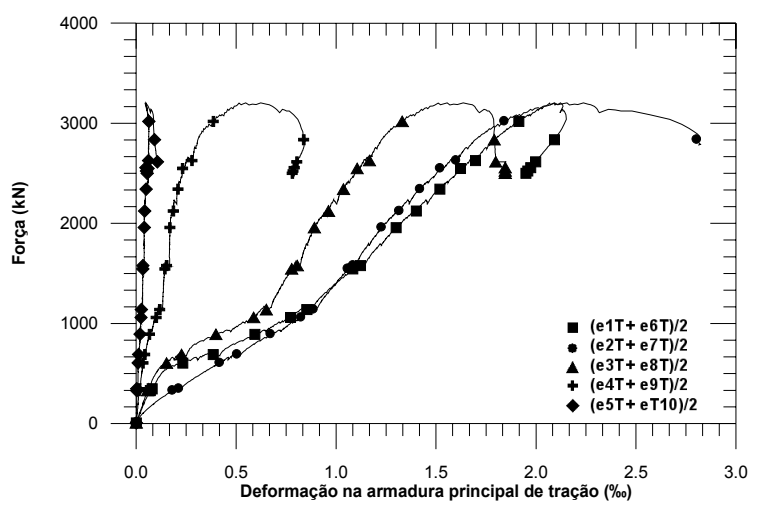

Figura 5.95 - Curva força vs. deformação, modelo B35P50E25e12,5.

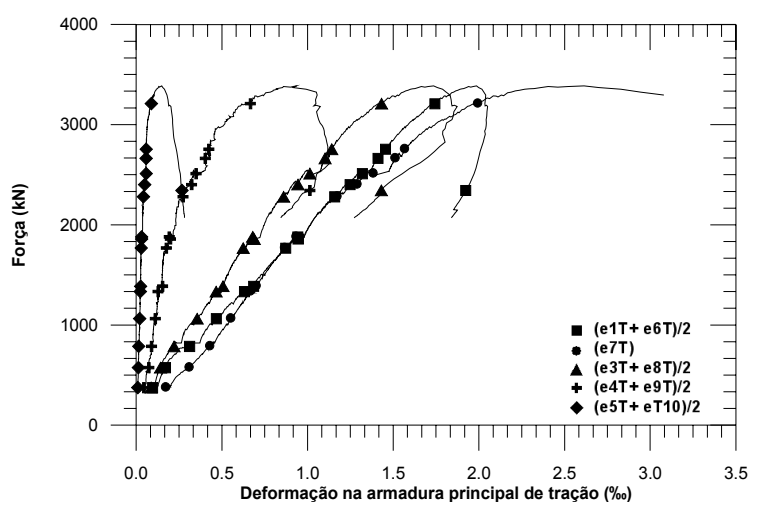

Figura 5.97 - Curva força vs. deformação, modelo B45P50E25e12,5. 
Analisando os gráficos anteriores, observa-se que as deformações e conseqüentemente as tensões nas barras de aço possuem a mesma ordem de grandeza na seção central do bloco e na seção da estaca mais afastada da extremidade do bloco. Em função da ação favorável das tensões de compressão oriundas das bielas, há redução significativa nas deformações das barras. Portanto, considerar a seção de início de ancoragem a partir da seção da estaca mais afastada da extremidade do bloco é correto.

\subsubsection{Deformações nas armaduras complementares superiores}

Os modelos B35P25E25e0A $A_{s w, C}$, B35P25E25A $A_{s w, 0}$, B45P25E25e0A $A_{s w, C}$ e B45P25E25 $A_{s w, 0}$ não foram projetados com barras complementares superiores (ver Figuras 5.11 e 5.13). Os demais modelos foram construídos com essas barras de aço, sendo que as barras de aço das séries B35P25 e B45P25 tinha diâmetro de 8 mm e das séries B35P50 e B45P50 tinha diâmetros de $10 \mathrm{~mm}$.

A Tabela 5.34 apresenta as deformações referentes às forças últimas de cada modelo de tais barras.

Durante os ensaios constatou-se falha no extensômetro elétrico de resistência $\mathrm{e}_{12 \mathrm{~S}}$ instalado na barra de aço complementar superior do modelo B45P25E25e0CG.

Tabela 5.34 - Deformações nas barras de aço da armadura complementar superior.

\begin{tabular}{c|c|c|c}
\hline \multirow{2}{*}{ Modelos } & $\begin{array}{c}\varepsilon_{\mathrm{e} 11 \mathrm{~s} \text { e } \varepsilon_{\mathrm{e} 6 \mathrm{~s}}{ }^{*}} \\
(\%)\end{array}$ & \begin{tabular}{c}
$\varepsilon_{\mathrm{e} 12 \mathrm{~s} \text { e } \varepsilon_{\mathrm{e} 7 \mathrm{~s}}{ }^{*}}(\% \mathrm{o})$ \\
\cline { 2 - 4 }
\end{tabular} & $\begin{array}{c}\varepsilon_{\mathrm{y}} \\
(\% 0)\end{array}$ \\
\hline Seção: meio do bloco & Seção: centro da estaca & 2,91 \\
\hline B35P25E25e0 & $-0,17$ & 0,20 & 2,91 \\
\hline B35P25E25e0CG & $-0,35$ & 0,06 & 2,91 \\
\hline B45P25E25e0 & 0,03 & 0,49 & 2,91 \\
\hline B45P25E25e5 & 0,80 & 0,95 & 2,91 \\
\hline B45P25E25e0CG & $-0,14$ & 0,18 & 2,91 \\
\hline B35P50E25e0 & $-0,35$ & - & 2,75 \\
\hline B35P50E25e12,5 & 0,18 & 2,05 & 2,75 \\
\hline B45P50E25e0 & $-0,23$ & 0,63 & 2,75 \\
\hline B45P50E25e12,5 & 0,64 & 0,99 & 2,75 \\
\hline \hline
\end{tabular}

Notas: $\varepsilon_{\text {eis, }}$ são as deformações nas barras de aço da armadura complementar superior, nas posições $\mathrm{i}$ consideradas e $\varepsilon_{y}$ é a deformação de escoamento das barras de aço da armadura complementar superior. * Referem-se às posições dos extensômetros nos modelos B35P25E25e0CG e B45P25E25e0CG.

Considerando a Tabela 5.34, observa-se que as barras de aço não atingiram a deformação de escoamento, além disso, (menos os modelos B45P25E25e0 e B45P50E25e0 que apresentaram deformações de tração com intensidades 
relativamente altas se comparadas com as outras) na seção de meio do vão as barras apresentaram deformações de compressão ou de tração (mas com pequena intensidade). Isso é uma constatação importante, pois, a suposição de se considerar comprimido o banzo superior do modelo de bielas e tirantes empregados nos blocos sobre estacas é correta.

Na seção dos blocos localizadas no centro das estacas, as tensões nas barras de aço foram de tração, mas, com pequenas intensidades.

Em função das pequenas deformações existentes nessas barras, é possível afirmar que sua utilização é restrita a absorver possíveis tensões provocadas por excentricidades acidentais quando da locação das estacas ou dos pilares.

As Figuras 5.98 e 5.107 mostram gráficos força vs. deformação das barras da armadura complementar superior.

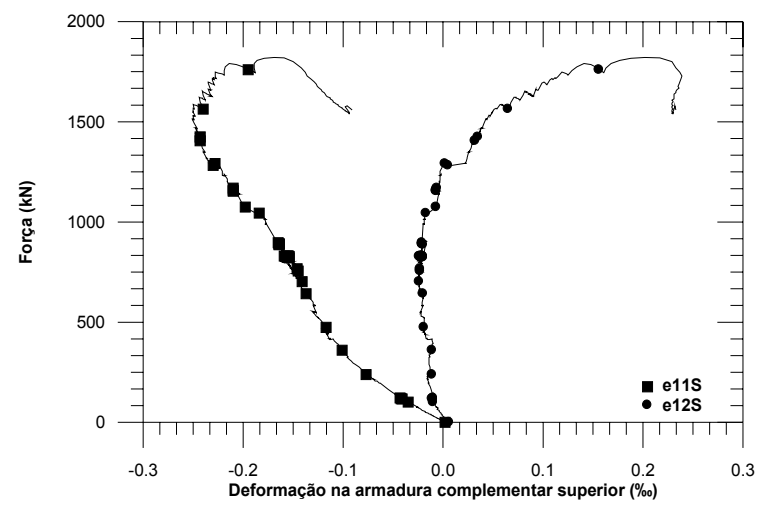

Figura 5.98 - Curva força vs. deformação, modelo B35P25E25e0.

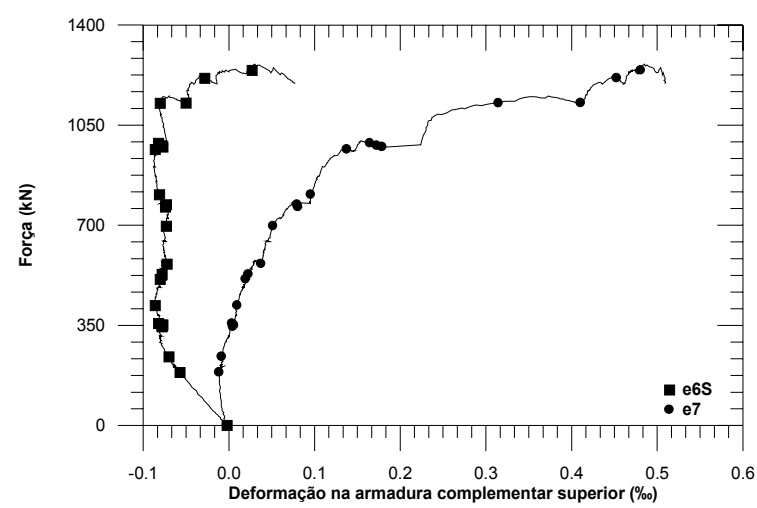

Figura 5.100 - Curva força vs. deformação, modelo B35P25E25e0CG.

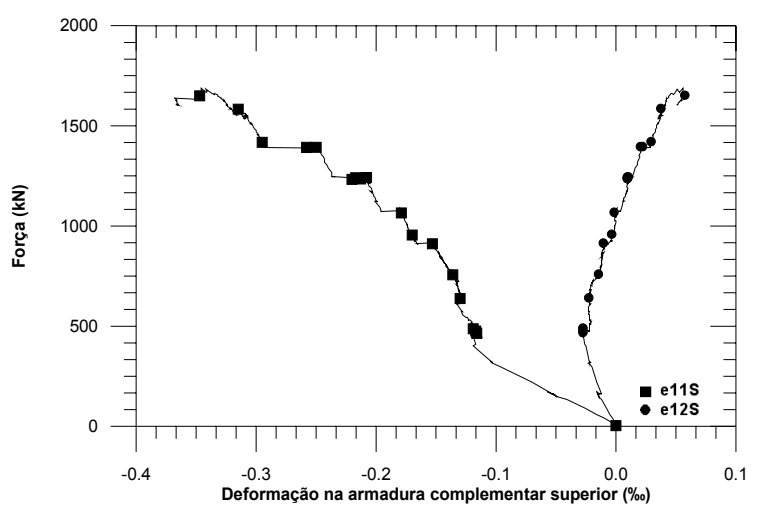

Figura 5.99 - Curva força vs. deformação, modelo B35P25E25e2,5.

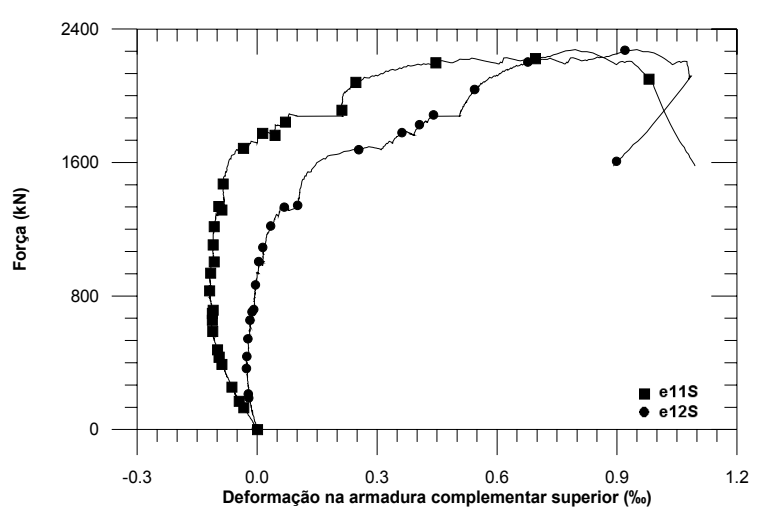

Figura 5.101 - Curva força vs. deformação, modelo B45P25E25e0. 


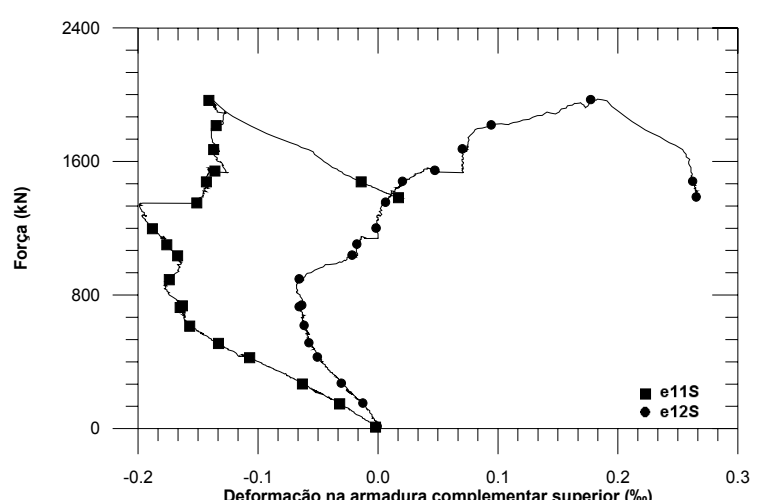

Figura 5.102 - Curva força vs. deformação, modelo B45P25E25e5.

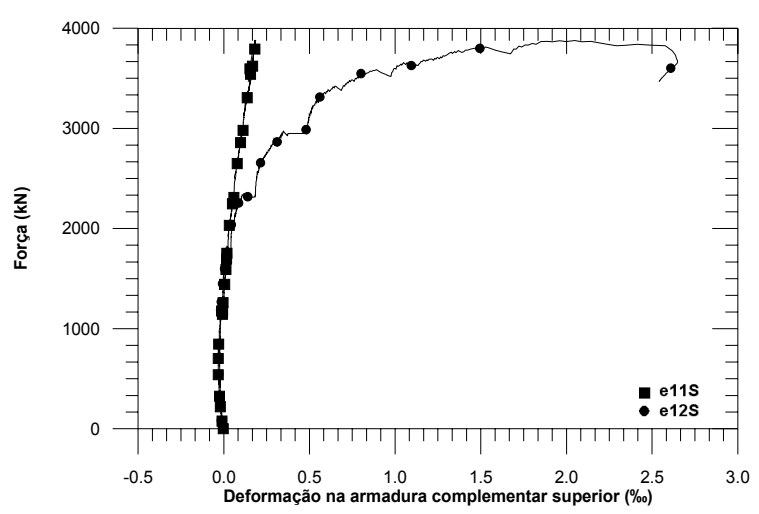

Figura 5.104 - Curva força vs. deformação, modelo B35P50E25e0.

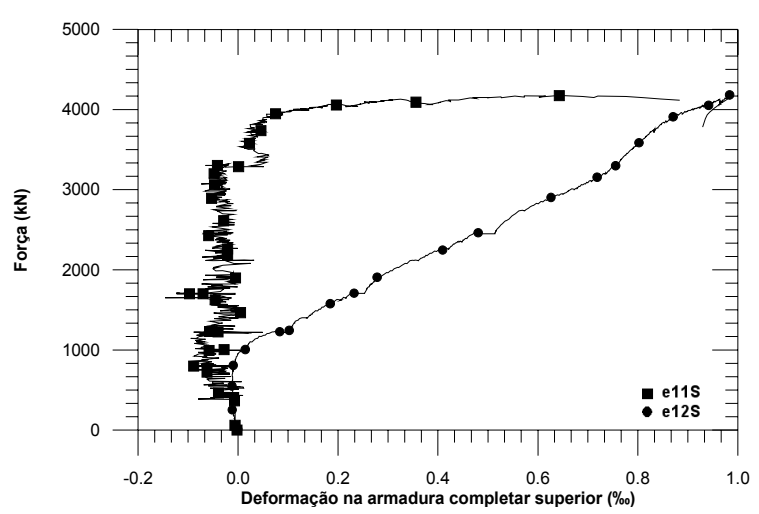

Figura 5.106 - Curva força vs. deformação, modelo B45P50E25e0.

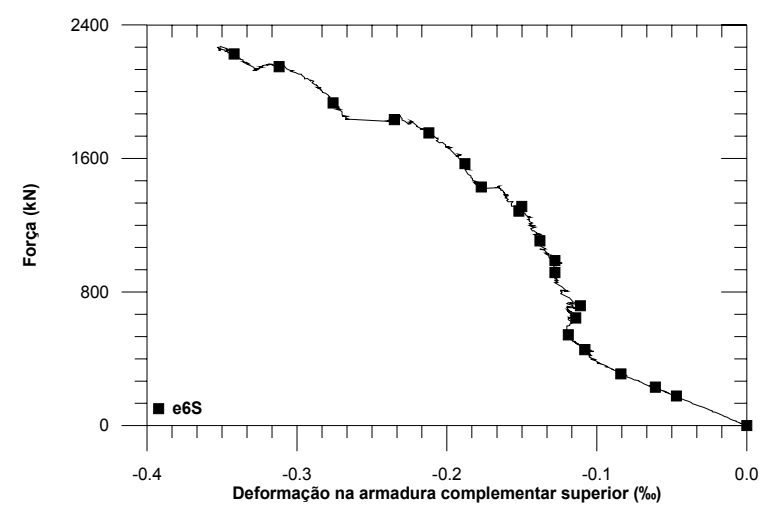

Figura 5.103 - Curva força vs. deformação, modelo B45P25E25e0CG.

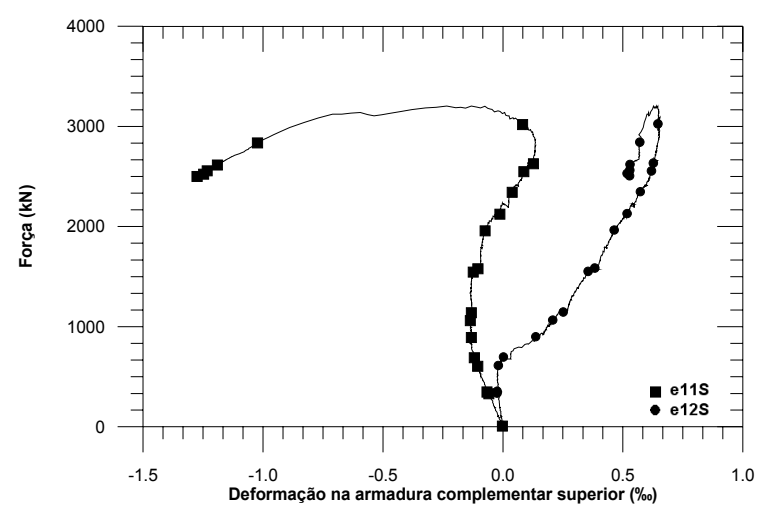

Figura 5.105 - Curva força vs. deformação, modelo B35P50E25e12,5.

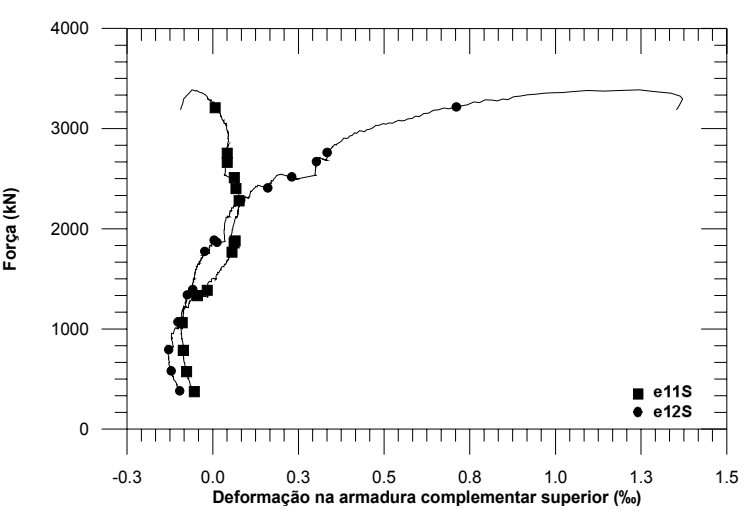

Figura 5.107 - Curva força vs. deformação, modelo B45P50E25e12,5. 


\subsubsection{Deformações nos estribos horizontais}

Neste item são analisadas as deformações dos estribos horizontais. Nos dois primeiros modelos ensaiados (B35P25E25e0 e B35P25E25e2,5), utilizaram-se quatro extensômetros elétricos de resistência, nos demais modelos dois, pois observou-se por meios dos resultados dos primeiros ensaios que a utilização de apenas dois extensômetros era suficiente. A Tabela 5.35 apresenta os resultados das deformações dos estribos horizontais em cada modelo. É válido lembrar que os modelos B35P25E25e0A $\mathrm{sw}_{\mathrm{sw}, \mathrm{C}}, \mathrm{B} 35 \mathrm{P} 25 \mathrm{E} 25 \mathrm{e} 0 \mathrm{~A}_{\mathrm{sw}, 0}, \mathrm{~B} 45 \mathrm{P} 25 \mathrm{E} 25 \mathrm{e} 0 \mathrm{~A}_{\mathrm{sw}, \mathrm{c}}$ e B35P25E25e0A $\mathrm{Aw}, 0_{\text {, não }}$ foram construídos com estribos horizontais. Os estribos da série B35P25 e B45P25 tinham diâmetros de $5 \mathrm{~mm}$, já os da série B35P50 e B45P50 tinham diâmetro de 6,3 $\mathrm{mm}$.

Durante os ensaios o extensômetro $e_{17 \mathrm{H}}$ do modelo B45P25E25e0CG apresentou defeito.

Tabela 5.35 - Deformações nas barras de aço dos estribos horizontais.

\begin{tabular}{c|c|c|c|c|c}
\hline \hline Modelos & $\begin{array}{c}\varepsilon_{\mathrm{e} 21 \mathrm{H}} \mathrm{e} \varepsilon_{\mathrm{e} 16 \mathrm{H}}{ }^{*} \\
(\% \mathrm{o})\end{array}$ & $\begin{array}{c}\varepsilon_{\mathrm{e} 22 \mathrm{H}} \mathrm{e} \varepsilon_{\mathrm{e} 17 \mathrm{H}}{ }^{*} \\
(\% \mathrm{o})\end{array}$ & $\begin{array}{c}\varepsilon_{\mathrm{e} 23 \mathrm{H}} \\
(\% \mathrm{o})\end{array}$ & $\begin{array}{c}\varepsilon_{\mathrm{e} 24 \mathrm{H}} \\
(\% \mathrm{o})\end{array}$ & $\begin{array}{c}\varepsilon_{\mathrm{y}} \\
(\% \mathrm{o})\end{array}$ \\
\hline B35P25E25e0 & 0,42 & 0,86 & 1,22 & 0,97 & 4,05 \\
\hline B35P25E25e2,5 & 0,84 & 0,87 & 1,06 & 1,45 & 4,05 \\
\hline B35P25E25e0CG & $-0,03$ & 0,47 & & & 4,05 \\
\hline B45P25E25e0 & 0,27 & 1,24 & & & 4,05 \\
\hline B45P25E25e5 & 1,07 & 1,78 & & & 4,05 \\
\hline B45P25E25e0CG & 0,32 & - & & & 4,05 \\
\hline B35P50E25e0 & 0,06 & 0,86 & & & 2,99 \\
\hline B35P50E25e12,5 & 0,91 & 1,81 & & & 2,99 \\
\hline B45P50E25e0 & 1,00 & 2,03 & & & 2,99 \\
\hline B45P50E25e12,5 & 0,51 & 2,44 & & & 2,99 \\
\hline \hline
\end{tabular}

Notas: $\varepsilon_{\text {eiH }}$, são as deformações nas barras de aço dos estribos horizontais, nas posições i consideradas e $\varepsilon_{y}$ é a deformação de escoamento das barras de aço dos estribos horizontais.

Referem-se às posições dos extensômetros nos modelos B35P25E25e0CG e B45P25E25e0CG.

Observou-se que os extensômetros instalados na seção do bloco localizada no centro da estacas apresentaram deformações mais intensas que as deformações localizadas na seção de meio de vão. Isso ocorreu em função das tensões de tração existentes perpendiculares às bielas de compressão, as quais foram absorvidas pela barra de aço do estribo horizontal. Observou-se também que, após a ruptura do concreto, as deformações nessas barras aumentaram em decorrência do esmagamento da biela, pois parte da força que estava migrando diretamente para as estacas, sofreu mudança de direção, em virtude da plastificação do concreto naquela região. 
As Figuras 5.108 a 5.117 apresentam curvas força vs. deformação das barras de aço dos estribos horizontais.

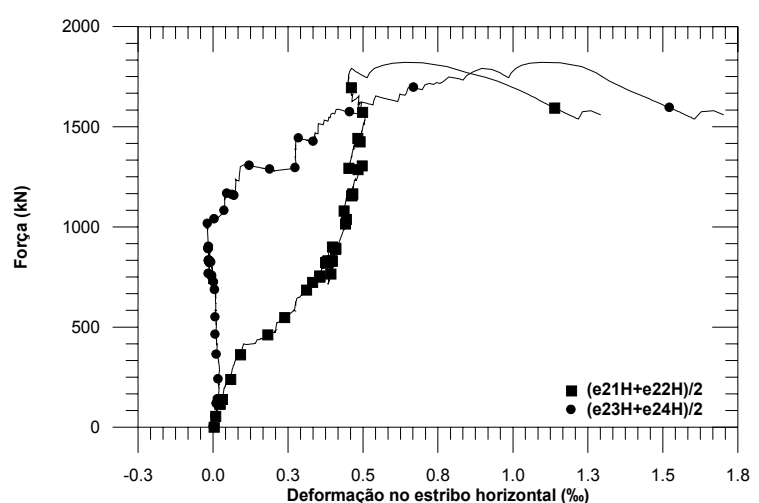

Figura 5.108 - Curva força vs. deformação, modelo B35P25E25e0.

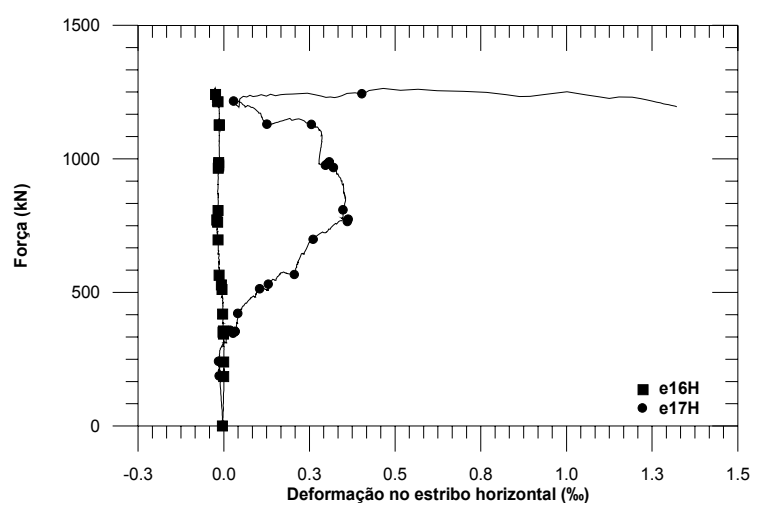

Figura 5.110 - Curva força vs. deformação, modelo B35P25E25e0CG.

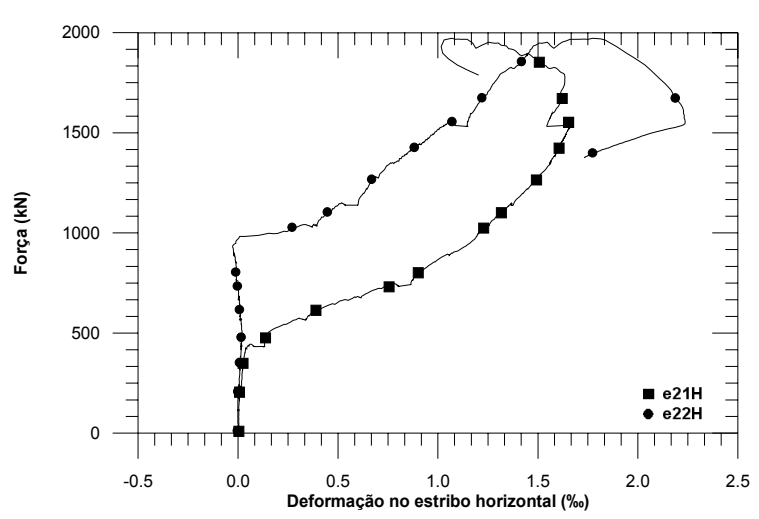

Figura 5.112 - Curva força vs. deformação, modelo B45P25E25e5.

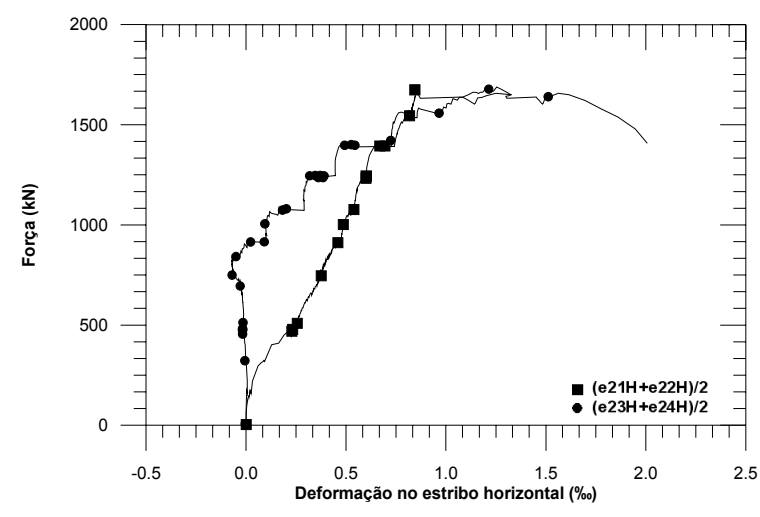

Figura 5.109 - Curva força vs. deformação, modelo B35P25E25e2,5.

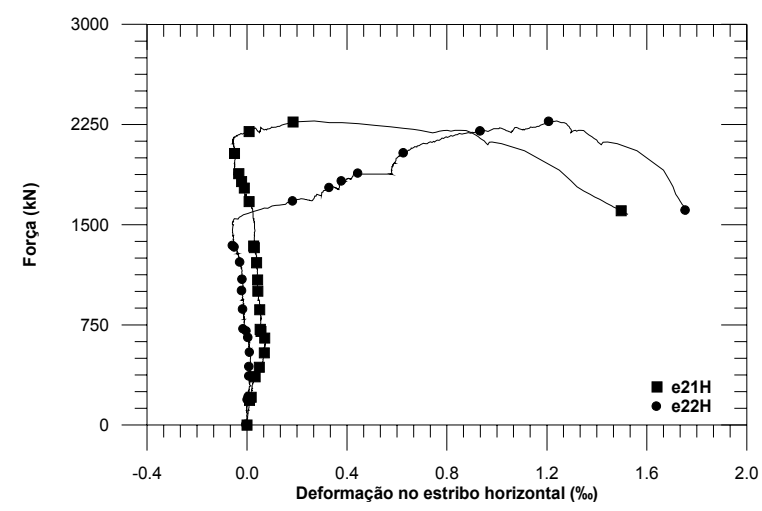

Figura 5.111 - Curva força vs. deformação, modelo B45P25E25e0.

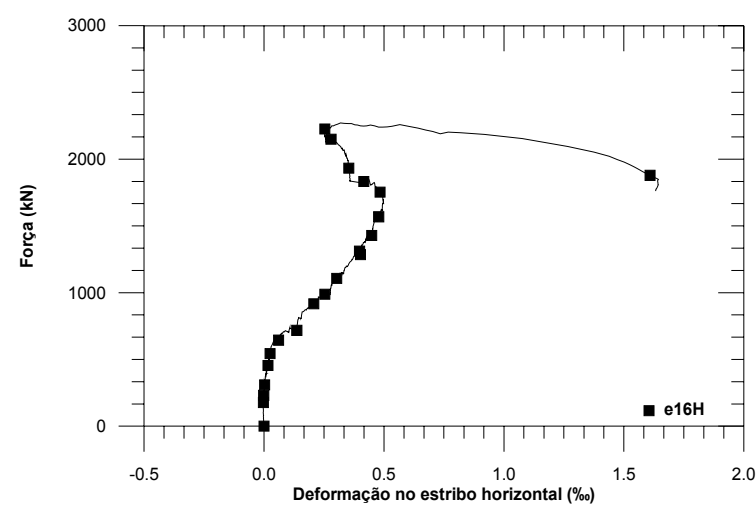

Figura 5.113 - Curva força vs. deformação, modelo B45P25E25e0CG. 


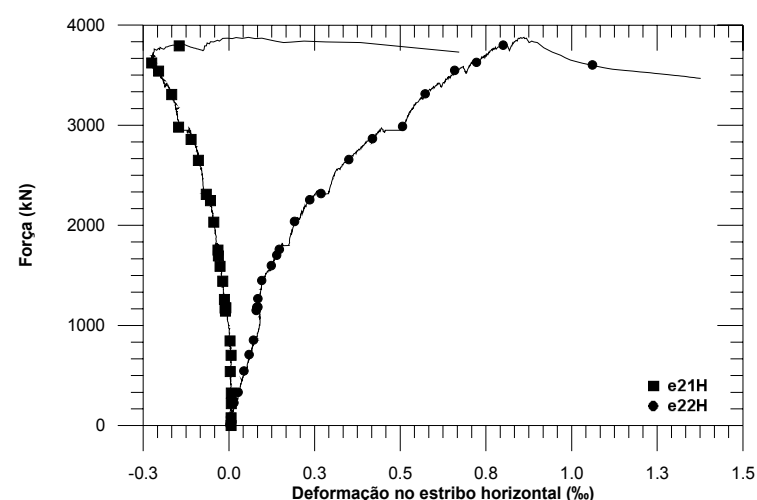

Figura 5.114 - Curva força vs. deformação, modelo B35P50E25e0.

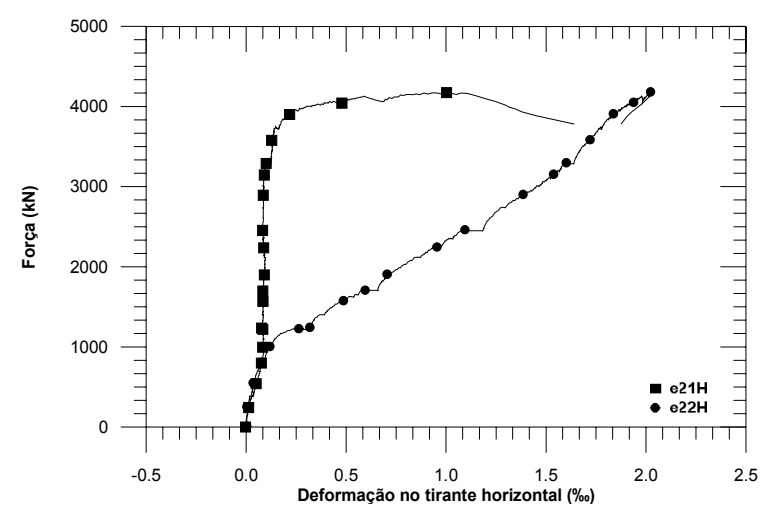

Figura 5.116 - Curva força vs. deformação, modelo B45P50E25e0.

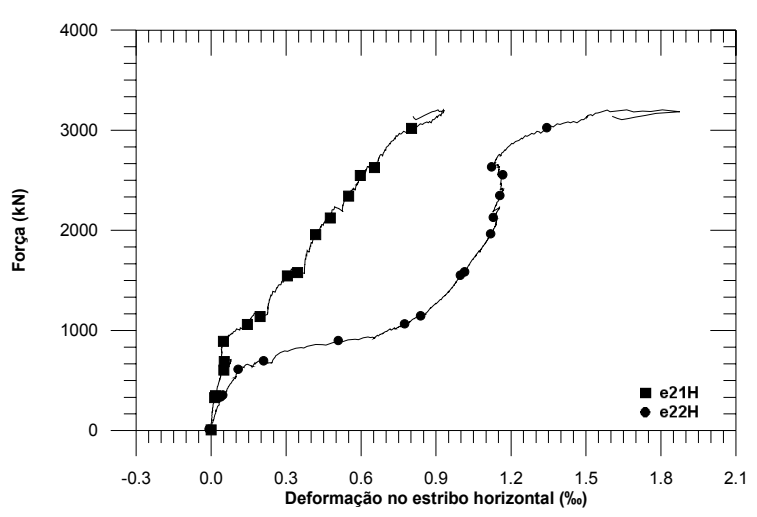

Figura 5.115 - Curva força vs. deformação, modelo B35P50E25e12,5.

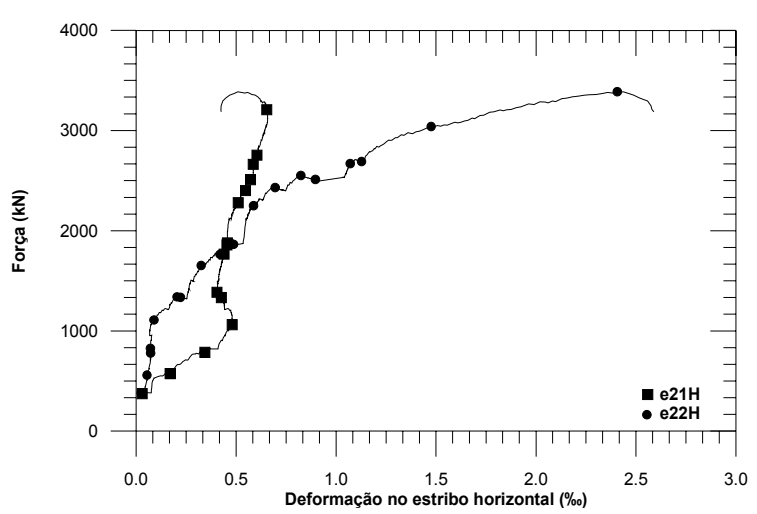

Figura 5.117 - Curva força vs. deformação, modelo B45P50E25e12,5.

\subsubsection{Deformações nos estribos verticais}

As deformações nos estribos verticais foram acompanhadas em duas seções: meio de vão do bloco e centro da estaca. Os modelos B35P25E25e0A $A_{s w, C}$, $B 35 P 25 E 25 e 0 A_{s w, 0}, B 45 P 25 E 25 e 0 A_{s w, C}$ e B45P25E25e0A $A_{s w, 0}$ não foram construídos com estribos verticais. $O$ objetivo de medir as deformações nesses estribos foi analisar seu comportamento durante as fases de serviço e ultima. As barras de aço utilizados nos estribos dos modelos das séries B35P25 e B45P25 tinham diâmetro de 5 mm, e os modelos das séries B35P50 e B45P50 diâmetros de $6,3 \mathrm{~mm}$.

Em função dos valores das forças últimas obtidas nos ensaios dos blocos, observou-se que as armaduras complementares (estribos horizontais e verticais) não tiveram relevância, ficando restritas à limitação das aberturas de fissuras e de possíveis esforços solicitantes adicionais provocados por excentricidades acidentais. 
Na Tabela 5.36 observa-se que as deformações nas barras dos estribos não atingiram o valor da deformação de escoamento, além disto, suas deformações são muito pequenas, comprovando que os estribos verticais, quanto os horizontais, não contribuíram na capacidade portante do bloco. As deformações apresentadas na Tabela 5.36 referem-se à força última de cada modelo. As Figuras 5.79 a 5.88 apresentam curvas força vs. deformações dos estribos verticais.

Durante a execução dos ensaios constataram-se problemas nos extensômetros elétricos de resistência $e_{12 \mathrm{~V}}$ do modelo B35P25E25e0CG, $e_{14 \mathrm{~V}}$ do modelo B45P25E25e0, e ev do modelo B45P25E25e5, e e $8 \mathrm{~V}$ e $e_{9}, e_{11 v}$ e e $e_{13 v}$ do modelo B45P25E25e0CG, $e_{17 V}$ do modelo B45P50E25e0 e $e_{15 \mathrm{~V}}$ e $e_{16 \mathrm{~V}}$ do modelo B45P20E25e12,5.

Tabela 5.36 - Deformações nas barras de aço dos estribos verticais.

\begin{tabular}{|c|c|c|c|c|c|c|c|c|c|}
\hline \multirow[t]{3}{*}{ Modelos } & $\begin{array}{c}\varepsilon_{\mathrm{e} 13 \mathrm{~V}} \\
\mathrm{e} \\
\varepsilon_{\mathrm{e} 8 \mathrm{~V}}{ }^{*} \\
(\% 0)\end{array}$ & $\begin{array}{c}\varepsilon_{\mathrm{e} 14 \mathrm{~V}} \\
\mathrm{e} \\
\varepsilon_{\mathrm{e} 9 \mathrm{v}}{ }^{*} \\
(\% \mathrm{o})\end{array}$ & $\begin{array}{c}\varepsilon_{\mathrm{e} 15 \mathrm{~V}} \\
\mathrm{e} \\
\varepsilon_{\mathrm{e} 10 \mathrm{~V}} \\
(\% \mathrm{o})\end{array}$ & $\begin{array}{c}\varepsilon_{\mathrm{e} 16 \mathrm{~V}} \\
\mathrm{e} \\
\varepsilon_{\mathrm{e} 11 \mathrm{v}} \\
(\%)\end{array}$ & $\begin{array}{c}\varepsilon_{\mathrm{e} 17 \mathrm{~V}} \\
\mathrm{e} \\
\varepsilon_{\mathrm{e} 12 \mathrm{~V}} \\
(\% 0)\end{array}$ & $\begin{array}{c}\varepsilon_{\mathrm{e} 18 \mathrm{~V}} \\
\mathrm{e} \\
\varepsilon_{\mathrm{e} 13 \mathrm{~V}} \\
(\% 0)\end{array}$ & $\begin{array}{c}\varepsilon_{\mathrm{e} 19 \mathrm{~V}} \\
\mathrm{e} \\
\varepsilon_{\mathrm{e} 14 \mathrm{v}} \\
(\% 0)\end{array}$ & $\begin{array}{c}\varepsilon_{\mathrm{e} 20 \mathrm{~V}} \\
\mathrm{e} \\
\varepsilon_{\mathrm{e} 15 \mathrm{v}} \\
(\% \mathrm{o})\end{array}$ & \multirow[t]{3}{*}{$\begin{array}{c}\varepsilon_{y} \\
(\% 0)\end{array}$} \\
\hline & \multicolumn{2}{|c|}{ Ramos horizontais } & \multicolumn{2}{|c|}{ Ramos verticais } & \multicolumn{2}{|c|}{ Ramos horizontais } & \multicolumn{2}{|c|}{ Ramos verticais } & \\
\hline & \multicolumn{4}{|c|}{ Seção: centro da estaca } & \multicolumn{4}{|c|}{ Seção: meio do vão do bloco } & \\
\hline B35P25E25e0 & 0,22 & 0,036 & 0,18 & 0,17 & 0,03 & 0,27 & 0,02 & 0,15 & 4,05 \\
\hline B35P25E25e2,5 & 0,25 & 0,02 & $-0,08$ & 0,13 & 0,09 & 0,27 & 0,67 & 0,55 & 4,05 \\
\hline B35P25E25e0CG & 0,23 & 0,19 & $-0,03$ & $-0,04$ & - & 0,21 & $-0,05$ & 0,19 & 4,05 \\
\hline B45P25E25e0 & 0,12 & - & $-0,04$ & $-0,02$ & 0,04 & 0,06 & $-0,11$ & $-0,05$ & 4,05 \\
\hline B45P25E25e5 & 0,75 & -0.01 & 0,63 & 0,87 & 0,28 & 0,80 & 0,80 & 0,60 & 4,05 \\
\hline B45P25E25e0CG & - & - & $-0,18$ & - & $-0,02$ & - & $-0,01$ & $-0,35$ & 4,05 \\
\hline B35P50E25e0 & 1,54 & 0,67 & $-0,50$ & $-0,80$ & 0,023 & 0,12 & 0,09 & 0,15 & 2,99 \\
\hline В35Р50E25e12,5 & 1,56 & 0,02 & 0,2 & 0,2 & 0,18 & 0,53 & 1,33 & 1,03 & 2,99 \\
\hline B45P50E25e0 & 0,22 & 0,10 & $-0,92$ & $-0,58$ & - & 0,12 & 0,634 & 0,01 & 2,99 \\
\hline B45P50E25e12,5 & 0,24 & 0,14 & - & - & 0,46 & 1,78 & 0,09 & $-0,83$ & 2,99 \\
\hline
\end{tabular}

Notas: $\varepsilon_{\text {eiv }}$, são as deformações nas barras de aço dos estribos verticais, nas posições i consideradas e $\varepsilon_{y}$ é a deformação de escoamento das barras de aço dos estribos horizontais.

* Referem-se às posições dos extensômetros nos modelos B35P25E25e0CG e B45P25E25e0CG.

Analisando a Tabela 5.36, observa-se um fenômeno interessante. O ramo horizontal inferior do estribo posicionado na seção do bloco no centro da estaca apresenta deformações maiores que o ramo horizontal superior, já, para o estribo posicionado na seção de meio do vão do bloco, essas deformações se invertem, ou seja, o ramo mais solicitado é o horizontal superior. Além disso, observou-se que em alguns modelos, o bloco sofreu torção ao longo de seu eixo longitudinal, pois, as deformações nos ramos verticais dos estribos instrumentados apresentaram sinais invertidos. Apesar das deformações nos ramos horizontais dos estribos terem sido pequenas, pôde-se concluir que nas regiões nodais inferior e superior que são altamente solicitadas por forças de compressão, surgem também, no sentido 
perpendicular ao eixo longitudinal do bloco tensões de tração, sendo assim, a utilização de ganchos nas zonas nodais inferiores e prolongamento dos estribos do pilar no interior do bloco seriam soluções ideais para absorver essas tensões. Analisando as Figuras 5.118 a 5.127, constata-se que os estribos foram mais solicitados após a ruptura do bloco, principalmente, os estribos localizados na seção do bloco sobre a estaca. Isso era esperado, pois, nessa seção ocorreu a plastificação do concreto nas zonas nodais inferior e superior, como também, fissuras perpendiculares à biela de compressão.
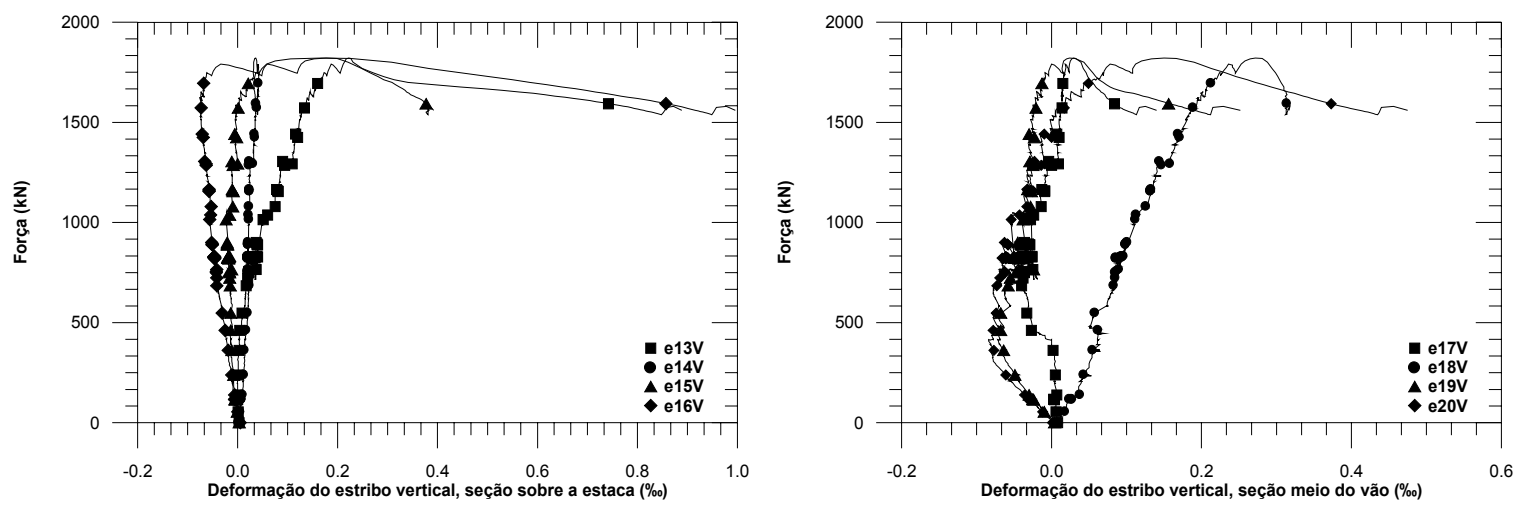

Figura 5.118 - Curva força vs. deformação, modelo B35P25E25e0.
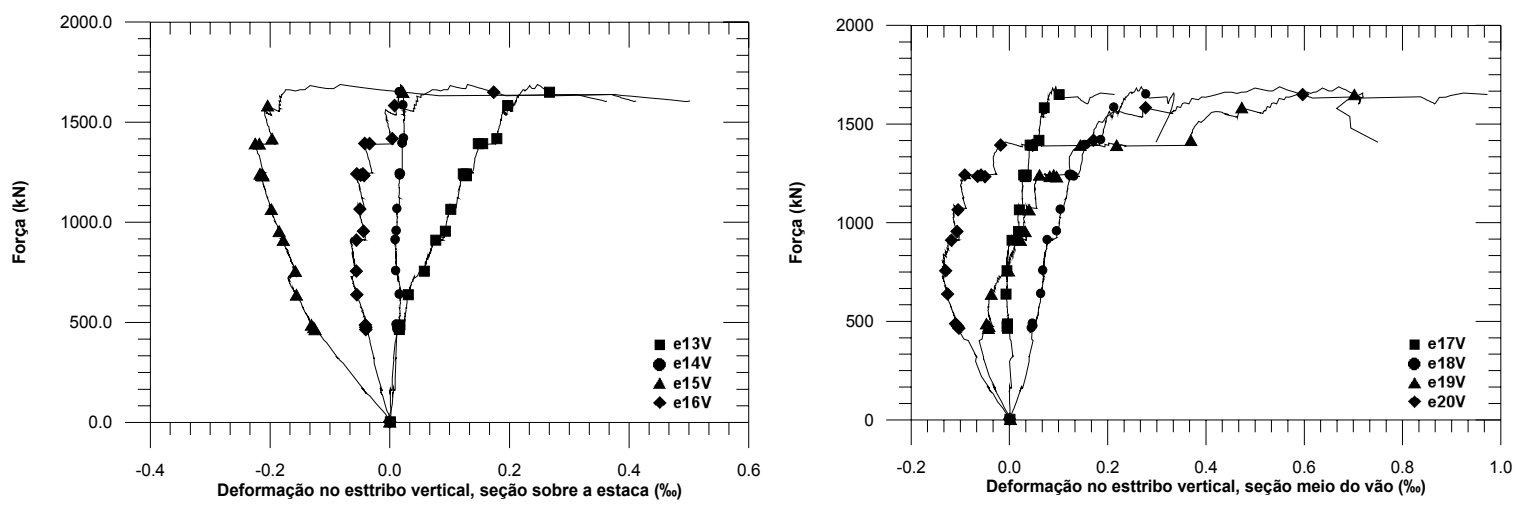

Figura 5.119 - Curva força vs. deformação, modelo B35P25E25e2,5.
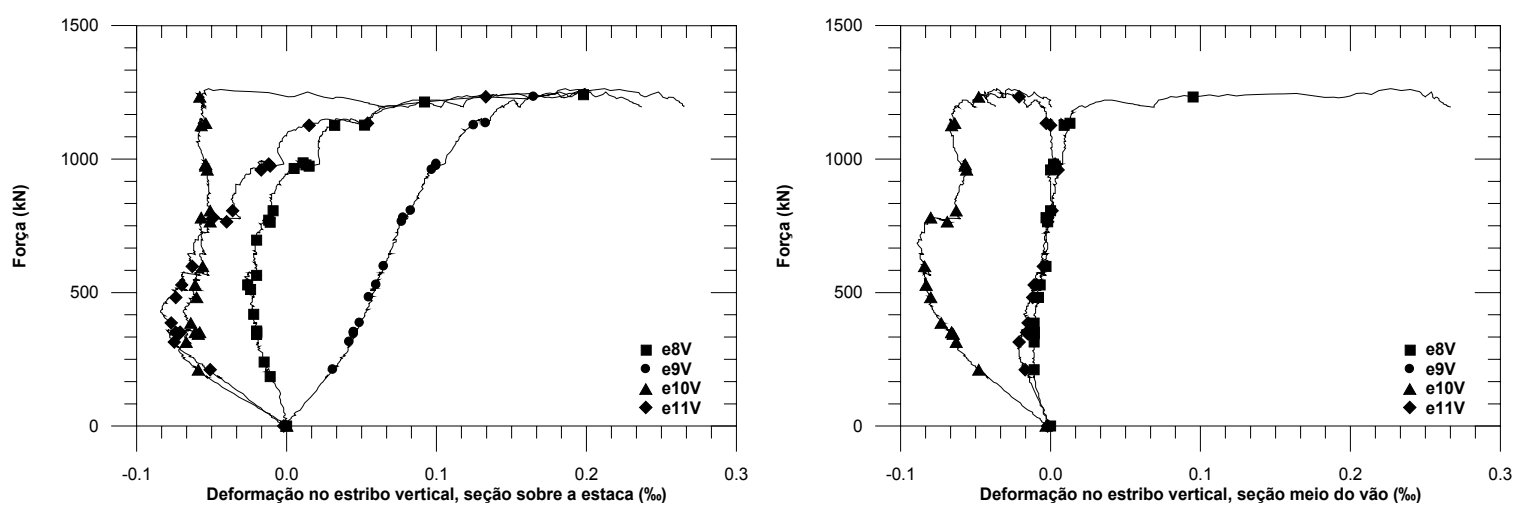

Figura 5.120 - Curva força vs. deformação, modelo B35P25E25e0CG. 

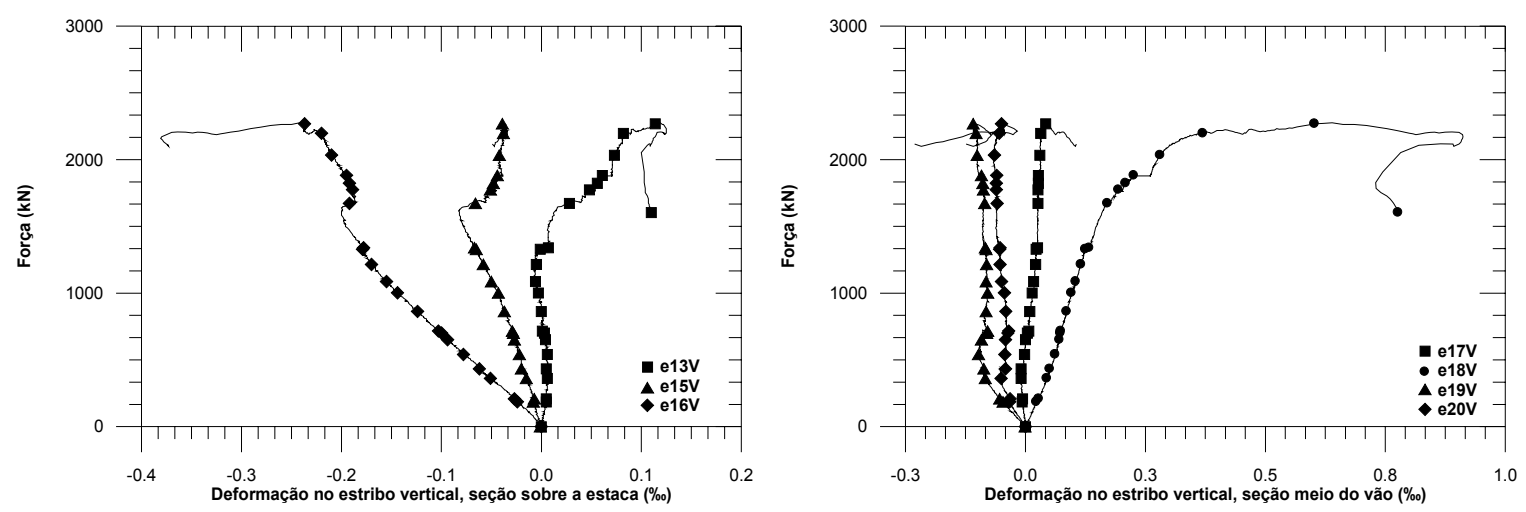

Figura 5.121 - Curva força vs. deformação, modelo B45P25E25e0.
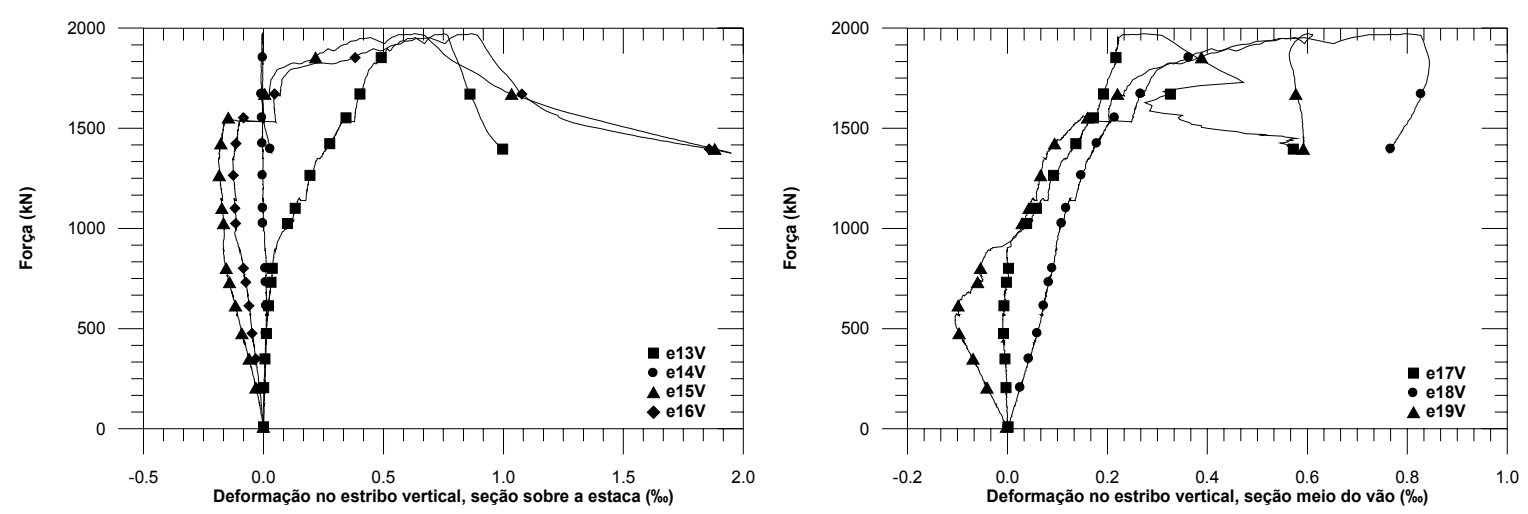

Figura 5.122 - Curva força vs. deformação, modelo B45P25E25e5.
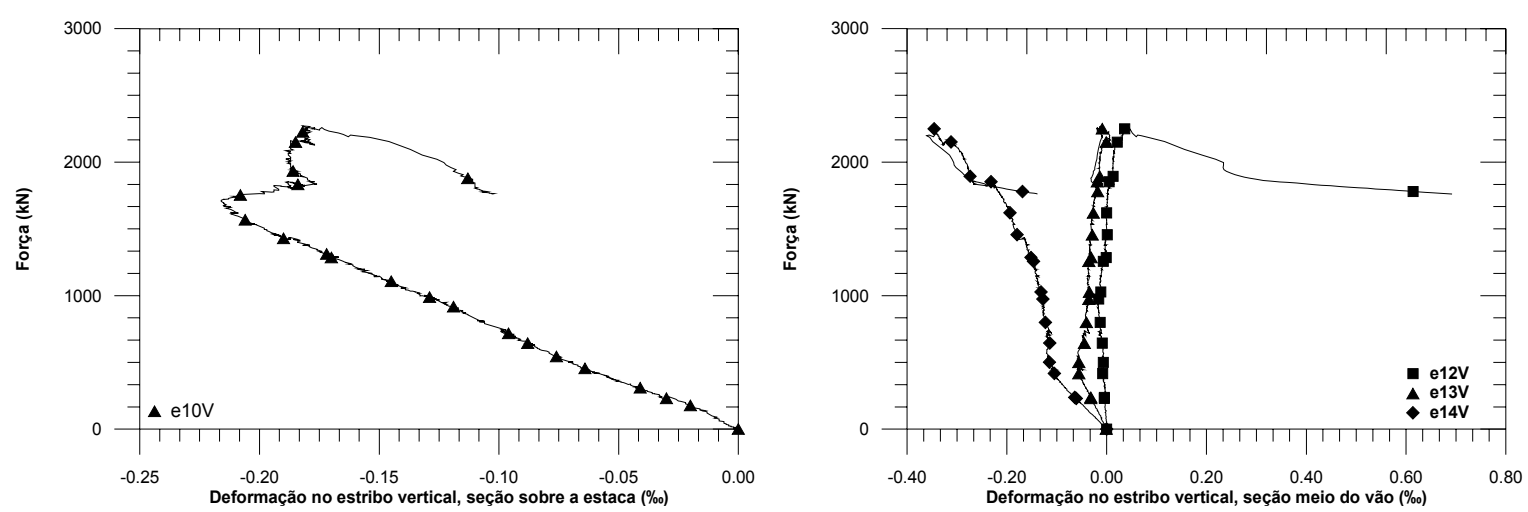

Figura 5.123 - Curva força vs. deformação, modelo B45P25E25e0CG. 

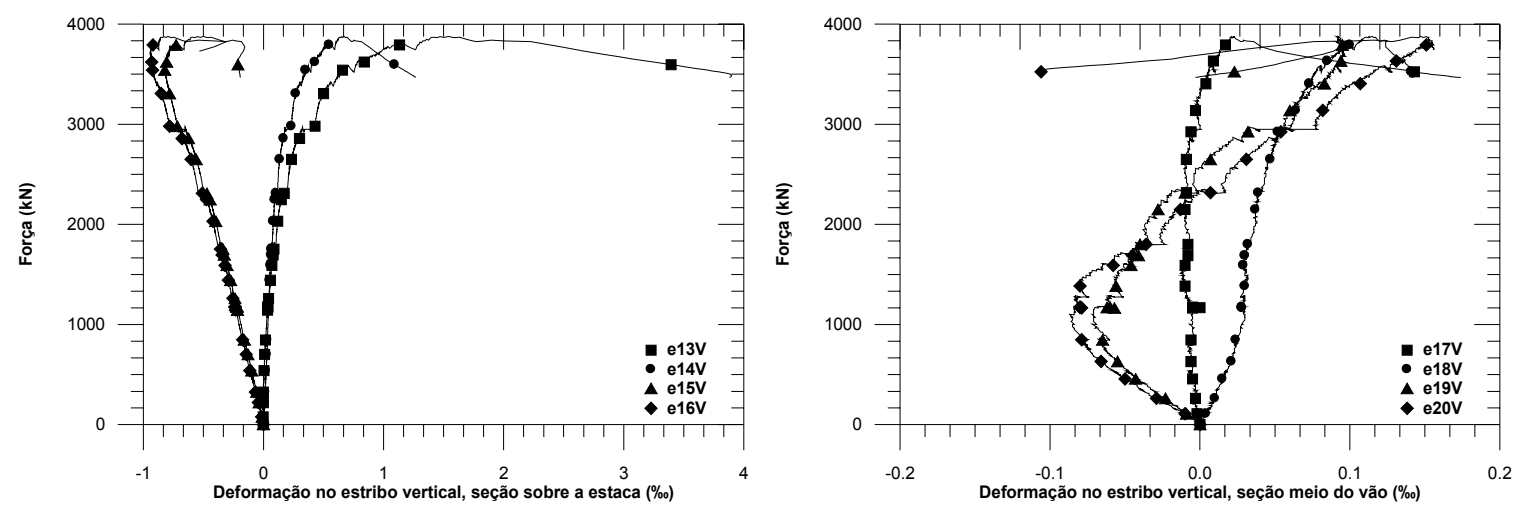

Figura 5.124 - Curva força vs. deformação, modelo B35P50E25e0.
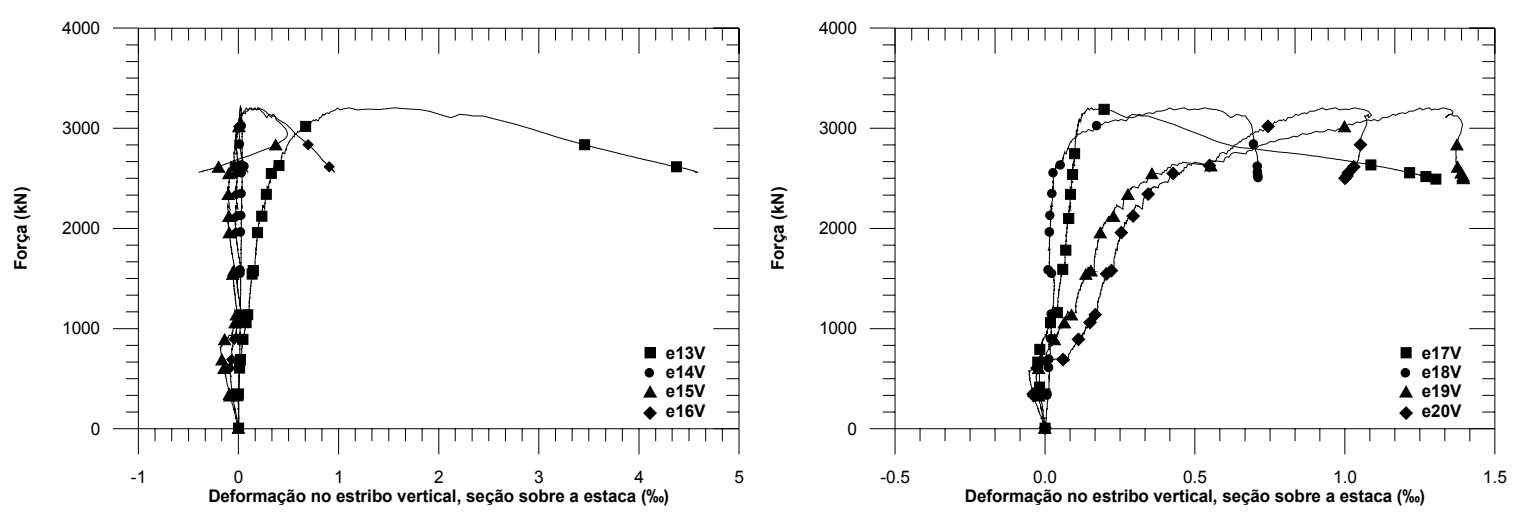

Figura 5.125 - Curva força vs. deformação, modelo B35P50E25e12,5.
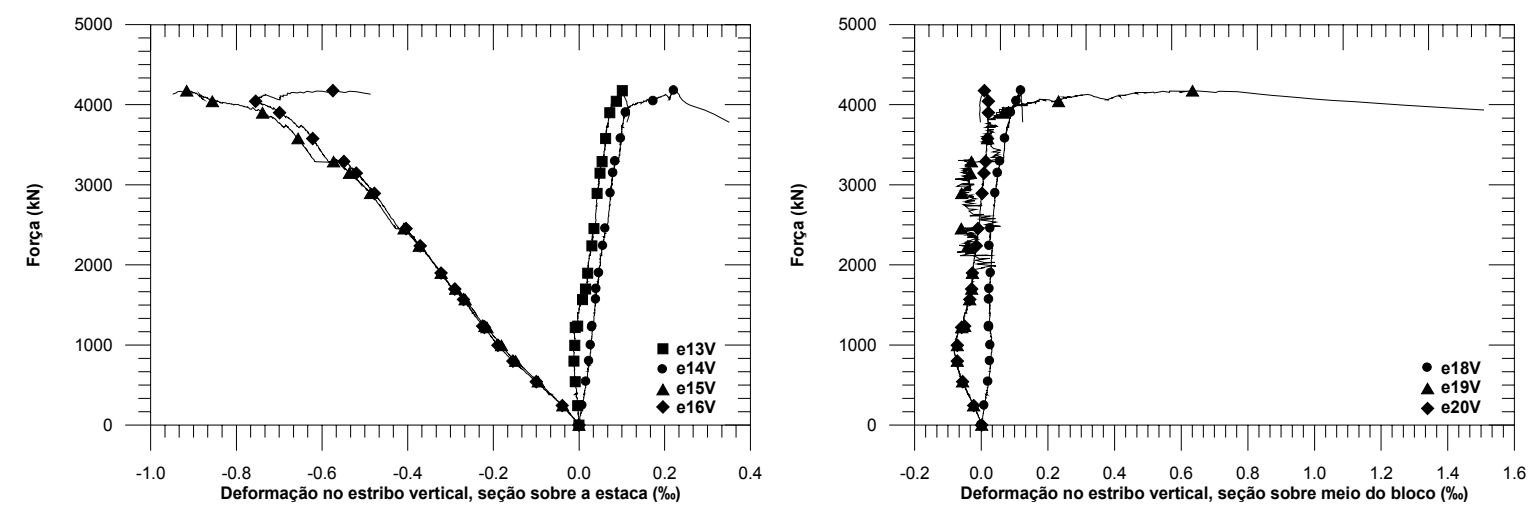

Figura 5.126 - Curva força vs. deformação, modelo B45P50E25e0. 

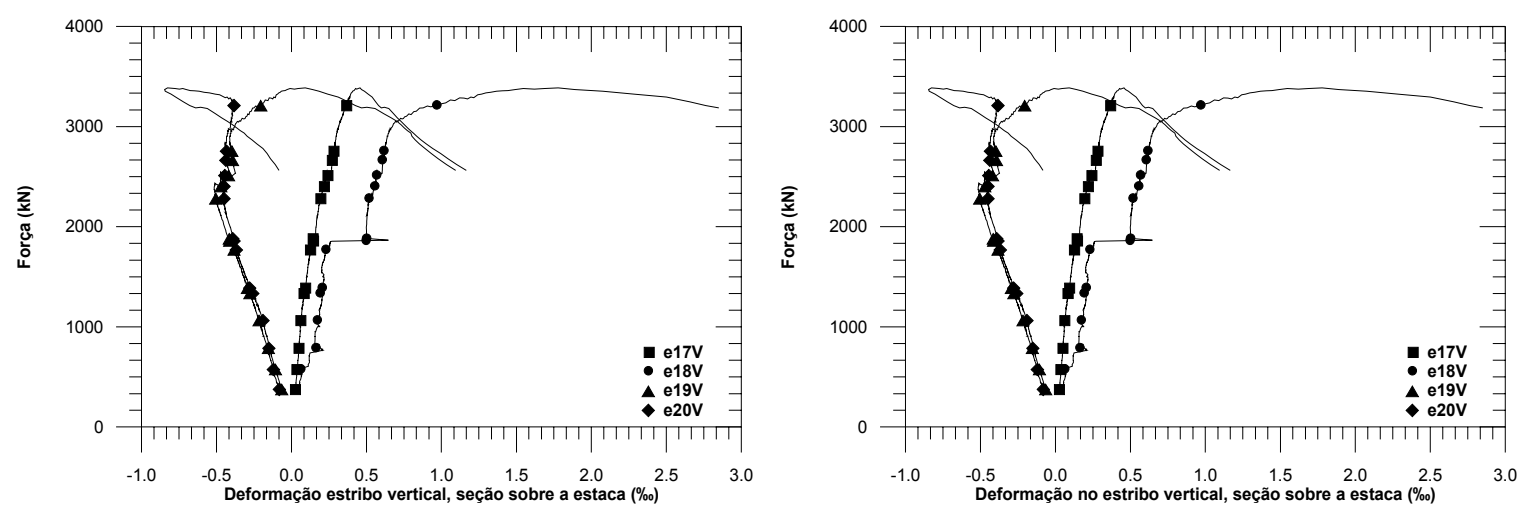

Figura 5.127 - Curva força vs. deformação, modelo B45P50E25e12,5.

5.3.6.5. Deformações na armadura complementar sugerida pelo autor

Essas barras foram utilizadas nas construções dos modelos B35P25E25e0A $A_{s w, C}$ e $B 45 P 25 E 25 e 0 A_{s w, C}$. Funcionam como armadura de costura, que atravessam às bielas de compressão, sendo responsáveis por resistir as forças de tração existente na direção perpendicular à biela. Como pode ser vista na Tabela 5.1, os blocos construídos com tal armadura, suportaram maiores forças. A Figura 5.11 mostra as posições dos extensômetros elétricos de resistência instalados nessas barras. As barras em questão tinham diâmetro de $16 \mathrm{~mm}$.

$\mathrm{Na}$ Tabela 5.37 podem ser vistos os resultados das deformações obtidas nos ensaios. Observa-se que as deformações das barras foram inferiores a deformação de escoamento. Os valores marcados com asterisco referem-se às deformações registradas pelos extensômetros na região do esmagamento da biela de compressão (Figura 5.27). As Figuras 5.128 e 5.129 apresentam curvas força vs. deformação das barras de aço dos modelos ensaiados. A deformação na posição $\mathrm{e}_{14 \mathrm{~F}}$ do modelo B35P25E25A $A_{s w, C}$ reforça a tese que a ancoragem destas barras de aço não foram satisfatórias, pois como já foi dito, no instante da ruína, surgiram fissuras na face superior do bloco. Verifica-se, que esse fenômeno ocorreu apenas no bloco menos rígido.

Tabela 5.37 - Deformações na armadura complementar sugerida.

\begin{tabular}{c|c|c|c|c|c}
\hline \hline Modelos & $\begin{array}{c}\varepsilon_{\mathrm{e} 11 \mathrm{~F}} \\
(\%)\end{array}$ & $\begin{array}{c}\varepsilon_{\mathrm{e} 12 \mathrm{H}} \\
(\%)\end{array}$ & $\begin{array}{c}\varepsilon_{\mathrm{e} 13 \mathrm{~F}} \\
(\%)\end{array}$ & $\begin{array}{c}\varepsilon_{\mathrm{e} 14 \mathrm{~F}} \\
(\%)\end{array}$ & $\begin{array}{c}\varepsilon_{\mathrm{y}} \\
(\%)\end{array}$ \\
\hline B35P25E25e0A $_{\mathrm{sw}, \mathrm{C}}$ & 0,64 & $1,44^{*}$ & 0,81 & $2,52^{*}$ & 2,74 \\
\hline B45P25E25e0A & 0,04 & 2,31 & 2,39 & 0,32 & 2,74 \\
\hline \hline
\end{tabular}

Notas: $\varepsilon_{\mathrm{eiF}}$, são as deformações nas barras de aço da armadura sugerida, nas posições i consideradas e $\varepsilon_{y}$ é a deformação de escoamento das barras de aço dos estribos horizontais. 


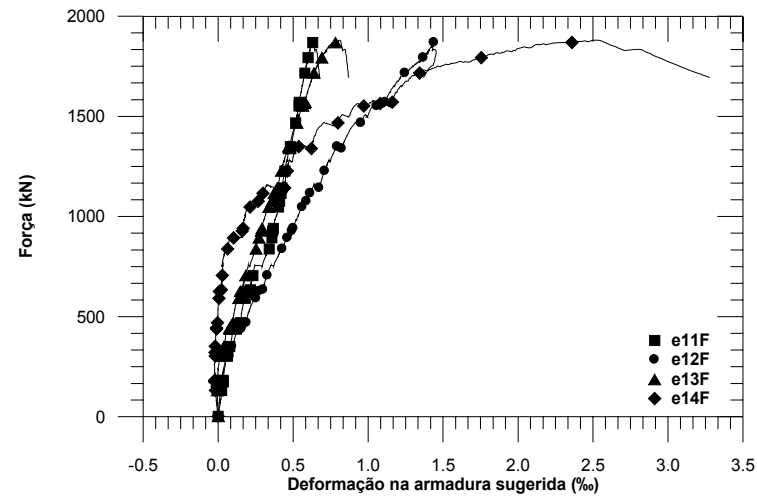

Figura 5.128 - Curva força vs. deformação, modelo B35P25E25A $A_{s w, 0}$.

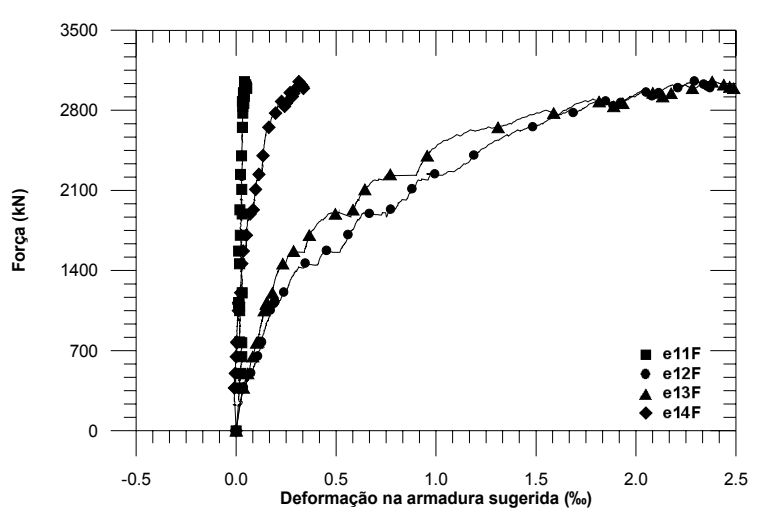

Figura 5.129 - Curva força vs. deformação, modelo B45P25E25e0A $\mathrm{sw,c}$.

Por meio das Figuras 5.128 e 5.129, observa-se que na posição em que as barras atravessam as bielas $\left(e_{12 F}\right.$ e $\left.e_{13 F}\right)$ às deformações são intensas em função das forças de tração existentes nessa região.

\subsubsection{Ensaios complementares}

Este item apresenta os resultados dos ensaios dos corpos-de-prova cilíndricos de concreto, utilizados na determinação das propriedades mecânicas do material concreto empregado na moldagem dos modelos experimentais. Foram moldados quarenta e dois corpos-de-prova com dimensões iguais a quinze centímetros de diâmetro e trinta centímetros de altura e sessenta corpos-de-prova com dimensões iguais a dez centímetros de diâmetro e vinte centímetros de altura. A moldagem e cura dos corpos-de-prova obedeceram às recomendações da NBR 5738:1984. A cura dos cilindros de concreto foi a mesma dos modelos em termos de condições ambientais e tempo. A norma citada sugere a utilização de corpos-de-prova cilíndricos com dimensões de quinze centímetros de diâmetro por trinta centímetros de altura, porém, em função da elevada resistência à compressão dos concretos das estacas e pilares, optou-se pela utilização de corpos-de-prova cilíndricos com dimensões de dez centímetros de altura e vinte centímetros de diâmetro.

Também são apresentados resultados dos ensaios de tração simples das barras de aço, sendo utilizadas três amostras para cada diâmetro de acordo com as recomendações da NBR 6152:1992. Para determinação do diâmetro efetivo das barras de aço ensaiadas, considerou-se massa específica do aço igual a $7,85 \mathrm{~g} / \mathrm{cm}^{3}$, conforme prescreve a NBR 7480:1996. 
5.3.7.1. Ensaio de compressão de corpos-de-prova cilíndricos de concreto

Os ensaios dos corpos-de-prova foram feitos de acordo com as recomendações da NBR 5739:1980. Após o capeamento com enxofre procedeu-se o ensaio. Em função do grande número de corpos-de-prova, foram utilizados os mesmos exemplares para as determinações das resistências médias a compressão e os módulos de elasticidade. Alguns corpos-de-prova foram ensaiados na máquina hidráulica ELE Autotest 2000 com capacidade nominal de 2000 kN, outros na máquina Instron com capacidade de 3000 kN, ambas pertencentes ao Laboratório de Estruturas da Escola de Engenharia de São Carlos, Universidade de São Paulo. Os ensaios foram feitos em máquinas diferentes, pois durante o desenvolvimento dos trabalhos experimentais a máquina ELE apresentou defeito, ficando fora de operação por um período. Os corpos-de-prova foram ensaiados com as mesmas idades dos blocos.

A Tabela 5.38 apresenta os resultados das resistências a compressão de cada corpo-de-prova com dimensões iguais a quinze centímetros de diâmetro e trinta centímetros de altura e a Tabela 5.39 os resultados dos corpos de prova com dez centímetros de diâmetro e vinte centímetros de altura.

Tabela 5.38 - Resistência à compressão, CP $15 \mathrm{~cm}$ x $30 \mathrm{~cm}$.

\begin{tabular}{|c|c|c|c|c|c|}
\hline Modelos & $\mathrm{N}^{\circ}$ C. P. & $\begin{array}{c}\text { Idade } \\
\text { (dias) }\end{array}$ & $\begin{array}{c}\mathbf{f}_{\mathbf{c}} \\
(\mathrm{MPa})\end{array}$ & $\begin{array}{c}\mathbf{f}_{\mathrm{cm}} \\
(\mathrm{MPa})\end{array}$ & $\begin{array}{c}\text { Abatimento } \\
(\mathrm{cm})\end{array}$ \\
\hline \multirow{3}{*}{$\begin{array}{c}\text { B35P25E25e0 } \\
e \\
\text { B35P25E25e2,5 }\end{array}$} & 01 & \multirow{3}{*}{72} & 42,17 & \multirow{3}{*}{40,6} & \multirow{3}{*}{11,2} \\
\hline & 02 & & 36,99 & & \\
\hline & 03 & & 42,61 & & \\
\hline \multirow{3}{*}{$\begin{array}{c}\mathrm{B} 35 \mathrm{P} 25 \mathrm{E} 25 \mathrm{e} 0 \mathrm{~A}_{\mathrm{sw}, \mathrm{C}} \\
\mathrm{e} \\
\mathrm{B} \\
\end{array}$} & 01 & \multirow{3}{*}{66} & 31,62 & \multirow{3}{*}{32,8} & \multirow{3}{*}{14,2} \\
\hline & 02 & & 33,94 & & \\
\hline & 03 & & 32,77 & & \\
\hline \multirow{3}{*}{$\begin{array}{c}\text { B35P25E25e0CG } \\
e \\
\text { B45P25E25e0CG }\end{array}$} & 01 & \multirow{3}{*}{64} & 29,23 & \multirow{3}{*}{28,9} & \multirow{3}{*}{9,2} \\
\hline & 02 & & 28,60 & & \\
\hline & 03 & & 28,72 & & \\
\hline \multirow{3}{*}{$\begin{array}{c}\text { B45P25E25e0 } \\
\text { e } \\
\text { B45P25E25e5 }\end{array}$} & 01 & \multirow{3}{*}{57} & 15,36 & \multirow{3}{*}{31} & \multirow{3}{*}{7,5} \\
\hline & 02 & & 31,29 & & \\
\hline & 03 & & 30,63 & & \\
\hline \multirow{3}{*}{$\begin{array}{c}\mathrm{B} 45 \mathrm{P} 25 \mathrm{E} 25 \mathrm{e} 0 \mathrm{~A}_{\mathrm{sw}, \mathrm{C}} \\
\mathrm{e} \\
\mathrm{B} 45 \mathrm{P} 25 \mathrm{E} 25 \mathrm{e} 0 \mathrm{~A}_{\mathrm{sw}, 0}\end{array}$} & 01 & \multirow{3}{*}{49} & 32,57 & \multirow{3}{*}{32,4} & \multirow{3}{*}{8,7} \\
\hline & 02 & & 31,88 & & \\
\hline & 03 & & 32,87 & & \\
\hline \multirow{3}{*}{$\begin{array}{c}\text { B35P50E25e0 } \\
e \\
\text { B45P50E25e0 }\end{array}$} & 01 & \multirow{3}{*}{42} & 35,53 & \multirow{3}{*}{35,8} & \multirow{3}{*}{9,5} \\
\hline & 02 & & 36,25 & & \\
\hline & 03 & & 35,67 & & \\
\hline \multirow{3}{*}{$\begin{array}{c}\text { B35P50E25e12,5 } \\
e \\
\text { B45P50E25e12,5 }\end{array}$} & 01 & \multirow{3}{*}{39} & 35,87 & \multirow{3}{*}{35,1} & \multirow{3}{*}{13} \\
\hline & 02 & & 34,34 & & \\
\hline & 03 & & 35,07 & & \\
\hline
\end{tabular}

Nota: valor descartado; $f_{c}$, resistência a compressão medida em corpos-de-prova cilíndricos; $f_{c m}$, resistência média a compressão; Abatimento, resultado do ensaio de abatimento de troco de cone (plasticidade do concreto fresco). 
Tabela 5.39 - Resistência à compressão, CP $10 \mathrm{~cm} \times 20 \mathrm{~cm}$.

\begin{tabular}{|c|c|c|c|c|c|}
\hline Modelos & $\mathrm{N}^{\circ}$ C. P. & $\begin{array}{r}\text { Idade } \\
\text { (dias) }\end{array}$ & $\begin{array}{c}\mathbf{f}_{\mathbf{c}} \\
(\mathrm{MPa})\end{array}$ & $\begin{array}{c}\mathbf{f}_{\mathrm{cm}} \\
(\mathrm{MPa})\end{array}$ & $\begin{array}{l}\text { Abatimento } \\
(\mathrm{cm})\end{array}$ \\
\hline \multirow{3}{*}{$\begin{array}{c}\text { Estacas do B35P25E25e0 e } \\
\text { B35P25E25e2,5 }\end{array}$} & 01 & \multirow{3}{*}{121} & 75,38 & \multirow{3}{*}{73,3} & \multirow{3}{*}{14,7} \\
\hline & 02 & & 69,98 & & \\
\hline & 03 & & 74,38 & & \\
\hline \multirow{3}{*}{ Estacas do B35P25E25e0CG } & 01 & \multirow{3}{*}{107} & 81,54 & \multirow{3}{*}{80,8} & \multirow{3}{*}{17} \\
\hline & 02 & & 79,07 & & \\
\hline & 03 & & 81,70 & & \\
\hline \multirow{3}{*}{$\begin{array}{l}\text { Estacas do B35P25E25e0A } \mathrm{A}_{\mathrm{sw}, \mathrm{c}} \mathrm{e} \\
\text { B35P25E25e0A }_{\mathrm{sw}, 0}\end{array}$} & 01 & \multirow{3}{*}{95} & 69,09 & \multirow{3}{*}{71,6} & \multirow{3}{*}{7,2} \\
\hline & 02 & & 70,50 & & \\
\hline & 03 & & 75,27 & & \\
\hline \multirow{3}{*}{$\begin{array}{c}\text { Pilar do B35P25E25e0 e } \\
\text { B35P25E25e2,5 }\end{array}$} & 01 & \multirow{3}{*}{74} & 72,83 & \multirow{3}{*}{72,3} & \multirow{3}{*}{4,8} \\
\hline & 02 & & 68,04 & & \\
\hline & 03 & & 75,94 & & \\
\hline \multirow{3}{*}{$\begin{array}{c}\text { Pilar do B35P25E25e0A } A_{s w, c} \text { e } \\
\text { B35P25E25e0A } A_{s w, 0} \\
\text { Estacas do B45P25E25e0 e } \\
\text { B45P25E25e5 }\end{array}$} & 01 & \multirow{3}{*}{65} & 51,90 & \multirow{3}{*}{51,8} & \multirow{3}{*}{7,2} \\
\hline & 02 & & 46,73 & & \\
\hline & 03 & & 59,69 & & \\
\hline \multirow{3}{*}{$\begin{array}{c}\text { Pilar do B35P25E25e0CG e } \\
\text { B45P25E25e0CG } \\
\text { Estacas do B45P25E25e0A } \text { A }_{\mathrm{sw}, \mathrm{c}} \mathrm{e} \\
\text { B45P25E25A }\end{array}$} & 01 & \multirow{3}{*}{74} & 54,81 & \multirow{3}{*}{55} & \multirow{3}{*}{24,3} \\
\hline & 02 & & 55,46 & & \\
\hline & 03 & & 54,84 & & \\
\hline \multirow{3}{*}{$\begin{array}{c}\text { Pilar do B45P25E25e0 e } \\
\text { B45P25E25e5 } \\
\text { Estacas do B45P25E25e0CG }\end{array}$} & 01 & \multirow{3}{*}{69} & 55,06 & \multirow{3}{*}{55,2} & \multirow{3}{*}{21} \\
\hline & 02 & & 55,51 & & \\
\hline & 03 & & 55,06 & & \\
\hline \multirow{3}{*}{$\begin{array}{c}\text { Pilar do B45P25E25e0A } A_{s w, c} \text { e } \\
\text { B45P25E25e0A } A_{s w, 0} \\
\text { Estacas do B35P50E25e0 e } \\
\text { B35P50E25e12,5 }\end{array}$} & 01 & \multirow{3}{*}{56} & 51,44 & \multirow{3}{*}{51,2} & \\
\hline & 02 & & 50,45 & & 24 \\
\hline & 03 & & 51,69 & & \\
\hline Pilar do B35P50E25e0 e & 01 & & 50,99 & & \\
\hline $\begin{array}{c}\text { B45P50E25e0 } \\
\text { Estacas do B45P50E25e0 e }\end{array}$ & 02 & 48 & 50,38 & 52,6 & 16,5 \\
\hline B45P50E25e12,5 & 03 & & 56,41 & & \\
\hline & 01 & & 50,75 & & \\
\hline $\begin{array}{c}\text { Pilar do B35P50E25e12,5 e } \\
\text { B45P50E25e12.5 }\end{array}$ & 02 & 38 & 53,31 & 50,6 & 26,5 \\
\hline & 03 & & 47,77 & & \\
\hline
\end{tabular}

Nota: $f_{c}$, resistência a compressão medida em corpos-de-prova cilíndricos; $f_{c m}$, resistência média a compressão; Abatimento, resultado do ensaio de abatimento de troco de cone (plasticidade do concreto fresco).

Por meio dos resultados apresentados na Tabela 5.38 e 5.39 , procedeu-se à classificação dos concretos utilizados na moldagem dos blocos, estacas e pilares, utilizando os critérios apresentados na NBR 8953:1992, sendo assim, tem-se: concreto utilizado na moldagem dos blocos com classe de resistência C35, grupo de resistência I; concreto utilizado na moldagem das estacas e pilares com classe de resistência C60, grupo de resistência II. 
5.3.7.2. Ensaio de compressão diametral de corpos-de-prova cilíndricos de concreto

Para a determinação das resistências à tração dos concretos utilizados na moldagem dos modelos, foram utilizadas as mesmas máquinas dos ensaios de compressão.

Os ensaios foram realizados de acordo com as recomendações da NBR 7222:1983. As Tabelas 5.40 e 5.41 mostram os resultados obtidos nos ensaios de compressão diametral.

Os ensaios para a determinação da resistência a tração foram realizados com as mesmas idades dos ensaios feitos para a obtenção da resistência à compressão.

Tabela 5.40 - Resistência à tração por compressão diametral, $C P 15 \mathrm{~cm} \times 30 \mathrm{~cm}$.

\begin{tabular}{|c|c|c|c|c|c|}
\hline Modelos & $N^{\circ}$ C. P. & $\begin{array}{l}\text { Idade } \\
\text { (dias) }\end{array}$ & $\begin{array}{c}\mathbf{f}_{\mathbf{t}} \\
(\mathrm{MPa})\end{array}$ & $\begin{array}{l}\mathbf{f}_{\text {tm,exp }} \\
(\mathrm{MPa})\end{array}$ & $\begin{array}{c}\text { Abatimento } \\
(\mathrm{cm})\end{array}$ \\
\hline \multirow{3}{*}{$\begin{array}{c}\text { B35P25E25e0 } \\
e \\
\text { B35P25E25e2,5 }\end{array}$} & 01 & \multirow{3}{*}{72} & 2,87 & \multirow{3}{*}{3,2} & \multirow{3}{*}{11,2} \\
\hline & 02 & & 3,33 & & \\
\hline & 03 & & 3,46 & & \\
\hline \multirow{3}{*}{$\begin{array}{c}\text { B35P25E25e0A } A_{s w, C} \\
e \\
\text { B35P25E25e0A }_{s w, 0}\end{array}$} & 01 & \multirow{3}{*}{66} & 2,78 & \multirow{3}{*}{2,9} & \multirow{3}{*}{14,2} \\
\hline & 02 & & 3,14 & & \\
\hline & 03 & & 2,85 & & \\
\hline \multirow{3}{*}{$\begin{array}{c}\text { B35P25E25e0CG } \\
e \\
\text { B45P25E25e0CG }\end{array}$} & 01 & \multirow{3}{*}{64} & 2,17 & \multirow{3}{*}{2,2} & \multirow{3}{*}{9,2} \\
\hline & 02 & & 2,78 & & \\
\hline & 03 & & 1,67 & & \\
\hline \multirow{3}{*}{$\begin{array}{c}\text { B45P25E25e0 } \\
e \\
\text { B45P25E25e5 }\end{array}$} & 01 & \multirow{3}{*}{57} & 2,89 & \multirow{3}{*}{2,9} & \multirow{3}{*}{7,5} \\
\hline & 02 & & 2,98 & & \\
\hline & 03 & & 2,70 & & \\
\hline \multirow{3}{*}{$\begin{array}{c}\text { B45P25E25e0A } \mathrm{A}_{\mathrm{sw}, \mathrm{C}} \\
\mathrm{e} \\
\mathrm{B} 45 \mathrm{P} 25 \mathrm{E} 25 \mathrm{e} 0 \mathrm{~A}_{\mathrm{sw}, 0}\end{array}$} & 01 & \multirow{3}{*}{49} & 1,61 & \multirow{3}{*}{2,3} & \multirow{3}{*}{8,7} \\
\hline & 02 & & 2,50 & & \\
\hline & 03 & & 2,88 & & \\
\hline \multirow{3}{*}{$\begin{array}{c}\text { B35P50E25e0 } \\
e \\
\text { B45P50E25e0 }\end{array}$} & 01 & \multirow{3}{*}{42} & 2,33 & \multirow{3}{*}{2,3} & \multirow{3}{*}{9,5} \\
\hline & 02 & & 2,65 & & \\
\hline & 03 & & 2,14 & & \\
\hline \multirow{3}{*}{$\begin{array}{c}\text { B35P50E25e12,5 } \\
e \\
\text { B45P50E25e12,5 }\end{array}$} & 01 & \multirow{3}{*}{39} & 3,31 & \multirow{3}{*}{3,3} & \multirow{3}{*}{13} \\
\hline & 02 & & 3,30 & & \\
\hline & 03 & & 3,13 & & \\
\hline
\end{tabular}

Nota: $\mathrm{f}_{\mathrm{t}}$, resistência a tração medida em corpos-de-prova cilíndricos, $\mathrm{f}_{\mathrm{tm} \text {,exp }}$, resistência média a tração; Abatimento, resultado do ensaio de abatimento de troco de cone (plasticidade do concreto fresco). 
Tabela 5.41 - Resistência à tração por compressão diametral, CP $10 \mathrm{~cm} \times 20 \mathrm{~cm}$.

\begin{tabular}{|c|c|c|c|c|c|}
\hline Modelos & $N^{\circ}$ C. P. & $\begin{array}{c}\text { Idade } \\
\text { (dias) }\end{array}$ & $\begin{array}{c}\mathbf{f}_{\mathbf{t}} \\
(\mathrm{MPa})\end{array}$ & $\begin{array}{l}\mathbf{f}_{\text {tm,exp }} \\
(\mathrm{MPa})\end{array}$ & $\begin{array}{l}\text { Abatimento } \\
(\mathrm{cm})\end{array}$ \\
\hline \multirow{3}{*}{$\begin{array}{c}\text { Estacas do B35P25E25e0 e } \\
\text { B35P25E25e2,5 }\end{array}$} & 01 & \multirow{3}{*}{121} & 4,88 & \multirow{3}{*}{4,6} & \multirow{3}{*}{14,7} \\
\hline & 02 & & 4,66 & & \\
\hline & 03 & & 4,10 & & \\
\hline \multirow{3}{*}{ Estacas do B35P25E25e0CG } & 01 & \multirow{3}{*}{107} & 3,98 & \multirow{3}{*}{3,7} & \multirow{3}{*}{17} \\
\hline & 02 & & 1,01 & & \\
\hline & 03 & & 3,31 & & \\
\hline \multirow{3}{*}{$\begin{array}{c}\text { Estacas do B35P25E25e0A } \mathrm{Asw}, \mathrm{c}_{\mathrm{e}} \\
\text { B35P25E25e0A } \\
\text { Bw }, 0\end{array}$} & 01 & \multirow{3}{*}{95} & 5,70 & \multirow{3}{*}{5,2} & \multirow{3}{*}{7,2} \\
\hline & 02 & & 4,82 & & \\
\hline & 03 & & 5,02 & & \\
\hline \multirow{3}{*}{$\begin{array}{l}\text { Pilar do B35P25E25e0 e } \\
\text { B35P25E25e2,5 }\end{array}$} & 01 & \multirow{3}{*}{74} & 4,18 & \multirow{3}{*}{3,8} & \multirow{3}{*}{4,8} \\
\hline & 02 & & $6,32^{*}$ & & \\
\hline & 03 & & 3,38 & & \\
\hline \multirow{3}{*}{$\begin{array}{c}\text { Pilar do B35P25E25e0A } A_{s w, C} \text { e } \\
\text { B35P25E25e0A } A_{s w, 0} \\
\text { Estacas do B45P25E25e0 e } \\
\text { B45P25E25e5 }\end{array}$} & 01 & \multirow{3}{*}{65} & 3,78 & \multirow{3}{*}{3,9} & \multirow{3}{*}{7,2} \\
\hline & 02 & & 3,97 & & \\
\hline & 03 & & 4,02 & & \\
\hline \multirow{3}{*}{$\begin{array}{c}\text { Pilar do B35P25E25e0CG e } \\
\text { B45P25E25e0CG } \\
\text { Estacas do B45P25E25e0A } A_{s w, c} \text { e } \\
\text { B45P25E25A } A_{s w, 0}\end{array}$} & 01 & \multirow{3}{*}{74} & 3,08 & \multirow{3}{*}{2,9} & \multirow{3}{*}{24,3} \\
\hline & 02 & & 3,01 & & \\
\hline & 03 & & 2,59 & & \\
\hline \multirow{3}{*}{$\begin{array}{c}\text { Pilar do B45P25E25e0 e } \\
\text { B45P25E25e5 } \\
\text { Estacas do B45P25E25e0CG }\end{array}$} & 01 & \multirow{3}{*}{69} & 2,87 & \multirow{3}{*}{3} & \multirow{3}{*}{21} \\
\hline & 02 & & 2,98 & & \\
\hline & 03 & & 3,13 & & \\
\hline \multirow{3}{*}{$\begin{array}{c}\text { Pilar do B45P25E25e0A } A_{s w, C} \text { e } \\
\text { B45P25E25e0A } A_{s w, 0} \\
\text { Estacas do B35P50E25e0 e } \\
\text { B35P50E25e12,5 }\end{array}$} & 01 & \multirow{3}{*}{56} & 3,26 & \multirow{3}{*}{3,3} & \\
\hline & 02 & & 3,25 & & 24 \\
\hline & 03 & & - & & \\
\hline Pilar do B35P50E25e0 e & 01 & & 3,39 & & \\
\hline $\begin{array}{c}\text { B45P50E25e0 } \\
\text { Estacas do B45P50E25e0 e }\end{array}$ & 02 & 48 & 3,30 & 3,4 & 16,5 \\
\hline B45P50E25e12,5 & 03 & & 3,64 & & \\
\hline & 01 & & 3,55 & & \\
\hline $\begin{array}{l}\text { Pilar do B35P50E25e12,5 e } \\
\text { B45P50E25e12.5 }\end{array}$ & 02 & 38 & 3,80 & 3,7 & 26,5 \\
\hline & 03 & & - & & \\
\hline
\end{tabular}

Nota: "valor descartado; $f_{t}$, resistência a tração medida em corpos-de-prova cilíndricos, $f_{t m, e x p}$, resistência média a tração; Abatimento, resultado do ensaio de abatimento de troco de cone (plasticidade do concreto fresco).

5.3.7.3. Ensaios para determinação do módulo de deformação tangente inicial do concreto

De acordo com Metha \& Monteiro (1994), pode-se calcular o módulo de elasticidade tangente inicial a partir da declividade da reta traçada da origem a um ponto da curva tensão vs. deformação correspondente a quarenta por cento da resistência de ruptura. A recomendação indicada pelos autores acima esta em desacordo com a NBR 8522:1984, a qual, determina que o módulo de elasticidade tangente inicial deve ser determinado da origem a um ponto da curva tensão vs. deformação correspondente a trinta por cento da resistência de ruptura. Neste texto, 
utilizou-se a recomendações da norma brasileira vigente. Contatou-se, que, os métodos apresentados pela NBR 8522:1984 e por Metha \& Monteiro (1994), não apresentam diferenças significativas, principalmente para os concretos do grupo II (NBR 8953:1992).

Para os corpos-de-prova ensaiados na máquina Instron, utilizou-se o sistema de aquisição de dados System 4000, da Measurements Group. Com esse equipamento foi possível a obtenção completa da curva tensão vs. deformação dos concretos.

Nos ensaios realizados na máquina ELE Autotest 2000, obtiveram-se medidas de deslocamentos relativos entre os pontos de contato dos extensômetros removíveis até cinqüenta por cento da força última prevista para cada corpo-de-prova, pois, as leituras das deformações foram feitas manualmente, já que, nessa máquina não existe acoplado sistema automático de aquisição de dados.

Os valores das intensidades das deformações foram obtidos por meio de extensômetros removíveis com base de $100 \mathrm{~mm}$ e $200 \mathrm{~mm}$ (para os corpos-de-prova com diâmetro igual a dez centímetros e altura igual a vinte centímetros, utilizaram-se bases com dimensão igual a dez centímetros. Para os corpos-de-prova com dimensões iguais a quinze centímetros de diâmetro e trinta centímetros de altura, foram utilizadas bases de vinte centímetros). A Figura 5.130 mostra a utilização do extensômetro durante o ensaio de módulo de deformação longitudinal do concreto.
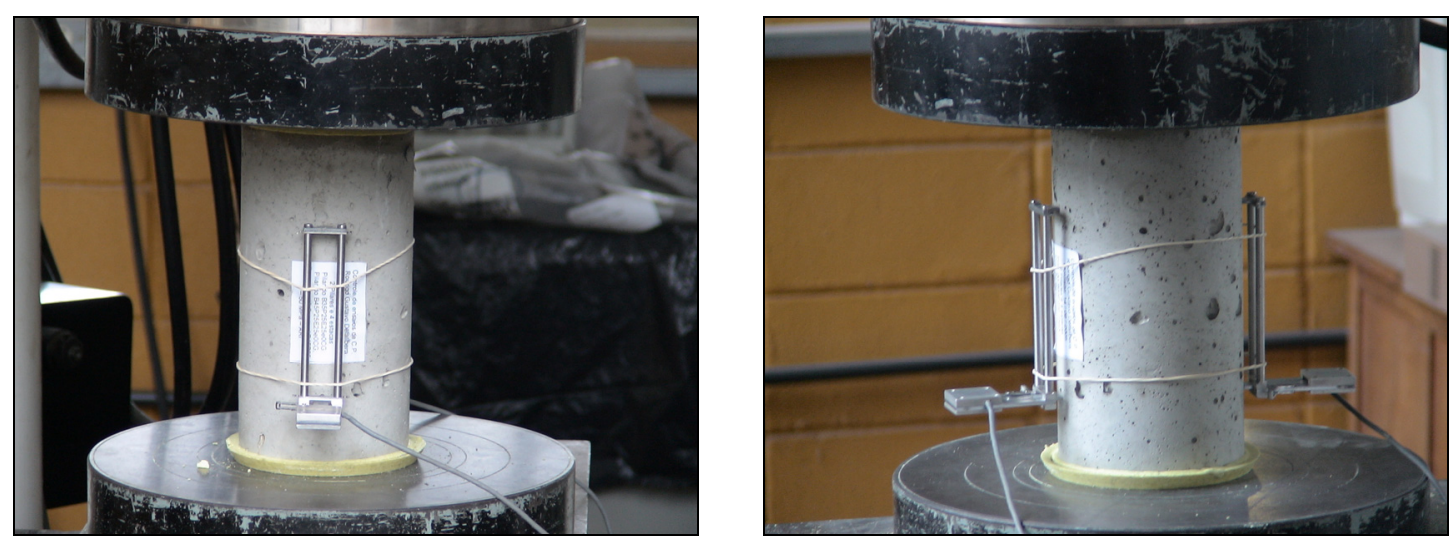

Figura 5.130 - Extensômetro removível, ensaio de módulo de elasticidade longitudinal do concreto.

Observa-se por meio da figura anterior que foram feitas duas medições de deslocamentos relativos entre os pontos de contato dos extensômetros removíveis. $O$ módulo de deformação longitudinal inicial do concreto foi obtido por meio da média aritmética entre os valores das duas leituras de deslocamentos relativos. 
A Tabela 5.42 fornece os resultados dos módulos de elasticidades dos concretos do grupo I e a Tabela 5.43 os módulos de elasticidade dos concretos do grupo II.

Tabela 5.42 - Módulo de deformação tangente inicial do concreto, CP $15 \mathrm{~cm} \times 30 \mathrm{~cm}$, grupo I de resistência.

\begin{tabular}{|c|c|c|c|c|c|c|}
\hline Modelos & $N^{\circ}$ C. P. & $\begin{array}{l}\mathbf{E}_{\text {ci,exp }} \\
(\mathrm{MPa})\end{array}$ & $\begin{array}{c}\mathbf{E}_{\text {ci,m,exp }} \\
(\mathrm{MPa})\end{array}$ & $\begin{array}{c}\mathbf{E}_{\mathrm{ci}} \\
(\mathrm{MPa})\end{array}$ & $\begin{array}{c}E_{c s} \\
(\mathrm{MPa})\end{array}$ & $E_{c i, m, \exp } / E_{c i}$ \\
\hline \multirow{3}{*}{$\begin{array}{c}\text { B35P25E25e0 } \\
e \\
\text { B35P25E25e2,5 }\end{array}$} & 01 & 30760 & \multirow{3}{*}{30203} & \multirow{3}{*}{35678} & \multirow{3}{*}{30326} & \multirow{3}{*}{0,85} \\
\hline & 02 & 30530 & & & & \\
\hline & 03 & 29320 & & & & \\
\hline \multirow{3}{*}{$\begin{array}{c}\text { B35P25E25e0A } A_{s w, C} \\
e \\
\text { B35P25E25e0A }_{s w, 0}\end{array}$} & 01 & 36250 & \multirow{3}{*}{37737} & \multirow{3}{*}{32062} & \multirow{3}{*}{27253} & \multirow{3}{*}{$1,18^{* *}$} \\
\hline & 02 & 38480 & & & & \\
\hline & 03 & 38480 & & & & \\
\hline \multirow{3}{*}{$\begin{array}{c}\text { B35P25E25e0CG } \\
e \\
\text { B45P25E25e0CG }\end{array}$} & 01 & 25510 & \multirow{3}{*}{25600} & \multirow{3}{*}{30079} & \multirow{3}{*}{25567} & \multirow{3}{*}{0,85} \\
\hline & 02 & 25690 & & & & \\
\hline & 03 & $12540^{\circ}$ & & & & \\
\hline \multirow{3}{*}{$\begin{array}{c}\text { B45P25E25e0 } \\
\text { e } \\
\text { B45P25E25e5 }\end{array}$} & 01 & - & \multirow{3}{*}{27490} & \multirow{3}{*}{31159} & \multirow{3}{*}{26485} & \multirow{3}{*}{0,88} \\
\hline & 02 & 28010 & & & & \\
\hline & 03 & 26970 & & & & \\
\hline \multirow{3}{*}{$\begin{array}{c}\text { B45P25E25e0A } A_{s w, C} \\
e \\
\text { B45P25E25e0A } \\
\text { sw }, 0\end{array}$} & 01 & 27290 & \multirow{3}{*}{27500} & \multirow{3}{*}{31895} & \multirow{3}{*}{27111} & \multirow{3}{*}{0,86} \\
\hline & 02 & 27480 & & & & \\
\hline & 03 & 17730 & & & & \\
\hline \multirow{3}{*}{$\begin{array}{c}\text { B35P50E25e0 } \\
e \\
\text { B45P50E } 25 e 0\end{array}$} & 01 & 30760 & \multirow{3}{*}{30203} & \multirow{3}{*}{33516} & \multirow{3}{*}{28489} & \multirow{3}{*}{0,90} \\
\hline & 02 & 30530 & & & & \\
\hline & 03 & 29320 & & & & \\
\hline \multirow{3}{*}{$\begin{array}{c}\text { B35P50E25e12,5 } \\
\text { e } \\
\text { B45P50E25e12,5 }\end{array}$} & 01 & 29160 & \multirow{3}{*}{28950} & \multirow{3}{*}{33173} & \multirow{3}{*}{28197} & \multirow{3}{*}{0,87} \\
\hline & 02 & 28970 & & & & \\
\hline & 03 & 28720 & & & & \\
\hline
\end{tabular}

Nota: "valor descartado; $E_{c i, e x p}$, módulo de elasticidade tangente inicial experimental; $E_{c i, m, e x p}$, módulo de elasticidade tangente inicial experimental médio; $\mathrm{E}_{\mathrm{ci}}$, módulo de elasticidade tangente inicial.

Analisando os módulos de elasticidade apresentados pela Tabela 5.42, observa-se que somente um valor dos resultados experimentais foi maior que os valores dos resultados calculados por meio da indicação da NBR 6118:2003. Portanto, pôde-se afirmar que para esses resultados a norma brasileira de projeto de estruturas de concreto estabelece valores que são contra a segurança a menos do concreto utilizado nos modelos B35P25E25e0A $\mathrm{sw}_{\mathrm{sw}, \mathrm{c}}$ e B35P25E25A $\mathrm{sw}_{\mathrm{sw}, 0}$. Essa afirmação é constatada por meio da relação $E_{c i, e x p} / E_{c i}$ lembrando que a NBR 6118:2003 estabelece que o módulo de elasticidade secante $\left(E_{c s}\right)$ deve ser utilizado em análises elásticas de projeto, na determinação dos esforços solicitantes e na verificação dos Estados Limites de Serviço, além disso, também pode ser empregado na análise isolada de um determinado elemento estrutural e o módulo de deformação tangente inicial $\left(E_{c i}\right)$ é utilizado na avaliação do comportamento global da estrutura. 
Como o módulo e elasticidade secante é menor que o inicial a afirmação anterior é correta.

Tabela 5.43 - Módulo de deformação tangente inicial do concreto, CP $10 \mathrm{~cm} \times 20 \mathrm{~cm}$, grupo II de resistência.

\begin{tabular}{|c|c|c|c|c|c|c|}
\hline Modelos & $N^{\circ}$ C. P. & $\begin{array}{l}\mathbf{E}_{\mathrm{ci}, \exp } \\
(\mathrm{MPa})\end{array}$ & $\begin{array}{c}\mathbf{E}_{c i, m, \exp } \\
(\mathrm{MPa})\end{array}$ & $\begin{array}{c}E_{\mathrm{ci}} \\
(\mathrm{MPa})\end{array}$ & $\begin{array}{c}E_{c s} \\
(\mathrm{MPa})\end{array}$ & $E_{c i, m, \exp } / E_{c i}$ \\
\hline \multirow{3}{*}{$\begin{array}{c}\text { Estacas do B35P25E25e0 e } \\
\text { B35P25E25e2,5 }\end{array}$} & 01 & 40860 & \multirow{3}{*}{41060} & \multirow{3}{*}{47928} & \multirow{3}{*}{40739} & \multirow{3}{*}{0,86} \\
\hline & 02 & 40690 & & & & \\
\hline & 03 & 41630 & & & & \\
\hline \multirow{3}{*}{ Estacas do B35P25E25e0CG } & 01 & 39180 & \multirow{3}{*}{42340} & \multirow{3}{*}{50328} & \multirow{3}{*}{42779} & \multirow{3}{*}{0,84} \\
\hline & 02 & 43160 & & & & \\
\hline & 03 & 44680 & & & & \\
\hline \multirow{3}{*}{$\begin{array}{l}\text { Estacas do B35P25E25e0A } A_{s w, C} \\
\text { e B35P25E25e0A } \\
\text { sw, } 0\end{array}$} & 01 & 42440 & \multirow{3}{*}{42223} & \multirow{3}{*}{47392} & \multirow{3}{*}{40283} & \multirow{3}{*}{0,89} \\
\hline & 02 & 43160 & & & & \\
\hline & 03 & 41070 & & & & \\
\hline \multirow{3}{*}{$\begin{array}{c}\text { Pilar do B35P25E25e0 e } \\
\text { B35P25E25e2,5 }\end{array}$} & 01 & 51970 & \multirow{3}{*}{50970} & \multirow{3}{*}{47607} & \multirow{3}{*}{40466} & \multirow{3}{*}{$1,07^{* *}$} \\
\hline & 02 & 51970 & & & & \\
\hline & 03 & 48970 & & & & \\
\hline \multirow{3}{*}{$\begin{array}{c}\text { Pilar do B35P25E25e0A } A_{s w, c} e \\
\text { B35P25E25e0A } \\
\text { Estacas do B45P25E25e0 e } \\
\text { B45P25E25e5 }\end{array}$} & 01 & 36380 & \multirow{3}{*}{38250} & \multirow{3}{*}{40293} & \multirow{3}{*}{34249} & \multirow{3}{*}{0,95} \\
\hline & 02 & 38580 & & & & \\
\hline & 03 & 39790 & & & & \\
\hline \multirow{3}{*}{$\begin{array}{c}\text { Pilar do B35P25E25e0CG e } \\
\text { B45P25E25e0CG } \\
\text { Estacas do B45P25E25e0A } \mathrm{A}_{\mathrm{sw}, \mathrm{C}} \\
\text { e B45P25E25A } \\
\text { sw ,0}\end{array}$} & 01 & 35800 & \multirow{3}{*}{34937} & \multirow{3}{*}{41546} & \multirow{3}{*}{35314} & \multirow{3}{*}{0,84} \\
\hline & 02 & 33290 & & & & \\
\hline & 03 & 35720 & & & & \\
\hline & 01 & 36860 & & & & \\
\hline B45P25E25e5 & 02 & 35110 & 36397 & 41610 & 35368 & 0,87 \\
\hline & 03 & 37220 & & & & \\
\hline Pilar do B45P25E25e0A $\mathrm{A}_{\mathrm{sw}, \mathrm{c}} \mathrm{e}$ & 01 & 29700 & & & & \\
\hline $\begin{array}{c}\text { B45P25E25e0A } \text { sw, } 0 \\
\text { Estacas do B35P50E25e0 e }\end{array}$ & 02 & 32030 & 31003 & 40066 & 34056 & 0,77 \\
\hline B35P50E25e12,5 & 03 & 31280 & & & & \\
\hline Pilar do B35P50E25e0 e & 01 & 39550 & & & & \\
\hline $\begin{array}{c}\text { B45P50E25e0 } \\
\text { Estacas do B45P50E25e0 e }\end{array}$ & 02 & 39120 & 39507 & 40611 & 34519 & 0,97 \\
\hline B45P50E $25 \mathrm{e} 12,5$ & 03 & 39850 & & & & \\
\hline & 01 & 32970 & & & & \\
\hline $\begin{array}{l}\text { Pllar do B35P50E25e12,5 e } \\
\text { B45P50E25e12.5 }\end{array}$ & 02 & - & 33255 & 39839 & 33863 & 0,83 \\
\hline & 03 & 33540 & & & & \\
\hline
\end{tabular}

Nota: $\mathrm{E}_{\mathrm{ci} \text { exp }}$, módulo de elasticidade tangente inicial experimental; $\mathrm{E}_{\mathrm{c}, \mathrm{m}, \mathrm{exp}}$, módulo de elasticidade tangente inicial experimental médio; $\mathrm{E}_{\mathrm{ci}}$, módulo de elasticidade tangente inicial.

Analisando os resultados da Tabela 5.43 atenta-se que apenas um dos valores dos módulos de deformação determinados por meios experimentais é maior que o valor do módulo tangente inicial estipulado pela NBR 6118:2003. Os resultados seguem a mesma tendência dos concretos do grupo I (corpos-de-prova cilíndricos de $15 \mathrm{~cm} \times 30 \mathrm{~cm}$, Tabela 5.42). 
Com objetivo de ilustração são expostos na Figuras 5.131e 5.137 diagramas tensão vs. deformação para os concreto utilizados nas moldagens dos blocos.

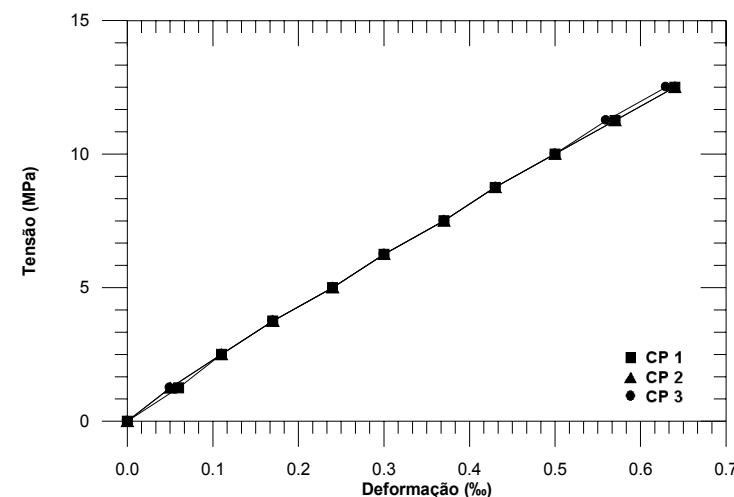

Figura 5.92 - Curva tensão vs. deformação, C.P. 1, 2 e 3, modelos B35P25E25e0 e B35P25E25e2,5.

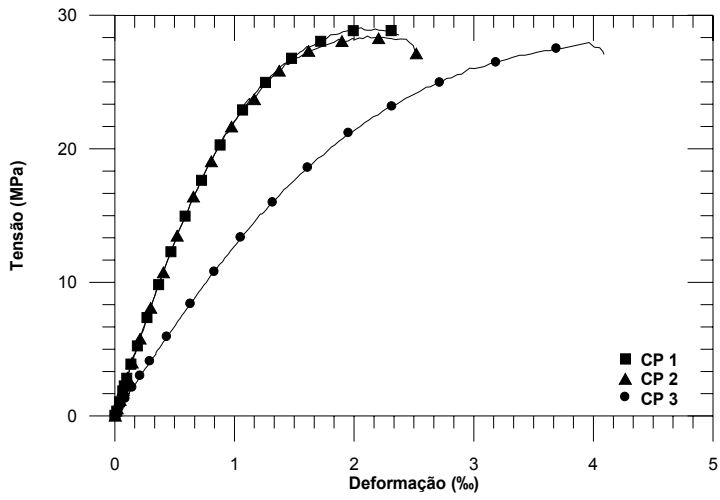

Figura 5.94 - Curva tensão vs. deformação, C.P. 1, 2 e 3, modelos B35P25E25e0CG e B45P25E25e0CG.

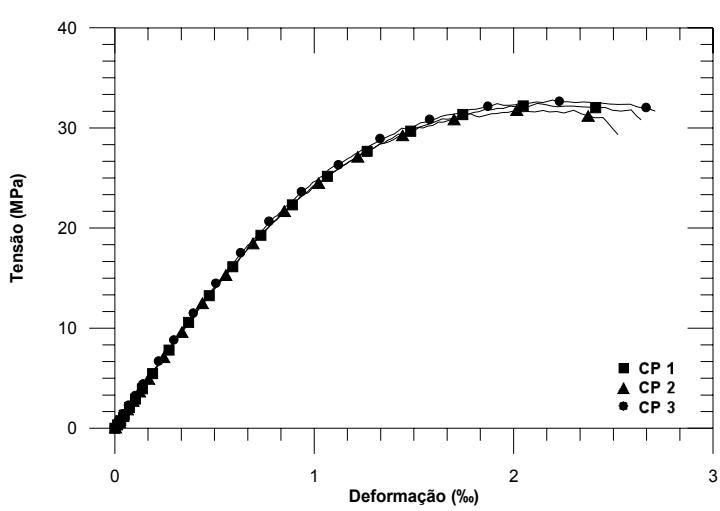

Figura 5.96 - Curva tensão vs. deformação C.P. 1, 2 e 3, modelos B45P25E25e0A sw,c e B45P25E25e0A $A_{s w, 0}$.

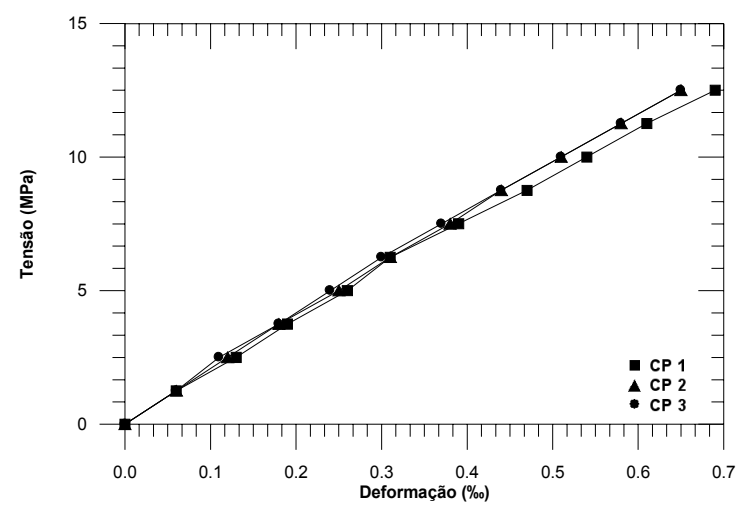

Figura 5.93 - Curva tensão vs. deformação, C.P. 1, 2 e 3, modelos B35P25E25e0A sw,c e B35P25E25e0A $\mathrm{sw}, 0$.

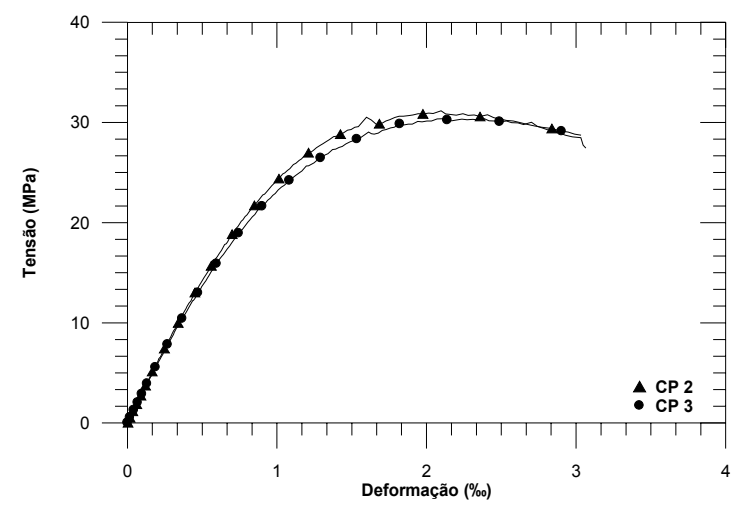

Figura 5.95 - Curva tensão vs. deformação, C.P. 1, 2 e 3, modelos B45P25E25e0 e B45P25E25e 5 .

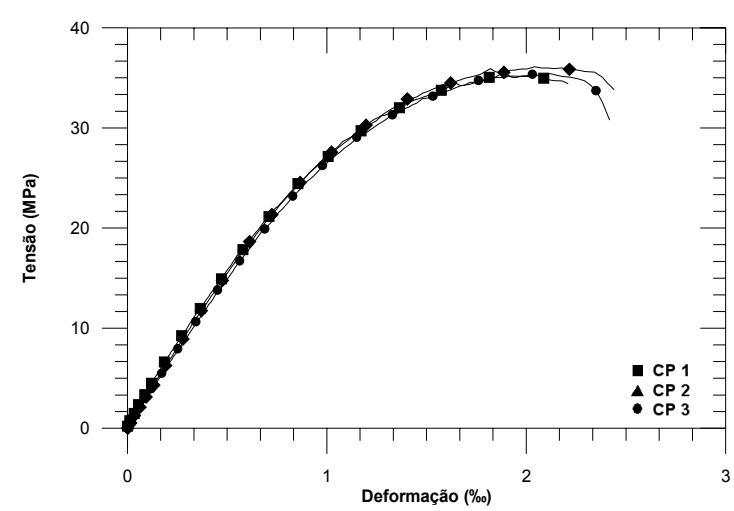

Figura 5.97 - Curva tensão vs. deformação, C.P. 1, 2 e 3, modelos B35P50E25e0 e B45P50E25e0. 


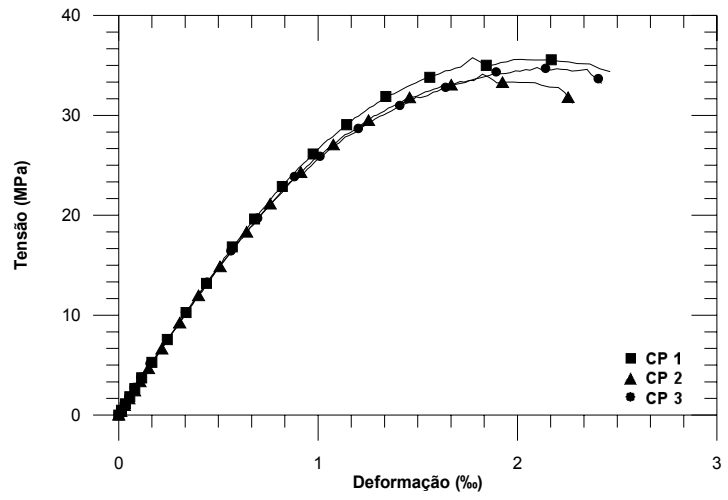

Figura 5.98 - Curva tensão vs. deformação, C.P. 1, 2 e 3, modelos B35P50E25e12,5 e B45P50E25e12,5.
Valores médios das propriedades mecânicas dos concretos do grupo de resistência I empregados na moldagem dos blocos

$\mathrm{f}_{\mathrm{c}, \mathrm{m}, \exp }=33,79 \mathrm{MPa}$;

$\mathrm{f}_{\mathrm{t}, \mathrm{m}, \exp }=2,73 \mathrm{MPa}$;

$E_{c i, m, \exp }=29669 \mathrm{MPa}$;

$E_{c i}=32552 \mathrm{MPa}(\mathrm{NBR} 6118: 2003)$;

$E_{c i, m, \exp } / E_{c i}=0,91$.

Por meio das Figuras 5.92 e 5.98 constata-se que os ensaios dos corpos-deprova dos concretos utilizados na moldagem dos blocos dos modelos B35P25E25e0, $\mathrm{B} 35 \mathrm{P} 25 \mathrm{E} 25 \mathrm{e} 2,5, \mathrm{~B} 35 \mathrm{P} 25 \mathrm{E} 25 \mathrm{e} 0 \mathrm{~A}_{\mathrm{sw}, \mathrm{C}}$ e B35P25E25e0A $\mathrm{Aw}_{\mathrm{sw}, 0}$, foram realizados na máquina hidráulica ELE Autotest 2000, pois, as curvas tensão vs. deformação foram registradas até cerca de cinqüenta por cento da força de ruptura de cada corpo-deprova.

Como já foi dito, em função das idades avançadas, ocorreram modificações nas resistências dos concretos, elevando suas resistências.

Constata-se que o valor da resistência média a tração $\left(\mathrm{f}_{\mathrm{ct}, \mathrm{m}}\right)$ calculada por meio de equação existente na NBR 6118:2003 é superior ao valor médio experimental, pois, registrou-se aumento de aproximadamente $13 \%$, ou seja, a relação $f_{t, m, \exp } / f_{c t, m}$ foi igual a 0,87 .

Consignou-se que o módulo de elasticidade tangente inicial calculado por meio das recomendações da norma brasileira de projeto de estruturas de concreto foi, para esses casos, superior em $9 \%$. Esse resultado é preocupante, pois, se for confirmado em novos ensaios esses resultados, os valores apresentados pela norma estão contra a segurança, com relação às verificações dos Estados Limites de Serviço.

5.3.7.4. Resistência ao escoamento e módulo de elasticidade das barras de aço

Em todas as barras ensaiadas utilizou-se extensômetro removível com base igual a $50 \mathrm{~mm}$ e sistema de aquisição de dados System 4000. Os ensaios foram realizados na máquina hidráulica Instron. 
A Tabela 5.44 apresenta os resultados das propriedades mecânicas dos aços e as Figuras 5.138 a 5.144 apresentam curvas tensão vs. deformação das barras de aço submetidas a ensaio de tração simples.

Os ensaios seguiram as recomendações contidas na NBR 6152:1992. As barras e fios de aço foram classificados em função das indicações prescritas na NBR 7480:1996 e por meio dos valores da resistência de escoamento das barras de aço. A categoria CA-60 fica limitada aos fios, enquanto, a categoria CA-50 às barras.

$O$ modulo de deformação longitudinal do aço $\left(E_{s}\right)$ determinado experimentalmente apresentou valores médios em torno de $200 \mathrm{GPa}$.

Tabela 5.44 - Propriedades mecânicas das barras de aço.

\begin{tabular}{|c|c|c|c|c|c|c|c|c|c|c|}
\hline C. P. & $\begin{array}{c}\emptyset_{\text {nom }} \\
(\mathrm{mm})\end{array}$ & $\begin{array}{l}\text { Comp. } \\
(\mathrm{cm})\end{array}$ & $\begin{array}{c}\text { Massa } \\
(\mathrm{g}) \\
\end{array}$ & $\begin{array}{c}\boldsymbol{\emptyset}_{\text {efetivo }} \\
(\mathrm{mm}) \\
\end{array}$ & $\begin{array}{c}\mathbf{f}_{\mathbf{y}} \\
(\mathrm{MPa})\end{array}$ & $\begin{array}{c}\varepsilon_{y} \\
(\% 0)\end{array}$ & $\begin{array}{c}\mathbf{f}_{\mathrm{y}, \mathrm{m}} \\
(\mathrm{MPa})\end{array}$ & $\begin{array}{l}\varepsilon_{y, m} \\
(\% 0)\end{array}$ & $\begin{array}{c}\mathbf{f}_{\mathrm{u}} \\
(\mathrm{MPa})\end{array}$ & Classe \\
\hline 01 & \multirow{2}{*}{5} & 80,4 & 122,10 & 4,96 & 680 & 4,10 & \multirow{2}{*}{681} & \multirow{2}{*}{4,05} & \multirow{2}{*}{755} & \multirow{2}{*}{ CA-60 } \\
\hline 02 & & 80,6 & 122,4 & 4,96 & 681 & 4,00 & & & & \\
\hline 01 & \multirow{3}{*}{6,3} & 81,5 & 201,9 & 6,64 & 610 & 3,05 & \multirow{3}{*}{597} & \multirow{3}{*}{2,99} & \multirow{3}{*}{733} & \multirow{3}{*}{ CA-50 } \\
\hline 02 & & 87,5 & 213,9 & 6,60 & 609 & 3,05 & & & & \\
\hline 03 & & 81 & 200,7 & 6,64 & 571 & 2,86 & & & & \\
\hline 01 & \multirow{3}{*}{8} & 80,5 & 321,7 & 8,44 & 588 & 2,94 & \multirow{3}{*}{581} & \multirow{3}{*}{2,91} & \multirow{3}{*}{674} & \multirow{3}{*}{ CA-50 } \\
\hline 02 & & 80,5 & 319 & 8,40 & 582 & 2,91 & & & & \\
\hline 03 & & 80,9 & 319,7 & 8,39 & 573 & 2,87 & & & & \\
\hline 01 & \multirow{3}{*}{10} & 80,2 & 492,5 & 10,46 & 528 & 2,64 & \multirow{3}{*}{549} & \multirow{3}{*}{2,75} & \multirow{3}{*}{658} & \multirow{3}{*}{ CA-50 } \\
\hline 02 & & 80,5 & 494 & 10,45 & 557 & 2,71 & & & & \\
\hline 03 & & 80,4 & 497 & 10,49 & 561 & 2,81 & & & & \\
\hline 01 & \multirow{3}{*}{12,5} & 80 & 767 & 13,07 & 570 & 2,85 & \multirow{3}{*}{578} & \multirow{3}{*}{2,89} & \multirow{3}{*}{740} & \multirow{3}{*}{ CA-50 } \\
\hline 02 & & 80,3 & 753,8 & 12,93 & 578 & 2,89 & & & & \\
\hline 03 & & 80 & 754,9 & 12,96 & 591 & 2,96 & & & & \\
\hline 01 & \multirow{3}{*}{16} & 80,5 & 1030, & 16,05 & 543 & 2,72 & \multirow{3}{*}{547} & \multirow{3}{*}{2.74} & \multirow{3}{*}{671} & \multirow{3}{*}{ CA-50 } \\
\hline 02 & & 80,7 & 1035,8 & 15,93 & 542 & 2,71 & & & & \\
\hline 03 & & 79,6 & 1006,2 & 15,78 & 556 & 2,78 & & & & \\
\hline 01 & \multirow{3}{*}{20} & 79,9 & 1951,7 & 20,86 & 550 & 2,75 & \multirow{3}{*}{550} & \multirow{3}{*}{2,75} & & \\
\hline 02 & & 79,8 & 1954 & 20,88 & 548 & 2,74 & & & 719 & CA-50 \\
\hline 03 & & 79,9 & 1956,7 & 20,88 & 551 & 2,76 & & & & \\
\hline
\end{tabular}

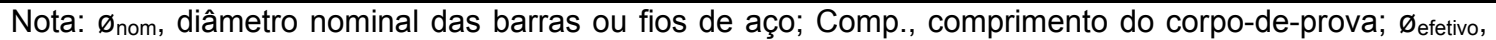
diâmetro efetivo das barras ou fios de aço; $f_{y}$, resistência ao escoamento das barras ou fios de aço; $\varepsilon_{y}$, deformação específica de escoamento do aço; $f_{y, m}$, resistência média ao escoamento das barras ou fios de aço; $\varepsilon_{y, m}$, deformação média de escoamento do aço; $f_{u}$, tensão de ruptura das barras ou fios de aço.

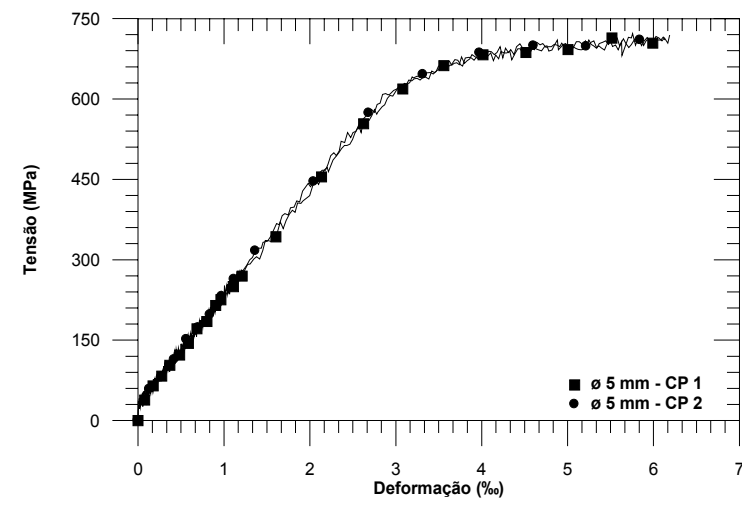

Figura 5.138 - Curva tensão vs. deformação, C.P. 1 e 2, ø $5 \mathrm{~mm}$.

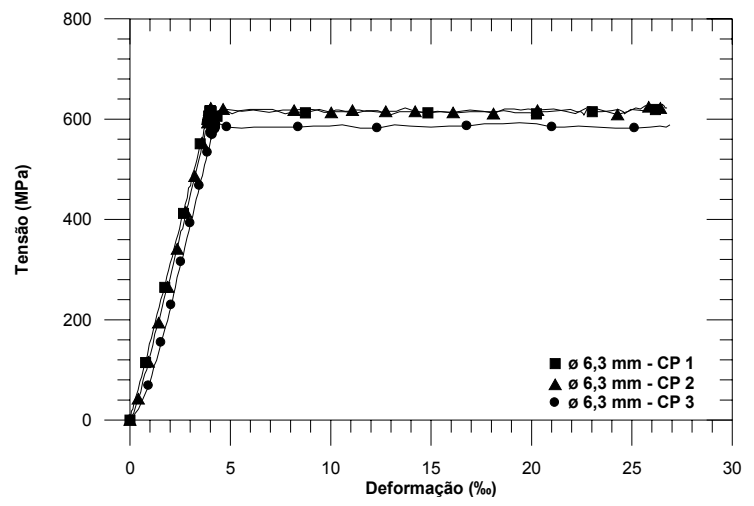

Figura 5.139 - Curva tensão vs. deformação, C.P. 1, 2 e 3, ø 6,3 mm. 


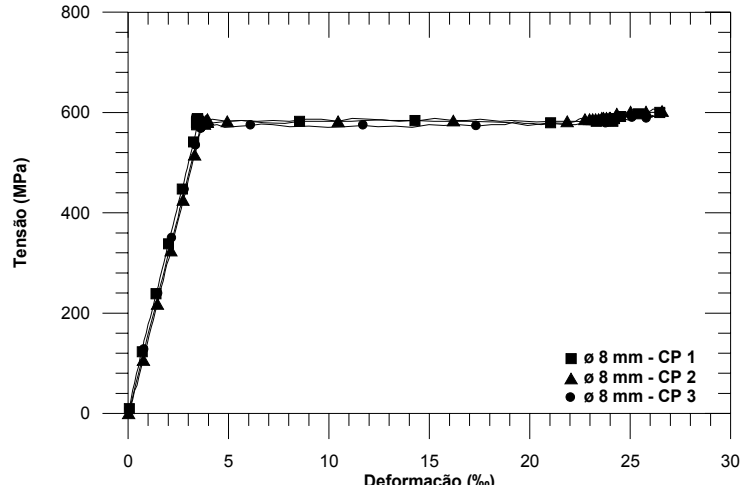

Figura 5.140 - Curva tensão vs. deformação, C.P. 1, 2 e 3, ø 8 mm.

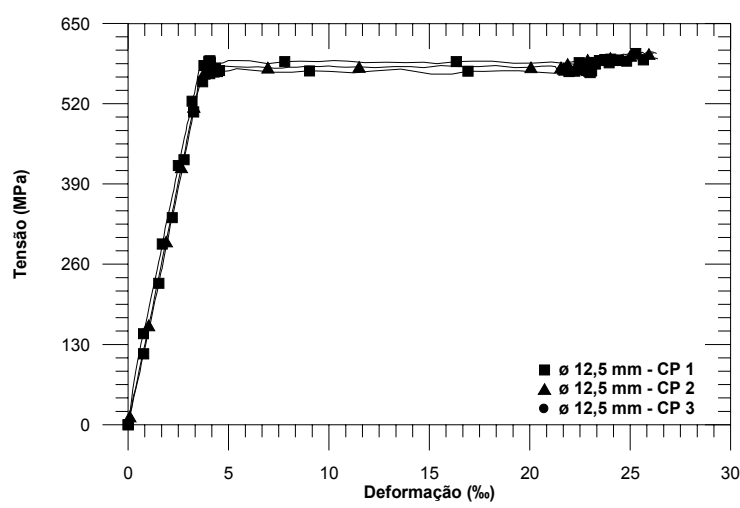

Figura 5.142 - Curva tensão vs. deformação, C.P. 1, 2 e 3, ø 12,5 mm.

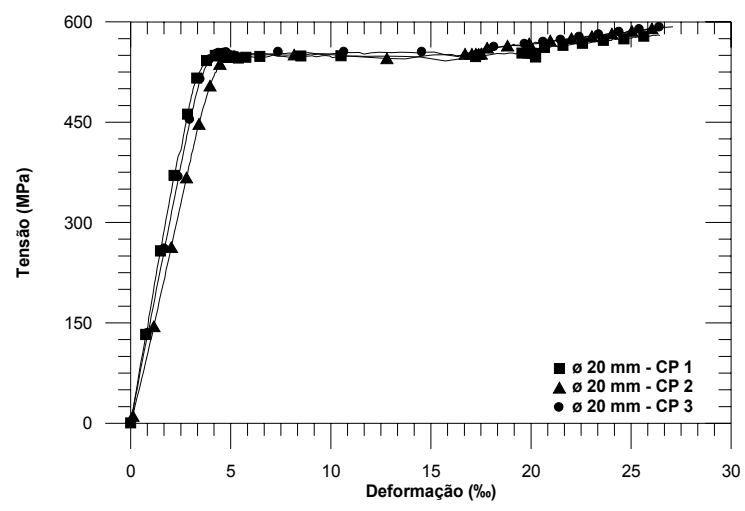

Figura 5.144 - Curva tensão vs. deformação, C.P. 1, 2 e 3, ø 20 mm.

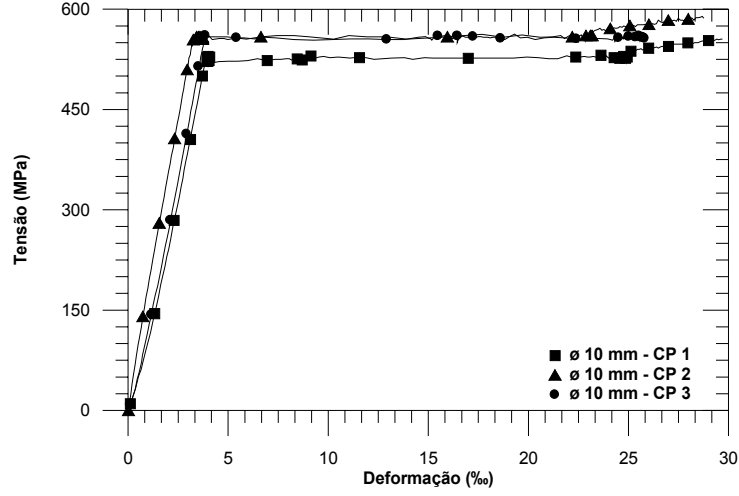

Figura 5.141 - Curva tensão vs. deformação, C.P. 1, 2 e 3, ø $10 \mathrm{~mm}$.

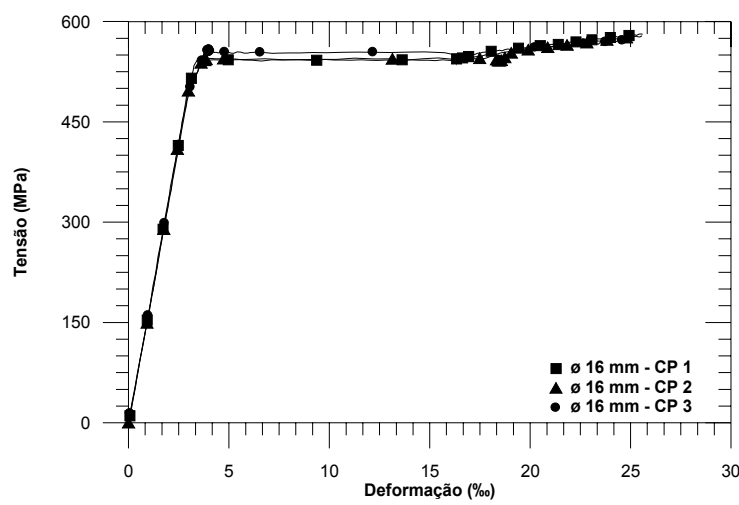

Figura 5.143 - Curva tensão vs. deformação, C.P. 1, 2 e 3, ø $16 \mathrm{~mm}$.

Por meio de análise das figuras anteriores, afirma-se que todas as barras de aço apresentam patamar de escoamento definido, a menos das barras cujo diagrama estão apresentados na Figura 5.138. Em função disso, o valor da resistência ao escoamento dos fios (ø $5 \mathrm{~mm}$ ) foram determinados em função da deformação correspondente a $2 \%$. 



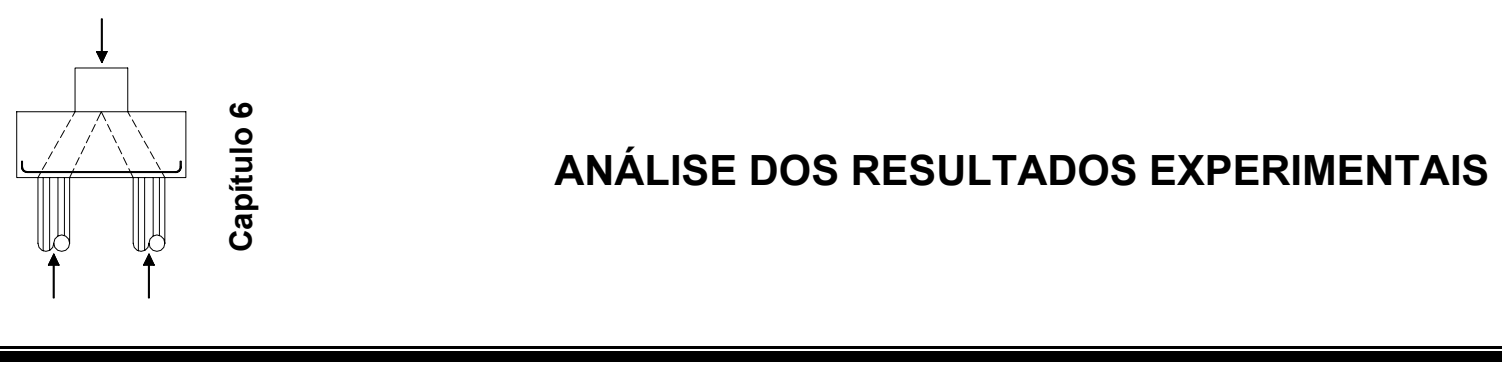

\subsection{Considerações iniciais}

Este capítulo analisa os valores dos resultados experimentais, como também, apresenta análises comparativas entre os resultados dos ensaios dos vários modelos.

São abordados nesta sessão itens como: modo de ruína; influência da rigidez dos blocos; influência do arranjo das armaduras; influência da excentricidade; deformações no concreto; e, deformações na armadura principal de tração.

\subsection{Modo de ruína}

Como apresentado no Capítulo 5, todos os blocos apresentaram os mesmos modos de ruína, ou seja, ruptura da biela comprimida junto ao pilar e ou junto à estaca.

Observou-se também a formação de dois tipos de fissuras diagonais, as primeiras correspondentes à distribuição das tensões internas, as últimas (surgiram próximo da força última) correspondem à ruptura por compressão. Em função da pequena resistência do concreto à tração, surgiram fissuras diagonais nos planos onde atuam as tensões principais de tração ao longo da biela comprimida. Estas fissuras provocam a diminuição da resistência à compressão do concreto das bielas.

O Código Modelo do CEB-FIP (1990) indica que a resistência de projeto de uma região sob compressão uniaxial em zona fissurada é igual a $f_{c d}=0,60 \cdot\left[1-f_{c k} / 250\right] \cdot f_{c d}$, sendo $f_{c k}$ expresso em MPa. Schafer \& Schlaich (1998) estabelecem a resistência da biela igual a $0,68 \cdot f_{c d}$, para campos de compressão com fissuras paralelas às tensões de compressão. 
Nos modelos que foram construídos sem armaduras complementares, observou-se que as forças resistidas foram menores, função da diminuição da resistência das bielas comprimidas.

Em todos os modelos, em função do aparecimento das fissuras ao longo das bielas comprimidas, observou-se claramente a formação de um plano de ruptura. Após o esmagamento do concreto na região nodal superior, e em alguns modelos na região nodal inferior, observou-se o esmagamento do concreto ao longo deste plano de ruptura. Este modo de ruptura pode ser chamado de ruptura por deslizamento, pois não existe uma superfície nítida de fratura e sim, forte desagregação ao longo de uma faixa que acompanha a superfície média de deslizamento.

O modo de ruína observado nos ensaios foi semelhante às ruínas descritas nos ensaios desenvolvidos por Mautoni (1972).

As Figuras 6.1 e 6.2 mostram o início do esmagamento do concreto junto ao pilar e junto à estaca. Na Figura 6.3 é mostrado o plano de ruptura.

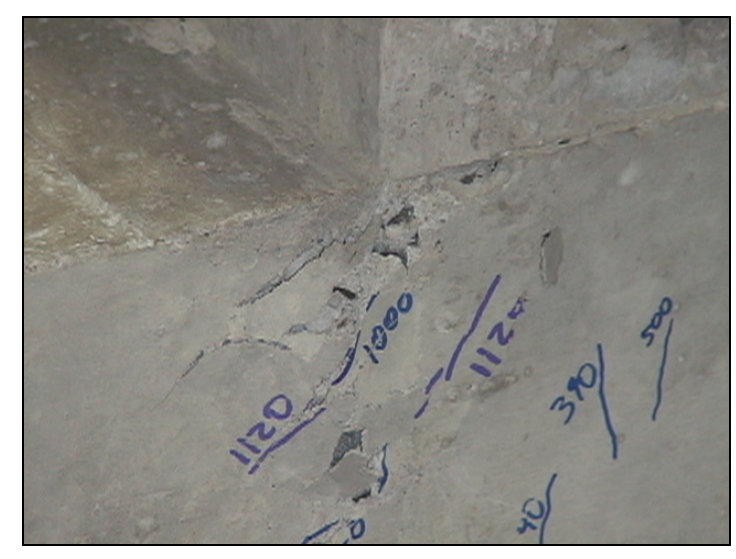

Figura 6.1 - Início do esmagamento do concreto junto ao pilar.

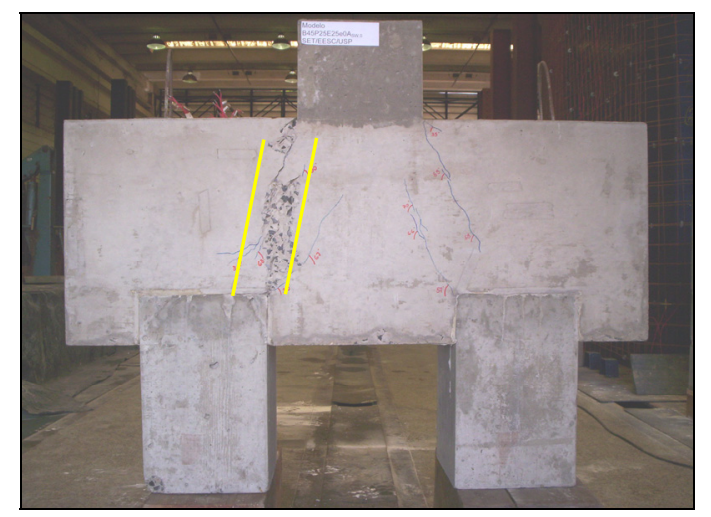

Figura 6.3 - Plano de ruptura ao longo da altura do bloco, modelo B45P25E25A $\mathrm{sw}_{\mathrm{sw}, \mathrm{c}}$, vista de frente.

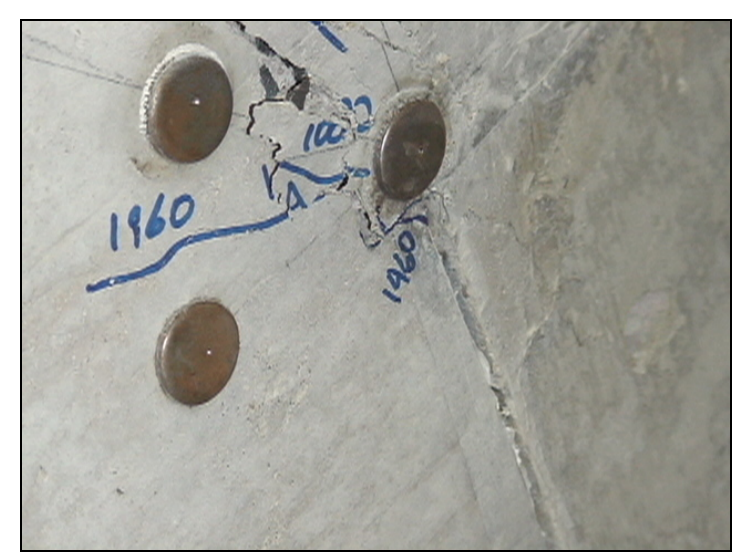

Figura 6.2 - Início do esmagamento do concreto junta à estaca.

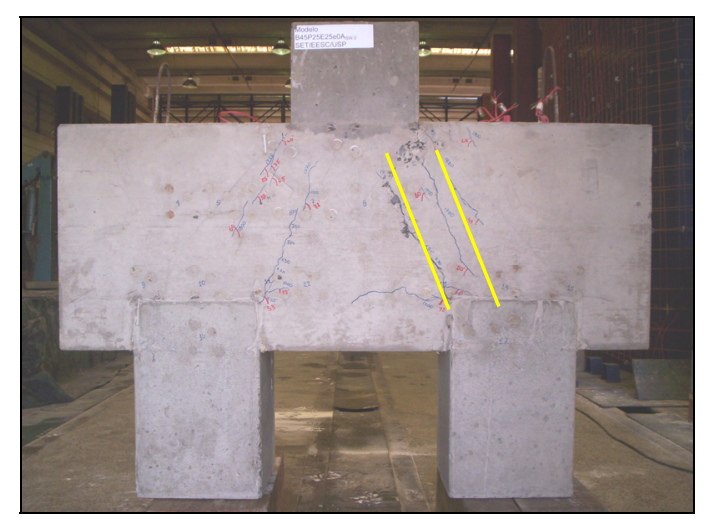

Figura 6.4 - Plano de ruptura ao longo da altura do bloco, modelo B45P25E25A $\mathrm{sw,C}$, vista de trás. 
Com relação às forças últimas registradas nos ensaios, essas deveriam ser menores, pois o início da ruptura diagonal por compressão já havia iniciado antes, em torno de $0,75 . F_{u}$ (esmagamento do concreto). A determinação da força máxima, portanto, não pode ser confundida com a força última obtida em ensaios rápidos.

\subsection{Influência da rigidez dos blocos}

Como esperado, os blocos mais rígidos apresentaram maior capacidade portante, em função do ângulo de inclinação da biela de compressão. A Tabela 6.1 apresenta relações entre força últimas dos blocos com arranjos de armaduras similares. Em função dos resultados destas relações, constatou-se que os blocos da série B45P25 foram em média, $53 \%$ mais resistentes que os blocos da série B35P25 e, os blocos da série B45P50 são em média apenas $7 \%$ mais resistentes que os blocos da série B35P50. Este valor é interessante, pois, a configuração geométrica do pilar tem influência direta na capacidade portante do bloco.

Tabela 6.1 - Relações entre as forças últimas, influência da rigidez dos blocos.

\begin{tabular}{|c|c|c|c|}
\hline Relações entre as séries & Relações entre as forças últimas & $F_{u,+r} / F_{u,-r}$ & $\theta_{+r} / \theta_{-r}$ \\
\hline \multirow{4}{*}{ B45P25 / B35P25 } & B45P25E25e0 / B35P25E25e0 & 1,25 & \multirow{4}{*}{1,21} \\
\hline & $\mathrm{B}^{2} 4 \mathrm{P} 25 \mathrm{E} 25 \mathrm{e} 0 \mathrm{~A}_{\mathrm{sw}, \mathrm{c}} / \mathrm{B} 35 \mathrm{P} 25 \mathrm{E} 25 \mathrm{e} 0 \mathrm{~A}_{\mathrm{sw}, \mathrm{C}}$ & 1,63 & \\
\hline & $\mathrm{B}^{2}$ P25E25e0A $\mathrm{A}_{\mathrm{sw}, 0} / \mathrm{B} 35 \mathrm{P} 25 \mathrm{E} 25 \mathrm{e} 0 \mathrm{~A}_{\mathrm{sw}, 0}$ & 1,45 & \\
\hline & B45P25E25e0CG / B35P25E25e0CG & 1,80 & \\
\hline \multirow{2}{*}{ B45P50 / B35P50 } & B45P50E25e0 / B35P50E25e0 & 1,08 & \multirow{2}{*}{1,16} \\
\hline & B45P50E25e12,5 / B35P50E25e12,5 & 1,06 & \\
\hline
\end{tabular}

Notas: $F_{u+r} / F_{u-r}$ é a relação entre as forças últimas dos modelos mais e menos rígidos; $\theta_{r r} / \theta_{-r}$ é a relação entre os ângulos de inclinação da biela de compressão dos modelos mais e menos rígidos.

As Figuras 6.5 a 6.10 mostram curvas força vs. deslocamentos dos modelos ensaiados com armaduras similares. Por meio delas, é possível observar claramente a influência que a rigidez do bloco tem na capacidade portante dos mesmos.

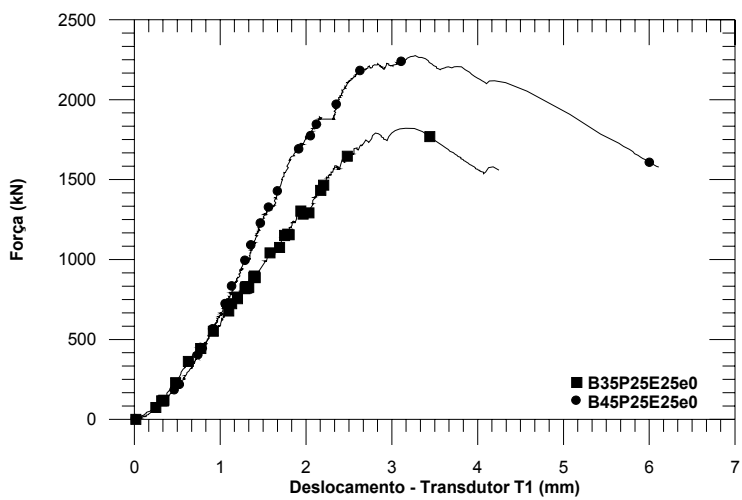

Figura 6.5 - Curva força vs. deslocamento, modelos B35P25E25e0 e B45P25E25e0.

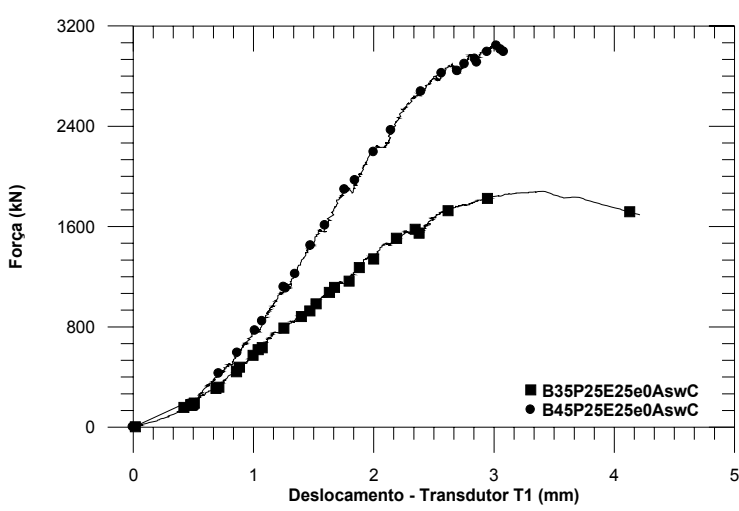

Figura 6.6 - Curva força vs. deslocamento, modelos B35P25E25e0A $A_{s w, c}$ e B45P25E25e0A $A_{s w, c}$ 


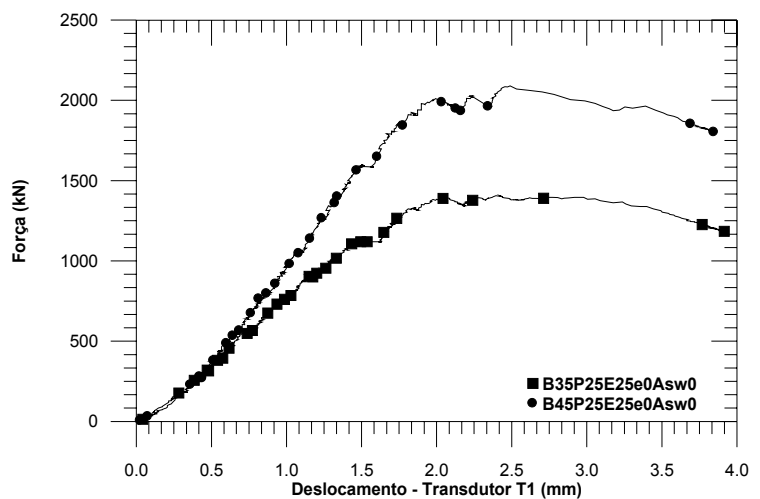

Figura 6.7 - Curva força vs. deslocamento, modelos B35P25E25e0A $\mathrm{Asw}, 0 \mathrm{e}$ B45P25E25e0A $A_{s w, 0}$.

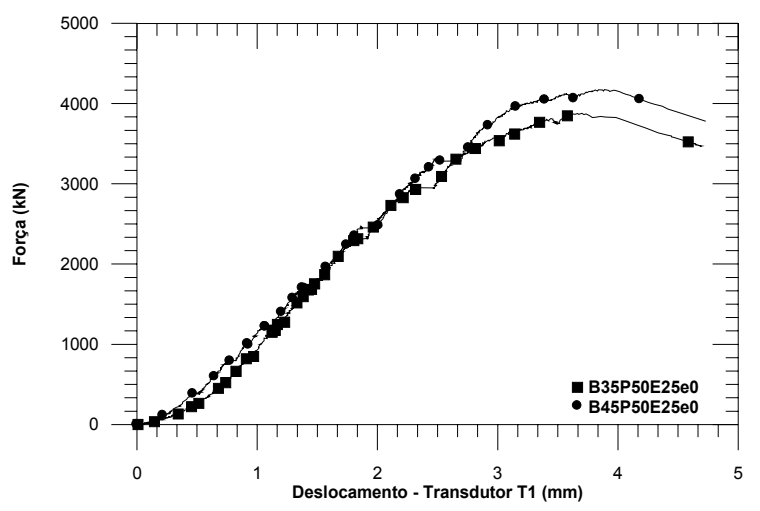

Figura 6.9 - Curva força vs. deslocamento, modelos B35P50E25e0 e B45P50E25e0.

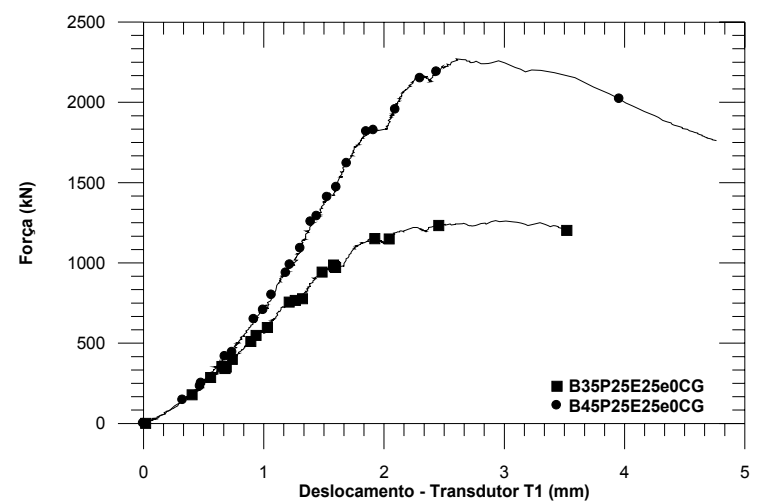

Figura 6.8 - Curva força vs. deslocamento, modelos B35P25E25e0CG e B45P25E25e0CG.

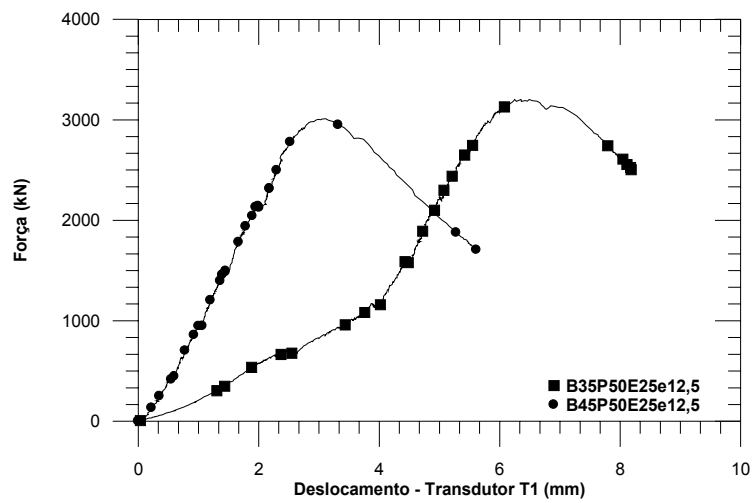

Figura 6.10 - Curva força vs. deslocamento, modelos B35P50E25e12,5 e B45P25E25e12,5.

Observa-se na Figura 6.10 que ocorreu, no início do ensaio do Modelo B35P50E25e12,5, uma acomodação até cerca de trinta por cento da força última, após isso, o modelo ganhou rigidez até o colapso.

Esses resultados mostram que a utilização de blocos mais rígidos pode ser vantajoso economicamente para a industria da construção civil, pois, além de utilizar menos aço, apresentaram melhor comportamento estrutural com relação à capacidade portante. É claro que um estudo de custo benefício entre os preços do concreto e aço deve ser realizado, ao tempo de cada projeto em função do preço de mercado.

A Tabela 6.2 apresenta relações entre forças, deslocamentos e módulos de rigidezes. Em função dos valores apresentados nessa tabela foi possível gerar uma superfície (ver Figura 6.11) que representa a influência que a rigidez provoca no comportamento estrutural dos blocos. 
Por meio de regressão não linear, obteve-se uma equação (Expressão 6.1) que exprime os valores dos deslocamentos máximos dos blocos em função de seus módulos de rigidezes e de suas forças últimas.

Tabela 6.2 - Módulo de rigidez dos blocos.

\begin{tabular}{|c|c|c|c|c|c|c|c|c|c|}
\hline SÉRIE & BLOCOS & $\begin{array}{c}\mathbf{f}_{\mathrm{cm}} \\
(\mathrm{MPa})\end{array}$ & $\begin{array}{c}F_{u} \\
(k N)\end{array}$ & $\begin{array}{c}\delta \delta_{1} 1 \\
(\mathrm{~mm})\end{array}$ & $\begin{array}{l}E_{\text {ci,exp }} \\
(\mathrm{MPa})\end{array}$ & $\begin{array}{c}\text { I } \\
\left(\mathrm{cm}^{4}\right)\end{array}$ & $\begin{array}{c}E_{c i, \exp . I} \\
\left(M N \cdot m^{2}\right)\end{array}$ & $\begin{array}{c}\mathbf{h}_{\mathbf{x}} \\
(\mathrm{cm})\end{array}$ & $\begin{array}{c}\theta \\
\text { (graus) }\end{array}$ \\
\hline \multirow{5}{*}{ B35P25 } & B35P25E25e0 & 40,6 & 1821 & 3,16 & 30203 & 89323 & 27 & 25 & 45 \\
\hline & B35P25E25e2,5 & 40,6 & 1688 & 2,44 & 30203 & 89323 & 27 & 25 & 45 \\
\hline & B35P25E25e0A $\mathrm{s}_{\mathrm{sw}, \mathrm{C}}$ & 32,8 & 1880 & 3,41 & 37737 & 89323 & 34 & 25 & 45 \\
\hline & $\mathrm{B}^{2} \mathrm{P} 25 \mathrm{E} 25 \mathrm{e} 0 \mathrm{~A}_{\mathrm{sw}, 0}$ & 32,8 & 1406 & 2,42 & 37737 & 89323 & 34 & 25 & 45 \\
\hline & B35P25E25e0CG & 28,9 & 1263 & 2,93 & 25600 & 89323 & 23 & 25 & 45 \\
\hline \multirow{5}{*}{ B45P25 } & B45P25E25e0 & 31 & 2276 & 3,27 & 27490 & 189844 & 52 & 25 & 54,5 \\
\hline & B45P25E25e5 & 31 & 1972 & 3,59 & 27490 & 189844 & 52 & 25 & 54,5 \\
\hline & B45P25E25e0A $A_{s w, C}$ & 32,4 & 3055 & 3,03 & 27500 & 189844 & 52 & 25 & 54,5 \\
\hline & 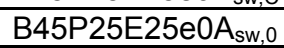 & 32,4 & 2090 & 2,49 & 27500 & 189844 & 52 & 25 & 54,5 \\
\hline & B45P25E25e0CG & 28,9 & 2270 & 2,60 & 25600 & 189844 & 49 & 25 & 54,5 \\
\hline \multirow{2}{*}{ B35P50 } & B35P50E25e0 & 35,8 & 3877 & 3,70 & 30203 & 89323 & 27 & 50 & 53,1 \\
\hline & B35P50E25e12,5 & 35,1 & 3202 & 6,49 & 28950 & 89323 & 55 & 50 & 53,1 \\
\hline \multirow{2}{*}{ B45P50 } & B45P50E25e0 & 35,9 & 4175 & 3,89 & 30203 & 189844 & 27 & 50 & 61,8 \\
\hline & B45P50E25e12,5 & 35,1 & 3386 & 4,33 & 28950 & 189844 & 55 & 50 & 61,8 \\
\hline
\end{tabular}

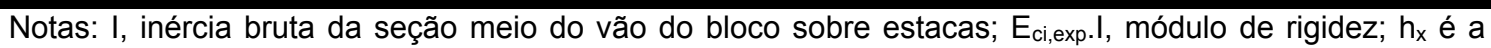
dimensão do pilar na direção longitudinal do bloco; $\theta$, ângulo de inclinação da biela de compressão.
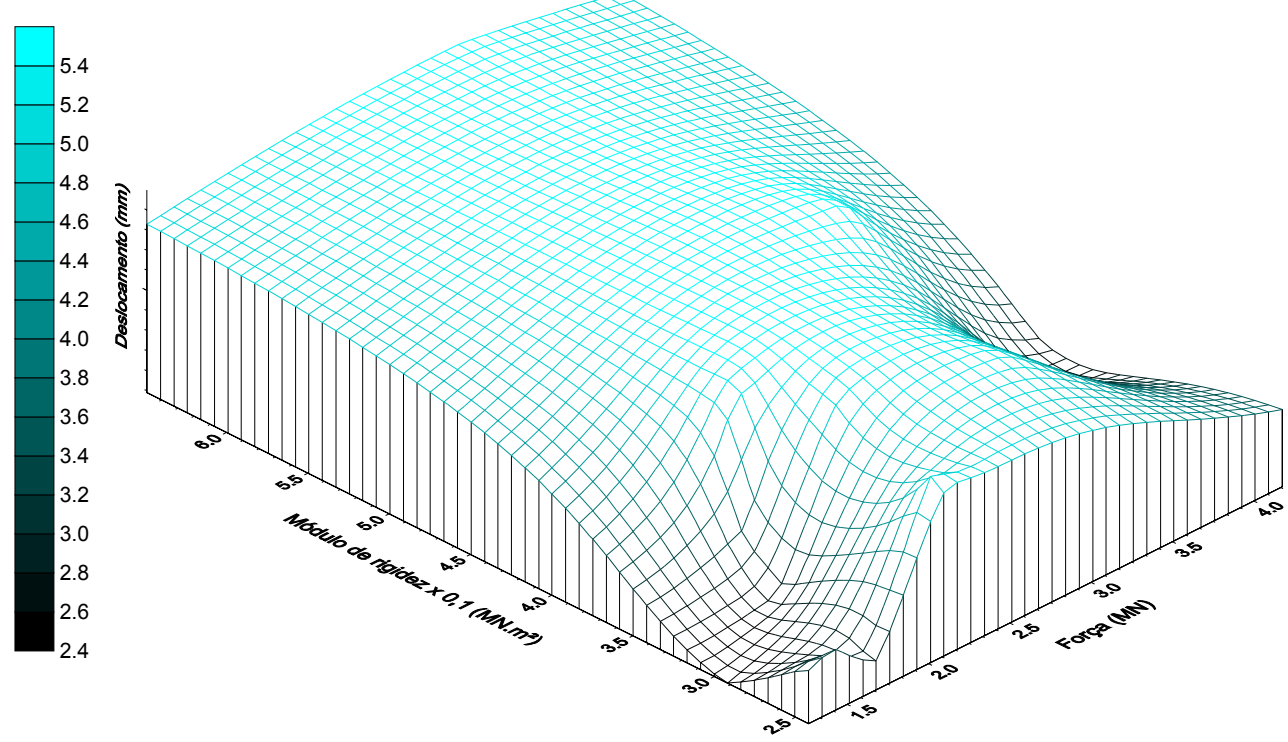

Figura 6.11 - Superfície dos blocos sobre estacas, $\delta\left(F_{u}, E_{c} l\right)$.

$$
\delta=7,55-6,78 \cdot 10^{-4} \cdot \mathrm{F}_{\mathrm{u}}+4,11 \cdot 10^{-8} \cdot \mathrm{F}_{\mathrm{u}}^{2}+3,11 \cdot 10^{-5} \cdot \mathrm{E}_{\mathrm{c}} \cdot \mathrm{I}-0,253 \cdot \mathrm{I}+2,43 \cdot 10^{-3} \cdot \mathrm{I}^{2}
$$

$\mathrm{Na}$ expressão anterior, o deslocamento $(\delta)$ é expresso em $\mathrm{mm}$, a força última $\left(F_{u}\right)$ em kN e o módulo de rigidez $\left(E_{c} . l\right)$ em $M N \cdot m^{2}$. O índice de correlação $R^{2}$ foi igual a $90 \%$. 
Em função das propriedades geométricas dos blocos determinou-se por meio de regressão não linear equação (Expressão 6.2) que exprime as forças últimas dos blocos em função do ângulo de inclinação da biela de compressão com relação ao plano horizontal e da dimensão do pilar paralela ao comprimento do bloco. As variáveis desta equação foram escolhidas em função da análise de variância realizada no Capítulo 3. A superfície mostrada na Figura 6.12 representa os valores das forças últimas em função do ângulo de inclinação da biela de compressão e da geometria do pilar.
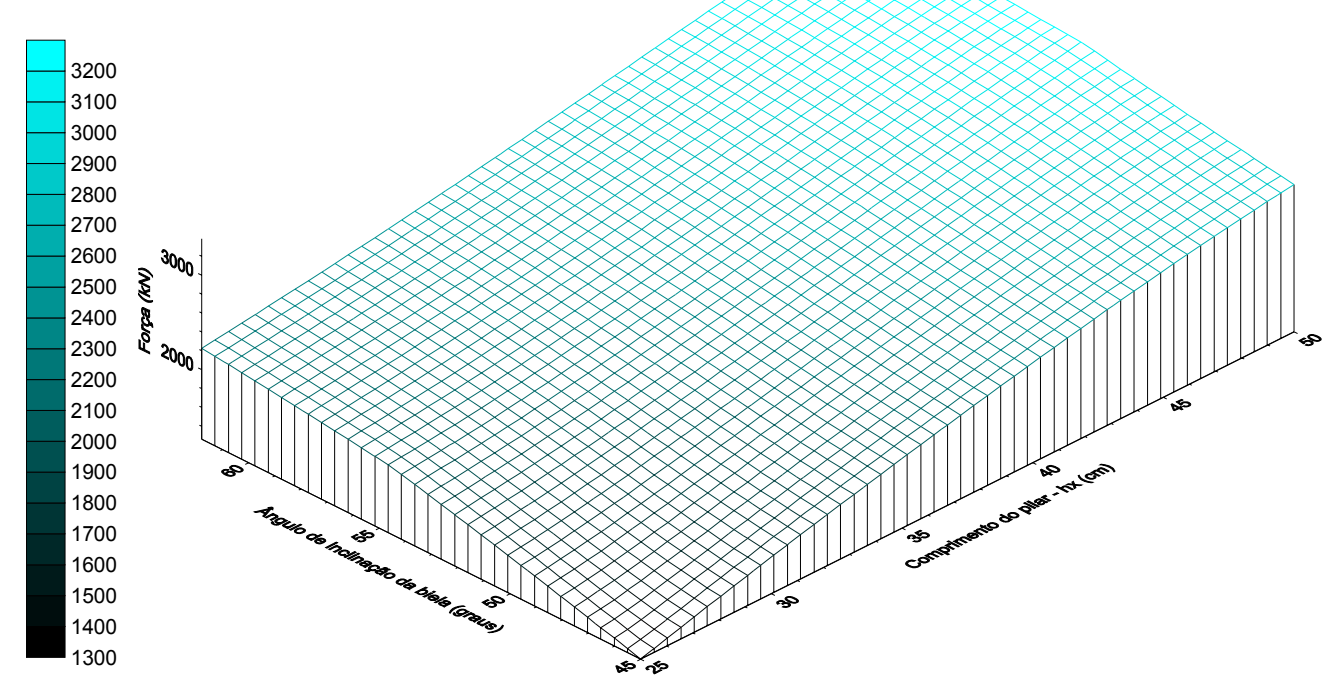

Figura 6.12 - Superfície dos blocos sobre estacas, $F_{u}\left(h_{x}, \theta\right)$.

$\mathrm{F}_{\mathrm{u}}=0,12+2,05 \cdot \mathrm{h}_{\mathrm{x}}+2,68 \cdot \mathrm{h}_{\mathrm{x}}^{2}-2,81 \cdot \mathrm{h}_{\mathrm{x}} \cdot \theta+3,18 \cdot \theta+1,44 \cdot \theta^{2}$

$\mathrm{O}$ valor de $\mathrm{F}_{\mathrm{u}}$ na Expressão 6.2 é expresso em $\mathrm{kN}, \mathrm{h}_{\mathrm{x}}$ em centímetros e $\theta$ em graus. O coeficiente de correlação da equação $\left(R^{2}\right)$ foi igual a $96 \%$. Esta expressão é válida para concretos com $\mathrm{f}_{\mathrm{cm}}=34 \mathrm{MPa}$.

\subsection{Influência do arranjo das armaduras}

Neste item são apresentadas análises comparativas entre modelos da mesma série com arranjos de armaduras diferentes. 
Observou-se nos modelos desprovidos de armaduras complementares redução da capacidade portante, função, como já foi dito, das capacidades resistentes das bielas comprimidas em virtude das fissuras que as atravessam.

\subsubsection{Armadura de costura sugerida}

Os modelos detalhados com armadura complementar sugerida pelo autor foram os que apresentaram maiores capacidades portantes. Essa armadura funciona como costura, atravessando as bielas comprimidas e absorvendo as tensões de tração ali existentes. A Tabela 6.3 mostra relações entre forças últimas, onde, os demais

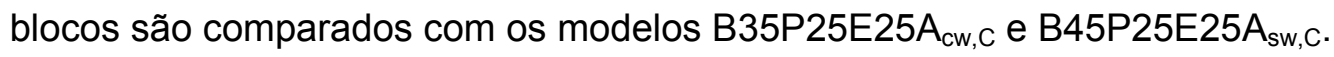

Tabela 6.3 - Relação entre as forças últimas e influência dos arranjos de armaduras.

\begin{tabular}{|c|c|c|c|c|c|}
\hline Séries & Modelos & $\begin{array}{c}\mathbf{F}_{\mathrm{u}} \\
(\mathrm{kN})\end{array}$ & $F_{u, B 35 P 25 E 25 A s w, c} / F_{u}$ & $F_{u, B 45 P 25 E 25 A s w, c} / F_{u}$ & Média \\
\hline \multirow{4}{*}{ B35P25 } & B35P25E25e0 & 1821 & 1,03 & - & \multirow{4}{*}{1,29} \\
\hline & B35P25E25e0A $A_{s w, C}$ & 1880 & 1 & - & \\
\hline & B45P25E25e0A $\mathrm{sw}, 0$ & 1406 & 1,34 & - & \\
\hline & B45P25E25e0CG & 1263 & 1,49 & - & \\
\hline \multirow{4}{*}{ B45P25 } & $\mathrm{B} 45 \mathrm{P} 25 \mathrm{E} 25 \mathrm{e} 0$ & 2276 & - & 1,34 & \multirow{4}{*}{1,38} \\
\hline & B35P50E25e0A ${ }_{\mathrm{sw}, \mathrm{C}}$ & 3055 & - & 1 & \\
\hline & $\mathrm{B} 35 \mathrm{P} 50 \mathrm{E} 25 \mathrm{e} 0 \mathrm{~A}_{\mathrm{sw}, 0}$ & 2090 & - & 1,46 & \\
\hline & B35P50E25e0CG & 2270 & - & 1,35 & \\
\hline
\end{tabular}

Notas: $F_{u, B 35 P 25 E 25 e 0 A s w, c} / F_{u}$ é a relação entre as forças últimas do modelo B35P25E25e0A $A_{s w, c}$ em relação ao demais modelos da mesma série e, $F_{\mathrm{u}, \mathrm{B} 45 \mathrm{P} 25 \mathrm{E} 25 \mathrm{e} 0 \mathrm{Asw}, \mathrm{c}} / \mathrm{F}_{\mathrm{u}}$ é a relação entre as forças últimas do modelo B45P25E25e0A $A_{s w, C}$ em relação ao demais modelos da mesma série.

Em geral, o modelo B35P25E25e0A $\mathrm{A}_{w, \mathrm{c}}$ suportou $29 \%$ a mais de força que os outros modelos da mesma série. O modelo B45P25E25e0A $A_{s w, C}$ apresentou mesma tendência do modelo menos rígido projetado com armadura complementar sugerida pelo autor, sendo $38 \%$ mais resistente que os modelos de sua série.

Estes resultados evidenciam a eficiência da armadura complementar em forma de cavalete. Como apresentado no Capítulo 5, as regiões das barras de aço que atravessam a biela foram as mais solicitadas. Por meio dessas deformações, obtiveram-se as forças de tração nas barras de aço. Essas forças, em virtude do concreto já apresentar fissuras na iminência da ruptura, foram confundidas com as forças de tração perpendicular às bielas, também conhecidas como forças de fendilhamento. A Tabela 6.4 mostra essas forças e apresenta as comparações com as forças teóricas previstas para essas barras.

A Figura 6.13 recorda as posições dos extensômetros elétricos de resistência instalados nestas barras. 
Tabela 6.4 - Força na armadura sugerida pelo autor, armadura em forma de cavalete.

\begin{tabular}{c|c|c|c|c|c|c|c}
\hline \hline Modelos & $\begin{array}{c}\mathbf{F}_{\mathrm{u}} \\
(\mathrm{kN})\end{array}$ & $\begin{array}{c}\mathbf{R}_{\text {st, teo }} \\
(\mathrm{kN})\end{array}$ & $\begin{array}{c}\left(\varepsilon_{\mathrm{e} 12 \mathrm{~F}}+\varepsilon_{\mathrm{e} 13 \mathrm{~F}}\right) / 2 \\
(\%)\end{array}$ & $\begin{array}{c}\mathbf{E}_{\mathbf{s}} \\
(\mathrm{GPa})\end{array}$ & $\begin{array}{c}\boldsymbol{\emptyset}_{\text {efetivo }} \\
(\mathrm{mm})\end{array}$ & $\begin{array}{c}\mathbf{R}_{\text {st,exp }} \\
(\mathrm{kN})\end{array}$ & $\mathbf{R}_{\text {st,teo }} / \mathbf{R}_{\text {st,exp }}$ \\
\hline B35P25E25e0A $\mathrm{sw}_{\mathrm{C}, \mathrm{C}}$ & 1880 & 446 & 1,44 & 200 & 14,39 & 288 & 1,5 \\
\hline B45P25E25e0A & 3055 & 552 & 2,39 & 200 & 14,39 & 478 & 1,2 \\
\hline \hline
\end{tabular}

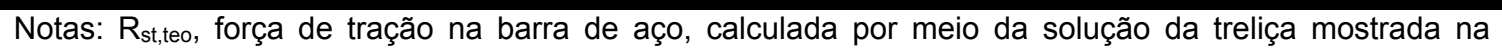
Figura 4.5 (todas as propriedades mecânicas da barra de aço, determinadas experimentalmente, foram levadas em consideração; $R_{s t, e x p}$, força de tração na barra de aço, calculada em função das deformações reais.

Observa-se na Tabela 6.4, que as forças de tração teóricas nas barras de aço são diferentes dos valores apresentados no Capítulo 4, pois, consideraram-se, agora, as forças últimas resistidas por cada modelo, como também, todas as propriedades mecânicas reais das barras de aço.

Apesar de nesses modelos as força últimas resistidas serem superiores aos modelos similares (com arranjos de armaduras diferentes) observou-se que a força teórica na armadura de tração em ambos modelos foi superior à experimental. Este fato confirma os modos de ruína dos modelos, que foram por esmagamento do concreto da biela comprimida, pois as barras da armadura complementar sugerida não foram capazes de absorver as tensões de tração após o esmagamento do concreto, em função da perda de rigidez brusca dos blocos que provocou o colapso. Além disso, em função das aproximações no modelo de treliça apresentado na Figura 4.5, os valores nas forças de tração nas barras de aço que atravessam as bielas de compressão na direção perpendicular às mesmas provocaram divergências entre as forças de tração teóricas e experimentais.

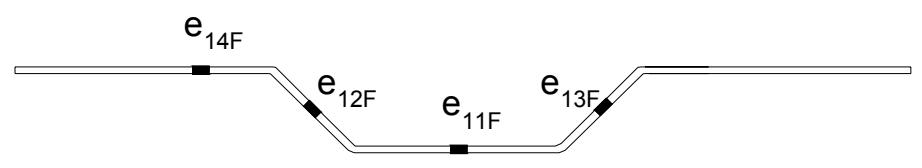

Figura 6.13 - Posição dos extensômetetros na barra de aço $A_{\text {sw,c. }}$

As Figuras 6.14 e 6.15 apresentam relações força vs. deslocamento dos blocos ensaiados, pelas quais é possível observar o aumento da capacidade portante dos blocos projetados com barras de aço em forma de cavalete, B35P25E25e0A $A_{s w, c}$ e B45P25E25e0A $\mathrm{sw}_{\mathrm{s}}$. 


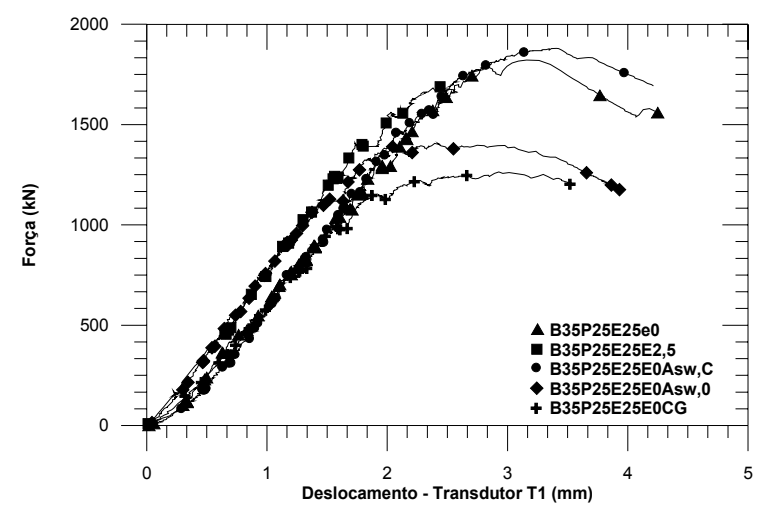

Figura 6.14 - Curvas força vs. deslocamento, série B35P25.

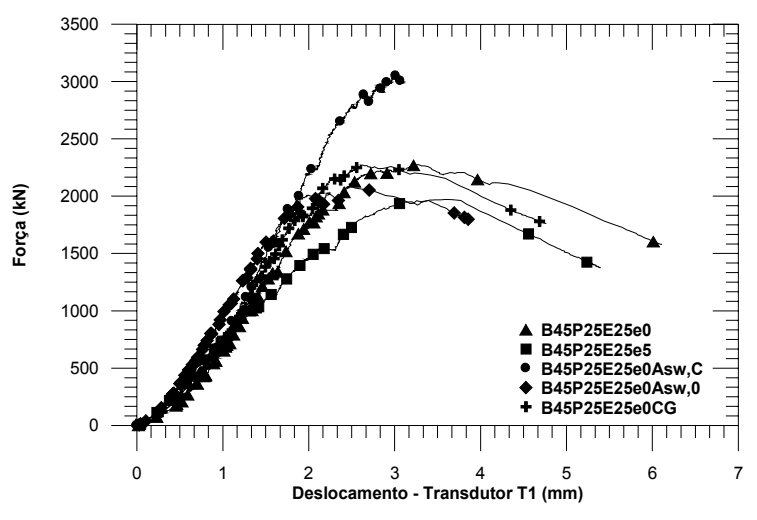

Figura 6.15 - Curvas força vs. deslocamento, série B45P25.

\subsubsection{Estribos horizontais e verticais}

Os modelos construídos com estribos horizontais e verticais, o quais foram determinados em função das recomendações do Boletim $n^{\circ} 73$ do CEB (1970) e da norma espanhola EHE (2002), também apresentaram melhor comportamento estrutural quando comparados com os modelos sem armaduras complementares. É válido lembrar que essa armadura foi mais eficiente em função da inexistência das abas de concreto dos blocos sobre estacas. Nos modelos construídos in-loco, com a utilização das abas de concreto, essa armadura se torna menos eficiente ficando limitada a reduzir as aberturas de fissuras - conclusões obtidas por Miguel (2000) e Delalibera (2005).

Como os ramos verticais dos estribos verticais e os ramos longitudinais dos estribos horizontais atravessaram as bielas de compressão, estes absorveram tensões de tração, funcionando também como armadura de costura, o que provocou aumento da capacidade portante dos modelos construídos com tais armaduras.

Em função das conclusões de Miguel (2000) e Delalibera (2005) e dos resultados aqui apresentados, a utilização da armadura em forma de cavalete, sugerida pelo autor, combinada com os estribos verticais e horizontais tornariam os blocos sobre estacas mais eficientes quanto à sua capacidade portante e ao Estado Limite de Abertura das Fissuras.

\subsubsection{Armadura principal de tração projetada com ganchos a $180^{\circ}$}

A NBR 6118:2003 e o ACl SP-208 (2002) recomendam que a armadura principal de tração para blocos sobre estacas sejam detalhadas com ganchos a $90^{\circ}$ ou 
$180^{\circ}$ dependendo do diâmetro da barra, já a norma canadense, CSA Standard A23.394 recomenda a utilização de ancoragem em ponta.

Por meio dos resultados obtidos verificou-se que a utilização dos ganchos para blocos rígidos sobre duas estacas pode ser revista, pois as deformações nos ganchos foram pequenas e sua utilização não aumentou, como era esperada, a capacidade resistente dos blocos.

$\mathrm{Na}$ análise numérica desenvolvida neste trabalho, os resultados obtidos se assemelham aos resultados experimentais, pois também os ganchos não contribuíram na capacidade portante dos blocos no Estado Limite Último.

Talvez a utilização de ganchos pode ser melhor aproveitada quando se projetar e construir blocos flexíveis, onde as tensões de tração na armadura principal tendem a ser maiores, podendo provocar, na iminência da ruptura, deslizamento entre as barras de aço e o concreto que as envolvem.

Observa-se por meio das Figuras 6.14 e 6.15 que a utilização dos ganchos não alterou o comportamento dos blocos nas fases de serviço e última. Observou-se também que não ocorreram deslizamentos entre as barras de aço e o concreto do entorno (item 5.3.6.1, Capítulo 5). O item 6.7 apresenta diagramas de deformações nas barras de aço da armadura principal de tração, onde se pode observar que as deformações no tirante e nas pontas das barras (nos modelos em que se utilizou ancoragem em ponta) são pequenas se comparadas com as deformações nas seções de meio do vão do bloco.

Em função disso, conclui-se que a utilização de ganchos em blocos rígidos sobre duas estacas pode ser reavaliada pela comissão da ABNT que foi responsável pela elaboração da NBR 6118:2003.

A Tabela 6.5 apresenta resultados da tensão de aderência nas barras de aço da armadura principal de tração na seção do gancho, considerando como comprimento da barra para o cálculo da tensão de aderência o comprimento do extensômetro elétrico de resistência, ou seja, cinco milímetros.

A tensão de aderência $\left(\tau_{b}\right)$ foi calcula por meio das propriedades mecânicas reais dos materiais: concreto e aço (Expressão 6.3).

$\tau_{\mathrm{b}}=\frac{\varepsilon_{\mathrm{s}} \cdot \mathrm{E}_{\mathrm{s}} \cdot \phi_{\text {non }}}{4 \cdot 0,005}$, expresso em megapascals. 
Tabela 6.5 - Tensão de aderência na ponta do tirante.

\begin{tabular}{|c|c|c|c|}
\hline Séries & Modelos & $\begin{array}{c}\tau_{\mathbf{b}}{ }^{{ }^{2}} \\
(\mathrm{MPa})\end{array}$ & $\begin{array}{l}\mathbf{R}_{\text {st,ponta }} \\
(\mathrm{kN})\end{array}$ \\
\hline \multirow{5}{*}{ B35P25 } & B35P25E25e0 & 2,7 & 19,2 \\
\hline & B35P25E25e2,5 & 1,4 & 9,6 \\
\hline & B35P25E25e0A ${ }_{\mathrm{sw}, \mathrm{C}}$ & 10,4 & 23,9 \\
\hline & B35P25E25e0A & 1,4 & 9,6 \\
\hline & B35P25E25e0CG & - & - \\
\hline \multirow{5}{*}{ B45P25 } & B45P25E25e0 & 10,4 & 23,9 \\
\hline & B45P25E25e5 & 6,8 & 47,9 \\
\hline & B45P25E25e0A $\mathrm{sw}_{\mathrm{sw}, \mathrm{c}}$ & 6,3 & 14,4 \\
\hline & $\mathrm{B} 45 \mathrm{P} 25 \mathrm{E} 25 \mathrm{e} 0 \mathrm{~A}_{\mathrm{sw}, 0}$ & 6,3 & 14,4 \\
\hline & B45P25E25e0CG & 18,8 & 43,1 \\
\hline \multirow{2}{*}{ B35P50 } & B35P50E25e0 & 6,3 & 14,4 \\
\hline & B35P50E25e12,5 & 10,4 & 23,9 \\
\hline \multirow{2}{*}{ B45P50 } & B45P50E25e0 & 8,4 & 19,2 \\
\hline & B45P50E25e12,5 & 10,3 & 71,8 \\
\hline
\end{tabular}

Nota: a tensão de aderência foi calculada para um comprimento dx igual a $5 \mathrm{~mm}$, ou seja, $\ell_{b}=5 \mathrm{~mm}$.

Observa-se por meio da Tabela anterior, que as forças na iminência da ruína são muito pequenas, solicitando muito pouco a massa de concreto que envolve as barras de aço, portanto, a utilização de ancoragem mecânica (gancho) não tem sentido nesses casos.

\subsection{Influência da excentricidade}

Por meio dos ensaios ficou claro que nos modelos com excentricidade a capacidade portante dos blocos é menor, em função das diferentes deformações existentes nas bielas de compressão. A excentricidade provoca concentração de tensões em um dos lados do bloco, modificando a distribuição do fluxo de tensões de compressão e tração.

Geralmente, o dimensionamento de blocos sobre estacas com atuação de momento e força normal é feito da seguinte maneira: primeiramente determinam-se as reações nas estacas; após isso, é verificado se há estacas tracionadas, caso existam, modelos particulares para o dimensionamento e detalhamento das armaduras devem ser utilizados, ver Fusco (1994); em se tratando de estacas somente comprimidas, multiplica-se o número de estacas pelo valor da reação da estaca mais comprimida e aplica-se esse valor no topo do pilar como sendo uma força normal centrada.

O critério apresentado anteriormente julga-se não ser o mais correto, pois considera que as bielas possuem as mesmas tensões, o que na realidade não ocorre. Um critério interessante para as verificações das tensões nas regiões nodais seria a 
utilização do modelo de bielas e tirantes, em que se aplicaria no topo do pilar as reações das estacas (ver Figura 6.16 - para o caso de blocos sobre duas estacas).

A Tabela 6.6 apresenta as reações nas estacas mais e menos solicitadas, como também, os valores das forças últimas teóricas determinadas por meio das observações efetuadas por Blévot \& Frémy (1967), ou seja, aumento de cerca de quarenta por cento na resistência do concreto na região nodal superior e tensão na biela de compressão igual a resistência do concreto na região nodal inferior.

Tabela 6.6 - Reações nas estacas mais e menos solicitadas.

\begin{tabular}{|c|c|c|c|c|c|c|c|c|c|}
\hline Modelos & $\begin{array}{c}\mathbf{F}_{\mathrm{u}} \\
(\mathrm{kN})\end{array}$ & $\begin{array}{l}\text { Est }_{1} \\
(\mathrm{kN})\end{array}$ & $\begin{array}{l}\text { Est }_{2} \\
(\mathrm{kN})\end{array}$ & $\begin{array}{l}\mathbf{e}_{\text {real }} \\
(\mathrm{cm})\end{array}$ & $\begin{array}{l}F_{\text {teo }} \\
(\mathrm{kN})\end{array}$ & $\begin{array}{c}\text { Est }_{1, \text { teo }} \\
(\mathrm{kN})\end{array}$ & $\begin{array}{c}\text { Est }_{2, \text { teo }} \\
(\mathrm{kN})\end{array}$ & $\mathrm{Est}_{1, \text { teo }} / \mathrm{Est}_{1}$ & $\mathrm{Est}_{2, \text { teo }} / \mathrm{Est}_{2}$ \\
\hline B35P25E25e2,5 & 1688 & 925 & 763 & 3 & 1776 & 973 & 803 & 1,05 & 1,05 \\
\hline B35P25E25e5 & 1972 & 1091 & 881 & 3,5 & 1796 & 999 & 797 & 0,92 & 0,90 \\
\hline \multicolumn{8}{|c|}{ Valores médios } & 0,99 & 0,98 \\
\hline
\end{tabular}

Nota: $E_{i, t e o}$, são as reações teóricas das estacas 1 e 2.

Por meio da tabela anterior, nota-se que o critério utilizado para a distribuição das forças nas estacas, para blocos rígidos, é satisfatório, pois apresenta boa correlação entre os resultados experimentais e teóricos. O critério analítico aqui empregado está descrito no Capítulo 4, item 4.2.3.

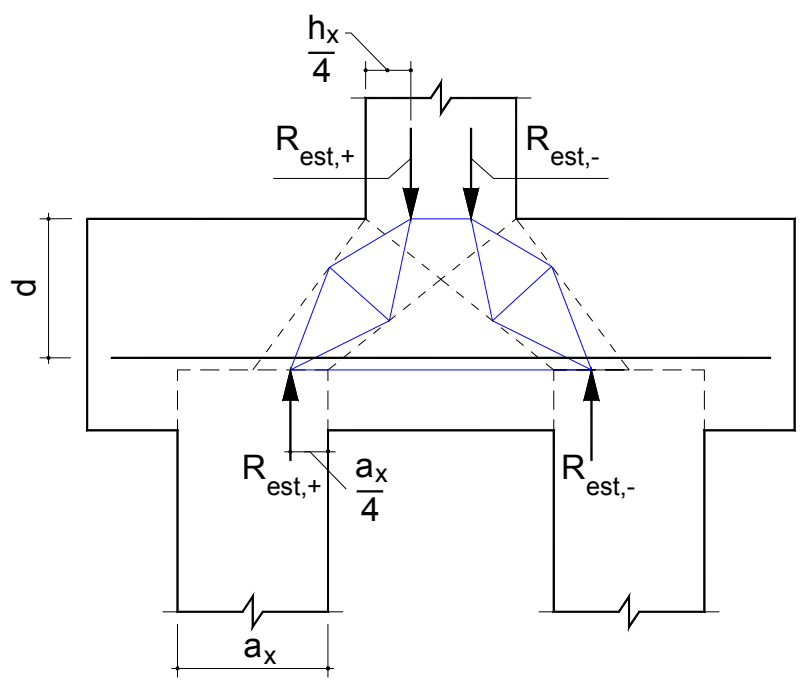

Figura 6.16 - Critério proposto para dimensionamento e verificações das tensões nodais superior e inferior.

Por meio das Figuras 6.17, 6.18, 6.19 e 6.20 que mostram curvas força vs. Deslocamento. Observa-se que a excentricidade reduziu a capacidade portante dos modelos. 


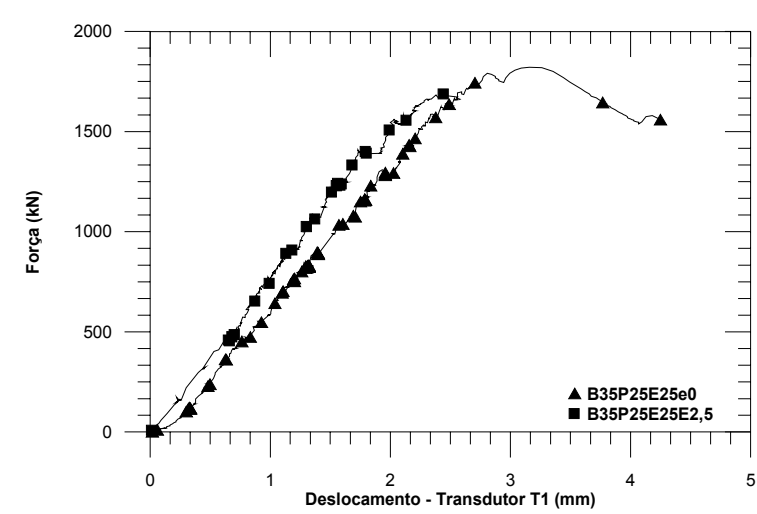

Figura 6.17 - Curva força vs. deslocamento, modelos B35P25E25e0 e B35P25E25e2,5.

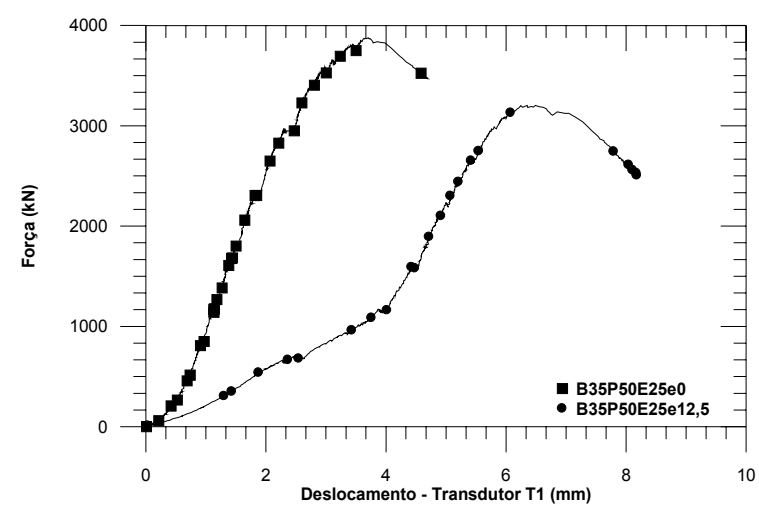

Figura 6.19 - Curva força vs. deslocamento, Figura 6.20 - Curva força vs. deslocamento, modelos B35P50E25e0 e B35P50E25e12,5.

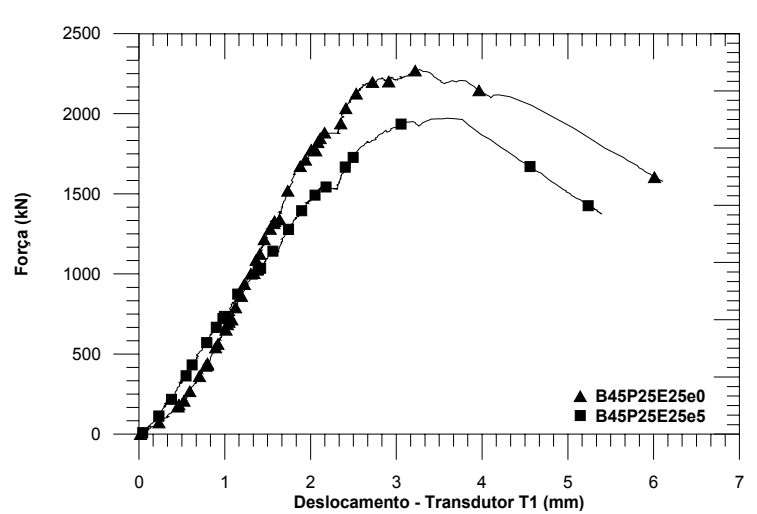

Figura 6.18 - Curva força vs. deslocamento, modelos B45P25E25e0 e B45P25E25e5.

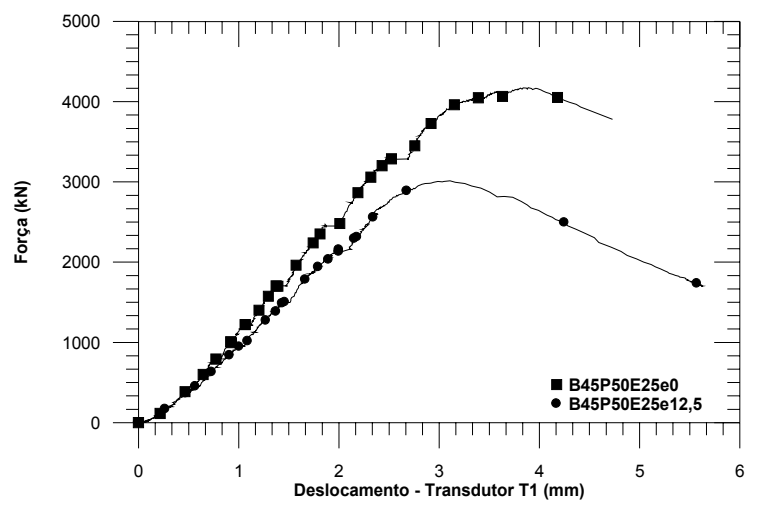

modelos B45P50E25e0 e B45P50E25e12,5.

Levando-se em consideração as excentricidades reais em todos os modelos analisados, foi possível determinar uma expressão, por meio de regressão não linear, que determina (de maneira aproximada) a força resistente última. A Expressão 6.4 apresenta o valor da força última em função da geometria do pilar e da excentricidade da força normal.

$\mathrm{F}_{\mathrm{u}}=9,36 \cdot 10^{-3}-175,64 \cdot \mathrm{e}+12,42 \cdot \mathrm{e}^{2}-0,035 \cdot \mathrm{e} \cdot \mathrm{A}_{\text {pilar }}+9,90 \cdot \mathrm{A}_{\text {pilar }}-4,52 \cdot 10^{-4} \cdot \mathrm{A}_{\text {pilar }}^{2}$

$\mathrm{Na}$ Expressão anterior, a força última $\left(\mathrm{F}_{\mathrm{u}}\right)$ é medida em quilonewtons, a excentricidade é expressa em centímetros e a área do pilar em centímetros quadrados. O coeficiente de correlação $\mathrm{R}^{2}$ foi igual a $95 \%$.

A Figura 6.21 apresenta uma superfície que representa a influência que a excentricidade provocou no comportamento estrutural dos modelos analisados. 


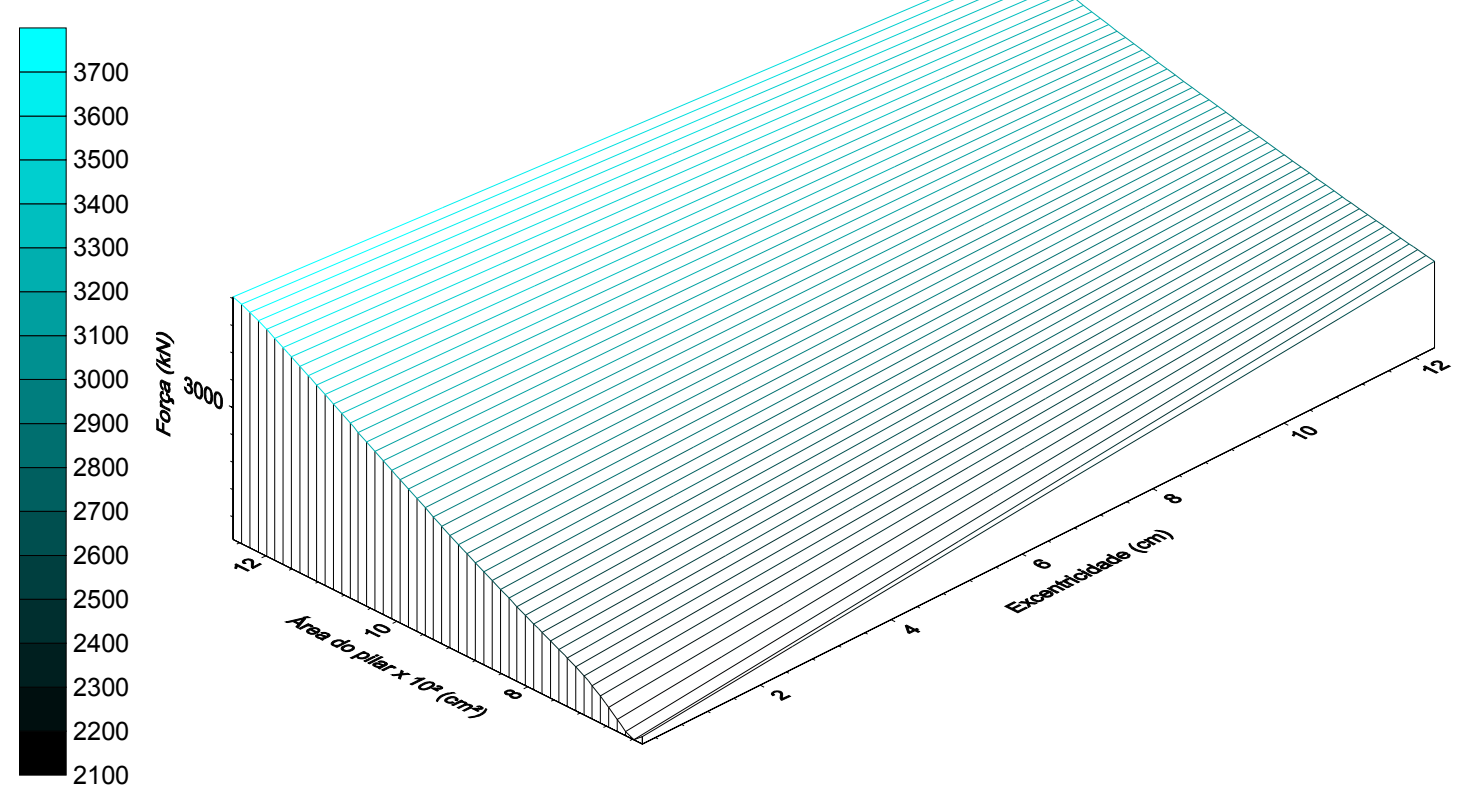

Figura 6.21 - Superfície dos blocos sobre estacas, $F_{u}\left(e, E_{c} l\right)$.

\subsection{Deformação na armadura principal de tração - tirante}

As deformações de tração na armadura principal de tração, obtidas por meio de extensômetros elétricos de resistência, são apresentadas a seguir por meio de diagramas.

Verifica-se que as deformações não são constantes ao longo do tirante (hipótese adotada nos modelos de bielas e tirantes), além disso, sofrem reduções significativas quando as barras de aço da armadura principal de tração atravessam as bielas comprimidas, em função das altas tensões de compressão existentes nestas regiões.

Em virtude desses valores, considerar que a seção de início das ancoragens das barras de aço da armadura principal de tração é a seção do bloco localizada na extremidade mais afastada da estaca com relação à borda do bloco, adotando a força de tração das barras de aço referentes à seção meio do vão do bloco é perfeitamente possível - Hipótese I.

Outra hipótese a ser considerada seria utilizar redução de $51 \%$ da força de tração no tirante referente à seção de meio do vão do bloco e iniciar a ancoragens das barras na seção do bloco concernente ao meio da estaca - Hipótese II. 
A Tabela 6.7 apresenta resultados de forças de tração nos tirantes e traz relações importantes entre as forças de tração na seção de meio do vão do bloco e na seção de meio da estaca.

Tabela 6.7 - Força de tração no tirante.

\begin{tabular}{|c|c|c|c|c|c|c|}
\hline \multirow[b]{2}{*}{ Modelos } & \multirow{2}{*}{$\begin{array}{c}\mathbf{F}_{\mathrm{u}} \\
(\mathrm{kN})\end{array}$} & $\begin{array}{c}\mathbf{R}_{\text {st,exp,mv }} \\
(\mathrm{kN})\end{array}$ & $\begin{array}{c}\mathbf{R}_{\text {st,exp,ce }} \\
(\mathrm{kN})\end{array}$ & $\begin{array}{c}\mathbf{R}_{\text {st,teo,mv }} \\
(\% 0)\end{array}$ & \multirow[b]{2}{*}{$\mathbf{R}_{\text {st,exp,ce }} / \mathbf{R}_{\text {st,exp,mv }}$} & \multirow[b]{2}{*}{$\mathbf{R}_{\text {st }, \text { exp }, \mathrm{mv}} / \mathbf{R}_{\text {st,teo,mv }}$} \\
\hline & & $\begin{array}{l}\text { Seção: } \\
\text { meio do } \\
\text { bloco }\end{array}$ & $\begin{array}{l}\text { Seção: } \\
\text { centro da } \\
\text { estaca }\end{array}$ & $\begin{array}{l}\text { Seção: } \\
\text { meio do } \\
\text { bloco }\end{array}$ & & \\
\hline B35P25E25e0 & 1821 & 670 & 325 & 381 & 0,48 & 1,76 \\
\hline B35P25E25e2,5 & 1688 & 763 & 438 & 411 & 0,57 & 1,86 \\
\hline B35P25E25e0A ${ }_{\mathrm{sw}, \mathrm{C}}$ & 1880 & 657 & 267 & 308 & 0,41 & 2,13 \\
\hline B35P25E25e0A $\mathrm{Asw}, 0$ & 1406 & 582 & 263 & 308 & 0,45 & 1,89 \\
\hline B35P25E25e0CG & 1263 & 551 & 198 & 271 & 0,36 & 2,03 \\
\hline B45P25E25e0 & 2276 & 667 & 298 & 275 & 0,45 & 2,43 \\
\hline B45P25E25e5 & 1972 & 746 & 475 & 319 & 0,64 & 2,34 \\
\hline B45P25E25e0A $A_{s w, C}$ & 3055 & 636 & 212 & 287 & 0,33 & 2,22 \\
\hline $\mathrm{B} 45 \mathrm{P} 25 \mathrm{E} 25 \mathrm{e} 0 \mathrm{~A}_{\mathrm{sw}, 0}$ & 2090 & 650 & 185 & 287 & 0,28 & 2,26 \\
\hline B45P25E25e0CG & 2270 & 735 & 198 & 257 & 0,27 & 2,86 \\
\hline B35P50E25e0 & 3877 & 688 & 455 & 644 & 0,66 & 1,07 \\
\hline B35P50E25e12,5 & 3202 & 725 & 561 & 885 & 0,77 & 0,82 \\
\hline B45P50E25e0 & 4175 & 862 & 540 & 560 & 0,63 & 1,54 \\
\hline B45P50E25e12,5 & 3386 & 681 & 595 & 767 & 0,87 & 0,89 \\
\hline \multicolumn{5}{|c|}{ Valores médios } & 0,51 & 1,86 \\
\hline
\end{tabular}

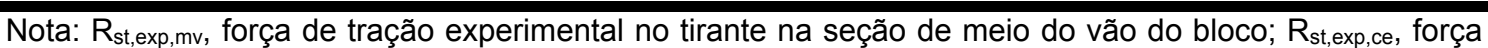
de tração na seção centro da estaca; e $R_{s, t e o, m v}$, força de tração de teórica do tirante na seção meio de vão do bloco (esta força foi calculada considerando a reação da estaca mais comprimida e tensão limite na biela de compressão igual a 0,6f $\mathrm{f}_{\mathrm{c}}$ - limite estabelecido por Blévot \& Frémy (1962)).

Analisando os resultados da Tabela 6.6, observa-se que a força no tirante tem redução, em média, de $51 \%$ na seção de meio da estaca. Este valor é muito interessante, pois em situações onde a excentricidade da força normal é bastante reduzida, ou seja, a relação $\frac{M_{d}}{F_{d} \cdot h_{x}} \leq 0,15$, pode-se considerar para a verificação das ancoragens da barras de aço da armadura principal de tração apenas $51 \%$ da força de cálculo de tração no tirante.

Verificou-se, também, que a força experimental no tirante na seção de meio de vão $\left(R_{\text {st,exp,mv }}\right)$ foi em média $86 \%$ superior a força de tração teórica, calcula com os critérios sugeridos por Blévot \& Fremy (1967), estabelecendo tensões máximas nas bielas igual a $0,6 \mathrm{f}_{\mathrm{c}}$.

Como a força de tração no tirante é função da força última e do ângulo de inclinação da biela de compressão, determinou-se uma equação que exprime o valor desta força função das duas variáveis envolvidas.

$$
\mathrm{R}_{\mathrm{st}}=949.8-0.016 \cdot \mathrm{F}_{\mathrm{u}}-9.13 \cdot 10^{-6} \cdot \mathrm{F}_{\mathrm{u}}^{2}+0,00184 \cdot \mathrm{F}_{\mathrm{u}} \cdot \theta-13,8 \cdot \theta+0.12 \cdot \theta^{2}
$$


A força no tirante $\left(R_{s t}\right)$ e a forca última $\left(F_{u}\right)$ são expressas em quilonewtons, enquanto o ângulo de inclinação da biela de compressão $(\theta)$ é expresso em graus.

A Figura 6.22 apresenta a curva de superfície que representa o valor da força no tirante em função da força última e o ângulo de inclinação da biela de compressão.

As Figuras 6.23 a 6.36 apresentam diagramas de deformação das barras de aço da armadura principal de tração. Por meio dessas figuras, é possível visualizar a redução das tensões de tração no tirante, quando, as barras de aço atravessam a zona nodal inferior.
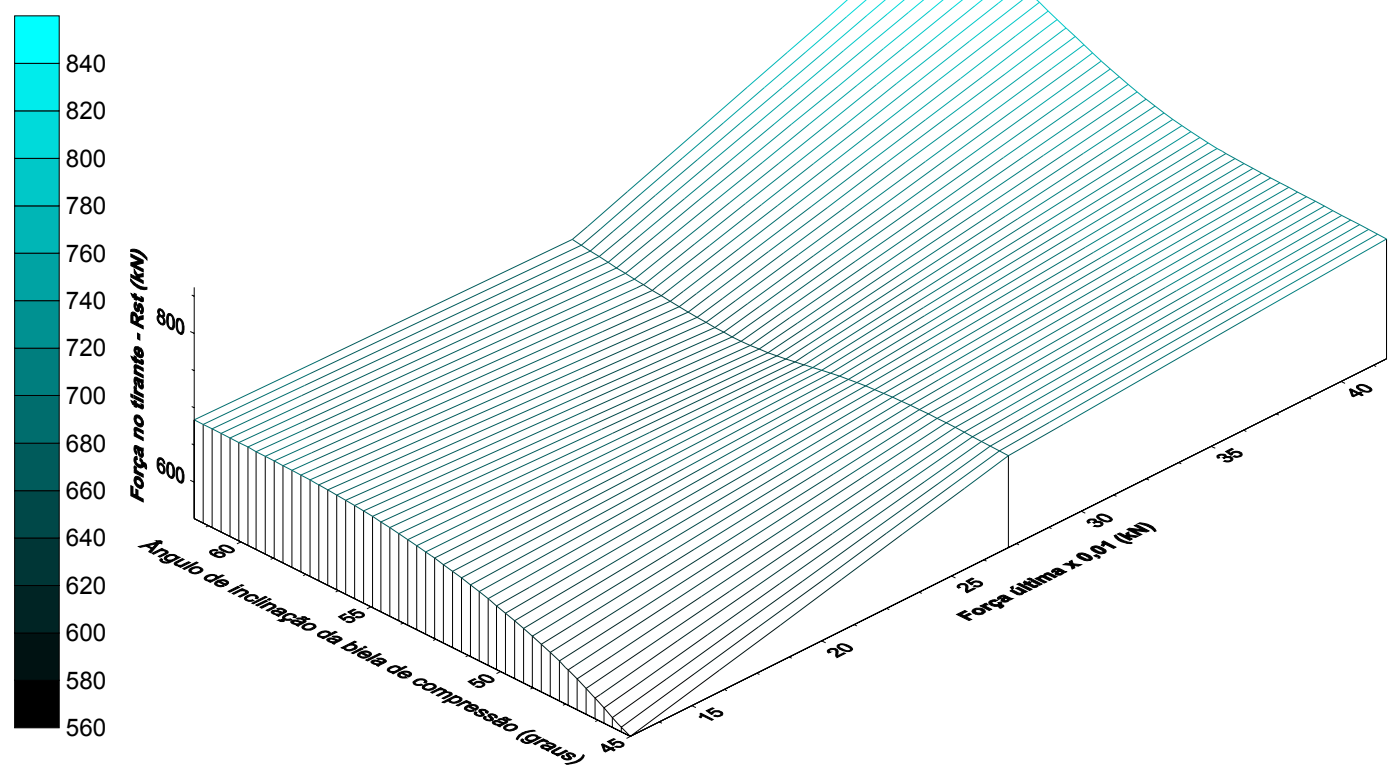

Figura 6.22 - Curva de superfície dos blocos sobre estacas, $R_{s t}\left(F_{u}, \theta\right)$.

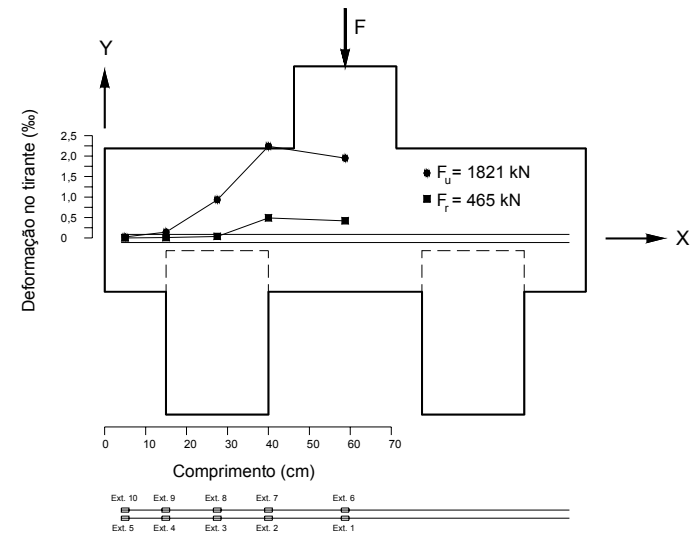

Figura 6.23 - Deformação no tirante, modelo B35P25E25e0.

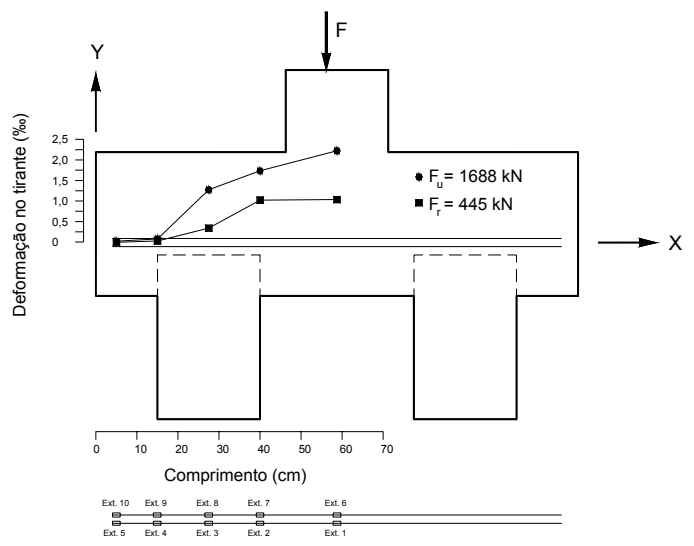

Figura 6.24 - Deformação no tirante, modelo B35P25E25e2,5. 


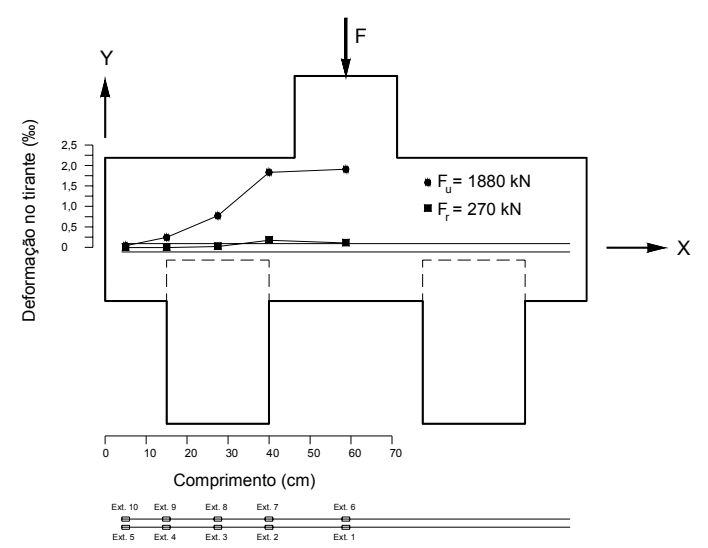

Figura 6.25 - Deformação no tirante, modelo B35P25E25e0A sw,c. $_{\text {. }}$

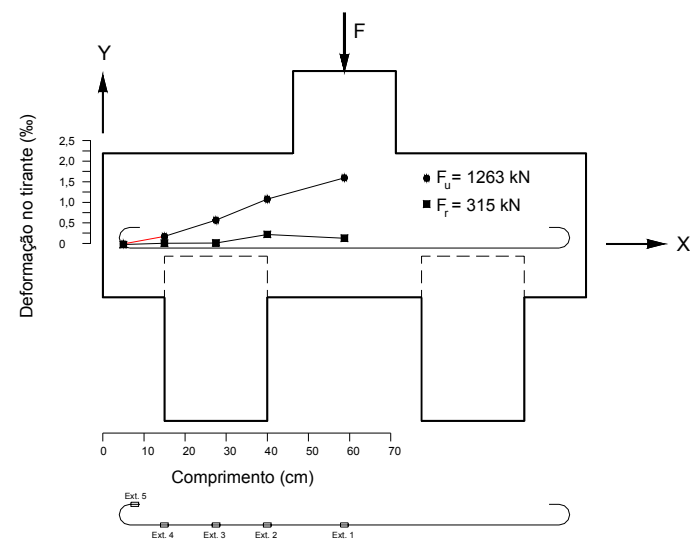

Figura 6.27 - Deformação no tirante, modelo B35P25E25e0CG.

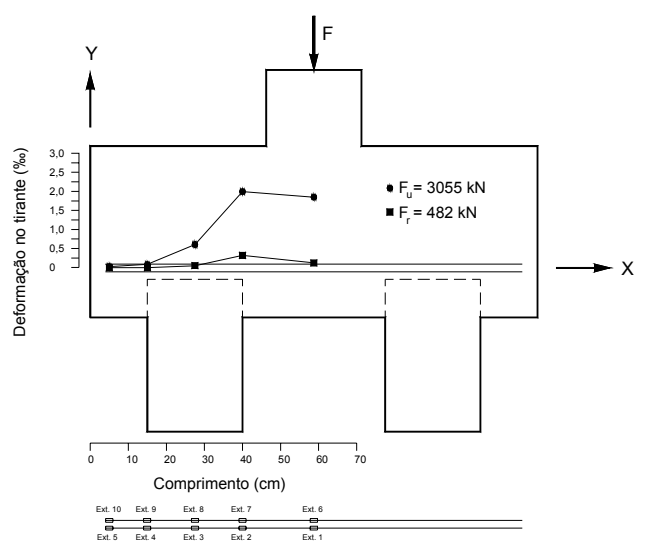

Figura 6.29 - Deformação no tirante, modelo B45P25E25e5.

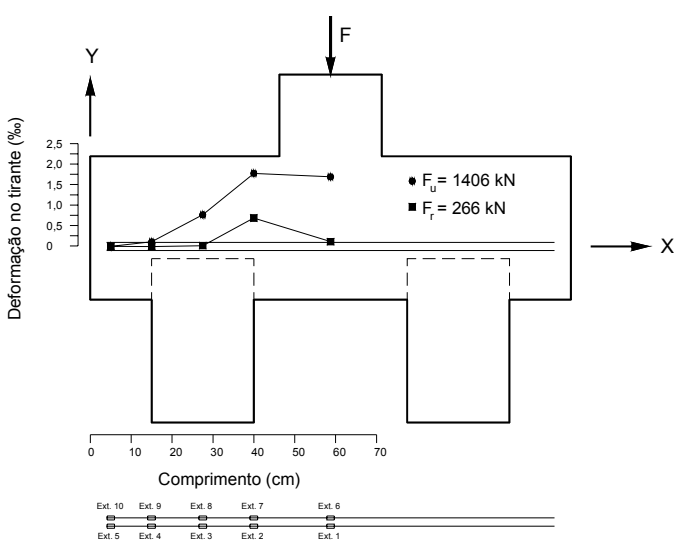

Figura 6.26 - Deformação no tirante, modelo B35P25E25e0A $A_{s w, 0}$.

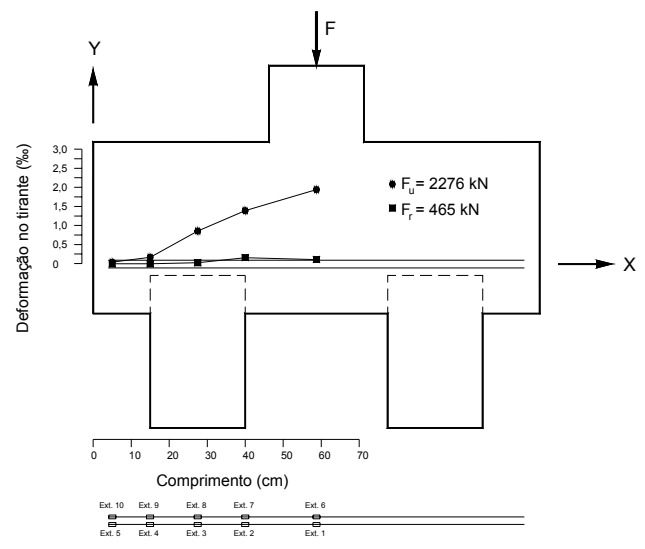

Figura 6.28 - Deformação no tirante, modelo B45P25E25e0.

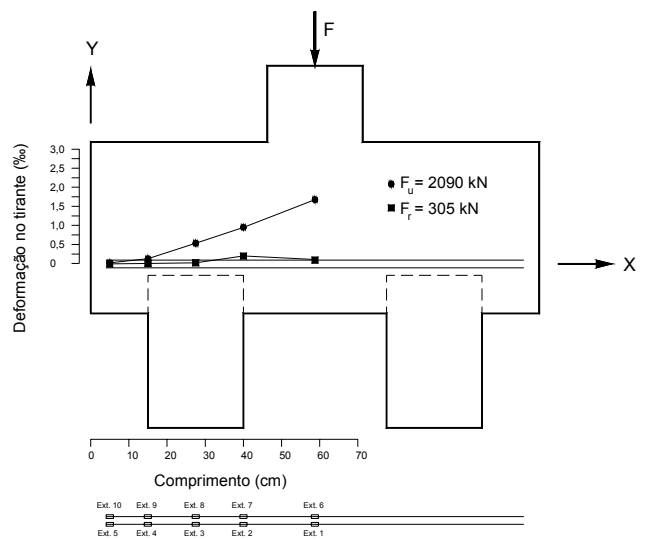

Figura 6.30 - Deformação no tirante, modelo B45P25E25e0A $\mathrm{sw}_{\mathrm{c}, \mathrm{c}}$. 


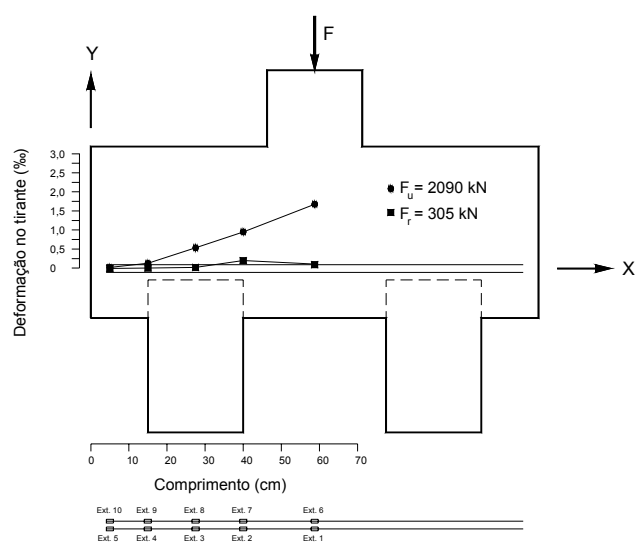

Figura 6.31 - Deformação no tirante,

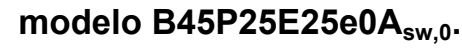

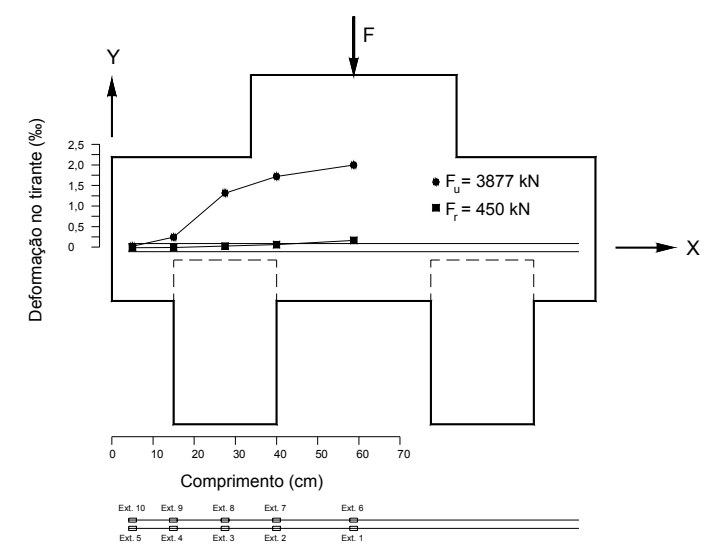

Figura 6.33 - Deformação no tirante, modelo B35P50E25e0.

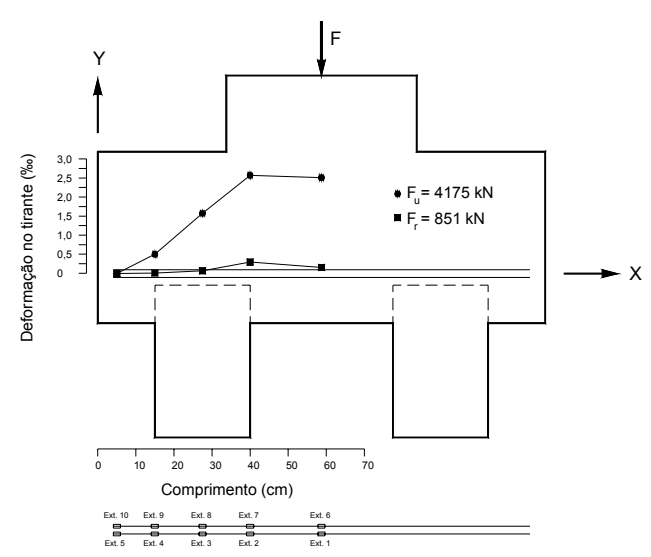

Figura 6.35 - Deformação no tirante, modelo B45P50E25e0.

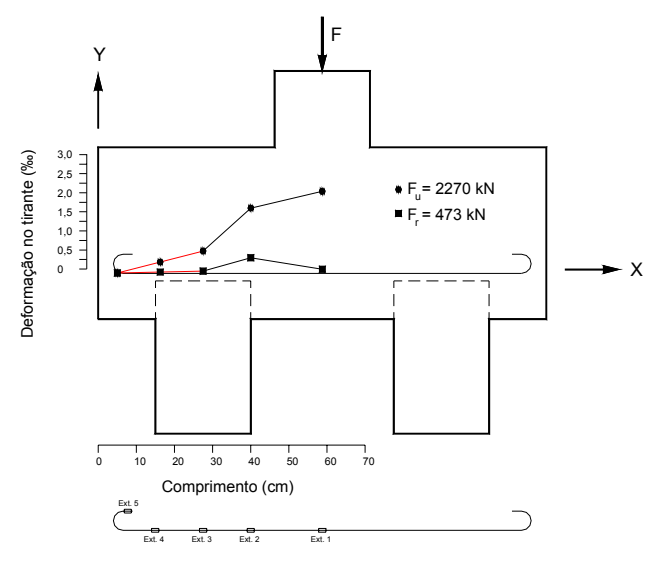

Figura 6.32 - Deformação no tirante, modelo B45P25E25e0CG.

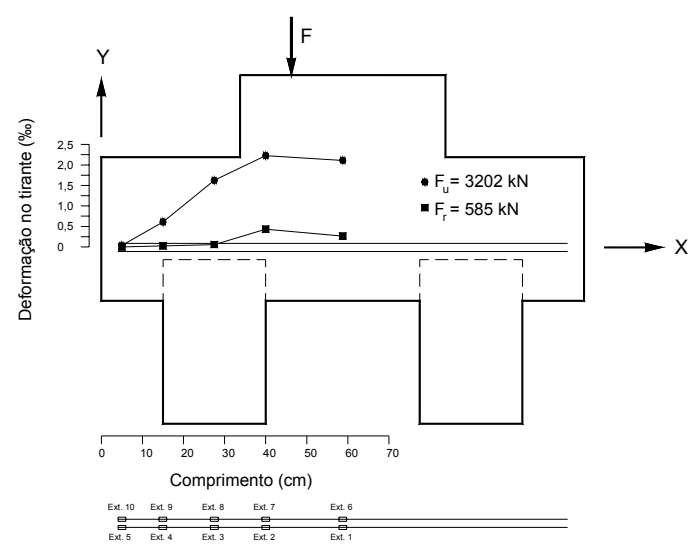

Figura 6.34 - Deformação no tirante, modelo B35P50E25e12,5.

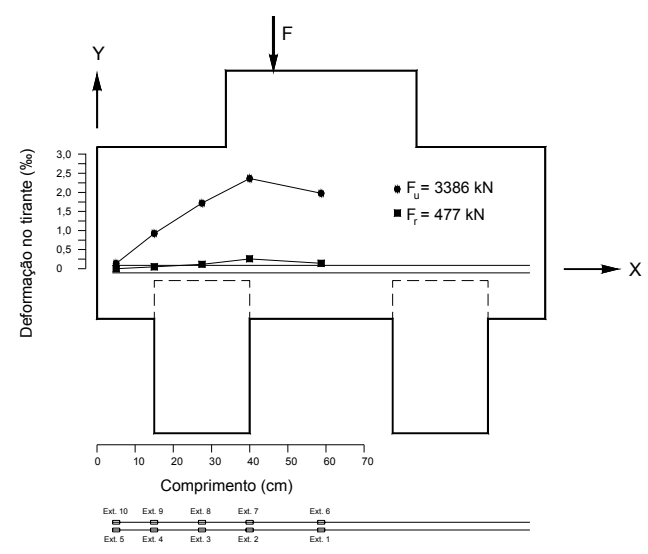

Figura 6.36 - Deformação no tirante, modelo B45P50E25e12,5. 
Considerando que a força no tirante na seção de meio de estaca é igual a $\mathrm{R}_{\mathrm{st}, \mathrm{exp}, \mathrm{ce}}=0,51 \cdot \mathrm{R}_{\mathrm{st}, \mathrm{exp}, \mathrm{mv}}$, determina-se a força teórica a ancorar na seção do bloco localizada no centro da estaca $\left(R_{\text {st,teo,anc,ce }}\right)$, ou seja:

$$
\mathrm{R}_{\text {st,teo,anc,ce }}=\frac{\mathrm{R}_{\text {st,exp,mv }}}{1,86} \cdot 0,51 \approx 0,30 \cdot \mathrm{R}_{\text {st,exp, mv }}
$$

A Tabela 6.8 apresenta os comprimentos de ancoragens necessários $\left(\ell_{b}\right)$, calculados com as duas hipóteses apresentadas e determinados por meio das recomendações da NBR 6118:2003, considerando zona de boa aderência, barras de aço com alta aderência (barras de aço nervuradas), $\mathrm{f}_{\mathrm{y}}=550 \mathrm{MPa}$ (valor experimental), $\gamma_{s}=1,15$, diâmetro das barras igual a vinte milímetros e área de aço efetiva igual às áreas de aço das barras utilizadas na construção dos modelos.

Tabela 6.8 - Comprimentos de ancoragens, hipóteses I e II.

\begin{tabular}{|c|c|c|c|c|c|c|c|c|c|c|c|c|}
\hline \multirow[t]{2}{*}{ Modelos } & \multirow{2}{*}{$\begin{array}{c}\mathbf{f}_{\mathrm{t}, \mathrm{m}} \\
(\mathrm{MPa})\end{array}$} & \multirow{2}{*}{$\begin{array}{l}\mathbf{R}_{\text {st,exp,mv }} \\
(\mathrm{kN})\end{array}$} & \multicolumn{5}{|c|}{$\begin{array}{c}\text { Seção: face mais afastada da borda } \\
\text { do bloco - hipótese I }\end{array}$} & \multicolumn{5}{|c|}{$\begin{array}{c}\text { Seção do centro da estaca } \\
\text { Hipótese II }\end{array}$} \\
\hline & & & $\begin{array}{l}\mathbf{R}_{\text {st,d,anc }} \\
(\mathrm{kN})\end{array}$ & $\begin{array}{l}A_{\text {st,calc }} \\
\left(\mathrm{cm}^{2}\right)\end{array}$ & $\begin{array}{l}A_{\text {st,ef }} \\
\left(\mathrm{cm}^{2}\right)\end{array}$ & $\begin{array}{l}\ell_{b, \text { nec }} \\
(\mathrm{cm})\end{array}$ & $\begin{array}{l}\ell_{b, \text { disp }} \\
(\mathrm{cm})\end{array}$ & $\begin{array}{l}\mathbf{R}_{\text {st,d,anc }} \\
(\mathrm{kN})\end{array}$ & $\begin{array}{l}\text { A st,calc }_{\text {s }} \\
\left(\mathrm{cm}^{2}\right)\end{array}$ & $\begin{array}{l}A_{\text {st,ef }} \\
\left(\mathrm{cm}^{2}\right)\end{array}$ & $\begin{array}{l}\ell_{b, \text { nec }} \\
(\mathrm{cm})\end{array}$ & $\begin{array}{l}\boldsymbol{e}_{\mathrm{b}, \text { disp }} \\
(\mathrm{cm})\end{array}$ \\
\hline B35P25E25e0 & 3,22 & 419 & 939 & 19,6 & 15,75 & 16,5 & 36 & 413 & 8,64 & 15,75 & 16,5 & 23,5 \\
\hline B35P25E25e2,5 & 3,22 & 477 & 1068 & 22,3 & 15,75 & 16,5 & 36 & 470 & 9,83 & 15,75 & 16,5 & 23,5 \\
\hline B35P25E25e0A $\mathrm{A}_{\mathrm{sw}, \mathrm{C}}$ & 2,92 & 411 & 920 & 19,2 & 15,75 & 18,2 & 36 & 405 & 8,46 & 15,75 & 18,2 & 23,5 \\
\hline B35P25E25e0A $\mathrm{sw}_{\mathrm{sw}, 0}$ & 2,92 & 363 & 814 & 17,0 & 15,75 & 18,2 & 36 & 358 & 7,49 & 15,75 & 18,2 & 23,5 \\
\hline B35P25E25e0CG & 2,21 & 275 & 771 & 16,1 & 12,60 & 24,0 & 36 & 339 & 7,09 & 12,60 & 24,0 & 23,5 \\
\hline $\mathrm{B} 45 \mathrm{P} 25 \mathrm{E} 25 \mathrm{e} 0$ & 2,86 & 417 & 934 & 19,5 & 15,75 & 18,6 & 36 & 411 & 8,59 & 15,75 & 18,6 & 23,5 \\
\hline B45P25E25e5 & 2,86 & 466 & 1044 & 21,8 & 15,75 & 18,6 & 36 & 459 & 9,61 & 15,75 & 18,6 & 23,5 \\
\hline B45P25E25e0A $\mathrm{A}_{\mathrm{sw}, \mathrm{C}}$ & 2,33 & 398 & 891 & 18,6 & 15,75 & 22,8 & 36 & 392 & 8,20 & 15,75 & 22,8 & 23,5 \\
\hline B45P25E25e0A $A_{s w, 0}$ & 2,33 & 406 & 910 & 19,0 & 15,75 & 22,8 & 36 & 400 & 8,37 & 15,75 & 22,8 & 23,5 \\
\hline B45P25E25e0CG & 2,21 & 368 & 1030 & 21,5 & 12,60 & 24,0 & 36 & 453 & 9,47 & 12,60 & 24,0 & 23,5 \\
\hline B35P50E25e0 & 2,36 & 516 & 963 & 20,1 & 18,90 & 22,5 & 36 & 424 & 8,86 & 18,90 & 22,5 & 23,5 \\
\hline B35P50E25e12,5 & 3,25 & 635 & 1015 & 21,2 & 22,05 & 16,4 & 36 & 447 & 9,34 & 22,05 & 16,4 & 23,5 \\
\hline B45P50E25e0 & 2,36 & 539 & 1207 & 25,2 & 15,75 & 22,5 & 36 & 531 & 11,10 & 15,75 & 22,5 & 23,5 \\
\hline B45P50E25e12,5 & 3,25 & 596 & 953 & 19,9 & 22,05 & 16,4 & 36 & 419 & 8,77 & 22,05 & 16,4 & 23,5 \\
\hline
\end{tabular}

Nota: As forças a ancorar foram majoradas pelo coeficiente $\gamma_{\mathrm{f}}=1,4$.

Com relação à área de aço necessária para ancorar a força de tração na zona nodal inferior, verifica-se por meio da Tabela 6.8 que a hipótese I, ou seja, considerar o início da ancoragem das barras na seção mais afastada da estaca com relação a borda do bloco é cerca de duas vezes maior que quando se considera a seção do bloco localizada no centro da estaca.

Em todos os modelos, considerando as duas hipóteses, os comprimentos de ancoragem necessários foram menores que os disponíveis mesmo considerando ancoragem reta, a menos dos modelos B35P25E25e0CG e B45P25E25e0G que 
apresentaram comprimento de ancoragem maior que o disponível quando se considerou a hipótese II, porém, com valores muito próximos.

Por meio de análise das Figuras 6.33 a 6.33 , observa-se que as deformações das barras da armadura principal de tração tiveram o mesmo comportamento das barras de aço dos modelos construídos com pilares de seção quadrado.

Como era esperado, nos modelos ensaiados com excentricidades da força de compressão, as deformações nas barras de aço da armadura principal de tração foram maiores do que as deformações das barras de aço dos modelos ensaiados com força centrada, função das diferentes reações nas estacas.

A Figura 6.37 apresenta uma representação gráfica das duas hipóteses apresentadas para a ancoragem das barras de aço da armadura principal de tração.

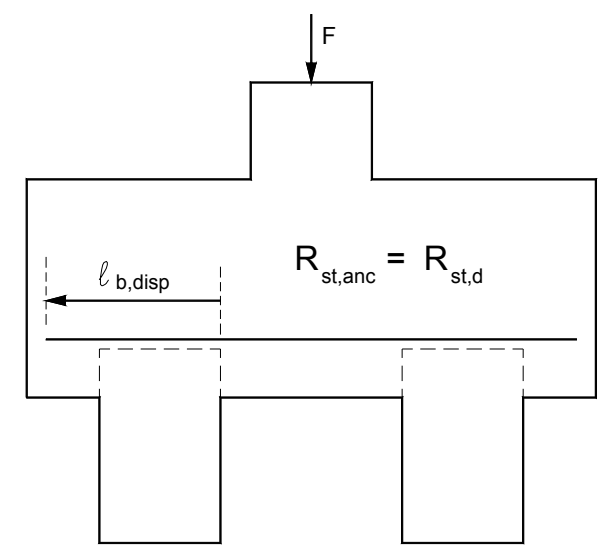

Hipótese I

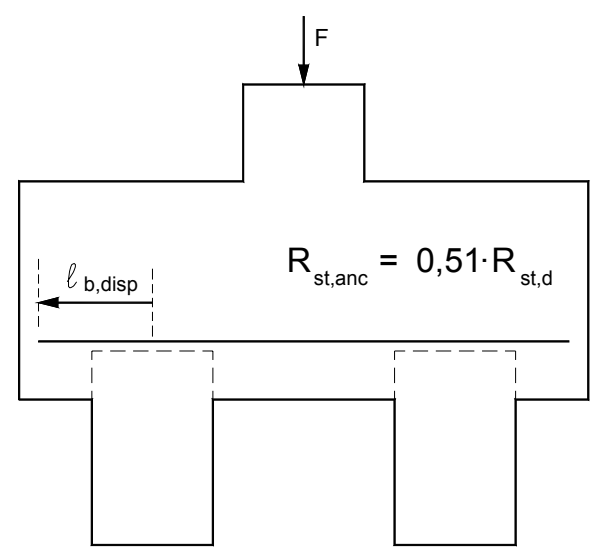

Hipótese II

Figura 6.37 - Comprimentos de ancoragens sugeridos para $\left(M_{d} / F_{d} \cdot h_{x}\right) \leq 0,15$.

\subsection{Aberturas das fissuras}

De acordo com o apresentado no item 5.3.3, as aberturas das fissuras foram acompanhadas por meio dos deslocamentos relativos entre as pastilhas de aço na direção longitudinal do bloco, ou seja, direção X.

Geralmente os blocos sobre estacas são reaterrados após sua construção, portanto ficam em contato direto com o solo. Em virtude disto, é conveniente que as fissuras tenham aberturas pequenas dificultando a penetração de água no interior da massa de concreto, retardando desta maneira o início da despassivação da armadura. 
Os cobrimentos adotados para as barras de aço de elementos de fundação, em geral, são maiores que quatro centímetros, correspondendo à classe de agressividade III, segundo classificação da NBR 6118:2003. Essa classe de agressividade sugere que a máxima abertura de uma fissura seja no máximo igual a $0,3 \mathrm{~mm}$, utilizando uma combinação freqüente. Nos ensaios esta combinação não se aplica, pois não existe separação das ações variáveis e permanentes.

A Tabela 6.9 apresenta os valores das aberturas das fissuras acompanhadas durante os ensaios e as compara com o valor limite estabelecido pela norma brasileira.

Tabela 6.9 - Verificação das aberturas das fissuras.

\begin{tabular}{|c|c|c|c|c|c|c|}
\hline Séries & Modelos & Ponto & $\begin{array}{c}\mathbf{F} / \mathbf{F}_{\mathrm{u}} \\
(\%)\end{array}$ & $\begin{array}{c}\text { Abertura } \\
\text { máxima } \\
(\mathrm{mm})\end{array}$ & $\begin{array}{l}\text { Ângulo de } \\
\text { inclinação } \\
\text { da fissura }\end{array}$ & $\begin{array}{c}\mathbf{W}_{\mathbf{k} \text {,máx }} \\
(\mathrm{mm})\end{array}$ \\
\hline \multirow{5}{*}{ B35P25 } & B35P25E25e0 & 14 & 67,28 & 0,32 & $57^{\circ}$ & 0,3 \\
\hline & B35P25E25e2,5 & 17 & 74,63 & 0,47 & $60^{\circ}$ & 0,3 \\
\hline & B35P25E25e0A $A_{s w, C}$ & 13 & 58,51 & 0,33 & $58^{\circ}$ & 0,3 \\
\hline & B35P25E25e0A $A_{s w, 0}$ & 7 & 72,54 & 0,30 & $55^{\circ}$ & 0,3 \\
\hline & B35P25E25e0CG & 13 & 75,22 & 0,41 & $36^{\circ}$ & 0,3 \\
\hline \multirow{5}{*}{ B45P25 } & B45P25E25e0 & 11 & 74,69 & 0,50 & $60^{\circ}$ & 0,3 \\
\hline & B45P25E25e5 & 13 & 76,06 & 0,38 & $60^{\circ}$ & 0,3 \\
\hline & B45P25E25e0A $A_{s w, C}$ & 11 & 65,47 & 0,41 & $50^{\circ}$ & 0,3 \\
\hline & B45P25E25e0A $A_{s w, 0}$ & 11 & 71,77 & 0,29 & $72^{\circ}$ & 0,3 \\
\hline & B45P25E25e0CG & 13 & 74,88 & 0,37 & $60^{\circ}$ & 0,3 \\
\hline \multirow{2}{*}{ B35P50 } & B35P50E25e0 & 12 & 72,22 & 0,37 & $65^{\circ}$ & 0,3 \\
\hline & B35P50E25e12,5 & 15 & 46,84 & 0,26 & $50^{\circ}$ & 0,3 \\
\hline \multirow{2}{*}{ B45P50 } & B45P50E25e0 & 12 & 74,25 & 0,46 & $60^{\circ}$ & 0,3 \\
\hline & B45P50E25e12,5 & 15 & 67,94 & 0,30 & $50^{\circ}$ & 0,3 \\
\hline \multicolumn{3}{|c|}{ Valores médios } & 69,45 & 0,37 & $57^{\circ}$ & - \\
\hline
\end{tabular}

Observa-se que para valores abaixo de 0,69. $F_{\mathrm{u}}$ as fissuras apresentam aberturas maiores que as permitidas pela norma. Em função disso, limitar a força última do em $0,65 . F_{u}$ seria uma alternativa para garantir que as aberturas de fissuras sejam menores que $0,3 \mathrm{~mm}$.

Como a abertura da fissura é função principalmente da resistência a tração do concreto, fez-se regressão não linear que possibilitou, de maneira aproximada, prever o valor da abertura da fissura em função da força aplicada e da resistência à tração do concreto para os blocos sobre duas estacas ensaiados.

Em função da grande variabilidade dos resultados, o coeficiente de correlação $\mathrm{R}^{2}$ da Expressão 6.7 foi de apenas $70 \%$. Esta equação apresenta valores de aberturas de fissuras (w) expressos em milímetros, a força é expressa em meganewtons e a resistência à tração do concreto em megapascals. 


$$
\mathrm{W}=-0,145+0,155 \cdot \mathrm{F}+0,00658 \cdot \mathrm{F}^{2}-0,073 \cdot \mathrm{F} \cdot \mathrm{f}_{\mathrm{ct}}+0,288 \cdot \mathrm{f}_{\mathrm{ct}}-0,288 \cdot \mathrm{f}_{\mathrm{ct}}^{2}
$$

A Figura 6.36 apresenta uma superfície que define os valores das aberturas de fissuras em função da força aplicada e da resistência à tração do concreto.

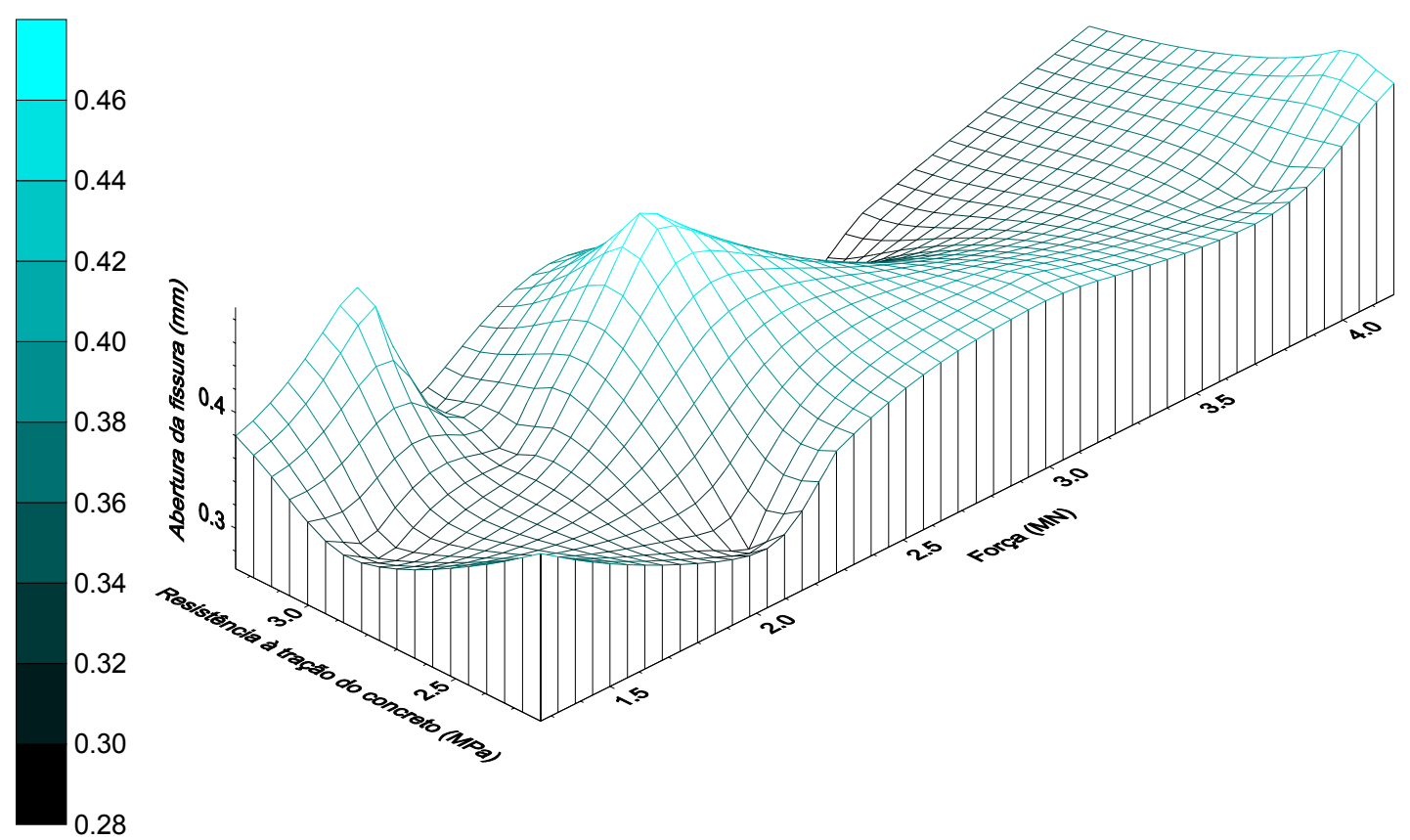

Figura 6.38 - Superfície dos blocos sobre estacas, $w\left(F, f_{c t}\right)$.

\subsection{Deformações e tensões nas zonas nodais inferior e superior}

Até o surgimento de uma fissura é possível calcular as tensões nas faces do bloco, numa determinada seção por meio de equações oriundas da teoria da elasticidade. Quando do aparecimento da fissura ou início de esmagamento, há ruptura do concreto por tração ou compressão, não sendo mais possível a utilização dos valores das deformações de tração ou compressão para o cálculo das tensões principais no concreto. Em função disso, foram calculadas tensões principais nas seções apenas onde não havia fissuras ou sinais de início de esmagamento do concreto. Estas tensões foram calculadas com os valores das últimas leituras de deslocamentos relativos entre as pastilhas de aço.

As tensões principais de tração e compressão $\left(\sigma_{1}\right.$ e $\left.\sigma_{2}\right)$ foram calculadas por meio da Expressão 6.8 . 


$$
\left.\begin{array}{l}
\sigma_{1} \\
\sigma_{2}
\end{array}=\frac{E_{\mathrm{ci}, \exp }}{3} \cdot\left\{\frac{\varepsilon_{0^{\circ}}+\varepsilon_{45^{\circ}}+\varepsilon_{90^{\circ}}}{1-v} \pm \frac{1}{1+v} \cdot \sqrt{2 \cdot\left[\left(\varepsilon_{0^{\circ}}-\varepsilon_{45^{\circ}}\right)^{2}+\left(\varepsilon_{45^{\circ}}-\varepsilon_{90^{\circ}}\right)^{2}+\left(\varepsilon_{0^{\circ}}-\varepsilon_{90^{\circ}}\right)^{2}\right.}\right]\right\}
$$

$\mathrm{Na}$ expressão 6.8, $\sigma_{1}$ e $\sigma_{2}$ representam as tensões principais de tração e compressão.

O coeficiente de Poisson $(v)$ foi considerado igual a 0,2 , segundo a recomendação da NBR 6118:2003 (quando a tensão for menor que 0,5f $f_{c}$ pode-se adotar coeficiente de Poisson igual a 0,2 ). Sabe-se, que para tensões no concreto maiores que $0,5 f_{c}$ ocorre aumento do coeficiente de Poisson, em função do aumento das intensidades das deformações no concreto na direção perpendicular à força aplicada, porém, como ainda não é a conhecida área de atuação dessa força de compressão, o valor da tensão não pôde ser calculada.

Como mencionado no Capítulo 5, as leituras dos deslocamentos relativos entre as pastilhas de aço foram realizadas até a iminência da ruptura por questões de segurança, portanto, as tensões apresentadas nas Tabelas 6.9 a 6.22 referem-se, em média, a $70 \%$ da força última suportada pelos modelos ensaiados.

As letras destacadas na cor vermelha significam que na seção onde foram realizadas às leituras dos deslocamentos relativos entre as pastilhas de aço, surgiu uma fissura. A Figura 6.39 explica melhor esse fenômeno e a Figura 6.40 apresenta as seções das zonas nodais onde foram calculadas as tensões no concreto.

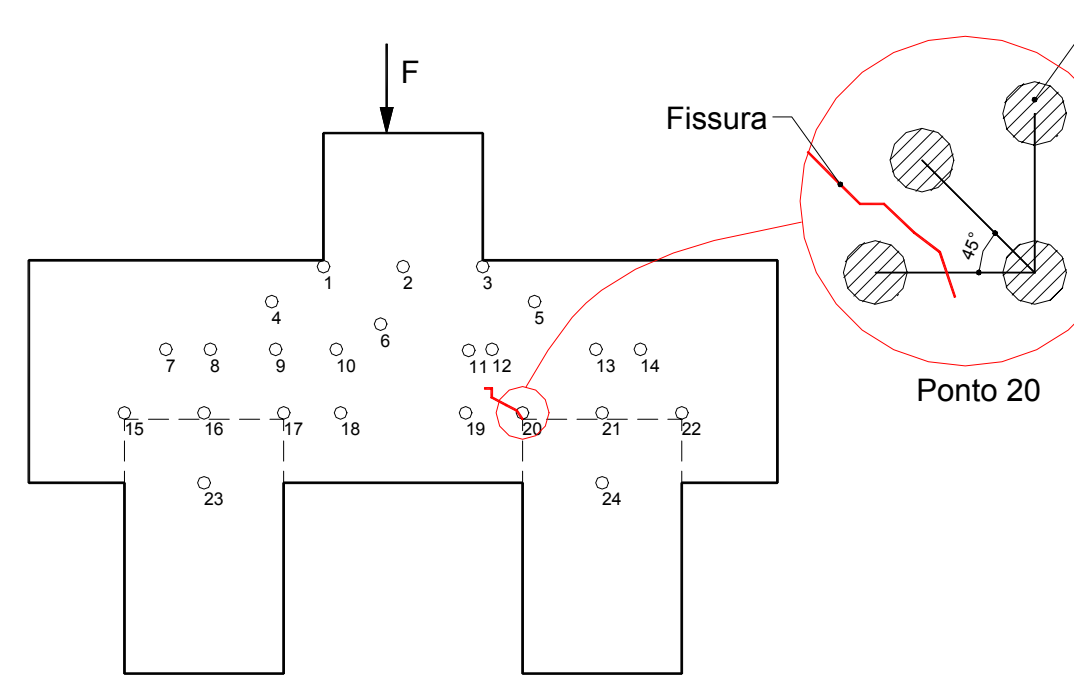

Pastilha de aço

Figura 6.39 - Fissura que atravessa um ponto de medida de deslocamento relativo entre as pastilhas de aço. 


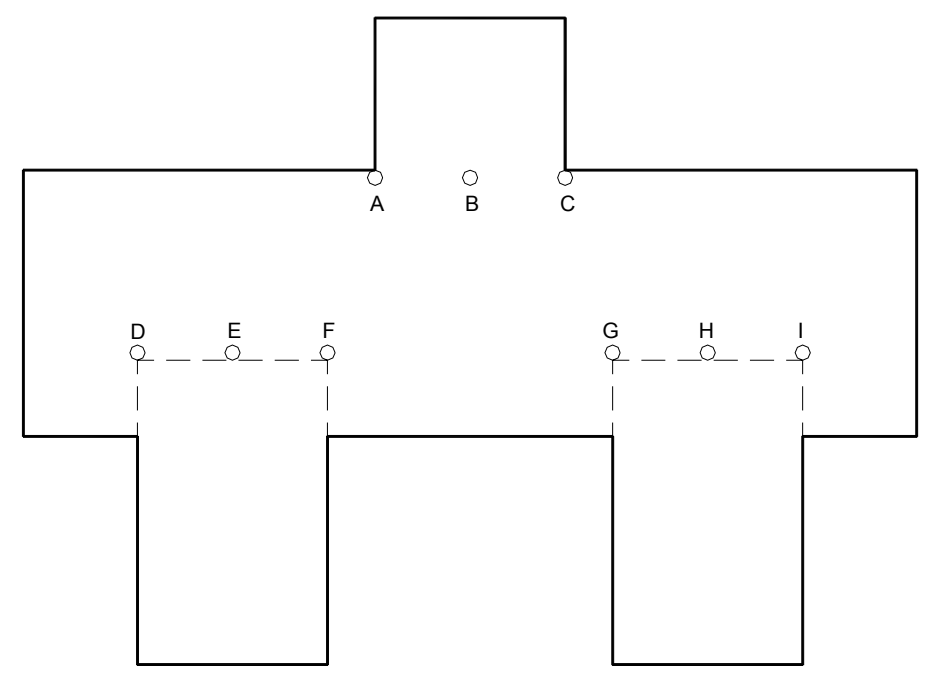

Figura 6.40 - Posição das seções nodais inferior e superior.

Tabela 6.9 - Deformações nas zonas, modelo B35P25E25e0, F = $1225 \mathrm{kN}$.

\begin{tabular}{|c|c|c|c|c|c|}
\hline \multicolumn{2}{|c|}{ Zona nodal superior } & \multicolumn{2}{|c|}{ Zona nodal inferior } & \multicolumn{2}{|c|}{ Zona nodal superior } \\
\hline \multirow{7}{*}{$\begin{array}{c}\text { Seção A } \\
\text { (ruptura por } \\
\text { compressão) }\end{array}$} & $\varepsilon_{0^{\circ}}=-0,3 \%$ & \multirow{7}{*}{ Seção D } & $\varepsilon_{0^{\circ}}=0,03 \%$ & \multirow{7}{*}{$\begin{array}{c}\text { Seção G } \\
\text { (ruptura por } \\
\text { tração) }\end{array}$} & $\varepsilon_{0^{\circ}}=6,34 \%$ \\
\hline & $\varepsilon_{90^{\circ}}=-0,94 \%$ & & $\varepsilon_{90^{\circ}}=-0,12 \%$ & & $\varepsilon 90^{\circ}=0,12 \%$ \\
\hline & $\varepsilon_{45^{\circ}}=-2,69 \%$ & & $\varepsilon_{45^{\circ}}=-0,11 \%$ & & $\varepsilon_{45^{\circ}}=0,78 \%$ \\
\hline & $\sigma_{1}=-$ & & $\sigma_{1}=0 \mathrm{MPa}$ & & $\sigma_{1}=-$ \\
\hline & $\sigma_{2}=-$ & & $\sigma_{2}=-21 \mathrm{MPa}$ & & $\sigma_{2}=-$ \\
\hline & $\alpha_{1}=-$ & & $\alpha_{1}=-21^{\circ}$ & & $\alpha_{1}=-$ \\
\hline & $\alpha_{2}=-$ & & $\alpha_{2}=69^{\circ}$ & & $\alpha_{2}=-$ \\
\hline \multirow{7}{*}{ Seção B } & $\varepsilon_{0^{\circ}}=-0,46 \%$ & \multirow{7}{*}{ Seção E } & $\varepsilon_{0^{\circ}}=0,29 \%$ & \multirow{7}{*}{$\begin{array}{c}\text { Seção H } \\
\text { (ruptura por } \\
\text { tração) }\end{array}$} & $\varepsilon_{0^{\circ}}=-0,02 \%$ \\
\hline & $\varepsilon 90^{\circ}=-0,15 \%$ & & $\varepsilon 90^{\circ}=-0,04 \%$ & & $\varepsilon 90^{\circ}=0,24 \%$ \\
\hline & $\varepsilon_{45^{\circ}}=-0,59 \%$ & & $\varepsilon 45^{\circ}=-0,34 \%$ & & $\varepsilon 45^{\circ}=1,96 \%$ \\
\hline & $\sigma_{1}=-9 \mathrm{MPa}$ & & $\sigma_{1}=8 \mathrm{MPa}$ & & $\sigma_{1}=-$ \\
\hline & $\sigma_{2}=-22 \mathrm{MPa}$ & & $\sigma_{2}=-10 \mathrm{MPa}$ & & $\sigma_{2}=-$ \\
\hline & $\alpha_{1}=31^{\circ}$ & & $\alpha_{1}=-35^{\circ}$ & & $\alpha_{1}=-$ \\
\hline & $\alpha_{2}=121^{\circ}$ & & $\alpha_{2}=55^{\circ}$ & & $\alpha_{2}=-$ \\
\hline \multirow{7}{*}{ Seção C } & $\varepsilon_{0^{\circ}}=-0,76 \%$ & \multirow{7}{*}{$\begin{array}{c}\text { Seção F } \\
\text { (ruptura por } \\
\text { tração) }\end{array}$} & $\varepsilon_{0^{\circ}}=5,32 \%$ & \multirow{7}{*}{ Seção I } & $\varepsilon_{0^{\circ}}=-0,2 \%$ \\
\hline & $\varepsilon_{90^{\circ}}=-0,68 \%$ & & $\varepsilon_{90^{\circ}}=0,04 \%$ & & $\varepsilon_{90^{\circ}}=0,2 \%$ \\
\hline & $\varepsilon_{45^{\circ}}=-0,14 \%$ & & $\varepsilon_{45^{\circ}}=0,4 \% 0$ & & $\varepsilon_{45^{\circ}}=-0,04 \% 0$ \\
\hline & $\sigma_{1}=-10 \mathrm{MPa}$ & & $\sigma_{1}=-$ & & $\sigma_{1}=6 \mathrm{Mpa}$ \\
\hline & $\sigma_{2}=-30 \mathrm{MPa}$ & & $\sigma_{2}=-$ & & $\sigma_{2}=-20 \mathrm{Mpa}$ \\
\hline & $\alpha_{1}=-43^{\circ}$ & & $\alpha_{1}=-$ & & $\alpha_{1}=6^{\circ}$ \\
\hline & $\alpha_{2}=47^{\circ}$ & & $\alpha_{2}=-$ & & $\alpha_{2}=96^{\circ}$ \\
\hline
\end{tabular}


Tabela 6.10 - Deformações nas zonas, modelo B35P25E25e2,5, F = 1260 kN.

\begin{tabular}{|c|c|c|c|c|c|}
\hline \multicolumn{2}{|c|}{ Zona nodal superior } & \multicolumn{2}{|c|}{ Zona nodal inferior } & \multicolumn{2}{|c|}{ Zona nodal superior } \\
\hline \multirow{7}{*}{$\begin{array}{c}\text { Seção A } \\
\text { (ruptura por } \\
\text { compressão) }\end{array}$} & $\varepsilon_{0^{\circ}}=2,54 \%$ & \multirow{7}{*}{ Seção D } & $\varepsilon_{0^{\circ}}=0,08 \%$ & \multirow{7}{*}{$\begin{array}{c}\text { Seção G } \\
\text { (ruptura por } \\
\text { tração) }\end{array}$} & $\varepsilon_{0^{\circ}}=2,06 \%$ \\
\hline & $\varepsilon_{90^{\circ}}=-0,82 \%$ & & $\varepsilon_{90^{\circ}}=-0,14 \%$ & & $\varepsilon_{90^{\circ}}=1,04 \%$ \\
\hline & $\varepsilon_{45^{\circ}}=-5,42 \%$ o & & $\varepsilon_{45^{\circ}}=-0,02 \%$ & & $\varepsilon_{45^{\circ}}=0,78 \%$ \\
\hline & $\sigma_{1}=-$ & & $\sigma_{1}=1 \mathrm{MPa}$ & & $\sigma_{1}=-$ \\
\hline & $\sigma_{2}=-$ & & $\sigma_{2}=-4 \mathrm{MPa}$ & & $\sigma_{2}=-$ \\
\hline & $\alpha_{1}=-$ & & $\alpha_{1}=17^{\circ}$ & & $\alpha_{1}=-$ \\
\hline & $\alpha_{2}=-$ & & $\alpha_{2}=107^{\circ}$ & & $\alpha_{2}=-$ \\
\hline \multirow{7}{*}{ Seção B } & $\varepsilon_{0^{\circ}}=-0,68 \%$ o & \multirow{7}{*}{ Seção E } & $\varepsilon_{0^{\circ}}=-0,06 \% 0$ & \multirow{7}{*}{ Seção H } & $\varepsilon_{0^{\circ}}=0,06 \%$ \\
\hline & $\varepsilon_{90^{\circ}}=-0,02 \%$ & & $\varepsilon_{90^{\circ}}=0,17 \%$ & & $\varepsilon_{90^{\circ}}=0,19 \%$ \\
\hline & $\varepsilon_{45^{\circ}}=-0,44 \%$ & & $\varepsilon_{45^{\circ}}=-0,5 \%$ & & $\varepsilon_{45^{\circ}}=-0,10 \%$ \\
\hline & $\sigma_{1}=-5 \mathrm{MPa}$ & & $\sigma_{1}=5 \mathrm{MPa}$ & & $\sigma_{1}=6 \mathrm{MPa}$ \\
\hline & $\sigma_{2}=-24 \mathrm{MPa}$ & & $\sigma_{2}=-14 \mathrm{MPa}$ & & $\sigma_{2}=-2 \mathrm{MPa}$ \\
\hline & $\alpha_{1}=8^{\circ}$ & & $\alpha_{1}=31^{\circ}$ & & $\alpha_{1}=37^{\circ}$ \\
\hline & $\alpha_{2}=98^{\circ}$ & & $\alpha_{2}=121^{\circ}$ & & $\alpha_{2}=127^{\circ}$ \\
\hline \multirow{7}{*}{ Seção C } & $\varepsilon_{0^{\circ}}=-0,43 \%$ o & \multirow{7}{*}{$\begin{array}{c}\text { Seção F } \\
\text { (ruptura por } \\
\text { tração) }\end{array}$} & $\varepsilon_{0^{\circ}}=9,4 \%$ & \multirow{7}{*}{ Seção I } & $\varepsilon_{0^{\circ}}=0,11 \%$ \\
\hline & $\varepsilon_{90^{\circ}}=-0,51 \%$ & & $\varepsilon_{90^{\circ}}=1,98 \%$ & & $\varepsilon_{90^{\circ}}=0,02 \%$ \\
\hline & $\varepsilon_{45^{\circ}}=-0,85 \%$ & & $\varepsilon_{45^{\circ}}=-2,48 \%$ & & $\varepsilon_{45^{\circ}}=-0,07 \%$ \\
\hline & $\sigma_{1}=-16 \mathrm{MPa}$ & & $\sigma_{1}=-$ & & $\sigma_{1}=4 \mathrm{MPa}$ \\
\hline & $\sigma_{2}=-29 \mathrm{MPa}$ & & $\sigma_{2}=-$ & & $\sigma_{2}=1 \mathrm{MPa}$ \\
\hline & $\alpha_{1}=-42^{\circ}$ & & $\alpha_{1}=-$ & & $\alpha_{1}=3^{\circ}$ \\
\hline & $\alpha_{2}=48^{\circ}$ & & $\alpha_{2}=-$ & & $\alpha_{2}=93^{\circ}$ \\
\hline
\end{tabular}

Tabela 6.11 - Deformações nas zonas, modelo B35P25E25e0A

\begin{tabular}{|c|c|c|c|c|c|}
\hline \multicolumn{2}{|c|}{ Zona nodal superior } & \multicolumn{2}{|c|}{ Zona nodal inferior } & \multicolumn{2}{|c|}{ Zona nodal superior } \\
\hline \multirow{7}{*}{$\begin{array}{c}\text { Seção A } \\
\text { (ruptura por } \\
\text { compressão) }\end{array}$} & $\varepsilon_{0^{\circ}}=-0,58 \%$ & \multirow{7}{*}{ Seção D } & $\varepsilon_{0^{\circ}}=0,05 \%$ & \multirow{7}{*}{$\begin{array}{c}\text { Seção G } \\
\text { (ruptura por } \\
\text { tração) }\end{array}$} & $\varepsilon_{0^{\circ}}=6,49 \%$ \\
\hline & $\varepsilon 90^{\circ}=-1,10 \%$ & & $\varepsilon_{90^{\circ}}=-0,5 \%$ & & $\varepsilon 90^{\circ}=0,36 \%$ \\
\hline & $\varepsilon_{45^{\circ}}=-1,54 \%$ & & $\varepsilon_{45^{\circ}}=-0,08 \%$ & & $\varepsilon_{45^{\circ}}=0,09 \%$ \\
\hline & $\sigma_{1}=-$ & & $\sigma_{1}=18 \mathrm{MPa}$ & & $\sigma_{1}=-$ \\
\hline & $\sigma_{2}=-$ & & $\sigma_{2}=-4 \mathrm{MPa}$ & & $\sigma_{2}=-$ \\
\hline & $\alpha_{1}=-$ & & $\alpha_{1}=29^{\circ}$ & & $\alpha_{1}=-$ \\
\hline & $\alpha_{2}=-$ & & $\alpha_{2}=119^{\circ}$ & & $\alpha_{2}=-$ \\
\hline \multirow{7}{*}{ Seção B } & $\varepsilon_{0^{\circ}}=-0,26 \%$ & \multirow{7}{*}{ Seção E } & $\varepsilon_{0^{\circ}}=0,87 \%$ & \multirow{7}{*}{ Seção H } & $\varepsilon_{0^{\circ}}=0,43 \%$ \\
\hline & $\varepsilon 90^{\circ}=-0,14 \%$ & & $\varepsilon 90^{\circ}=-0,12 \%$ & & $\varepsilon 90^{\circ}=-0,13 \%$ \\
\hline & $\varepsilon 45^{\circ}=-2,02 \%$ & & $\varepsilon_{45^{\circ}}=-2,13 \%$ & & $\varepsilon_{45^{\circ}}=-0,21 \%$ \\
\hline & $\sigma_{1}=0$ & & $\sigma_{1}=18 \mathrm{MPa}$ & & $\sigma_{1}=14 \mathrm{MPa}$ \\
\hline & $\sigma_{2}=-76 \mathrm{MPa}$ & & $\sigma_{2}=-33 \mathrm{MPa}$ & & $\sigma_{2}=-11 \mathrm{MPa}$ \\
\hline & $\alpha_{1}=44^{\circ}$ & & $\alpha_{1}=-39^{\circ}$ & & $\alpha_{1}=-26 \mathrm{MPa}$ \\
\hline & $\alpha_{2}=136^{\circ}$ & & $\alpha_{2}=51^{\circ}$ & & $\alpha_{2}=64 \mathrm{MPa}$ \\
\hline \multirow{7}{*}{$\begin{array}{c}\text { Seção C } \\
\text { (ruptura por } \\
\text { compressão) }\end{array}$} & $\varepsilon_{0^{\circ}}=0,66 \%$ & \multirow{7}{*}{$\begin{array}{c}\text { Seção F } \\
\text { (ruptura por } \\
\text { tração) }\end{array}$} & $\varepsilon_{0^{\circ}}=5,09 \%$ & \multirow{7}{*}{ Seção I } & $\varepsilon_{0^{\circ}}=0,08 \%$ \\
\hline & $\varepsilon 90^{\circ}=-0,54 \%$ & & $\varepsilon 90^{\circ}=-0,44 \% 0$ & & $\varepsilon 90^{\circ}=-0,61 \%$ \\
\hline & $\varepsilon_{45^{\circ}}=-1,44 \%$ & & $\varepsilon_{45^{\circ}}=-0,18 \%$ & & $\varepsilon_{45^{\circ}}=0,29 \%$ \\
\hline & $\sigma_{1}=-$ & & $\sigma_{1}=-$ & & $\sigma_{1}^{*}=25 \mathrm{MPa}$ \\
\hline & $\sigma_{2}=-$ & & $\sigma_{2}=-$ & & $\sigma_{2}=6 \mathrm{MPa}$ \\
\hline & $\alpha_{1}=$ & & $\alpha_{1}=-$ & & $\alpha_{1}=6^{\circ}$ \\
\hline & $\alpha_{2}=$ & & $\alpha_{2}=-$ & & $\alpha_{2}=96^{\circ}$ \\
\hline
\end{tabular}

Nota: * Resultado descartado (tensão principal de tração muito maior que a tensão de tração do concreto). 
Tabela 6.12 - Deformações nas zonas, modelo B35P25E25e0A sw,0, $_{\text {, }}=1020 \mathrm{kN}$.

\begin{tabular}{|c|c|c|c|c|c|}
\hline \multicolumn{2}{|c|}{ Zona nodal superior } & \multicolumn{2}{|c|}{ Zona nodal inferior } & \multicolumn{2}{|c|}{ Zona nodal superior } \\
\hline \multirow{7}{*}{$\begin{array}{c}\text { Seção A } \\
\text { (ruptura por } \\
\text { compressão) }\end{array}$} & $\varepsilon_{0^{\circ}}=2,45 \%$ & \multirow{7}{*}{ Seção D } & $\varepsilon_{0^{\circ}}=0,48 \%$ & \multirow{7}{*}{$\begin{array}{c}\text { Seção G } \\
\text { (ruptura por } \\
\text { tração) }\end{array}$} & $\varepsilon_{0^{\circ}}=4,08 \%$ \\
\hline & $\varepsilon_{90^{\circ}}=-0,81 \%$ & & $\varepsilon_{90^{\circ}}=-0,01 \%$ & & $\varepsilon_{90^{\circ}}=7,22 \%$ \\
\hline & $\varepsilon_{45^{\circ}}=-2,99 \%$ & & $\varepsilon_{45^{\circ}}=-0,56 \%$ & & $\varepsilon_{45^{\circ}}=-0,95 \%$ \\
\hline & $\sigma_{1}=-$ & & $\sigma_{1}=17 \mathrm{MPa}$ & & $\sigma_{1}=-$ \\
\hline & $\sigma_{2}=-$ & & $\sigma_{2}=-20 \mathrm{MPa}$ & & $\sigma_{2}=-$ \\
\hline & $\alpha_{1}=-$ & & $\alpha_{1}=-36^{\circ}$ & & $\alpha_{1}=-$ \\
\hline & $\alpha_{2}=-$ & & $\alpha_{2}=54^{\circ}$ & & $\alpha_{2}=-$ \\
\hline \multirow{7}{*}{ Seção B } & $\varepsilon_{0^{\circ}}=-0,47 \%$ & \multirow{7}{*}{ Seção E } & $\varepsilon_{0^{\circ}}=-0,9 \%$ & \multirow{7}{*}{ Seção H } & $\varepsilon_{0^{\circ}}=-0,33 \%$ \\
\hline & $\varepsilon_{90^{\circ}}=-0,35 \%$ & & $\varepsilon_{90^{\circ}}=-1,58 \%$ & & $\varepsilon_{90^{\circ}}=-0,69 \%$ \\
\hline & $\varepsilon_{45^{\circ}}=-1,59 \%$ & & $\varepsilon_{45^{\circ}}=-0,16 \%$ & & $\varepsilon_{45^{\circ}}=-0,17 \%$ \\
\hline & $\sigma_{1}=-13 \mathrm{MPa}$ & & $\sigma_{1}=-16 \mathrm{MPa}$ & & $\sigma_{1}=-9 \mathrm{MPa}$ \\
\hline & $\sigma_{2}=-63 \mathrm{MPa}$ & & $\sigma_{2}=-67 \mathrm{MPa}$ & & $\sigma_{2}=-28 \mathrm{MPa}$ \\
\hline & $\alpha_{1}=44^{\circ}$ & & $\alpha_{1}=36^{\circ}$ & & $\alpha_{1}=37^{\circ}$ \\
\hline & $\alpha_{2}=136^{\circ}$ & & $\alpha_{2}=54^{\circ}$ & & $\alpha_{2}=127^{\circ}$ \\
\hline \multirow{7}{*}{$\begin{array}{c}\text { Seção C } \\
\text { (ruptura por } \\
\text { compressão) }\end{array}$} & $\varepsilon_{0^{\circ}}=2,46 \%$ & \multirow{7}{*}{$\begin{array}{c}\text { Seção F } \\
\text { (ruptura por } \\
\text { tração) }\end{array}$} & $\varepsilon_{0^{\circ}}=4,55 \%$ & \multirow{7}{*}{ Seção I } & $\varepsilon_{0^{\circ}}=1,04 \%$ \\
\hline & $\varepsilon_{90^{\circ}}=-0,66 \%$ & & $\varepsilon_{90^{\circ}}=0,2 \%$ & & $\varepsilon_{90^{\circ}}=-0,2 \% 0$ \\
\hline & $\varepsilon_{45^{\circ}}=-0,33 \%$ & & $\varepsilon_{45^{\circ}}=-2,03 \%$ & & $\varepsilon_{45^{\circ}}=-0,2 \%$ o \\
\hline & $\sigma_{1}=-$ & & $\sigma_{1}=-$ & & $\sigma_{1}=36 \mathrm{MPa}$ \\
\hline & $\sigma_{2}=-$ & & $\sigma_{2}=-$ & & $\sigma_{2}=-16 \mathrm{MPa}$ \\
\hline & $\alpha_{1}=-$ & & $\alpha_{1}=-$ & & $\alpha_{1}=-22^{\circ}$ \\
\hline & $\alpha_{2}=-$ & & $\alpha_{2}=-$ & & $\alpha_{2}=68^{\circ}$ \\
\hline
\end{tabular}

Tabela 6.13 - Deformações nas zonas, modelo B35P25E25e0CG, F = $950 \mathrm{kN}$.

\begin{tabular}{|c|c|c|c|c|c|}
\hline \multicolumn{2}{|c|}{ Zona nodal superior } & \multicolumn{2}{|c|}{ Zona nodal inferior } & \multicolumn{2}{|c|}{ Zona nodal superior } \\
\hline \multirow{7}{*}{ Seção A } & $\varepsilon_{0^{\circ}}=-0,32 \%$ & \multirow{7}{*}{ Seção D } & $\varepsilon_{0^{\circ}}=0,03 \%$ & \multirow{7}{*}{$\begin{array}{c}\text { Seção } \\
\text { G(ruptura por } \\
\text { tração) }\end{array}$} & $\varepsilon_{0^{\circ}}=8,1 \%$ \\
\hline & $\varepsilon_{90^{\circ}}=-0,72 \%$ & & $\varepsilon 90^{\circ}=0,06 \%$ & & $\varepsilon 90^{\circ}=3,75 \%$ \\
\hline & $\varepsilon_{45^{\circ}}=-0,99 \%$ & & $\varepsilon_{45^{\circ}}=0,01 \%$ & & $\varepsilon_{45^{\circ}}=-0,37 \%$ \\
\hline & $\sigma_{1}=-13 \mathrm{MPa}$ & & $\sigma_{1}=2 \mathrm{MPa}$ & & $\sigma_{1}=-$ \\
\hline & $\sigma_{2}=-30 \mathrm{MPa}$ & & $\sigma_{2}=0 \mathrm{MPa}$ & & $\sigma_{2}=-$ \\
\hline & $\alpha_{1}=-33^{\circ}$ & & $\alpha_{1}=33^{\circ}$ & & $\alpha_{1}=-$ \\
\hline & $\alpha_{2}=57^{\circ}$ & & $\alpha_{2}=123^{\circ}$ & & $\alpha_{2}=-$ \\
\hline \multirow{7}{*}{ Seção B } & $\varepsilon_{0^{\circ}}=-0,26 \%$ o & \multirow{7}{*}{ Seção E } & $\varepsilon_{0^{\circ}}=-0,14 \%$ & \multirow{7}{*}{ Seção H } & $\varepsilon_{0^{\circ}}=-0,28 \%$ \\
\hline & $\varepsilon 90^{\circ}=-0,24 \%$ & & $\varepsilon_{90^{\circ}}=-0,02 \%$ & & $\varepsilon_{90^{\circ}}=-0,06 \%$ \\
\hline & $\varepsilon_{45^{\circ}}=-0,12 \%$ & & $\varepsilon_{45^{\circ}}=-0,12 \%$ & & $\varepsilon_{45^{\circ}}=-0,41 \%$ \\
\hline & $\sigma_{1}=-5 \mathrm{MPa}$ & & $\sigma_{1}=-1 \mathrm{MPa}$ & & $\sigma_{1}=-4 \mathrm{MPa}$ \\
\hline & $\sigma_{2}=-8 \mathrm{MPa}$ & & $\sigma_{2}=-5 \mathrm{MPa}$ & & $\sigma_{2}=-12 \mathrm{MPa}$ \\
\hline & $\alpha_{1}=-43^{\circ}$ & & $\alpha_{1}=17^{\circ}$ & & $\alpha_{1}=33^{\circ}$ \\
\hline & $\alpha_{2}=47^{\circ}$ & & $\alpha_{2}=107^{\circ}$ & & $\alpha_{2}=123^{\circ}$ \\
\hline \multirow{7}{*}{$\begin{array}{c}\text { Seção C } \\
\text { (ruptura por } \\
\text { compressão) }\end{array}$} & $\varepsilon_{0^{\circ}}=3,18 \%$ & \multirow{7}{*}{$\begin{array}{c}\text { Seção F } \\
\text { (ruptura por } \\
\text { tração) }\end{array}$} & $\varepsilon_{0^{\circ}}=6,67 \%$ & \multirow{7}{*}{ Seção I } & $\varepsilon_{0^{\circ}}=0,03 \%$ \\
\hline & $\varepsilon 90^{\circ}=1,89 \%$ & & $\varepsilon_{90^{\circ}}=-0,12 \%$ & & $\varepsilon 90^{\circ}=-0,04 \%$ \\
\hline & $\varepsilon_{45^{\circ}}=-0,66 \%$ & & $\varepsilon_{45^{\circ}}=-0,13 \%$ & & $\varepsilon 45^{\circ}=-0,09 \%$ \\
\hline & $\sigma_{1}=-$ & & $\sigma_{1}=-$ & & $\sigma_{1}=0 \mathrm{MPa}$ \\
\hline & $\sigma_{2}=-$ & & $\sigma_{2}=-$ & & $\sigma_{2}=-3 \mathrm{MPa}$ \\
\hline & $\alpha_{1}=-$ & & $\alpha_{1}=-$ & & $\alpha_{1}=-35^{\circ}$ \\
\hline & $\alpha_{2}=-$ & & $\alpha_{2}=-$ & & $\alpha_{2}=125^{\circ}$ \\
\hline
\end{tabular}


Tabela 6.14 - Deformações nas zonas, modelo B45P25E25e0, F = $1700 \mathrm{kN}$.

\begin{tabular}{|c|c|c|c|c|c|}
\hline \multicolumn{2}{|c|}{ Zona nodal superior } & \multicolumn{2}{|c|}{ Zona nodal inferior } & \multicolumn{2}{|c|}{ Zona nodal superior } \\
\hline \multirow{7}{*}{$\begin{array}{c}\text { Seção A } \\
\text { (ruptura por } \\
\text { compressão) }\end{array}$} & $\varepsilon_{0^{\circ}}=-2,92 \%$ & \multirow{7}{*}{ Seção D } & $\varepsilon_{0^{\circ}}=-0,02 \%$ & \multirow{7}{*}{$\begin{array}{c}\text { Seção G } \\
\text { (ruptura por } \\
\text { tração) }\end{array}$} & $\varepsilon_{0^{\circ}}=4,42 \%$ \\
\hline & $\varepsilon_{90^{\circ}}=0,62 \%$ & & $\varepsilon_{90^{\circ}}=-0,19 \%$ & & $\varepsilon_{90^{\circ}}=-0,32 \% 0$ \\
\hline & $\varepsilon_{45^{\circ}}=-2,81 \%$ & & $\varepsilon_{45^{\circ}}=-0,24 \%$ & & $\varepsilon_{45^{\circ}}=1,02 \%$ \\
\hline & $\sigma_{1}=-$ & & $\sigma_{1}=-2 \mathrm{MPa}$ & & $\sigma_{1}=-$ \\
\hline & $\sigma_{2}=-$ & & $\sigma_{2}=-8 \mathrm{MPa}$ & & $\sigma_{2}=-$ \\
\hline & $\alpha_{1}=-$ & & $\alpha_{1}=-29^{\circ}$ & & $\alpha_{1}=-$ \\
\hline & $\alpha_{2}=-$ & & $\alpha_{2}=61^{\circ}$ & & $\alpha_{2}=-$ \\
\hline \multirow{7}{*}{ Seção B } & $\varepsilon_{0^{\circ}}=-0,42 \%$ & \multirow{7}{*}{ Seção E } & $\varepsilon_{0^{\circ}}=0,08 \%$ & \multirow{7}{*}{ Seção H } & $\varepsilon_{0^{\circ}}=-0,17 \%$ \\
\hline & $\varepsilon_{90^{\circ}}=-0,23 \%$ & & $\varepsilon_{90^{\circ}}=0,01 \%$ & & $\varepsilon_{90^{\circ}}=0,04 \%$ \\
\hline & $\varepsilon_{45^{\circ}}=-0,51 \%$ & & $\varepsilon_{45^{\circ}}=0,56 \%$ o & & $\varepsilon_{45^{\circ}}=0$ \\
\hline & $\sigma_{1}=-9 \mathrm{MPa}$ & & $\sigma_{1}=4 \mathrm{MPa}$ & & $\sigma_{1}=1 \mathrm{MPa}$ \\
\hline & $\sigma_{2}=-17 \mathrm{MPa}$ & & $\sigma_{2}=-15 \mathrm{MPa}$ & & $\sigma_{2}=-4 \mathrm{MPa}$ \\
\hline & $\alpha_{1}=31^{\circ}$ & & $\alpha_{1}=-43^{\circ}$ & & $\alpha_{1}=-16^{\circ}$ \\
\hline & $\alpha_{2}=121^{\circ}$ & & $\alpha_{2}=47^{\circ}$ & & $\alpha_{2}=74^{\circ}$ \\
\hline \multirow{7}{*}{ Seção C } & $\varepsilon_{0^{\circ}}=-0,32 \% 0$ & \multirow{7}{*}{$\begin{array}{c}\text { Seção F } \\
\text { (ruptura por } \\
\text { tração) }\end{array}$} & $\varepsilon_{0^{\circ}}=9,97 \%$ & \multirow{7}{*}{ Seção I } & $\varepsilon_{0^{\circ}}=0,12 \% 0$ \\
\hline & $\varepsilon_{90^{\circ}}=-0,3 \%$ & & $\varepsilon_{90^{\circ}}=-0,31 \%$ & & $\varepsilon_{90^{\circ}}=-0,03 \%$ \\
\hline & $\varepsilon_{45^{\circ}}=-1,09 \%$ & & $\varepsilon_{45^{\circ}}=-0,9 \%$ & & $\varepsilon_{45^{\circ}}=0,01 \%$ \\
\hline & $\sigma_{1}=-7 \mathrm{MPa}$ & & $\sigma_{1}=-$ & & $\sigma_{1}=3 \mathrm{MPa}$ \\
\hline & $\sigma_{2}=-32 \mathrm{MPa}$ & & $\sigma_{2}=-$ & & $\sigma_{2}=-1 \mathrm{MPa}$ \\
\hline & $\alpha_{1}=45^{\circ}$ & & $\alpha_{1}=-$ & & $\alpha_{1}=-13^{\circ}$ \\
\hline & $\alpha_{2}=135^{\circ}$ & & $\alpha_{2}=-$ & & $\alpha_{2}=77^{\circ}$ \\
\hline
\end{tabular}

Tabela 6.15 - Deformações nas zonas, modelo B45P25E25e5, F = 1500 kN.

\begin{tabular}{|c|c|c|c|c|c|}
\hline \multicolumn{2}{|c|}{ Zona nodal superior } & \multicolumn{2}{|c|}{ Zona nodal inferior } & \multicolumn{2}{|c|}{ Zona nodal superior } \\
\hline \multirow{7}{*}{$\begin{array}{c}\text { Seção A } \\
\text { (ruptura por } \\
\text { compressão) }\end{array}$} & $\varepsilon_{0^{\circ}}=1,46 \%$ & \multirow{7}{*}{ Seção D } & $\varepsilon_{0^{\circ}}=-0,13 \%$ & \multirow{7}{*}{$\begin{array}{c}\text { Seção G } \\
\text { (ruptura por } \\
\text { tração) }\end{array}$} & $\varepsilon_{0^{\circ}}=6,54 \%$ \\
\hline & $\varepsilon 90^{\circ}=-2,23 \%$ & & $\varepsilon 90^{\circ}=-0,05 \%$ & & $\varepsilon 90^{\circ}=-0,07 \%$ \\
\hline & $\varepsilon_{45^{\circ}}=-4,27 \% 0$ & & $\varepsilon_{45^{\circ}}=-0,18 \%$ & & $\varepsilon_{45^{\circ}}=-0,43 \%$ \\
\hline & $\sigma_{1}=-$ & & $\sigma_{1}=-2 \mathrm{MPa}$ & & $\sigma_{1}=-$ \\
\hline & $\sigma_{2}=-$ & & $\sigma_{2}=-6 \mathrm{MPa}$ & & $\sigma_{2}=-$ \\
\hline & $\alpha_{1}=-$ & & $\alpha_{1}=28^{\circ}$ & & $\alpha_{1}=-$ \\
\hline & $\alpha_{2}=-$ & & $\alpha_{2}=118^{\circ}$ & & $\alpha_{2}=-$ \\
\hline \multirow{7}{*}{ Seção B } & $\varepsilon_{0^{\circ}}=-0,87 \%$ & \multirow{7}{*}{$\begin{array}{c}\text { Seção E } \\
\text { (ruptura por } \\
\text { tração) }\end{array}$} & $\varepsilon_{0^{\circ}}=0,37 \%$ & \multirow{7}{*}{ Seção H } & $\varepsilon_{0^{\circ}}=-0,09 \%$ \\
\hline & $\varepsilon 90^{\circ}=-0,76 \%$ & & $\varepsilon 90^{\circ}=2,08 \%$ & & $\varepsilon 90^{\circ}=-0,15 \%$ \\
\hline & $\varepsilon_{45^{\circ}}=-0,11 \% 0$ & & $\varepsilon 45^{\circ}=-0,11 \% 0$ & & $\varepsilon_{45^{\circ}}=-0,21 \%$ \\
\hline & $\sigma_{1}=-9 \mathrm{MPa}$ & & $\sigma_{1}=-$ & & $\sigma_{1}=-4 \mathrm{MPa}$ \\
\hline & $\sigma_{2}=-31 \mathrm{MPa}$ & & $\sigma_{2}=-$ & & $\sigma_{2}=-7 \mathrm{MPa}$ \\
\hline & $\alpha_{1}=-43^{\circ}$ & & $\alpha_{1}=-$ & & $\alpha_{1}=-36^{\circ}$ \\
\hline & $\alpha_{2}=47^{\circ}$ & & $\alpha_{2}=-$ & & $\alpha_{2}=54^{\circ}$ \\
\hline \multirow{7}{*}{ Seção C } & $\varepsilon_{0^{\circ}}=-0,35 \%$ & \multirow{7}{*}{$\begin{array}{c}\text { Seção F } \\
\text { (ruptura por } \\
\text { tração) }\end{array}$} & $\varepsilon_{0^{\circ}}=7,68 \%$ & \multirow{7}{*}{ Seção I } & $\varepsilon_{0^{\circ}}=0,01 \%$ \\
\hline & $\varepsilon_{90^{\circ}}=-0,44 \% 0$ & & $\varepsilon_{90^{\circ}}=1,01 \%$ & & $\varepsilon_{90^{\circ}}=0,01 \%$ \\
\hline & $\varepsilon_{45^{\circ}}=-0,5 \%$ o & & $\varepsilon_{45^{\circ}}=-2,28 \%$ & & $\varepsilon_{45^{\circ}}=0,03 \%$ \\
\hline & $\sigma_{1}=-12 \mathrm{MPa}$ & & $\sigma_{1}=-$ & & $\sigma_{1}=0,5 \mathrm{MPa}$ \\
\hline & $\sigma_{2}=-19 \mathrm{MPa}$ & & $\sigma_{2}=-$ & & $\sigma_{2}=-0,5 \mathrm{MPa}$ \\
\hline & $\alpha_{1}=-39^{\circ}$ & & $\alpha_{1}=-$ & & $\alpha_{1}=-22^{\circ}$ \\
\hline & $\alpha_{2}=51^{\circ}$ & & $\alpha_{2}=-$ & & $\alpha_{2}=68^{\circ}$ \\
\hline
\end{tabular}


Tabela 6.16 - Deformações nas zonas, modelo B45P25E25e0A sw,c $_{\text {, }} F=1500 \mathrm{kN}$.

\begin{tabular}{|c|c|c|c|c|c|}
\hline \multicolumn{2}{|c|}{ Zona nodal superior } & \multicolumn{2}{|c|}{ Zona nodal inferior } & \multicolumn{2}{|c|}{ Zona nodal superior } \\
\hline \multirow{7}{*}{$\begin{array}{c}\text { Seção A } \\
\text { (ruptura por } \\
\text { compressão) }\end{array}$} & $\varepsilon_{0^{\circ}}=1,93 \%$ & \multirow{7}{*}{ Seção D } & $\varepsilon_{0^{\circ}}=0,27 \%$ & \multirow{7}{*}{$\begin{array}{c}\text { Seção G } \\
\text { (ruptura por } \\
\text { tração) }\end{array}$} & $\varepsilon_{0^{\circ}}=5,82 \%$ \\
\hline & $\varepsilon_{90^{\circ}}=-1,46 \%$ & & $\varepsilon_{90^{\circ}}=-0,05 \%$ & & $\varepsilon_{90^{\circ}}=-0,12 \%$ \\
\hline & $\varepsilon_{45^{\circ}}=-1,81 \%$ & & $\varepsilon_{45^{\circ}}=-0,07 \%$ & & $\varepsilon_{45^{\circ}}=-1,43 \%$ \\
\hline & $\sigma_{1}=-$ & & $\sigma_{1}=7 \mathrm{MPa}$ & & $\sigma_{1}=-$ \\
\hline & $\sigma_{2}=-$ & & $\sigma_{2}=-3 \mathrm{MPa}$ & & $\sigma_{2}=-$ \\
\hline & $\alpha_{1}=-$ & & $\alpha_{1}=-24^{\circ}$ & & $\alpha_{1}=-$ \\
\hline & $\alpha_{2}=-$ & & $\alpha_{2}=66^{\circ}$ & & $\alpha_{2}=-$ \\
\hline \multirow{7}{*}{ Seção B } & $\varepsilon_{0^{\circ}}=-0,08 \%$ & \multirow{7}{*}{ Seção E } & $\varepsilon_{0^{\circ}}=-0,13 \%$ & \multirow{7}{*}{ Seção H } & $\varepsilon_{0^{\circ}}=-0,18 \%$ o \\
\hline & $\varepsilon_{90^{\circ}}=-0,56 \%$ & & $\varepsilon_{90^{\circ}}=-0,28 \%$ & & $\varepsilon_{90^{\circ}}=-0,04 \%$ \\
\hline & $\varepsilon_{45^{\circ}}=-1,29 \%$ & & $\varepsilon_{45^{\circ}}=-0,20 \%$ & & $\varepsilon_{45^{\circ}}=-1,84 \%$ \\
\hline & $\sigma_{1}=-6 \mathrm{MPa}$ & & $\sigma_{1}=-5 \mathrm{MPa}$ & & $\sigma_{1}=5 \mathrm{MPa}$ \\
\hline & $\sigma_{2}=-38 \mathrm{MPa}$ & & $\sigma_{2}=-9 \mathrm{MPa}$ & & $\sigma_{2}=-50 \mathrm{MPa}$ \\
\hline & $\alpha_{1}=-38^{\circ}$ & & $\alpha_{1}=2$ & & $\alpha_{1}=43^{\circ}$ \\
\hline & $\alpha_{2}=52^{\circ}$ & & $\alpha_{2}=92$ & & $\alpha_{2}=133^{\circ}$ \\
\hline \multirow{7}{*}{ Seção C } & $\varepsilon_{0^{\circ}}=-0,69 \%$ & \multirow{7}{*}{$\begin{array}{l}\text { Seção F } \\
\text { (ruptura por } \\
\text { tração) }\end{array}$} & $\varepsilon_{0^{\circ}}=8,14 \%$ & \multirow{7}{*}{ Seção I } & $\varepsilon_{0^{\circ}}=0,03 \%$ \\
\hline & $\varepsilon_{90^{\circ}}=-0,70 \%$ & & $\varepsilon_{90^{\circ}}=-1,15 \%$ & & $\varepsilon_{90^{\circ}}=-0,05 \%$ \\
\hline & $\varepsilon_{45^{\circ}}=-1,61 \%$ & & $\varepsilon_{45^{\circ}}=1,61 \%$ & & $\varepsilon_{45^{\circ}}=-0,02 \%$ \\
\hline & $\sigma_{1}=-20 \mathrm{MPa}$ & & $\sigma_{1}=-$ & & $\sigma_{1}=1 \mathrm{MPa}$ \\
\hline & $\sigma_{2}=-48 \mathrm{MPa}$ & & $\sigma_{2}=-$ & & $\sigma_{2}=-2 \mathrm{MPa}$ \\
\hline & $\alpha_{1}=-45^{\circ}$ & & $\alpha_{1}=-$ & & $\alpha_{1}=-7^{\circ}$ \\
\hline & $\alpha_{2}=45^{\circ}$ & & $\alpha_{2}=-$ & & $\alpha_{2}=83^{\circ}$ \\
\hline
\end{tabular}

Tabela 6.17 - Deformações nas zonas, modelo B45P25E25e0A sw, $0, F=1500 \mathrm{kN}$.

\begin{tabular}{|c|c|c|c|c|c|}
\hline \multicolumn{2}{|c|}{ Zona nodal superior } & \multicolumn{2}{|c|}{ Zona nodal inferior } & \multicolumn{2}{|c|}{ Zona nodal superior } \\
\hline \multirow{7}{*}{ Seção A } & $\varepsilon_{0^{\circ}}=-0,54 \%$ & \multirow{7}{*}{ Seção D } & $\varepsilon_{0^{\circ}}=0,04 \%$ & \multirow{7}{*}{$\begin{array}{c}\text { Seção G } \\
\text { (ruptura por } \\
\text { tração) }\end{array}$} & $\varepsilon_{0^{\circ}}=3,70 \%$ \\
\hline & $\varepsilon 90^{\circ}=-1,52 \%$ & & $\varepsilon 90^{\circ}=-0,02 \%$ & & $\varepsilon 90^{\circ}=0,04 \% 0$ \\
\hline & $\varepsilon_{45^{\circ}}=0,28 \%$ & & $\varepsilon_{45^{\circ}}=0$ & & $\varepsilon_{45^{\circ}}=-0,48 \%$ \\
\hline & $\sigma_{1}=3 \mathrm{MPa}$ & & $\sigma_{1}=1 \mathrm{MPa}$ & & $\sigma_{1}=-$ \\
\hline & $\sigma_{2}=-44 \mathrm{MPa}$ & & $\sigma_{2}=-1 \mathrm{MPa}$ & & $\sigma_{2}=-$ \\
\hline & $\alpha_{1}=35^{\circ}$ & & $\alpha_{1}=-9^{\circ}$ & & $\alpha_{1}=-$ \\
\hline & $\alpha_{2}=125^{\circ}$ & & $\alpha_{2}=81^{\circ}$ & & $\alpha_{2}=-$ \\
\hline \multirow{7}{*}{ Seção B } & $\varepsilon_{0^{\circ}}=-0,39 \%$ & \multirow{7}{*}{ Seção E } & $\varepsilon_{0^{\circ}}=-0,09 \%$ & \multirow{7}{*}{ Seção H } & $\varepsilon_{0^{\circ}}=-0,16 \%$ \\
\hline & $\varepsilon_{90^{\circ}}=-0,22 \%$ & & $\varepsilon_{90^{\circ}}=-0,07 \%$ & & $\varepsilon 90^{\circ}=0,03 \%$ \\
\hline & $\varepsilon_{45^{\circ}}=-0,19 \%$ & & $\varepsilon_{45^{\circ}}=-0,2 \%$ & & $\varepsilon_{45^{\circ}}=0$ \\
\hline & $\sigma_{1}=-6 \mathrm{MPa}$ & & $\sigma_{1}=-2 \mathrm{MPa}$ & & $\sigma_{1}=1 \mathrm{MPa}$ \\
\hline & $\sigma_{2}=-12 \mathrm{MPa}$ & & $\sigma_{2}=-6 \mathrm{MPa}$ & & $\sigma_{2}=-4 \mathrm{MPa}$ \\
\hline & $\alpha_{1}=-27^{\circ}$ & & $\alpha_{1}=43$ & & $\alpha_{1}=-17^{\circ}$ \\
\hline & $\alpha_{2}=63^{\circ}$ & & $\alpha_{2}=133$ & & $\alpha_{2}=73^{\circ}$ \\
\hline \multirow{7}{*}{ Seção C } & $\varepsilon_{0^{\circ}}=-0,17 \%$ & \multirow{7}{*}{$\begin{array}{c}\text { Seção F } \\
\text { (ruptura por } \\
\text { tração) }\end{array}$} & $\varepsilon_{0^{\circ}}=5,83 \%$ & \multirow{7}{*}{ Seção I } & $\varepsilon_{0^{\circ}}=0,03 \%$ \\
\hline & $\varepsilon 90^{\circ}=-0,29 \%$ & & $\varepsilon 90^{\circ}=-0,08 \%$ & & $\varepsilon 90^{\circ}=0,08 \% 0$ \\
\hline & $\varepsilon_{45^{\circ}}=-0,55 \% 0$ & & $\varepsilon 45^{\circ}=0,78 \%$ & & $\varepsilon 45^{\circ}=-0,02 \%$ \\
\hline & $\sigma_{1}=-6 \mathrm{MPa}$ & & $\sigma_{1}=-$ & & $\sigma_{1}=2 \mathrm{MPa}$ \\
\hline & $\sigma_{2}=-17 \mathrm{MPa}$ & & $\sigma_{2}=-$ & & $\sigma_{2}=0$ \\
\hline & $\alpha_{1}=-40^{\circ}$ & & $\alpha_{1}=-$ & & $\alpha_{1}=36^{\circ}$ \\
\hline & $\alpha_{2}=50^{\circ}$ & & $\alpha_{2}=-$ & & $\alpha_{2}=126^{\circ}$ \\
\hline
\end{tabular}


Tabela 6.18 - Deformações nas zonas, modelo B45P25E25e0CG, F = 1700 kN.

\begin{tabular}{|c|c|c|c|c|c|}
\hline \multicolumn{2}{|c|}{ Zona nodal superior } & \multicolumn{2}{|c|}{ Zona nodal inferior } & \multicolumn{2}{|c|}{ Zona nodal superior } \\
\hline \multirow{7}{*}{$\begin{array}{c}\text { Seção A } \\
\text { (ruptura por } \\
\text { compressão) }\end{array}$} & $\varepsilon_{0^{\circ}}=0,47 \%$ & \multirow{7}{*}{ Seção D } & $\varepsilon_{0^{\circ}}=0,18 \%$ & \multirow{7}{*}{$\begin{array}{l}\text { Seção G } \\
\text { (ruptura por } \\
\text { tração) }\end{array}$} & $\varepsilon_{0^{\circ}}=7,46 \%$ \\
\hline & $\varepsilon_{90^{\circ}}=-2,52 \%$ & & $\varepsilon_{90^{\circ}}=-0,02 \%$ & & $\varepsilon_{90^{\circ}}=-0,72 \%$ \\
\hline & $\varepsilon_{45^{\circ}}=-3,16 \%$ & & $\varepsilon_{45^{\circ}}=-0,08 \%$ & & $\varepsilon_{45^{\circ}}=-0,46 \%$ \\
\hline & $\sigma_{1}=-$ & & $\sigma_{1}=4 \mathrm{MPa}$ & & $\sigma_{1}=-$ \\
\hline & $\sigma_{2}=-$ & & $\sigma_{2}=-3 \mathrm{MPa}$ & & $\sigma_{2}=-$ \\
\hline & $\alpha_{1}=-$ & & $\alpha_{1}=-29^{\circ}$ & & $\alpha_{1}=-$ \\
\hline & $\alpha_{2}=-$ & & $\alpha_{2}=61^{\circ}$ & & $\alpha_{2}=-$ \\
\hline \multirow{7}{*}{ Seção B } & $\varepsilon_{0^{\circ}}=-0,08 \%$ & \multirow{7}{*}{ Seção E } & $\varepsilon_{0^{\circ}}=-0,01 \%$ & \multirow{7}{*}{ Seção H } & $\varepsilon_{0^{\circ}}=-0,2 \%$ \\
\hline & $\varepsilon_{90^{\circ}}=-1,32 \%$ & & $\varepsilon_{90^{\circ}}=-0,2 \%$ & & $\varepsilon_{90^{\circ}}=-0,19 \%$ \\
\hline & $\varepsilon_{45^{\circ}}=-1,27 \%$ & & $\varepsilon_{45^{\circ}}=-0,44 \%$ & & $\varepsilon_{45^{\circ}}=-0,25 \%$ \\
\hline & $\sigma_{1}=-11 \mathrm{MPa}$ & & $\sigma_{1}=2 \mathrm{MPa}$ & & $\sigma_{1}=-6 \mathrm{MPa}$ \\
\hline & $\sigma_{2}=-46 \mathrm{MPa}$ & & $\sigma_{2}=-12 \mathrm{MPa}$ & & $\sigma_{2}=-8 \mathrm{MPa}$ \\
\hline & $\alpha_{1}=-21^{\circ}$ & & $\alpha_{1}=37^{\circ}$ & & $\alpha_{1}=42^{\circ}$ \\
\hline & $\alpha_{2}=69^{\circ}$ & & $\alpha_{2}=53^{\circ}$ & & $\alpha_{2}=132^{\circ}$ \\
\hline \multirow{7}{*}{$\begin{array}{c}\text { Seção C } \\
\text { (ruptura por } \\
\text { compressão) }\end{array}$} & $\varepsilon_{0^{\circ}}=-0,91 \%$ & \multirow{7}{*}{$\begin{array}{c}\text { Seção F } \\
\text { (ruptura por } \\
\text { tração) }\end{array}$} & $\varepsilon_{0^{\circ}}=3,99 \%$ & \multirow{7}{*}{ Seção I } & $\varepsilon_{0^{\circ}}=0$ \\
\hline & $\varepsilon_{90^{\circ}}=-0,31 \%$ & & $\varepsilon_{90^{\circ}}=1,61 \%$ & & $\varepsilon_{90^{\circ}}=-0,01 \%$ \\
\hline & $\varepsilon_{45^{\circ}}=-2,44 \%$ & & $\varepsilon_{45^{\circ}}=-0,64 \%$ & & $\varepsilon_{45^{\circ}}=-0,06 \%$ \\
\hline & $\sigma_{1}=-$ & & $\sigma_{1}=-$ & & $\sigma_{1}=0$ \\
\hline & $\sigma_{2}=-$ & & $\sigma_{2}=-$ & & $\sigma_{2}=-2 \mathrm{MPa}$ \\
\hline & $\alpha_{1}=-$ & & $\alpha_{1}=-$ & & $\alpha_{1}=42^{\circ}$ \\
\hline & $\alpha_{2}=-$ & & $\alpha_{2}=-$ & & $\alpha_{2}=48^{\circ}$ \\
\hline
\end{tabular}

Tabela 6.19 - Deformações nas zonas, modelo B35P50E25e0, F = 2800 kN.

\begin{tabular}{|c|c|c|c|c|c|}
\hline \multicolumn{2}{|c|}{ Zona nodal superior } & \multicolumn{2}{|c|}{ Zona nodal inferior } & \multicolumn{2}{|c|}{ Zona nodal superior } \\
\hline \multirow{7}{*}{$\begin{array}{c}\text { Seção A } \\
\text { (ruptura por } \\
\text { compressão) }\end{array}$} & $\varepsilon_{0^{\circ}}=0,50 \%$ & \multirow{7}{*}{ Seção D } & $\varepsilon_{0^{\circ}}=0,05 \%$ & \multirow{7}{*}{$\begin{array}{c}\text { Seção G } \\
\text { (ruptura por } \\
\text { tração) }\end{array}$} & $\varepsilon_{0^{\circ}}=5,54 \%$ \\
\hline & $\varepsilon 90^{\circ}=-1,19 \%$ & & $\varepsilon 90^{\circ}=-0,09 \%$ & & $\varepsilon 90^{\circ}=2,68 \%$ \\
\hline & $\varepsilon_{45^{\circ}}=-1,62 \%$ & & $\varepsilon_{45^{\circ}}=-0,18 \%$ & & $\varepsilon_{45^{\circ}}=-1,90 \%$ \\
\hline & $\sigma_{1}=-$ & & $\sigma_{1}=0,5 \mathrm{MPa}$ & & $\sigma_{1}=-$ \\
\hline & $\sigma_{2}=-$ & & $\sigma_{2}=-6 \mathrm{MPa}$ & & $\sigma_{2}=-$ \\
\hline & $\alpha_{1}=-$ & & $\alpha_{1}=-33^{\circ}$ & & $\alpha_{1}=-$ \\
\hline & $\alpha_{2}=-$ & & $\alpha_{2}=57^{\circ}$ & & $\alpha_{2}=-$ \\
\hline \multirow{7}{*}{ Seção B } & $\varepsilon_{0^{\circ}}=-0,23 \%$ & \multirow{7}{*}{ Seção E } & $\varepsilon_{0^{\circ}}=0$ & \multirow{7}{*}{ Seção H } & $\varepsilon_{0^{\circ}}=-0,4 \% 0$ \\
\hline & $\varepsilon_{90^{\circ}}=-0,56 \%$ & & $\varepsilon_{90^{\circ}}=0,06 \%$ & & $\varepsilon_{90^{\circ}}=-0,24 \%$ \\
\hline & $\varepsilon 45^{\circ}=-0,82 \%$ & & $\varepsilon_{45^{\circ}}=-0,46 \%$ & & $\varepsilon_{45^{\circ}}=-0,50 \%$ \\
\hline & $\sigma_{1}=-11 \mathrm{MPa}$ & & $\sigma_{1}=-13 \mathrm{MPa}$ & & $\sigma_{1}=-10 \mathrm{MPa}$ \\
\hline & $\sigma_{2}=-29 \mathrm{MPa}$ & & $\sigma_{2}=43 \mathrm{MPa}$ & & $\sigma_{2}=-18 \mathrm{MPa}$ \\
\hline & $\alpha_{1}=-21^{\circ}$ & & $\alpha_{1}=133^{\circ}$ & & $\alpha_{1}=33^{\circ}$ \\
\hline & $\alpha_{2}=69^{\circ}$ & & $\alpha_{2}=53^{\circ}$ & & $\alpha_{2}=123^{\circ}$ \\
\hline \multirow{7}{*}{ Seção C } & $\varepsilon_{0^{\circ}}=-0,12 \%$ & \multirow{7}{*}{$\begin{array}{c}\text { Seção F } \\
\text { (ruptura por } \\
\text { tração) }\end{array}$} & $\varepsilon_{0^{\circ}}=7,28 \%$ & \multirow{7}{*}{ Seção I } & $\varepsilon_{0^{\circ}}=0,19 \%$ \\
\hline & $\varepsilon_{90^{\circ}}=-1,18 \%$ & & $\varepsilon 90^{\circ}=-0,78 \%$ & & $\varepsilon 90^{\circ}=-0,02 \%$ \\
\hline & $\varepsilon_{45^{\circ}}=-0,67 \%$ & & $\varepsilon_{45^{\circ}}=0,72 \%$ & & $\varepsilon_{45^{\circ}}=-0,01 \%$ \\
\hline & $\sigma_{1}=-9 \mathrm{MPa}$ & & $\sigma_{1}=-$ & & $\sigma_{1}=5 \mathrm{MPa}$ \\
\hline & $\sigma_{2}=-40 \mathrm{MPa}$ & & $\sigma_{2}=-$ & & $\sigma_{2}=-1 \mathrm{MPa}$ \\
\hline & $\alpha_{1}=-1^{\circ}$ & & $\alpha_{1}=-$ & & $\alpha_{1}=-21^{\circ}$ \\
\hline & $\alpha_{2}=-89^{\circ}$ & & $\alpha_{2}=-$ & & $\alpha_{2}=69^{\circ}$ \\
\hline
\end{tabular}


Tabela 6.20 - Deformações nas zonas, modelo B35P50E25e12,5, F = $1500 \mathrm{kN}$.

\begin{tabular}{|c|c|c|c|c|c|}
\hline \multicolumn{2}{|c|}{ Zona nodal superior } & \multicolumn{2}{|c|}{ Zona nodal inferior } & \multicolumn{2}{|c|}{ Zona nodal superior } \\
\hline \multirow{7}{*}{ Seção A } & $\varepsilon_{0^{\circ}}=-0,16 \%$ & \multirow{7}{*}{ Seção D } & $\varepsilon_{0^{\circ}}=0,36 \%$ & \multirow{7}{*}{$\begin{array}{c}\text { Seção G } \\
\text { (ruptura por } \\
\text { tração) }\end{array}$} & $\varepsilon_{0^{\circ}}=1,17 \%$ \\
\hline & $\varepsilon_{90^{\circ}}=0,06 \%$ & & $\varepsilon_{90^{\circ}}=-0,01 \%$ & & $\varepsilon_{90^{\circ}}=5,04 \%$ \\
\hline & $\varepsilon_{45^{\circ}}=0,06 \%$ & & $\varepsilon_{45^{\circ}}=-0,04 \%$ & & $\varepsilon_{45^{\circ}}=-0,42 \%$ \\
\hline & $\sigma_{1}=3 \mathrm{MPa}$ & & $\sigma_{1}=10 \mathrm{MPa}$ & & $\sigma_{1}=-$ \\
\hline & $\sigma_{2}=-4 \mathrm{MPa}$ & & $\sigma_{2}=-3 \mathrm{MPa}$ & & $\sigma_{2}=-$ \\
\hline & $\alpha_{1}=3^{\circ}$ & & $\alpha_{1}=-25^{\circ}$ & & $\alpha_{1}=-$ \\
\hline & $\alpha_{2}=93^{\circ}$ & & $\alpha_{2}=65^{\circ}$ & & $\alpha_{2}=-$ \\
\hline \multirow{7}{*}{$\begin{array}{c}\text { Seção B } \\
\text { (ruptura por } \\
\text { compressão) }\end{array}$} & $\varepsilon_{0^{\circ}}=0,44 \%$ & \multirow{7}{*}{ Seção E } & $\varepsilon_{0^{\circ}}=0,05 \%$ & \multirow{7}{*}{ Seção H } & $\varepsilon_{0^{\circ}}=-0,12 \%$ \\
\hline & $\varepsilon_{90^{\circ}}=1,26 \%$ & & $\varepsilon_{90^{\circ}}=0,08 \%$ & & $\varepsilon_{90^{\circ}}=-0,18 \%$ \\
\hline & $\varepsilon_{45^{\circ}}=1,03 \%$ & & $\varepsilon_{45^{\circ}}=0,03 \%$ & & $\varepsilon_{45^{\circ}}=-0,22 \%$ \\
\hline & $\sigma_{1}=-$ & & $\sigma_{1}=3 \mathrm{MPa}$ & & $\sigma_{1}=-5 \mathrm{MPa}$ \\
\hline & $\sigma_{2}=-$ & & $\sigma_{2}=1 \mathrm{MPa}$ & & $\sigma_{2}=-8 \mathrm{MPa}$ \\
\hline & $\alpha_{1}=-$ & & $\alpha_{1}=133^{\circ}$ & & $\alpha_{1}=-33^{\circ}$ \\
\hline & $\alpha_{2}=-$ & & $\alpha_{2}=53^{\circ}$ & & $\alpha_{2}=57^{\circ}$ \\
\hline \multirow{7}{*}{ Seção C } & $\varepsilon_{0^{\circ}}=-1,88 \%$ & \multirow{7}{*}{$\begin{array}{l}\text { Seção F } \\
\text { (ruptura por } \\
\text { tração) }\end{array}$} & $\varepsilon_{0^{\circ}}=5,28 \% 0$ & \multirow{7}{*}{ Seção I } & $\varepsilon_{0^{\circ}}=-0,12 \%$ \\
\hline & $\varepsilon_{90^{\circ}}=0$ & & $\varepsilon_{90^{\circ}}=0,84 \%$ & & $\varepsilon_{90^{\circ}}=-0,02 \%$ \\
\hline & $\varepsilon_{45^{\circ}}=-2,20 \%$ & & $\varepsilon_{45^{\circ}}=0,24 \%$ & & $\varepsilon_{45^{\circ}}=-0,08 \%$ \\
\hline & $\sigma_{1}=-16 \mathrm{MPa}$ & & $\sigma_{1}=-$ & & $\sigma_{1}=-1 \mathrm{MPa}$ \\
\hline & $\sigma_{2}=-86 \mathrm{MPa}$ & & $\sigma_{2}=-$ & & $\sigma_{2}=-4 \mathrm{MPa}$ \\
\hline & $\alpha_{1}=27^{\circ}$ & & $\alpha_{1}=-$ & & $\alpha_{1}=6^{\circ}$ \\
\hline & $\alpha_{2}=117^{\circ}$ & & $\alpha_{2}=-$ & & $\alpha_{2}=96^{\circ}$ \\
\hline
\end{tabular}

Tabela 6.21 - Deformações nas zonas, modelo B45P50E25e0, F = $3100 \mathrm{kN}$.

\begin{tabular}{|c|c|c|c|c|c|}
\hline \multicolumn{2}{|c|}{ Zona nodal superior } & \multicolumn{2}{|c|}{ Zona nodal inferior } & \multicolumn{2}{|c|}{ Zona nodal superior } \\
\hline \multirow{7}{*}{ Seção A } & $\varepsilon_{0^{\circ}}=-0,93 \%$ & \multirow{7}{*}{ Seção D } & $\varepsilon_{0^{\circ}}=0,25 \%$ & \multirow{7}{*}{$\begin{array}{l}\text { Seção G } \\
\text { (ruptura por } \\
\text { tração) }\end{array}$} & $\varepsilon_{0^{\circ}}=9,06 \%$ \\
\hline & $\varepsilon 90^{\circ}=-1 \%$ & & $\varepsilon 90^{\circ}=-0,08 \%$ & & $\varepsilon 90^{\circ}=-0,62 \%$ \\
\hline & $\varepsilon_{45^{\circ}}=-0,86 \%$ & & $\varepsilon_{45^{\circ}}=-0,32 \%$ & & $\varepsilon_{45^{\circ}}=0,06 \%$ \\
\hline & $\sigma_{1}=-3 \mathrm{MPa}$ & & $\sigma_{1}=6 \mathrm{MPa}$ & & $\sigma_{1}=-$ \\
\hline & $\sigma_{2}=-37 \mathrm{MPa}$ & & $\sigma_{2}=-10 \mathrm{MPa}$ & & $\sigma_{2}=-$ \\
\hline & $\alpha_{1}=27^{\circ}$ & & $\alpha_{1}=-34^{\circ}$ & & $\alpha_{1}=-$ \\
\hline & $\alpha_{2}=117^{\circ}$ & & $\alpha_{2}=56^{\circ}$ & & $\alpha_{2}=-$ \\
\hline \multirow{7}{*}{ Seção B } & $\varepsilon_{0^{\circ}}=0,12 \%$ & \multirow{7}{*}{ Seção E } & $\varepsilon_{0^{\circ}}=-0,21 \%$ & \multirow{7}{*}{ Seção H } & $\varepsilon_{0^{\circ}}=-0,18 \%$ \\
\hline & $\varepsilon 90^{\circ}=-0,36 \%$ & & $\varepsilon_{90^{\circ}}=-0,32 \%$ & & $\varepsilon 90^{\circ}=-0,38 \%$ \\
\hline & $\varepsilon 45^{\circ}=0$ & & $\varepsilon_{45^{\circ}}=-0,34 \%$ & & $\varepsilon_{45^{\circ}}=-0,27 \%$ \\
\hline & $\sigma_{1}=4 \mathrm{MPa}$ & & $\sigma_{1}=-9 \mathrm{MPa}$ & & $\sigma_{1}=-8 \mathrm{MPa}$ \\
\hline & $\sigma_{2}=-10 \mathrm{Mpa}$ & & $\sigma_{2}=-13 \mathrm{MPa}$ & & $\sigma_{2}=-13 \mathrm{MPa}$ \\
\hline & $\alpha_{1}=13^{\circ}$ & & $\alpha_{1}=-27^{\circ}$ & & $\alpha_{1}=3^{\circ}$ \\
\hline & $\alpha_{2}=103^{\circ}$ & & $\alpha_{2}=63^{\circ}$ & & $\alpha_{2}=93^{\circ}$ \\
\hline \multirow{7}{*}{ Seção C } & $\varepsilon_{0^{\circ}}=-0,01 \%$ & \multirow{7}{*}{$\begin{array}{c}\text { Seção F } \\
\text { (ruptura por } \\
\text { tração) }\end{array}$} & $\varepsilon_{0^{\circ}}=9,19 \%$ & \multirow{7}{*}{ Seção I } & $\varepsilon_{0^{\circ}}=0,04 \%$ \\
\hline & $\varepsilon 90^{\circ}=-0,65 \%$ & & $\varepsilon 90^{\circ}=-0,71 \%$ & & $\varepsilon 90^{\circ}=-0,02 \%$ \\
\hline & $\varepsilon_{45^{\circ}}=-0,74 \%$ & & $\varepsilon 45^{\circ}=1,97 \%$ & & $\varepsilon_{45^{\circ}}=0,04 \%$ \\
\hline & $\sigma_{1}=-6 \mathrm{MPa}$ & & $\sigma_{1}=-$ & & $\sigma_{1}=2 \mathrm{MPa}$ \\
\hline & $\sigma_{2}=-30 \mathrm{MPa}$ & & $\sigma_{2}=-$ & & $\sigma_{2}=0$ \\
\hline & $\alpha_{1}=-26^{\circ}$ & & $\alpha_{1}=-$ & & $\alpha_{1}=23^{\circ}$ \\
\hline & $\alpha_{2}=64^{\circ}$ & & $\alpha_{2}=-$ & & $\alpha_{2}=113^{\circ}$ \\
\hline
\end{tabular}


Tabela 6.22 - Deformações nas zonas, modelo B45P50E25e12,5, F = 2300 kN.

\begin{tabular}{|c|c|c|c|c|c|}
\hline \multicolumn{2}{|c|}{ Zona nodal superior } & \multicolumn{2}{|c|}{ Zona nodal inferior } & \multicolumn{2}{|c|}{ Zona nodal superior } \\
\hline \multirow{7}{*}{ Seção A } & $\varepsilon_{0^{\circ}}=-1,83 \%$ & \multirow{7}{*}{ Seção D } & $\varepsilon_{0^{\circ}}=0,3 \%$ & \multirow{7}{*}{$\begin{array}{c}\text { Seção G } \\
\text { (ruptura por } \\
\text { tração) }\end{array}$} & $\varepsilon_{0^{\circ}}=4,87 \%$ \\
\hline & $\varepsilon 90^{\circ}=-1,04 \%$ & & $\varepsilon_{90^{\circ}}=-0,29 \%$ & & $\varepsilon 90^{\circ}=0,26 \%$ \\
\hline & $\varepsilon_{45^{\circ}}=-1,96 \%$ & & $\varepsilon_{45^{\circ}}=-0,44 \%$ & & $\varepsilon_{45^{\circ}}=0,35 \%$ \\
\hline & $\sigma_{1}=-14 \mathrm{MPa}$ & & $\sigma_{1}=1 \mathrm{MPa}$ & & $\sigma_{1}=-$ \\
\hline & $\sigma_{2}=-80 \mathrm{MPa}$ & & $\sigma_{2}=-1 \mathrm{MPa}$ & & $\sigma_{2}=-$ \\
\hline & $\alpha_{1}=27^{\circ}$ & & $\alpha_{1}=-28^{\circ}$ & & $\alpha_{1}=-$ \\
\hline & $\alpha_{2}=117^{\circ}$ & & $\alpha_{2}=62^{\circ}$ & & $\alpha_{2}=-$ \\
\hline \multirow{7}{*}{$\begin{array}{c}\text { Seção B } \\
\text { (ruptura por } \\
\text { compressão) }\end{array}$} & $\varepsilon_{0^{\circ}}=-0,16 \%$ & \multirow{7}{*}{ Seção E } & $\varepsilon_{0^{\circ}}=-0,09 \%$ & \multirow{7}{*}{ Seção H } & $\varepsilon_{0^{\circ}}=0,08 \%$ \\
\hline & $\varepsilon_{90^{\circ}}=-0,17 \%$ & & $\varepsilon_{90^{\circ}}=-0,3 \%$ & & $\varepsilon_{90^{\circ}}=0,02 \%$ \\
\hline & $\varepsilon_{45^{\circ}}=0,32 \% 0$ & & $\varepsilon_{45^{\circ}}=-0,34 \%$ & & $\varepsilon_{45^{\circ}}=-0,01 \% 0$ \\
\hline & $\sigma_{1}=-$ & & $\sigma_{1}=-5 \mathrm{MPa}$ & & $\sigma_{1}=2 \mathrm{MPa}$ \\
\hline & $\sigma_{2}=-$ & & $\sigma_{2}=-12 \mathrm{MPa}$ & & $\sigma_{2}=0$ \\
\hline & $\alpha_{1}=-$ & & $\alpha_{1}=-27^{\circ}$ & & $\alpha_{1}=-32^{\circ}$ \\
\hline & $\alpha_{2}=-$ & & $\alpha_{2}=63^{\circ}$ & & $\alpha_{2}=58^{\circ}$ \\
\hline \multirow{7}{*}{ Seção C } & $\varepsilon_{0^{\circ}}=0,03 \%$ & \multirow{7}{*}{$\begin{array}{c}\text { Seção F } \\
\text { (ruptura por } \\
\text { tração) }\end{array}$} & $\varepsilon_{0^{\circ}}=5,95 \%$ & \multirow{7}{*}{ Seção I } & $\varepsilon_{0^{\circ}}=0,02 \%$ \\
\hline & $\varepsilon_{90^{\circ}}=-0,04 \%$ & & $\varepsilon_{90^{\circ}}=-0,85 \%$ & & $\varepsilon_{90^{\circ}}=-0,06 \%$ \\
\hline & $\varepsilon_{45^{\circ}}=0,02 \%$ & & $\varepsilon_{45^{\circ}}=0,90 \%$ & & $\varepsilon_{45^{\circ}}=-0,04 \%$ \\
\hline & $\sigma_{1}=-1 \mathrm{MPa}$ & & $\sigma_{1}=-$ & & $\sigma_{1}=0$ \\
\hline & $\sigma_{2}=-1 \mathrm{MPa}$ & & $\sigma_{2}=-$ & & $\sigma_{2}=-2 \mathrm{Mpa}$ \\
\hline & $\alpha_{1}=18^{\circ}$ & & $\alpha_{1}=-$ & & $\alpha_{1}=-13^{\circ}$ \\
\hline & $\alpha_{2}=108^{\circ}$ & & $\alpha_{2}=-$ & & $\alpha_{2}=77^{\circ}$ \\
\hline
\end{tabular}

Se, implementarmos um critério de ruptura associado aos resultados experimentais, como por exemplo, o critério de Willam-Warnke (ver anexo A) que é utilizado nas simulações numéricas, observa-se por meio dos resultados das Tabelas 6.9 a 6.22, que as tensões existentes nos modelos ensaiados experimentalmente fizeram com que algumas seções dos blocos apresentassem ruptura por esmagamento do concreto (compressão-compressão-compressão, junto à zona nodal superior) e ruptura por tração do concreto (tração-compressão-compressão, junto às zonas nodais inferiores). Apesar do fato de que algumas regiões dos modelos estarem plastificadas, outras ainda permaneceram em regime elástico, como pode ser observado principalmente nas zonas nodais inferiores, pois as seções dos blocos mais próximas das extremidades (seções $\mathrm{D}$ e I) apresentaram deformações e tensões de pequena intensidade, ao contrário das regiões mais afastadas das extremidades dos blocos (Seções F e G) que sofreram ruptura.

Como a maioria das seções dos blocos não apresentaram tensões que excediam à tensão de plastificação do concreto $\left(f_{c}\right.$ e $\left.f_{t}\right)$ para a intensidade de força onde as tensões foram calculadas, os mesmos ainda foram capazes de suportar forças, atingindo o colapso somente quando as forças externas produziram tensões superiores à tensão de plastificação do material - Teorema do Limite Inferior. Como, trata-se de concreto armado, sendo o aço responsável por absorver às tensões de 
tração existentes nos modelos, as rupturas dos modelos ficam restritas então ao esmagamento do concreto e ao escoamento das barras de aço.

Em função destes resultados é possível entender por que o código Modelo CEB-FIP (1990) restringe o valor da tensão nas bielas em sessenta por cento da resistência de cálculo do concreto à compressão - pois, faz-se necessário a transmissão das forças existentes na zona nodal inferior (que apresentam fissuras) para as barras de aço da armadura principal de tração. Mas, o valor de $f_{c d}=0,60 \cdot\left[1-f_{c k} / 250\right] \cdot f_{c d}$ apresentado pelo Código Modelo é muito conservador, pois nos modelos em que a ruptura ocorreu junto à zona nodal inferior e superior simultaneamente (modelos das séries B35P50 e B45P50), essas tensões foram em média iguais ao valor da resistência $1,17 \mathrm{f}_{\mathrm{cm}}$ (o valor das tensões efetivas $\left(\sigma_{\mathrm{ef}}\right)$ nos modelos foram determinadas em função dos critérios de Blévot \& Fremy (1967) que considera que a área da biela é igual à área de toda a estaca num plano inclinado cujo ângulo vale $\left(90^{\circ}-\theta\right)$, sendo $\theta$ o ângulo de inclinação da biela de compressão com relação à horizontal).

Já, para a zona nodal superior, o Código Modelo do CEB-FIP (1990) restringe o valor da tensão na biela em $f_{c d}=0,85 \cdot\left[1-f_{c k} / 250\right] \cdot f_{c d}$ (mesmo valor sugerido por Machado (1973) - 0,85f $f_{c d}$ ). Utilizando o mesmo método para a determinação da tensão efetiva da biela junto ao pilar, ou seja, considerando que a área da biela na zona nodal superior é igual à metade da área do pilar num plano inclinado cujo ângulo com relação à horizontal vale $\left(90^{\circ}-\theta\right)$, determinou-se a relação $\sigma_{\text {ef,biela }} / f_{c}$ cujo valor é igual em média a 1,51. Neste caso, verifica-se também que o Código Modelo apresenta resultados conservadores. $O$ valor de $\sigma_{\text {ef,biela }} / f_{c}=1,51$ evidencia a ação de confinamento do concreto na zona nodal superior provocado pelas bielas.

Algo muito importante, que condiz com as análises numéricas desenvolvidas, relaciona-se às tensões nas regiões nodais inferiores. Analisando-se os resultados das Tabela 6.8 a 6.21 , verifica-se que nas seções $\mathrm{D}$ e I as tensões possuem pequena intensidade, ao contrário das seções E, F, G e H. Mesmo, sem saber o valor das tensões nas seções F e G, pôde-se concluir que estas seções são mais solicitadas que as demais (pois foram as primeiras seções que apresentaram esmagamento do concreto), portanto, considerar que a força da biela de compressão seja distribuída de maneira uniforme em toda a seção transversal da estaca, num plano inclinado de $\left(90^{\circ}\right.$ - $\theta$ ) é incorreto. Os resultados dos ensaios mostraram que as seções mais afastadas da extremidade dos blocos sobre as estacas foram mais solicitadas pela força de 
compressão oriunda da biela. Estes resultados confirmam a hipótese apresentada no capítulo 3, onde considera-se que somente parte da estaca (metade) esta solicitada pela força de compressão da biela.

\subsection{Forma geométrica da biela de compressão}

Em função dos resultados obtidos por meio das deformações nas faces dos blocos, foi possível identificar, mesmo que de maneira aproximada, a forma geométrica do fluxo de tensões de compressão.

Como já foi dito no item anterior, fica claro, que para as seções dos blocos localizadas sobre as seções das estacas mais próximas das extremidades dos blocos, as intensidades das deformações são pequenas se comparadas com as intensidades das tensões das seções dos blocos situadas sobre as seções das estacas mais afastadas das extremidades dos blocos. Portanto, pode-se admitir que apenas parte da estaca é solicitada de maneira mais intensa (esse modelo é mais próximo do real, do que o modelo que considera que toda a estaca esteja solicitada pela mesma força de compressão da biela).

Com relação a zona nodal superior, há grande concentração de tensões logo abaixo do pilar. Em função disto, considerar que metade da área da seção transversal do pilar é solicitada pela metade da força aplicada no topo do pilar é correto.

Ao contrário do que afirma Adebar et al. (1990) em seu modelo de biela e tirante refinado, aplicado aos blocos sobre estacas, não ocorreram nesses ensaios expansão do fluxo de tensão de compressão ao longo da altura do bloco, ao contrário, as deformações foram maiores nas seções dos blocos mais próximas da extremidades dos pilares e da seção da estaca mais afastada da extremidade do bloco.

A forma geométrica das bielas apresentada neste trabalho difere dos demais modelos de bielas e tirantes existentes, pois a mesma foi concebida para os blocos com seções já plastificadas, desta forma o modelo de biela e tirante a ser proposto pode ser garantido pela teoria do limite inferior.

É claro, que o modelo proposto (ver Capítulo 8) apresenta aproximações, como todo o modelo de bielas e tirantes, porém, acredita-se que em função das observações experimentais e dos resultados obtidos, este modelo apresenta maiores condições de segurança quanto à verificação da tensão limite de compressão da zona nodal inferior.

As Figuras 6.41 a 6.54 apresentam sugestões da geometria do fluxo de tensões em função das deformações nas faces dos blocos e das fissuras observadas após a ruína dos modelos. 

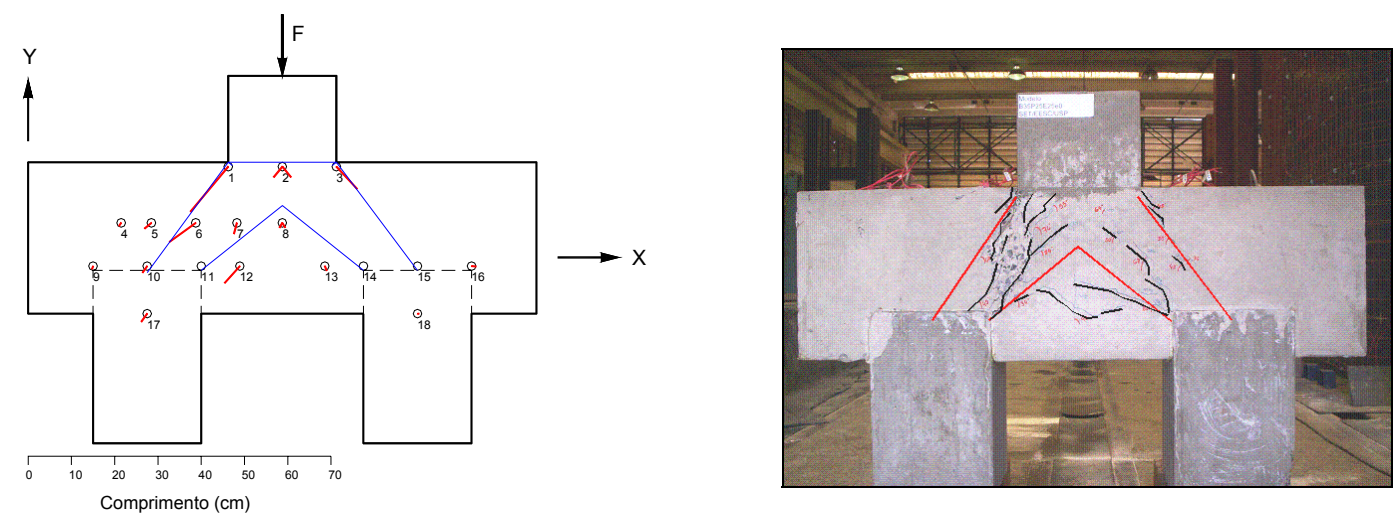

Figura 6.39 - Fluxo de tensões de compressão, modelo B35P25E25e0.
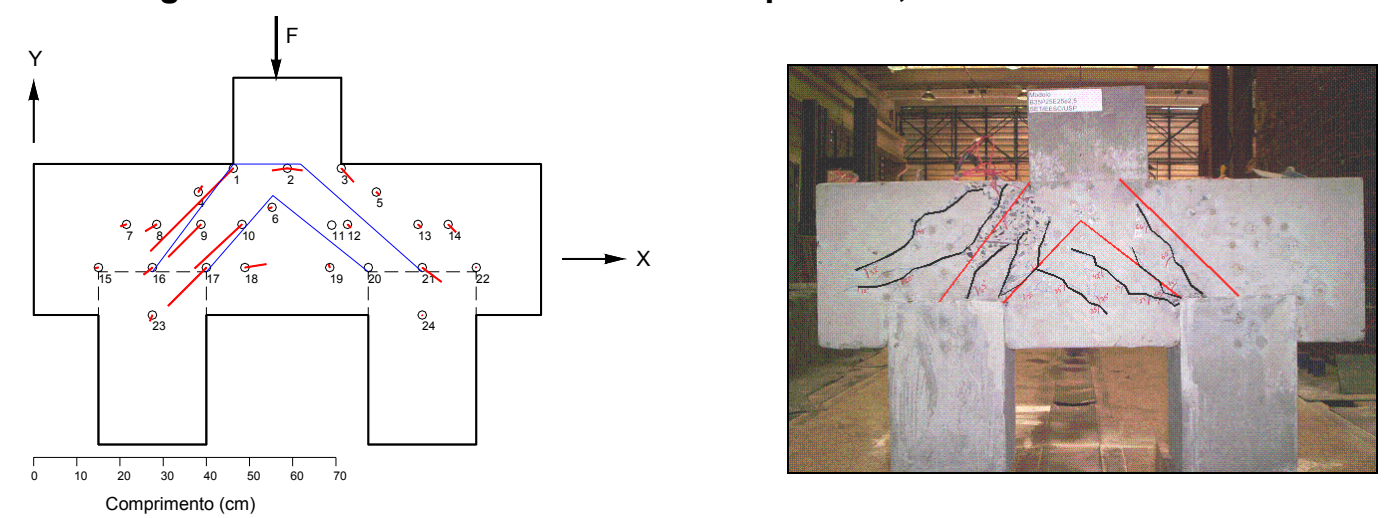

Figura 6.40 - Fluxo de tensões de compressão, modelo B35P25E25e2,5.
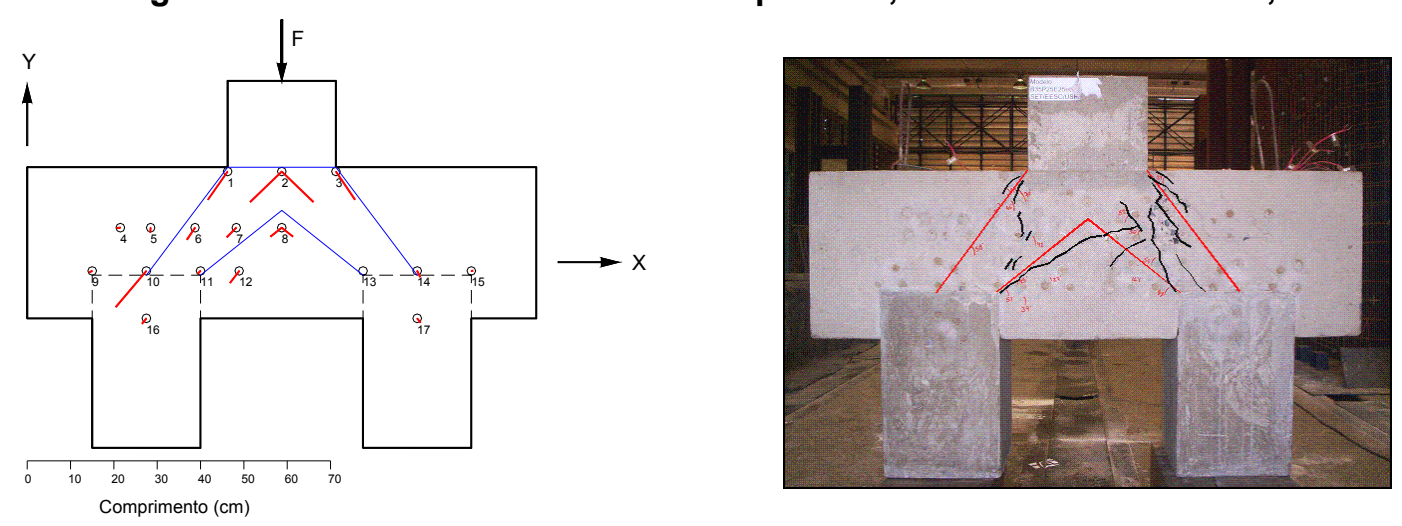

Figura 6.41 - Fluxo de tensões de compressão, modelo B35P25E25e0A $\mathrm{sw}_{\mathrm{s}, \mathrm{C}}$.
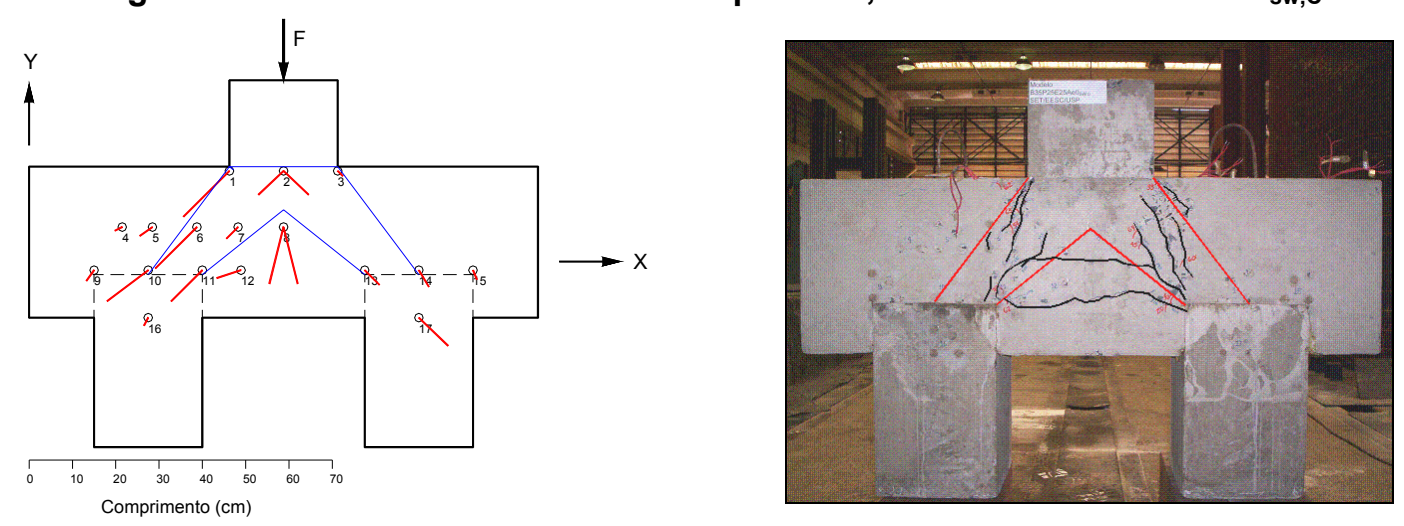

Figura 6.42 - Fluxo de tensões de compressão, modelo B35P25E25e0A $A_{s w, 0}$. 

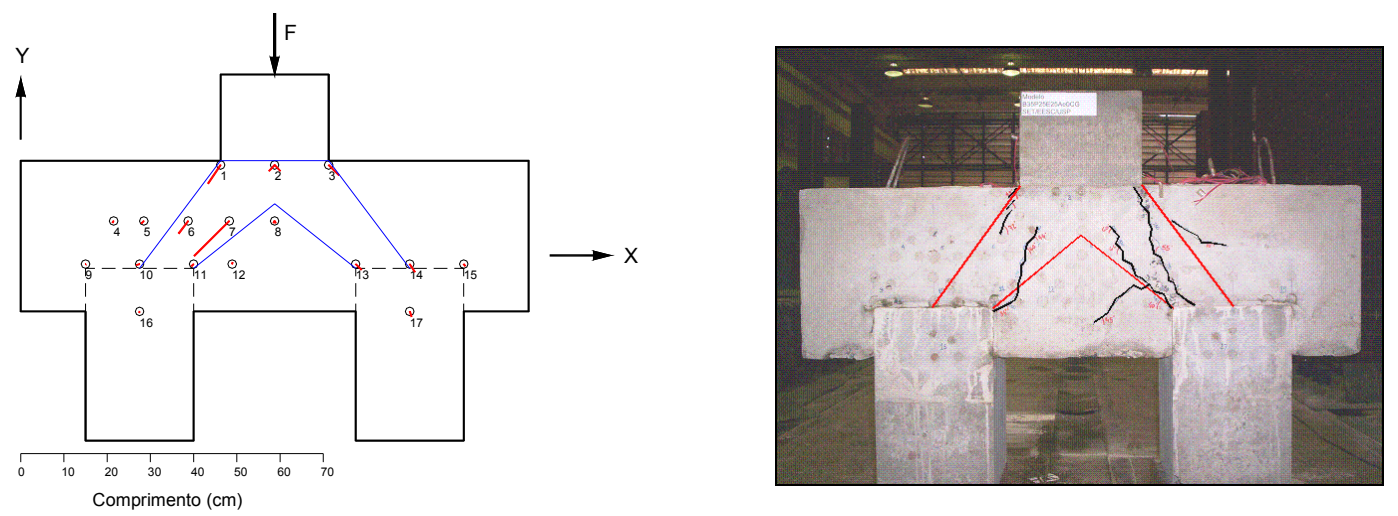

Figura 6.43 - Fluxo de tensões de compressão, modelo B35P25E25e0CG.
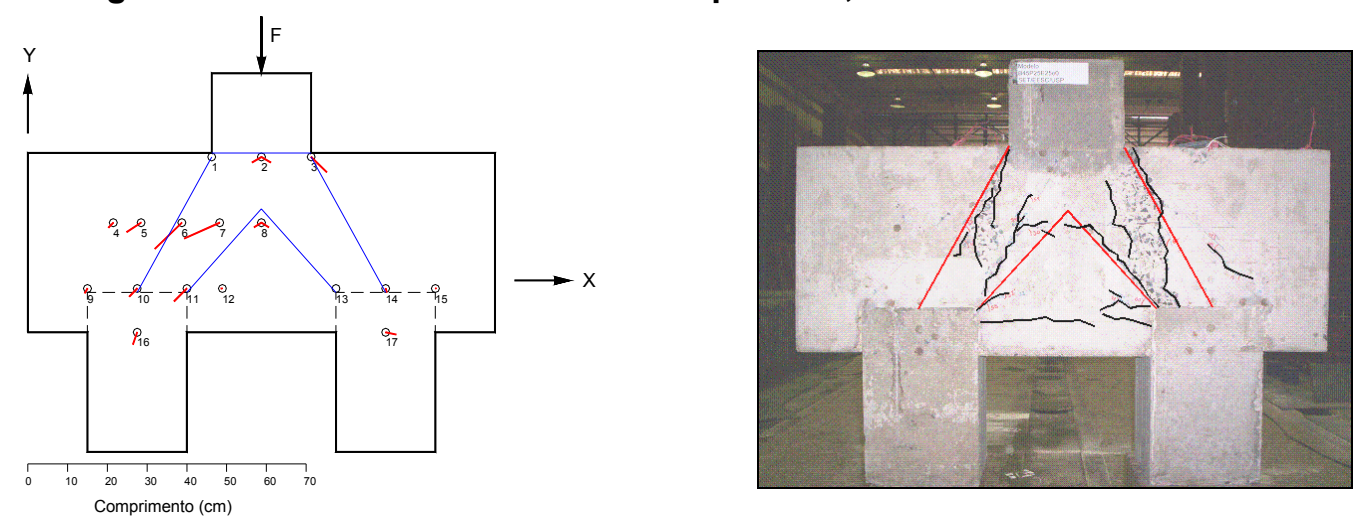

Figura 6.44 - Fluxo de tensões de compressão, modelo B45P25E25e0.
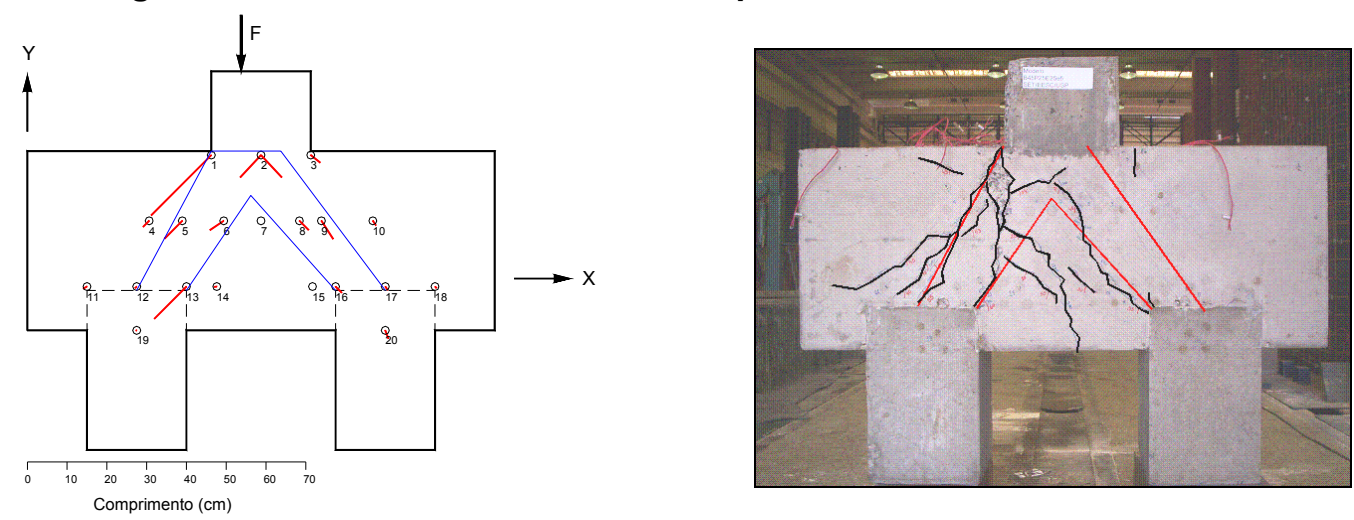

Figura 6.45 - Fluxo de tensões de compressão, modelo B45P25E25e5.
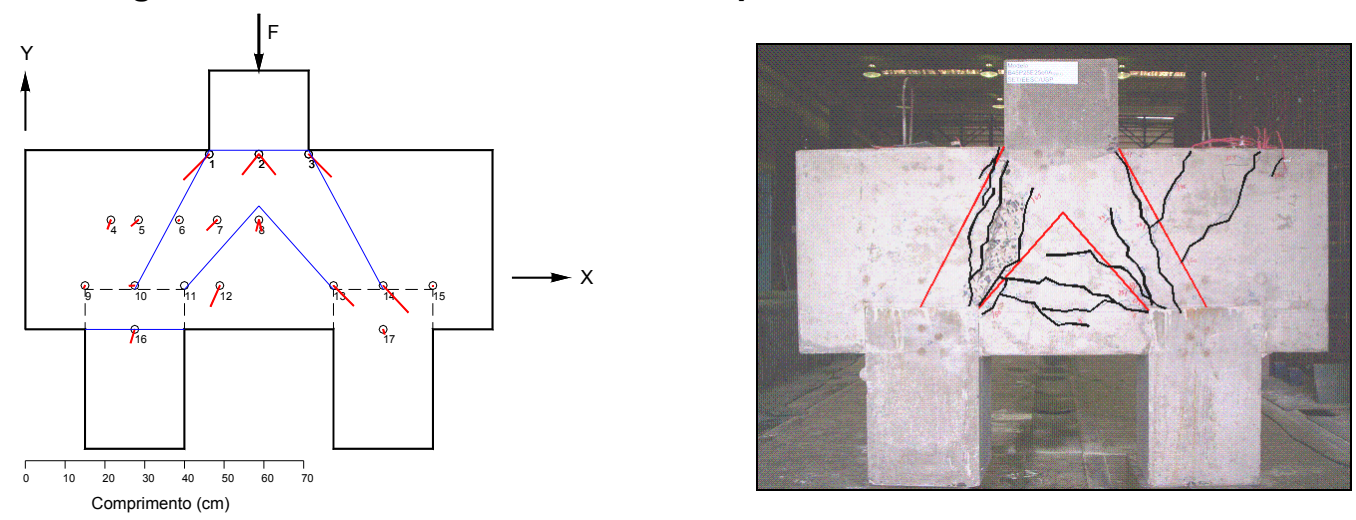

Figura 6.46 - Fluxo de tensões de compressão, modelo B45P25E25e0A 

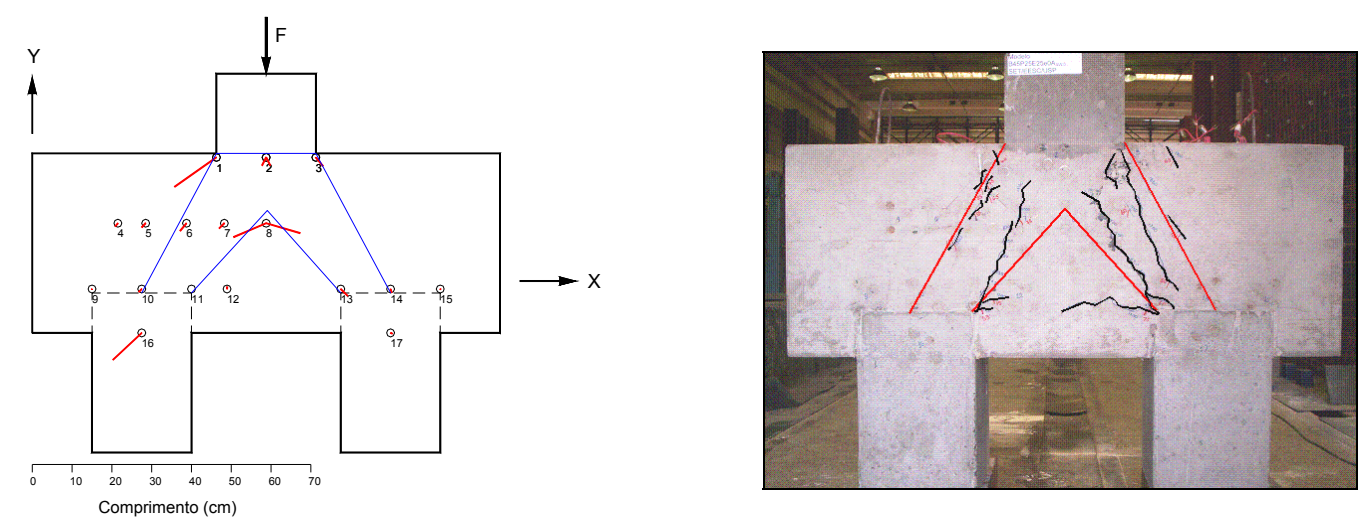

Figura 6.47 - Fluxo de tensões de compressão, modelo B45P25E25e0A $\mathrm{sw}_{\mathrm{sw}, 0}$.
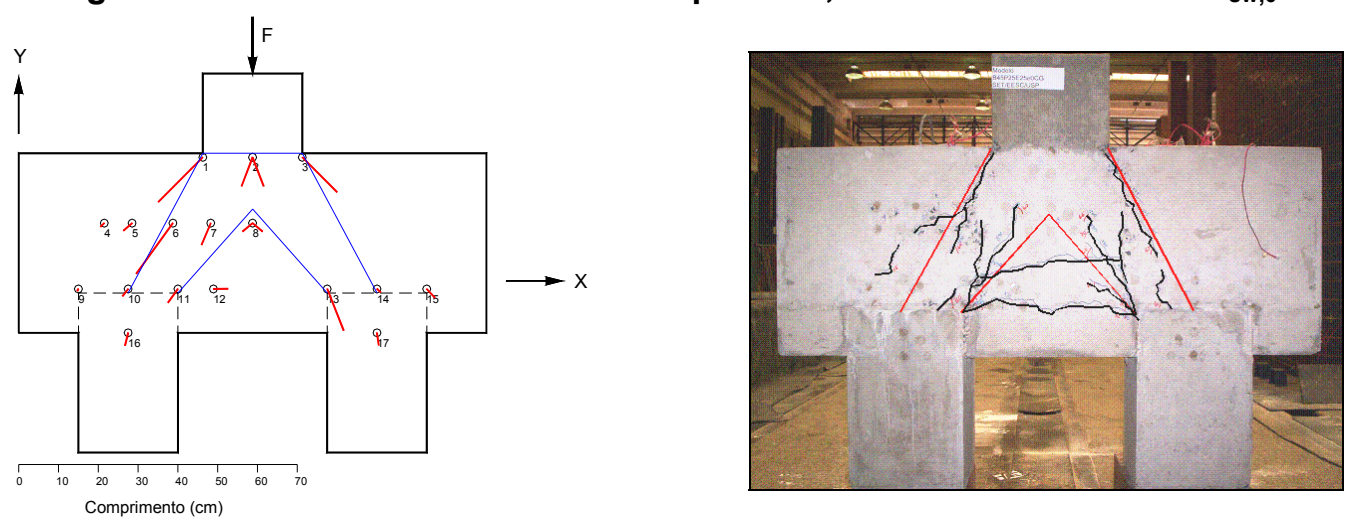

Figura 6.48 - Fluxo de tensões de compressão, modelo B45P25E25e0CG.
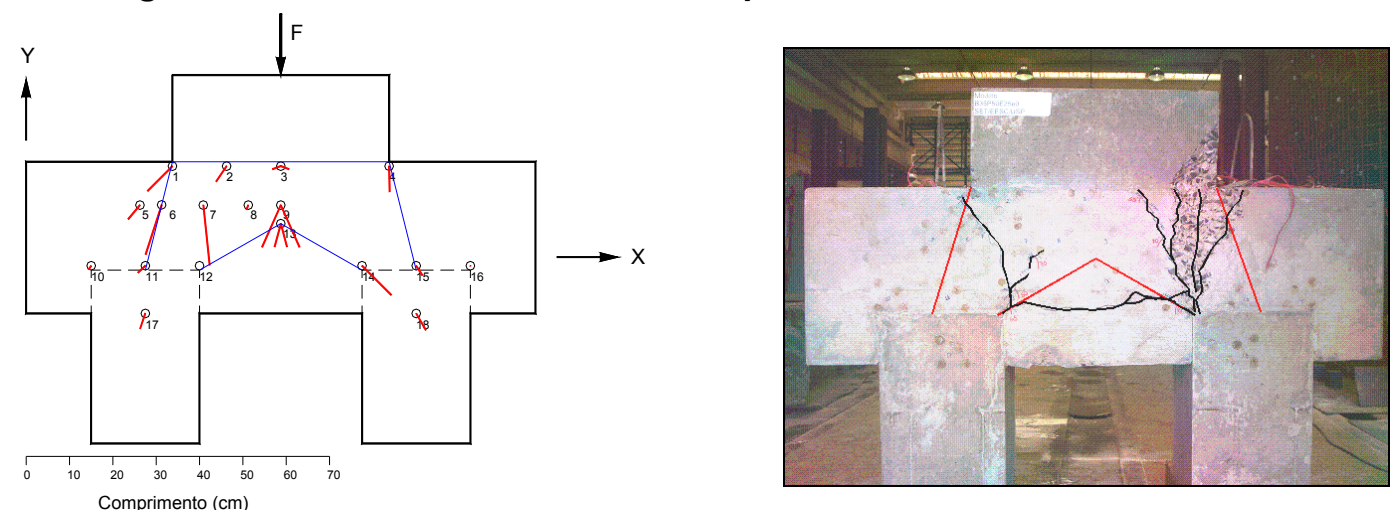

Figura 6.49 - Fluxo de tensões de compressão, modelo B35P50E25e0.
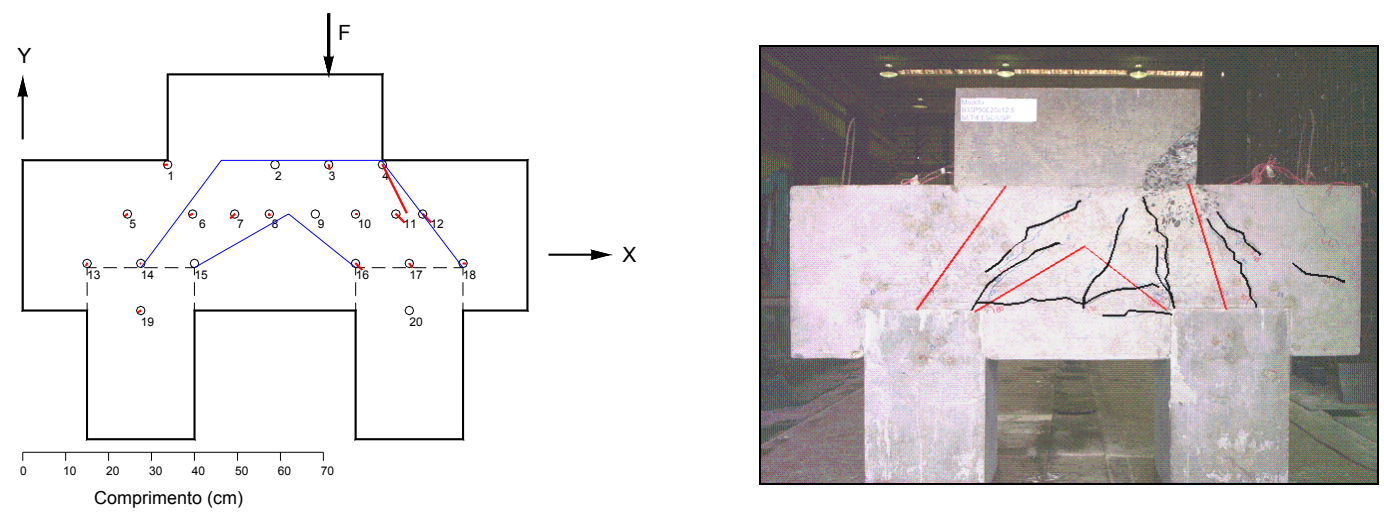

Figura 6.50 - Fluxo de tensões de compressão, modelo B35P50E25e12,5. 

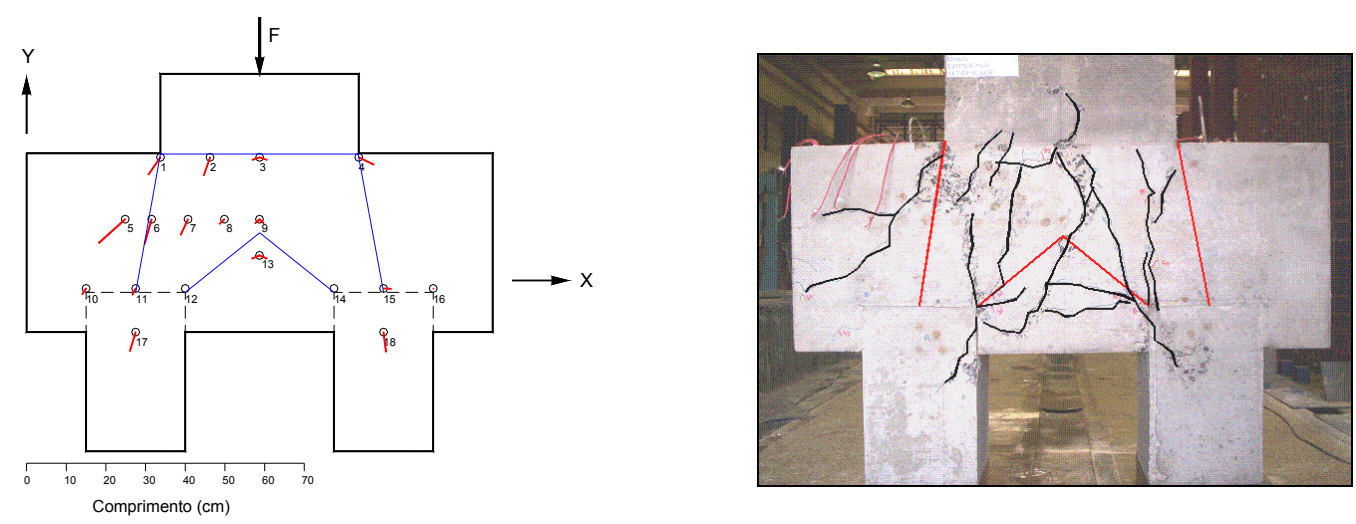

Figura 6.51 - Fluxo de tensões de compressão, modelo B45P50E25e0.
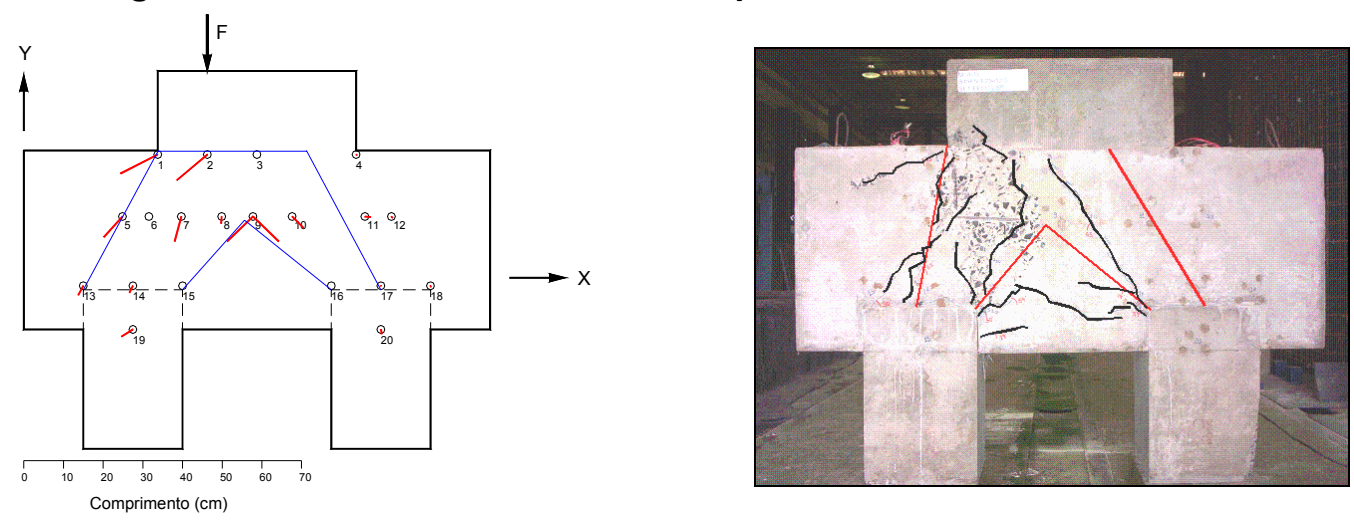

Figura 6.52 - Fluxo de tensões de compressão, modelo B45P50E25e12,5. 



\section{SIMULAÇÃO NUMÉRICA}

\subsection{Considerações iniciais}

Este capítulo tem como objetivo apresentar resultados obtidos por meio de programa computacional baseado no Método dos Elementos Finitos. A análise numérica desenvolvida segue os mesmo critérios da análise feita no Capítulo 3.

Todos os blocos ensaiados experimentalmente foram modelados $\mathrm{e}$ as condições de contorno e aplicação das forças foram no sentido se aproximar o máximo possível dos protótipos. As propriedades mecânicas dos materiais utilizados na implementação dos modelos numéricos foram as determinadas para os dos modelos reais.

O principal objetivo da análise numérica foi analisar o fluxo das tensões principais de compressão e comparar os resultados com os obtidos nos ensaios. Em funções dos resultados adquiridos nas análises experimentais e numéricas foi possível desenvolver um modelo de bielas e tirantes aplicado aos blocos sobre duas estacas.

\subsection{Discretização, condições de contorno e solicitações}

Como foi dito do Capítulo 3, para o material concreto dos blocos, estacas e pilares, utilizou-se o elemento Solid 65, existente na biblioteca do programa de computador, Ansys ${ }^{\circledR}$. As armaduras foram discretizadas com elementos de barra (Link 8) e consideradas discretas no interior dos modelos.

Nestas análises, as geometrias dos modelos foram criadas utilizando o programa de computador AutoCad ${ }^{\circledR}$ e exportadas para o programa de análise estrutural por meio da extensão SAT. A Figura 7.1 mostra a discretização da rede de elementos finitos utilizada, como também, a discretização das barras de aço. 
Também aqui, utilizou-se o critério de ruptura Concrete para simular o material concreto e as barras de aço foram supostas com comportamento elasto-plástico perfeito.

Como nos ensaios experimentais os modelos apenas foram apoiados sobre a base metálica que serviu como uma ponte para transferir as forças das estacas para as células de carga, nos modelos numéricos apenas foram impedidas às translações na direção Z (direção vertical).

Nos modelos onde à força aplicada foi centrada (supostamente) aplicou-se pressão no topo do pilar, já, para os modelos ensaiados com excentricidade, aplicouse força diretamente nos nós, simulando a existência de excentricidade. A Figura 7.2 apresenta às condições de contorno imposta e a aplicação da força.

As forças nos nós e a pressão no topo do pilar foram aplicadas por meio de cem incrementos.
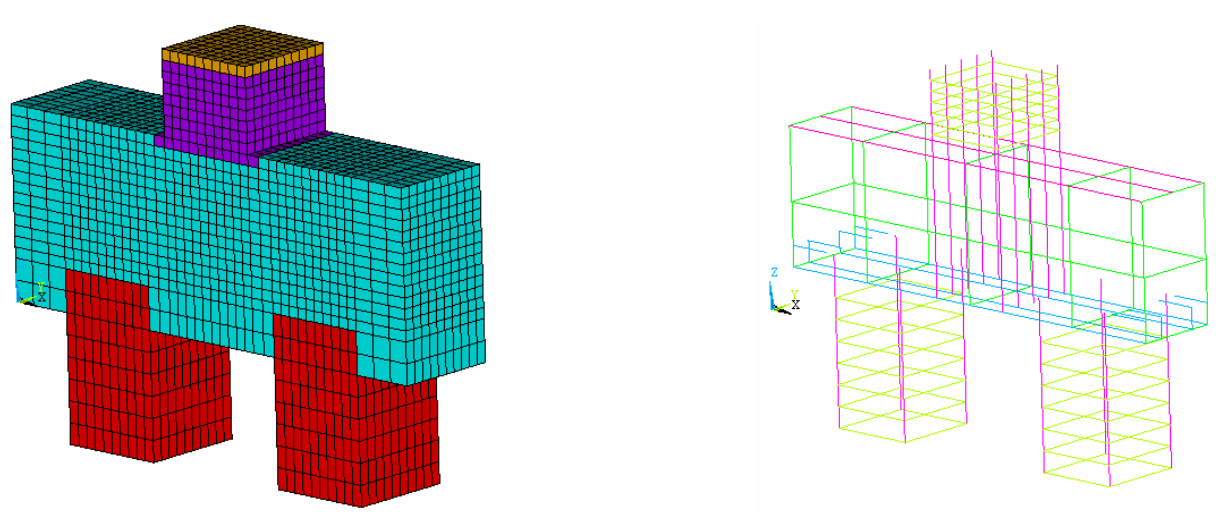

Figura 7.1 - Discretização, modelo B45P25E25e0CG.
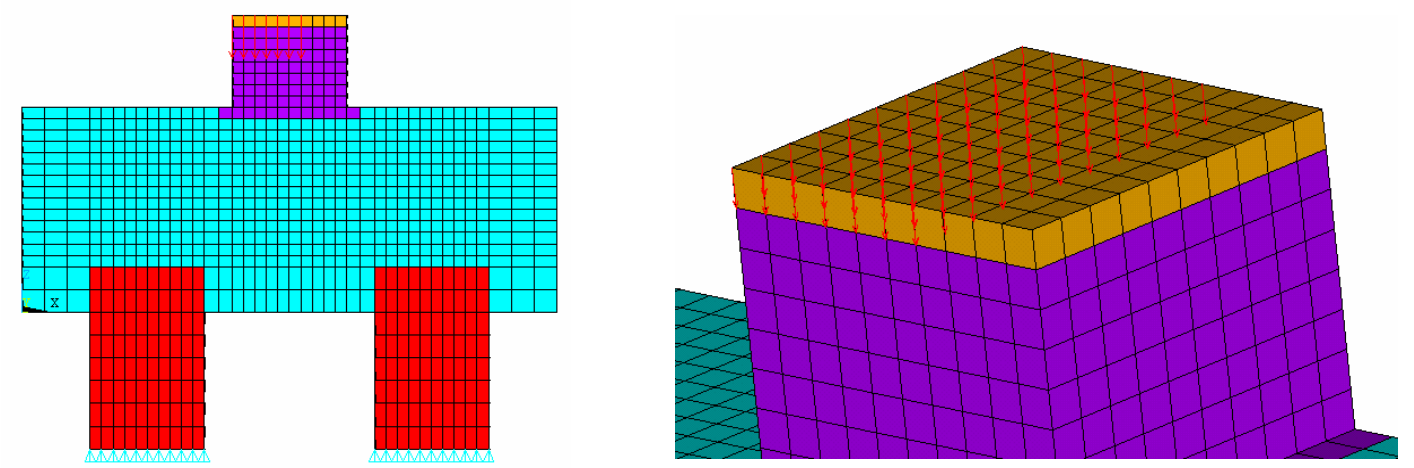

Figura 7.2 - Condições de contorno e aplicação da força, modelo B45P25E25e5.

Observa-se por meio das Figuras 7.1 e 7.2 que no topo do pilar existe um material com propriedade mecânica diferente. Isso foi feito, pois, nesta região existem 
grandes concentrações de tensões, assim, o topo do pilar foi modelado como sendo uma placa de aço com comportamento elástico.

\subsection{Resultados obtidos}

Em geral, os resultados oriundos da análise numérica tiveram a mesma tendência dos resultados experimentais.

Por meio do fluxo das tensões principais de compressão, observa-se que existem maiores concentrações de tensões nas zonas nodais inferior (junto à estaca na seção mais afastada da borda do bloco) e superior. Observou-se também, que não ocorreram expansões do fluxo das tensões de compressão ao longo da altura do bloco, apresentando o mesmo comportamento dos resultados experimentais (ver item 6.9, Capítulo 6).

A tensão na armadura principal de tração também teve comportamento similar em relação aos valores experimentais. As maiores tensões ocorreram na seção de meio de vão do bloco, diminuindo sensivelmente nas seções junto às estacas.

Apesar dos modelos numéricos apresentarem bons resultados principalmente com relação às forças últimas, todos os modelos se apresentaram mais rígidos que os valores experimentais. Possivelmente esse fenômeno ocorreu por três motivos: acomodação dos protótipos no início dos ensaios; a suposição de aderência perfeita entre as barras de aço e o concreto do entorno; e, por fim, a ligação perfeita entre as estacas e o bloco.

Com relação ao primeiro motivo, observa-se na relação força vs. deslocamento do meio do vão do bloco, uma acomodação no início do ensaio. Apesar de ter sido previsto o escorvamento do modelo, ainda pode ter ocorrido acomodações das estacas.

O segundo motivo, ou seja, a consideração de aderência perfeita entre as barras de aço e o concreto do entorno pode ter permitido maior rigidez aos elementos estruturais analisados, porém, esse fato não se confirmou em alguns testes preliminares feitos antes da análise numérica desenvolvida no Capítulo 3. Os resultados dos modelos considerando aderência perfeita e considerando deslocamentos relativos entre as barras de aço e o concreto (a aderência foi simulada por meio de molas) se mostraram muito próximos. Em função disto, decidiu-se optar pela modelagem com aderência perfeita, pois, haveria um grande trabalho computacional para obter os mesmos resultados. 
O terceiro motivo, e provavelmente o que mais colaborou com o aumento da rigidez dos elementos estruturais analisados numericamente, foi a suposição de ligação monolítica entre as estacas e o bloco. Apesar das estacas terem sido construídas com arranques, observou-se durante os ensaios um deslocamento da face do bloco em relação à face da estaca (ver Figura 7.3), o que provavelmente aumentou os deslocamentos verticais. Talvez, este fenômeno seria menos representativo se os blocos fossem construídos com abas de concreto envolvendo as estacas. Uma solução para este problema seria a modelagem desta ligação com elementos de contato.

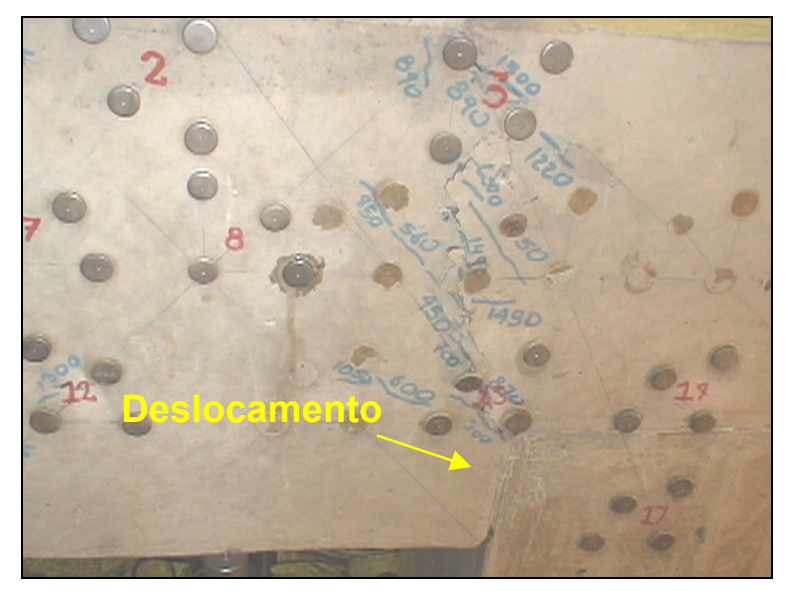

Figura 7.3 - Deslocamento horizontal entre a face do bloco e a face da estaca.

Apesar deste problema, as tensões nas regiões nodais apresentaram bons resultados, como também, as tensões nas barras de aço.

\subsubsection{Tensões principais}

Neste item são apresentadas as tensões principais obtidas por meio da análise numérica. Observando as Figuras 7.4 a 7.31 é possível notar a formação das bielas. Além disto, verifica-se que as seções dos blocos posicionadas coincidentes com as seções das estacas mais afastadas das bordas do bloco são as mais solicitadas. Estas observações também foram constadas nos resultados experimentais.

Observa-se que a análise numérica representou bem a ruína dos modelos, pois, as maiores tensões se desenvolveram junto aos pilares (nos modelos das séries B35P25 e B45P25, blocos construídos com pilares com seção transversal quadrada) e lembrando que a ruptura dos modelos destas séries se iniciaram por esmagamento do concreto junto ao pilar. 
A unidade das tensões é megapascal.

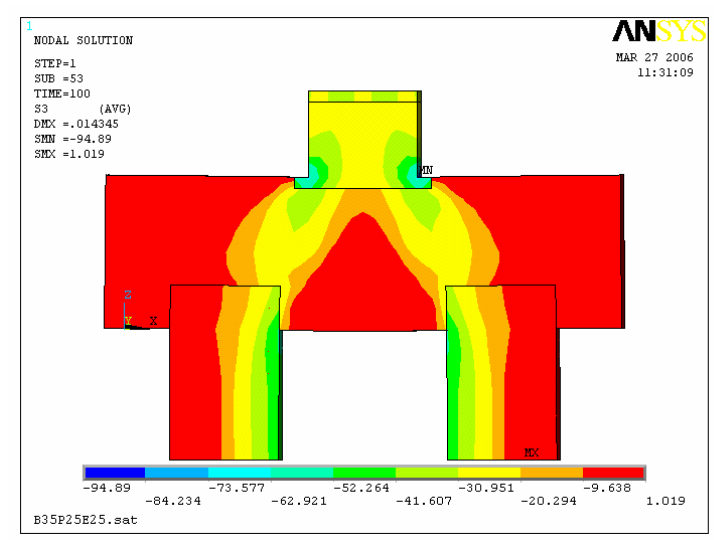

Figura 7.4 - Tensão principal de compressão, modelo B35P25E25e0.

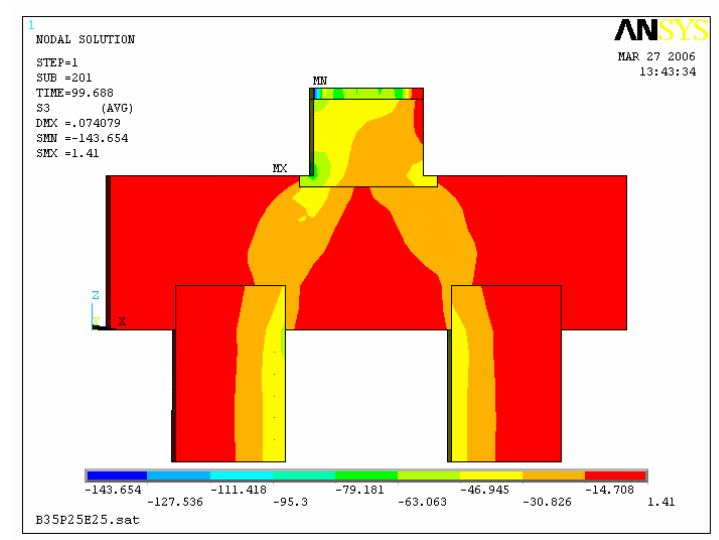

Figura 7.6 - Tensão principal de compressão, modelo B35P25E25e2,5.

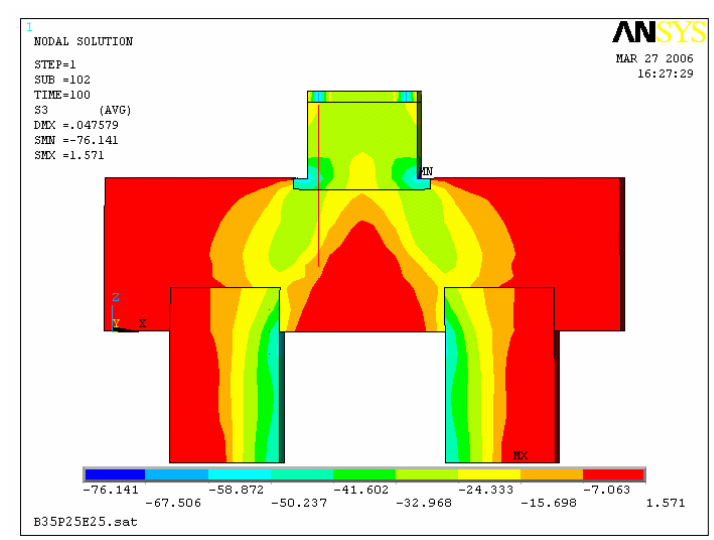

Figura 7.8 - Tensão principal de compressão, modelo B35P25E25e0A $\mathrm{sw}_{\mathrm{s}, \mathrm{C}}$.

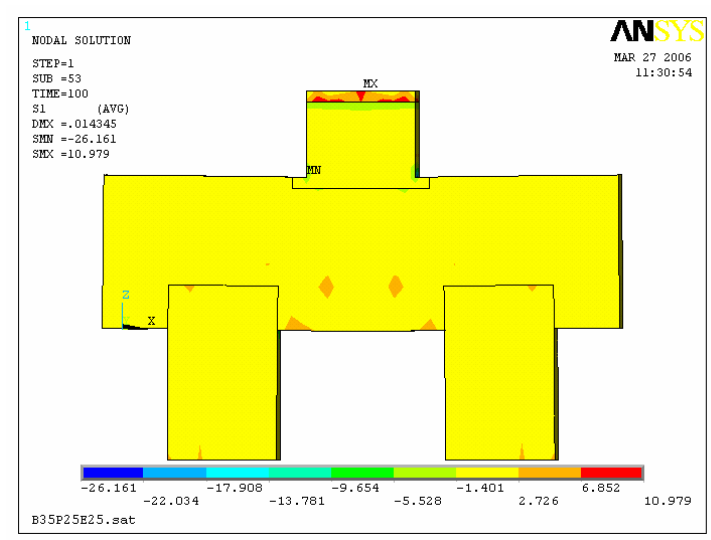

Figura 7.5 - Tensão principal de tração, modelo B35P25E25e0.

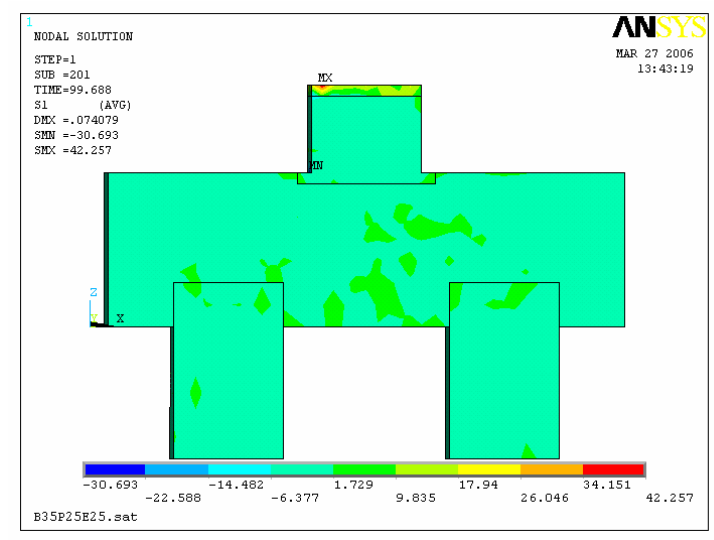

Figura 7.7 - Tensão principal de tração, modelo B35P25E25e2,5.

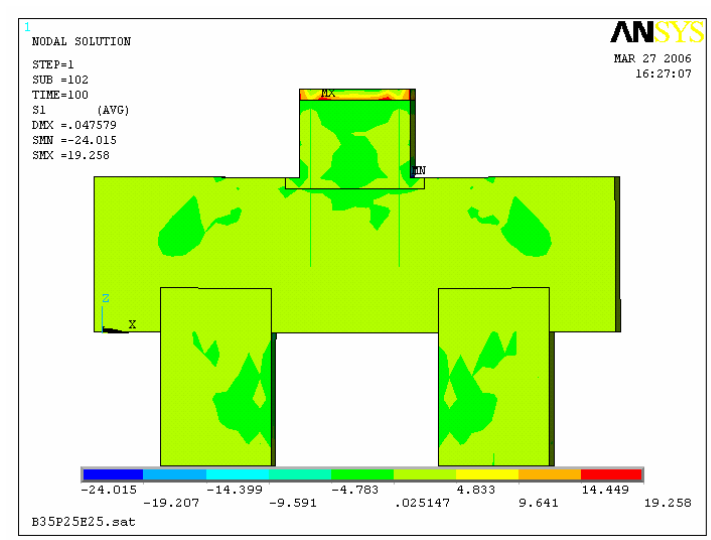

Figura 7.9 - Tensão principal de tração, modelo B35P25E25e0A sw,c. $_{\text {. }}$ 


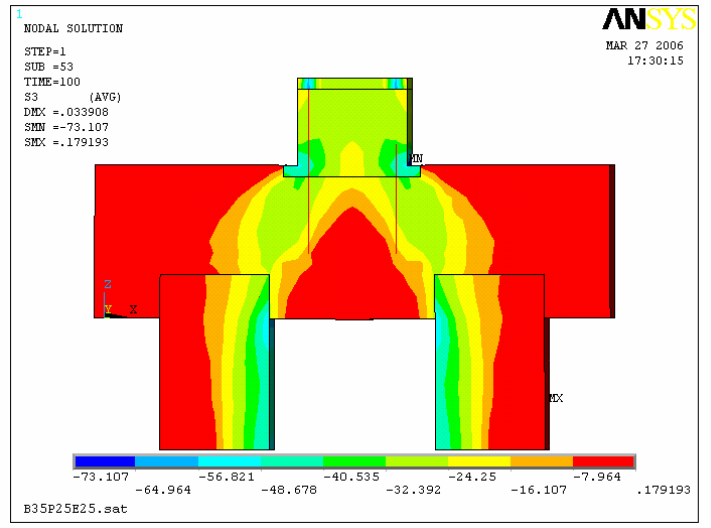

Figura 7.10 - Tensão principal de compressão, modelo B35P25E25e0A $\mathrm{sw}_{\mathrm{sw}, 0}$.

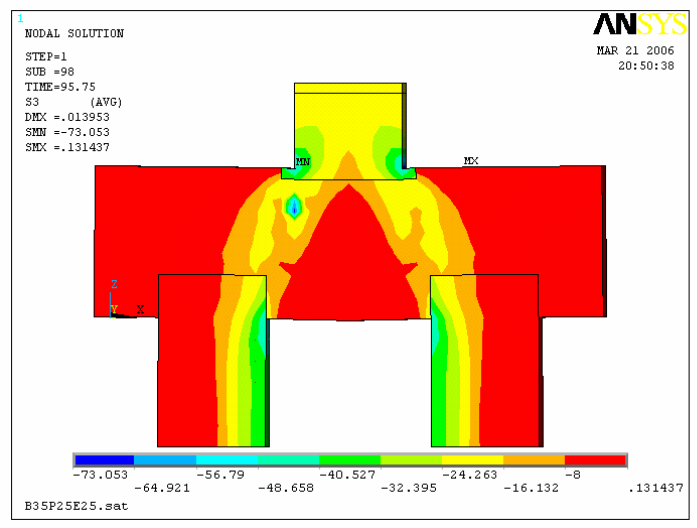

Figura 7.12 - Tensão principal de compressão, modelo B35P25E25e0CG.

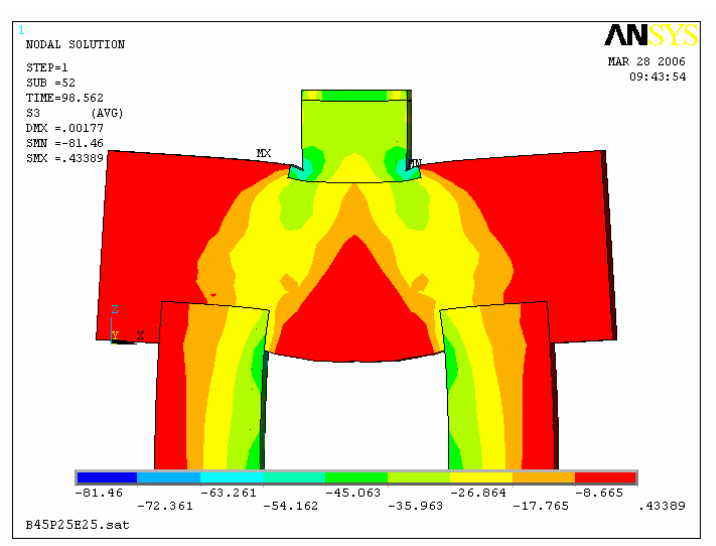

Figura 7.14 - Tensão principal de compressão, modelo B45P25E25e0.

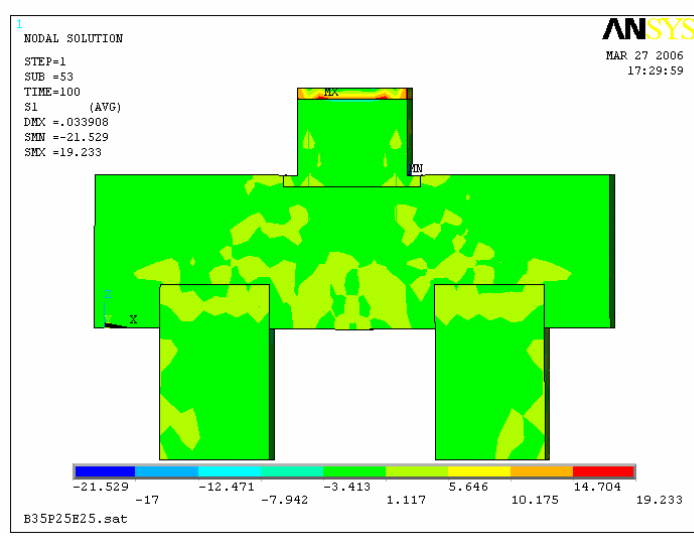

Figura 7.11 - Tensão principal de tração, modelo B35P25E25e0A $A_{s w, 0}$.

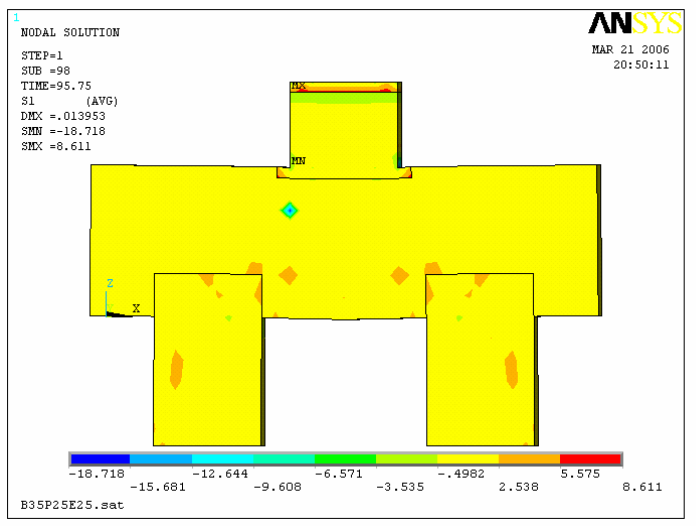

Figura 7.13 - Tensão principal de tração, modelo B35P25E25e0CG.

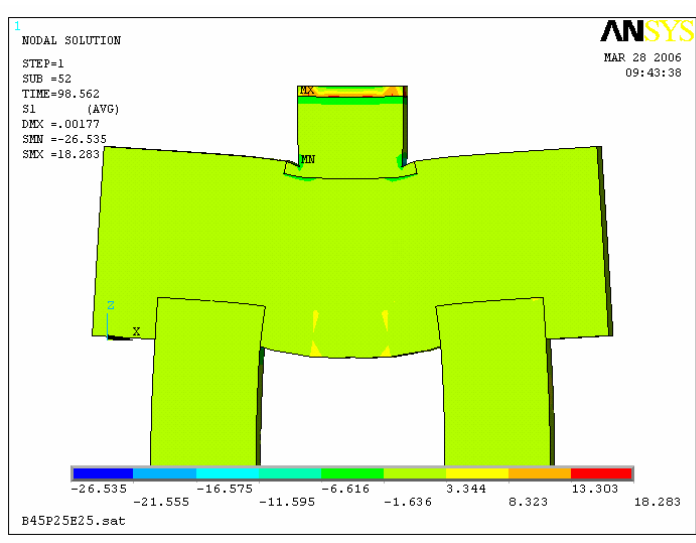

Figura 7.15 - Tensão principal de tração, modelo B45P25E25e0. 


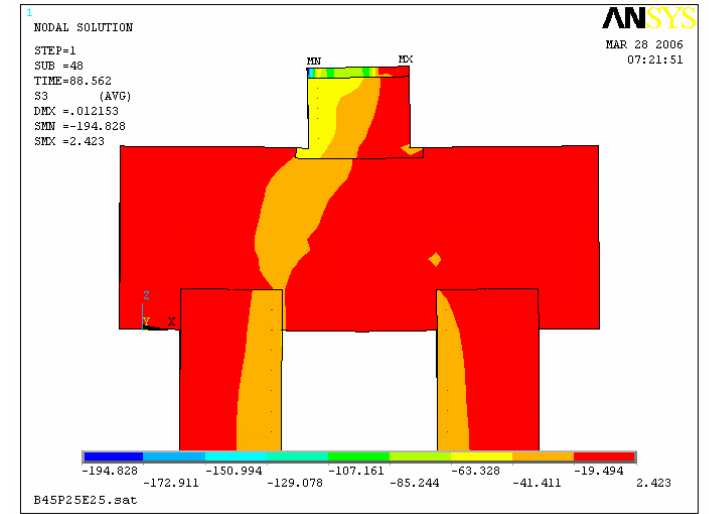

Figura 7.16 - Tensão principal de compressão, modelo B45P25E25e5.

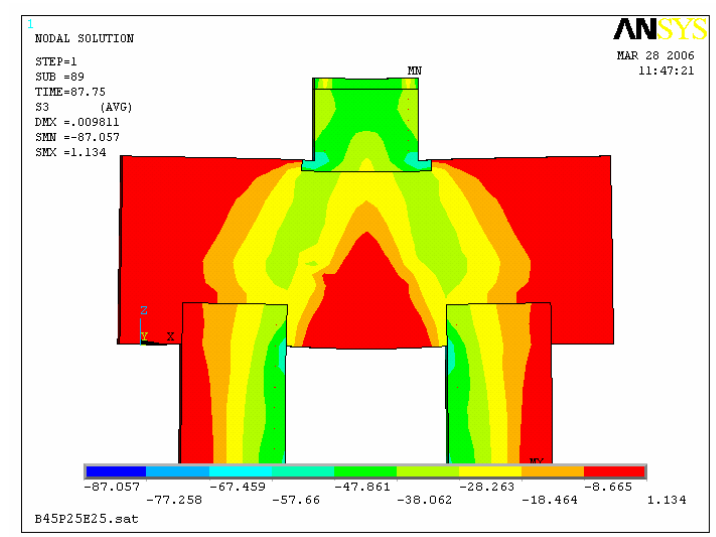

Figura 7.18 - Tensão principal de compressão, modelo B45P25E25e0A $\mathrm{sw}_{\mathrm{sw}, \mathrm{C}}$.

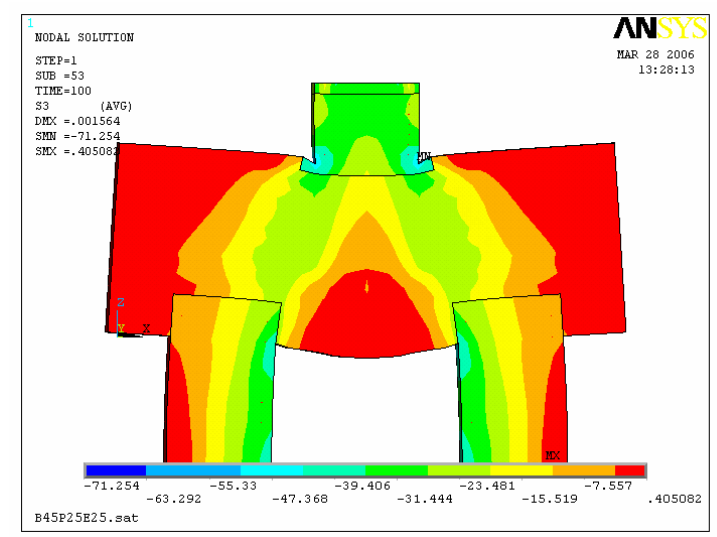

Figura 7.20 - Tensão principal de compressão, modelo $\mathrm{B} 45 \mathrm{P} 25 \mathrm{E} 25 \mathrm{e} 0 \mathrm{~A}_{\mathrm{sw}, 0}$.

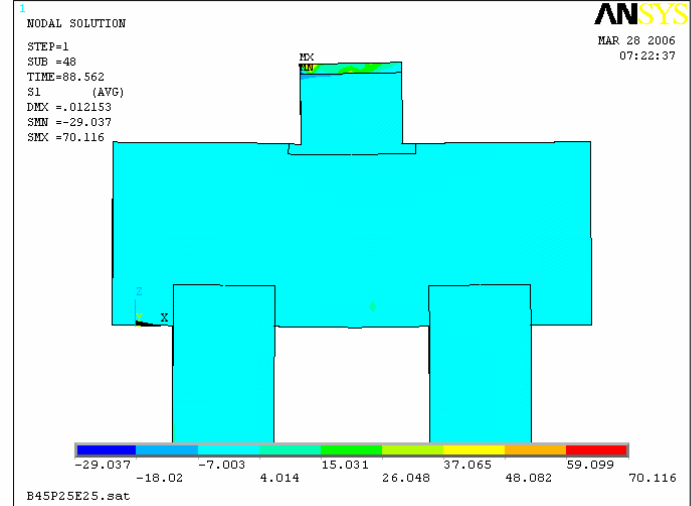

Figura 7.17 - Tensão principal de tração, modelo B45P25E25e5.

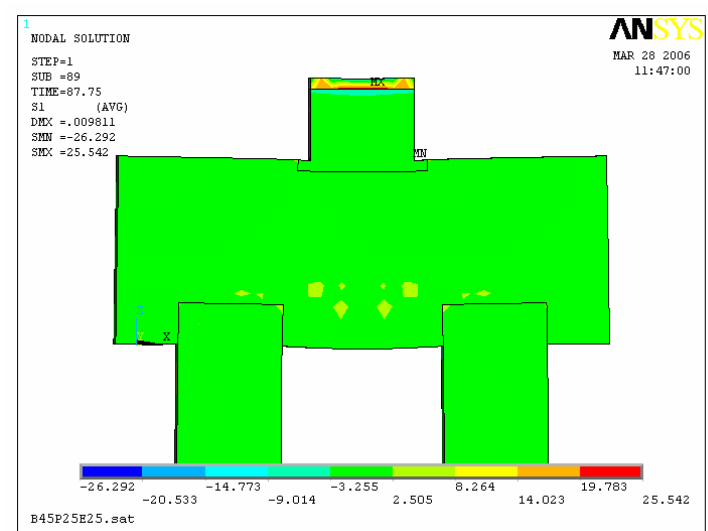

Figura 7.17 - Tensão principal de tração, modelo B45P25E25e0A $A_{s w, c}$.

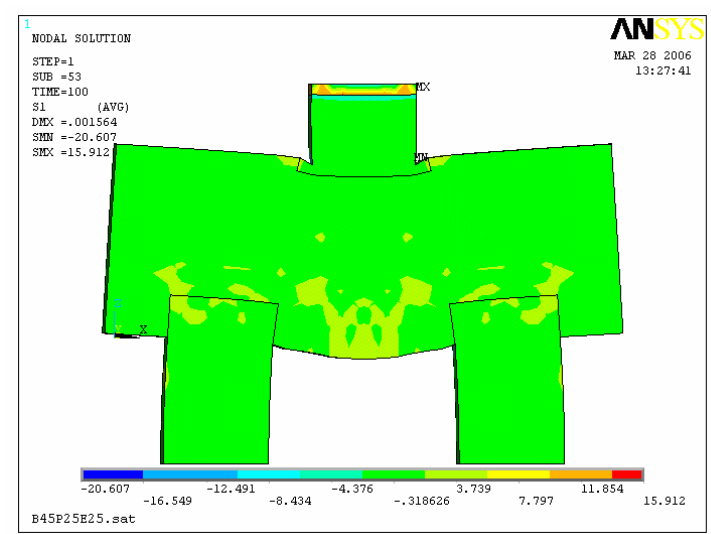

Figura 7.21 - Tensão principal de tração, modelo B45P25E25e0A $A_{s w, 0}$. 


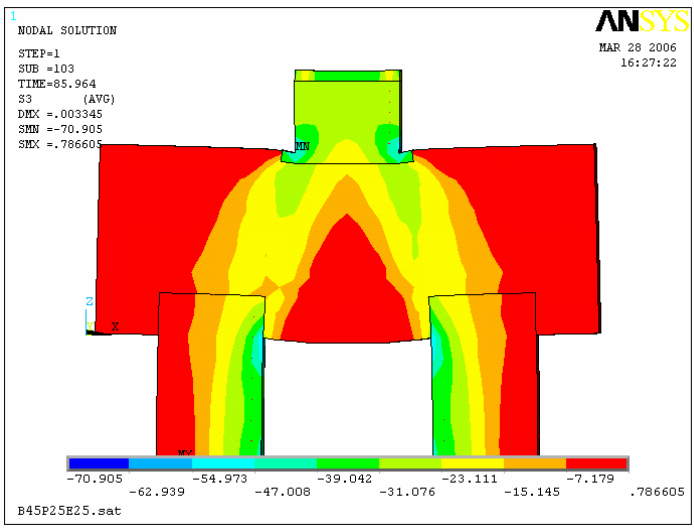

Figura 7.22 - Tensão principal de compressão, modelo B45P25E25e0CG.

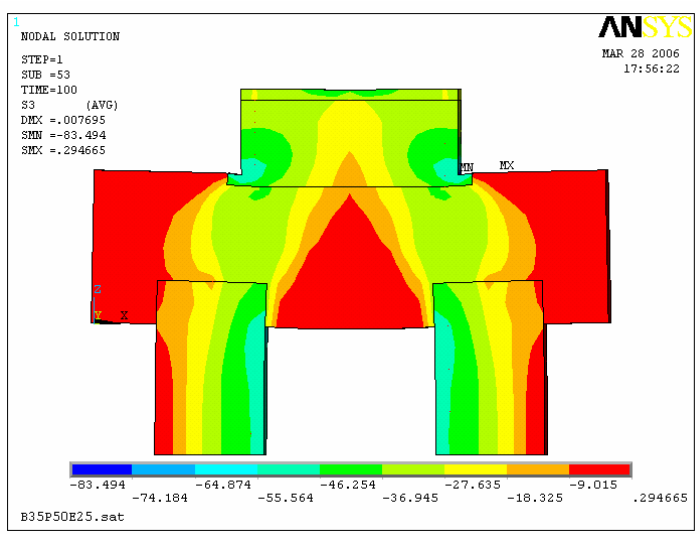

Figura 7.24 - Tensão principal de compressão, modelo B35P50E25e0.

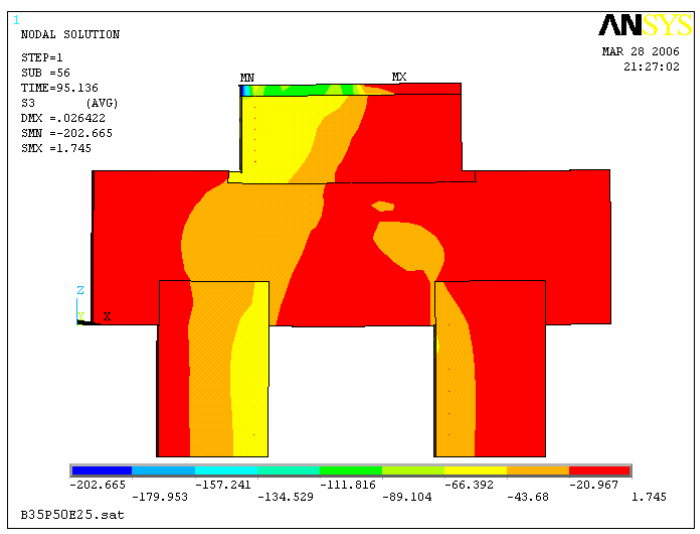

Figura 7.26 - Tensão principal de compressão, modelo B35P50E25e12,5.

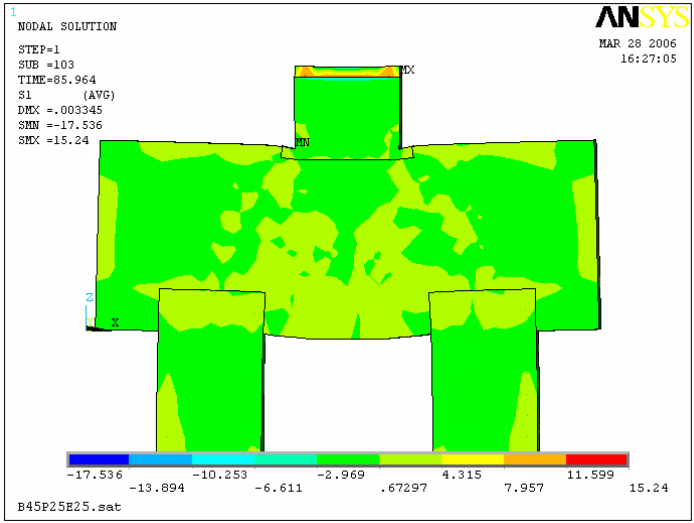

Figura 7.23 - Tensão principal de tração, modelo B45P25E25e0CG.

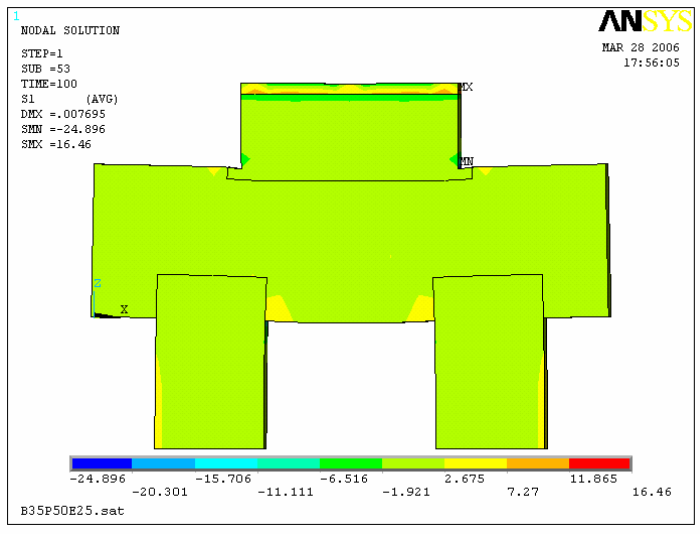

Figura 7.25 - Tensão principal de tração, modelo B35P50E25e0.

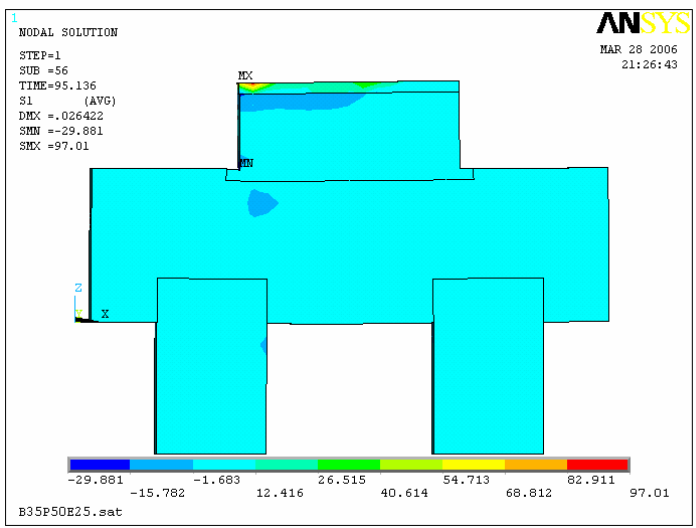

Figura 7.27 - Tensão principal de tração, modelo B35P50E25e12,5. 


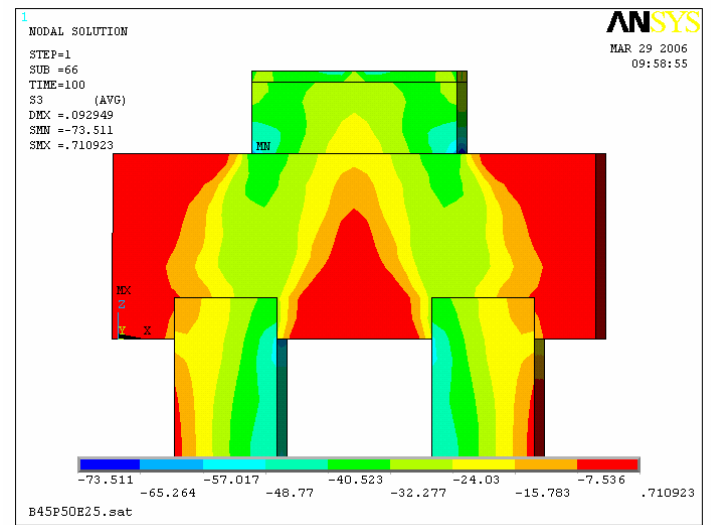

Figura 7.28 - Tensão principal de compressão, modelo B45P50E25e0.

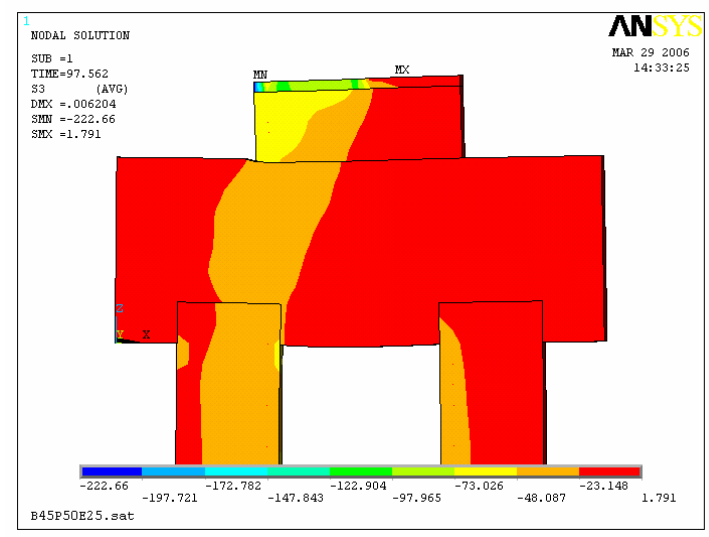

Figura 7.30 - Tensão principal de compressão, modelo B45P50E25e12,5.

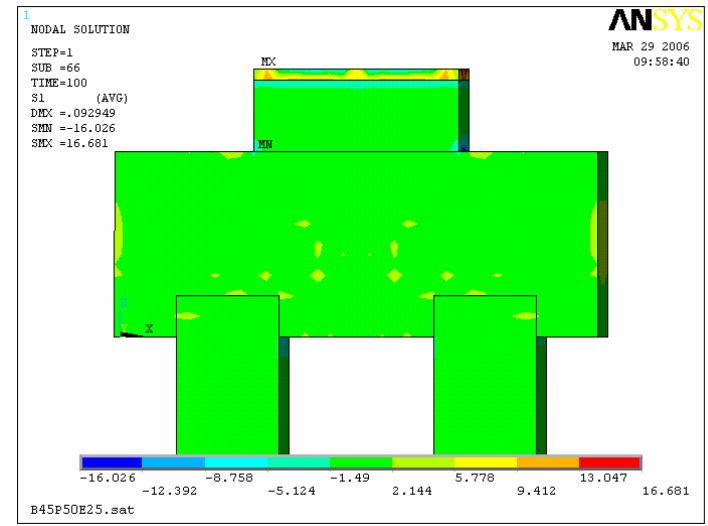

Figura 7.29 - Tensão principal de tração, modelo B45P50E25e0.

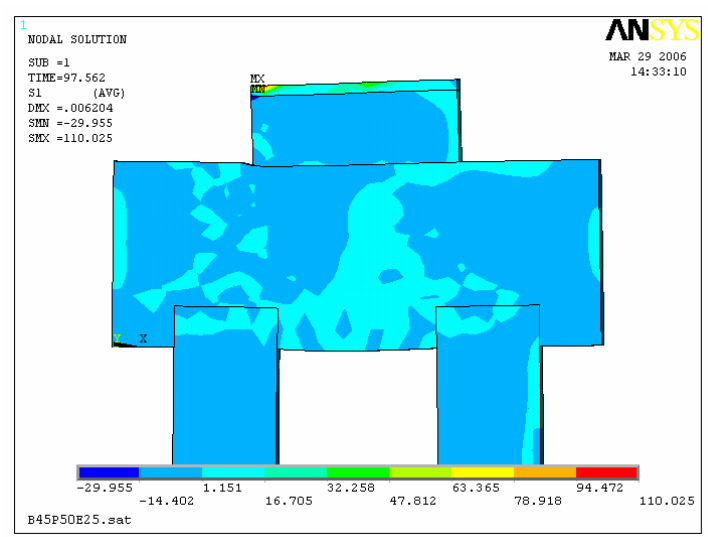

Figura 7.31 - Tensão principal de tração, modelo B45P50E25e12,5.

Uma observação muito importante é com relação ao dimensionamento das estacas que ficam solicitadas por uma força excêntrica o que provoca flexocompressão, conforme pode-se observar analisando-se as Figuras 7.4, 7.6, 7.8, 7.10, 7.12, 7.14, 7.16, 7.18, 7.20, 7.22, 7.24, 7.26, 7.28 e 7.30.

Este fenômeno também foi observado nos resultados experimentais, pois as tensões de compressão são maiores nas seções das estacas mais afastadas da borda do bloco. Mesmo para as estacas longas (ver Capítulo 3) este fenômeno aconteceu. Portanto, sugere-se que as estacas sejam dimensionadas para resistir às tensões oriundas da flexão e compressão.

O modelo proposto pelo autor leva em conta este critério, pois a reação da estaca não está posicionada em seu centro geométrico e sim a uma distância equivalente a um quarto de uma das dimensões da seção transversal, na direção paralela ao eixo longitudinal do bloco. 


\subsubsection{Fluxo de tensões}

Este item é o mais importante da análise numérica, pois, por meio da distribuição do fluxo de tensões de compressão, foi possível verificar a forma geométrica da biela de compressão sugerida no Capítulo 6.

As Figuras 7.32 a 7.59 apresentam a distribuição do fluxo de tensões principais de compressão.

Por meio destas figuras, foi possível observa que a geometria sugerida para as bielas de compressão no Capítulo 6 está adequada. Em função disto, foi proposto um modelo de biela e tirante o qual leva em consideração a geometria das bielas de compressão e a posição da força de compressão no topo do pilar.

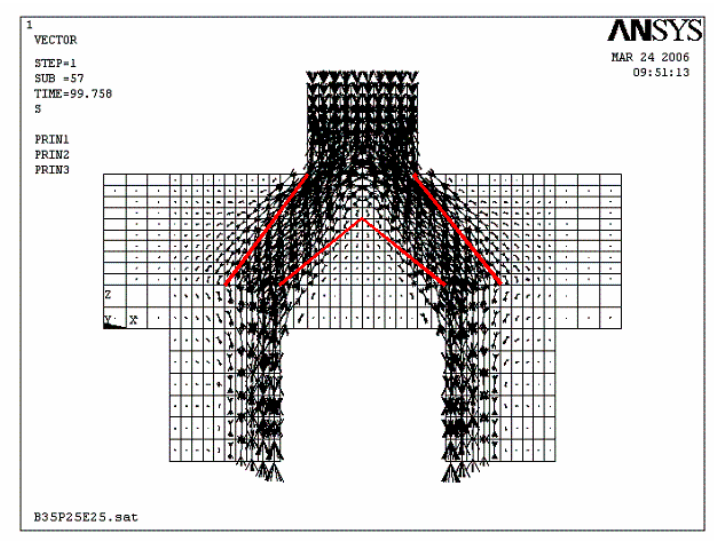

Figura 7.32 - Fluxo das tensões principais de compressão, modelo B35P25E25e0.

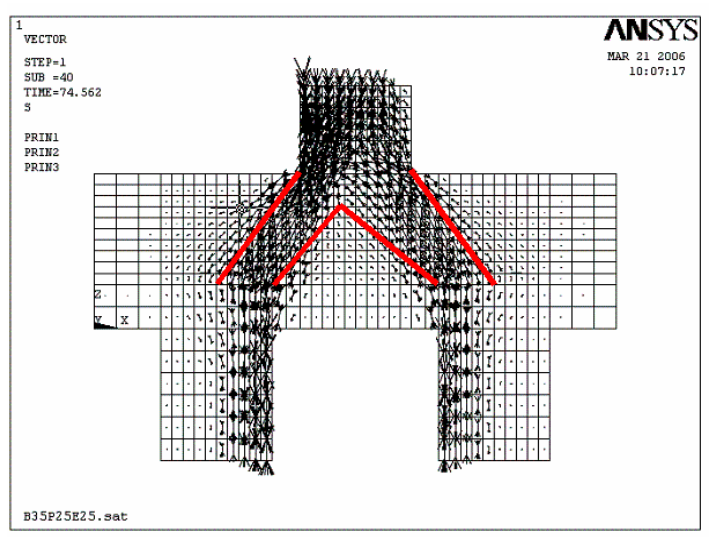

Figura 7.34 - Fluxo das tensões principais de compressão, modelo B35P25E25e2,5.

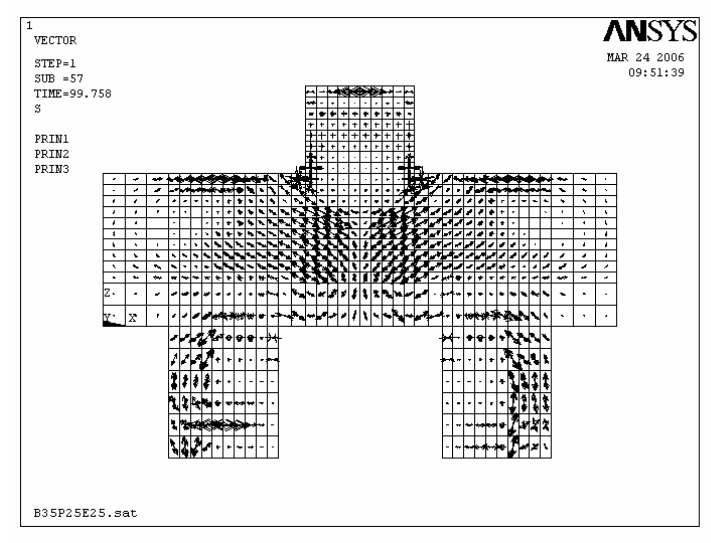

Figura 7.33 - Fluxo das tensões principais de tração, modelo B35P25E25e0.

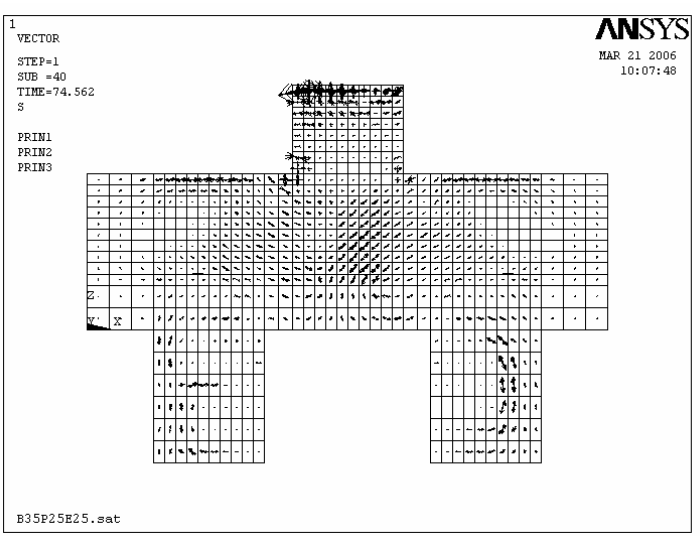

Figura 7.35 - Fluxo das tensões principais de tração, modelo B35P25E25e2,5. 


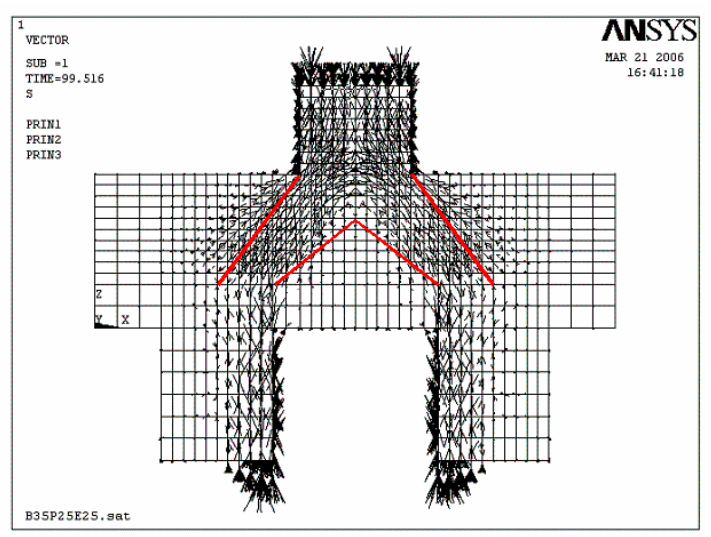

Figura 7.36 - Fluxo das tensões principais de compressão, modelo B35P25E25e0A $A_{\text {sw,c. }}$

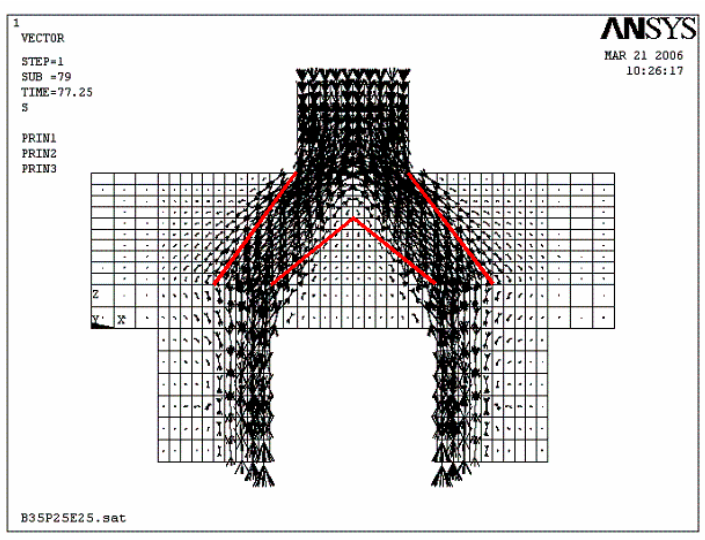

Figura 7.38 - Fluxo das tensões principais de compressão, modelo B35P25E25e0A $A_{s w, 0}$.

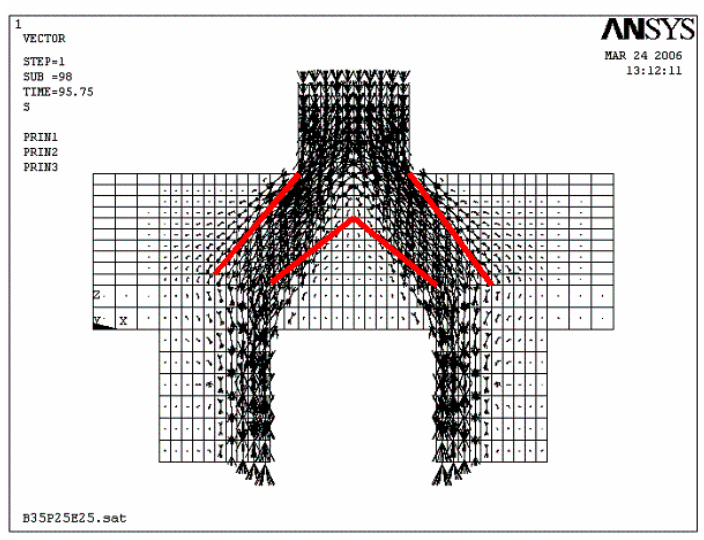

Figura 7.40 - Fluxo das tensões principais de compressão, modelo B35P25E25e0CG.

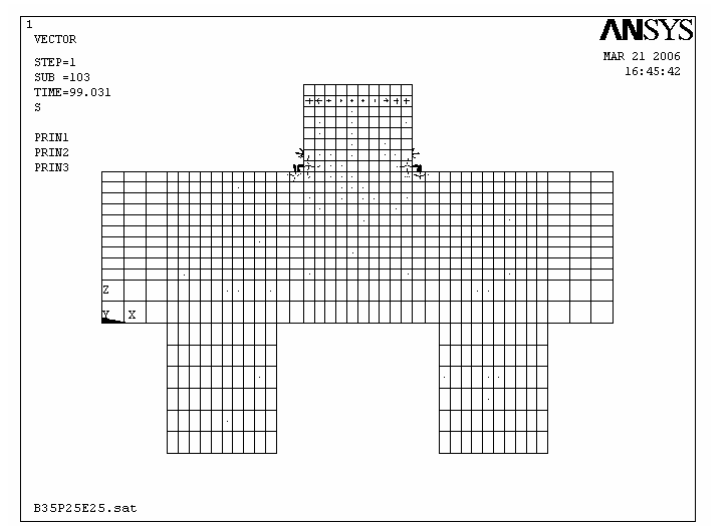

Figura 7.37 - Fluxo das tensões principais de tração, modelo B35P25E25e0A $A_{\text {sw,c. }}$

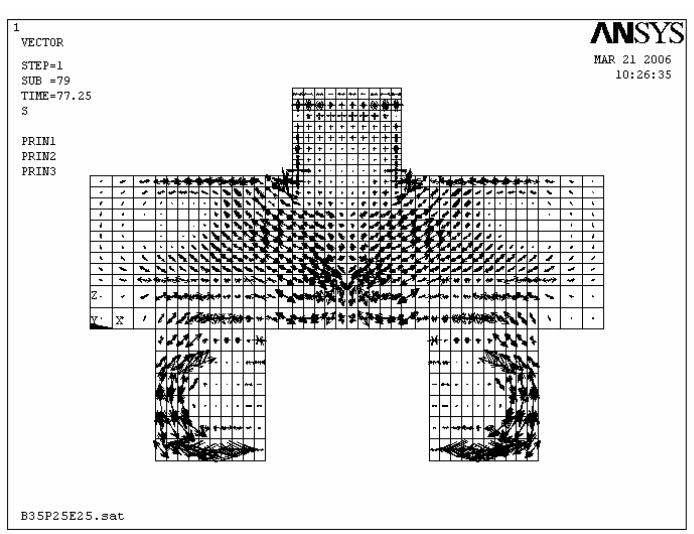

Figura 7.39 - Fluxo das tensões principais de tração, modelo B35P25E25e0A $\mathrm{sw}, 0$.

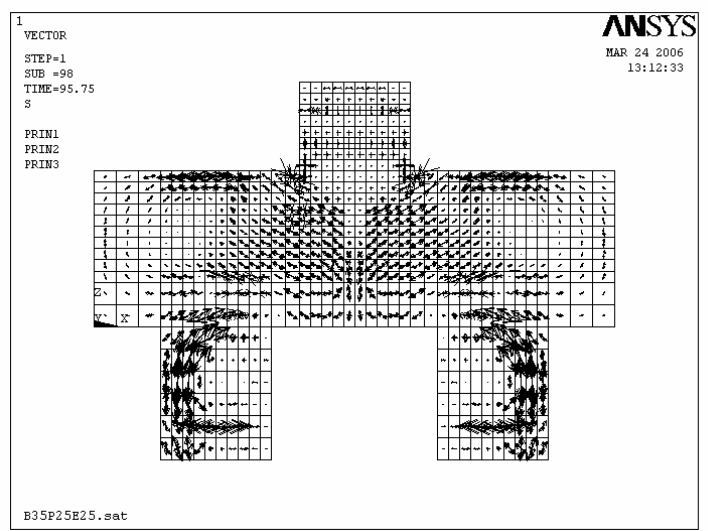

Figura 7.41 - Fluxo das tensões principais de tração, modelo B35P25E25e0CG. 


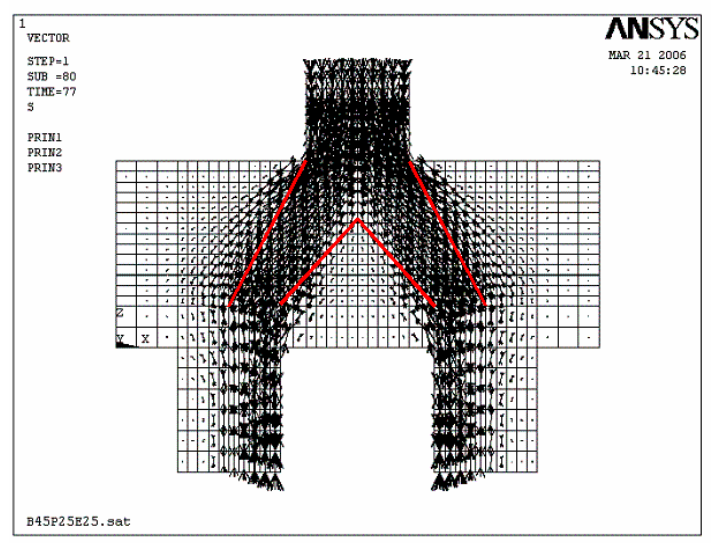

Figura 7.42 - Fluxo das tensões principais de compressão, modelo B45P25E25e0.

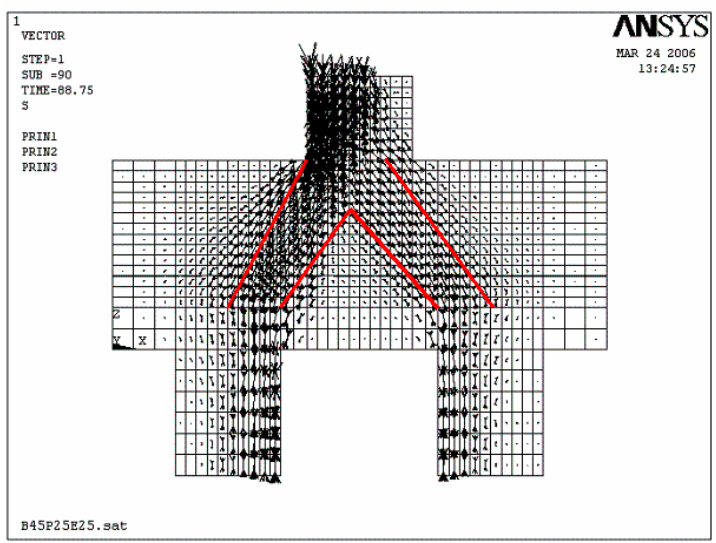

Figura 7.44 - Fluxo das tensões principais de compressão, modelo B45P25E25e5.

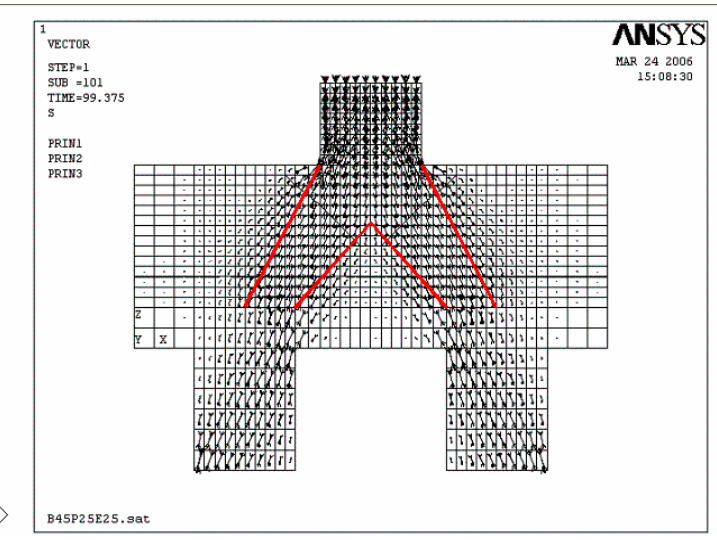

Figura 7.46 - Fluxo das tensões principais de compressão, modelo B45P25E25e0A $\mathrm{Aw}_{\text {, }}$.

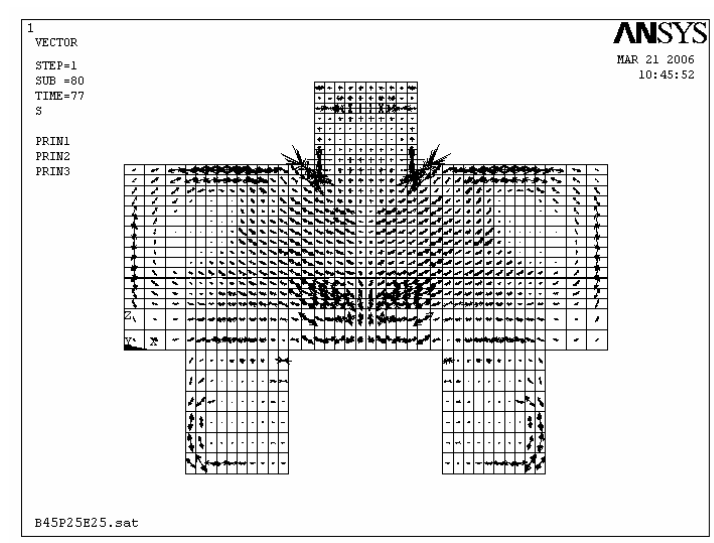

Figura 7.43 - Fluxo das tensões principais de tração, modelo B45P25E25e0.

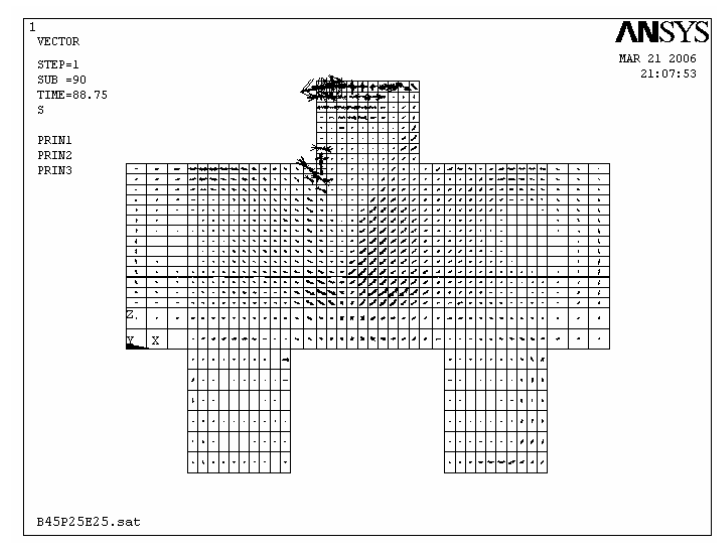

Figura 7.45 - Fluxo das tensões principais de tração, modelo B45P25E25e5.

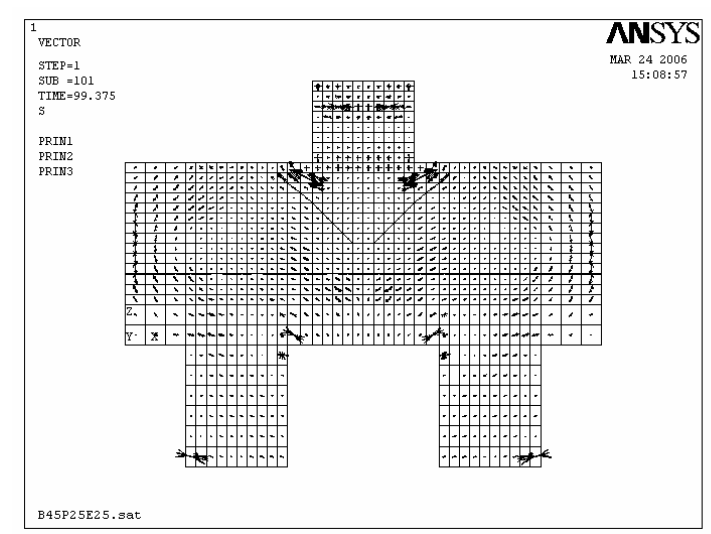

Figura 7.47 - Fluxo das tensões principais de tração, modelo B45P25E25e0A $A_{s w, c}$. 


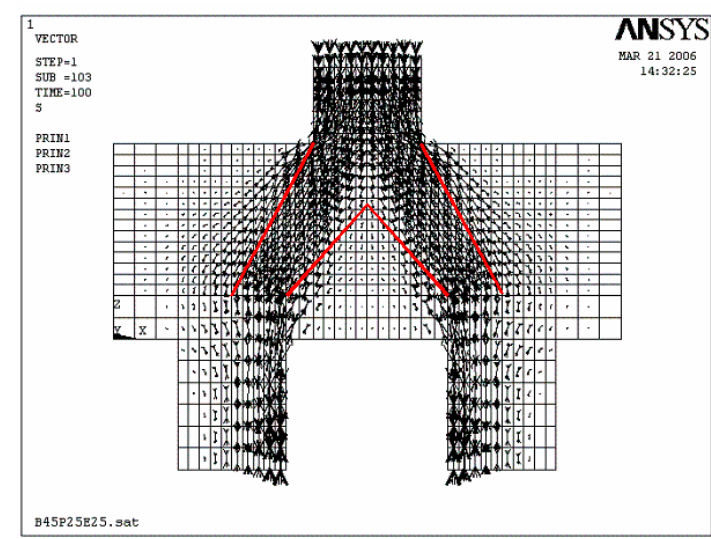

Figura 7.48 - Fluxo das tensões principais de compressão, modelo B45P25E25e0A $A_{s w, 0}$.

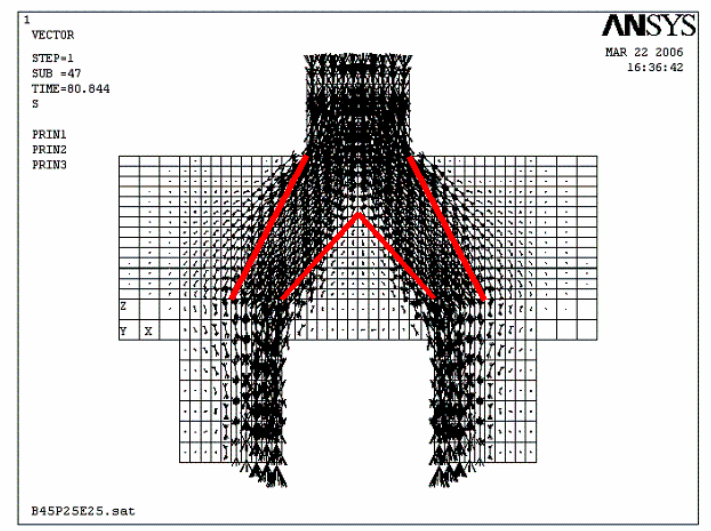

Figura 7.50 - Fluxo das tensões principais de compressão, modelo B45P25E25e0CG.

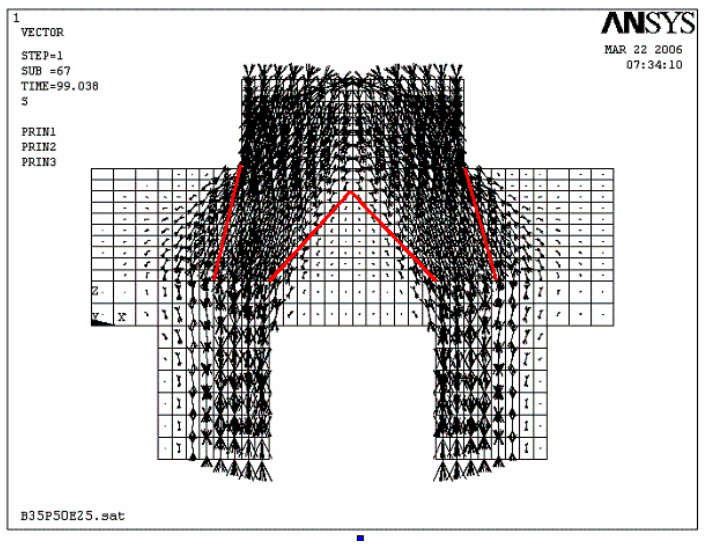

Figura 7.52 - Fluxo das tensões principais de compressão, modelo B35P50E25e0.

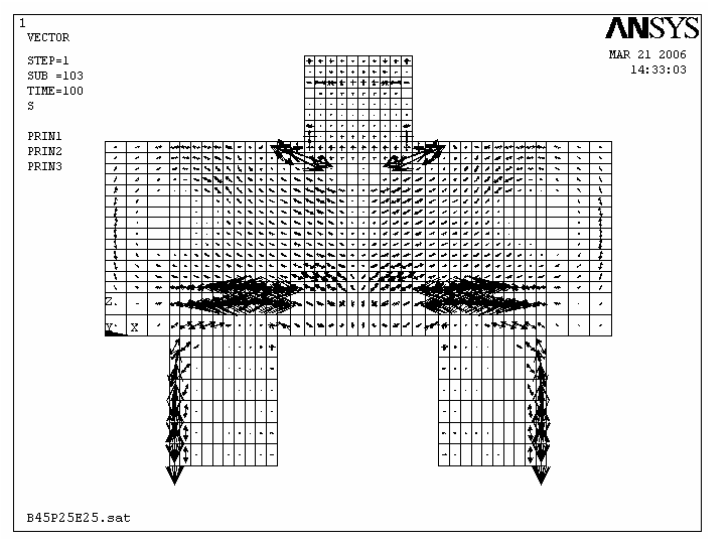

Figura 7.49 - Fluxo das tensões principais de tração, modelo B45P25E25e0A $\mathrm{A}_{\mathrm{sw}, 0}$.

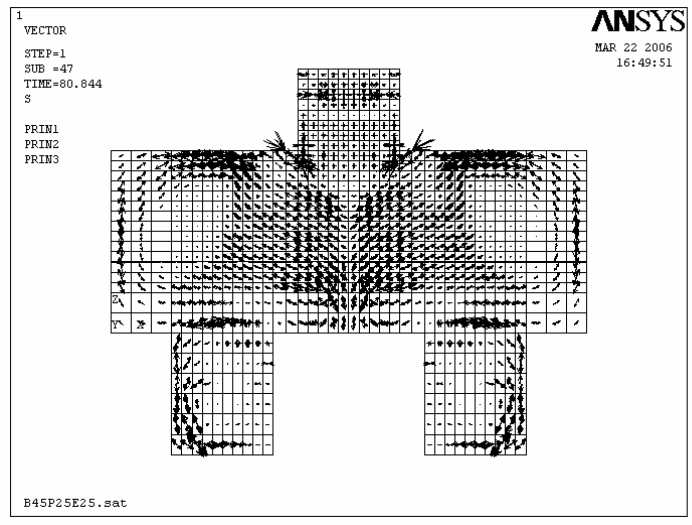

Figura 7.51 - Fluxo das tensões principais de tração, modelo B45P25E25e0CG.

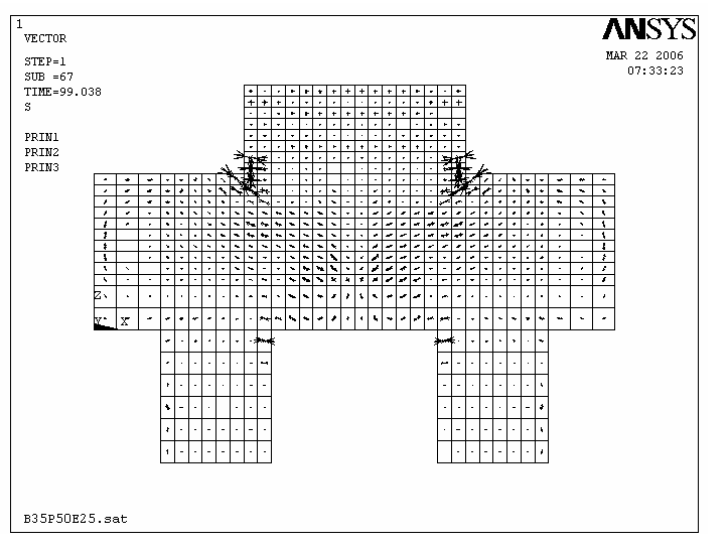

Figura 7.53 - Fluxo das tensões principais de tração, modelo B35P25E50e0. 


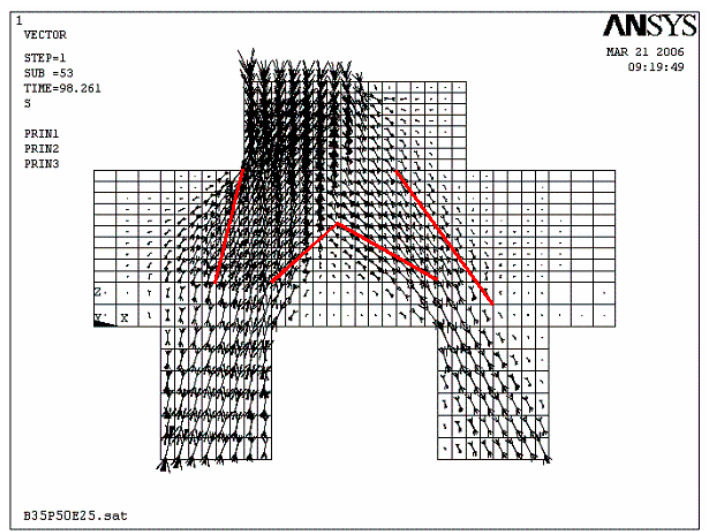

Figura 7.54 - Fluxo das tensões principais de compressão, modelo B35P50E25e12,5.

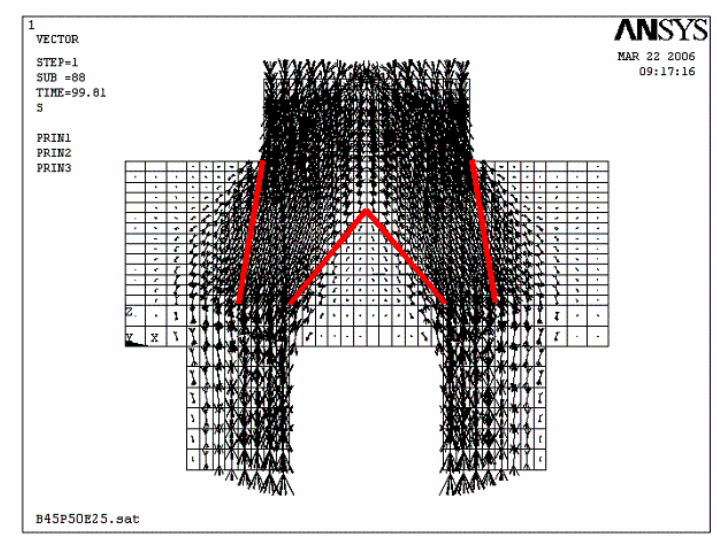

Figura 7.56 - Fluxo das tensões principais de compressão, modelo B45P50E25e0.

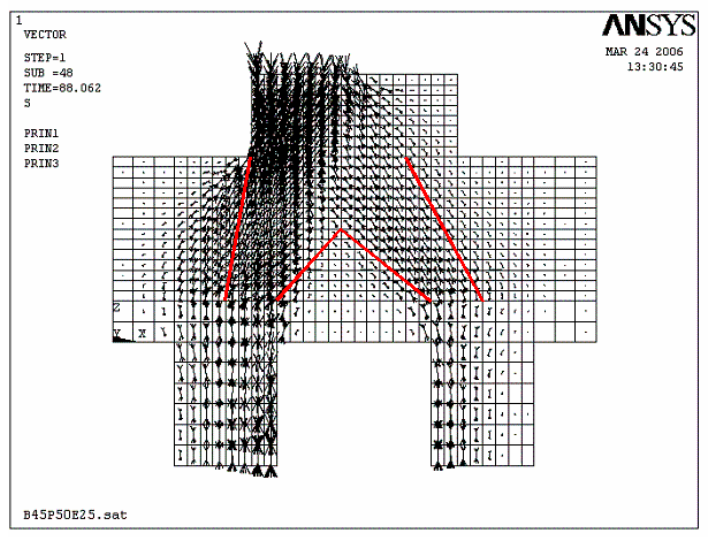

Figura 7.58 - Fluxo das tensões principais de compressão, modelo B45P50E25e12,5.

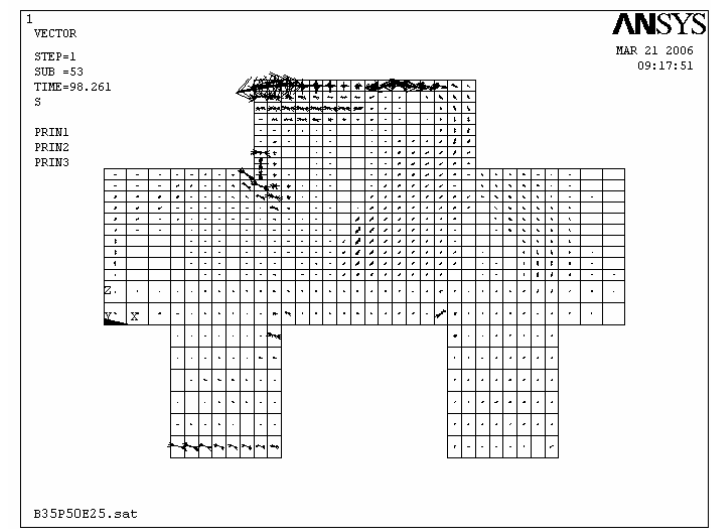

Figura 7.55 - Fluxo das tensões principais de tração, modelo B35P25E50e12,5.

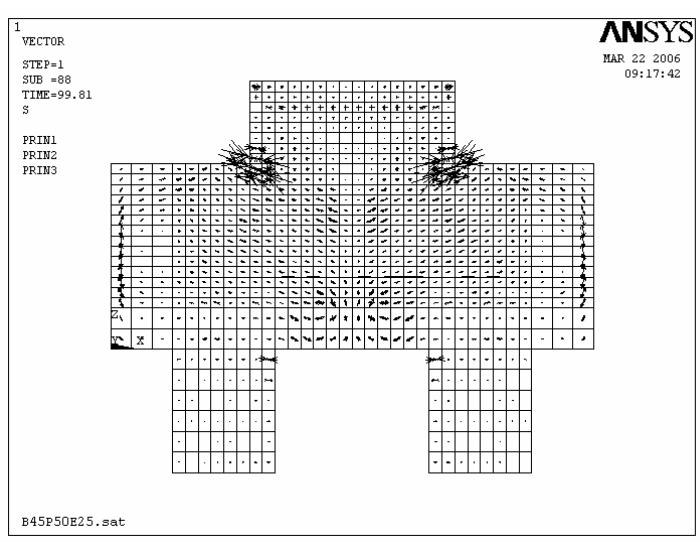

Figura 7.57 - Fluxo das tensões principais de tração, modelo B45P25E50e0.

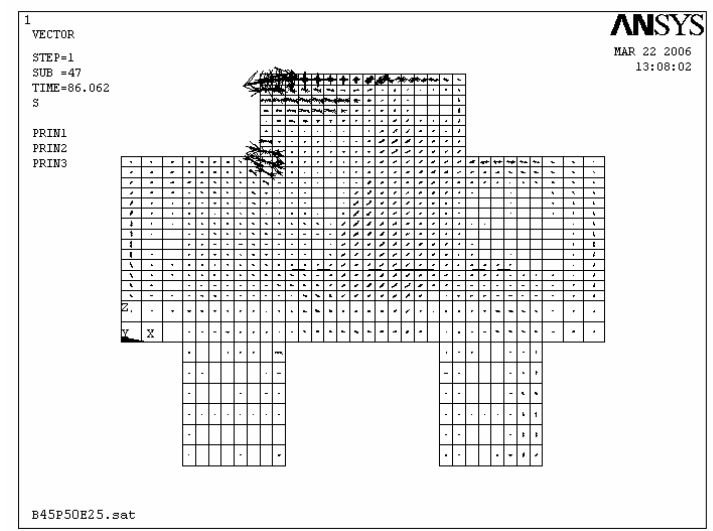

Figura 7.59 - Fluxo das tensões principais de tração, modelo B45P25E50e12,5. 
Observa-se por meio das figuras anteriores que existem tensões de tração ao longo das bielas de compressão. Essa observação é importante, pois por meio dela foi possível sugerir área de armadura mínima para absorver as tensões de tração perpendiculares às bielas.

\subsubsection{Tensões nas armaduras}

O comportamento das barras de aço das armaduras dos modelos numéricos foi semelhante ao comportamento das barras de aço das armaduras dos modelos ensaiados experimentalmente.

Com relação à armadura principal de tração do tirante, as máximas tensões ocorreram na seção de meio de vão do bloco e, nas seções sobre as estacas sofreram reduções significativas função da ação favorável das bielas.

Nota-se que os estribos horizontais foram solicitados por tensões de tração quando atravessaram as regiões das bielas.

Um fato muito importante, que também pode ser constatado no item 7.3.2, é com relação a flexo-compressão das estacas, observa-se que às barras de aço das mesmas apresentaram tensões com diferentes intensidades e em alguns casos as barras mais próximas da borda do bloco foram tracionadas.

A Tabela 7.1 mostra os valores das tensões (experimental e numérica) das barras de aço da armadura principal de tração na seção de meio do vão do bloco.

Tabela 7.1 - Tensões médias nas armaduras, no E.L.U.

\begin{tabular}{|c|c|c|c|}
\hline \multirow[t]{2}{*}{ Modelos } & $\begin{array}{c}\sigma_{\mathrm{y}, \text { exp,m }} \\
(\mathrm{MPa})\end{array}$ & $\begin{array}{c}\sigma_{y, \text { num,m }} \\
(\mathrm{MPa})\end{array}$ & \multirow[t]{2}{*}{$\sigma_{y, \exp , m} / \sigma_{y, n u m, m}$} \\
\hline & Seção: meio do bloco & Seção: meio do bloco & \\
\hline B35P25E25e0 & 392 & 413 & 0,95 \\
\hline B35P25E25e2,5 & 446 & 409 & 1,09 \\
\hline $\mathrm{B}^{2}$ P25E25e0A $\mathrm{A}_{\mathrm{sw}, \mathrm{C}}$ & 384 & 353 & 1,09 \\
\hline B35P25E25e0A $A_{s w, 0}$ & 340 & 390 & 0,87 \\
\hline B35P25E25e0CG & 322 & 352 & 0,99 \\
\hline B45P25E25e0 & 590 & 505 & 1,17 \\
\hline B45P25E25e5 & 436 & 386 & 1,13 \\
\hline B45P25E25e0A $A_{s w, C}$ & 372 & 459 & 0,81 \\
\hline B45P25E25e0A $A_{s w, 0}$ & 380 & 353 & 1,08 \\
\hline B45P25E25e0CG & 430 & 416 & 1,03 \\
\hline B35P50E25e0 & 402 & 407 & 0,99 \\
\hline B35P50E25e12,5 & 424 & 428 & 0,99 \\
\hline B45P50E25e0 & 504 & 437 & 1,15 \\
\hline B45P50E25e12,5 & 398 & 401 & 0,99 \\
\hline \multicolumn{3}{|c|}{ Valores médios } & 1,03 \\
\hline
\end{tabular}

Nota: $\sigma_{y, e x p, m}$, tensão de tração média experimental nas barras de aço; $\sigma_{y, n u m, m}$, tensão de tração média numérica nas barras de aço; * diferença máxima e mínima entre os resultados numéricos e experimentais. 
Em geral, os valores das tensões obtidas por meio das simulações numéricas apresentaram boa correlação, a menos do modelo B45P50E25e0A $\mathrm{sw}_{\mathrm{s}, \mathrm{c}}$ que apresentou diferença de dezenove por cento.

As Figuras 7.60 a 7.73 mostram as tensões nas barras de aço no último incremento de carregamento, em megapascals, para cada modelo analisado.

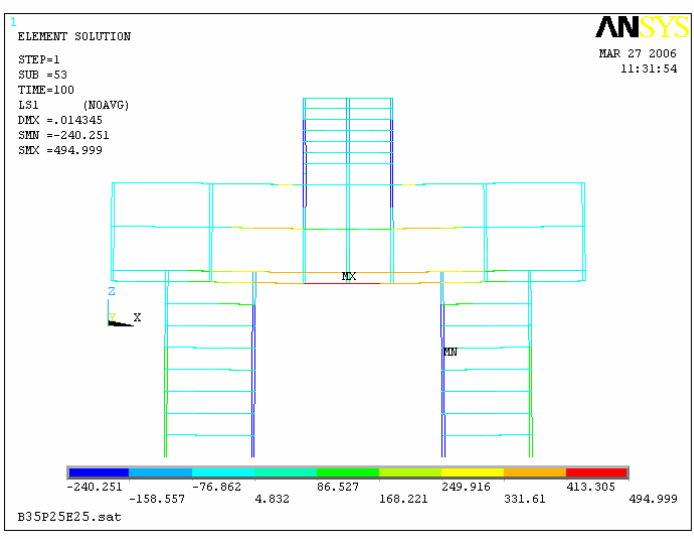

Figura 7.60 - Tensões nas barras de aço, modelo B35P25E25e0.

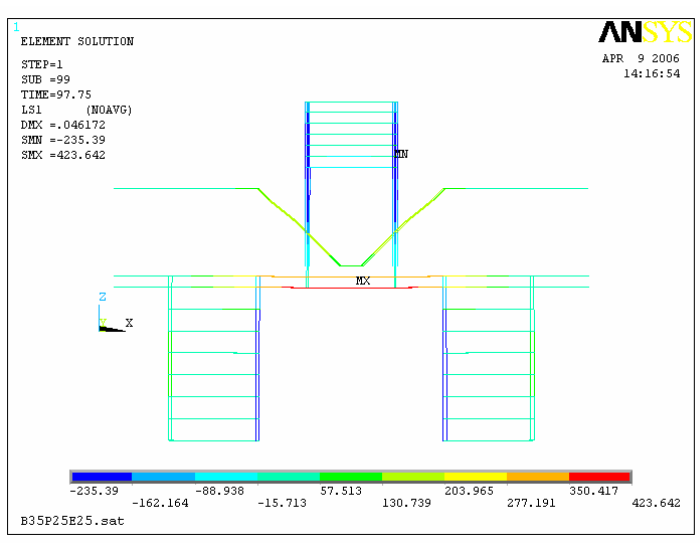

Figura 7.62 - Tensões nas barras de aço, modelo B35P25E25e0A $A_{s w, C}$.

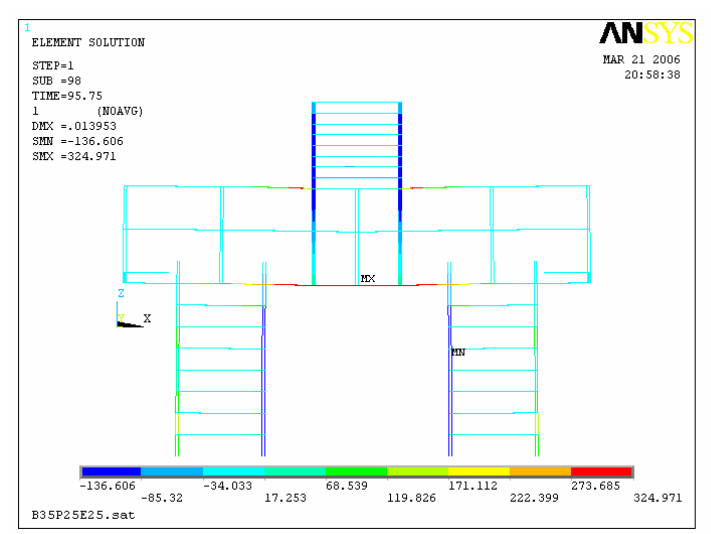

Figura 7.64 - Tensões nas barras de aço, modelo B35P25E25e0CG.

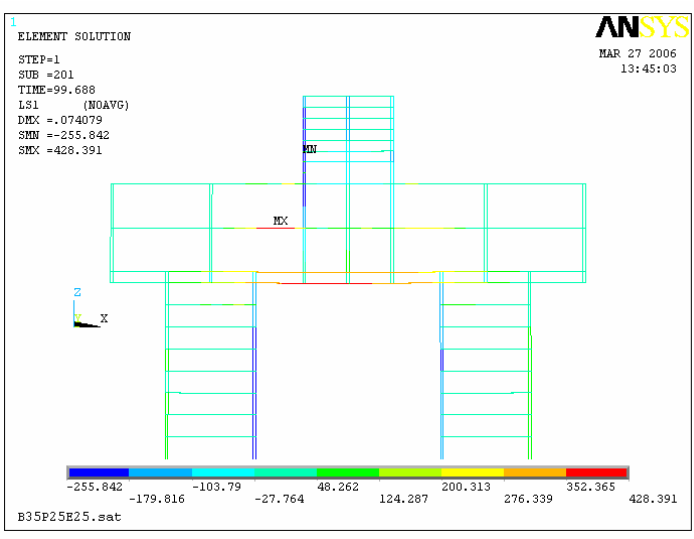

Figura 7.61 - Tensões nas barras de aço, modelo B35P25E25e2,5.

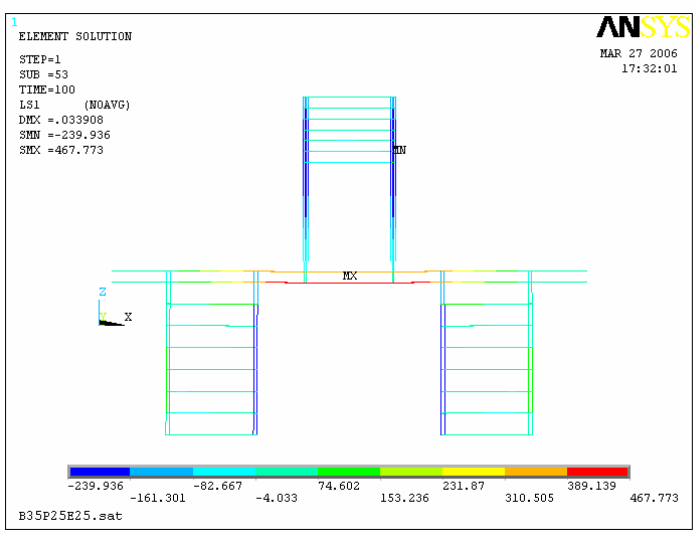

Figura 7.63 - Tensões nas barras de aço,

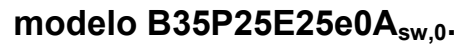

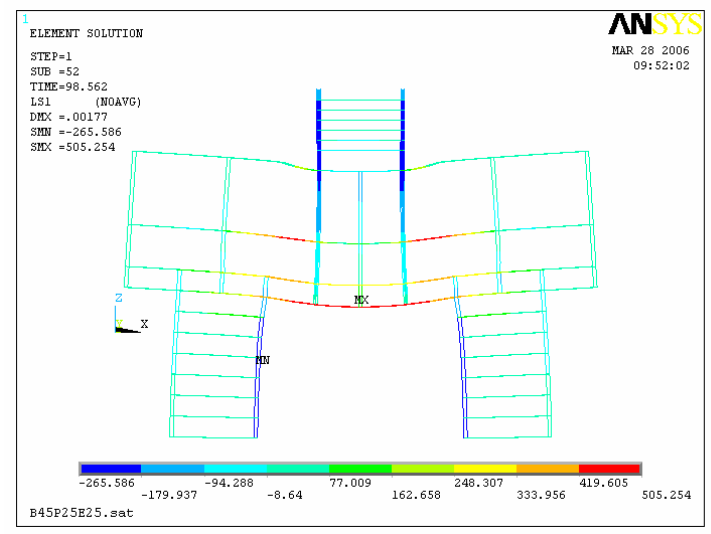

Figura 7.65 - Tensões nas barras de aço, modelo B45P25E25e0. 


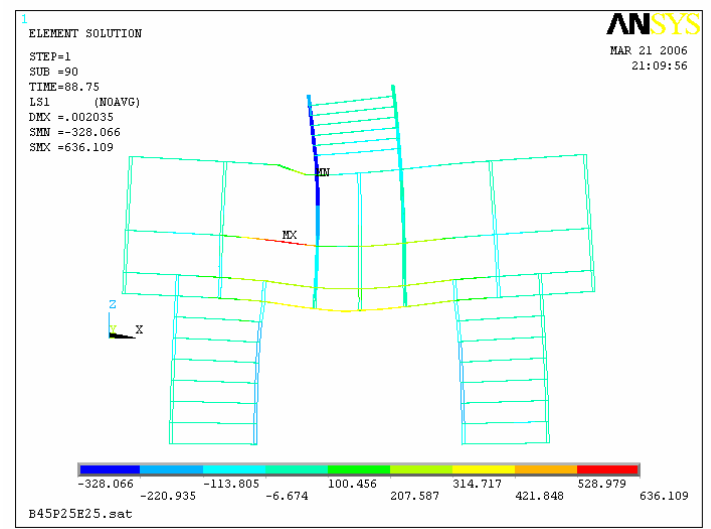

Figura 7.66 - Tensões nas barras de aço, modelo B45P25E25e5.

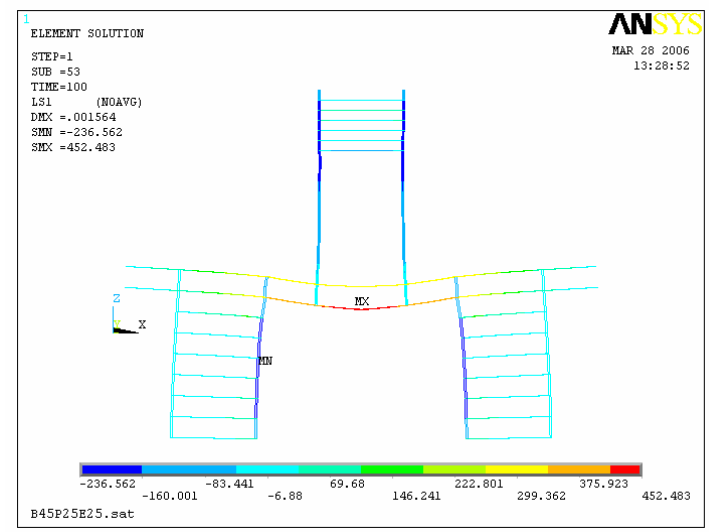

Figura 7.68 - Tensões nas barras de aço, modelo B45P25E25e0A $A_{s w, 0}$.

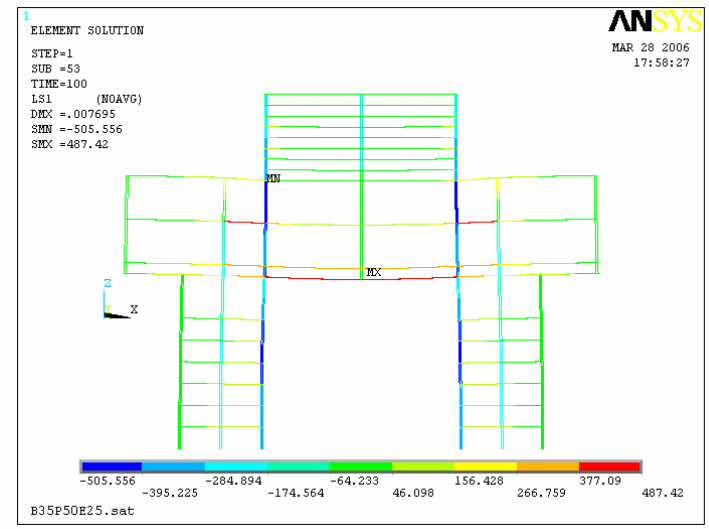

Figura 7.70 - Tensões nas barras de aço, modelo B35P50E25e0.

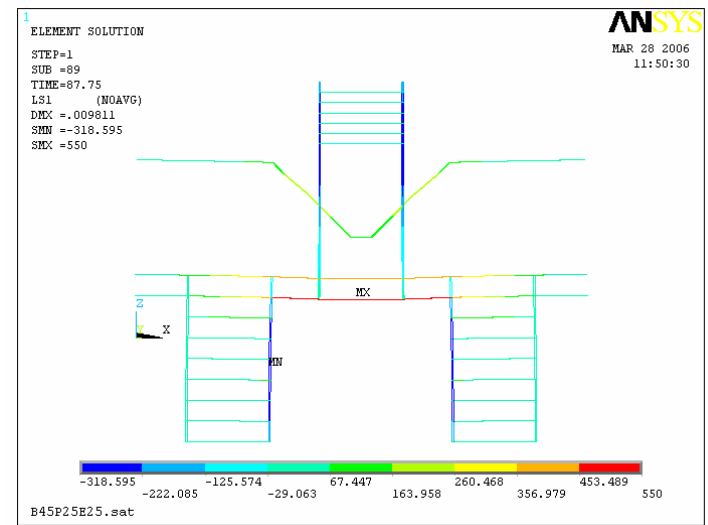

Figura 7.67 - Tensões nas barras de aço,

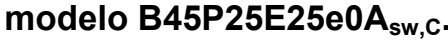

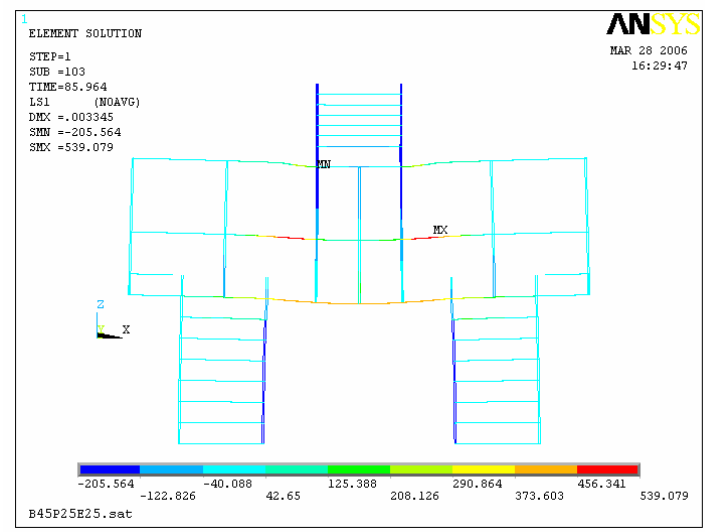

Figura 7.69 - Tensões nas barras de aço, modelo B45P25E25e0CG.

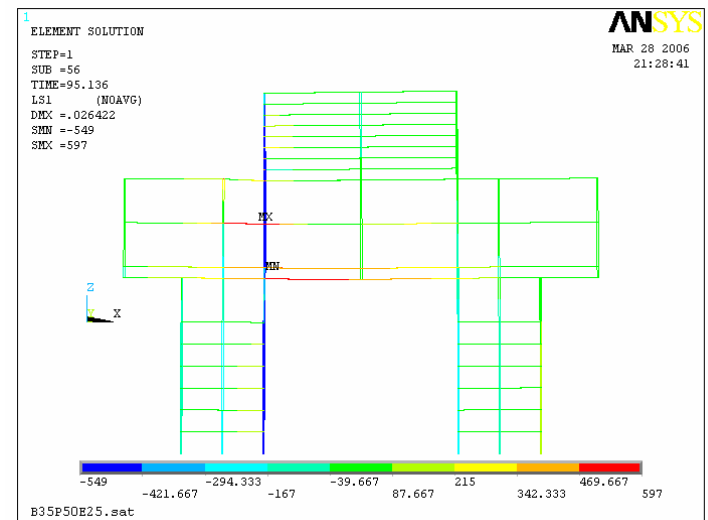

Figura 7.71 - Tensões nas barras de aço, modelo B35P50E25e12,5. 


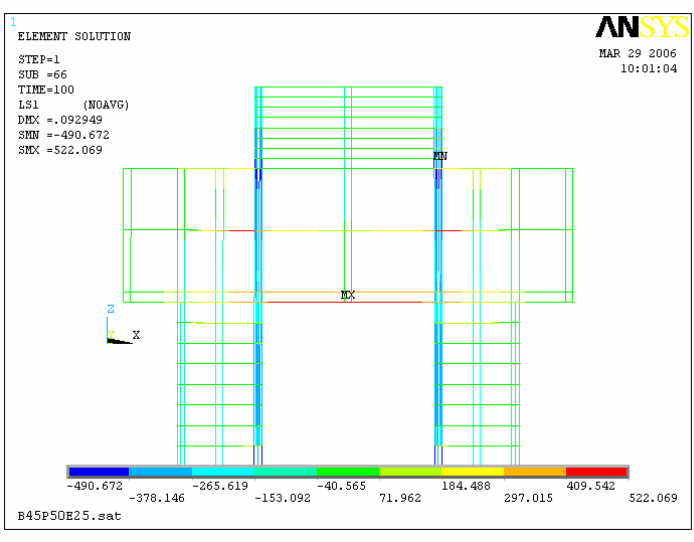

Figura 7.72 - Tensões nas barras de aço, modelo B45P50E25e0.

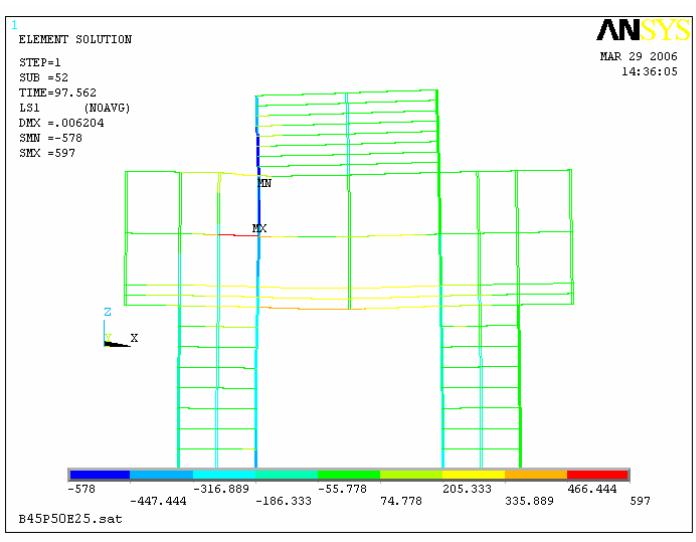

Figura 7.73 - Tensões nas barras de aço, modelo B45P50E25e12,5.

Nos modelos B35P25E25e0A $A_{s w, c}$ e B45P25E25e0A $A_{s w, c}$ observa-se que a armadura sugerida pelo autor realmente é mais solicitada na região em que atravessam as bielas.

Em função da existência de tensões de tração nos estribos horizontais e na armadura sugerida pelo autor, comprova-se à existência das tensões de tração perpendicular às bielas que podem causar fendilhamento.

\subsubsection{Relação força vs. deslocamento}

Este item apresenta gráficos que comparam o comportamento dos modelos numérico e experimental como já mencionado, os modelos numéricos se apresentaram mais rígidos que os experimentais.

A Tabela 7.2 apresenta a relação entre as forças últimas obtidas por meio das análises numérica e experimental notando-se boa correlação entre os valores.

As Figuras 7.74 a 7.87 apresentam as curvas força vs. deslocamento da seção de meio de vão dos modelos analisados.

Fundamentado na teoria da análise limite, que diz: "para fins de determinação da capacidade limite de carga de uma estrutura, é possível dispensar uma análise evolutiva das tensões e das deformações, admitindo-se, simplificadamente, que o material tenha comportamento elasto-plástico perfeito". E como, o modelo de biela e tirante é garantido pelo Teorema do Limite inferior considera-se que, para fins de obtenção da distribuição do fluxo de tensões na iminência da ruína os resultados da análise numérica foram proveitosos, apesar das diferenças existentes entre as rigidezes dos modelos numéricos e experimentais. 
Tabela 7.1 - Forças últimas.

\begin{tabular}{|c|c|c|c|}
\hline Modelos & $\begin{array}{c}F_{u, \exp } \\
(k N)\end{array}$ & $\begin{array}{c}F_{u, \text { num }} \\
(\mathrm{kN})\end{array}$ & $F_{u, \exp } / F_{u, \text { num }}$ \\
\hline В35P25E25e0 & 1821 & 1971 & 0,92 \\
\hline B35P25E25e2,5 & 1688 & 1668 & 1,02 \\
\hline B35P25E25e0A $A_{s w, C}$ & 1880 & 1891 & 0,99 \\
\hline B35P25E25e0A $\mathrm{s}_{\mathrm{sw}, 0}$ & 1406 & 1616 & 0,87 \\
\hline B35P25E25e0CG & 1263 & 1436 & 0,88 \\
\hline B45P25E25e0 & 2276 & 2267 & 1,01 \\
\hline B45P25E25e5 & 1972 & 1797 & 1,10 \\
\hline B45P25E25e0A $A_{s w, C}$ & 3055 & 3081 & 0,99 \\
\hline B45P25E25e0A ${ }_{s w, 0}$ & 2090 & 2100 & 0,99 \\
\hline B45P25E25e0CG & 2270 & 1966 & 1,15 \\
\hline B35P50E25e0 & 3877 & 3862 & 1,00 \\
\hline B35P50E25e12,5 & 3202 & 3193 & 1,00 \\
\hline B45P50E25e0 & 4175 & 4175 & 1,00 \\
\hline B45P50E25e12,5 & 3386 & 3319 & 1,02 \\
\hline \multicolumn{3}{|c|}{ Valores médios } & 0,99 \\
\hline
\end{tabular}

Nota: $F_{u, e x p}$, força última obtida experimentalmente; $F_{u, n u m}$, força última obtida numericamente.

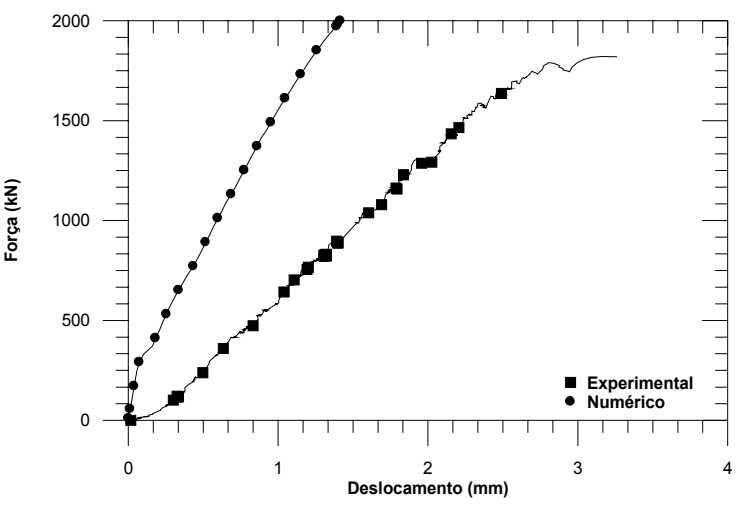

Figura 7.74 - Curva força vs. deslocamento no meio do vão do bloco, modelo B35P25E25e0.

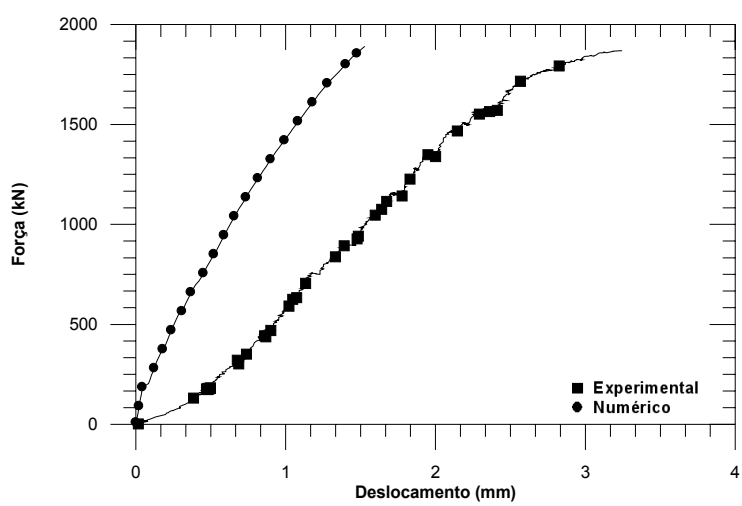

Figura 7.76 - Curva força vs. deslocamento no meio do vão do bloco, modelo B35P25E25e0A $A_{s w, c}$.

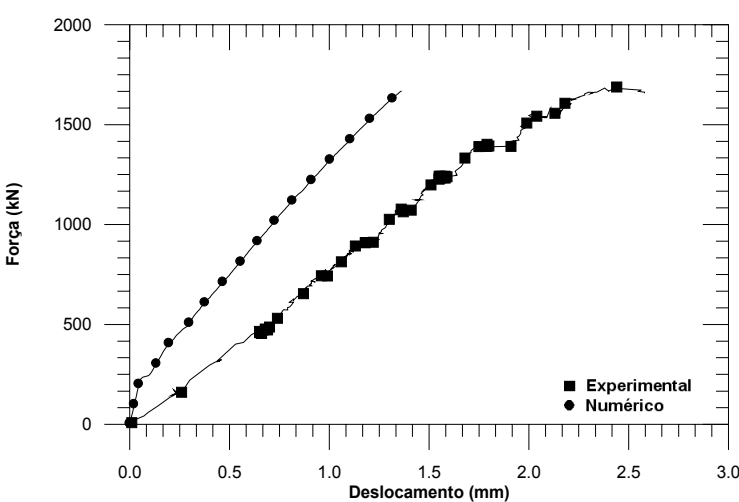

Figura 7.75 - Curva força vs. deslocamento no meio do vão do bloco, modelo B35P25E25e2,5.

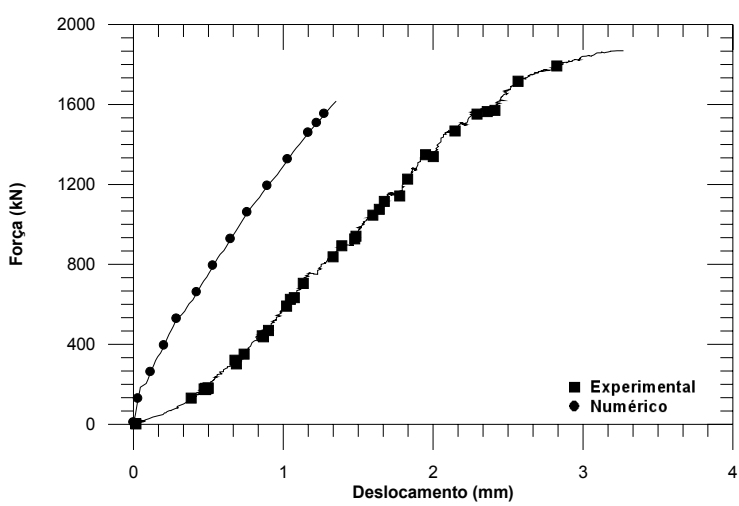

Figura 7.77 - Curva força vs. deslocamento no meio do vão do bloco, modelo B35P25E25e0A $A_{s w, 0}$. 


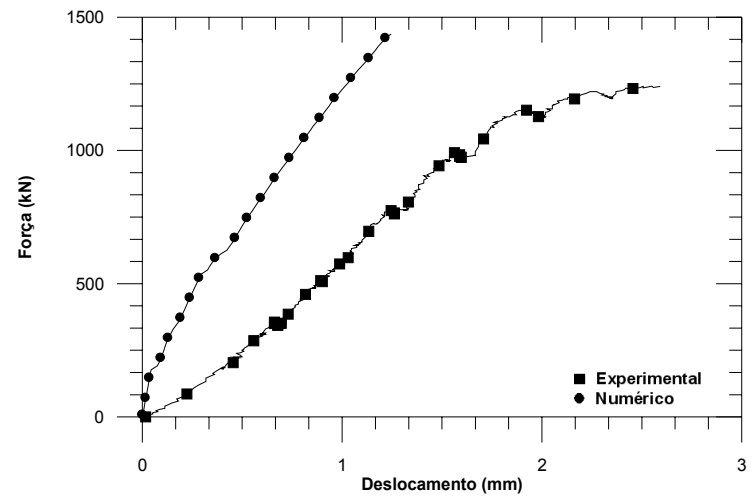

Figura 7.78 - Curva força vs. deslocamento no meio do vão do bloco, modelo B35P25E25e0CG.

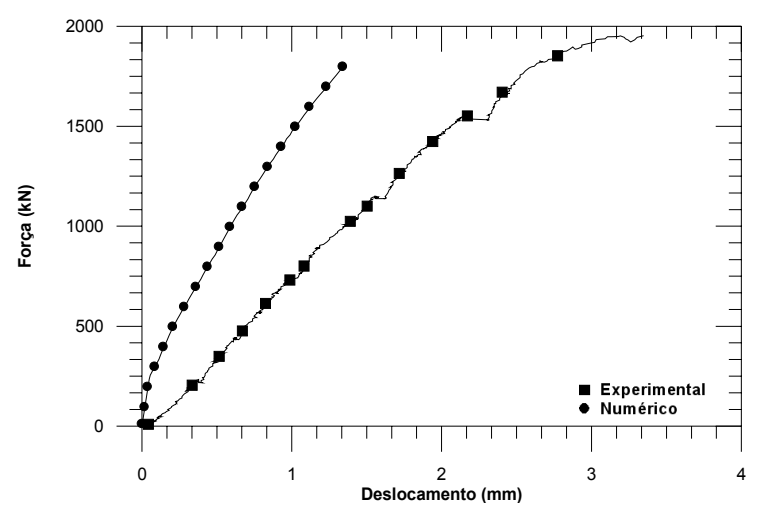

Figura 7.80 - Curva força vs. deslocamento no meio do vão do bloco, modelo B45P25E25e5.

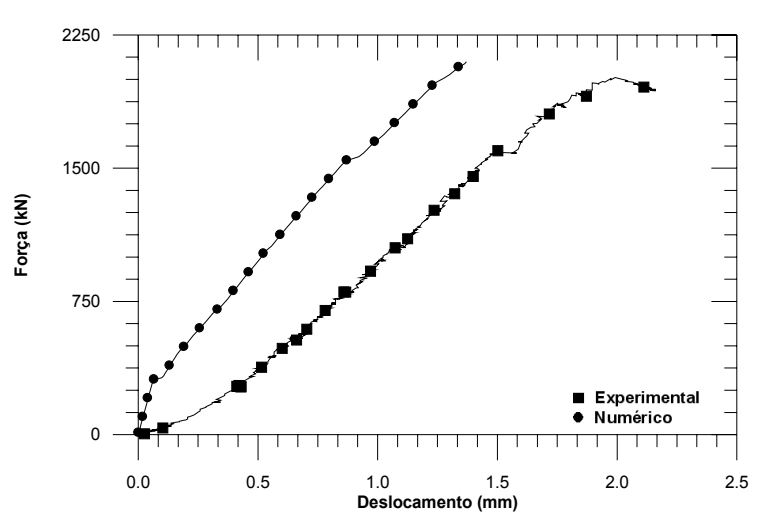

Figura 7.82 - Curva força vs. deslocamento no meio do vão do bloco, modelo B45P25E25e0A $A_{s w, 0}$.

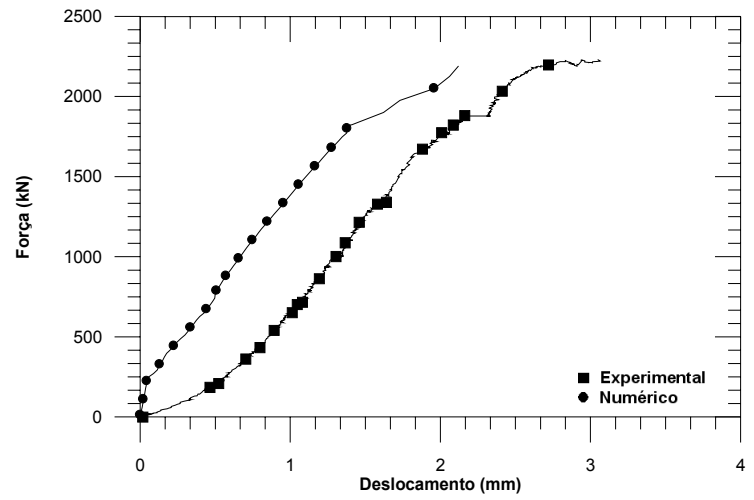

Figura 7.79 - Curva força vs. deslocamento no meio do vão do bloco, modelo B45P25E25e0.

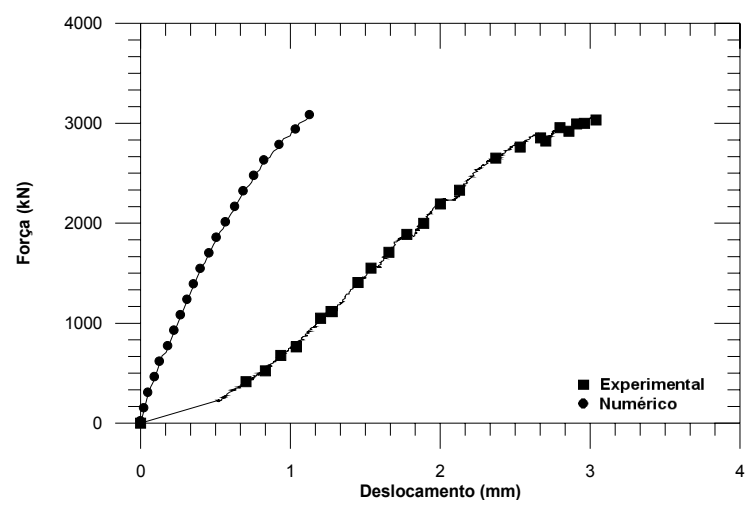

Figura 7.81 - Curva força vs. deslocamento no meio do vão do bloco, modelo B45P25E25e0A $A_{s w, c}$.

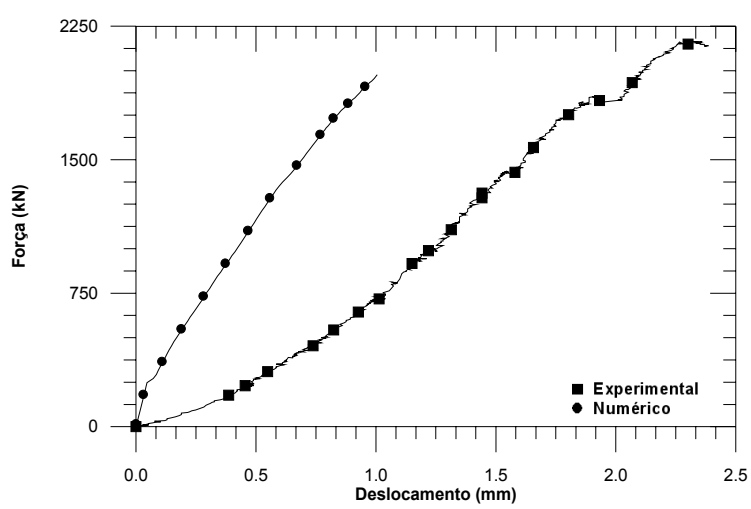

Figura 7.83 - Curva força vs. deslocamento no meio do vão do bloco, modelo B45P25E25e0CG. 


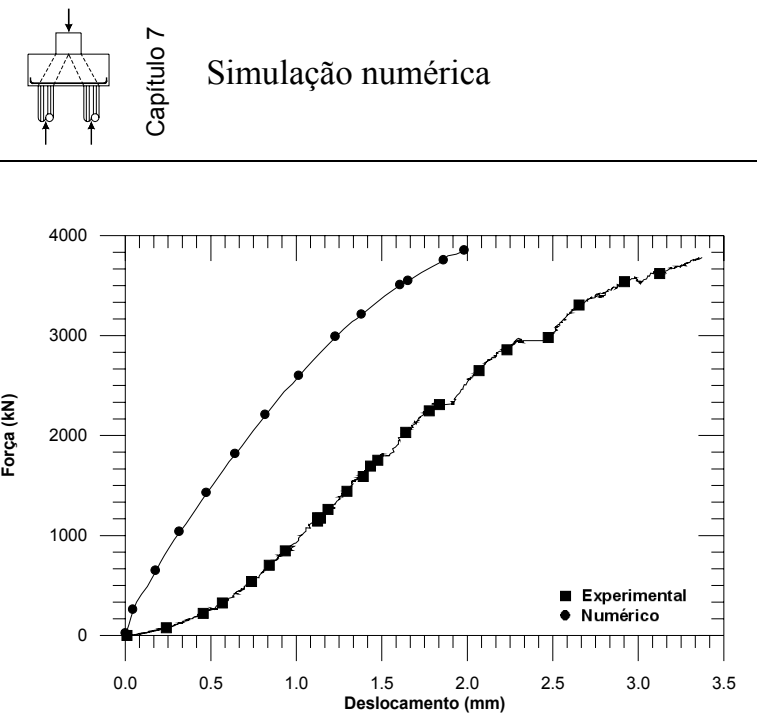

Figura 7.84 - Curva força vs. deslocamento no meio do vão do bloco, modelo B35P50E25e0.

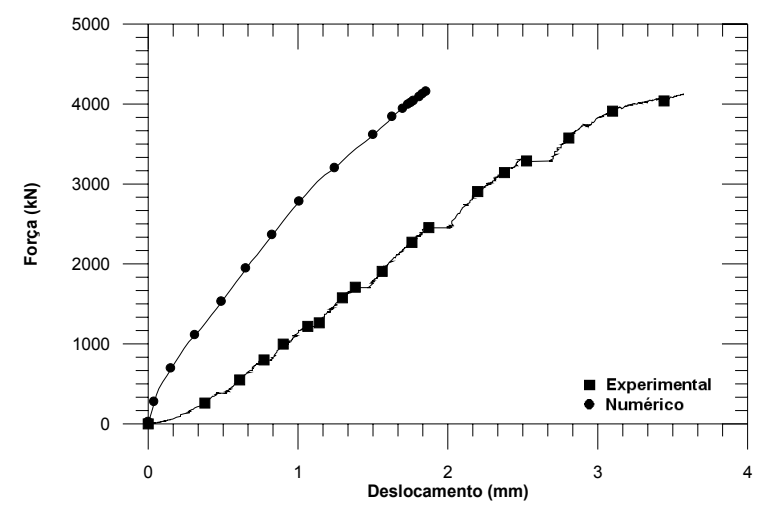

Figura 7.86 - Curva força vs. deslocamento no meio do vão do bloco, modelo B45P50E25e0.

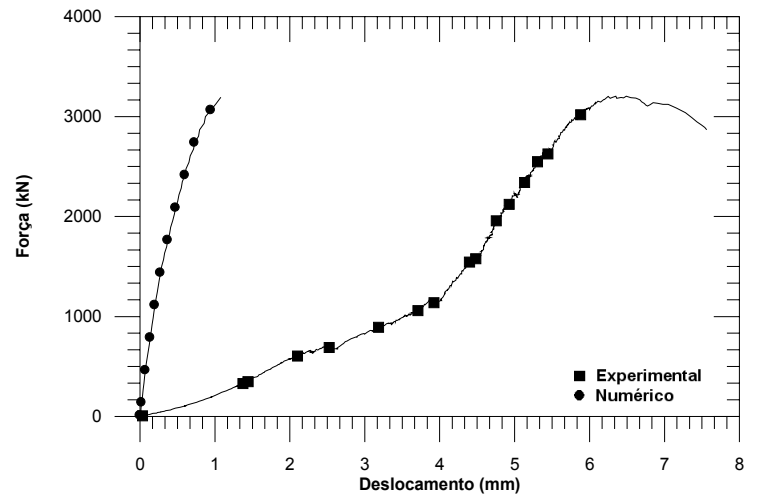

Figura 7.85 - Curva força vs. deslocamento no meio do vão do bloco, modelo B35P50E25e12,5.

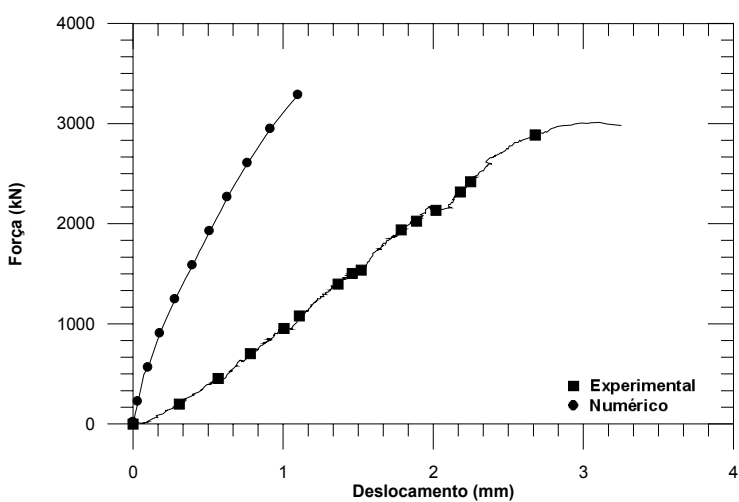

Figura 7.87 - Curva força vs. deslocamento no meio do vão do bloco, modelo B45P50E25e12,5.

Todos os modelos tiveram comportamento similar, a menos do modelo B35P50E25e12,5 (Figura 7.85). Observa-se que durante o início do ensaio experimental o modelo sofreu acomodações, após isto, ganhou rigidez e apresentou o mesmo comportamento dos demais modelos. 



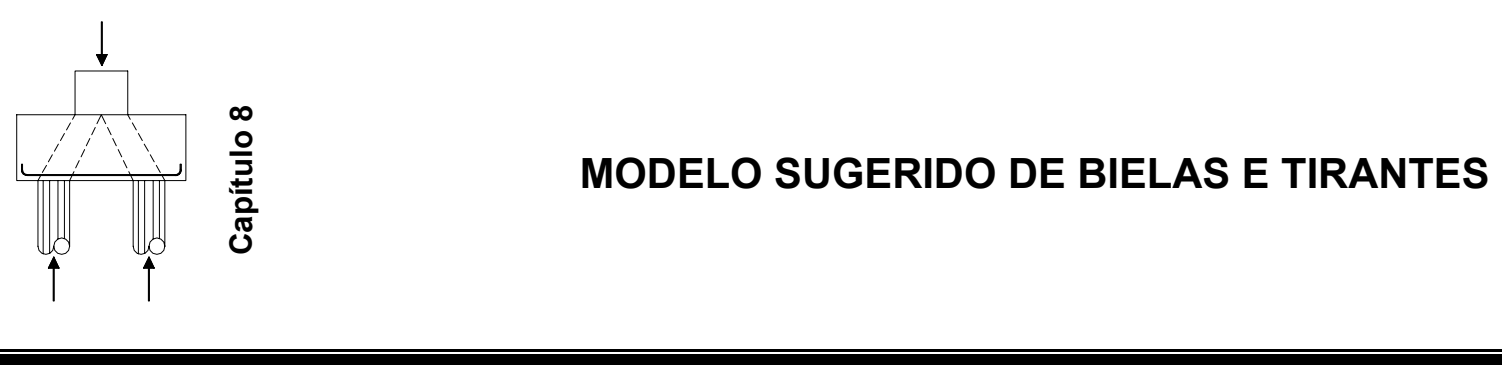

\subsection{Considerações iniciais}

Em função dos resultados experimentais e numéricos foi possível desenvolver um modelo de dimensionamento de blocos sobre duas estacas baseado na analogia de Bielas e Tirantes.

Ficou claro que apenas parte da estaca é solicitada de maneira mais intensa, em função disto admitiu-se, a favor da segurança, que a zona nodal inferior seja composta por apenas metade da área da estaca. Além disto, uma armadura para absorver às tensões perpendiculares à direção da biela (armadura de fendilhamento) foi sugerida.

Este modelo é simples e traz modificações com relação aos demais modelos existentes na literatura técnica, como a verificação das tensões na região nodal inferior, a existência de uma armadura de fendilhamento e a maneira que a estaca é solicitada.

\subsection{Idealização do modelo}

O modelo foi idealizado em função da distribuição do fluxo das tensões principais de compressão.

Simplificadamente admitiu-se que as bielas de compressão estejam delimitadas pelas linhas (na cor vermelha) que unem as regiões nodais inferior e superior, como mostrado na Figura 8.1 e 8.2.

A verificação das tensões nas zonas nodais inferior e superior são realizadas em função da área da seção transversal estaca, da seção transversal do pilar e do ângulo de inclinação da biela de compressão $\theta_{\mathrm{m}}$. 
As tensões limites foram estabelecidas em função dos resultados experimentais. A Tabela 1 apresenta as tensões atuantes nas regiões nodais inferior e superior.

As linhas tracejadas nas Figuras 8.1 e 8.2 representam as bielas enquanto que as linhas contínuas representam os tirantes. Observa-se que os tirantes utilizados para absorver as tensões de tração existentes na direção perpendicular às bielas foram idealizados na metade da altura útil do bloco.

São apresentados dois modelos de cálculo, um para o caso com força centrada e outro para força excêntrica.

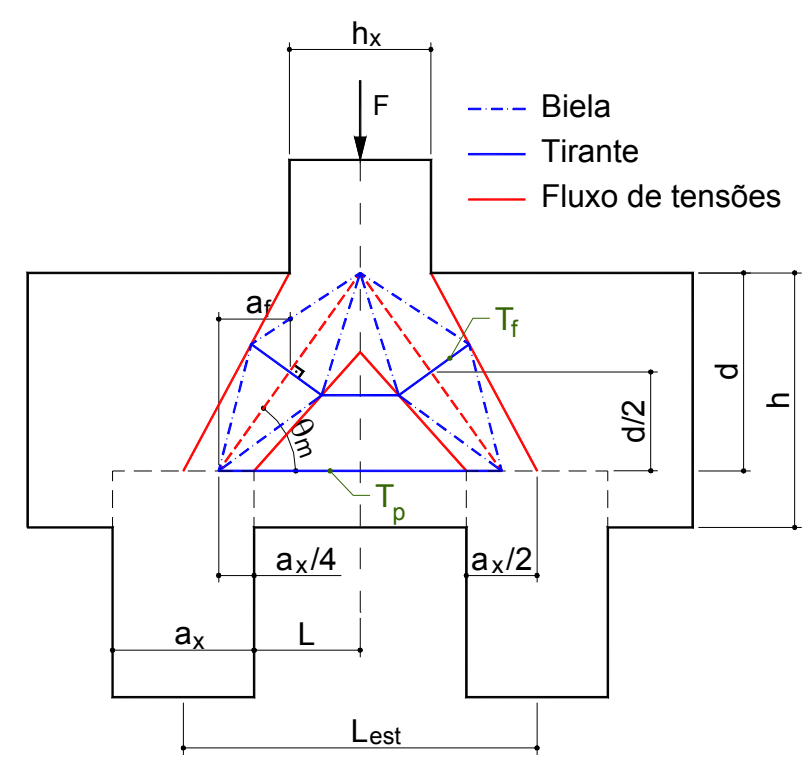

Figura 8.1 - Modelo de Bielas e Tirantes proposto para força centrada.

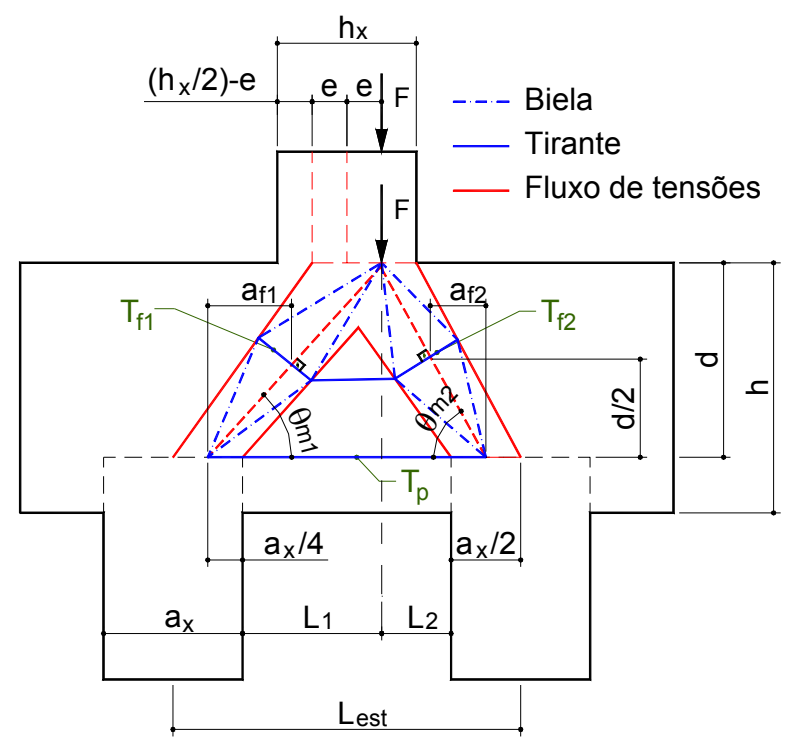

Figura 8.2 - Modelo de Bielas e Tirantes proposto para força excêntrica. 


\subsection{Modelo analítico}

Neste item são apresentadas equações para a determinação das tensões nodais inferior e superior como, também, informações necessárias para a construção do modelo de Bielas e Tirantes proposto.

\subsubsection{Modelo considerando força centrada}

A Figura 8.3 apresenta as regiões nodais inferior e superior como também as áreas idealizadas das bielas junto ao pilar e junto às estacas.

O ângulo de inclinação da biela de compressão $\theta_{\mathrm{m}}$ é definido por meio da Expressão 8.1.

$\theta_{\mathrm{m}}=\arctan \left(\frac{4 \cdot \mathrm{d}}{2 \cdot \mathrm{L}_{\text {est }}-\mathrm{a}_{\mathrm{x}}}\right)$

sendo:

- d, altura útil do bloco;

- $\quad L_{\text {est }}$, distância entre eixos das estacas;

- $a_{x}$, dimensão da estaca na direção considerada.

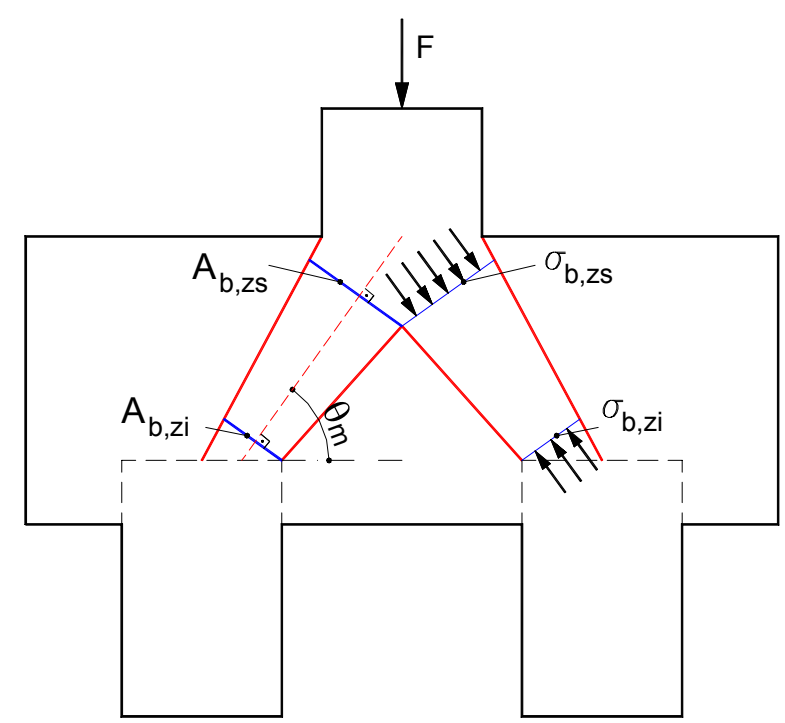

Figura 8.3 - Modelo de Bielas e Tirantes proposto para força centrada, tensões nas zonas nodais. 
A área da biela de compressão junto ao pilar é definida pela Expressão 8.2.

$$
\mathrm{A}_{\mathrm{b} . \mathrm{zs}}=\frac{\mathrm{h}_{\mathrm{x}} \cdot \mathrm{h}_{\mathrm{y}}}{2} \cdot \operatorname{sen}\left(\theta_{\mathrm{m}}\right)
$$

sendo:

- $h_{x}$ e $h_{y}$, dimensões da seção transversal do pilar;

- $A_{b, z s}$, área da biela junto ao pilar, zona nodal superior.

A área da biela de compressão junto à estaca é determinada por meio da Expressão 8.3.

$$
\mathrm{A}_{\mathrm{b} . \mathrm{zi}}=\frac{\mathrm{a}_{\mathrm{x}} \cdot \mathrm{a}_{\mathrm{y}}}{2} \cdot \operatorname{sen}\left(\theta_{\mathrm{m}}\right)
$$

sendo:

- $a_{x}$ e $a_{y}$, dimensões da seção transversal das estacas, normalmente, $a_{x}$ é igual à $a_{y}$, (estaca pré-moldadas), portanto:

$$
\mathrm{A}_{\mathrm{b} . \mathrm{ii}}=\frac{\mathrm{a}_{\mathrm{x}}^{2}}{2} \cdot \operatorname{sen}\left(\theta_{\mathrm{m}}\right)
$$

com:

- $\quad A_{b, z i}$, área da biela junto à estaca, zona nodal inferior.

Em se tratando de estacas de seção transversal circular, $a_{x}$ pode ser substituído pelo diâmetro da estaca.

Em função da força oriunda da superestrutura e das áreas das bielas junto às zonas nodais inferior e superior, determinam-se as tensões nas bielas junto às estacas e junto ao pilar (Expressões 8.5 e 8.6).

$$
\begin{aligned}
\sigma_{\mathrm{b} . \mathrm{zi}} & =\frac{\mathrm{F}}{\left[\operatorname{sen}\left(\theta_{\mathrm{m}}\right)\right]^{2} \cdot \mathrm{a}_{\mathrm{x}}^{2}} \\
\sigma_{\mathrm{b} . \mathrm{zs}} & =\frac{\mathrm{F}}{\left[\operatorname{sen}\left(\theta_{\mathrm{m}}\right)\right]^{2} \cdot \mathrm{h}_{\mathrm{x}} \cdot \mathrm{h}_{\mathrm{y}}}
\end{aligned}
$$

sendo:

- $\sigma_{\mathrm{b}, \mathrm{zi}}$, tensão na biela junto à estaca, zona nodal inferior;

- $\quad \sigma_{b, z s}$, tensão na biela junto ao pilar, zona nodal superior; 
A distância $a_{f}$ (Figura 8.1) é fornecida pela Expressão 8.7. Esta distância é importante, pois por meio dela procede-se o posicionamento correto dos tirantes destinados a absorverem as tensões de tração existentes na direção perpendicular à biela de compressão.

$$
\mathrm{a}_{\mathrm{f}}=\frac{2 \cdot \mathrm{L}_{\mathrm{est}}-\mathrm{a}_{\mathrm{x}}}{8}
$$

\subsubsection{Modelo considerando força excêntrica}

A Figura 8.4 apresenta as tensões nas regiões nodais inferior e superior. Observa-se que em função da excentricidade da força, às áreas das bielas de compressão têm dimensões diferentes. Este modelo pode ser aplicado para $e<h_{x} / 2$.

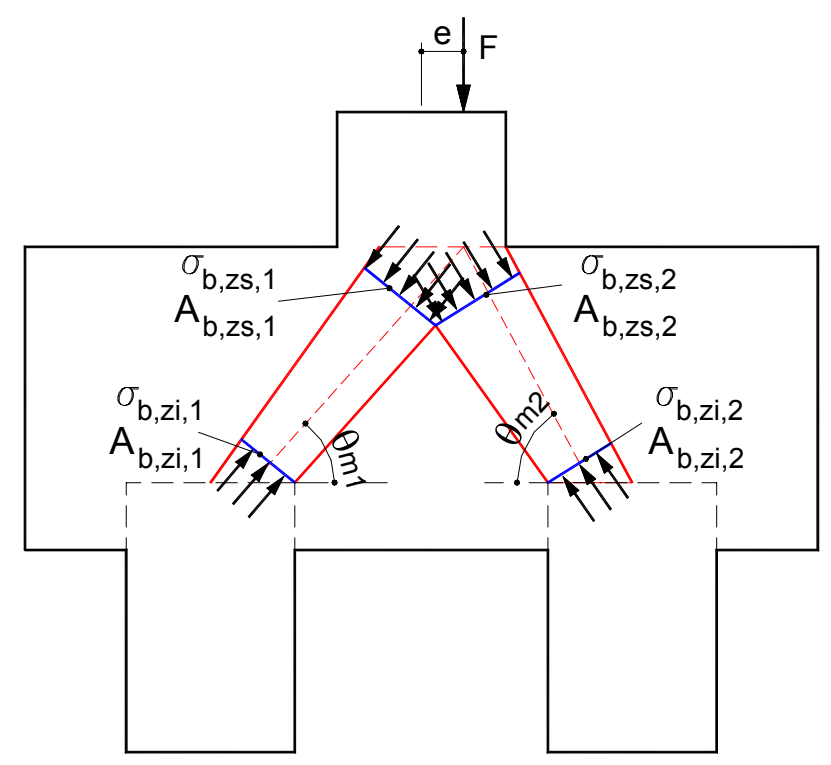

Figura 8.4 - Modelo de Bielas e Tirantes proposto para força excêntrica, tensões.

O ângulo de inclinação das bielas de compressão, $\theta_{\mathrm{m} 1}$ e $\theta_{\mathrm{m} 2}$ são calculados por meio da Expressão 8.8 e 8.9.

$$
\begin{aligned}
& \theta_{\mathrm{m} 1}=\arctan \left(\frac{4 \cdot \mathrm{d}}{2 \cdot \mathrm{L}_{\text {est }}-\mathrm{a}_{\mathrm{x}}+4 \cdot \mathrm{e}}\right) \\
& \theta_{\mathrm{m} 1}=\arctan \left(\frac{4 \cdot \mathrm{d}}{2 \cdot \mathrm{L}_{\text {est }}-\mathrm{a}_{\mathrm{x}}-4 \cdot \mathrm{e}}\right)
\end{aligned}
$$


sendo:

- e, a excentricidade da força de compressão.

As áreas das bielas de compressão junto ao pilar e junto às estacas (ver Figura 8.4) são calculadas por meio das Expressões 8.10 a 8.13.

$$
\begin{aligned}
& \mathrm{A}_{\mathrm{b}, \mathrm{zs}, 1}=\left[\left(\frac{\mathrm{h}_{\mathrm{x}}}{2}+\mathrm{e}\right) \cdot \mathrm{h}_{\mathrm{y}}\right] \cdot \operatorname{sen}\left(\theta_{\mathrm{m} 1}\right) \\
& \mathrm{A}_{\mathrm{b}, \mathrm{zs}, 2}=\left[\left(\frac{\mathrm{h}_{\mathrm{x}}}{2}+\mathrm{e}\right) \cdot \mathrm{h}_{\mathrm{y}}\right] \cdot \operatorname{sen}\left(\theta_{\mathrm{m} 2}\right) \\
& \mathrm{A}_{\mathrm{b}, \mathrm{zi}, 1}=\frac{\mathrm{a}_{\mathrm{x}}^{2}}{2} \cdot \operatorname{sen}\left(\theta_{\mathrm{m} 1}\right) \\
& \mathrm{A}_{\mathrm{b}, \mathrm{zi}, 2}=\frac{\mathrm{a}_{\mathrm{x}}^{2}}{2} \cdot \operatorname{sen}\left(\theta_{\mathrm{m} 2}\right)
\end{aligned}
$$

As tensões nas zonas nodais superior e inferior são determinadas por meio das Expressões 8.14, 8.15, 8.16 e 8.17. Estas tensões estão indicadas na Figura 8.4.

$$
\begin{aligned}
\sigma_{\mathrm{b} . \mathrm{zi}, 1} & =\frac{\mathrm{F}\left(1-\frac{\xi}{2}\right)}{\operatorname{sen}\left(\theta_{\mathrm{m} 1}\right) \cdot \mathrm{A}_{\mathrm{b}, \mathrm{zi}, 1}} \\
\sigma_{\mathrm{b} . \mathrm{zi}, 2} & =\frac{\mathrm{F} \cdot \xi}{\operatorname{sen}\left(\theta_{\mathrm{m} 2}\right) \cdot \mathrm{A}_{\mathrm{b}, \mathrm{zi}, 2}} \\
\sigma_{\mathrm{b} . \mathrm{zs}, 1} & =\frac{\mathrm{F}\left(1-\frac{\xi}{2}\right)}{\operatorname{sen}\left(\theta_{\mathrm{m} 1}\right) \cdot \mathrm{A}_{\mathrm{b}, \mathrm{zs}, 1}} \\
\sigma_{\mathrm{b} . \mathrm{zs}, 2} & =\frac{\mathrm{F} \cdot \xi}{\operatorname{sen}\left(\theta_{\mathrm{m} 2}\right) \cdot \mathrm{A}_{\mathrm{b}, \mathrm{zs}, 2}}
\end{aligned}
$$

sendo:

$$
\xi=\frac{2 \cdot \mathrm{L}_{\mathrm{est}}-\mathrm{a}_{\mathrm{x}}+4 \cdot \mathrm{e}}{2 \cdot \mathrm{L}_{\mathrm{est}}-\mathrm{a}_{\mathrm{x}}}
$$

As distâncias $a_{\mathrm{f} 1}$ e $a_{\mathfrak{f} 2}$ (ver Figura 8.2) a construção do modelo são determinadas em por meio das Expressões 8.19 e 8.20. 


$$
\begin{aligned}
& \mathrm{a}_{\mathrm{f} 1}=\frac{2 \cdot \mathrm{L}_{\text {est }}-\mathrm{a}_{\mathrm{x}}+4 \cdot \mathrm{e}}{8} \\
& \mathrm{a}_{\mathrm{f} 1}=\frac{2 \cdot \mathrm{L}_{\text {est }}-\mathrm{a}_{\mathrm{x}}-4 \cdot \mathrm{e}}{8}
\end{aligned}
$$

\subsection{3. Áreas de aço dos tirantes}

As áreas das barras de aço das armaduras dos tirantes são calculadas em função das forças de tração existentes nas barras tracionadas das treliças.

Fazendo o equilíbrio dos nós das treliças apresentadas nas Figuras 8.1 e 8.2 determinam-se às forças nos Tirantes $T_{p}$ (modelo I e II), $T_{f}$ (modelo I), $T_{f 1}$ e $T_{f 2}$ (modelo II).

Para a obtenção das áreas de aço, basta dividir à força no tirante pela resistência ao escoamento de cálculo do aço utilizado no dimensionamento dos modelos.

$$
A_{s t}=\frac{T_{i}}{f_{y d}}
$$

sendo:

- $\mathrm{T}_{\mathrm{i}}$, a força nos tirantes.

\subsubsection{Armadura mínima de fendilhamento}

Em todos os dimensionamentos apresentados na revisão bibliográfica deste trabalho, nenhum autor sugere que seja considerada armadura para limitar as aberturas das fissuras por fendilhamento. Esta armadura será disposta para absorver as tensões de tração existentes na direção perpendicular às bielas de compressão (tirantes $T_{f}, T_{f 1}$ e $T_{f 2}$ ).

Em função de observações durante os ensaios experimentais, das deformações experimentais nas barras de aço sugeridas pelo autor nos modelos $B 35 P 25 E 25 e 0 A_{s w, C}$ e B45P25E25e0A $A_{s w, C}$, dos fluxos de tensões de tração e das tensões nas barras de aço dos modelos analisados numericamente apresentados no Capítulo 7, foi possível desenvolver um método para a determinação de uma área mínima de armadura para combater o fendilhamento das bielas comprimidas. 
Como a primeira fissura em todos os modelos analisados experimentalmente, surgiu na zona nodal inferior e se propagou até a zona nodal superior, supôs-se que as tensões de tração ocorrem ao longo da altura do bloco, acompanhando a evolução da fissura (ver Figura 8.5). A seqüência de fotografias mostrada na Figura 5.68 apresenta a evolução da primeira fissura ao longo da altura do bloco.

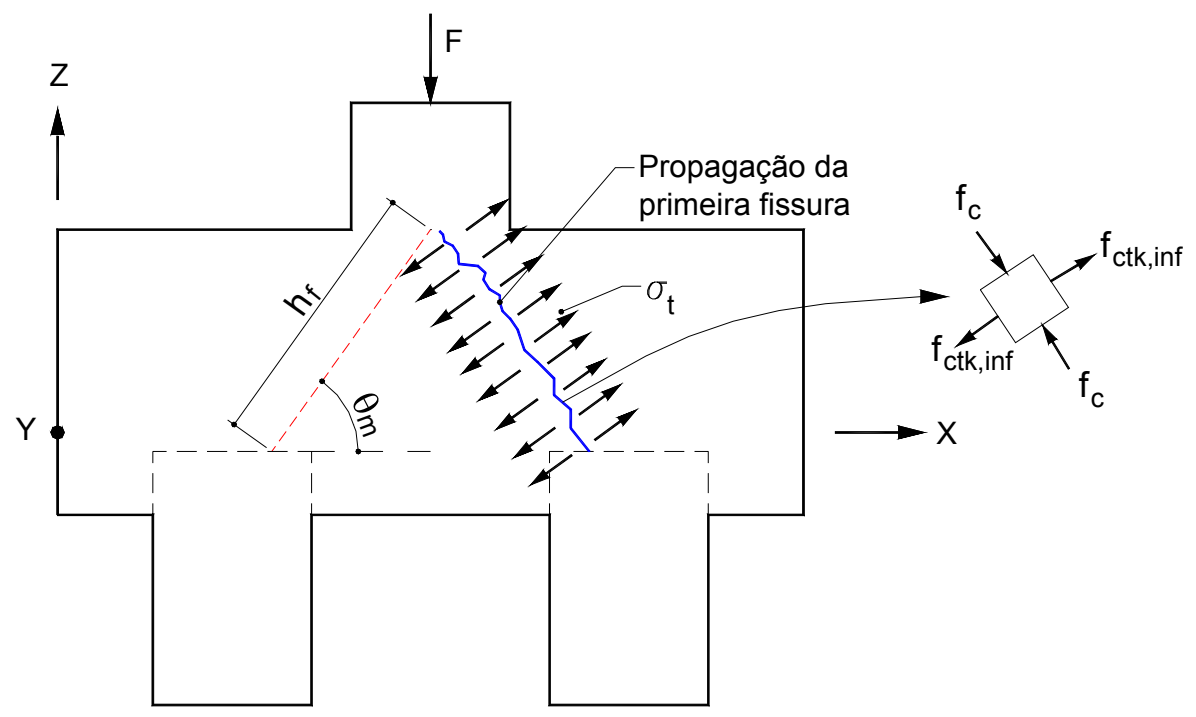

Figura 8.5 - Método para determinação da armadura mínima de fendilhamento.

As tensões de tração ao longo da altura do bloco podem ser observadas por meio dos diagramas de fluxo de tensões de tração.

Analisando a Figura 8.5 é possível imaginar que, ao longo das fissuras, surgem tensões de tração $\left(\sigma_{t}\right)$ com direção conhecida, ou seja, perpendicular à fissura. Isolando um elemento infinitesimal e como pretende-se estabelecer um critério para a determinação de uma área mínima de armadura, faz-se a substituição da tensão de tração $\left(\sigma_{t}\right)$ pela resistência característica à tração do concreto com valor inferior, $f_{c t k \text {,inf }}$ (NBR 6118:2003). Portanto, para a determinação da área mínima de armadura, basta descobrir qual é a força de tração mínima produzida pela resistência à tração do concreto com valor inferior e dividir essa força pela resistência ao escoamento do aço.

A determinação da força de tração mínima, aqui chamada de $R_{c t \text { miń }}$ é determinada por meio da integração ao longo da altura do bloco, Expressão 8.22. Imaginando que o eixo $\mathrm{Y}$ é o eixo que delimita à largura do bloco, faz-se:

$\mathrm{R}_{\mathrm{ct}, \text { min }}=\mathrm{h}_{\mathrm{f}} \cdot \int_{0}^{\mathrm{h}_{\mathrm{y}}} \mathrm{dy} \cdot \mathrm{f}_{\mathrm{ctk}, \text { inf }}$ 
Procedendo-se a integral, determina-se a força de tração mínima:

$$
\mathrm{R}_{\mathrm{ct}, \text { min }}=\mathrm{h}_{\mathrm{f}} \cdot \mathrm{h}_{\mathrm{y}} \cdot \mathrm{f}_{\mathrm{ctk}, \text {,inf }}
$$

Portanto, a área mínima de armadura de fendilhamento, $A_{s f, m i n}$ é determinada por meio da Expressão 8.24.

$$
A_{s f, \text { min }}=\frac{R_{c t, \text { min }}}{f_{y d}}
$$

Nota-se que a força de tração mínima é limitada pela largura do pilar e pelo ângulo de inclinação da biela de compressão.

A dimensão $h_{f}$ para o modelo de cálculo I (com força centrada) é descrita na Expressão 8.25.

$$
\mathrm{h}_{\mathrm{f}}=\sqrt{\left(\frac{\mathrm{L}_{\text {est }}}{2}-\frac{\mathrm{a}_{\mathrm{x}}}{4}\right)^{2}+\mathrm{d}^{2}}
$$

No modelo de cálculo considerando força excêntrica faz-se necessário a determinação de duas dimensões para $h_{f}$, a primeira será chamada de $h_{f 1}$ e será referente ao ângulo de inclinação da biela de compressão $\theta_{\mathrm{m} 1}$, a segunda será nomeada de $\mathrm{h}_{\mathrm{f} 2}$ e será referente ao ângulo $\theta_{\mathrm{m} 2}$.

Como as dimensões $h_{\mathfrak{f} 1}$ e $h_{\mathfrak{f} 2}$ são diferentes, existirão duas áreas mínimas de armadura, uma com relação à $h_{f 1}$ e outra com relação à $h_{\mathfrak{f} 2}$.

As dimensões $\mathrm{h}_{\mathrm{f} 1}$ e $\mathrm{h}_{\mathrm{f} 2}$ são descritas nas Expressões 8.26 e 8.27.

$$
\begin{aligned}
& \mathrm{h}_{\mathrm{f} 1}=\sqrt{\left(\mathrm{L}_{1}+\frac{\mathrm{a}_{\mathrm{x}}}{4}\right)^{2}+\mathrm{d}^{2}} \\
& \mathrm{~h}_{\mathrm{f} 2}=\sqrt{\left(\mathrm{L}_{2}+\frac{\mathrm{a}_{\mathrm{x}}}{4}\right)^{2}+\mathrm{d}^{2}}
\end{aligned}
$$

As dimensões $L_{1}$ e $L_{2}$ são apresentadas a seguir. 
$\mathrm{L}_{1}=\frac{\mathrm{L}_{\mathrm{est}}}{2}-\frac{\mathrm{a}_{\mathrm{x}}}{2}+\mathrm{e}$, Figura 8.2.

$\mathrm{L}_{2}=\frac{\mathrm{L}_{\text {est }}}{2}-\frac{\mathrm{a}_{\mathrm{x}}}{2}-\mathrm{e}$, Figura 8.2.

\subsubsection{Detalhamento da armadura de fendilhamento}

As barras das armaduras de fendilhamento podem ser dispostas em forma de cavalete (semelhante ao detalhamento utilizado pelo autor) em forma de estribos horizontais e verticais.

Caso se opte pela utilização de estribos, faz-se necessária a decomposição da força nos Tirantes $T_{f}, T_{f 1}$ e $T_{f 2}$ nas direções horizontal e vertical.

É muito importante que as armaduras atravessem as bielas de compressão. $\mathrm{O}$ detalhamento que geralmente é empregado, com estribos horizontais e verticais posicionados nas laterais dos blocos, não têm efeito.

\subsection{Tensões limites}

Um fato essencial nos modelos de bielas e tirantes é com relação às tensões limites a serem consideradas nas zonas nodais inferior e superior para que não ocorra esmagamento do concreto.

Por meio das forças últimas registradas nos ensaios experimentais, determinaram-se as tensões nas regiões nodais inferior e superior em função das áreas das bielas (item 8.31 e 8.32) de compressão junto ao pilar e junto às estacas.

Nos modelos com excentricidades, consideraram-se apenas as máximas tensões nas regiões nodais inferior e superior.

A Tabela 8.1 apresenta os resultados das tensões nas regiões nodais inferior e superior de todos os modelos analisados experimentalmente. Estas tensões foram comparadas com os valores máximos das tensões de compressão apresentadas no Capítulo 7, obtidas por meio da análise numérica desenvolvida. A Tabela 8.2 apresenta estes resultados.

Analisando os resultados mostrados na Tabela 8.1 , foi possível estabelecer limites para as tensões nas regiões nodais inferior e superior.

Em função das relações entre tensões dos modelos da série B45P25 serem maiores que os modelos da série B35P25, a favor da segurança, utilizou-se apenas os 
valores das relações entre tensões dos modelos da série B35P25 a menos dos modelos B35P25E25A $A_{s w, c}$ e B35P25E25e2,5 (foram ensaiados apenas um modelo com a armadura de fendilhamento sugerida pelo autor e um modelo com excentricidade. Faz-se necessário, portanto, maior número de ensaios para estabelecer as tensões limites para as regiões nodais).

Tabela 8.1 - Tensões máximas nas zonas nodais.

\begin{tabular}{|c|c|c|c|c|c|c|c|c|c|}
\hline SÉRIE & BLOCOS & $\begin{array}{c}\mathbf{f}_{\mathrm{cm}} \\
(\mathrm{MPa})\end{array}$ & $\begin{array}{c}F_{\mathrm{u}} \\
(\mathrm{kN})\end{array}$ & $\begin{array}{l}A_{b, z s} \\
\left(\mathrm{~cm}^{2}\right)\end{array}$ & $\begin{array}{l}\mathbf{A}_{\mathrm{b}, \mathrm{zi}} \\
\left(\mathrm{cm}^{2}\right)\end{array}$ & $\begin{array}{c}\sigma_{\mathbf{b}, \mathbf{z s}} \\
(\mathrm{MPa})\end{array}$ & $\begin{array}{c}\sigma_{\mathrm{b}, \mathbf{z i}} \\
(\mathrm{MPa})\end{array}$ & $\sigma_{\mathrm{b}, \mathbf{z s}} / \mathbf{f}_{\mathrm{cm}}$ & $\sigma_{\mathrm{b}, \mathrm{zi}} / \mathbf{f}_{\mathrm{cm}}$ \\
\hline \multirow{5}{*}{ B35P25 } & B35P25E25e0 & 40,6 & 1821 & 221 & 221 & 58,3 & 58,3 & 1,44 & 1,77 \\
\hline & B35P25E25e2,5 & 40,6 & 1688 & 279 & 232 & 44,8 & 53,8 & 1,10 & 1,33 \\
\hline & B35P25E25e0A $A_{s w, C}$ & 32,8 & 1880 & 221 & 221 & 54 & 54 & 1,64 & 1,64 \\
\hline & $\mathrm{B}_{5} \mathrm{P} 25 \mathrm{E} 25 \mathrm{e} 0 \mathrm{~A}_{\mathrm{sw}, 0}$ & 32,8 & 1406 & 221 & 221 & 45 & 45 & 1,37 & 1,37 \\
\hline & B35P25E25e0CG & 28,9 & 1263 & 221 & 211 & 40,4 & 40,4 & 1,40 & 1,40 \\
\hline \multirow{5}{*}{ B45P25 } & B45P25E25e0 & 31 & 2276 & 254 & 254 & 55 & 55 & 1,77 & 1,77 \\
\hline & B45P25E25e5 & 31 & 1972 & 380 & 271 & 35,9 & 50,2 & 1,16 & 1,62 \\
\hline & 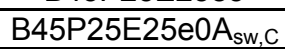 & 32,4 & 3055 & 254 & 254 & 73,8 & 73,8 & 2,28 & 2,28 \\
\hline & $\mathrm{B}_{4} \mathrm{P} 25 \mathrm{E} 25 \mathrm{e} 0 \mathrm{~A}_{\mathrm{sw}, 0}$ & 32,4 & 2090 & 254 & 254 & 50,5 & 50,5 & 1,56 & 1,56 \\
\hline & B45P25E25e0CG & 28,9 & 2270 & 254 & 254 & 54,8 & 54,8 & 1,90 & 1,90 \\
\hline \multirow{2}{*}{ B35P50 } & B35P50E25e0 & 35,8 & 3877 & 442 & 221 & 62 & 124 & 1,73 & 3,22 \\
\hline & B35P50E25e12,5 & 35,1 & 3202 & 839 & 280 & 32 & 96 & 0,91 & 2,74 \\
\hline \multirow{2}{*}{ B45P50 } & B45P50E25e0 & 35,9 & 4175 & 509 & 254 & 43,7 & 87,4 & 1,21 & 2,43 \\
\hline & B45P50E25e12,5 & 35,1 & 3386 & 882 & 294 & 30,5 & 91,6 & 0,87 & 2,61 \\
\hline
\end{tabular}

Notas: $A_{b, z s}$, área da biela na zona nodal superior, junto ao pilar; $A_{b, z i}$, área da biela na zona nodal inferior, junto à estaca; $\sigma_{\mathrm{b}, z \mathrm{~s}}$, tensão na biela na zona nodal superior; e $\sigma_{\mathrm{b}, \mathrm{zi}}$, tensão na biela na zona nodal inferior.

Desta maneira, obtiveram-se as relações médias entre tensões nas zonas nodais e a resistência à compressão média do concreto.

$$
\frac{\sigma_{\mathrm{b}, \mathrm{P} 25}}{\mathrm{f}_{\mathrm{cm}}}=1,40
$$

Sendo $\sigma_{b, P 25}$, tensão média na biela nas zonas nodais inferior e superior dos modelos das séries B35P25 e B45P25.

Empregando o método semiprobabilístico na expressão acima e tomando como valor para o coeficiente de minoração do material concreto, $\gamma_{c}=1,4$, determina-se a tensão limite nas zonas nodais inferior e superior para os modelos das séries B35P25 e B45P25 $\left(\sigma_{\text {lim }}\right)$ com força centrada.

$$
\sigma_{\lim }=\mathrm{f}_{\mathrm{ck}}
$$

É válido lembrar que Blévot \& Frémy (1967) estabeleceram tensão limite nas zonas nodais inferior e superior igual a $0,6 \mathrm{f}_{\mathrm{c}}$. 
Para os modelos com excentricidade, observa-se que há redução das relações entre as tensões nas regiões nodais e a resistência à compressão média do concreto, portanto, estabeleceu-se como tensão limite a menor relação entre tensão na biela e resistência do concreto dos modelos ensaiados, assim obteve-se a seguinte para a tensão limite:

$\sigma_{\text {lim, }, \neq 0}=0,6 \cdot f_{c k},\left(\gamma_{c}=1,4\right.$ já considerado $)$

Sendo, $\sigma_{\text {lim,e } \neq \text {, }}$ a tensão limite para as regiões nodais com excentricidade da força de compressão diferente de zero.

Para os modelos das séries B35P50 e B45P50, a menos dos modelos com excentricidade (B35P25E25e12,5 e B45P25E25e12,5), adotou-se para a determinação da tensão limite o menor valor das relações entre as tensões nas regiões nodais e a resistência à compressão média do concreto.

$$
\begin{aligned}
& \frac{\sigma_{\mathrm{bs}, \mathrm{P} 50}}{\mathrm{f}_{\mathrm{cm}}}=1,21 \\
& \frac{\sigma_{\mathrm{bi}, \mathrm{P} 50}}{\mathrm{f}_{\mathrm{cm}}}=1,86
\end{aligned}
$$

Sendo, $\sigma_{\mathrm{bs}, \mathrm{P} 50}$ e $\sigma_{\mathrm{bi}, \mathrm{P50}}$ as tensões nas regiões nodais superior e inferior dos modelos das séries B335P50 e B45P50 com excentricidade igual a zero.

Portanto, as tensões limites na biela de compressão junto à zona nodal superior e inferior para os modelos das séries B35P50 e B45P50 ( $\sigma_{\text {lim,P50,zs }}$ e $\left.\sigma_{\text {lim,P50,zi }}\right)$ com excentricidade igual a zero são:

$$
\begin{aligned}
& \sigma_{\text {lim,P } \mathrm{P} 0, \mathrm{zs}}=0,85 \cdot \mathrm{f}_{\mathrm{ck}},\left(\gamma_{\mathrm{c}}=1,4 \text { já considerado }\right) \\
& \sigma_{\mathrm{lim}, \mathrm{P} 50, \mathrm{zi}}=1,30 \cdot \mathrm{f}_{\mathrm{ck}},\left(\gamma_{\mathrm{c}}=1,4 \text { já considerado }\right)
\end{aligned}
$$

Observa-se na Tabela 8.2, boa correlação entre as tensões calculadas por meio dos modelos propostos e obtidas por meio das simulações numéricas. Verifica-se que os modelos que apresentaram maiores diferenças são os das séries B35P50 e B45P50, provavelmente em função da seção alongada do pilar. 
Tabela 8.2 - Comparação entre tensões máximas nas zonas nodais.

\begin{tabular}{|c|c|c|c|c|c|c|c|}
\hline SÉRIE & BLOCOS & $\begin{array}{c}\sigma_{b, z s} \\
(\mathrm{MPa})\end{array}$ & $\begin{array}{c}\sigma_{b, z i} \\
(\mathrm{MPa})\end{array}$ & $\begin{array}{c}\sigma_{b, z s, n u m} \\
(\mathrm{MPa})\end{array}$ & $\begin{array}{c}\sigma_{\text {b,zi,num }} \\
(\mathrm{MPa})\end{array}$ & $\sigma_{\mathrm{b}, \mathbf{z s}} / \sigma_{\mathrm{b}, \mathbf{z s}, \mathrm{num}}$ & $\sigma_{b, z i} / \sigma_{b, z i, n u m}$ \\
\hline \multirow{5}{*}{ B35P25 } & B35P25E25e0 & 58,3 & 58,3 & 52 & 52 & 1,12 & 1,12 \\
\hline & B35P25E25e2,5 & 44,8 & 53,8 & 47 & 47 & 0,95 & 1,14 \\
\hline & $\mathrm{B}_{5} \mathrm{P} 25 \mathrm{E} 25 \mathrm{e} 0 \mathrm{~A}_{\mathrm{sw}, \mathrm{C}}$ & 54 & 54 & 50 & 50 & 1,08 & 0,93 \\
\hline & $\mathrm{B}^{2} \mathrm{P} 25 \mathrm{E} 25 \mathrm{e} 0 \mathrm{~A}_{\mathrm{sw}, 0}$ & 45 & 45 & 40 & 40 & 1,13 & 1,13 \\
\hline & B35P25E25e0CG & 40,4 & 40,4 & 40 & 32 & 1,01 & 1,26 \\
\hline \multirow{5}{*}{ B45P25 } & B45P25E25e0 & 55 & 55 & 54 & 45 & 1,02 & 1,22 \\
\hline & B45P25E25e5 & 35,9 & 50,2 & 41 & 41 & 0,88 & 1,22 \\
\hline & $\mathrm{B}_{45} 25 \mathrm{E} 25 \mathrm{e} 0 \mathrm{~A}_{\mathrm{sw}, \mathrm{C}}$ & 73,8 & 73,8 & 58 & 48 & 1,27 & 1,54 \\
\hline & B45P25E25e0A $A_{s w, 0}$ & 50,5 & 50,5 & 47 & 39 & 1,07 & 0,99 \\
\hline & B45P25E25e0CG & 54,8 & 54,8 & 55 & 55 & 0,99 & 0,99 \\
\hline \multirow{2}{*}{ B35P50 } & B35P50E25e0 & 62 & 124 & 65 & 65 & 0,95 & 1,91 \\
\hline & B35P50E25e12,5 & 32 & 96 & 44 & 66 & 0,73 & 1,45 \\
\hline \multirow{2}{*}{ B45P50 } & B45P50E25e0 & 43,7 & 87,4 & 40 & 40 & 1,09 & 2,19 \\
\hline & B45P50E25e12,5 & 30,5 & 91,6 & 48 & 48 & 0,64 & 1,28 \\
\hline
\end{tabular}

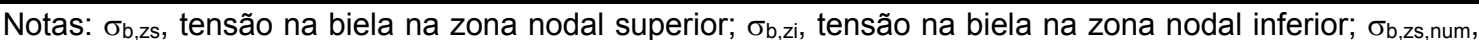
tensão máxima na biela na zona nodal superior, valor numérico, $\sigma_{\mathrm{b}, z s, n u m}$, tensão máxima na biela na zona nodal superior, valor numérico.

\subsection{Considerações necessárias para o dimensionamento da estaca}

Os modelos propostos consideram que as reações nas estacas sejam deslocadas a uma distância igual $a a_{x} / 4$, sendo $a_{x}$ a dimensão na estaca da direção considerada. Em função disto a estaca é solicitada por flexo-compressão.

Este modelo se assemelha mais ao comportamento real dos blocos sobre duas estacas, pois foi constatado por meio dos ensaios experimentais e das simulações numéricas que as estacas foram solicitadas de maneira mais intensa apenas nas regiões mais afastadas da borda do bloco.

O dimensionamento das estacas precisa ser feito considerando a força $F_{\text {est }}$ deslocada como mostra a Figura 8.6.

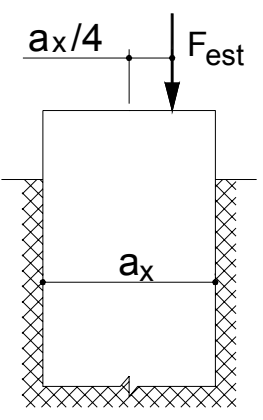

Figura 8.6 - Considerações para o dimensionamento da estaca. 


\subsection{Exemplos}

Este item apresenta como ilustração exemplos de dimensionamento de dois blocos sobre duas estacas, um considerando que a força oriunda da superestrutura é centrada e outro considerando momento na direção do eixo das estacas.

Os resultados dos blocos dimensionados com os modelos propostos serão comparados com os resultados dos blocos dimensionados com os critérios estabelecidos por Blévot \& Frémy (1967).

Supondo que os pilares tenham seção retangular de $20 \mathrm{~cm} \times 30 \mathrm{~cm}$ e estejam solicitados por ações descritas na Tabela 8.3.

Tabela 8.3 - Propriedades geométricas e mecânicas dos blocos dimensionados.

\begin{tabular}{c|c|c|c|c|c|c|c|c|c|c}
\hline \hline Blocos & Pilar & $\begin{array}{c}\mathbf{F}_{\mathbf{d}} \\
(\mathrm{kN})\end{array}$ & $\begin{array}{c}\mathbf{M}_{\mathbf{x d}} \\
(\mathrm{kNm})\end{array}$ & $\begin{array}{c}\mathbf{f}_{\mathbf{c k , b l o c o}} \\
(\mathrm{MPa})\end{array}$ & $\begin{array}{c}\mathbf{a}_{\mathbf{x}}=\mathbf{a}_{\mathbf{y}} \\
(\mathrm{cm})\end{array}$ & $\begin{array}{c}\mathbf{d} \\
(\mathrm{cm})\end{array}$ & $\begin{array}{c}\mathbf{h} \\
(\mathrm{cm})\end{array}$ & $\begin{array}{c}\mathbf{L}_{\text {est }} \\
(\mathrm{cm})\end{array}$ & $\begin{array}{c}\mathbf{B}_{\mathrm{Lx}} \\
(\mathrm{cm})\end{array}$ & $\begin{array}{c}\mathbf{B}_{\mathrm{Ly}} \\
(\mathrm{cm})\end{array}$ \\
\hline BL01 & $\mathrm{P} 01(20 \times 30)$ & 900 & 0 & 30 & 25 & 24 & 34 & 62,5 & 117,5 & 55 \\
\hline BL02 & $\mathrm{P} 02(20 \times 30)$ & 900 & 45 & 30 & 25 & 24 & 34 & 62,5 & 117,5 & 55 \\
\hline
\end{tabular}

Notas: $F_{d}$, força normal de cálculo; $M_{x d}$, Momento fletor de cálculo na direção $X$ (paralelo ao eixo das estacas); $a_{x}$ e $a_{y}$ dimensão das estacas (supondo estacas com seção transversal quadrada); $d$, altura útil do bloco; $h$, altura total do bloco; $L_{\mathrm{est}}$, distância entre os eixos das estacas; $B_{\mathrm{Lx}}$, comprimento do bloco; $\mathrm{B}_{\mathrm{Ly}}$, largura do bloco.

A Tabela 8.4 apresenta os resultados obtidos pelos dois métodos de cálculo.

Nos exemplos utilizou-se aço categoria CA-50 e $\gamma_{s}=1,15$.

Para a determinação das tensões limites nas zonas nodais inferior e superior no modelo de Blévot \& Frémy (1967) utilizaram-se às modificações sugeridas por Machado (1973), ou seja, $\sigma_{\text {lim }}=0,85 \cdot f_{\text {cd }}$.

Tabela 8.4 - Comparações entre os modelos.

\begin{tabular}{|c|c|c|c|c|c|c|c|c|c|c|c|c|c|}
\hline \multirow{2}{*}{ Blocos } & \multicolumn{7}{|c|}{ Modelo Proposto } & \multicolumn{6}{|c|}{ Modelo de Blévot \& Frémy (1967) } \\
\hline & $\begin{array}{c}\mathbf{R}_{\text {est,+ }} \\
(\mathrm{kN})\end{array}$ & $\begin{array}{l}\mathbf{R}_{\text {est,- }} \\
(\mathrm{kN})\end{array}$ & $\begin{array}{l}\mathbf{A}_{\text {st,d }} \\
\left(\mathrm{cm}^{2}\right)\end{array}$ & $\begin{array}{c}\mathbf{A}_{\text {sf, }} \mathbf{d} \\
\left(\mathrm{cm}^{2}\right)\end{array}$ & $\begin{array}{c}\sigma_{\mathrm{b}, \mathbf{z s}} \\
(\mathrm{MPa})\end{array}$ & $\begin{array}{c}\sigma_{\mathbf{b}, \mathbf{z i}} \\
(\mathrm{MPa})\end{array}$ & $\begin{array}{c}\sigma_{b, \lim } \\
(\mathrm{MPa})\end{array}$ & $\begin{array}{l}\mathbf{R}_{\text {est,++ }} \\
(\mathrm{kN})\end{array}$ & $\begin{array}{l}\mathbf{R}_{\text {est,- }} \\
\text { (kN) }\end{array}$ & $\begin{array}{c}\mathbf{A}_{\text {st, } \mathbf{d}} \\
\left(\mathrm{cm}^{2}\right) \\
\end{array}$ & $\begin{array}{c}\sigma_{\mathrm{b}, \mathbf{z s}} \\
(\mathrm{MPa})\end{array}$ & $\begin{array}{c}\sigma_{\mathrm{b}, \mathrm{zi}} \\
(\mathrm{MPa})\end{array}$ & $\begin{array}{c}\sigma_{b, \lim } \\
(\mathrm{MPa})\end{array}$ \\
\hline BL01 & 450 & 450 & 7,17 & 8,20 & 31 & 30 & 30 & 450 & 450 & 10,34 & 30 & 14 & 18,21 \\
\hline BL02 & 540 & 360 & 7,86 & 7,76 & 23 & 29 & 18 & 522 & 378 & 12 & 35 & 17 & 18,21 \\
\hline
\end{tabular}

Verifica-se que o modelo de Blévot \& Frémy (1967) é conservativo com relação às áreas de armadura do tirante e contra a segurança com relação à verificação da tensão na zona nodal inferior. Analisando no modelo de Blévot \& Frémy, verifica-se que a tensão na zona nodal inferior é cerda de duas vezes menor que a tensão no mesmo local do modelo proposto. Podem existir situações em que o concreto da 
região nodal inferior sofrerá esmagamento em função das intensidades das tensões que o modelo dos pesquisadores franceses apresentam.

As áreas de armadura mínima de fendilhamento para os exemplos da Tabela 8.4 são:

- Bloco BL01: $A_{s, \min , f}=3,23 \mathrm{~cm}^{2}$;

- Bloco BL02: $A_{s, m i n, f}=3,64 \mathrm{~cm}^{2}$. 



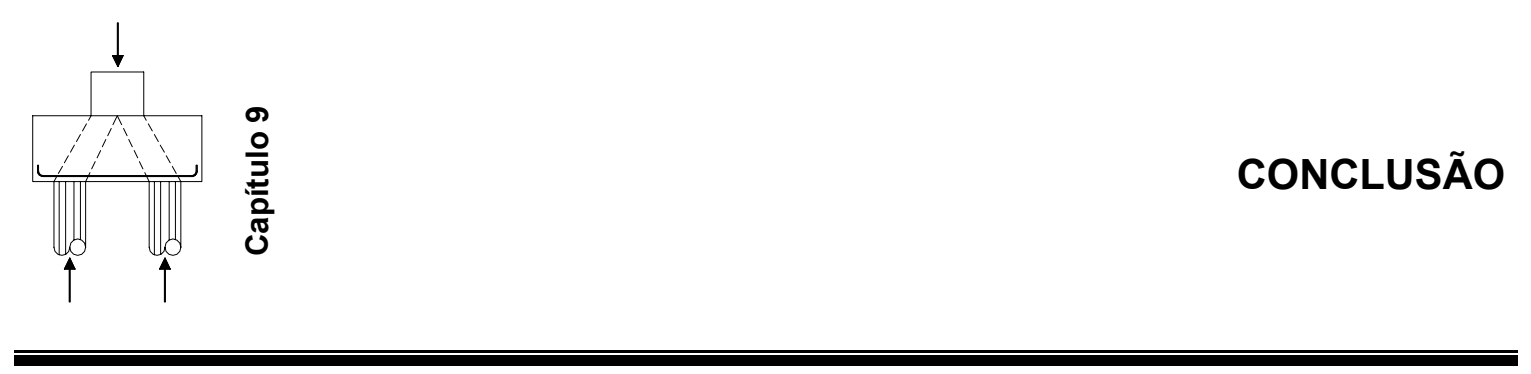

\subsection{Considerações finais}

Esta pesquisa teve como fim principal apresentar ao meio técnico e científico critério de dimensionamento seguro e que represente com maior precisão o comportamento real do elemento estrutural blocos sobre estacas.

Todos os objetivos propostos na pesquisa foram alcançados. Em função disto, propuseram-se modelos analíticos para o projeto de blocos sobre estacas fundamentados na analogia de bielas e tirantes.

Por meio da análise de variância desenvolvida otimizou-se o programa experimental possibilitando investigar somente as variáveis que realmente tinham influência relevante no comportamento estrutural do elemento em questão.

Em função dos resultados da análise experimental desenvolvida e, posteriormente, da simulação numérica, constataram-se informações de grande relevância que modifica os critérios usuais de dimensionamento de blocos sobre duas estacas.

\subsection{Principais conclusões}

A seguir são descritas as principais conclusões obtidas.

\section{- Fluxo das tensões principais de compressão}

Por meio das simulações numéricas e dos ensaios experimentais desenvolvidos, foi possível determinar com maior exatidão a distribuição do fluxo das tensões principais de compressão.

Em função desta distribuição constatou-se que somente parte da estaca é solicitada de maneira mais intensa, ou seja, considerar que a estaca esteja submetida 
em toda sua seção transversal pela mesma tensão de compressão não é correto. Deste modo, sugeriu-se que apenas parte da estaca, mais precisamente a metade, seja considerada para a verificação da tensão na biela junto à zona nodal inferior.

Os fluxos das tensões principais de compressão forneceram subsídios para a determinação da geometria das bielas de compressão.

\section{- Modo de ruína}

Todos os blocos ensaiados apresentaram os mesmos modos de ruína, ou seja, ruptura da biela comprimida junto ao pilar e ou junto à estaca. Observou-se que o esmagamento do concreto somente se deu após fissuração intensa na direção paralela às bielas ao longo da altura dos blocos. Essas fissuras influenciam negativamente a resistência à compressão do concreto existente na biela fendilhamento. Portanto, a utilização de barras de aço dispostas na direção perpendicular à biela de compressão, limitaria a abertura das fissuras, conferindo às bielas maior capacidade portante. Em síntese, o esmagamento da biela comprimida se deu após o fendilhamento da mesma.

\section{- Estado Limite de Abertura das fissuras}

As aberturas das fissuras foram acompanhadas até aproximadamente $70 \%$ da força última de cada modelo. Apesar disto, levando-se em consideração que o elemento bloco sobre estaca na maioria dos casos é reaterrado após sua construção, faz-se necessário limitar a abertura da fissura dificultando desta maneira a penetração de água no interior da massa de concreto, retardando desta maneira o início da despassivação das barras de aço da armadura. Em geral limita-se esta abertura em $0,3 \mathrm{~mm}$. Acontece que em todos os protótipos ensaiados o valor limite estabelecido pela NBR 6118:2003 foi atingido, ou seja, apresentaram resultados contra a segurança com relação ao Estado Limite de Abertura das Fissuras. Em média as abertura das fissuras dos blocos ensaiados foi de $0,37 \mathrm{~mm}$.

\section{- Influência da seção transversal do pilar}

Os resultados obtidos por meio da análise de variância desenvolvida no Capítulo 3 foram comprovados por meio dos ensaios experimentais, pois constatou-se que os blocos com pilares de maior seção transversal apresentaram maior capacidade portante em relação aos blocos construídos com pilares de seção transversal menor.

Os modelos das séries B35P50 e B45P50 apresentaram maiores forças últimas que os modelos das séries B35P25 e B45P25. 


\section{- Rigidez dos blocos}

Contatou-se, por meio dos resultados dos ensaios experimentais e por meio dos resultados das análises numéricas que o ângulo de inclinação da biela de compressão, que é função da altura do bloco e da distância entre os eixos das estacas tem importância fundamental na capacidade portante dos blocos. Os modelos mais rígidos (com maior altura e, portanto, com maior ângulo de inclinação da biela de compressão), séries B45P25 e B45P50 apresentaram maior capacidade portante quando comparados com os modelos de menor rigidez, séries B35P25 e B35P50.

\section{- Excentricidade da força normal}

Também aqui os resultados da análise de variância se assemelharam aos resultados da análise experimental, pois os blocos construídos e ensaiados com força vertical excêntrica apresentaram menor capacidade portante. Como, as bielas de compressão são solicitadas de maneira diferente, as tensões nas regiões nodais inferior e superior também apresentam valores de tensões diferentes, sendo assim, há ruptura por esmagamento do concreto na biela mais comprimida, com menor intensidade de força quando comparado com modelos com força centrada. Os blocos ensaiados com excentricidade da força vertical, modelos B35P25E25e2,5, B45P25E25e5, B35P50E25e12,5 e B45P50E25e12,5 apresentaram menor capacidade portante em relação aos seus modelos similares sem excentricidade, B35P25E25e0, B45P25E25e0, B35P50E25e0 e B45P50E25e0.

\section{- Armaduras complementares}

Contatou-se que os blocos construídos com armaduras complementares (estribos verticais e horizontais) apresentaram melhor comportamento que os blocos desprovidos de tais armaduras (B35P25E25e0A $\mathrm{Asw}, 0_{0}$ e B45P25E25e0A $\mathrm{A}_{\mathrm{sw}, 0}$ ). Porém, estas armaduras só terão efeito se, e somente se, estiverem atravessando as bielas de compressão. A utilização de armaduras complementares (estribos verticais e horizontais) nas faces dos blocos, costumeiramente utilizadas no meio técnico, não têm nenhuma influência com relação à capacidade portante dos blocos, apenas trabalham limitando as aberturas das fissuras. Verificou-se, por meio dos resultados experimentais e numéricos, que os estribos horizontais nas seções onde atravessaram as bielas de compressão foram mais solicitados. É conveniente lembrar que, como os blocos não foram construídos com as abas laterais de concreto, as armaduras complementares utilizadas nos modelos atravessaram as bielas. 
Com relação às armaduras complementares superiores, dispostas na face superior do bloco, constatou-se que sua utilização será apenas construtiva, pois apresentaram pequenas intensidades de deformações. Sua utilização torna-se interessante em blocos sobre duas estacas, pois atuariam absorvendo possíveis tensões oriundas da má locação das estacas e ou do pilar, juntamente com os estribos verticais.

\section{- Armadura de fendilhamento - costura}

Um resultando muito importante relaciona-se à armadura adicional sugerida pelo autor. Verificou-se por meio dos ensaios experimentais que a utilização de tal armadura (armadura de costura em forma de cavalete) nos modelos B35P25E25e0A $\mathrm{sw}_{\mathrm{s}, \mathrm{C}}$ e B45P25E25e0A $\mathrm{sw}_{\mathrm{s}, \mathrm{C}}$ aumentou de maneira significativa a capacidade portante dos blocos. Esta armadura absorveu as tensões de tração na direção perpendicular às bielas de compressão, limitando as aberturas das fissuras e aumentado a resistência à compressão da biela.

A utilização de armadura de fendilhamento, dispostas de maneira que atravessem as bielas de compressão, juntamente com armadura em malha posicionadas nas faces dos blocos, limitando às aberturas das fissuras, levariam o elemento estrutural blocos sobre estacas a ter ótimo desempenho quanto ao Estado Limite Último e ao Estado Limite de Abertura das Fissuras.

\section{- Armadura principal de tração - tirante}

Constatado por outros pesquisadores e confirmado nesta pesquisa, os ganchos, exigidos pela norma brasileira vigente de projeto de estruturas de concreto armado, não tiveram nenhuma influência no comportamento estrutural dos blocos na iminência da ruptura e em serviço. Apresentaram pequenas deformações, praticamente nulas, o que implica que sua utilização pode ser revista quando do projeto blocos rígidos sobre estacas.

Faz-se necessário, porém, ensaios com áreas menores das barras de aço da armadura principal de tração, o que levaria o tirante a sofrer escoamento, assim, seria possível verificar se os ganchos são eficazes nestes casos (área de aço das barras da armadura principal de tração menor que o valor calculado pelos modelos de dimensionamentos existentes).

Constatou-se que as deformações não são constantes ao longo das barras de aço que compõem à armadura principal de tração (tirante) apresentando sensível redução nas seções que atravessam às bielas comprimidas. A redução das tensões 
nas barras de aço da armadura principal de tração é função do efeito favorável da força de compressão da biela.

Por meio de análise dos valores das deformações experimentais nas barras de aço da armadura principal de tração, foram propostas duas hipóteses para a ancoragem desta armadura. Uma considerando que a seção de início de ancoragem se dê a partir da seção da estaca mais afastada da borda do bloco, considerando-se a força a ancorar igual à força no tirante. A outra hipótese considera que a ancoragem das barras inicie a partir do meio da estaca, porém, considerando cinqüenta por cento da força de tração no tirante.

\section{- Modelos de bielas e tirantes}

Baseados em resultados experimentais e numéricos foram sugeridos dois métodos de dimensionamento para blocos sobre estacas, fundamentados na analogia de bielas e tirante. Os modelos de bielas e tirante foram desenvolvidos em função das distribuições dos fluxos das tensões principais de tração e compressão e levam em consideração a existência ou não de momento no pilar.

As forças de tração existentes na direção perpendicular às bielas de compressão foram previstas nos modelos de dimensionamento por meio de tirantes posicionados nas regiões das bielas (formando ângulo reto entre a biela e o tirante) a uma distância igual à metade da altura útil do bloco medida a partir do centro geométrico das barras da armadura principal de tração.

Também foi proposta armadura mínima de fendilhamento, formulada em função dos panoramas de fissuração desenvolvidos no bloco durante os ensaios experimentais.

Faz-se necessário o aprimoramento do modelo sugerido, considerado a existência de flexão na biela comprimida junto à estaca e junto ao pilar (modelo de pórtico) e consideração da distribuição triangular das tensões nas interfaces estacabloco e estaca-pilar.

\section{- Considerações a respeito do dimensionamento estrutural das estacas}

Em função das observações efetuadas por meio das análises experimental e numérica, sugere-se que a estaca seja dimensionada a flexo-compressão, com o vetor que representa a reação da estaca, posicionado a um quarto da face da estaca mais afastada da borda do bloco. 
Esta sugestão garantiria às estacas maior segurança, evitando ruptura por esmagamento do concreto na região da estaca mais afastada da borda do bloco (interface estaca-bloco), como ocorreu em alguns dos modelos ensaiados.

\subsection{Sugestões para trabalhos futuros}

Apesar de ter sido realizado um número razoável de ensaios, faz-se necessário o desenvolvimento de outras análises com intuito de atestar e avançar as sugestões de dimensionamento e projeto aqui apresentadas.

Como é inviável o ensaio de blocos sobre estacas com fuste longo, análises numéricas com este fim são necessárias.

Abaixo apresentam-se algumas sugestões para futuras pesquisas:

- Análise numérica de blocos sobre duas estacas, com fustes longos, com finalidade de observar a distribuição das tensões ao longo dos fustes das estacas;

- Análise numérica de blocos sobre três, quatro, cinco e $\mathrm{n}$ estacas, com finalidade de observar a distribuição do fluxo das tensões principais de compressão e criar subsídios para novos modelos de bielas e tirantes;

- Análise experimental de blocos flexíveis sobre duas estacas, com finalidade de verificar se a analogia de bielas e tirantes pode ser aplicada nestes casos, além de estabelecer limites para as tensões nas zonas nodais inferior e superior;

- Em função da armadura de fendilhamento aumentar a capacidade portante dos blocos, faz-se necessário analisar experimentalmente blocos sobre duas estacas projetados e construídos com esta armadura, com o fim principal de obter valores das tensões nas regiões nodais superior e inferior.

- Análise experimental e numérica de blocos flexíveis, com o objetivo de analisar a distribuição das tensões ao longo da armadura principal de tração. 


\section{REFERÊNCIAS BIBLIOGRÁFICAS}

1. ADEBAR, P.; KUCHMA, D.; COLLINS, M. P. (1990). Strut-and-tie models for design of pile caps: an experimental study. ACI Journal, v. 87, p. 81-91, Jan/Feb;

2. ADEBAR, P.; ZHOU, Z. (1995). Design of deep pile caps using strut-and-tie models. In: Restructuring: America and Beyond Structural Congress, ASCE, New York, USA. Proceeding, v. 2, p. 1623-1626.

3. ALBIERO, J. H.; CINTRA, J. C. A. (1984). Projeto de fundações. Escola de Engenharia de São Carlos, Universidade de São Paulo, São Carlos;

4. ALONSO, U. R. (1983). Exercícios de Fundações. Ed. Edgard Blücher Ltda., São Paulo;

5. AMERICAN CONCRETE INSTITUTE (1983). Design Handbook, v. 1: Beams, one-way, brackets, footings and pile caps (ACI 340. IR-84). ACI SP-17;

6. AMERICAN CONCRETE INSTITUTE (1994). ACI 318M - Building code requirements for reinforced concrete. Detroit, USA;

7. AMERICAN CONCRETE INSTITUTE(2002). SP-208, Examples for the design of structural concrete with strut-and-tie models. Michigan, USA;

8. ANSYS User's Manual (1988). Theory Manual, ANSYS revision 5.5;

9. ASIN, M.; WALRAVEN, J. C.; CERVENKA, V. (1994). Reinforced concrete continuous deep beams: numerical and experimental behavior. Computer modeling of concrete structures. Proceedings of EURO-C 1994 International Conference held in Innsbruck, Austria.

10. ASSOCIAÇÃO BRASILEIRA DE NORMA TÉCNICAS (1986). NBR 6122:1996 - Projeto e execuções de fundações. Rio de Janeiro;

11. ASSOCIAÇÃO BRASILEIRA DE NORMA TÉCNICAS (2003). NBR 6118:2003 - Projeto de estruturas de concreto. Rio de Janeiro; 
12. ASSOCIAÇÃO BRASILEIRA DE NORMAS TÉCNICAS (1980). NBR 5739:1980 - Ensaio de compressão de corpos-de-prova cilíndricos de concreto. Rio de Janeiro.

13. ASSOCIAÇÃO BRASILEIRA DE NORMAS TÉCNICAS (1982). NBR 7251:1982 - Agregados em estado solto - determinação da massa unitária. Rio de Janeiro;

14. ASSOCIAÇÃO BRASILEIRA DE NORMAS TÉCNICAS (1983). NBR 7222:1983 - Argamassa e concretos - determinação da resistência à tração por compressão diametral de corpos-de-prova cilindricos. Rio de Janeiro;

15. ASSOCIAÇÃO BRASILEIRA DE NORMAS TÉCNICAS (1984). NBR 5738:1984 - Moldagem e cura de corpos-de-prova de concreto cilíndricos ou prismáticos. Rio de Janeiro;

16. ASSOCIAÇÃO BRASILEIRA DE NORMAS TÉCNICAS (1984). NBR 8522:1984 - Concreto - determinação do módulo de deformação estática e diagrama - tensão-deformação. Rio de Janeiro.

17. ASSOCIAÇÃO BRASILEIRA DE NORMAS TÉCNICAS (1987). NBR 7217:1987 - Agregados - determinação da composição granulométrica. Rio de Janeiro;

18. ASSOCIAÇÃO BRASILEIRA DE NORMAS TÉCNICAS (1987). NBR 9776:1987 - Agregados - determinação da massa específica de agregados miúdos por meio do frasco Chapman. Rio de Janeiro.

19. ASSOCIAÇÃO BRASILEIRA DE NORMAS TÉCNICAS (1992). NBR 6152:1992 - Materiais metálicos - determinação das propriedades mecânicas à tração: método de ensaio. Rio de Janeiro;

20. ASSOCIAÇÃO BRASILEIRA DE NORMAS TÉCNICAS (1992). NBR 8953:1992 - Concreto para fins estruturais - classificação por grupos de resistência. Rio de Janeiro;

21. ASSOCIAÇÃO BRASILEIRA DE NORMAS TÉCNICAS (1996). NBR 7480:1996 - Barras e fios de aço destinados a armaduras para concreto armado. Rio de Janeiro;

22. BLÉVOT, J.; FRÉMY, R. (1967). Semelles sur piex. Analles d'Institut Techique du Bâtiment et des Travaux Publics, Paris, v. 20, n. 230, p. 223295, fev;

23. BRITISH STANDARD FOR STRUCTURAL USE OF CONCRETE (1985). BS 8110 - Code of practice for design and construction. Part I; 
24. BURKE JR., J.U. (1977). Blocos rígidos sobre apoios diretos. São Paulo, Maubertec;

25. CALAVERA, J. (1991). Calculo de estrutucturas de cimentacion. Instituto Técnico de Materiales y Construcciones - INTEMAC. Ed. Torreangulo Arte Gráfico, ed. $3^{\mathrm{a}}$, Madrid, Espanha;

26. CARVALHO, I. S. (1994). Análise experimental de blocos sobre grupos de estacas escavadas de pequeno diâmetro. Dissertação (Mestrado) - Escola de Engenharia de São Carlos, Universidade de São Paulo, São Carlos;

27. CHAN, T. K.; POH, C. K. (2000). Behavior of precast reinforced concrete pile caps. Construction and Building Materials, v. 14, p. 73-78, Jan;

28. CLARKE, J. L. (1973). Behavior and design of pile caps with four piles. Cement and Concrete Association, London, 19 p. (Technical Report, n. 42.489);

29. COMISIÓN PERMANENTE DEL HORMIGÓN (2002). Ministerio de Fomento. Centro de Publicaciones. Instrucción española de hormigón armado (EHE), Madrid;

30. COMITE EURO-INTERNACIONAL DU BÉTON (1970). CEB-FIP, Recommandations particulières na calcul et à l'execution des semelles de fundations. Bulletin D'Information, Paris, n. 73;

31. COMITE EURO-INTERNACIONAL DU BÉTON (1990). CEB-FIP Model code for concrete structures. Bulletin D'Information, Paris, n. 203-205, July;

32. COOK, W. MITCHELL, D. (1988). Studies of disturbe regions near discontinuities in reinforced concrete members. ACI Journal, v. 85, n. 2, p. 206-216, Mar/Apr;

33. CSA STANDARD A23.3-94 (1994). Design of Concrete Structures with Explanatory Notes. Canadian Portland Cement Association, Ontario, Canadá;

34. DELALIBERA, R. G. (2002). Análise teórica e experimental de vigas de concreto armado com armadura de confinamento. Dissertação (Mestrado), Escola de Engenharia de São Carlos, Universidade de São Paulo, São Carlos;

35. DELALIBERA, R. G.; GIONGO, J. S. (2004 - b). Influência da rigidez do bloco de coroamento nos estaqueamentos em linha. $46^{\circ}$ Congresso Brasileiro do Concreto. CDROM, Florianópolis;

36. DELALIBERA, R. G.; GIONGO, J. S. (2004 - a). Simulação numérica nãolinear de blocos de concreto armado. XXXI Jornadas Sul-Americanas de Engenharia Estrutural. CDROM, Mendonza, Argentina; 
37. DELALIBERA, R. G.; GIONGO, J. S. (2005 - a). Influência das armaduras adicionais em blocos sobre duas estacas. ABPE - Congresso de pontes e estruturas. Rio de Janeiro - RJ;

38. DESAYI, P.; KRISHNAN, S. (1964). Equation for the Stress-Strain Curve of Concrete. Journal of the American Concrete Institute. v. 61, p. 345-350, March;

39. FUSCO, P. B. (1985). Investigação experimental sobre o valor limite $\tau_{w u}$ das tensões de cisalhamento no concreto estrutural. BT/PEF-8505, São Paulo;

40. FUSCO, P. B. (1994). Técnicas de armar estruturas de concreto. Editora Pini Ltda., São Paulo;

41. HACHICH, W.; FACONI, F. F.; SAES, J. L.; FROTA, R. G. Q.; CARVALHO, C. S.; NIYAMA, S. (1998). Fundações: teoria e prática. Editora Pini Ltda., São Paulo;

42. HARISIS, A., FARDIS, M. N. (1991). Computer-Aided Automatic Construction of Strut-and-Tie Models. Structural Concrete, IABSE Colloquium, Stuttgart, International Association for Bridge and Structural Engineering, Zürich, p. 533-538, Março;

43. HELENE, P.; TERZIAN, P. R. (1995). Manual de dosagem e controle do concreto. São Paulo, Pini.

44. HOBBS, N. B.; STEIN, P. (1957). An investigation into the stress distribution in pile caps with some notes on design. Proceedings of the Institution of Civil Engineers., v. 57, pg. 559-628;

45. ITURRIOZ, I.; D'AVILA, V. M. R.; RAUSH, A. (2000). Análise experimentalcomputacional de um bloco de estacas de concreto armado. XXXIX Jornadas Sul-Americanas de engenharia estrutural, In: CD-ROOM;

46. IYER, P. K.; SAM, C. (1991). 3-D elastic analysis of three-pile caps. Journal of Engineering Mechanics, ASCE, v. 117, n. 12, p. 2862-2883, Dec;

47. IYER, P. K.; SAM, C. (1992). Three-dimensional analysis of pile caps. Computers and Structures, v. 42, n. 3, p. 395-411, Feb;

48. IYER, P. K.; SAM, C. (1995 - a). Nonlinear finite element analysis of reinforced concrete four-pile caps. International Journal of Structures, v. 15, n. 1, p. 1834, Jan/Jun;

49. IYER, P. K.; SAM, C. (1995 - b). Nonlinear finite element analysis of reinforced concrete two-pile caps. Computers and Structures, v. 57, p. 605-622, Nov; 
50. IYER, P. K.; SAM, C. (1996). Three-dimensional photoestastic analysis of pile caps. Journal of Strain Analysis for Engineering Design, v. 3, n. 1, p. 35-42, Jan;

51. KACHLAKEV, D.; MILLER, T; YIM, S.; CHANSAWAT, K.; POTISUK, T. (2001). Finite element modeling of reinforced concrete structures strengthened with frp laminates. Final Report, Oregon Department of Transportation, May.

52. LEONARDT, F. \& MÖNNING, E. (1978). Construções de concreto. Ed. Interciência, v. 01, 02, 03 e 04, Rio de Janeiro;

53. LIMA JÚNIOR, H. C. (2003). Avaliação da ductilidade de pilares de concreto armado, submetidos a flexo-compressão reta com e sem adição de fibras metálicas. Tese (Doutorado), Escola de Engenharia de São Carlos, Universidade de São Paulo, São Carlos;

54. LONGO, H. I. (2000). Modelagem de estruturas de concreto pelo modelo de bielas e tirantes utilizando o método dos elementos finitos. XXXIX Jornadas Sul-Americanas de engenharia estrutural, In: CD-ROOM;

55. MacGREGOR, J. G. (1988). Reinforced concrete: mechanics and design. Englewood Cliffs, Prentice Hall, New Jersey;

56. MACHADO, C. P. (1979). Elementos especiais estruturais de concreto armado. São Paulo, FDTE- EPUSP - IPT. (Notas de Aula), v1;

57. MARQUES, J.; JIRSA, J. (1975). A study of a Hooked Bar Anchorages in Beam Joints, ACI Journal, May.

58. MAUTONI, M. (1972). Blocos sobre dois apoios. São Paulo, Grêmio Politécnico;

59. METHA, P. K.; MONTEIRO, P. J. M. (1994). Concreto: estrutura, propriedades e materiais. São Paulo, Pini.

60. MIGUEL, G. M. (2000). Análise experimental e numérica de blocos sobre três estacas. Tese (doutorado) - Escola de Engenharia de São Carlos, Universidade de São Paulo, São Carlos;

61. MIGUEL, M. Giongo, J. S.; Takeya, T. (2000). Análise experimental de blocos sobre três estacas. XXIX Jornadas Sul-Americanas de Engenharia Estrutural. CDROM, Brasília.

62. MINOR, J.; JIRSA, J. (1975). Behavior of Bent Bar Anchorages, ACI Journal, p.141-149, April;

63. MONTGOMERY, D. C. (1996). Design and Analysis of Experiments Fourth Edition. Arizona State University, John Wiley \& Sons; 
64. MONTOYA, P. J.; MESEgUER, A.; CABRE, M. (2000). Hormigón armado. $14^{a}$ Edición basada em EHE ajustada al Código Modelo y al Eurocódigo. Gustavo Gili, Barcelona, Espanha.

65. MORAES, M. C. (1976). Estruturas de Fundações. Ed. McGraw-Hill do Brasil, São Paulo;

66. Munhoz, F. S. (2004). Análise do comportamento de blocos de concreto armado sobre estacas submetidos à ação de força centrada. Dissertação (Mestrado), Escola de Engenharia de São Carlos, Universidade de São Paulo, São Carlos;

67. MUNHOZ, F. S.; DELALIBERA, R. G.; GIONGO, J. S. (2004 - A). Análise numérica elástica linear de blocos de concreto armado sobre duas estacas. XXXI Jornadas Sul-Americanas de Engenharia Estrutural. CDROM, Mendonza, Argentina;

68. MUNHOZ, F. S.; DELALIBERA, R. G.; GIONGO, J. S. (2004 - B). Avaliação da rigidez de blocos de coroamento em estaqueamentos paralelos com ações verticais excêntricas. $4^{\circ}$ Congresso Brasileiro do Concreto. CDROM, Florianópolis, SC;

69. MUNHOZ, F. S.; DELALIBERA, R. G.; GIONGO, J. S. (2005 - a). Análise do comportamento de blocos de concreto armado sobre cinco estacas submetidos à ação de força centrada. $47^{\circ}$ Congresso Brasileiro do Concreto. CDROM, Olinda, PE;

70. MUNHOZ, F. S.; DELALIBERA, R. G.; GIONGO, J. S. (2005 - b). Análise do comportamento de blocos de concreto armado sobre uma estaca. ABPE Congresso de pontes e estruturas. Rio de Janeiro, RJ;

71. NORMA BOLIVIANA DEL HORMIGÓN ARMADO (1997). CBH-87, Ministerio de Urbanismo y Vivienda, Bolivia;

72. OLIVEIRA, R. (1998). Determinação de Modelos de Bielas e Tirantes com utilização de Técnicas de Otimização Topológica. Dissertação (Mestrado) Departamento de Engenharia Civil, Pontifica Universidade Católica do Rio de Janeiro;

73. RAUSH, A.; D'ASCENSO, N.; GOLDSCHMIDT, P.; NATALINI, M. (1997). Analisis experimental sobre cabezales de pilotes sometidos a cargas verticals. XXVIII Jornadas Sul-Americanas de engenharia estrutural, v. 1, p. 309-318, São Carlos;

74. SABNIS, G. M.; GOGATE, A. B. (1984). Investigation of thick slab (Pile Cap) behavior. ACI Journal. Title n. 81-5, p. 35-39, Jan/Feb; 
75. SCHAFER, K., SCHLAICH, J. (1988). Consistent design of structural concrete using strut-and-tie models. In: COLÓQUIO SOBRE COMPORTAMENTO E PROJETO DE ESTRUTURAS, 5., Rio de Janeiro. Anais. PUC/RJ;

76. SCHAFER, K.; SCHALICH, J. (1988). Consistent design of structural concrete using strut and tie models. Colóquio sobre comportamento de projeto de estruturas, 5. Anais, PUC - RJ, Rio de Janeiro - RJ;

77. SCHLAICH, J., SCHAFER, K. (1991). Design and detailing of structural concrete using strut-and-tie models. The Structural Engineer, v.69, n.6, p.113125, March.

78. SCHLAICH, J.; SCHAFER, K.; JENNEWEIN, M. (1987). Toward a consistent design of reinforced structural concrete. Journal of Prestressed Concrete Institute, v. 32, n. 3, p. 74-150, May-June;

79. SENNA JÚNIOR, R. S. (1993). Distribuição de carga em grupos de estacas escavadas de pequeno diâmetro. Dissertação (Mestrado), Escola de Engenharia de São Carlos, Universidade de São Paulo, São Carlos;

80. SIAO, W, B. (1993). Strut-and-tie model for shear behavior in deep beams and pile caps failing in diagonal splitting. ACI Structural Journal. Title n. 90-S38, v. 90, n. 4, p. 356-363, Jul/Aug;

81. SIAO, W. B. (1993). Strut-and-Tie models for shear behavior in deep beams and caps failing in diagonal splitting. ACI Structural Journal, v. 90, n. 4, Jul/Aug;

82. SILVA, R, C.; GIONGO, J. S. (2000). Modelos de bielas e tirantes aplicados a estruturas de concreto armado. Projeto REENGE, Escola de Engenharia de São Carlos, Universidade de São Paulo, São Carlos;

83. SOUZA, R. A.; BITTENCOURT, T. N.; FIgueiRAS, J. A.; PIMENTEL, M. J. (2004). Dimensionamento e verificação de uma viga-parede complexa utilizando o método das bielas e análise não-linear. $46^{\circ}$ Congresso Brasileiro do Concreto. CDROM, Florianópolis.

84. TAKEIA, T. (2001). Análise experimental de estruturas - notas de aula. Escola de Engenharia de São Carlos, Universidade de São Paulo, São Carlos.

85. TAYLOR, H. P. J.; CLARKE, J. L. (1976). Some detailing problems in concrete frame structures. The Structural Engineer, January.

86. TJHIN, T. N.; KUCHMA, D. (2002). Computer-Based Tools for Design by Strutand-Tie Method: Advances and Challenges. ACI Structural Journal, p. 586594, Sep/Oct; 
87. VELLOSO, D. A.; LOPES, F. R. (1996). Fundações. COPPE/UFRJ, Rio de Janeiro;

88. WALRAVEN, J. C.; LEHWALTER, N. (1989). A capacidade portante de bielas de concreto em modelos de treliça, tomando como exemplo vigas curtas. Beton und Stahlbetonbau 84, H.4. 


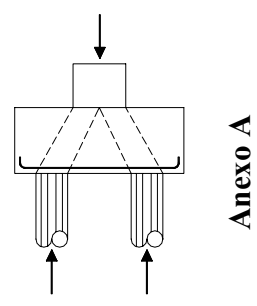

ANEXO A - Critério de ruptura do modelo Concrete

O modelo de ruptura Concrete existente no programa ANSYS é formulado com o critério de ruptura para o estado de tensão multiaxial, proposto por "Willam-Warnke" e expresso na forma:

$$
\frac{F}{f_{c}}-S \geq 0
$$

Sendo:

- $\quad F$, função do estado principal de tensões ( $\sigma_{x p}, \sigma_{y p}$ e $\left.\sigma_{z p}\right)$;

- $\quad$ S, a superfície de ruptura expresso em termos das tensões principais e dos parâmetros $f_{t}, f_{c}, f_{c b}, f_{1}$ e $f_{2}$;

- $\quad f_{c}$, a resistência uniaxial à compressão do concreto.

Se a Equação A1 não for satisfeita, o material terá comportamento elástico e linear, caso contrário, o material apresentara fissuras se qualquer tensão principal for de tração, ou esmagara se todas as tensões principais forem de compressão.

De acordo com o manual do programa ANSYS, os coeficientes $\mathrm{f}_{\mathrm{cb}}$ (resistência biaxial a compressão do material), $f_{1}$ (Resistência ultima a compressão para o estado biaxial de compressão superposta ao estado de tensão hidrostático ambiente) e $f_{2}$ (Resistência ultima a compressão para o estado uniaxial de compressão superposta ao estado de tensão hidrostático ambiente) são expressos por meios das Equações A2, A3 e A4.

$\mathrm{f}_{\mathrm{cb}}=1,2 \cdot \mathrm{f}_{\mathrm{c}}$

$\mathrm{f}_{1}=1,45 \cdot \mathrm{f}_{\mathrm{c}}$ 


$$
\mathrm{f}_{2}=1,725 \cdot \mathrm{f}_{\mathrm{c}}
$$

Os valores obtidos nas expressões A2, A3 e A4 representam o material quando a Equação A5 é atendida, caso contrário, a resistência do material pode ser avaliada de maneira incorreta.

$\left|\sigma_{h}\right| \leq 1,732 \cdot f_{c}$

$\sigma_{\mathrm{h}}=\frac{1}{3} \cdot\left(\sigma_{\mathrm{xp}}+\sigma_{\mathrm{yp}}+\sigma_{\mathrm{zp}}\right) \rightarrow$ estado de tensão hidrostática.

onde:

$$
\sigma_{x p}, \sigma_{x p} \text { e } \sigma_{x p} \text { são tensões nas direções x, y e z. }
$$

A superfície de ruptura para o material pode ser definida apenas por meio das resistências uniaxiais a compressão $\left(f_{c}\right)$ e tração $\left(f_{t}\right)$, sendo que, os valores de $\sigma_{h}{ }^{a}, f_{c b}$, $\mathrm{f}_{1}$ e $\mathrm{f}_{2}$ são tomados como padrão pelo programa de computador ANSYS.

As tensões principais denominadas $\sigma_{1}, \sigma_{2}$ e $\sigma_{3}$ são funções de $\sigma_{x p}, \sigma_{x p}$ e $\sigma_{x p}$.

$$
\begin{aligned}
& \sigma_{1}=\max \left(\sigma_{x p}, \sigma_{y p}, \sigma_{z p}\right) \\
& \sigma_{3}=\min \left(\sigma_{x p}, \sigma_{y p}, \sigma_{z p}\right)
\end{aligned}
$$

Como $\sigma_{1} \geq \sigma_{2} \geq \sigma_{3}$, a ruptura do concreto é classificada dentro de quatro domínios:

Domínio A: $0 \geq \sigma_{1} \geq \sigma_{2} \geq \sigma_{3}$, compressão - compressão - compressão;

Domínio B: $\sigma_{1} \geq 0 \geq \sigma_{2} \geq \sigma_{3}$, tração - compressão - compressão;

Domínio C: $\sigma_{1} \geq \sigma_{2} \geq 0 \geq \sigma_{3}$, tração - tração - compressão;

Domínio $\mathrm{D}: \sigma_{1} \geq \sigma_{2} \geq \sigma_{3} \geq 0$, tração - tração - tração.

As expressões de cada domínio para a determinação de $F$ e $S$ são apresentadas a seguir. 


\section{1 - Domínio A}

$$
\begin{aligned}
& \mathrm{F}=\mathrm{F}_{1}=\frac{1}{\sqrt{15}}\left[\left(\sigma_{1}-\sigma_{2}\right)^{2}+\left(\sigma_{2}-\sigma_{3}\right)^{2}+\left(\sigma_{3}-\sigma_{1}\right)^{2}\right]^{\frac{1}{2}} \\
& \mathrm{~S}=\mathrm{S}_{1}=\frac{2 \mathrm{r}_{2}\left(\mathrm{r}_{2}{ }^{2}-\mathrm{r}_{1}{ }^{2}\right) \cos \eta+\mathrm{r}_{2}\left(2 \mathrm{r}_{1}-\mathrm{r}_{2}\right)\left[4\left(\mathrm{r}_{2}{ }^{2}-\mathrm{r}_{1}{ }^{2}\right) \cos ^{2} \eta+5 \mathrm{r}_{1}^{2}-4 \mathrm{r}_{1} \mathrm{r}_{2}\right]^{\frac{1}{2}}}{4\left(\mathrm{r}_{2}^{2}-\mathrm{r}_{1}^{2}\right) \cos ^{2} \eta+\left(\mathrm{r}_{2}-2 \mathrm{r}_{1}\right)^{2}}
\end{aligned}
$$

Onde os termos que definem S são:

$$
\begin{aligned}
& \cos \eta=\frac{2 \sigma_{1}-\sigma_{2}-\sigma_{3}}{\sqrt{2}\left[\left(\sigma_{1}-\sigma_{2}\right)^{2}+\left(\sigma_{2}-\sigma_{3}\right)^{2}+\left(\sigma_{3}-\sigma_{1}\right)^{2}\right]^{\frac{1}{2}}} \\
& \mathrm{r}_{1}=\mathrm{a}_{0}+\mathrm{a}_{1} \xi+\mathrm{a}_{2} \xi^{2} \\
& \mathrm{r}_{2}=\mathrm{b}_{0}+\mathrm{b}_{1} \xi+\mathrm{b}_{2} \xi^{2} \\
& \xi=\sigma_{\mathrm{h}} / \mathrm{f}_{\mathrm{c}}
\end{aligned}
$$

A Figura A1 mostra a superfície de ruptura no espaço das tensões principais, sendo que, o ângulo de similaridade $\eta$ estabelece as dimensões relativas das tensões principais. Na Equação $\mathrm{A} 30, \eta=0^{\circ}$ refere-se ao estado de tensão tal que $\sigma_{3}=\sigma_{2}>\sigma_{1}$. Por outro lado, $\eta=60^{\circ}$ refere-se ao estado de tensão tal que $\sigma_{3}>\sigma_{2}=\sigma_{1}$. Todos os estados de tensões multiaxiais possuem ângulos de similaridade no intervalo: $0^{\circ} \leq \eta \leq$ $60^{\circ}$.

Se, $\eta=0^{\circ}, S_{1}$ torna-se igual a $r_{1}$, mas, se $\eta=60^{\circ}, S_{1}$ fica igual a $r_{2}$. Portanto, a função $r_{1}$ representa a superfície de ruptura para todos os estado de tensões com $\eta=0^{\circ}$.

A seção transversal do plano ruptura tem simetria em intervalos de $120^{\circ}$.

A função $r_{1}$ é determinada pelo ajuste de $a_{0}, a_{1}$ e $a_{2}, e, f_{t}, f_{c b}$ e $f_{1}$ obrigatoriamente devem estar na superfície de ruptura. Os valores sugeridos para esses coeficientes são determinados em função do sistema abaixo:

$$
\left\{\begin{array}{l}
\frac{\mathrm{F}_{1}}{\mathrm{f}_{\mathrm{c}}}\left(\sigma_{1}=\mathrm{f}_{\mathrm{t}}, \sigma_{2}=\sigma_{3}=0\right) \\
\frac{\mathrm{F}_{1}}{\mathrm{f}_{\mathrm{c}}}\left(\sigma_{1}=0, \sigma_{2}=\sigma_{3}=-\mathrm{f}_{\mathrm{cb}}\right. \\
\frac{\mathrm{F}_{1}}{\mathrm{f}_{\mathrm{c}}}\left(\sigma_{1}=-\sigma_{\mathrm{h}}^{\mathrm{a}}, \sigma_{2}=\sigma_{3}=-\sigma_{\mathrm{h}}^{\mathrm{a}}-\mathrm{f}_{1}\right.
\end{array}\right\}=\left[\begin{array}{ccc}
1 & \xi_{\mathrm{t}} & \xi_{\mathrm{t}}^{2} \\
1 & \xi_{\mathrm{cb}} & \xi_{\mathrm{cb}}{ }^{2} \\
1 & \xi_{1} & \xi_{1}^{2}
\end{array}\right]\left\{\begin{array}{l}
\mathrm{a}_{0} \\
\mathrm{a}_{1} \\
\mathrm{a}_{2}
\end{array}\right\}
$$




$$
\begin{aligned}
& \xi_{\mathrm{t}}=\frac{\mathrm{f}_{\mathrm{t}}}{3 \mathrm{f}_{\mathrm{c}}} \\
& \xi_{\mathrm{cb}}=-\frac{2 \mathrm{f}_{\mathrm{cb}}}{3 \mathrm{f}_{\mathrm{c}}} \\
& \xi_{1}=-\frac{\sigma_{\mathrm{h}}^{\mathrm{a}}}{\mathrm{f}_{\mathrm{c}}}-\frac{2 \mathrm{f}_{1}}{3 \mathrm{f}_{\mathrm{c}}}
\end{aligned}
$$

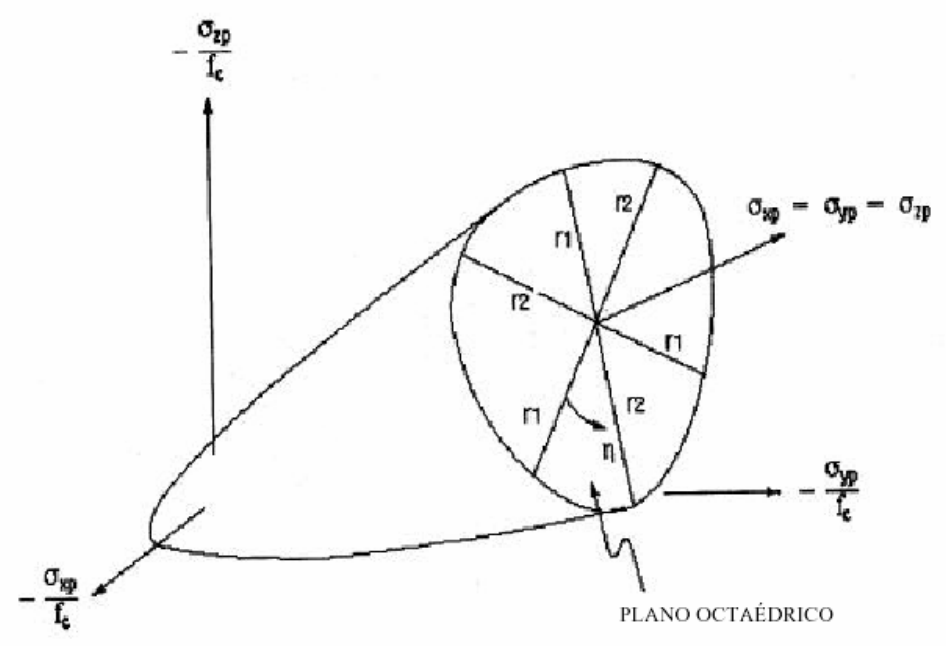

Figura A1 - Superfície de ruptura no espação das tensões principais, ANSYS (1988).

A função $r_{2}$ é calculada ajustando os valores de $b_{0}, b_{1}$ e $b_{2}$ para satisfazer as condições do sistema abaixo.

$$
\left\{\begin{array}{l}
\frac{F_{1}}{f_{c}}\left(\sigma_{1}=\sigma_{2}=0, \sigma_{3}=-f\right) \\
\frac{F_{1}}{f_{c}}\left(\sigma_{1}=\sigma_{2}=-\sigma_{h}^{a}, \sigma_{3}=-\sigma_{h}^{a}-\frac{f_{2}}{3 f_{c}}\right. \\
0
\end{array}\right\}=\left[\begin{array}{ccc}
1 & -\frac{1}{3} & \frac{1}{9} \\
1 & \xi_{2} & \xi_{2}{ }^{2} \\
1 & \xi_{0} & \xi_{0}^{2}
\end{array}\right]\left[\begin{array}{l}
b_{0} \\
b_{1} \\
b_{2}
\end{array}\right\}
$$

Onde:

$\varepsilon_{0}$ é a raiz positiva da Equação 38;

$\varepsilon_{2}$ é expresso por meio da Equação 39. 


$$
\begin{aligned}
& \mathrm{r}_{2}\left(\varepsilon_{0}\right)=\mathrm{a}_{0}+\mathrm{a}_{1} \varepsilon_{0}+\mathrm{a}_{2} \varepsilon_{0}{ }^{2}=0 \\
& \xi_{2}=-\frac{\sigma_{\mathrm{h}}^{\mathrm{a}}}{\mathrm{f}_{\mathrm{c}}}-\frac{\mathrm{f}_{2}}{3 \mathrm{f}_{\mathrm{c}}}
\end{aligned}
$$

Os coeficientes $a_{0}, a_{1}, a_{2}, b_{0}, b_{1}$ e $b_{2}$ são determinados por meio dos Sistemas 33 e 37 respectivamente e precisam satisfazer as seguintes condições:

$$
\begin{aligned}
& \mathrm{a}_{0}>0, \mathrm{a}_{1} \leq 0, \mathrm{a}_{2} \leq 0 \\
& \mathrm{~b}_{0}>0, \mathrm{~b}_{1} \leq 0, \mathrm{~b}_{2} \leq 0
\end{aligned}
$$

Sendo assim, ocorre um fechamento da superfície de ruptura e a ruína ocorrerá sob pressão hidrostática elevada. O fechamento da superfície de ruptura não pode ser verificado experimentalmente. A forma cilíndrica de Von Mises é a superfície mais indicada para valores de compressão $\sigma_{\mathrm{h}}$ elevados. Conseqüentemente, recomenda-se que valores de $f_{1}$ e $f_{2}$ sejam adotados, com valores semelhantes ao da tensão hidrostática máxima encontrada na estrutura.

A superfície de ruptura tem os meridianos representados por parábolas (ver Figura A2) e estão em função da tensão de cisalhamento $\left(\tau_{\mathrm{ct}}\right)$ e de um parâmetro adimensional $(\xi)$.

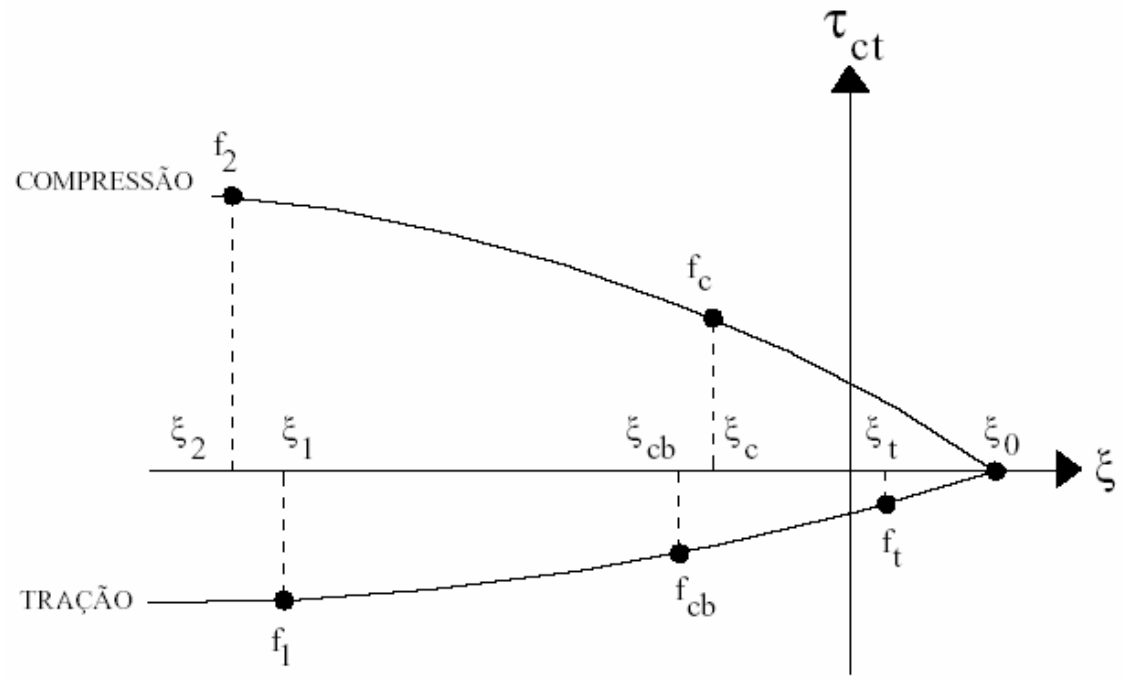

Figura A2 - Superfície de ruptura associado ao modelo Concrete, função de $\xi$, ANSYS (1988). 
Neste domínio, se o critério de ruptura for atendido, o material é assumido como esmagado.

\section{2-Domínio B}

Para esse domínio, F e S são determinados em função das Equações A23 e A24.

$$
\begin{aligned}
& \mathrm{F}=\mathrm{F}_{2}=\frac{1}{\sqrt{15}}\left[\left(\sigma_{2}-\sigma_{3}\right)^{2}+\left(\sigma_{2}\right)^{2}-\left(\sigma_{3}\right)^{2}\right]^{\frac{1}{2}} \\
& \mathrm{~S}=\mathrm{S}_{2}=\left(1-\frac{\sigma_{1}}{\mathrm{f}_{\mathrm{t}}}\right) \frac{2 \mathrm{p}_{2}\left(\mathrm{p}_{2}{ }^{2}-\mathrm{p}_{1}{ }^{2}\right) \cos \eta+\mathrm{p}_{2}\left(2 \mathrm{p}_{1}-\mathrm{p}_{2}\right)\left[4\left(\mathrm{p}_{2}{ }^{2}-\mathrm{p}_{1}{ }^{2}\right) \cos ^{2} \eta+5 \mathrm{p}_{1}^{2}-4 \mathrm{p}_{1} \mathrm{p}_{2}\right]^{\frac{1}{2}}}{4\left(\mathrm{p}_{2}^{2}-\mathrm{p}_{1}^{2}\right) \cos ^{2} \eta+\left(\mathrm{p}_{2}-2 \mathrm{p}_{1}\right)^{2}}
\end{aligned}
$$

$O$ valor de $\cos \eta$ é definido na Equação $A 30$ e os parâmetros $p_{1}, p_{2}$ e $\chi$ são expressos por meio das Equações A25, A26 e A27.

$$
\begin{aligned}
& \mathrm{p}_{1}=\mathrm{a}_{0}+\mathrm{a}_{1} \chi+\mathrm{a}_{2} \chi^{2} \\
& \mathrm{p}_{2}=\mathrm{b}_{0}+\mathrm{b}_{1} \chi+\mathrm{b}_{2} \chi^{2} \\
& \chi=\frac{1}{3}\left(\sigma_{2}+\sigma_{3}\right)
\end{aligned}
$$

Os coeficientes $a_{0}, a_{1}, a_{2}, b_{0}, b_{1}$ e $b_{2}$ são determinados por meio dos Sistemas 33 e 37 respectivamente.

Neste domínio, atendido o critério de ruptura, surgirão fissuras no plano perpendicular a tensão principal $\sigma_{1}$.

\section{3-Domínio C}

As Equações A28 e A29 representam as funções F e S no Domínio C.

$$
\begin{aligned}
& \mathrm{F}=\mathrm{F}_{3}=\sigma_{\mathrm{i}} ; \mathrm{i}=1,2 \\
& \mathrm{~S}=\mathrm{S}_{3}=\frac{\mathrm{f}_{\mathrm{t}}}{\mathrm{f}_{\mathrm{c}}}\left(1+\frac{\sigma_{3}}{\mathrm{~S}_{2}\left(\sigma_{\mathrm{i}}, 0, \sigma_{3}\right)}\right) \mathrm{i}=1,2
\end{aligned}
$$


Se o critério de ruptura para i $=1,2$ for satisfeito, ocorrerão fissuras nos planos perpendiculares as tensões principais $\sigma_{1}$ e $\sigma_{2}$, mas, se o critério for válido apenas para $\mathrm{i}=1$, as fissuras irão aparecer no plano perpendicular a tensão principal $\sigma_{1}$.

\section{4 - Domínio D}

O Domínio D é definido por meio das Equações A50 e A51.

$\mathrm{F}=\mathrm{F}_{4}=\sigma_{\mathrm{i}}, \mathrm{i}=1,2,3$

$S=S_{4}=\frac{f_{t}}{f_{c}}$

Se o critério de ruptura for atendido nas direções 1, 2 e 3, ocorrerão fissuras nos planos perpendiculares às tensões principais $\sigma_{1}, \sigma_{2}$ e $\sigma_{3}$.

Mas, se o critério for satisfeito apenas nas direções 1 e 2, as fissuras surgirão nos planos perpendiculares às tensões principais $\sigma_{1}$ e $\sigma_{2}$. Mas, se o critério de for satisfeito somente na direção 1 , as fissuras irão se formar apenas no plano perpendicular à tensão principal $\sigma_{1}$. 


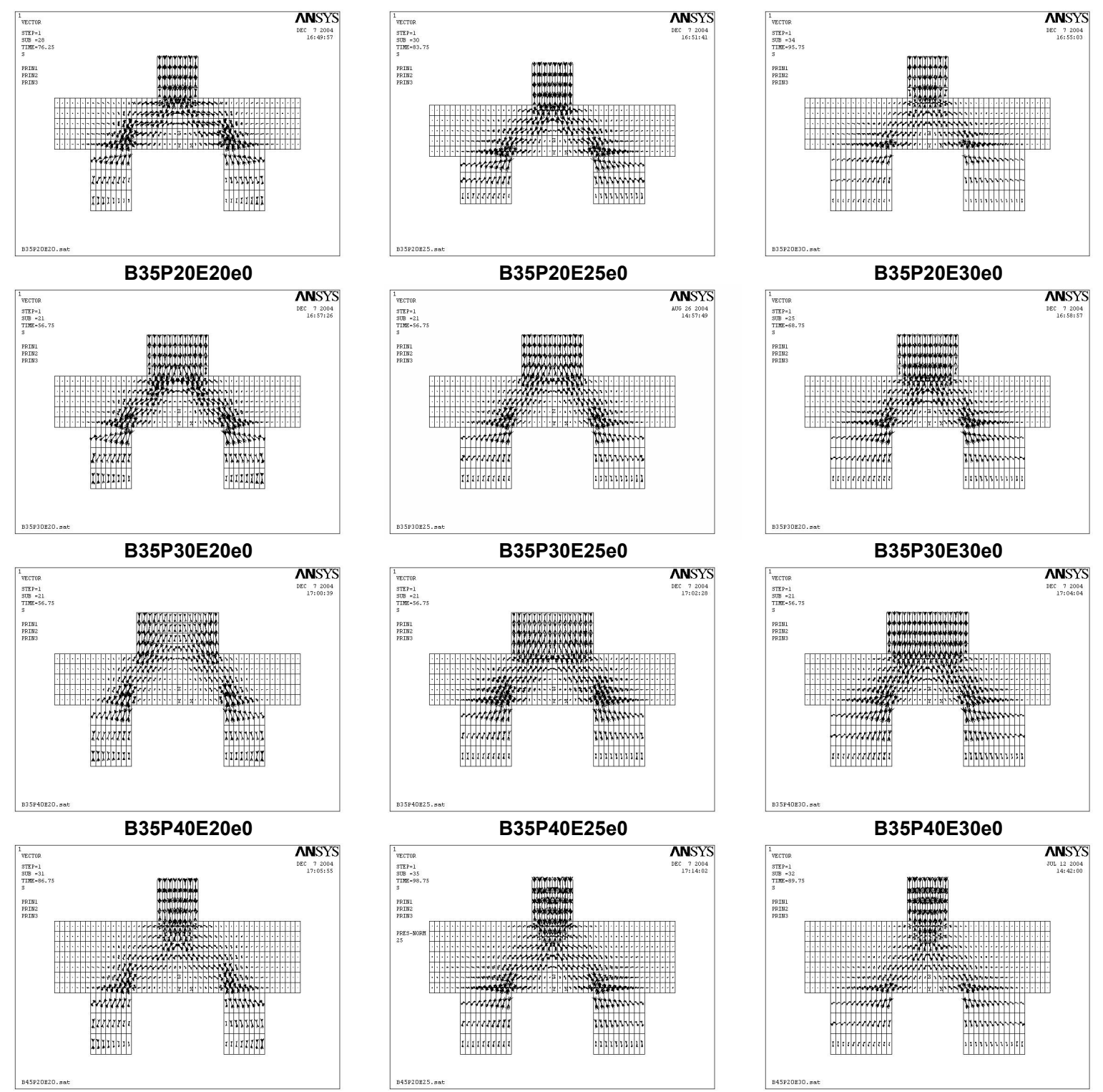

B45P20E20e0
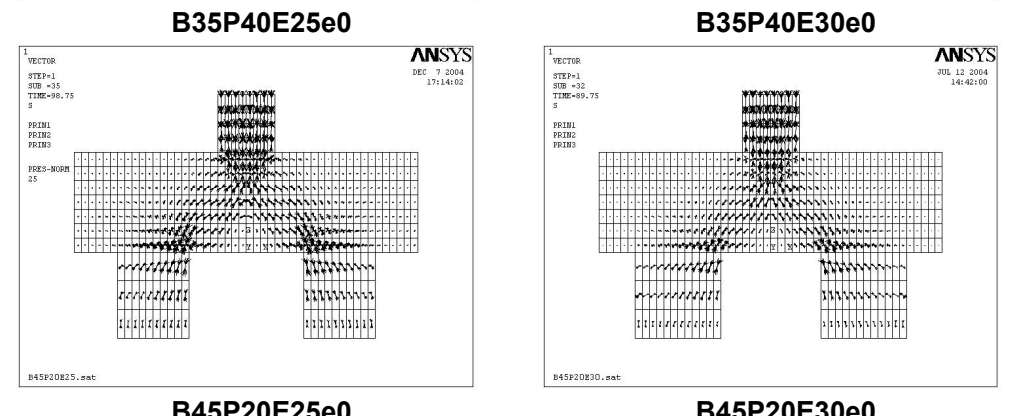

B45P20E30e0 

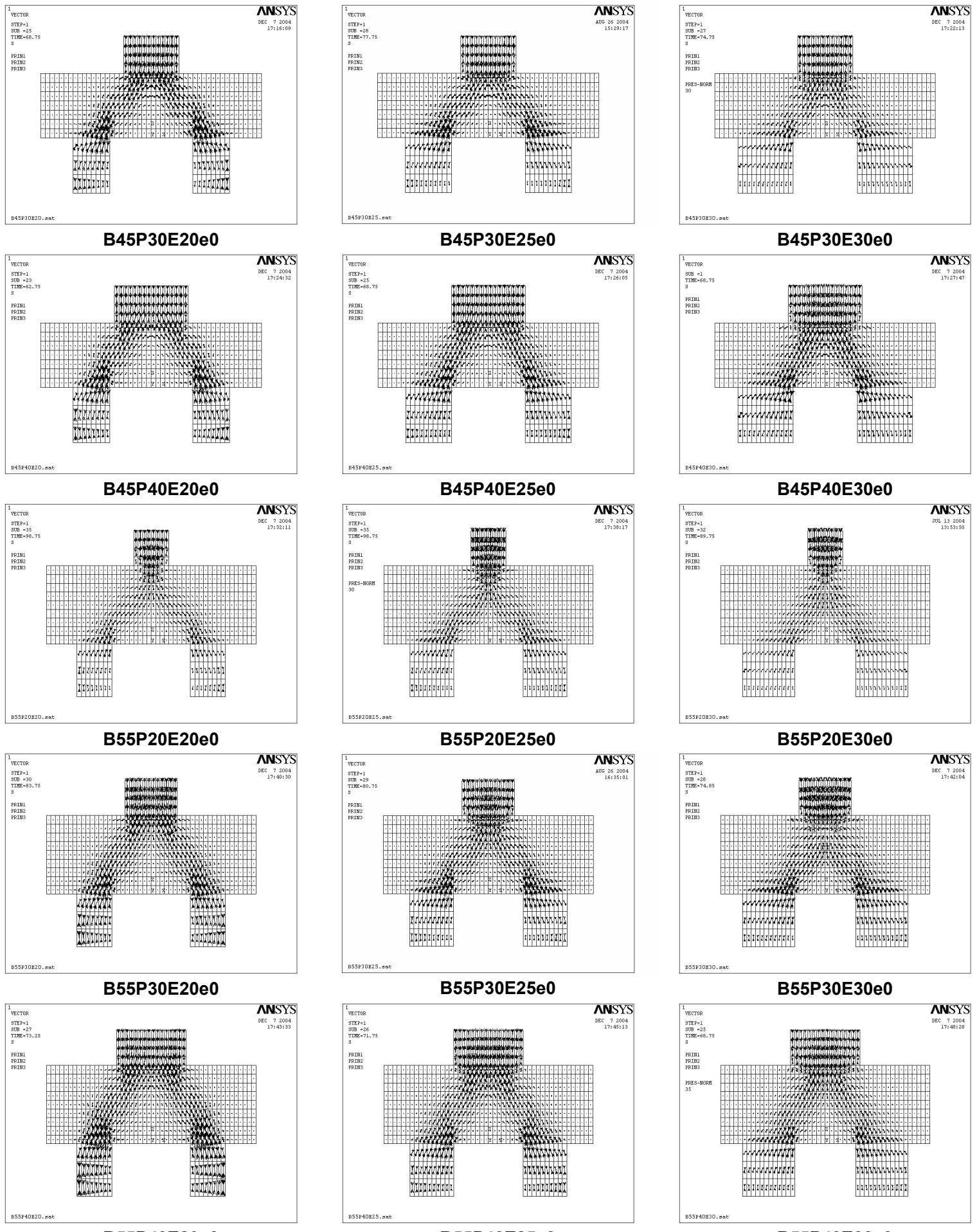

B55P40E20e0

B55P40E25e0

B55P40E30e0

Figura B1 - Blocos com excentricidade igual a zero. 

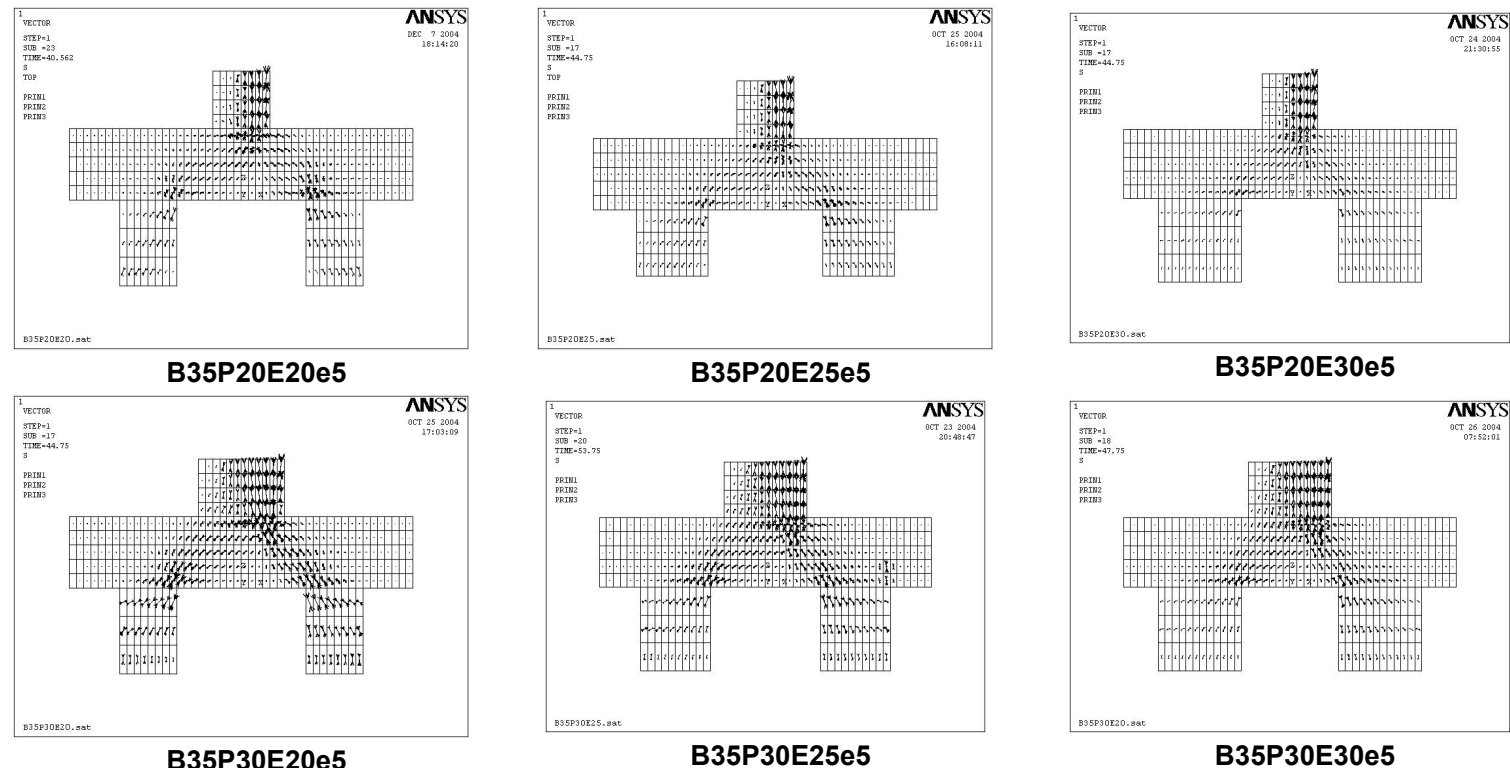

B35P20E30e5
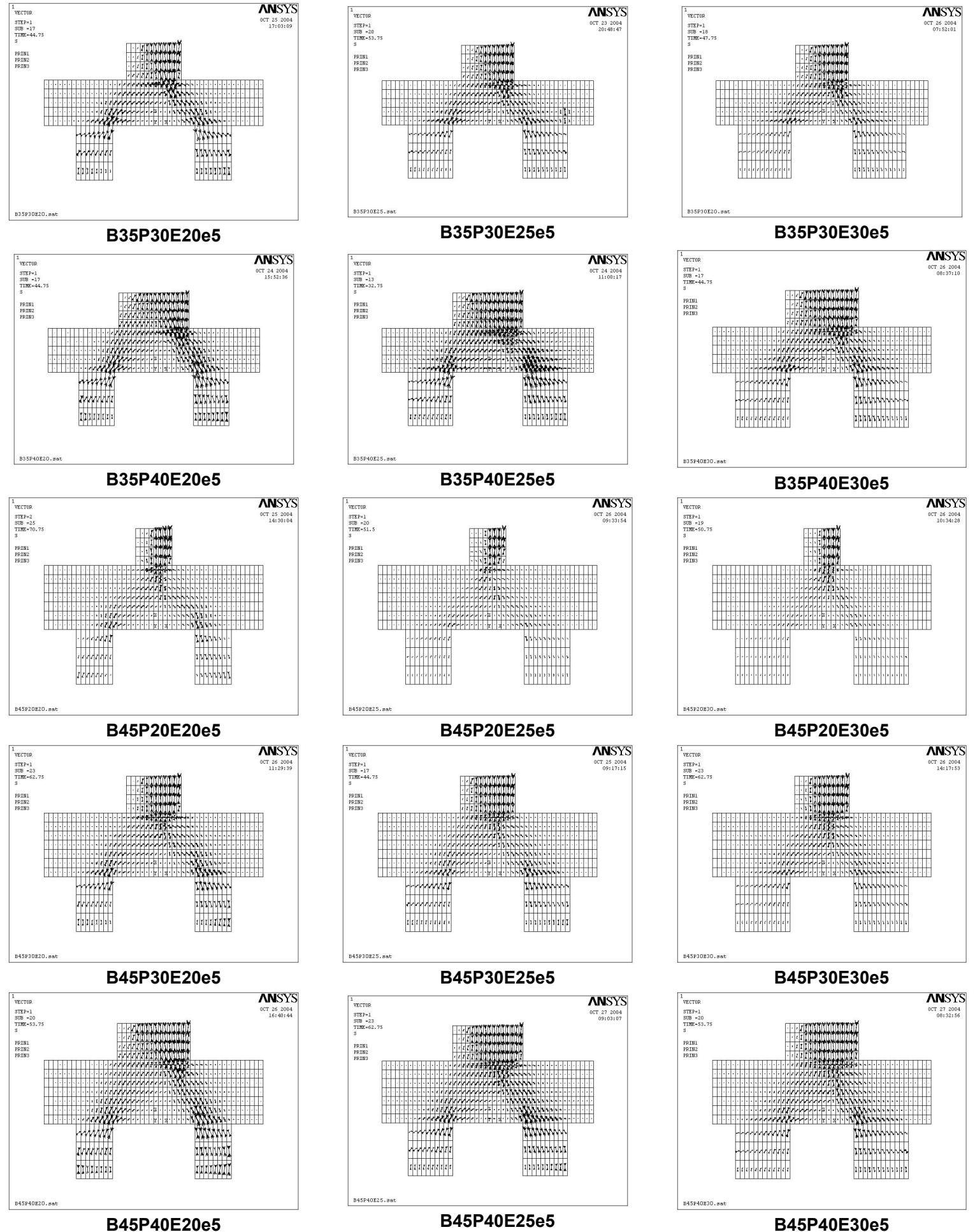

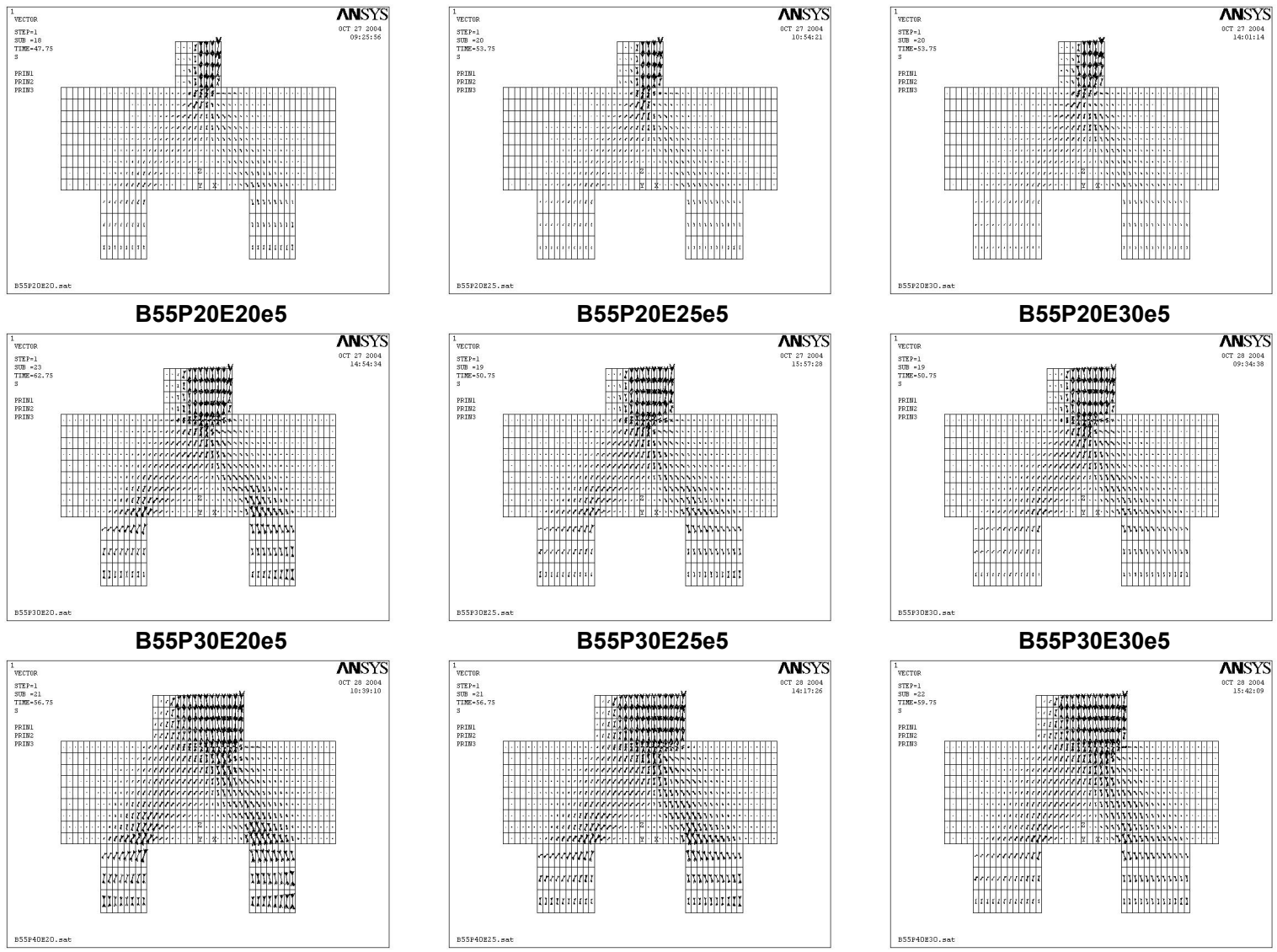

B55P40E20e5

B55P40E25e5
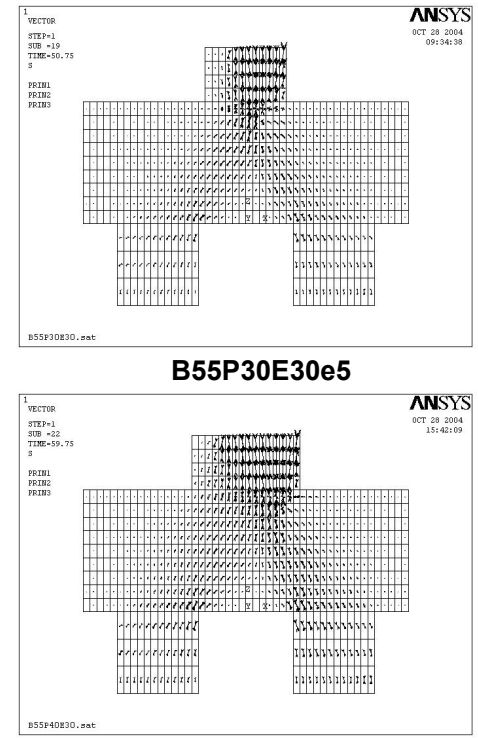

B55P40E30e5

Figura B2 - Blocos com excentricidade igual a cinco centímetros. 

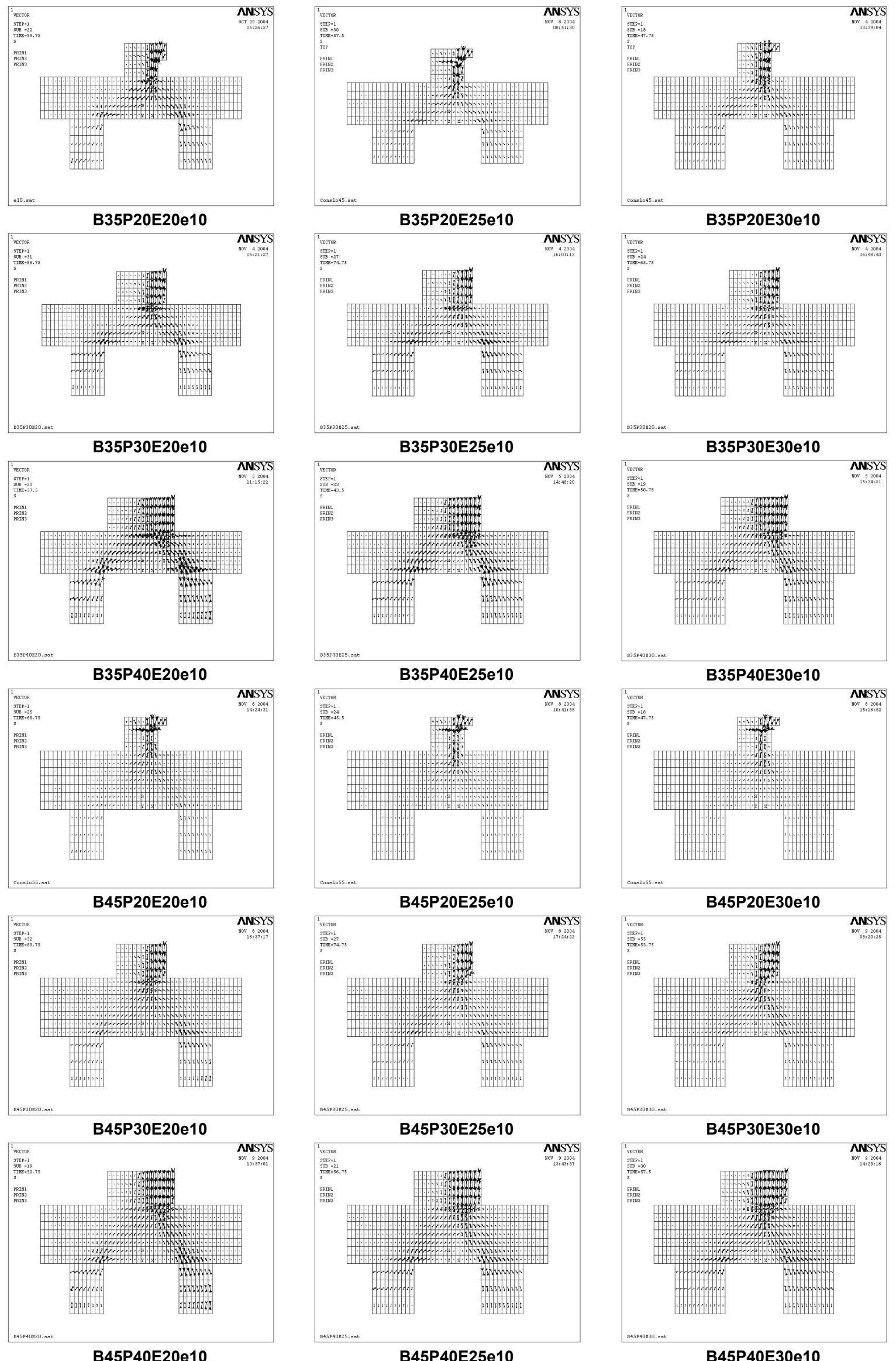

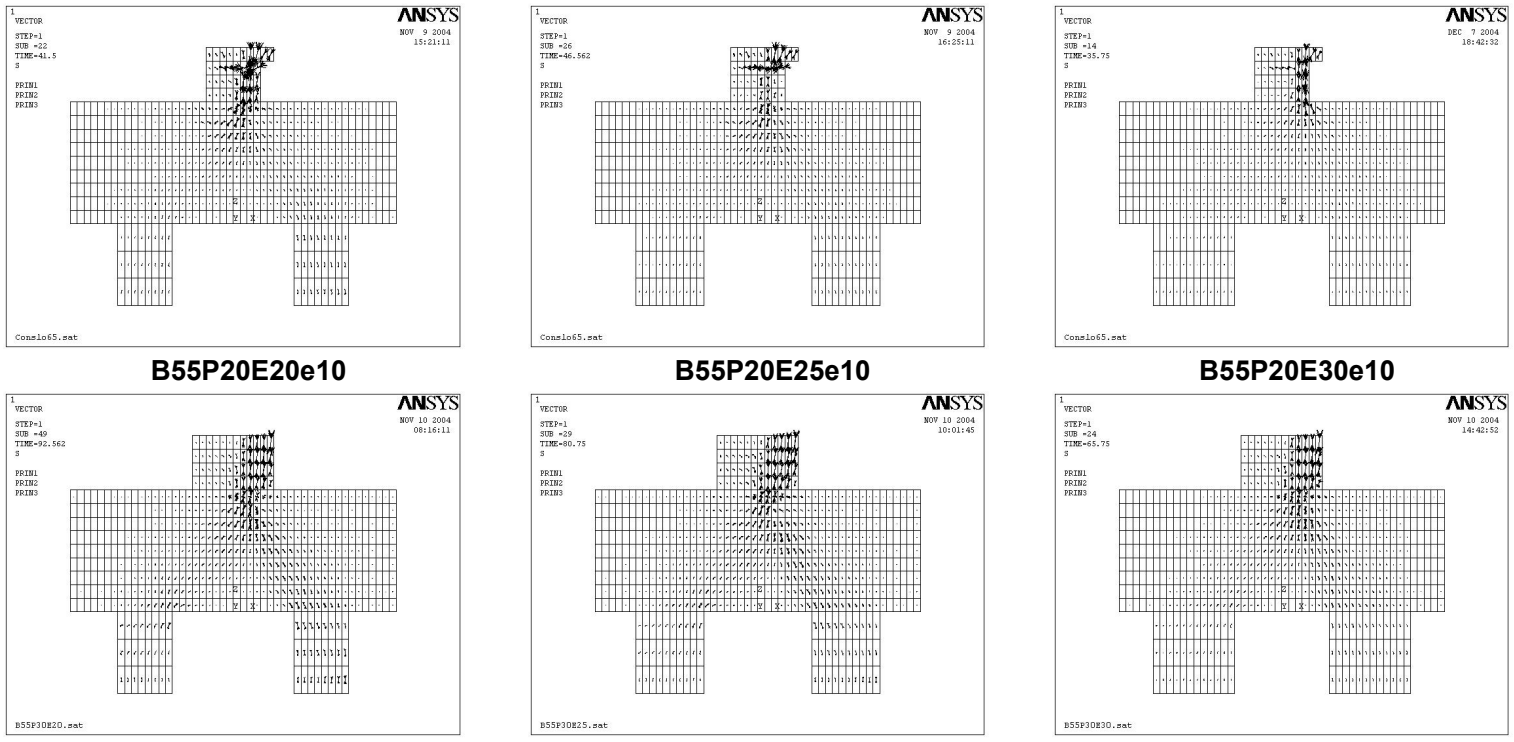

B55P30E20e10

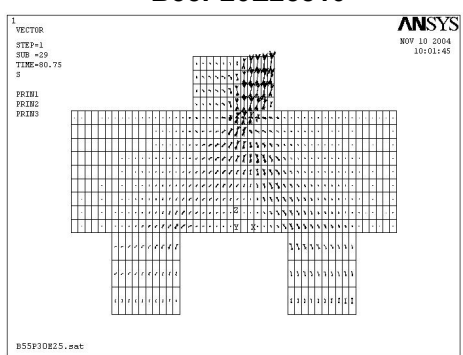

B55P20E30e10

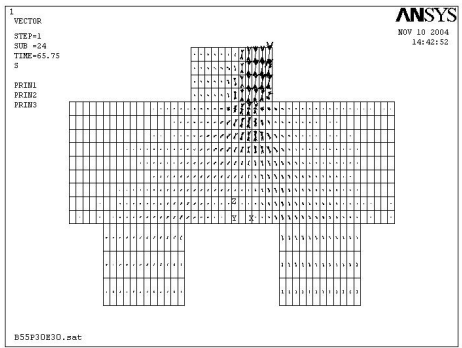

B55P30E30e10
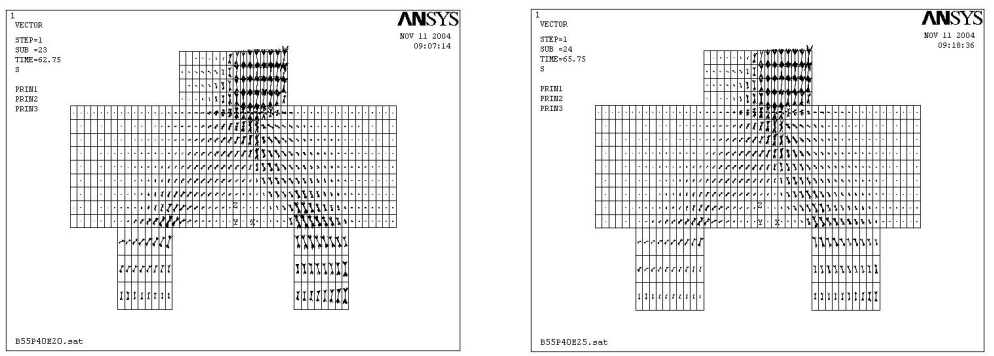

B55P40E25e10

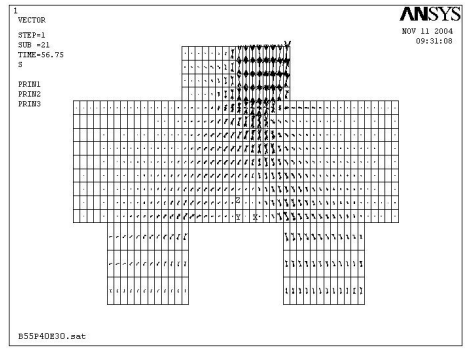

B55P40E30e10

Figura B3 - Blocos com excentricidade igual a dez centímetros. 

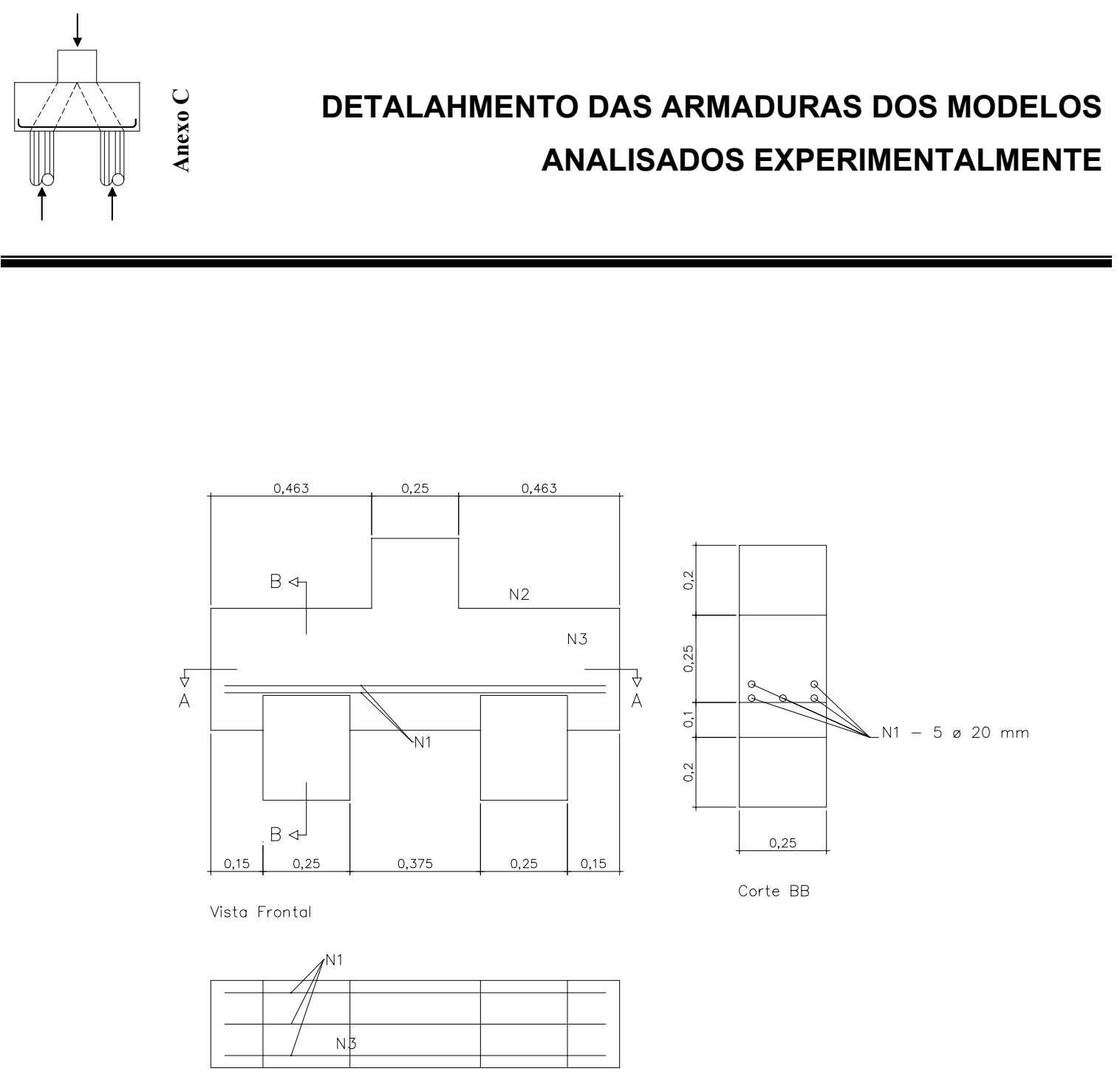

Corte AA

B35P25E25e0Asw0 


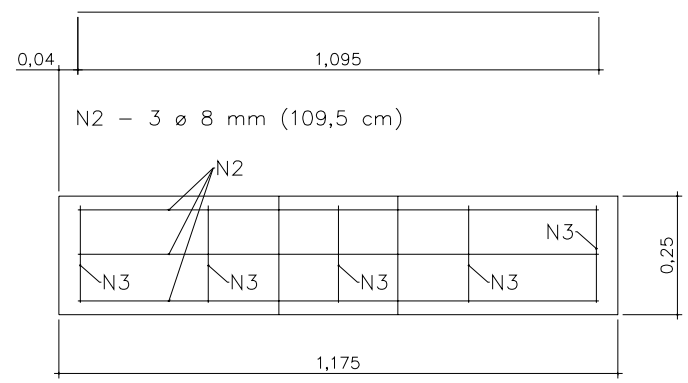

Corte BB
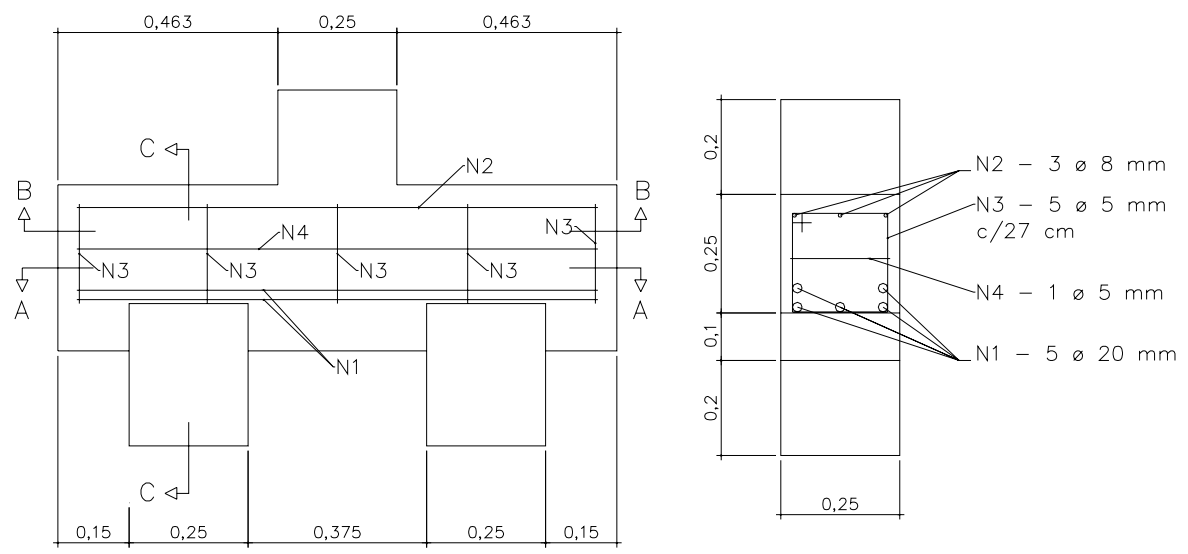

Visto Frontal

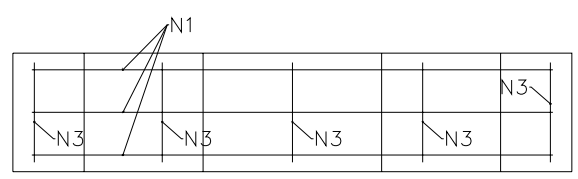

Corte CO

Corte AA - Esc. 1:20

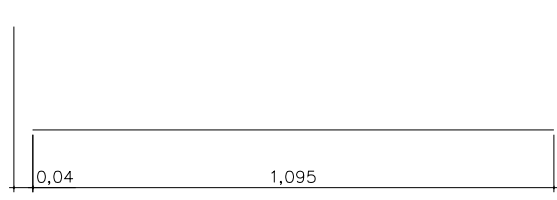

$\mathrm{N1}-5 \varnothing 20 \mathrm{~mm}(109,5 \mathrm{~cm})$

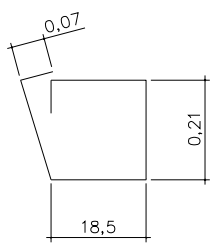

$\mathrm{N} 3-5 \varnothing 5 \mathrm{~mm}$

c) $27 \mathrm{~cm}(93 \mathrm{~cm})$

\section{B35P25E25e0}

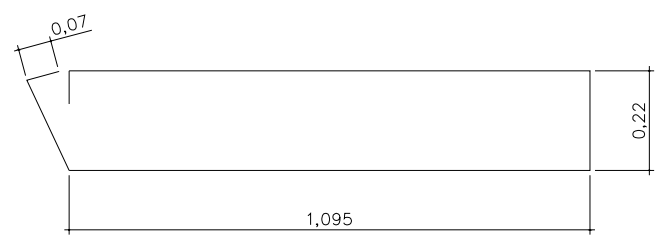

$\mathrm{N} 4-1 \varnothing 5 \mathrm{~mm}(277 \mathrm{~cm})$ 


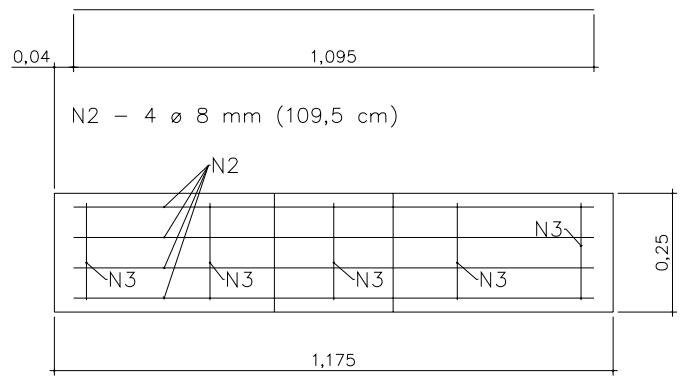

Corte BB
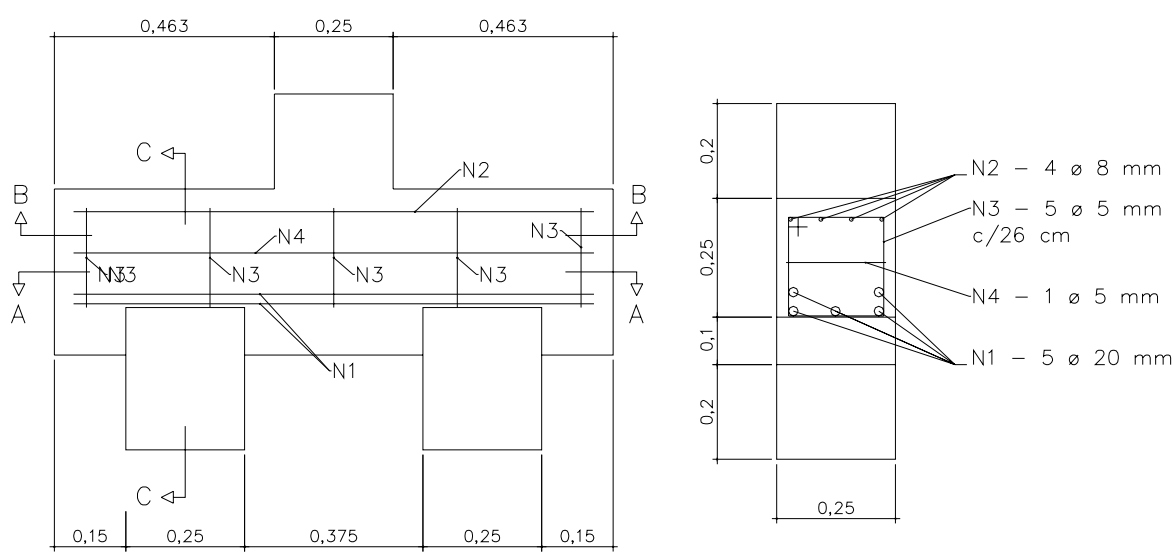

Visto Fronto
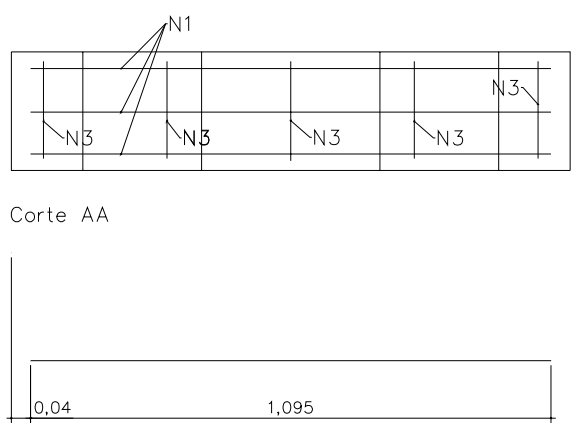

$\mathrm{N}^{1}-5 \otimes 20 \mathrm{~mm}(109,5 \mathrm{~cm})$

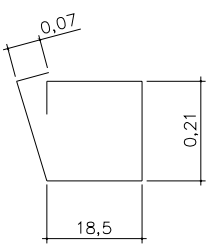

$\mathrm{N} 3-5 \varnothing 5 \mathrm{~mm}$

c) $26 \mathrm{~cm}(93 \mathrm{~cm})$

B35P25E25e2,5

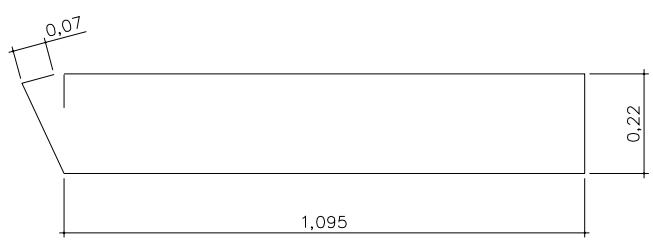

$\mathrm{N} 4-1 \oslash 5 \mathrm{~mm}(277 \mathrm{~cm})$ 


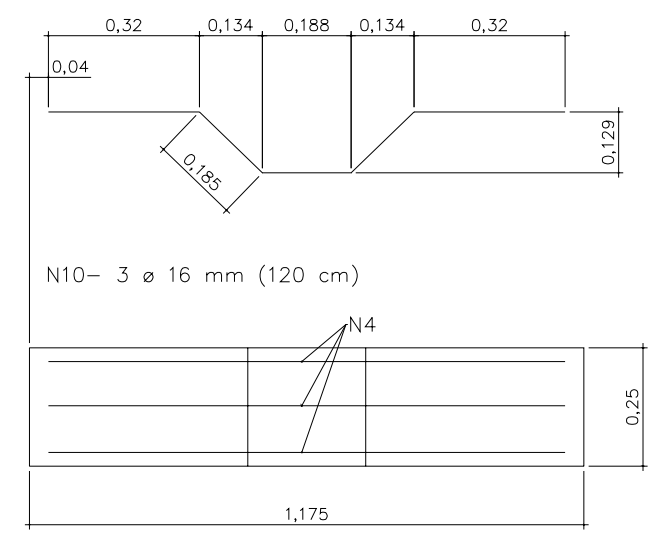

Corte BB
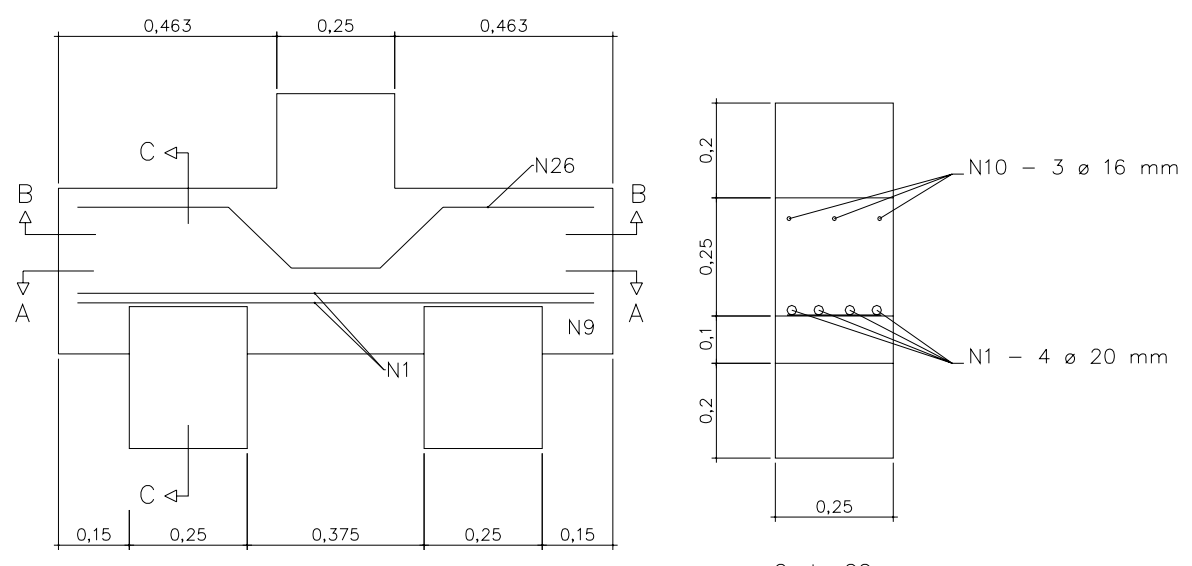

Visto Fronto

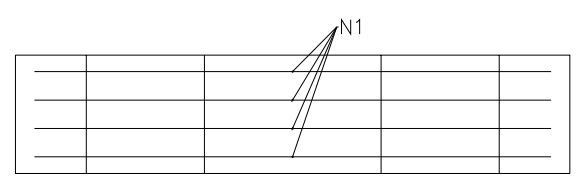

Corte $\mathrm{CC}$

Corte AA

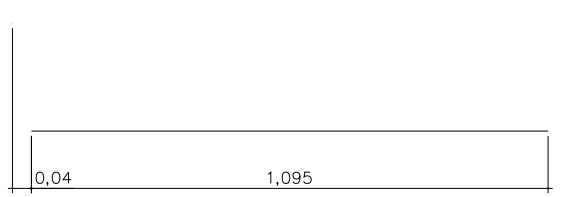

$\mathrm{N} 1-4 \varnothing 20 \mathrm{~mm}(109,5 \mathrm{~cm})$

B35P25E25e0Asw,c 


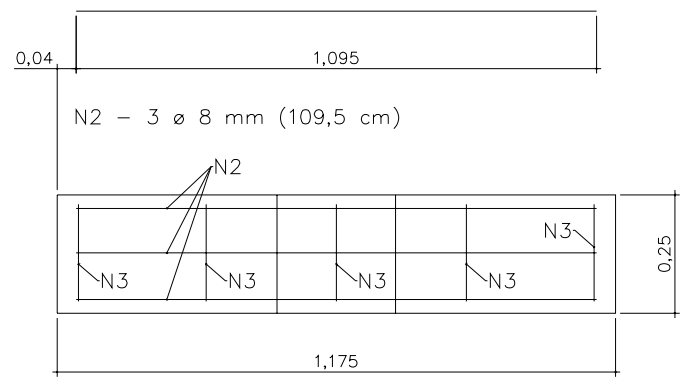

Corte BB
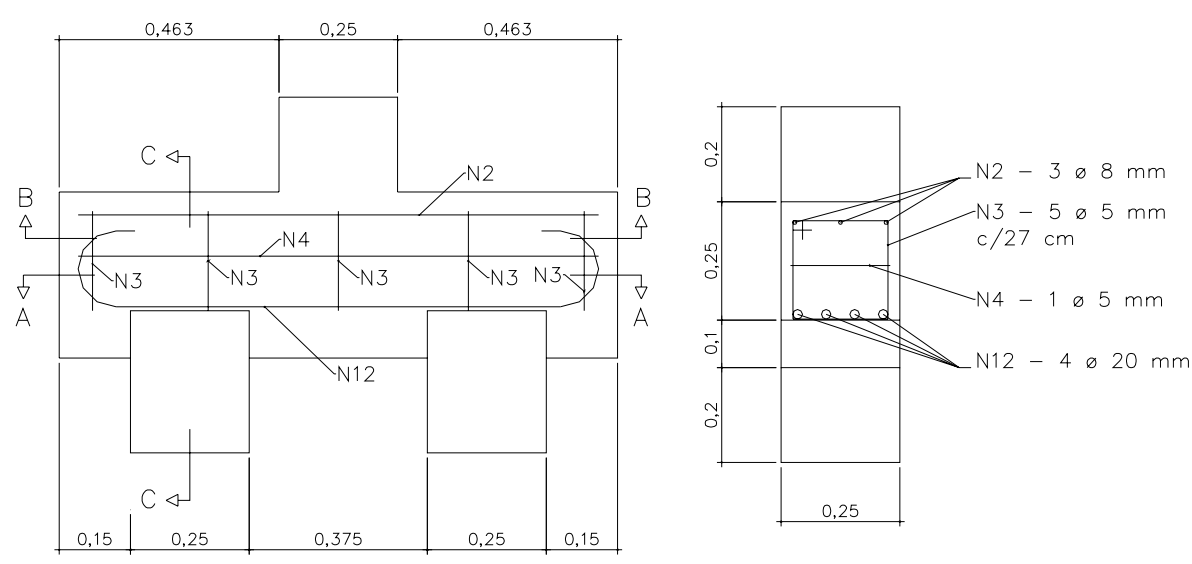

Visto Fronto

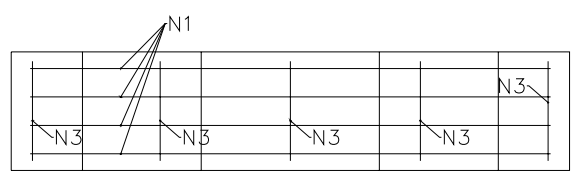

Corte AA - Esc. 1:20

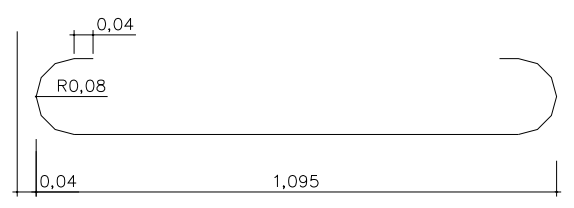

Corte CC

$\mathrm{N} 12-4 \varnothing 20 \mathrm{~mm}(160 \mathrm{~cm})$

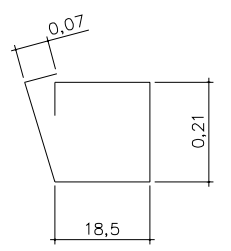

$\mathrm{N} 3-5 \varnothing 5 \mathrm{~mm}$

c) $27 \mathrm{~cm}(94 \mathrm{~cm})$

\section{B35P25E25e0CG}

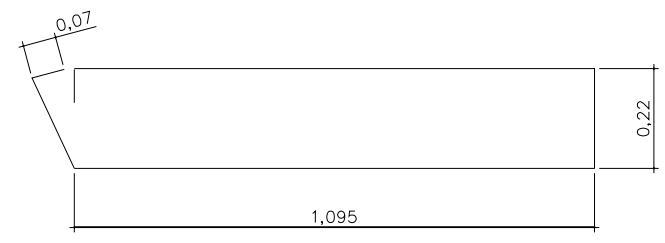

$\mathrm{N4}-1 \varnothing 5 \mathrm{~mm}(277 \mathrm{~cm})$ 


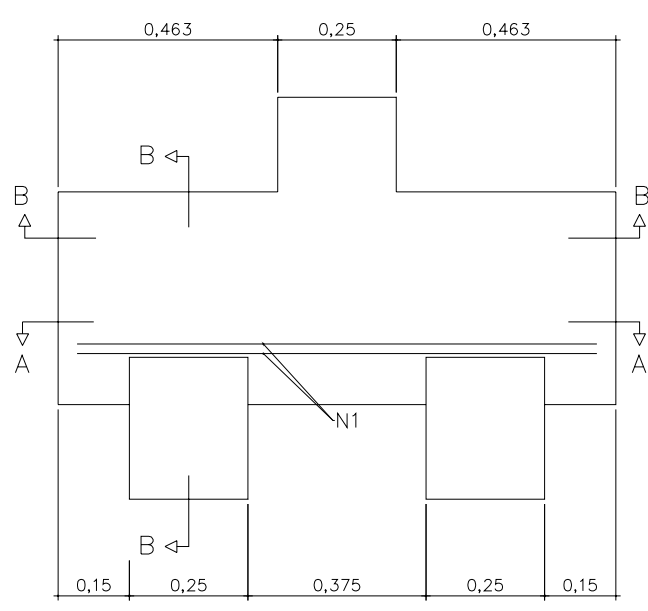

Vista Frontal

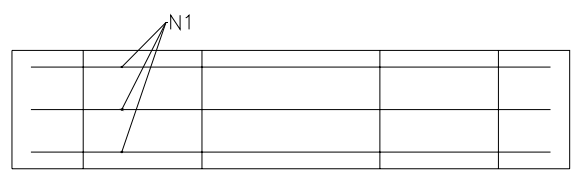

Corte AA

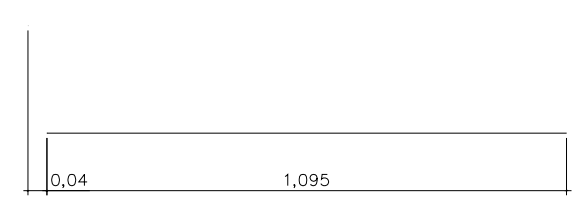

$\mathrm{N} 1-5 \varnothing 20 \mathrm{~mm}(109,5 \mathrm{~cm})$

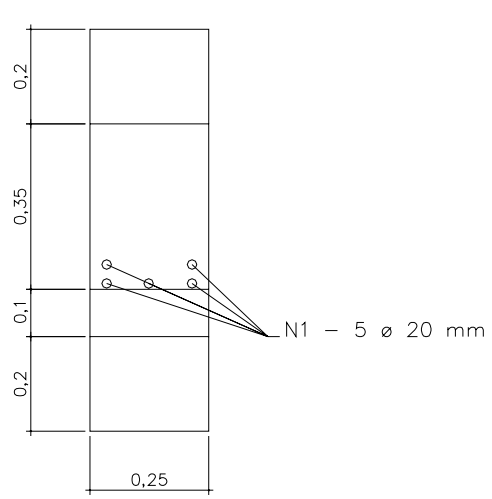

Corte BB

B45P25E25e0Asw0 

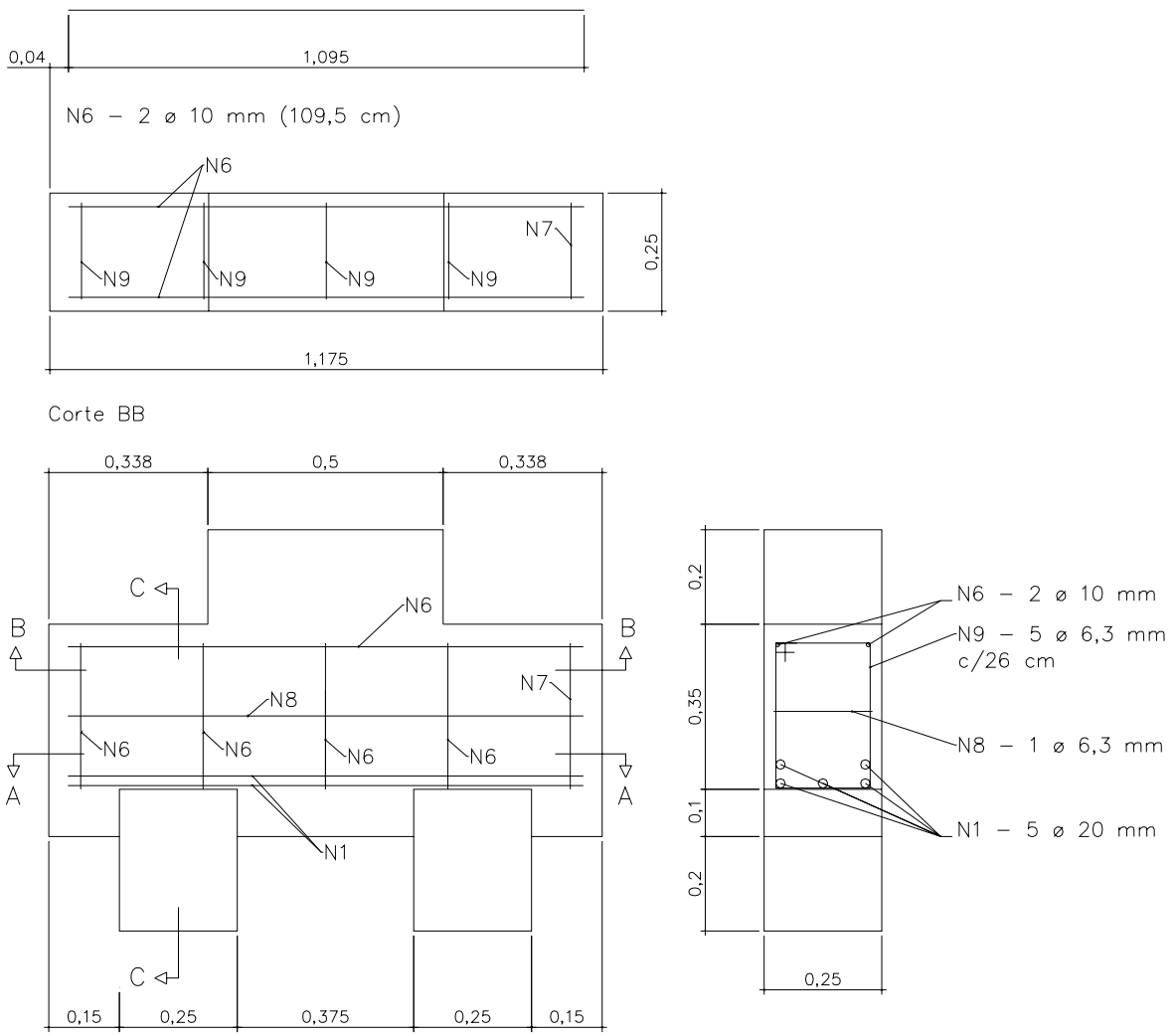

Vista Frontol

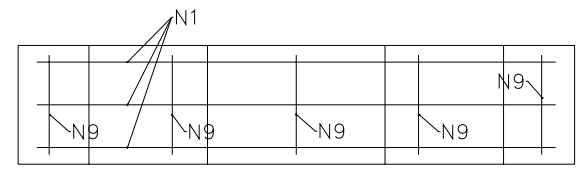

Corte AA - Esc. 1:20

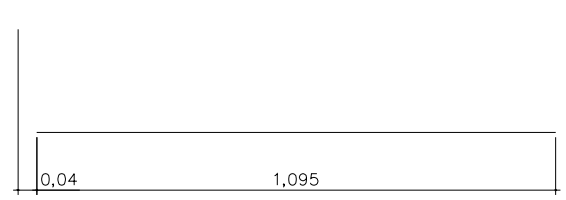

$N 1-5 \varnothing 20 \mathrm{~mm}(109,5 \mathrm{~cm})$

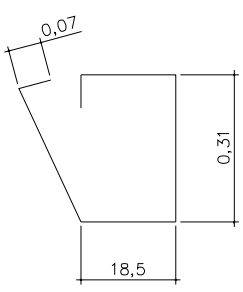

v9 $-5 \varnothing 6,3 \mathrm{~mm}$

c) $26 \mathrm{~cm}(113 \mathrm{~cm})$

B45P50E25e0

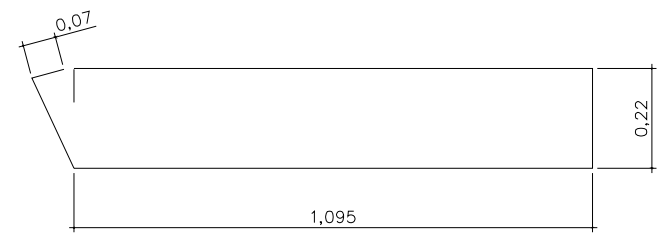




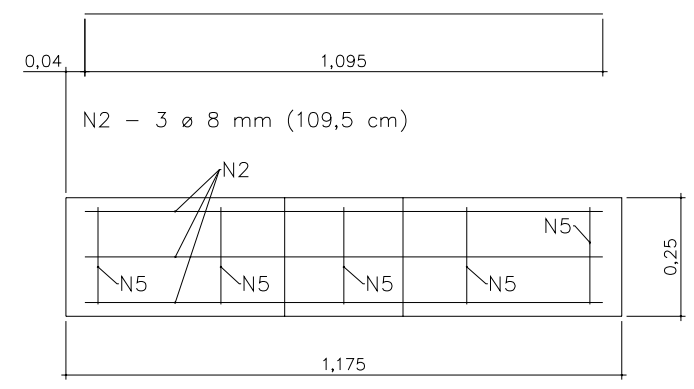

Corte BB
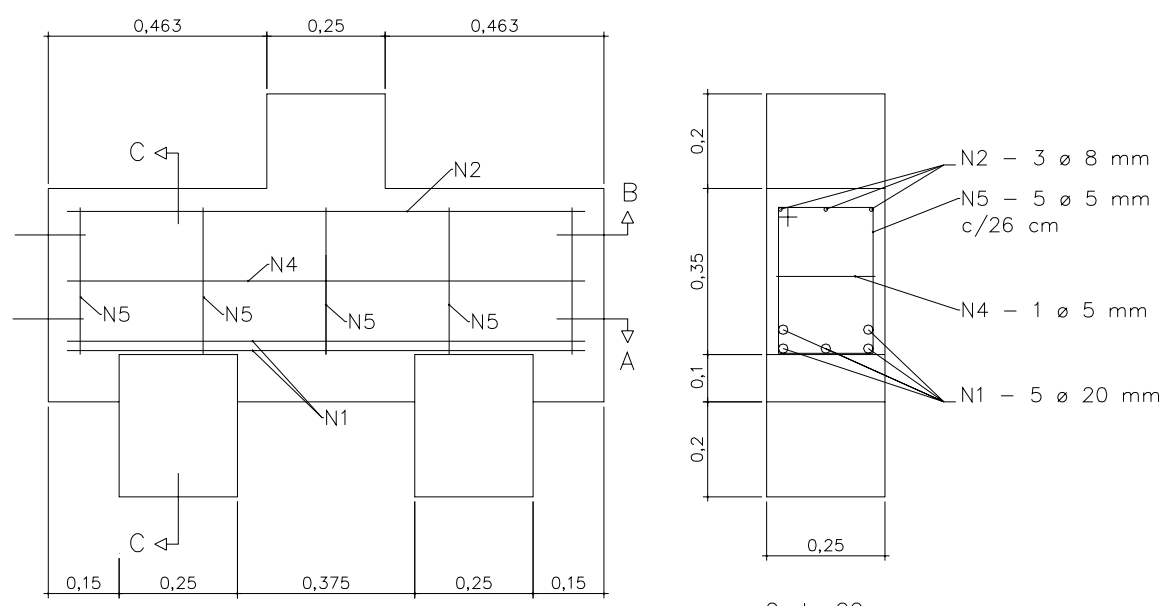

Vista Frontal

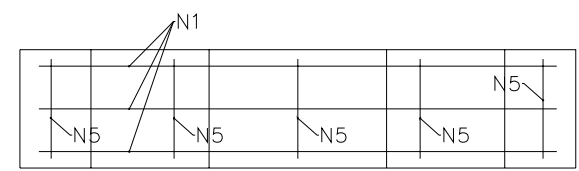

Corte AA - Esc. 1:20

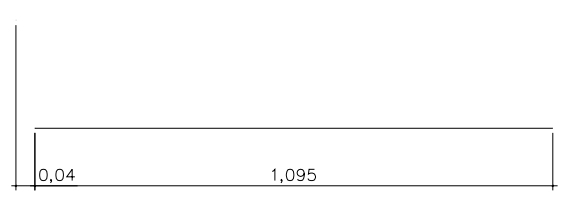

$\mathrm{N1}-5 \varnothing 20 \mathrm{~mm}(109,5 \mathrm{~cm})$

Corte CC

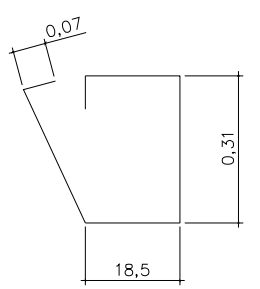

$\mathrm{N} 5-5 \varnothing 5 \mathrm{~mm}$

c) $26 \mathrm{~cm}(113 \mathrm{~cm})$

B45P25E25e5

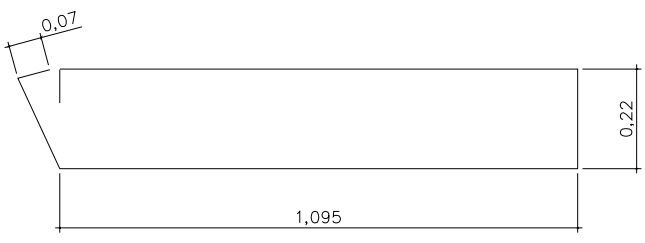

$\mathrm{N} 4-1 \varnothing 5 \mathrm{~mm}(277 \mathrm{~cm})$ 


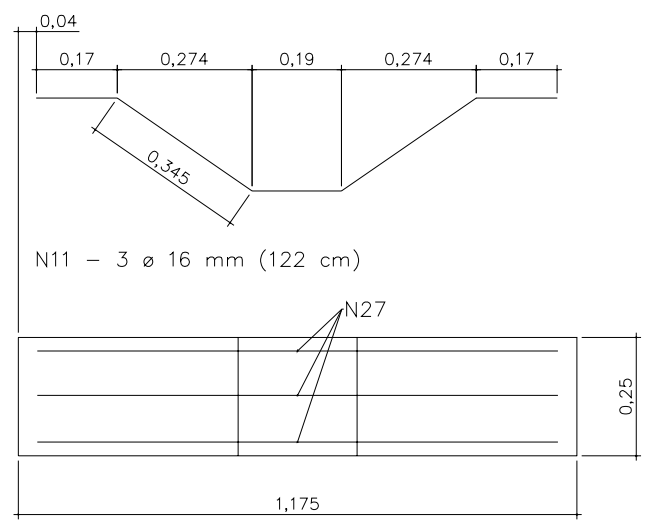

Corte BB
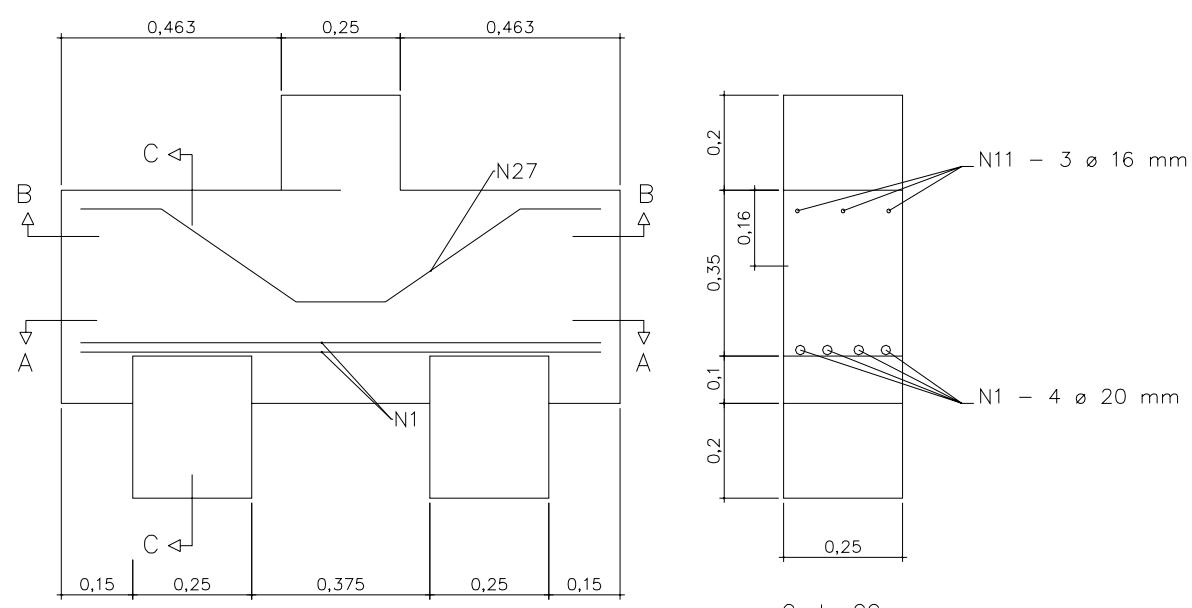

Visto Frontal - Esc. 1:20

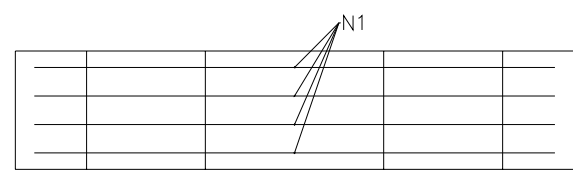

Corte AA

Corte CC

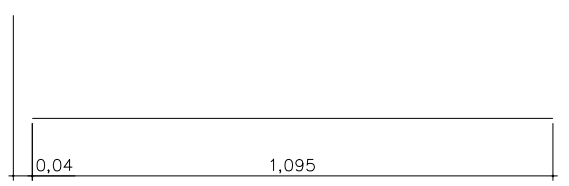

$N_{1}-6 \varnothing 20 \mathrm{~mm}(109,5 \mathrm{~cm})$

B45P25E25e0Asw,c 

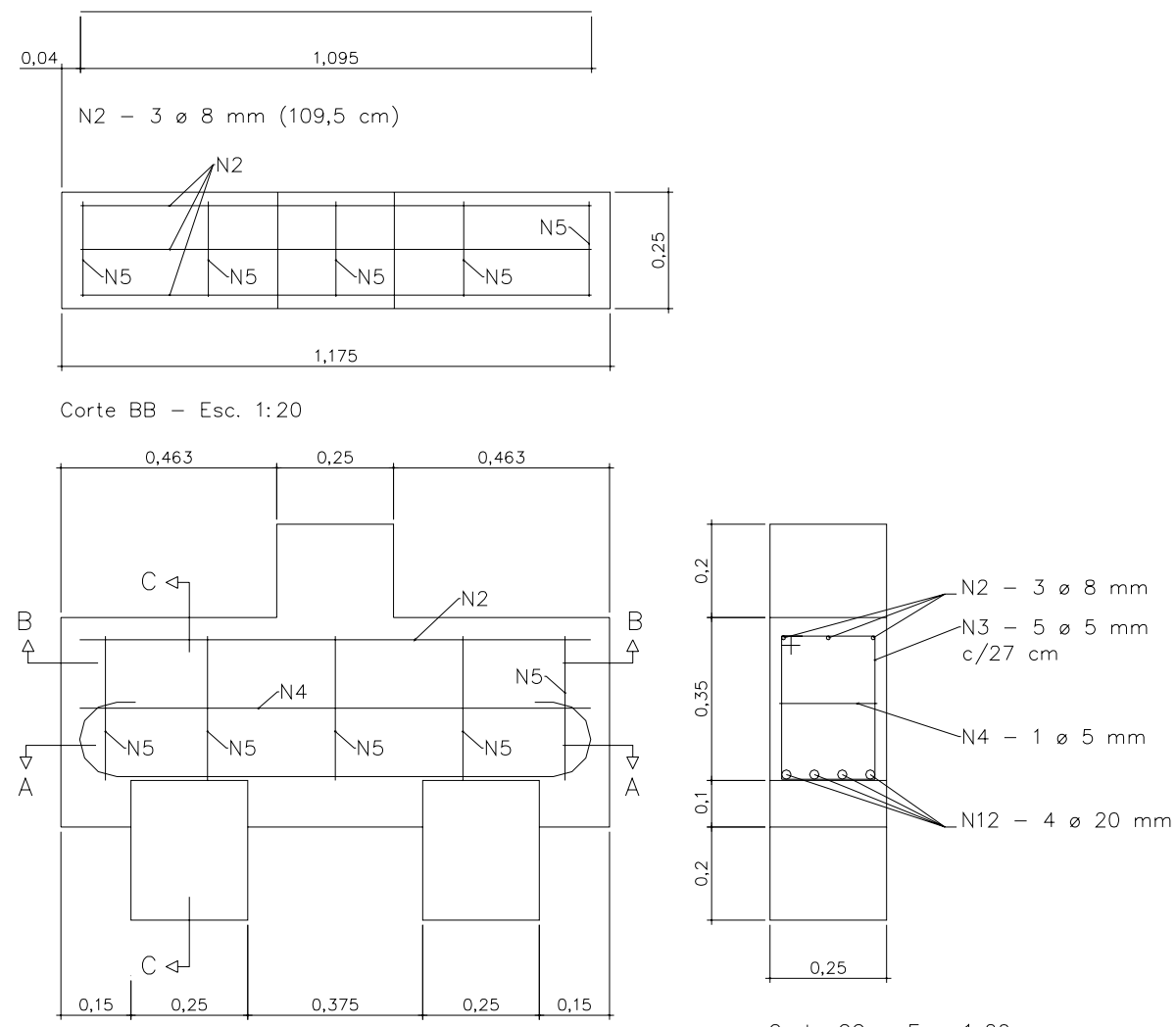

Vista Frontal - Esc. 1:20

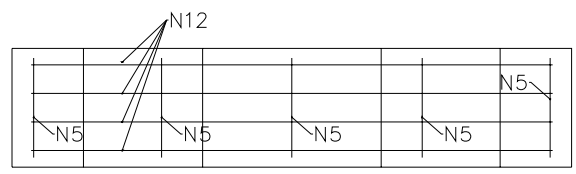

Corte AA - EsC. 1:20
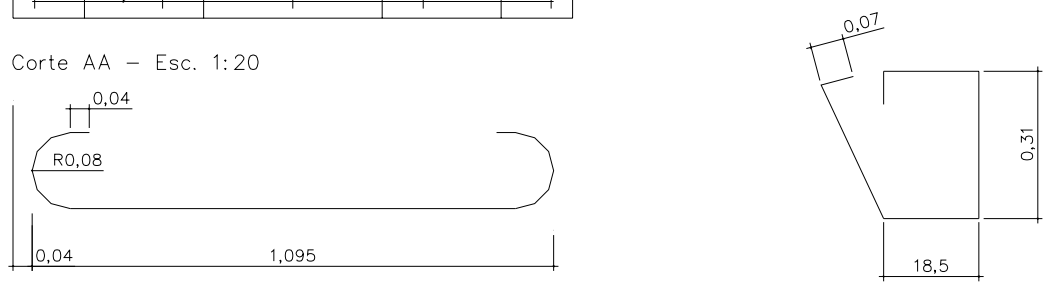

$\mathrm{N} 12-4 \varnothing 20 \mathrm{~mm}(160 \mathrm{~cm})$

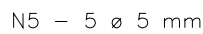

c) $27 \mathrm{~cm}(113 \mathrm{~cm})$

B45P25E25e0CG

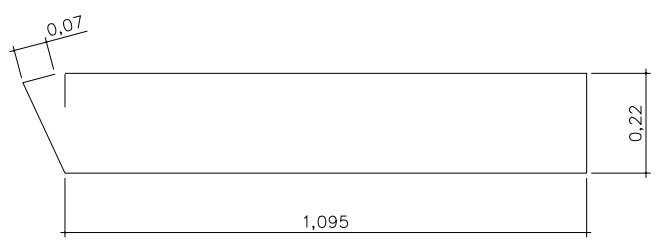

$\mathrm{N} 4-1 \varnothing 5 \mathrm{~mm}(277 \mathrm{~cm})$ 


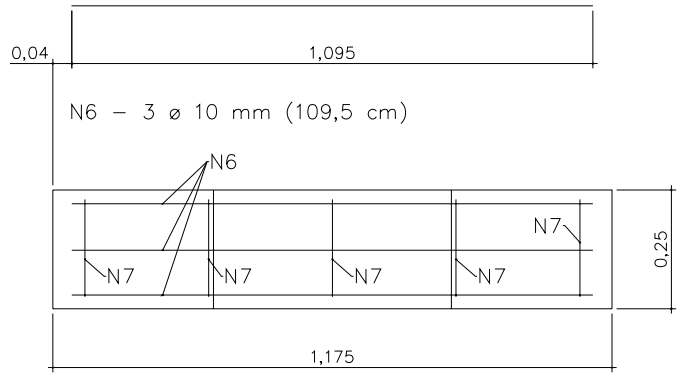

Corte BB
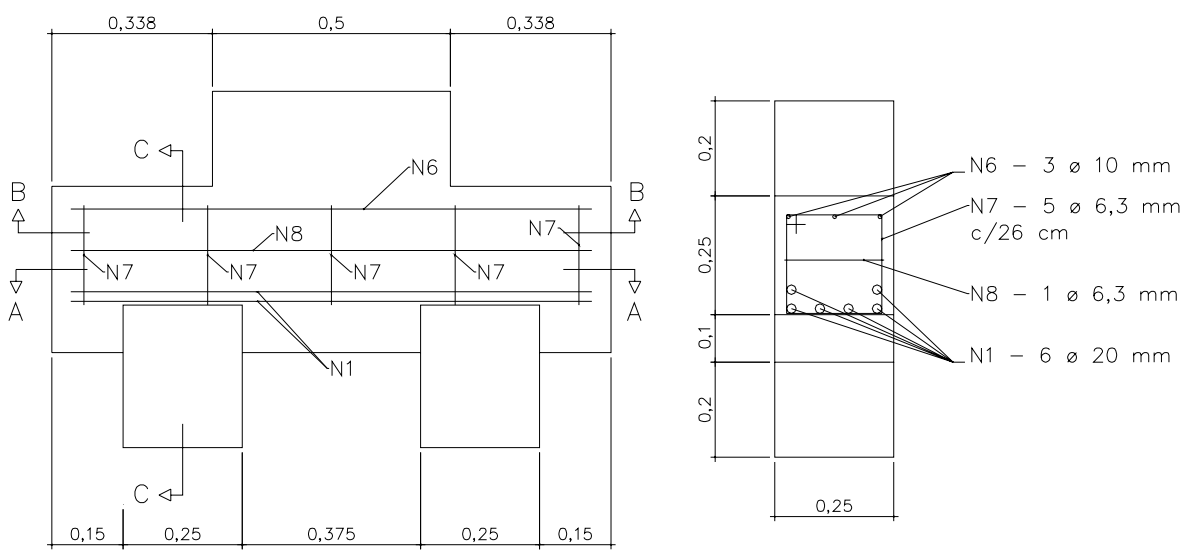

Vista Frontal

Corte CC

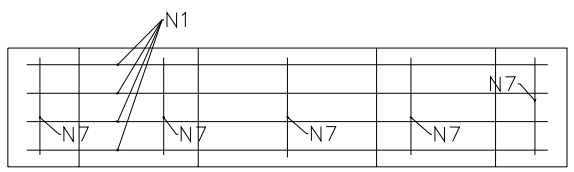

Corte AA
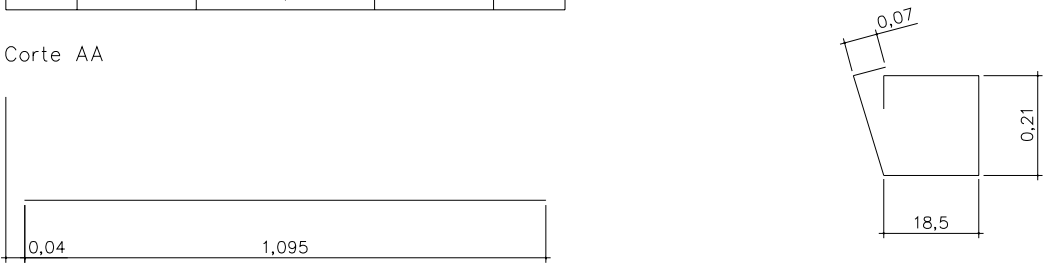

$N^{\prime}-6 \varnothing 20 \mathrm{~mm}(109,5 \mathrm{~cm})$

$\mathrm{N} 7-5 \varnothing 6,3 \mathrm{~mm}$

c) $26 \mathrm{~cm}(93 \mathrm{~cm})$

\section{B35P50E25e0}

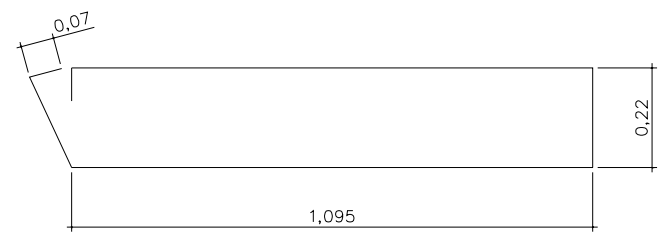




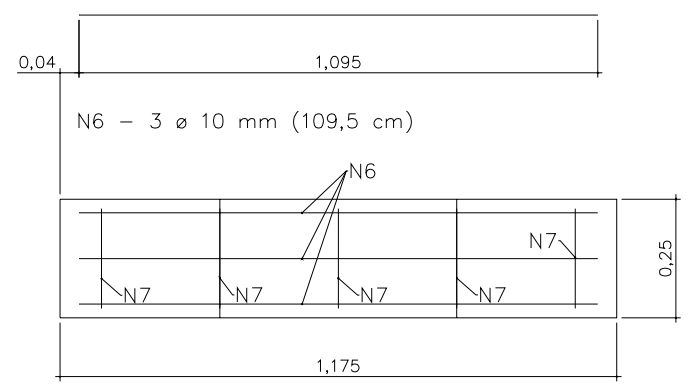

Corte BB

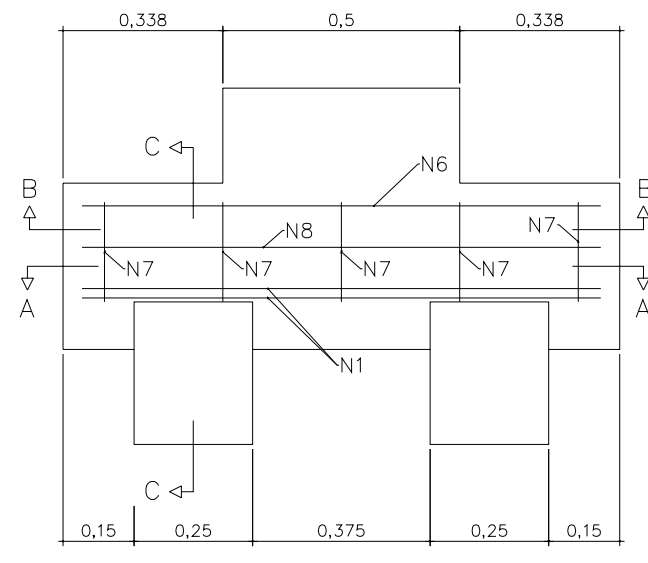

Vista Frontal

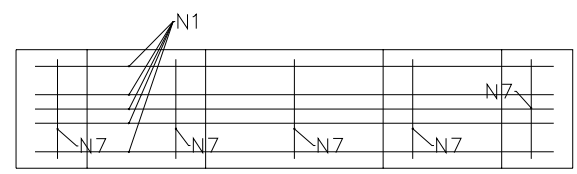

Corte AA - Esc. 1:20

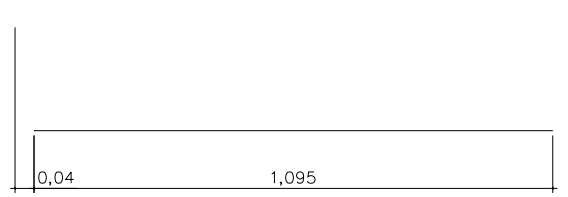

$\mathrm{N1}-7 \varnothing 20 \mathrm{~mm}(109,5 \mathrm{~cm})$

B35P50E25e12,5

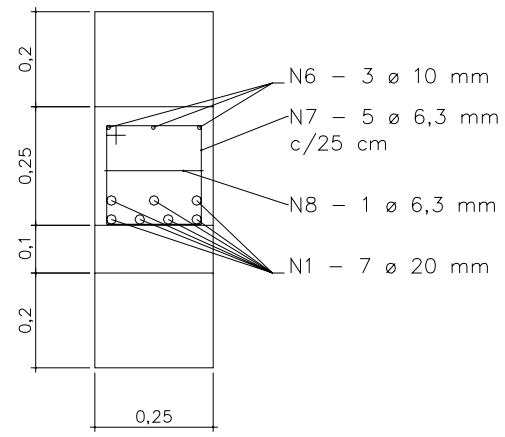

Corte Cc

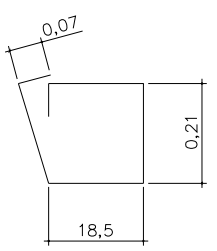

$\mathrm{N} 7-5 \varnothing 6,3 \mathrm{~mm}$ c) $19 \mathrm{~cm}(93 \mathrm{~cm})$

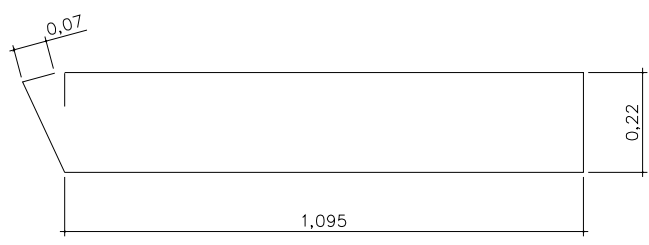

$\mathrm{N} 8-1 \varnothing 6,3 \mathrm{~mm}(277 \mathrm{~cm})$ 

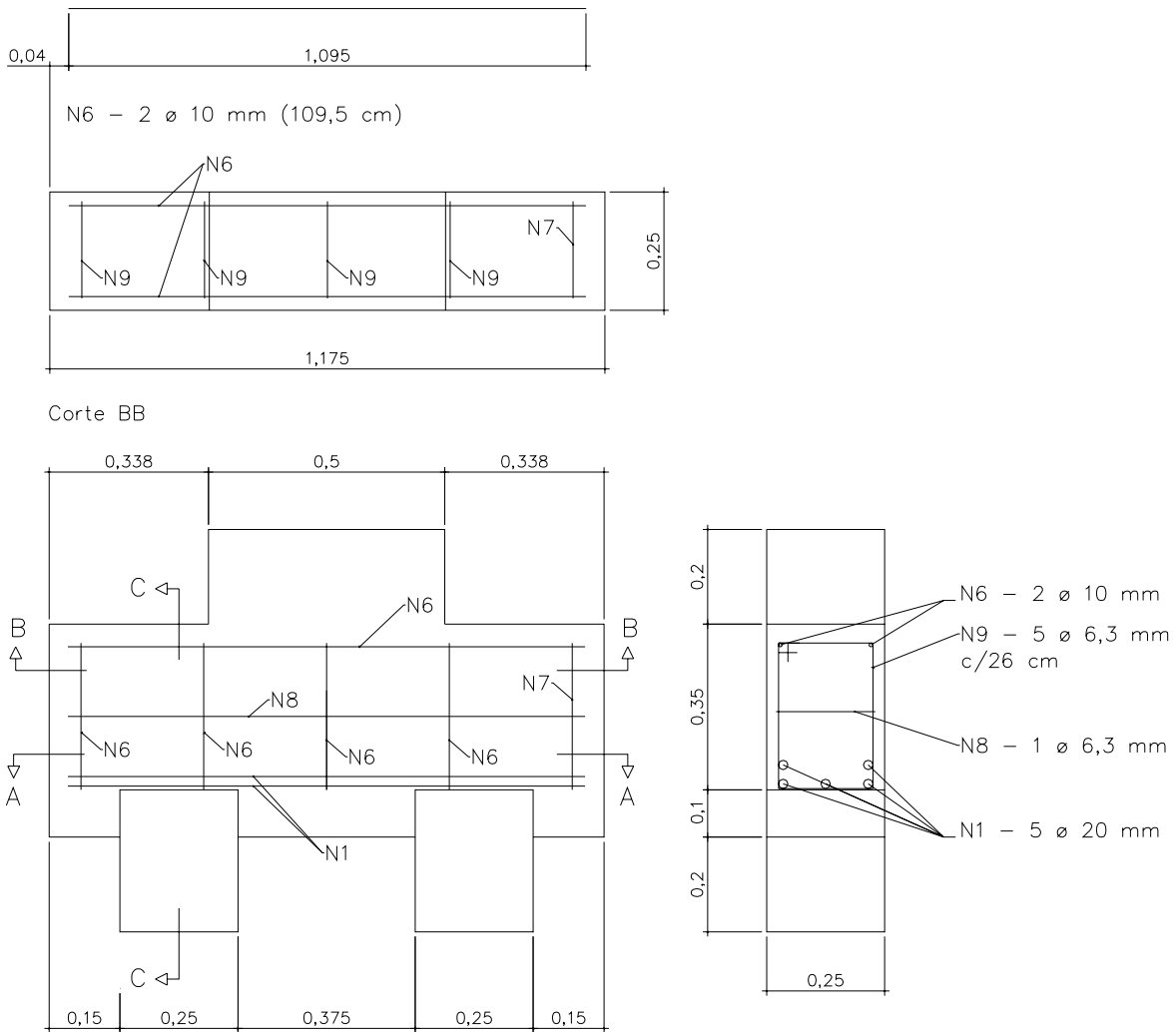

Vista Fronta
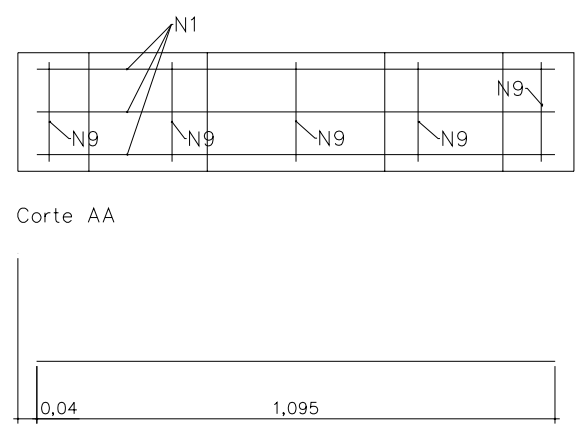

$\mathrm{N1}-5 \varnothing 20 \mathrm{~mm}(109,5 \mathrm{~cm})$

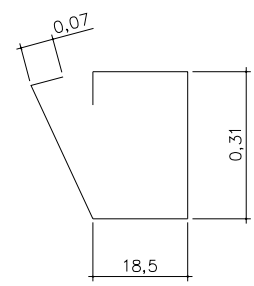

$19-5 \varnothing 6,3 \mathrm{~mm}$

c) $26 \mathrm{~cm}(113 \mathrm{~cm})$

B45P50E25e0

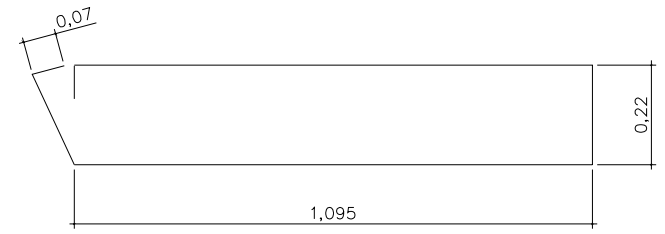

$18-1 \otimes 6,3 \mathrm{~mm}(277 \mathrm{~cm})$ 

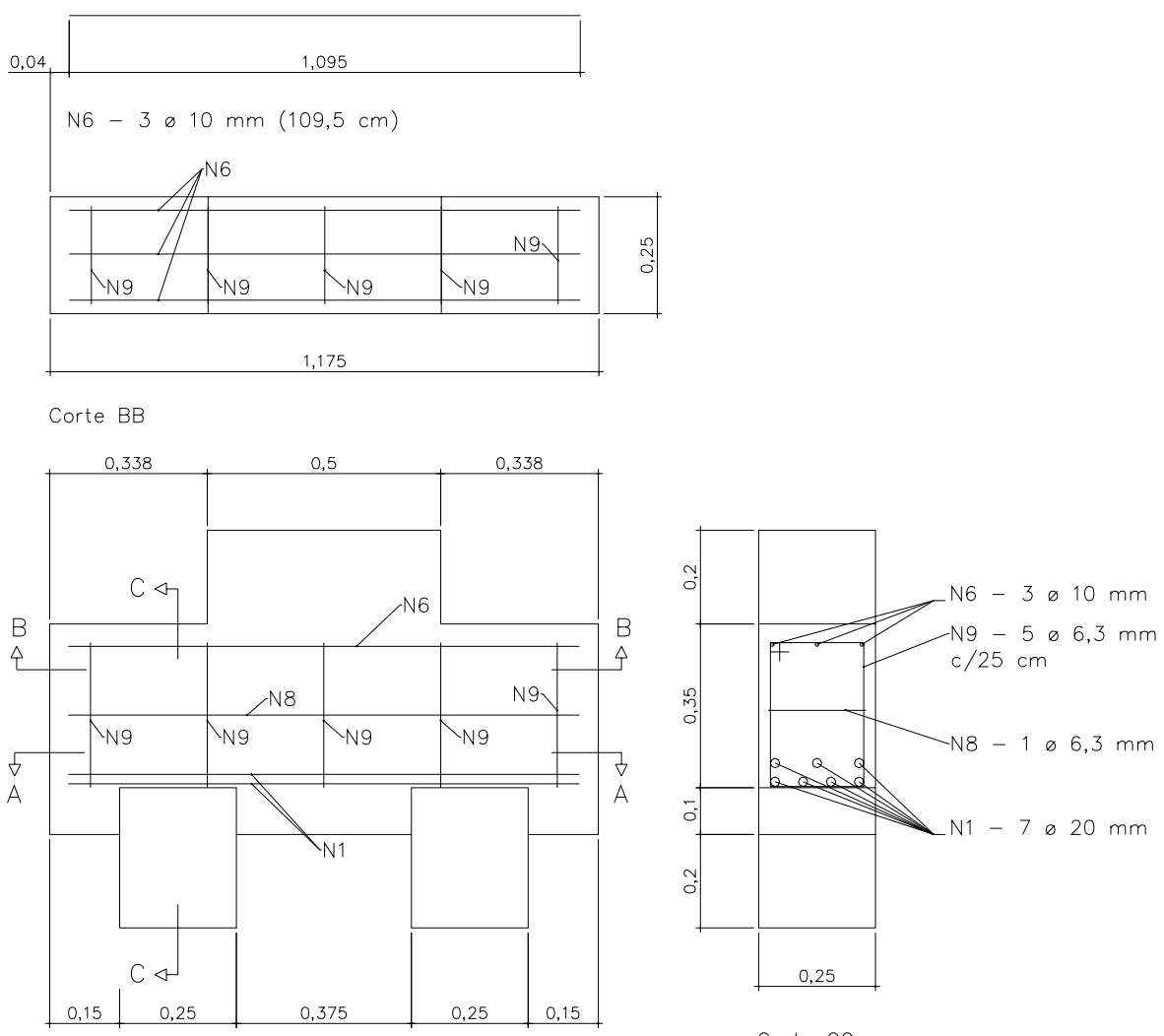

Vista Frontal
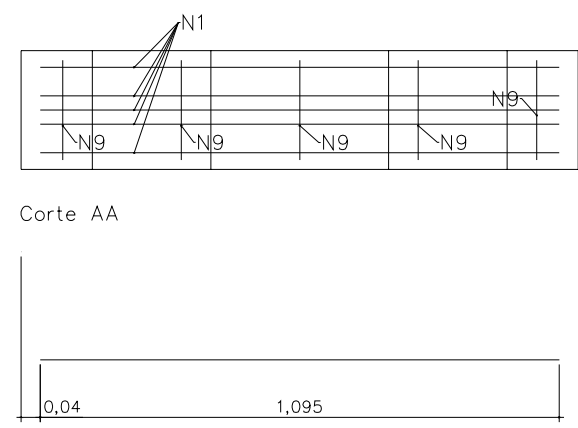

$\mathrm{N} 1-7 \varnothing 20 \mathrm{~mm}(109,5 \mathrm{~cm})$

B45P50E25e12,5

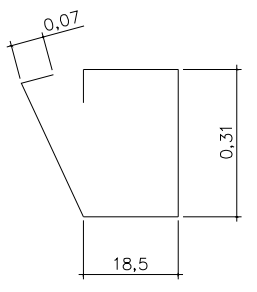

$\mathrm{N9}-5 \varnothing 6,3 \mathrm{~mm}$ c) $25 \mathrm{~cm}(113 \mathrm{~cm})$

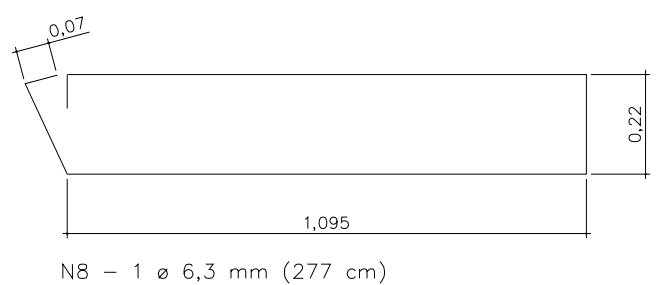




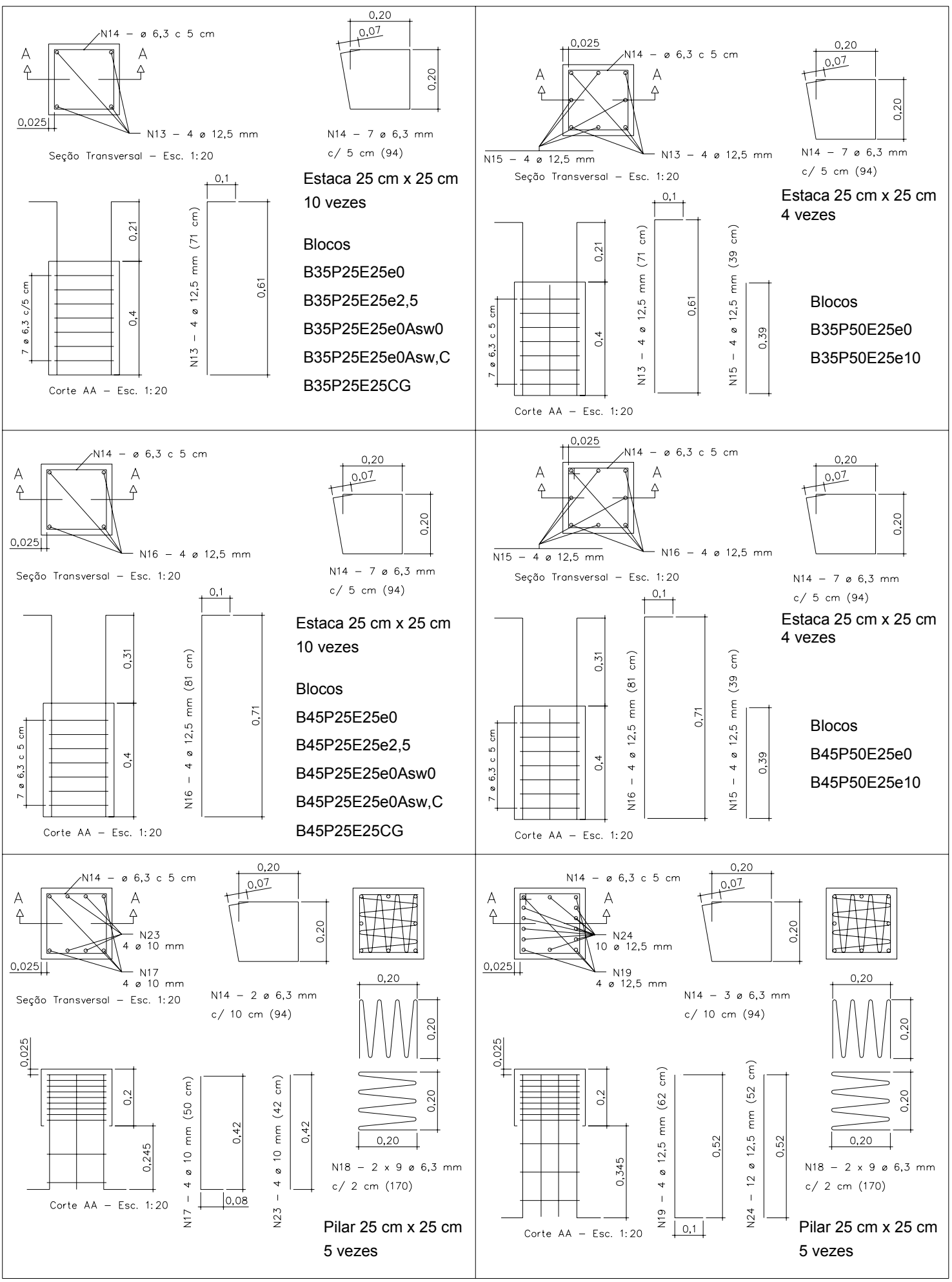




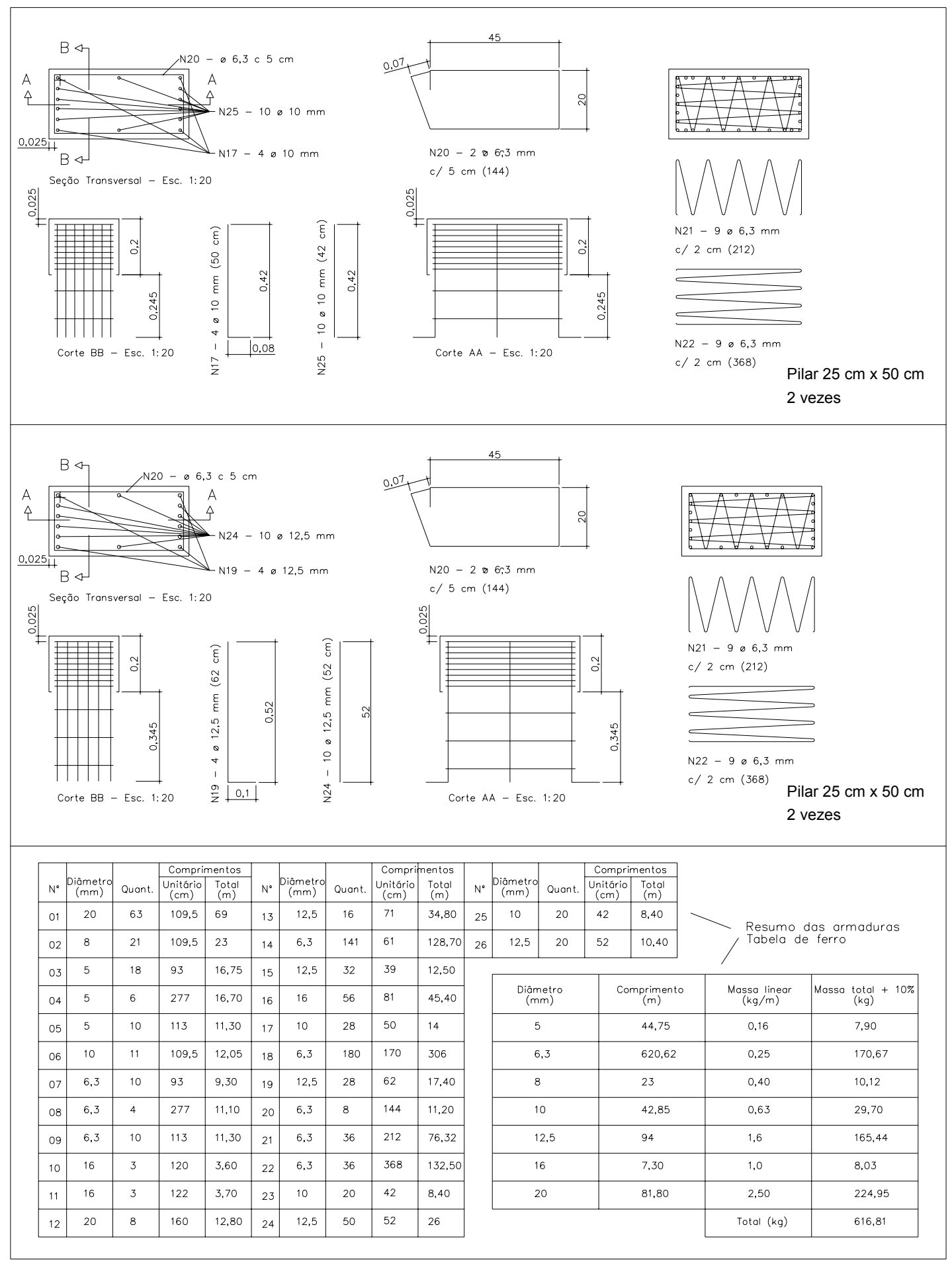

